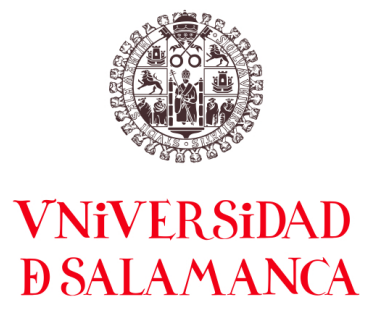

\title{
Kandinsky y la abstracción: nuevas interpretaciones
}

Julia Martínez Benito

Tesis Doctoral, 2011

Director: José Luis Molinuevo

Departamento de Filosofía, Lógica y Estética Universidad de Salamanca 



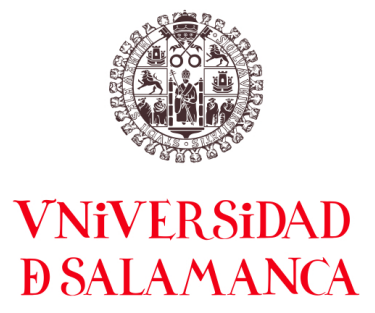

\title{
Kandinsky and Abstract Art: New Interpretations
}

\author{
Julia Martínez Benito
}

PhD Thesis, 2011

Supervisor: José Luis Molinuevo

Department of Philosophy, Logic and Aesthetics University of Salamanca, Spain 



\section{Kandinsky y la abstracción: nuevas interpretaciones}

Tesis presentada por Julia Martínez Benito para optar al grado de Doctor por la Universidad de Salamanca con la Mención de "Doctor Europeus", bajo la dirección de José Luis Molinuevo. 



\section{Kandinsky y la abstracción: nuevas interpretaciones}

Julia Martínez Benito 



\section{Índice}

Agradecimientos 5

$\begin{array}{ll}\text { Prefacio } & 7\end{array}$

Introducción 9

Parte I Kandinsky y la abstracción: contexto y proyecto intelectual 15

$1 \quad$ Wassily Kandinsky 19

$\begin{array}{lll}1.1 & \text { Breve referencia biográfica } & 20\end{array}$

1.2 Episodios relevantes de la biografía artística 21

$2 \quad$ El contexto histórico: en torno a 1900-1914 31

2.1 La nueva física $\quad 32$

2.1.1 La división del átomo $\quad 36$

2.1.2 La Teoría de la Relatividad 37

2.1.3 La física cuántica 39

2.2 La pintura 41

2.2.1 Monet y los impresionistas 44

2.2.2 Cézanne, Matisse y Picasso 48

2.2.3 Los expresionistas 54

2.3 La música 56

2.3.1 La música pre-atonal: Wagner, R. Strauss, Debussy 57

2.3.2 La música atonal: Arnold Schönberg 61

2.3.3 Kandinsky y la música atonal $\quad 64$

$\begin{array}{lll}2.4 & \text { Las bases ideológicas } & 69\end{array}$

2.4.1 Empatía y abstracción: T. Lipps y W. Worringer 70

$\begin{array}{lll}\text { 2.4.2 Rudolf Steiner y la Antroposofía } & 76\end{array}$

$3 \quad$ El proyecto de Kandinsky $\quad 85$

3.1 El camino a la abstracción $\quad 86$

$\begin{array}{lll}\text { 3.1.1 Las escuelas de pintura } & 86\end{array}$ 
3.1.2 Los viajes y la NKVM $\quad 92$

3.1.3 El Jinete Azul 95

$\begin{array}{ll}\text { 3.1.4 Las publicaciones } & 100\end{array}$

$\begin{array}{lll}3.2 & \text { El arte abstracto } & 107\end{array}$

$\begin{array}{ll}3.2 .1 & \text { La pintura de composición } \\ 3.2 .2 & 110\end{array}$

$\begin{array}{ll}\text { 3.2.2 El elemento interior o contenido } & 112\end{array}$

$\begin{array}{ll}\text { 3.2.3 El elemento exterior o forma } & 117\end{array}$

Parte II Kandinsky y la abstracción: nuevas interpretaciones $\quad 127$

$4 \quad$ El arte abstracto como reducción a lo esencial 131

4.1 La simplificación de las formas como exigencia 133

$\begin{array}{lll}\text { 4.1.1 La búsqueda de la tranquilidad } & 133\end{array}$

$\begin{array}{lll}\text { 4.1.2 } & \text { El papel de la naturaleza } & 137\end{array}$

4.1.3 La influencia de la ornamentación $\quad 140$

$\begin{array}{ll}4.2 & 145\end{array}$

$\begin{array}{ll}\text { 4.2.1 La esencia mínima o necesidad interior } & 146\end{array}$

$\begin{array}{ll}\text { 4.2.2 La pérdida de lo figurativo } & 150\end{array}$

$\begin{array}{ll}4.3 & \text { La depuración de la forma } \\ & 158\end{array}$

$\begin{array}{lll}\text { 4.3.1 Del caballo al círculo } & 159\end{array}$

$\begin{array}{ll}\text { 4.3.2 Del boceto al cuadro } & 167\end{array}$

$5 \quad$ El arte abstracto como expresión multisensorial $\quad 177$

$\begin{array}{llr}5.1 & \text { La riqueza sensorial } & 179\end{array}$

$\begin{array}{lll}\text { 5.1.1 El mundo interior } & 179\end{array}$

$\begin{array}{ll}\text { 5.1.2 La proyección del mundo interior } & 183\end{array}$

$\begin{array}{lll}5.2 & \text { La expresividad del lenguaje abstracto } & 187\end{array}$

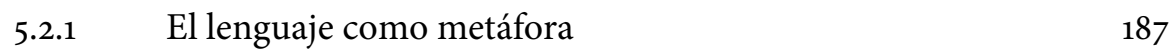

$\begin{array}{ll}\text { 5.2.2 La revalorización del espacio } & 194\end{array}$

5.2.3 La obra sintética o la presencia de otras artes 198

5.3 La resonancia de los medios pictóricos 205

$\begin{array}{lll}\text { 5.3.1 El color } & 205\end{array}$

$\begin{array}{ll}\text { 5.3.2 La forma } & 215\end{array}$

$\begin{array}{ll}\text { 5.3.3 La obra pictórica } & \mathbf{2 2 5}\end{array}$

$6 \quad$ El arte abstracto como experiencia espiritual 229 
6.1 La búsqueda de lo espiritual 231

6.1.1 El rechazo al materialismo 231

6.1.2 La controversia sobre la Antroposofía 234

6.1.3 El arte como salvación $\quad 239$

$\begin{array}{lll}6.2 & \text { La expresión interior } & 247\end{array}$

$\begin{array}{lll}\text { 6.2.1 La vibración del alma } & 247\end{array}$

6.2.2 El lenguaje espiritual 251

6.3 La presencia del mundo espiritual 259

$\begin{array}{lll}\text { 6.3.1 La pintura religiosa } & 259\end{array}$

6.3.2 El jinete que vence al dragón $\quad 265$

$\begin{array}{lll}\text { 6.3.3 El círculo cósmico } & 268\end{array}$

$7 \quad$ El arte abstracto como condición neuroestética 273

$\begin{array}{lll}7.1 & \text { Lo neuro- } & 275\end{array}$

$\begin{array}{lll}7.1 .1 & \text { Qué es la neuroestética } & 277\end{array}$

$\begin{array}{lll}\text { 7.1.2 Los primeros resultados } & \mathbf{2 8 5}\end{array}$

7.1.3 Las primeras reacciones 292

$\begin{array}{lll}7.2 & \text { Lo -estético } & 297\end{array}$

7.2.1 La sinestesia, condición biológica 297

7.2.2 El lenguaje abstracto cerebral 305

$\begin{array}{lll}7.3 & \text { La obra neuroestética } & 312\end{array}$

7.3.1 Reinterpretando a Kandinsky $\quad 312$

$\begin{array}{lll}\text { 7.3.2 La sinestesia en el arte actual } & 317\end{array}$

$\begin{array}{ll}\text { Conclusión } & 325\end{array}$

English version $\quad 329$

Introduction $\quad 329$

Summary $\quad 335$

Conclusion $\quad 366$

$\begin{array}{ll}\text { Materiales } & 369\end{array}$

$\begin{array}{ll}\text { Bibliografía } & 371\end{array}$ 



\section{Agradecimientos}

Empezar una tesis es fácil. Pero terminarla requiere mucho trabajo y algo más que ganas. Se necesita apoyo académico, confianza y libertad para desarrollar nuevas ideas, y eso es lo que me ha brindado mi tutor, José Luis Molinuevo. La posibilidad de investigar en otra universidad y de tener acceso a más recursos y bibliotecas siempre enriquece el proceso y suele apreciarse en los resultados: en mi caso, ha sido una larga estancia en la Ludwig-Maximilians-Universität de Múnich, en el grupo de doctorandos del profesor Günter Zöller. También agradezco la ayuda de José Luis Fuertes, Steffen Krämer, Ulises Moulines y Wolfgang Rathert: cada uno en su momento, contribuyeron a solucionar problemas y a que pudiera seguir adelante.

Gran parte de mi proyecto doctoral ha sido financiado por becas de dos Fundaciones españolas. La primera fue una Beca de Posgrado, concedida por Mutua Madrileña durante dos años. La segunda, una de las generosas Becas Nacionales de Investigación que otorga la Fundación Social de Ibercaja. Además del apoyo económico, quiero agradecer a Jose Antonio Campón, de Mutua Madrileña y a Paulino Savirón, de la Fundación Ibercaja, su ayuda siempre atenta y agradable.

La apariencia atractiva y $\tan$ legible del formato final debe mucho a Oliver Buerschaper, que ha sabido solucionar en ConT $\mathrm{E} X t$ las exigencias tipográficas y mis deseos estéticos. La calidad de imagen de los bocetos y dibujos de Kandinsky es obra de Ester Lanseros, al hacer visibles los trazos sin comprometer nunca los originales. El diseño de portada lo ha perfeccionado Maximilian Mandl (benandanti.de), dando mucho más que color a tantas páginas en blanco y negro.

Y el apoyo personal, imprescindible no sólo para terminar la tesis sino también para sobrellevarla, se lo agradezco a mi querida Meri, compañera de doctorado, procrastinación y esperanza; a las personas que han estado ahí y a Oli, for the love in the time of PhD. 



\section{Prefacio}

Bauhaus, Weimar 1922. Kandinsky lleva unas semanas ejerciendo de profesor de pintura mural. Un alumno, algo confundido con el arte abstracto, ha ido a ver a Kandinsky. El relato lo cuenta Lothar Schreyer en su libro Erinnerungen an Sturm und Bauhaus (1956):

«Señor Schreyer (...) tengo que contarle lo que ha pasado. Usted sabe que tengo ciertas dificultades con la pintura no figurativa. Cuando designaron a Kandinsky y él expuso sus cuadros en la Bauhaus, yo estaba tan horrorizado que vine a usted para pedirle consejo. ¿Es esto realmente pintura? Usted lo llamó, incluso, pintura absoluta. ¿A dónde vamos a parar? Primero se abstrae el objeto. Luego se elimina el objeto del todo. Sólo quedan manchas de color. Luego se abstraen las manchas de color a figuras geométricas. Lo único que queda es eliminarlas a ellas también. Y al final, la pintura absoluta termina necesariamente en la nada. Usted me dijo entonces que hablara directamente con Kandinsky. He estado un par de semanas dándole vueltas. Pero hoy, ahora mismo, acabo de hablar con Kandinsky.»

«¿Y qué ha pasado?», pregunté yo.

«Me he preparado a conciencia (...). Primero he pintado un cuadro, con témpera porque tenía que secar rápido, sobre una cartulina de $44: 44 \mathrm{~cm}$, es decir, el famoso número 4 del que Kandinsky y usted cuentan maravillas por ser el número místico de la Tierra. Y el 4 multiplicado por 11, el 11 como símbolo del renacer. Y además, la forma cuadrada como forma simbólica de la Tierra. Señor Schreyer, jesto que hacemos en la Bauhaus con los símbolos es una auténtica tontería!»

«Cuidado, cuidado!», respondí yo. «A menudo parecen tonterías cosas que no se entienden (...).»

«Vale, vale, señor Schreyer. Kandinsky me ha dicho lo mismo hace media hora (...). Pero le cuento sobre mi cuadro. He pintado la cartulina de blanco, 


\section{Prefacio}

completamente de blanco. Así se la llevé a Kandinsky, y le dije cortés: "Maestro Kandinsky: por fin he conseguido crear en términos de pintura absoluta un cuadro de la Nada absoluta”.»

Yo solté una carcajada. «iQué chiste tan bueno!»

«¡No, no! Yo lo decía muy en serio. (...) Kandinsky también se tomó mi cuadro muy en serio. Lo colocó delante de nosotros y dijo: "Las medidas del cuadro están bien. Hablan de lo terrenal. El color terrenal es el rojo. ¿Por qué ha escogido usted el color blanco?" Yo contesté: porque la superficie blanca representa la Nada. "La Nada es mucho", dijo Kandinsky. "De la Nada creó Dios el mundo. Y nosotros queremos utilizar un poco esa fuerza creadora y crear de la Nada un pequeño mundo". Entonces cogió pintura y un pincel y puso sobre la superficie blanca una mancha roja, una amarilla, una azul y dejó alrededor una sombra verde clara. Y de repente, allí había un cuadro, un cuadro de verdad, un cuadro espléndido. ¡Eso es maravilloso!, exclamé. “Todo depende de la pureza y del orden”, dijo Kandinsky objetivo y amable, dejó el pincel a un lado y me dio el cuadro.»

«¿Y dónde está el cuadro?», pregunté rápidamente.

«Hm, el cuadro. Yo me sentía muy raro allí, con un pequeño y maravilloso cuadro de Kandinsky. Así que se lo regalé. Él lo aceptó con una sonrisa, como cuando un abuelo agradece a su nieto un regalo de cumpleaños.» 


\section{Introducción}

Un siglo después de que Kandinsky pintara su primera acuarela abstracta (1910), el arte abstracto sigue siendo incomprensible para el gran público. A pesar de ocupar sin problemas museos de renombre y revistas divulgativas, el arte abstracto sigue planteando más preguntas que respuestas entre los espectadores, por no hablar de la sensación generalizada de tomadura de pelo. Las preguntas que surgen frente a un cuadro abstracto son muchas, $y$ generalmente inciden en la incomprensión («qué querrá decir ese punto con tres líneas») o en la calidad y valor de la obra («por qué ese cuadro valdrá tanto»).

Ambas son preguntas interesantes de responder, no hay duda. Pero a mi modo de ver, en realidad esconden una pregunta más amplia y aún más interesante: la del porqué. Por qué se elimina el objeto del cuadro, por qué se prescinde de lo imprescindible. A poco que se revise la historia del arte, en los últimos veinte siglos el objeto nunca ha desaparecido del cuadro: se han sucedido variedad de estilos, de formas, de temas y de teorías, pero la forma figurativa siempre ha estado presente. La filosofía ha propuesto algunas hipótesis y los historiadores han presentado sus explicaciones, pero la mayoría de ellas se centra en cómo se ha llegado al arte abstracto, en cómo ha ido evolucionado el arte hasta que el objeto finalmente desaparece del cuadro.

Dar una respuesta al porqué del arte abstracto en términos generales sería una pretensión desorbitada para una tesis doctoral. Por eso, manteniendo la idea y la curiosidad por satisfacer ese porqué, he decidido centrar mi investigación en un solo autor. La elección del pintor Wassily Kandinsky es casi obligada si se quiere explicar el paso de lo figurativo a lo abstracto. Es uno de los padres de la abstracción, si no el primero que pintó un cuadro abstracto, y es el único que dejó escrita una teoría sólida que respalda su creación artística. La obra de Kandinsky es compleja y está llena de interrogantes, y evidentemente no todos se responden con sus escritos teóricos. Pero estas fuentes directas sí permiten una base estable sobre la que asentar la investigación, lo que marca la diferencia con otros autores que están limitados a la literatura secundaria. 


\section{Introducción}

Las preguntas iniciales con las que me acerqué a Kandinsky fueron dos. Por un lado, quería saber por qué alguien que domina la técnica realista y está dotado de una memoria visual extraordinaria decide crear un estilo precisamente como la abstracción. Y qué le lleva a romper con siglos de tradición figurativa. Por otro lado, el paralelismo entre la pintura abstracta y la música atonal me obligaba a considerar esos porqués desde la perspectiva de un contexto interdisciplinar. Y me planteaba qué relación guarda el arte abstracto de Kandinsky con la música y otras artes.

Como en toda investigación, el interés por responder a las preguntas iniciales se va mezclando con la cantidad y la calidad de la bibliografía existente. El estudio de la literatura es quien ofrece algunas respuestas, conduce a preguntas nuevas y pone de manifiesto dónde están las carencias. La obra de Kandinsky, y más la pictórica que la teórica, ha sido objeto de estudio desde diversos ángulos: histórico, artístico y estético. Pero aún quedan interrogantes que resolver y sobre todo, falta mucho trabajo de interpretación, que es en el que yo me he centrado.

La escasez de interpretación se manifiesta en el trato que la bibliografía posterior ha dado al contexto histórico y biográfico. Hay que reconocer que la biografía publicada de Kandinsky es escasa, y eso no ayuda a la hora de establecer relaciones con su obra artística. Sin embargo, algunos acontecimientos históricos y episodios personales sí influyeron de manera determinante en la creación de su obra y no siempre se les ha dedicado la atención que en mi opinión merecen. Por ejemplo, el descubrimiento de la divisón del átomo y la creación de nuevas leyes en el campo de la física hacen mella en Kandinsky y en su manera de entender el arte, y salvo un par de autores que hacen referencia al tema, la mayoría narra el episodio de manera anecdótica. Lo mismo sucede con la tesis de W. Worringer sobre empatía y abstracción, tesis que Kandinsky lee en su día y entiende como una de las justificaciones del arte abstracto. A estos dos ejemplos se suman otros, como la visión tan parcial que se ofrece sobre la antroposofía y su vínculo con el arte abstracto o como la sinestesia de Kandinsky, que muchas veces incluso se pasa por alto. Gran parte de la bibliografía explica el nacimiento de la abstracción sin interpretar a la vez el contexto histórico y biográfico de Kandinsky. Esta situación fragmentaria es la que he intentado subsanar en mi investigación. El capítulo 1 presenta los episodios biográficos de Kandinsky que tienen relación directa con su proyec- 
to intelectual. Y el capítulo 2 interpreta los acontecimientos históricos a la luz de lo que será la creación del arte abstracto. Como exponer el contexto de una época siempre se hace inabarcable, me he centrado en los hechos que tienen mayor relevancia y en los más olvidados por la bibliografía existente.

Otro de los puntos débiles es, a mi juicio, el estudio individualizado de las obras teóricas de Kandinsky. Kandinsky escribe dos obras fundamentales, De lo espiritual en el arte y Punto y línea sobre el plano. Ambas son la base teórica de la creación artística abstracta: la primera se centra en el análisis del color y la segunda está enfocada al estudio de la forma. Pero De lo espiritual en el arte está escrito cuando Kandinsky aún no se ha liberado de lo figurativo y Punto $y$ línea sobre el plano ya refleja los años de pura abstracción. Es decir, entre ambas obras transcurren casi quince años que son los que marcan el punto de inflexión. En ese periodo de tiempo se fragua y se define precisamente el paso de lo figurativo a lo abstracto. Y la literatura actual ha dedicado tiempo y estudios a las dos obras, pero a menudo por separado. Falta la relación entre ellas, falta la explicación de qué sucede durante esos años y por qué las dos obras están tan relacionadas. Hay, obviamente, una descripción de los sucesos biográficos, artísticos y contextuales de esa época, pero falta una interpretación. Por este motivo, he prestado especial atención a estas obras de Kandinsky pero también a los escritos intermedios, a la correspondencia personal de esos años y a las actividades que llevó a cabo. La relación de todas ellas conforma la base teórica del proyecto de Kandinsky, que presento en el capítulo 3 .

La evolución del arte abstracto de Kandinsky está bien documentada por críticos e historiadores del arte. Las etapas de su pintura han sido diferenciadas según el grado de abstracción y las grandes monografías recopilan valiosa información secundaria: bocetos, cartas no publicadas o la transcripción de anotaciones manuales. La información suele ser detallada, clara y completa, pero la exposición es mayormente descriptiva. Las monografías y los estudios de investigación sobre Kandinsky presentan el nacimiento del arte abstracto describiendo los resultados artísticos. Y la interpretación de las causas y de esos resultados suele ocupar un segundo plano. Salvo ciertas excepciones, esa interpretación no sólo es secundaria sino que está tan centrada en un solo aspecto que, a mi juicio, termina siendo parcial. El arte abstracto de Kandinsky se presenta, principalmente, como una abstracción de las imágenes a formas 


\section{Introducción}

geométricas. Y de manera accesoria se nombra la relación con la música, se comenta su afinidad con la antroposofía y se relata con divertimento su posible sinestesia. La interpretación dominante es que las imágenes se convierten en líneas y colores, que lo real se transforma en abstracto.

Es cierto que, a primera vista, el arte abstracto de Kandinsky es una reducción de las formas. Pero el proyecto teórico y práctico que sustenta el nacimiento de la abstracción es, en realidad, mucho más complejo. Complejo en el sentido de imbricado, de que la reducción no es el pilar fundamental y la música o la sinestesia son cuestiones accesorias. Creo que estos aspectos tienen la misma importancia que la reducción en sí, y por lo tanto, merecen tener el mismo peso interpretativo. Por esta razón, he abierto mi investigación a la pluralidad de interpretaciones. He considerado todos los aspectos como posibles protagonistas de una interpretación global. El resultado son cuatro interpretaciones, y cada una de ellas explica de manera consistente el porqué del arte abstracto de Kandinsky. Entre ellas no hay jerarquías ni son excluyentes: son diferentes interpretaciones que se necesitan y se complementan para dar una explicación compleja a un proyecto complejo. Es posible que, en ocasiones, ideas expuestas en una interpretación parezcan contradecir lo que se afirma en otra. Pero si se observan las cuatro perspectivas como partes de una interpretación global, se descubre que las aparentes incomodidades lógicas son en realidad una riqueza estética. Porque son ideas que reflejan la coexistencia de muchos aspectos, el engranaje de diferentes realidades. El nacimiento del arte abstracto hay que contemplarlo desde la complejidad y desterrar toda concepción lineal. Porque la creación del arte abstracto no es una evolución ordenada, aunque se la presente así a menudo. Hasta que se asienta, es un proyecto que va y viene, que salta en el tiempo y que se apoya en diferentes ideas, experimentos artísticos y justificaciones. Y todas ellas, aunque a primera vista parezcan contradecirse, en el fondo son complementarias.

Cada una de esas cuatro interpretaciones ocupa un capítulo de la segunda parte. El capítulo 4 entiende el arte abstracto desde la perspectiva de la reducción formal. El capítulo 5 se centra en la expresión de un contenido interior y considera la abstracción como un lenguaje multisensorial. El capítulo 6 interpreta las formas abstractas como portadoras de una experiencia espiritual. Y el capítulo 7 cierra la serie de interpretaciones con una novedad: la hipótesis de que la sinestesia de Kandinsky, en tanto condición neurológica, pudo ser determinante para la creación del arte abstracto. 
La consideración paralela de cuatro interpretaciones diferentes y a la vez complementarias ha exigido no sólo mucha lectura, sino mucha lectura crítica. Las obras del propio Kandinsky tratan de ser didácticas y analíticas pero, a menudo, su lenguaje simbólico y arácnido entorpece la lectura y flexibiliza en exceso la interpretación. Las grandes monografías (Grohmann 1958, Overy 1969, Weiss 1979, Kleine 1991 y Hahl-Koch 1993) ofrecen muchos detalles, pero su interpretación es algo cerrada en sí misma y eso exige un gran esfuerzo de coordinación para poder relacionar las ideas entre sí y a la vez desgranarlas en diferentes perspectivas. La literatura secundaria aporta múltiples puntos de vista, pero sólo son valiosos una vez filtradas las afirmaciones basadas en tópicos ("Kandinsky pintaba música"), las ideas que provienen de los grandes estudios y los detalles erróneos pero asentados ("El Jinete Azul era un grupo" o "Kandinsky no dominaba la técnica"). Si bien la lectura crítica es parte habitual de toda investigación, en mi caso la dificultad añadida ha sido el juego de distancias. Durante la investigación y, especialmente en el proceso de redacción, las cuatro perspectivas exigían una posición de distancia para considerarlas en sí mismas, pero a la vez, una cercanía que las pudiera relacionar entre sí. He tenido que considerar cada expresión artística y cada idea teórica como parte de una interpretación múltiple y, a la vez, reconocerles la consistencia de una interpretación única sin entorpecer el desarrollo de las demás. Esta dificultad ha exigido mucho trabajo crítico y comparativo, pero también ha conseguido enriquecer las respuestas al considerarlas desde diferentes puntos de vista.

El tema de la sinestesia, tema de por sí controvertido, ha sido otra de las dificultades. No hay unanimidad en la literatura sobre el fenómeno en general y mucho menos sobre la situación concreta de Kandinsky. Razón por la cual, seguramente, gran parte de la bibliografía kandinskyana prefiere ignorarla o sólo comentarla de pasada. Sin embargo, los descubrimientos recientes de la neurología en torno a la percepción visual han arrojado una nueva luz sobre el fenómeno. La sinestesia tiene ahora una base neuronal reconocida, lo que permite estudiarla más a fondo y relacionarla con la creación artística, como bien empieza a observar la neuroestética. La interpretación final (cap. 7) se acoge precisamente a esta nueva perspectiva y examina el nacimiento del arte abstracto con la sinestesia como protagonista. Esta hipótesis no sólo le devuelve el protagonismo que la bibliografía ha estado omitiendo, también presenta el arte abstracto como la llave que puede explicar lo que parece ser 
Introducción

el arte del futuro: un arte centrado en las sensaciones múltiples, poliestéticas, plurisensoriales; sinestésicas, en fin. 


\section{Kandinsky y la abstracción: contexto y proyecto intelectual}


Kandinsky y la abstracción es el tema central de esta investigación que se divide en dos partes: una dedicada al contexto y proyecto intelectual del artista, y otra centrada en las nuevas interpretaciones. La primera parte se compone de tres capítulos (1, 2 y 3). En ellos se establece el marco de referencia común para entender el proyecto de Kandinsky. Son las bases biográficas y contextuales sobre las que se apoyarán las interpretaciones que componen la segunda parte.

El capítulo 1 se centra en la biografía de Kandinsky, en aquellos episodios personales y aptitudes o cualidades que influyen directamente en su proyecto intelectual. La biografía de Kandinsky no es una presentación accesoria, es un estimable punto de partida porque contiene información relevante para comprender después ciertos aspectos de la creación del arte abstracto. En este primer capítulo se ofrece una visión conjunta de todos los pasajes biográficos; a medida que avanza el texto, en los capítulos posteriores, se irá enlazando cada uno de ellos con su repercusión en el proyecto de Kandinsky.

El capítulo 2 sitúa la creación del arte abstracto a la luz del contexto histórico. Presenta los acontecimientos que arroparon a Kandinsky en el nacimiento de la abstracción, aproximadamente desde comienzos del siglo xx hasta el estallido de la Primera Guerra Mundial. Sin pretensión de realizar un manual de Historia, el capítulo se ciñe exclusivamente al contexto relevante, a los acontecimientos que contribuyeron directa o indirectamente a modelar el camino de la abstracción.

El capítulo 3, último de esta primera parte, examina la trayectoria de Kandinsky a través de sus escritos teóricos, su obras pictóricas y toda actividad relacionada con el nacimiento de la abstracción. La interpretación de esta base teórica aclara cómo se inicia el proyecto del arte abstracto y, especialmente, cuál es el punto de inflexión al que llega Kandinsky y que le encamina hacia la creación de ese nuevo arte. 



\section{Wassily Kandinsky}

La creación del arte abstracto es un proceso progresivo y paulatino. Son muchos los factores que intervienen en su desarrollo y es preciso conocerlos para poder explicar, finalmente, el porqué de la abstracción.

El primero de esos factores es sin duda su creador: Wassily Kandinsky. Este primer capítulo está dedicado a la figura de Kandinsky como persona y como artista, con la idea de presentar una imagen del autor que permita más adelante comprender su obra. No se reproduce un relato biográfico completo, sólo aquellos detalles o episodios que tienen relevancia para la investigación: los que tratan de ubicar al autor en su contexto histórico y los que enlazan la biografía personal con la producción artística. Para conocer otros detalles o episodios biográficos, consúltense las referencias aportadas en la bibliografía. ${ }^{1}$

El primer apartado se centra en la presentación biográfica de Kandinsky, y es breve y ceñida a lo esencial: lo suficiente para situar la vida del autor dentro del siglo xx. La segunda parte del capítulo, algo más extensa, presenta aquellos episodios biográficos que incidirán después en su trabajo artístico; bien porque sean un punto de partida para la creación, bien porque puedan cambiar la perspectiva de entender el arte abstracto.

La fuente bibliográfica principal de este capítulo es Mirada retrospectiva, la única biografía publicada de W. Kandinsky que es, en realidad, un escrito autobiográfico. Este libro de Kandinsky, su segundo escrito, es el menos conocido y por ende el menos estudiado; sin embargo, es el más personal y directo y el único que permite acercarse a su biografía en busca de respuestas artísticas desde otros puntos de vista. Kandinsky escribió dos versiones de Mirada retros-

1 Estrictamente hablando, no existe una biografía de Kandinsky, pero sí hay material biográfico. Lo más cercano es el libro que escribió su mujer Nina, Kandinsky und ich, plagado de relatos personales y anécdotas más o menos íntimas. Con un carácter similar se puede añadir el libro de Gisela Kleine, Gabriele Münter und Wassily Kandinsky, que es una biografía de la pareja. Además de los propios escritos de Kandinsky, como Mirada retrospectiva o Nota autobiográfica, de los que se habla más adelante, hay dos monografías excelentes. Se trata de las obras de Will Grohmann (1958) y de Jelena Hahl-Koch (1993) que, aunque sean un tratado académico-pictórico de la obra de Kandinsky, aportan múltiples referencias biográficas, incluyendo las epistolares. 
pectiva. La primera de ellas, Rückblick (“Mirada retrospectiva”), está fechada en 1913 en Múnich y publicada por Der Sturm en Berlín; la segunda data de 1918 y se firmó en Moscú. Escritas en alemán y ruso respectivamente, podría decirse que la versión de Moscú es una traducción o corrección lingüística de la primera. El contenido es muy similar, cambian ciertos adjetivos o frases que aportan sutilidad al texto, más que nuevas ideas. ${ }^{2}$

Aunque en menor medida, también hay alguna referencia autobiográfica en dos lugares más: el primero es una Nota autobiográfica que aparece en la segunda edición del catálogo Kandinsky: Kollektiv-Austellung, 1902-12, editado en Múnich por Hans Goltz y que luego reimprime Herwarth Walden en Berlín para Der Sturm incluyendo un anexo (1913). Y el segundo es el libro Escritos sobre arte y artistas, publicado en 1955. Este libro no fue concebido como tal, sino que, tras la muerte del pintor en 1944, se editó como recopilación de los artículos de Kandinsky que habían aparecido en distintas publicaciones a lo largo de los años, unidos a la transcripción de alguna de las conferencias que dio en vida. ${ }^{3}$

\subsection{Breve referencia biográfica}

Wassily Kandinsky nace en Moscú en 1866 en el seno de una familia aco-

2 En realidad, el porqué y cómo de la versión rusa es una cuestión muy amplia. Además de ligeras modificaciones y aclaraciones filológicas (Kandinsky dominaba el alemán, pero no tanto como su lengua materna, el ruso), también hay supresiones significativas y ciertas acotaciones que se deben a motivos histórico-políticos. El tema es demasiado amplio para tratarlo en estas páginas. Si se quiere profundizar, hay una primera traducción al inglés de la versión rusa publicada en 1945 en Nueva York, en In Memory of Wassily Kandinsky y una traducción al español de los pasajes que cambian en la versión rusa con respecto a la alemana en el libro de Mirada retrospectiva publicado en Emecé Editores (véase la bibliografía). El mejor estudio crítico sobre el texto de Mirada retrospectiva, que incluye un análisis histórico, político y personal del porqué de la versión rusa en comparación con la versión alemana, es el de Jean-Paul Bouillon en Regards sur le passé. En español, este análisis de Bouillon se ha incluido en las páginas 42-47 de la versión de Mirada retrospectiva publicada en Emecé.

Como se puede ver en la bibliografía, las citas aquí empleadas corresponden a la versión alemana de 1913 y/o a la traducción española (Emecé). Si en algún caso se ha recurrido a la versión rusa porque el matiz diferenciador era relevante, se ha indicado en la nota a pie de página.

3 La versión aquí utilizada es la traducción al español de 2003 o la edición alemana de 1973, editada por Benteli. Véase la bibliografía. 
modada. La educación artística está presente desde su infancia: con ocho años empieza a tocar el piano y el violonchelo y durante la adolescencia recibe clases de dibujo. A los 30 años, y dejando atrás una fructífera carrera de Derecho en Moscú, se traslada a Alemania para dedicarse por entero a la pintura. Múnich es uno de los centros europeos del arte a principios del siglo xx y el lugar elegido por Kandinsky para empezar su vida como artista. Los primeros años asiste a clases: en la escuela de Anton Ažbe primero y en la de Franz von Stuck después. Más adelante, crea su propio grupo o escuela de pintores.

La Guerra del 14 pone punto final a su estancia en Múnich y lo devuelve a su Rusia natal. En Moscú trabaja en diferentes museos, comités artísticos e instituciones oficiales hasta que Walter Gropius lo llama para formar parte del cuerpo docente de la Bauhaus, en 1922. Se traslada con la Bauhaus a Dessau y luego a Berlín, hasta su clausura. En 1933, Kandinsky marcha a París y se instala en Neuilly, donde permance hasta su muerte en 1944.

Gabriele Münter, pareja del pintor durante los años de Múnich, y la que fue su segunda esposa, Nina Kandinsky, tendrán un papel relevante en la creación y distribución artística de Wassily Kandinsky. ${ }^{4}$

\subsection{Episodios relevantes de la biografía artística}

La educación artística que Kandinsky recibe desde niño, tanto la musical como la pictórica, son algo más que un complemento a su formación. Las clases de dibujo le permiten encauzar la sensibilidad especial que demuestra hacia lo artístico y le ayudan a satisfacer unas exigencias sensoriales que escapan de lo común: más intensas, visuales y sonoras de manera simultánea, puramente estéticas.

Su libro autobiográfico de 1913, Mirada retrospectiva, ofrece pasajes que

4 Muchas de las obras de Kandinsky que alberga la galería Lenbachhaus de Múnich fueron donadas por Gabriele Münter en 1957, con motivo de su 80 cumpleaños. La colección se fue completando con el legado de Bernhard Koehler y otras donaciones de la Fundación Gabriele Münter y Johannes Eichner. Las obras pertenecen al periodo que Kandinsky vivió en el sur de Alemania (1896 - 1914): su etapa expresionista y los comienzos de la abstracción.

Tras la muerte del pintor en 1944 será Nina Kandinsky, nacida Andreievskaia y esposa de Kandinsky desde 1917, la que cuida con esmero y recelo el legado del pintor. Gran parte de su obra descansa en el Centro Pompidou de París: parcialmente vendida, parcialmente legada por Nina. Son obras fechadas a partir de los años 20: el periodo de plena abstracción. 


\section{Wassily Kandinsky}

revelan esa relación peculiar que Kandinsky tiene con el entorno que le rodea. Estas características personales, que más tarde se descubrirán en su obra, pueden agruparse en cuatro.

La primera es la manera que tiene de percibir el mundo y de recordar sus impresiones. Kandinsky era incapaz de aprender de memoria cifras, nombres o poemas, pero poseía una memoria visual extraordinaria que retenía y absorbía cualquier detalle, por nimio que fuera. El mundo exterior era para Kandinsky un cúmulo de impresiones visuales que continuamente se le quedaban registradas, llevándolo a un «estado de agotamiento mental, de saturación» ${ }^{5}$. Esta facultad, que con los años aprendió a dominar y a canalizar, era tan intrínseca («vivía en mí, de una manera orgánica, desde siempre») como inconsciente («sin tener la menor conciencia de ello»); y además, le era inevitable ( «yo me encontraba en la obligación de no dejar de ver» ${ }^{6}$ ).

Una memoria visual de estas características no sólo ayudó a Kandinsky en la vida diaria (a aprobar exámenes, por ejemplo) ${ }^{7}$ sino que le dotó de una capacidad especial con la que podía reproducir mentalmente y con gran exactitud cualquier percepción visual anterior. Esto le permitía «pintar en casa y de memoria cuadros que [le] habían cautivado particularmente en exposiciones», reviviendo multiplicidad de experiencias artísticas e incrementando así su conocimiento y perspectiva sobre el arte. Si a esto se añade que «pintaba mejor un paisaje de memoria que copiándolo de la naturaleza» ${ }^{8}$, no parece extrañar que más adelante la imitación natural desaparezca por completo de sus cuadros y dé paso a un lenguaje lleno de impresiones y sensaciones internas.

El relato de Kandinsky sobre su capacidad de registrar y proyectar lo percibido tiene una base más sólida que la de la sinceridad con la que el relato parece escrito. La psicología admite varios tipos de memoria, entre ellos la memoria del tipo "imagen gráfica o eidética”, que fue descrita por los hermanos Jaensch, psicólogos alemanes. Aleksandr R. Luria explica este fenómeno en su libro Atención y memoria. Según su definición, es un tipo de imagen sucesiva

5 Todas las citas presentes en este párrafo y las referidas a la memoria visual pertenecen a Kandinsky, Mirada retrospectiva, pp. 112 y 113.

6 La cursiva es original.

7 Kandinsky cuenta cómo superaba los exámenes de estadística gracias a que en su mente veía las cifras, y no porque pudiera recordarlas.

8 La cursiva es original. 
que perdura en la memoria de una forma muy vívida y precisa: una imagen «de objetos vistos anteriormente o de escenas completas, y que persisten durante mucho tiempo después de haber cesado la presencia de los mismos. (...) Puede conservarse tanto tiempo como se quiera; y si ulteriormente desaparece, el sujeto puede suscitarla de nuevo sin trabajo alguno» ${ }^{9}$, incluso meses o años después de haber visto la imagen por primera vez. Esta imagen mental es, además, móvil: es decir, si la imagen es de una calle, cambiará según se mueva el sujeto mentalmente por ella.

Ahora se puede dar un nombre a esa extraordinaria memoria visual de Kandinsky, imagen eidética, aunque lo que importa no es la nomenclatura sino resaltar su capacidad de proyectar las impresiones visuales, su capacidad de pintar de memoria. La imagen eidética le proporciona un mundo interior de impresiones que provienen del mundo exterior y que constituirán después el contenido de gran parte de su obra. Cuando, de adulto, Kandinsky explica su "ley de creación” lo deja claro: «El pintor se nutre de impresiones externas (vida externa) y las transforma dentro de su alma (vida interna) (...) El resultado es una obra.» ${ }^{10}$

La palabra "alma” que Kandinsky menciona en su ley de creación, indica que existe un vínculo entre lo que percibe sensorialmente y lo que procesa internamente, en su alma. Ésta es la segunda característica: la relación de Kandinsky con el mundo externo es intensa en lo sensorial y profunda en lo emocional, es una relación sentida. "Alma” aparece de forma recurrente en sus escritos. Siempre entremezclada con términos pictóricos: para reforzar el poder de una sensación, o para indicar de dónde viene la fuerza expresiva de una obra. Las impresiones eidéticas le son intensas porque son vívidas, porque las recuerda de manera excepcional; pero sobre todo, porque parece dotarlas de espiritualidad: «[esas impresiones] (...) me deparaban una alegría que me conmovía hasta el fondo del alma y que llegaba hasta el éxtasis» ${ }^{11}$.

A través de los sentidos de Kandinsky, el mundo externo ofrece una fuerte carga emocional. Como si cada cosa que le rodea se impregnara de trascendencia: «Toda cosa "muerta” palpitaba. No solamente las estrellas, la luna, los

9 LURIA, Atención y memoria, p. 84.

10 Kandinsky, Escritos sobre arte y artistas, p. 153. La cursiva es original.

11 Kandinsky, Mirada retrospectiva, p. 98. 


\section{Wassily Kandinsky}

bosques, las flores, de que hablan los poetas, sino también una colilla en un cenicero, un botón blanco, (...) una pequeña brizna de hierba dócil, (...) una hoja de calendario, (...) todo eso me mostraba su rostro, su ser interior, el alma que con más frecuencia calla que habla» ${ }^{12}$.

Si cualquier objeto le abre una puerta a lo espiritual, el arte lo consigue aún con más fuerza. «El arte (...) tenía el poder de transportarme fuera del tiempo y del espacio (...) de suerte que hasta perdía el sentido de mí mismo». ${ }^{13}$ Las experiencias artísticas originan un «estado de vibración» en el alma que contagia lo sensorial de lo espiritual y viceversa. Hay un episodio en su biografía que refleja esta fusión.

En 1889, años antes de marchar a Múnich y dedicarse a la pintura, Kandinsky viaja a la región de Vologda (Rusia) en calidad de etnógrafo. Describe que las gentes de la zona van vestidas «de manera tan abigarrada y con colores tan vivos, que parecían cuadros móviles con dos piernas» ${ }^{14}$. Las casas también están adornadas y pintadas de manera excesiva, de tal manera que Kandinsky siente haber cruzado una línea entre aquí y allá y ahora se encuentra dentro de un cuadro:
«En esas isbas ${ }^{15}$ extraordinarias viví por primera vez un milagro que ulteriormente se convirtió en uno de los ele- mentos de mis trabajos. Esas casas me enseñaron a mover- me en el seno mismo del cuadro, a vivir dentro del cuadro. (...) Me sentí rodeado por todas partes de la pintura en la cual había, pues, penetrado. ${ }^{16}{ }{ }$

La misma sensación la experimentará años después en algunas capillas bávaras y tirolesas. Pero ahora, en Vologda, descubre que el arte tiene una especie de vida interior y siente por primera vez que su alma puede pasear por ella. La sensación debió de ser tan intensa que, ya de artista, la busca en cada uno de sus cuadros. Quiere que el espectador reviva esa experiencia casi mística de sentirse dentro del cuadro y lo invita a penetrar en él, como

12 Kandinsky, Mirada retrospectiva, p. 99.

13 Kandinsky, Mirada retrospectiva, pp. 101 y 104.

14 Kandinsky, Mirada retrospectiva, p. 243.

15 Vivienda rural de madera típica de ciertos países del norte de Europa y en especial de Rusia.

16 En este pasaje, la traducción es más cercana a la versión rusa, véase Kandinsky, Mirada retrospectiva, pp. 109 y 243. La cursiva es original. 
abriéndole la puerta a una nueva dimensión.

La influencia que tiene Vologda en la obra artística de Kandinsky no es sólo la apertura a lo espiritual. De la profusión con la que están decoradas las casas y sus estancias, o de la manera de vestir de sus gentes destaca un aspecto: el color. Colores vivos, colores abigarrados que se imponen sobre las cosas, sobre los objetos mismos. De hecho, la fuerza del color llega a anular la presencia de lo figurativo: «[los ornamentos] estaban pintados con una fuerza tal que el objeto se fundía en ellos». ${ }^{17}$

El capítulo de Vologda sugiere que el color es la puerta a la dimensión espiritual y además, o precisamente por ello, que posee una fuerza expresiva que prevalece sobre los objetos. Aunque la propia obra de Kandinsky lo confirmará después, otras citas biográficas también lo adelantan: «esas sensaciones de los colores en la paleta (...) se convirtieron en experiencias espirituales.» ${ }^{18}$ O cuando «intentaba (...) fijar sobre la tela el "corazón de los colores" (así lo llamaba yo), que surgiendo de la naturaleza irrumpía en toda mi alma y la conmovía.» $^{19}$

¿Cuál es la relación que tiene Kandinsky con el color para que éste adquiera tal magnitud? Es, sin duda, una relación especial (ésta es la tercera característica). Ya desde niño siente una atracción apasionada por los colores. Así de directo se lo explica a Nierendorf en una entrevista: «ya de muy joven sentía la inusitada fuerza expresiva del color» ${ }^{20}$. Tampoco ocultó nunca que, frente al lienzo, no sólo prefería sino que dominaba el color frente al dibujo, como se verá más adelante. ${ }^{21}$

17 KANDINSKY, Mirada retrospectiva, p. 109. La cursiva es original.

18 KANDINSKY, Mirada retrospectiva, p. 115.

19 KANDINsKy, Mirada retrospectiva, p. 99.

20 KANDINSKY, Escritos sobre arte y artistas, p. 193. Karl Nierendorf era el comerciante de arte que representaba a Kandinsky en Estados Unidos. En 1937 solicitó a Kandinsky una entrevista, que se reproduce en las páginas 193-196.

21 Cuando Kandinsky llega a Múnich estudia durante dos años con Anton Ažbe, con la idea de ingresar después en la escuela de Franz von Stuck, considerado "el primer dibujante de Alemania". Cuando von Stuck ve sus trabajos, le aconseja encarecidamente que estudie en la Academia un año, pero sólo dibujo. Kandinsky no aprueba el examen de ingreso y necesitará un año entero de estudio individual para aprobarlo. Una vez admitido, Franz von Stuck sigue pensando que la forma de pintar de Kandinsky es demasiado expresiva y, oponiéndose a sus "extravagancias de color" (así lo relata Kandinsky), le aconseja pintar sólo en blanco y negro para que estudie únicamente la forma y se olvide del color. El episodio 


\section{Wassily Kandinsky}

El color llega a ser el protagonista de la obra kandinskyana, pero no por simple contraposición a la forma o el dibujo. La explicación detallada de por qué esto es así vendrá en los capítulos siguentes, ahora basta resaltar que el trato de Kandinsky hacia el color, la manera de entenderlo, fue siempre singular. «Recuerdo muy bien cuánto me gustaba el material mismo, cuán particularmente atrayentes, hermosos y vivos me parecían los colores y los lápices». ${ }^{22}$ Este pequeño atisbo de personificar el color (hermoso y vivo) se queda corto si se considera la cita siguiente, una de las más conocidas:
«Aún hoy siento lo que experimenté entonces (...) viendo cómo los colores salían del tubo. Una presión del dedo y triunfantes, sonoros, reflexivos, soñadores, absortos en sí mismos, con profunda seriedad, con chispeante diablu- ra, con un suspiro de liberación, con una fuerza y una resistencia picarescas, una dulzura y una abnegación en la capitulación, un dominio pertinaz de sí, tanta sensibi- lidad en su equilibrio inestable, esos seres extraños, que llamamos colores, llegaban uno detrás del otro vivos en sí y para sí, autónomos y (...) a cada instante dispuestos (...) mezclarse los unos con los otros y a crear una infinidad de mundos nuevos. ${ }^{23}{ }^{\prime}$

No cabe duda de que el color tiene para Kandinsky otra entidad. En primer lugar por esa concepción personificada, por esa manera de hablar de tú a tú al color, algo que para muchos, no es más que un medio pictórico más. Y en segundo lugar, porque incluso en los escritos biográficos (en los escritos artísticos es evidente) se deja entrever la autonomía del color. El color es un ser autónomo, independiente, existente por sí mismo. Que el color tiene fuerza suficiente para anular al objeto, se vio en el relato de Vologda. Que el color tiene existencia propia y no tiene por qué pertencer a un objeto o ser una propiedad de él, se desprende del siguiente relato.

A la edad de tres años, Kandinsky viaja con sus padres a Italia. Del viaje

puede leerse en KAndinsky, Mirada retrospectiva, p. 119 y completarse en HeIsserer, Wo die Geister wandern, pp. 189-191.

22 Kandinsky, Mirada retrospectiva, p. 104.

23 Kandinsky, Mirada retrospectiva, p. 113. 
sólo recuerda colores: «el verde claro, lleno de savia, el blanco, el rojo carmín, el negro y el ocre amarillento» ${ }^{24}$. Y lo que es más, colores desprendidos de los objetos: «Vi esos colores en diferentes objetos que hoy no logro representarme con tanta claridad como los colores mismos».

Teniendo como base estas premisas sobre la naturaleza del color, será fácil entender en los capítulos posteriores que el color sea la puerta a nuevas dimensiones (incluidas las espirituales), que el color lleve el protagonismo del cuadro o que la autonomía del color sea la causa de nuevas creaciones artísticas.

No obstante, aún queda por explicar una última característica, la cuarta, que sigue presentando relación con el color. A la personificación y autonomía que Kandinsky otorga al color hay que sumarle una percepción sensorial diferente. El color es, por lo habitual, un estímulo que se percibe por la vista y que provoca sensaciones visuales. En muchos pasajes de Kandinsky, sin embargo, parece inferirse que el color no es solamente visual. Un pequeño fragmento como introducción: «Los buzones amarillo vivo lanzaban desde las esquinas de las calles su canto vibrante de canario» ${ }^{25}$. Kandinsky percibe el color por la vista pero no le provoca sólo sensaciones visuales, también auditivas. Es decir, Kandinsky no sólo ve los colores, también parece oírlos.

Si un estímulo provoca diferentes respuestas sensoriales, como parece ser el caso de Kandinsky con el color, recibe el nombre de sinestesia. Sin querer dar ahora una definición formal y final de la sinestesia (tema que corresponde al capítulo 7), puede decirse que a medio camino entre trastorno y condición cognitiva, lo definitorio de la sinestesia es que en el acto de la percepción hay dos, a veces más, esferas sensoriales que se unen; o una esfera sensorial que responde a un estímulo provocado en otra. Una experiencia sinestésica consiste, por ejemplo, en escuchar un sonido mientras se ve un color, o en tener una sensación táctil al escuchar un idioma.

En el caso de Kandinsky se trataría de una sinestesia visual-auditiva, es decir, de una respuesta visual a lo sonoro o de una sensación auditiva al percibir algo con la vista. A pesar de los numerosos ejemplos en su biografía que hacen referencia de manera más o menos directa a esta fusión de sensaciones,

24 Esta cita y la siguiente se encuentran en KANDINSKY, Mirada retrospectiva, p. 94.

25 Kandinsky, Mirada retrospectiva, p. 96. 


\section{Wassily Kandinsky}

Kandinsky nunca utilizó la palabra sinestesia para describirlas. Solamente a raíz de sus escritos tampoco puede asegurarse que su sinestesia fuera real, entendiendo real como una condición neurológica, o que fuera simplemente una sinestesia empleada como metáfora. Ambas son hipótesis probables que se estudiarán más adelante. Lo que sí queda reflejado en sus escritos es una relación fuerte entre estímulos visuales (colores) y auditivos (sonoros), como se aprecia en los siguientes ejemplos.

El primero hace referencia a sus útiles de pintura: «Parecíame a veces que el pincel, que con una voluntad inflexible arranca fragmentos de ese ser vivo de los colores, hacía nacer una tonalidad musical cada vez que arrancaba un fragmento. A veces oía el sonido sibilante de los colores al mezclarse. Era como una experiencia oída en la misteriosa cocina de un alquimista envuelto en el misterio.» ${ }^{26}$

Sensaciones musicales también se las producen las pinturas de Rembrandt, que «producían el efecto de un gigantesco acorde de dos notas» ${ }^{27}$. Por su parte, la audición de la ópera Lohengrin de Wagner, despierta sensaciones visuales: «Lohengrin me pareció que era una realización perfecta (...). Mentalmente veía todos los colores; los tenía ante mis ojos. Líneas salvajes, casi dementes, se dibujaban frente a mí» ${ }^{28}$.

Y el ejemplo más claro de estas experiencias sinestésicas es la descripción del atardecer de Moscú. Para Kandinsky es la hora más hermosa del día, una hora en la que se funden los colores como en una sinfonía:

«El sol hace que toda Moscú se funda en una mancha que, como una tuba enloquecida, hace entrar en vibración todo el ser interior, el alma entera. ¡No, no es la hora del rojo uniforme la más bella de todas! Ella no es más que el acorde final de la sinfonía que lleva cada color al paroxismo de la vida y triunfa sobre toda Moscú haciéndola resonar como el fortissimo final de una orquesta gigante. El rosa, el lila, el amarillo, el blanco, el azul, el verde pistacho, el rojo flamígero de las casas, de las iglesias - cada una con su melodía propia-, el césped de un verde demente, los

26 KAndinsky, Mirada retrospectiva, p. 114.

27 Kandinsky, Mirada retrospectiva, p. 105.

28 Kandinsky, Mirada retrospectiva, p. 103. 
árboles de grave zumbido, o la nieve de mil voces cantarinas, o también el allegretto de las peladas ramas, el anillo rojo, rígido y silencioso de las paredes del Kremlin y, por encima, dominándolo todo como un grito de triunfo, como un aleluya olvidado de sí mismo, el largo trazo blanco, graciosamente severo, del campanario de Ivan Veliky. ${ }^{29}{ }$ "

Por el momento, estos ejemplos bastan para dar una idea de la sinestesia kandinskyana, de su percepción visual-auditiva. De aquí en adelante, la puerta queda abierta para entender la sinestesia como una expresión metafórica (capítulo 5) o para asumirla como una condición neurológica (capítulo 7).

El estudio de la biografía de Kandinsky es, como se ha visto, mucho más que el de un simple contexto biográfico. Su modo de relacionarse y de aprehender el mundo no sólo es peculiar, sino que reaparecerá a lo largo de su obra. La visión eidética (o su magnífica memoria visual) tendrá un papel determinante en el proceso de creación; la espiritualidad teñirá de trascendencia su arte; el color, personificado y autónomo, llevará el peso del cuadro; y la percepción sinestésica abrirá una nueva dimensión artística. La comunión de todos estos factores exigirá la creación de un nuevo lenguaje para el arte.

29 KAndinsky, Mirada retrospectiva, p. 97. Las cursivas son originales. 



\section{El contexto histórico: en torno a 1900-1914}

No intellectual discipline exists in a vacuum but evolves in response to events taking place in other, neighboring fields.

ROBERT F. BORNSTEIN

La época que abre el siglo xx es una época intensa y llena de cambios. En los casi quince años que preceden al desastre de la Guerra, la llamada "Mitteleuropa" y en mayor medida los centros de Londres y París, asisten a un carrusel de novedades, descubrimientos y florecimientos artísticos como hacía tiempo no se daba. Albert Einstein publica en 1905 su Teoría de la Relatividad, Freud termina poco antes La interpretación de los sueños, el impresionismo deja paso a estilos pictóricos rompedores como el fauvismo o el cubismo y Arnold Schönberg deconstruye la armonía musical para componer atonalmente. En ese mismo periodo aparece el cinematógrafo, se publican los Principia Mathematica de Russel, Franz Kafka escribe historias modernistas y el expresionismo contagia al teatro, a la poesía y hasta a la arquitectura.

Kandinsky llega a esta Europa prolífera y de intensa actividad en 1896. En los casi veinte años que vive en Múnich (hasta la Primera Guerra Mundial), su trabajo irá evolucionando al ritmo del tiempo, incorporando novedades y una creación pictórica rompedora: la pintura no figurativa, el arte abstracto.

Este capítulo presenta a Kandinsky a la luz de su contexto y explica el marco histórico de principios del siglo xx que vio nacer la abstracción. El contexto es muy amplio y sería tentador (y muy interesante) realizar una investigación en exclusiva, relacionando a Kandinsky con los acontecimientos que recoge la Historia del Arte antes y después de la abstracción; o, más atractivo aún, realizar un paralelismo con los descubrimientos científicos de la época. Pero no es ése el objetivo de esta investigación.

Este capítulo contextual es necesario para, más adelante, comprender las interpretaciones que se darán del arte abstracto. Por lo tanto, para no extenderse en lo que sería un manual de Historia -del Arte o de la Ciencia-, cada uno de los apartados del capítulo se ciñe a las condiciones culturales, históricas, etc. que tuvieron especial importancia para Kandinsky y la creación 
del nuevo lenguaje del arte: bien de manera personal (como el encuentro con Arnold Schönberg), bien de manera indirecta (como el descubrimiento de la división del átomo).

La nueva física, la pintura, la música y las bases ideológicas de la época son las cuatro secciones que componen este capítulo. A pesar de que el mismo Kandinsky no sólo pintara sino que también escribiera poemas y un par de obras de teatro, la literatura, el teatro y la danza quedarán fuera de este análisis. La razón principal es que, dada la escasa bibliografía que hay sobre el tema (los poemas de Kandinsky apenas sí están traducidos, por ejemplo) ésta no añadiría datos más relevantes que los que aportan las secciones comentadas y haría que el capítulo se extendiera innecesariamente. No obstante, en la bibliografía final se cita alguna obra que recoge el contexto de la época, incluyendo la literatura o la danza. ${ }^{1}$

Lo último que queda por señalar es que en el análisis de la pintura (apartado 2.2), el foco de atención lo tienen los medios pictóricos y no los temas. Es decir, el color y la forma son los aspectos relevantes para entender a Kandinsky, no el tema.

\subsection{La nueva física}

Sin quitar importancia a ninguna de las grandes creaciones de principios del xx, podría decirse que la "gran revolución" de ese siglo fue la científica. La ciencia, y especialmente la física, abre una época marcada por los cambios. El descubrimiento de los rayos $\mathrm{x}$, la descomposición del átomo; Einstein y sus dos teorías de la relatividad, la especial de 1905 y la general de 1915; Max Planck y la hipótesis de los quantos; el modelo planetario que presenta Rutherford para el átomo... y un largo etcétera. Domina una nueva concepción del espacio-tiempo, la introducción de un sistema de referencia relativo y la ruptura con la física clásica al hacer su aparición la mecánica cuántica. Las aplicaciones de las nuevas teorías tardan un poco en aparecer, pero cuando llegan, lo hacen introduciendo notables cambios incluso en el día a día. Por su parte, las consecuencias teóricas son de tal magnitud que no sólo cambian

1 Véase, por ejemplo, Schneede, Die zwanziger Jahre, Eller-Rüter, Kandinsky o Brinkmann, Wassily Kandinski als Dichter. 
la perspectiva científica, sino que salpican, y mucho, a la Filosofía o al Arte.

Aunque es probable que ni Kandinsky ni Picasso (por citar dos ejemplos que revolucionaron en el mismo periodo el campo del arte) llegaran a comprender todas o alguna de las implicaciones que acarreaba la nueva ciencia, no hay duda de que los movimientos culturales del siglo $\mathrm{xx}$ aceptaron y se vieron influidos por las nuevas teorías, aun desconcertantes, de la nueva física.

La influencia notoria y directa de las teorías científicas en los círculos de la Bauhaus durante la República de Weimar es conocida y ha sido bien estudiada. ${ }^{2}$ Parece que la Bauhaus se contagia del clima que se respira en la época de Weimar, un clima propenso a aceptar la nueva idea de relatividad, dejando el escepticismo -curiosamente- para la física clásica. Según Peter Gay, la Bauhaus sintoniza con la nueva actitud alemana que trae ese régimen más abierto y democrático, apostando por ideas y conceptos que habían estado marginados durante la Alemania Guillermina (el Kaiserreich): «La cultura de Weimar fue una creación de forasteros propulsada por la historia hacia el interior, durante un periodo breve, vertiginoso y frágil». ${ }^{3}$

Las mismas ideas de Walter Gropius para con la Bauhaus también facilitan la comunión de ciencia y arte. En la búsqueda de nuevas ideas y perspectivas para la arquitectura (que incluía por ejemplo la dilución de las barreras del arte), las teorías einsteinianas fueron casi, con total seguridad algo más que un mero trasfondo.

A Kandinsky, el clima de la Bauhaus lo envuelve durante su estancia como profesor de pintura mural (1922-1933). Teniendo en cuenta que su primera acuarela abstracta data de 1910, la influencia que ejerce ese clima es más de confirmación que de inducción. En esa época se consolida la abstracción en sus cuadros y en sus escritos, tanto en las clases que imparte como en el libro que publica, Punto y línea sobre el plano (1926). Pero la semilla estaba ya plantada. El cambio de perspectiva -de Weltanschauung- que exige la revolución científica la sigue Kandinsky desde sus comienzos. Y no de manera del todo positiva. Kandinsky asiste a este periodo de cambios con la formación de un

2 "The scientific and cultural communities in the German-speaking world before the First World War soon caught on to the vocabulary if not the substance of the 'new physics' ", en Webel, Modernist Creativity, p. 543. Véase también McTague, Modern Physics, Kandinsky, and Klee o GAY, Weimar Culture, que incluyen a su vez más referencias.

3 GAY, Weimar Culture, p. xiv. 
jurista ${ }^{4}$ : abstracta, sistemática, racional y con la fe puesta en la ciencia, tomando su sentido amplio. Y tanta novedad le desconcierta. Charles P. Webel ${ }^{5}$ es de la opinión que la reacción de Kandinsky fue más emocional que netamente cognoscitiva. Sea como fuere, los cambios trascendentales que anuncian Einstein o Planck hacen que a Kandinsky se le tambalee el mundo bajo los pies y que su confianza en la ciencia se debilite. He aquí una cita clave y que será recurrente:

«...la división del átomo. En mi alma, la desintegración del átomo era lo mismo que la desintegración del mundo entero [aquello resonó como la destrucción súbita]. De pronto caían los muros más sólidos. Todo resultaba inseguro, vacilante, blando. No me habría asombrado ver una piedra fundirse en el aire frente a mí y hacerse invisible. Me parecía que la ciencia había sido aniquilada: sus fundamentos no eran más que una ilusión, un error de los científicos que no construían, rodeados de un nimbo, su edificio divino con mano segura y piedra a piedra, sino que buscaban las verdades a tientas en la oscuridad y confundían una cosa por otra. ${ }^{6}{ }$,

La verdad es que no queda muy claro a qué descubrimiento científico se refiere Kandinsky con la desintegración del átomo. Porque escribe: «...la división del átomo. En mi alma, la desintegración del átomo...» ¿Quiere decir realmente «división» o «desintegración»? ¿'Se refiere con «división» a que el átomo deja de ser inseparable y con "desintegración» al descubrimiento de la radiactividad? En primer lugar, se podría pensar que es un problema puramente lingüístico. Que Kandinsky utilizó el término correcto en la versión original, Rückblick de 1913, y que fueron las traducciones quienes han desdoblado el

\footnotetext{
4 Recuérdese que Kandinsky había estudiado Derecho y optaba a una plaza de en la Universidad cuando, allá por 1896, decide dar un vuelco a su vida para dedicarse al arte en Múnich.

5 Webel, Modernist Creativity, p. 548.

6 Aunque el pasaje pertenece a Rückblick y su traducción española Mirada retrospectiva (2002, p. 103), esta traducción es la realizada por Genoveva Dieterich para el prólogo de Max Bill a De lo espiritual en el arte (edición de 1996), preferida por mayor aproximación lingüística con el original. La frase que aparece entre corchetes corresponde a la versión rusa de Rückblick, según se comentó en la nota a pie número 2 del capítulo 1.
} 
término. Pero no es así: Kandinsky escribe en alemán «...die weitere Teilung des Atoms. Das Zerfallen des Atoms war in meiner Seele...», es decir, dos términos diferentes. Los traductores al inglés o al español no han hecho sino bien en traducir die weitere Teilung por "division" y "división", respectivamente, y Zerfallen por "collapse" y "desintegración". ' Desechada la hipótesis de la traducción errónea, la única posibilidad que queda, pues, es asumir que Kandinsky utilizó ambos términos como sinónimos. Quizá porque el alemán (idioma en el que escribió originariamente Rückblick) tampoco era su lengua materna. Pero más probablemente porque a principios del siglo $\mathrm{xx}$ sólo los entendidos en la materia y cercanos a los descubrimientos podían hacer tal diferenciación. Hay que tener en cuenta lo pródiga que fue la física en este tema y cuánta de tanta información, y con qué precisión lingüística, podría llegar a los círculos sociales.

Al respecto de si lo que desestabilizó el mundo personal de Kandinsky fue uno u otro acontecimiento, hay dos posibilidades. Nina Kandinsky dice que es el descubrimiento de la radiactividad. Y según Jean-Paul Bouillon en su edición crítica al texto de Mirada Retrospectiva ${ }^{8}$, Kandinsky entiende con esa expresión «el descubrimiento de los electrones», «la cuestión de la indivisibilidad del átomo discutida a fines del siglo XIX" y no los trabajos de Planck o Einstein. Para Nina Kandinsky o Bouillon, la cuestión no es en absoluto lingüística. Son de la opinión que la duda viene marcada por un pasaje del libro De lo espiritual en el arte, en el que Kandinsky se refiere a este tema como lo que se hace «en la actualidad». Dado que el libro fue publicado en 1912, estaría más cercano ya a la física cuántica o a la Teoría de la Relatividad de Einstein. Sin embargo, no se puede olvidar que De lo espiritual... fue un libro nacido a raíz de apuntes teóricos a lo largo de diez años, ${ }^{9}$ lo que hace el deíctico "en la actualidad" muy flexible y, por otro lado, que los avances físicos al respecto estaban muy relacionados entre sí.

7 La versión original consultada es Rückblick (edición de 1955). La traducción inglesa es la presente en Lindsay y Vergo, Complete Writings on Art y la traducción española es de Mirada retrospectiva (2002).

8 La traducción al español se encuentra en KANDinsky, Mirada retrospectiva, p. 264.

9 Dos notas en el prólogo de De lo espiritual en el arte lo aclaran: «Las ideas aquí desarrolladas son resultado de observaciones y experiencias que he acumulado en el curso de los cinco o seis últimos años» (pág. 16) y «De lo espiritual en el arte estuvo terminado y guardado durante varios años en mi cajón» (pág. 8). 
En cualquier caso, hay que asumir que Kandinsky utiliza los dos términos como sinónimos a la hora de estudiar sus escritos. Y por otro lado, tampoco es tan relevante decidir qué fue exactamente lo que generó el desconcierto, si la división o la desintegración. Lo importante es resaltar que del periodo de descubrimientos científicos que se inició con el siglo, hay tres acontecimientos de especial relevancia. Aun sin poder determinar con exactitud lo influyentes o determinantes que fueron para Kandinsky, no cabe duda de que arroparon históricamente el nacimiento del arte abstracto. Se trata de la división del átomo (o del descubrimiento de la radiactividad), de la Teoría de la Relatividad y de la física cuántica.

\subsubsection{La división del átomo}

La teoría electromagnética de J. C. Maxwell y la radiactividad que descubrió Henri Becquerel en 1896 (el mismo año en que Kandinsky decide dedicarse al arte), son parte de los descubrimientos y experimentos que avecinan un gran cambio: J. J. Thompson descubre el electrón y con ello anuncia que el átomo es divisible. El modelo atómico lo perfeccionarán después Rutherford, Bohr y otros; determinante es la constatación de que lo que durante siglos se creyó estable e indivisible, a principios del xx se convierte en alterable.

El nuevo modelo atómico supone un cambio de paradigma. No es el único factor, como ya se ha visto, pero sí uno de los concluyentes. El átomo era sinónimo de lo sólido, lo seguro, lo estable. Era la composición estructurada del todo y cada una de las cosas. Pero el descubrimiento del electrón (la división del átomo) pone en tela de juicio no sólo muchas de las teorías científicas sino también de las filosóficas. La unidad mínima del ser en cuanto materia ahora puede descomponerse, puede desintegrarse. «Allí están los sabios profesionales que analizan una y otra vez la materia, que no tienen miedo a ninguna pregunta, y que, finalmente, ponen en tela de juicio la misma materia sobre la que ayer descansaba todo y sobre la que se apoyaba todo el universo» ${ }^{10}$, dice Kandinsky en De lo espiritual en el arte. "No me habría asombrado ver una piedra fundirse en el aire frente a mí y hacerse invisible», comentaba Kandinsky en la cita anterior (que no conviene perder de vista). Las palabras

10 Kandinsky, De lo espiritual en el arte, p. 36. 
de inestabilidad, inseguridad y desintegración flotan en el ambiente.

Kandinsky interpreta átomo como objeto. O extiende lo recién descubierto en el átomo a los objetos. Si el átomo se descompone, ¿por qué no habría de hacerlo un objeto, que no es sino un cúmulo de átomos? Ante esta pregunta surge un doble planteamiento. En primer lugar, se pierde la base de seguridad. Hasta el descubrimiento del electrón no se dudaba de la integridad de los objetos, eran algo sólido y estable. Pero si ahora resultan ser desintegrables, ¿cómo seguir aferrándonos a ellos? ¿Qué estabilidad puede aportar algo que en cualquier momento podría volatilizarse? (así lo explica Kandinsky en otro momento). Aún es pronto para que el Kandinsky artista decida que el objeto es prescindible, pero sí se acerca a otro planteamiento: la necesidad de cambio. Lo sólido ha pasado a ser frágil, lo estable se ha convertido en indeterminado, lo inseparable ha resultado ser divisible. Es necesario un cambio de perspectiva: si hay que entender al átomo de otra forma, al objeto también hay que tratarlo de manera diferente. ¿Cómo, pues, algo que se desintegra podría llevar el peso de un cuadro?

La física cuestiona a Kandinsky la integridad de lo que ve. Le destruye la base de lo que hasta entonces él creía seguro y le hace sentir que el mundo entero se desintegra, que «la materia desaparece» ${ }^{11}$. Según Nina Kandinsky, este acontecimiento fue uno de los que preponderó a la hora de decidirse por el arte y dejar atrás el mundo jurídico: «Kandinsky veía en el arte una alternativa que no estaba amenazada por la descomposición del mundo, un refugio que aguantaría bien la tormenta de la separación del átomo». ${ }^{12}$

\subsubsection{La Teoría de la Relatividad}

En 1905, Einstein publica el artículo Zur Elektrodynamik bewegter Körper (Sobre la electrodinámica de los cuerpos en movimiento). En él no sólo recoge el testigo de Maxwell y sus ecuaciones sobre el electromagnetismo, sino que presenta al mundo el comienzo de una revolución: la Teoría de la Relatividad Especial. Esta teoría y su ampliación a la general diez años después (Teoría de

11 Kandinsky, Mirada retrospectiva, p. 265

12 Kandinsky, Kandinsky und ich, p. 31. 
la Relatividad General) son hoy más que conocidas; de ahí que baste ahora resumir la idea principal para entender cómo influyó en Kandinsky y en el camino a la abstracción.

Einstein formula dos postulados básicos: el primero es que la luz se propaga en el vacío a una velocidad constante (c), independientemente de si el cuerpo que la emite está o no en movimiento. Y el segundo es que no existe un sistema de referencia privilegiado o absoluto, sino que la percepción del espacio y tiempo depende del estado de movimiento del observador, es decir, es relativa a él. Podría decirse que cada sistema de referencia tiene su propio tiempo y espacio.

El primer postulado, que la velocidad de la luz sea una constante no parece implicar demasiado a la filosofía. Pero eliminar toda posibilidad de que existan un espacio y tiempo absolutos (el segundo postulado) le influye directamente. Para empezar, obliga a reinterpretar los mismos conceptos de espacio y de tiempo, tan kantianos desde el siglo xviII. Es una reformulación tetradimensional del espacio (las tres dimensiones propiamentes espaciales $x, y, z \mathrm{y}$ el tiempo $t$, que se añade), en la que otros conceptos también cambian. Al añadir e tiempo, el "punto" se convierte en "evento": ahora es un fenómeno definido en un tiempo y en un lugar. Y lo mismo ocurre con la "distancia", que pasa a ser "intervalo".

La reformulación del espacio sobrevuela en el campo del arte, especialmente en la pintura. Si Monet y Cézanne comenzaron por desdibujar contornos y diluir espacios, con Kandinsky y Klee el espacio se transforma por completo en relativo. La mayoría de las pinturas de Kandinsky (las pertenecientes a la abstracción) ni siquiera tienen un núcleo central, no hay un espacio en el que se sitúe el tema del cuadro. Robert McTague lo explica con precisión: «De la misma forma que el espacio no es una categoría absoluta en la Teoría General de la Relatividad, la mayoría de las obras de Kandinsky y Klee no tienen sentido del espacio absoluto, de una perspectiva final o de un núcleo central». ${ }^{13}$

Una de las consecuencias que tendrá esta falta de foco central, es que la ausencia de espacio concreto y definido -esto es, absoluto- obligará al espectador a considerar otras dimensiones. Por ejemplo, la dimensión que

13 McTague, Modern Physics, Kandinsky, and Klee, p. 68. 
se refiere únicamente al tiempo o la dimensión sensorial, la que requiere de los cinco sentidos (y no sólo la vista) para contemplar un cuadro. Cómo interpretar estas dimensiones en relación a la obra de Kandinsky se verá en los capítulos 4-7, ahora se trata de constatar el paralelismo entre el no-espacio kandinskyano y el espacio relativo de Einstein.

Junto a la nueva concepción del espacio, Einstein postula la pérdida de un sistema de referencia absoluto, que también deja huella en Kandinsky. Si el sistema de referencia es relativo al observador, el punto de vista sobre un mismo acontecimiento se multiplica según el número de observadores. Observadores, hay en el arte al menos dos: el artista y un espectador. Si en física el espacio-tiempo depende del estado de movimiento del que observa, frente a un cuadro la percepción es relativa al espectador. Kandinsky, al principio desolado por la falta de unanimidad que le ofrece la ciencia, aprovecha la nueva circunstancia para darle un nuevo enfoque a su arte y al papel del espectador. El espectador y el artista no tienen por qué percibir exactamente lo mismo frente al cuadro. Si en el cuadro hay un pez, artista y espectador verán un pez. Pero si en el cuadro hay una línea ondulada que además puede apelar a otras dimensiones (un color que evoque un sonido, como le ocurre a Kandinsky), es muy probable que artista y espectador ya no vean lo mismo. La percepción se ha vuelto relativa a un sistema de referencia concreto, el del observador.

\subsubsection{La física cuántica}

El 14 de diciembre de 1900, en una conferencia que imparte en Berlín, ${ }^{14}$ Max Planck introduce el concepto de quanto y con ello anuncia el comienzo de una nueva física. Las hipótesis que enuncia Planck no sólo contradicen la física teórica aceptada hasta entonces, sino que sientan las bases de la física cuántica, que germinaría más tarde con los trabajos de Einstein o Bohr.

Sin entrar en detalles áridos de física cuántica, conviene recordar por qué surge esta nueva concepción de la física (si se decía que la mecánica clásica newtoniana era más que estable $)^{15}$ y qué supone la nueva teoría.

14 Se trata de una conferencia de la Deutsche Physikalische Gesellschaft (Sociedad Alemana de Física), institución que Planck dirigiría años después. 
El descubrimiento de la luz como fenómeno cuántico puso en entredicho a la física clásica. Como ocurría con la luz, otros fenómenos tampoco encontraban una explicación coherente en las teorías habituales, lo que invitó a ciertos científicos a buscar explicaciones alternativas. Los resultados de pequeños descubrimientos que no podían obviarse y la formulación paso a paso de ciertas teorías (los quantos de Planck fueron durante un tiempo sólo "paquetes discretos de energía") supusieron el alejamiento progresivo de la física clásica, hasta que llegó a definirse la ruptura entre los dos sistemas: el clásico y el cuántico. Al tiempo se comprendió y se estableció que ciertos fenómenos necesitaban realmente nuevas reglas, sin que eso anulara del todo la física clásica. Ésta, la clásica, define las leyes del mundo macroscópico y de la astronomía, mientras que la física cuántica explica el mundo microscópico, de tamaño menor que el átomo.

Con Planck, Einstein o Hertz entre sus filas, las universidades de Berlín y Múnich asisten activamente a la creación del nuevo modelo científico. En los primeros lustros del siglo xx los grupos de artistas también se concentran en torno a esas mismas ciudades, lo que hace que el mundo cultural no tarde en impregnarse de las ideas revolucionarias que trae la física cuántica. Dejando de lado (por no repetir discusión) si fue exactamente la física cuántica la que influyó directamente en Kandinsky, lo cierto es que en su pintura desarrolló conceptos paralelos a los de la física. Max Bill llega a afirmar que «los resultados artísticos precedían a los físicos en el sentido de que pasaron de una manera más inmediata y directa de la teoría a la realidad». ${ }^{16}$

De la física cuántica Kandinsky asimila dos cosas. Una: la ruptura con la física clásica significa para Kandinsky el alejamiento del mundo clásico del arte, la ruptura con el realismo y la pintura figurativa. $Y$ dos: aceptar que se deben formular nuevas leyes para explicar el mundo subatómico le lleva a plantearse la necesidad de nuevas leyes para ese (su) nuevo tipo de pintura. Si el mundo microscópico recién descubierto necesita nuevas leyes, el nuevo

15 Cuando Max Planck tuvo que decidir qué estudiar en la universidad (no sólo destacaba en ciencias, también en letras y en música), le preguntó su opinión a uno de los profesores de física de la Universidad de Múnich, Philipp von Jolly. Éste quiso disuadirle diciéndole que en física ya estaba todo descubierto, concepción que, parece ser, compartían ciertos investigadores de la época. Afortunadamente, Jolly no convenció a Planck.

16 Kandinsky, De lo espiritual en el arte, p. 12. 
arte que está formulando necesitará también nuevas leyes. Para llegar a ellas, experimenta con todo tipo de formas nuevas, arropado por la ciencia de que no hay validez absoluta. Él mismo enuncia en su proyecto de creación una serie de normas que aplicar al arte, reunidas bajo el nombre de "la gramática de la creación" (que se explicará en el capítulo 3).

Se ha explicado el contexto científico en el que Kandinsky nace y crece como artista. Un clima que vive los cambios desde primera fila, tan abierto a la novedad como inquieto ante el nuevo paradigma. La división del átomo llama a la puerta de Kandinsky cuando éste empieza en su atelier, y lo persigue con la Teoría de la Relatividad y la física cuántica durante su camino hacia la abstracción, hacia la pérdida del objeto.

Al igual que el público iba aceptando las nuevas leyes de la física como verdaderas aunque no las comprendieran, ${ }^{17}$ Kandinsky, cada vez más convencido, afianza su pintura paulatinamente hasta llegar a prescindir totalmente del objeto (algo que, curiosamente, el público tardó más en aceptar -incluso sigue sin hacerlo-).

Sin embargo y como cabe suponer, no fue sólo la física quien animó a Kandinsky a prescindir del objeto. La relación con otros ámbitos del conocimiento, como el mismo campo del arte, tienen también mucho que decir.

\subsection{La pintura}

La concepción artística decimonónica no sobrevive al cambio de siglo. El Romanticismo es, a principios del $\mathrm{xx}$, un capítulo cerrado que arrastra tras de sí al realismo y al naturalismo. El siglo xx trae a la pintura ideas nuevas y pródigas, como ya las dio en el terreno de la ciencia.

Pero el cambio radical que da el siglo xx no impide considerar las posibles influencias del siglo anterior. Estimulados por la pintura de Goya, Turner o Courbet, los impresionistas franceses comienzan una revolución artística que va contra las normas de representación habituales y contra todo academicismo. Esta transgresión da pie a los nuevos estilos del siglo xx como el fauvismo, el

17 Viene muy a propósito la famosa cita de Niels Bohr: "Anyone who is not shocked by quantum theory has not understood it». 
expresionismo y, cómo no, la abstracción de Kandinsky.

El mismo Kandinsky sufre su pequeña "revolución" personal. Inmerso en una carrera brillante como jurista, su cambio finisecular significa dejar el ámbito académico para lanzarse sin red al campo del arte. Es un cambio arriesgado, un cambio de perspectiva vital similar, al fin y al cabo, al cambio que estaba dando la física con la Teoría de la Relatividad o el arte con el Simbolismo. El inicio del siglo xx es época de cambios, en todos los aspectos.

A finales de 1896, Kandinsky abandona Moscú y se establece en Múnich para estudiar pintura. Antes de la Primera Guerra Mundial, Múnich era el centro preferido por rusos, italianos y anglosajones para estudiar arte. ${ }^{18} \mathrm{Cuan}-$ do llega a la capital bávara, Kandinsky revive los cuentos alemanes que de niño le contaba su abuela ${ }^{19} \mathrm{y}$ siente que la ciudad corrobora esa decisión tan arriesgada de dejarlo todo y empezar un nuevo camino. «Yo me sentía en una ciudad de arte, lo que para mí era como una ciudad de cuentos de hadas. ${ }^{20}$

La situación real del Múnich de principios de siglo es algo heterogénea. Por una parte, la Secesión muniquesa se crea en 1892 como reacción contra las tendencias académicas del siglo xIx; pero expone obras que van desde Delacroix a Van Gogh, no siempre presentándolas en orden cronológico y además algo desfasadas de lo que se está haciendo en ese momento en París. Sin embargo, a pesar de estos descubrimientos tardíos y del gran peso de la tradición que sobrevuela Baviera, Múnich cuenta con una vida artística muy animada, que rebosa originalidad e intensidad creativa. August Endell, Paul Klee, Gabriele Münter, Franz Marc, Alexej von Jawlensky, Alfred Kubin, Lyonel Feininger, Marx Bergmann, Adolf Erbslöh, Naum Gabo, Thomas Mann, Hermann Obrist, Rainer M. Rilke y, entre otros, el mismo Wassily Kandinsky dotan a la ciudad de un gran período de renovación artística. El Jugendstil irrumpe hacia 1898. Ernst Ludwig Kirchner, antes de convertirse Berlín en el centro del expresionismo tras la Guerra, descubre la pintura de vanguardia en un viaje a Múnich allá por 1913. Y Duchamp, entonces sólo un joven artista francés, visita Múnich el verano de 1912 y pinta allí sus últimos cuadros como pintor. Dos años más tarde, en 1914, Duchamp presenta el primer ready made. ${ }^{21}$

18 Véanse las páginas 17-19 de la Introducción de Overy, Kandinsky.

19 Su abuela materna era alemana y con ella hablaba en alemán.

20 Kandinsky, Mirada retrospectiva, p. 96. 
En este ambiente en el que se mezcla tradición y novedad, atraso y vanguardia, el barrio de Schwabing es el centro artístico de Múnich. Con casi tantos atelieres como edificios por normativa municipal ${ }^{22}$ y sus calles llenas de artistas portando lienzos, paletas y pinturas, Schwabing era algo más que el distrito norte de Múnich. "Schwabing es un estado mental. (...) Schwabing es una isla espiritual del gran mundo, de Alemania, pero sobre todo del mismo Múnich.» ${ }^{23}$. En Schwabing viven la mayoría de los artistas arriba citados, incluido Kandinsky. En Schwabing está la academia de Anton Ažbe y la de Franz von Stuck, en las que estudia Kandinsky y donde encontrará a Jawlensky o a Klee. Las galerías de Schwabing, como Thannhauser y Heinemann, exponen a Cézanne, Gauguin, Monet y algunas obras de los nuevos artistas. Schwabing es un ambiente artístico excepcional, al que Kandinsky añade sus contactos rusos que consigue, en parte, gracias a Apollon.

En otoño de 1909 y hasta otoño de 1910, Kandinsky trabaja de corresponsal en Múnich para la revista Apollon. Esta revista, editada por Sergei Makovsky en San Petersburgo, publicaba poemas y ensayos de escritores simbolistas de la época. Suponía la presentación de la vida artística de Rusia antes de la Guerra y contaba además con un espacio fijo dedicado a corresponsales en el extranjero, que mantenían informados a los lectores de las novedades artísticas de París, Roma, Múnich o Berlín. Kandinsky escribía sus Pis'mo iz Miunkhena (Cartas desde Múnich), informando del panorama artístico actual. A través de esta revista, Kandinsky conoce a muchos artistas rusos que también viven en Alemania, a otros tantos que publican en Rusia y que Kandinsky traduce al alemán (poetas, ensayistas) y a algunos más que Kandinsky, finalmente, invitará a trabajar o colaborar en sus propios proyectos. ${ }^{24}$

21 Para profundizar sobre la situación de Múnich en los primeros años del siglo xx véase, como ejemplo y desde diferentes puntos de vista, Overy, Kandinsky, KLEIne, Gabriele Münter und Wassily Kandinsky, HeIsserer, Wo die Geister wandern, o la Introducción de KANDINSKY, Mirada retrospectiva.

22 "[Prinzregent Luitpold] hatte verfügt, daß in jedem vierten Haus Schwabing ein Dachatelier gebaut werden müsse. So steigerte er das gedeihliche Klima für kreative Geister», en KLEINE, Gabriele Münter und Wassily Kandinsky, p. 95.

23 Overy, Kandinsky, p. 18. Aunque existe una traducción al español, en Kandinsky, Escritos sobre arte y artistas, p. 124, ésta es una traducción propia, del inglés, porque el texto español es un tanto farragoso y poco claro.

24 Las Cartas desde Múnich pueden leerse (traducción inglesa) en Lindsay y Vergo, Complete Writings on Art, p. 54-8o. 
Éste es el ambiente artístico en el que Kandinsky nace como artista, y el mismo ambiente que verá el nacimiento de la abstracción. Un recorrido breve pero más concreto por cada uno de los estilos relacionará las características de la obra kandinskyana con las influencias pictóricas de la época, prestando especial atención a los medios pictóricos: el color y la forma.

\subsubsection{Monet y los impresionistas}

El impresionismo se fragua en la segunda mitad del siglo xix y empieza a convertirse en estilo cuando un grupo de pintores -Monet, Renoir, Sisley o Pisarro entre otros- expone en el Salón de los Rechazados de París en 1874. El nombre se lo pone el crítico de arte Louis Leroy a raíz del cuadro Impresión: sol naciente de Monet, la historia es conocida. El impresionismo, aun perteneciendo al siglo XIX, sigue teniendo mucha presencia en el primer cuarto del siglo xx. Al igual que ocurría en Múnich, las galerías de los centros culturales de Europa exhibían las obras de los impresionistas franceses, en cierta reverencia a París.

El nuevo estilo del impresionismo, sus maneras nuevas y transgresoras fueron clave en el desarrollo posterior del arte, empezando muy de cerca por el fauvismo, el expresionismo y en cierto modo la abstracción. Kandinsky conoce gran parte de la obra de los impresionistas (o al menos la que quedaba a su alcance) $y$, aunque a medida que su propia obra evoluciona él rechace los temas impresionistas, hay aspectos formales de los que aprende o que hasta cierto punto asimila.

Esos aspectos son el color, la forma y, a modo de unión, el tipo de pincelada. La luz es el protagonista principal del impresionismo, que busca plasmar un instante de luz, una impresión visual determinada por ciertas condiciones lumínicas. La combinación de la luz y un nuevo uso de los colores (primer aspecto) producen una "impresión" más enérgica y vigorosa. El uso del color cambia no sólo por la búsqueda de la luz, también influye el contexto científico. Los nuevos descubrimientos químicos permiten crear otros pigmentos, utilizar colores más puros y guardarlos en tubos o envases portátiles. La facilidad de transportar la pintura y un modelo nuevo de caballete (el french box easel) saca al artista al campo y con ello comienza la pintura "plein-air": de ahí el 
interés por la luz y las condiciones lumínicas del paisaje.

Buscando la luz, el color se convierte casi en el elemento principal del cuadro, relegando la forma a un segundo plano aunque siempre en pro de las exigencias de la luminosidad que exija el tema. Ese inicio de protagonismo que los impresionistas conceden al color, lo llevará Kandinsky años más tarde al extremo, cuando el color no sólo no se deba a la forma sino ni tan siquiera al tema. Al respecto, además de recordar la relación especial y personal que Kandinsky tenía con el color, un comentario de Gabriele Münter en conversación con Edouard Roditi: «[Kandinsky] me contaba que ya desde niño prefería los colores a los temas. La forma y el color eran su interés principal». ${ }^{25}$

Partiendo en cierto modo de la relación luz-color de los impresionistas, Kandinsky desarrolla en sus años de la Bauhaus toda una teoría sobre el color, un estudio analítico bien estructurado. ${ }^{26}$ Sin avanzar demasiado porque ahora no ha lugar, sí puede decirse que Kandinsky no sólo se centra en la capacidad cromática del color en cuanto a la luz o a otros colores, sino que ofrece un estudio del color desde puntos de vista muy diferentes: el físico-químico (la naturaleza del color), el fisiológico (su recepción) y el psicológico (el efecto que provoca).

El segundo aspecto impresionista del que Kandinsky toma nota es el uso de la forma. La forma empieza a perder protagonismo con los impresionistas: bien porque el color asume parte de ese protagonismo; bien porque la importancia de la luz hace que la identidad de lo proyectado pierda fuerza; o bien porque era la continuación lógica a la desatención al objeto que inició Manet.

Las superficies se difuminan y parecen llenarse de vapor, como en aquel cuadro de Turner Lluvia, vapor y velocidad que tanto gustaba a los impresionistas. Las imágenes se vuelven borrosas, lo que enfatiza la ausencia de contornos y de bordes naturales. La forma, subordinada a la luz y al color, queda diluida en el cuadro. La identidad de lo proyectado no es primordial, y por ello la forma se desvanece. Sigue siendo pintura figurativa, pero ya es el primer paso hacia la abstracción kandinskyana.

25 Roditı, Dialoge über Kunst, p. 212. Gabriele Münter fue la pareja de Kandinsky durante su estancia en Alemania, hasta 1914.

26 El artículo Curso y seminario sobre el color lo escribe para un libro recopilatorio de la Bauhaus, Staatliches Bauhaus in Weimer, 1919-1923, donde recoge las ideas con las que organiza su clase de pintura mural y su curso sobre la teoría de los colores, hacia 1922. 
Manet no llegó a diluir las formas pero sí comenzó con él un cierto (y primerizo) desprecio por el objeto. Era más bien un desprecio por la forma natural objetivizándola, alienándola, como en Le Déjeuner sur l'herbe (traducido como Desayuno en la hierba o Merienda campestre) donde la composición con figuras humanas no es sino un bodegón de naturaleza muerta. Las figuras estáticas, la falta de profundidad, la iluminación artificial... forman un cuadro en el que, si bien la forma es definida y está presente, aparece desprestigiada.

Kandinsky visita una exposición de Manet en la galería Thannhauser, primavera de 1910. Lleva en Múnich casi quince años y su primera acuarela abstracta está al caer. La dilución de las formas ya ha comenzado, el color gana protagonismo: la pérdida del objeto es inminente. Así que no es de extrañar que Kandinsky acuda a la exposición de Manet convencido de que va a ver cuadros "del pasado": «Volví esta primavera a la Galería Moderna Thannhauser, pensando que la colección de Manet, al margen de su reputación, raramente podría transmitirme algo nuevo; pensé que volvería a ver otra vez al gran maestro que había visto tantas veces en el pasado». ${ }^{27} \mathrm{Y}$, sin embargo, Kandinsky se encuentra con algo inesperado, se encuentra con un Manet que, a pesar de sus cuadros figurativos, transmite un halo de abstracción: «La atmósfera de la habitación parecía inundada por un talento devorador, fantástico, sobrehumano, elemental. Olvidé todo lo que no me gustaba sobre este tipo de arte. (...) Este amor por la pintura sin bordes, sin objeto me había conquistado. ¡Sí, sin objeto! $»^{28}$

La cita raramente se encuentra en los estudios sobre Kandinsky. Probablemente por la dificultad de encontrar el texto de Cartas desde Múnich, pero a lo mejor también porque el "reconocimiento abstracto" en Édouard Manet sólo confirma lo que Kandinsky llevaba rumiando unos cuantos años, el camino hacia la abstracción. Sin duda, hay una cita mucho más importante (y que nunca falta al hablar de Kandinsky): el encuentro con Claude Monet, por ser uno de los detonantes de la pérdida del objeto.

Rusia gozaba de cierta fertilidad creativa a finales del siglo xIx y principios

27 Cartas desde Múnich para la revista Apollon, en Lindsay y Vergo, Complete Writings on Art, p. 78.

28 Lindsay y Vergo, Complete Writings on Art, p. 79. 
del xx. Ligada a las formas del occidente europeo y con miras especiales sobre París, las exposiciones exhibían con frecuencia a los impresionistas franceses. En 1895 a Kandinsky aún le queda un año para marcharse a Múnich, pero el interés por la pintura lo tiene desde niño. Ese año asiste a una de esas exposiciones y ve por vez primera el Almiar de Monet. Los quince cuadros de parvas de heno de Monet se habían expuesto inicialmente en París en 1891. Suscitaron no sólo el lógico interés por la variación de la luz sobre un mismo tema sino otros valores más expresivos, más sensoriales que iban más allá del impresionismo y que algunos historiadores ${ }^{29}$ ven como el inicio del arte abstracto: «De todas estas fisonomías (...) se exhalan expresiones que se parecen a sonrisas, a lentos oscurecimientos, a gravedades y estupores mudos, a certezas de fuerza y pasión, a violentas embriagueces.» ${ }^{30}$

Seguramente no sería esa la crítica general a las exposiciones de Monet, pero es preciso señalarla para comprender la reacción particular de Kandinsky ante el Almiar. ${ }^{31}$ Kandinsky sólo conocía el arte realista de los autores rusos y empezaba a conocer la pintura francesa gracias a dos viajes a París (en 1889 y en 1892). En aquella exposición, delante del montón de heno, Kandinsky ve

«por primera vez un cuadro. El catálogo me aclaró que se trataba de un montón de heno. Me molestó no haberlo reconocido. Además me parecía que el pintor no tenía ningún derecho a pintar de una manera tan imprecisa. Sentía oscuramente que el cuadro no tenía objeto y notaba asombrado y confuso que no sólo me cautivaba, sino que se fijaba indeleblemente en mi memoria y que flotaba, siempre inesperadamente, hasta el último detalle ante mis ojos. Todo esto no estaba muy claro y yo era incapaz de

\footnotetext{
29 John Rewald en Geschichte des Impressionismus, p. 357 y ss., por ejemplo.

30 Solana, El impresionismo, p. 290.

31 Jean-Paul Bouillon, en su edición crítica a Mirada retrospectiva (2002, p. 261), añade un comentario que aunque no es determinante, no deja de ser conveniente reproducir por la información que aporta: «La identificación precisa del cuadro que vio Kandinsky no es en modo alguno indiferente, ya que el estilo de Monet evolucionó marcadamente en el período en que pintó las [quince] parvas (alrededor de 1886 a 1893); pero en el estado actual en que se halla la documentación no es posible pronunciarse con seguridad y ni siquiera es seguro que el descubrimiento del catálogo al que alude Kandinsky aporte sobre este punto información suficiente.»
} 
sacar las consecuencias simples de esta experiencia. Sin embargo comprendí con toda claridad la fuerza insospechada, hasta entonces escondida, de los colores, que iba más allá de todos mis sueños. De pronto la pintura era una fuerza maravillosa y magnífica. Al mismo tiempo -e inevitablemente- se desacreditó por completo el objeto como elemento necesario del cuadro. ${ }^{32}{ }$

El encuentro con Monet marca, sin duda, un punto de inflexión en Kandinsky. No es sólo porque constate la influencia de los impresionistas, de Monet en este caso, por la dilución de formas o la ausencia de contornos. El Almiar le anuncia la opción de pintar sin objeto, por un lado, y la «fuerza inospechada» de los colores por el otro. Es aún 1895 y Kandinsky no ha empezado formalmente su carrera como pintor; pero según Nina Kandinsky en su libro Kandinsky und ich, ésta fue la primera vez que Kandinsky pensó en la idea de la abstracción: «ipor qué no ir más allá de Monet y pintar con total libertad e independencia del objeto? ${ }^{33} \mathrm{Y}$ así es como empieza, en palabras del propio Kandinsky, a «mirar la pintura de iconos rusa con otros ojos, quiero decir que "tuve ojos" para lo abstracto de esa pintura». ${ }^{34}$

\subsubsection{Cézanne, Matisse y Picasso}

En su libro de 1912, De lo espiritual en el arte, Kandinsky se centra en los efectos del color, en el lenguaje de las formas y en la obra de arte y el artista. Pero antes de introducir la que será su teoría de la pintura, dedica un apartado a analizar la situación general del arte y el cambio de rumbo al que asiste el recién estrenado siglo xx. En este apartado, Kandinsky nombra y comenta brevemente el trabajo de ciertos artistas que, según él, han influido o contribuyen actualmente (en torno a 1911) a crear una nueva dimensión artística. $^{35}$

32 Kandinsky, Mirada retrospectiva, p. 102.

33 Kandinsky, Kandinsky und ich, p. 36.

34 KANDINSKY, Escritos sobre arte y artistas, p. 194.

35 Véanse las páginas 38-44 de la edición española, De lo espiritual en el arte (1996). 
Kandinsky no se ciñe exclusivamente al campo de la pintura, sino que contempla el arte en su definición más amplia. Surgen así nombres como el de Wagner y Schönberg para la música o el de Maeterlinck en la literatura. Propiamente pintores, Kandinsky habla de Cézanne, Matisse y Picasso, a los que nombra los «buscadores de lo interior en lo exterior».

La denominación tiene que ver no sólo con la influencia, directa o indirecta, que estos tres pintores y sus respectivos estilos ejercieron en Kandinsky. También con la constatación de que el nuevo rumbo que toma el arte del siglo xx está marcado por una dimensión interna que se hace protagonista frente a lo externo y la apariencia de las cosas. En el capítulo biográfico de Kandinsky se comentó la relación interior, relación sentida y profunda en lo emocional que tiene con el mundo externo. Ahora encaja esa relación interior, "espiritual" que diría Kandinsky, con el contexto de la época. O al menos así lo ve él: en estos tres pintores, Kandinsky reconoce el giro interior que él mismo quiere darle a la pintura, por eso son los buscadores de lo interior en lo exterior.

Paul Cézanne es considerado artísticamente el puente entre los impresionistas y los cubistas. Al igual que Monet, Cézanne también se decanta por los contornos desdibujados y los espacios diluidos, pero él añade una concepción diferente del dibujo. Cézanne consigue en su etapa de madurez (aprox. 1878-1905) sintetizar los elementos básicos de la composición y ordenar el mundo real, el mundo aparente, en figuras simples y planos de color.

Los impresionistas que supieron apreciar a Cézanne tomaron de él su observación de la naturaleza y su manera de darle color. Los cubistas, años más tarde, aprendieron a representar la estructura tridimensional del mundo real a través de las formas geométricas más simples, como el cubo. Estuvieron atentos a las palabras de Cézanne, aquí obvias y conocidas: «todo en la naturaleza se modela según la esfera, el cono, el cilindro».

Por su parte, lo que Kandinsky ve en Cézanne es su capacidad de abstraer la naturaleza. Cézanne sigue usando figuras reconocibles, pero ya piensa en plasmar la esencia de los objetos, la estructura última e interna de las cosas. Aunque Cézanne piense en esferas y conos, Kandinsky dice de él que reconoce en los objetos su ser íntimo y animado: "[Cézanne] convirtió una taza de té en un ser animado o, mejor dicho, reconoció en esa taza un ser.» ${ }^{36}$

36 Kandinsky, De lo espiritual en el arte, p. 43. 
Bajo la perspectiva de Kandinsky, Cézanne es el investigador de la nueva ley de la forma, que, utilizando los medios pictóricos más puros (forma y color), consigue elevar la naturaleza muerta a una altura en la que las cosas cobran vida. Los objetos de Cézanne (naturales: frutas, paisajes, etc.) cobran vida al reducirlos a la esencia de su ser, al plasmar en el cuadro su "vida interior" y no precisamente su apariencia externa. Fascinado por esta revelación de los cuadros de Cézanne, Kandinsky, en actitud similar a la que tuvo frente al Almiar de Monet, se pregunta si, siendo la esencia lo más importante del objeto, no podría eliminar del todo la apariencia externa y representar sólo la vida interior.

El reconocimiento de Kandinsky hacia Cézanne y la apertura del camino a la abstracción, quedan patentes en esta cita de De lo espiritual en el arte:

«Cézanne crea la expresión cromática de las cosas, su nota pictórica interior, y las encaja en la forma que eleva a fórmula de resonancia abstracta, llena de armonía y a menudo puramente matemática. No es un hombre, ni una manzana, ni un árbol lo representado, sino que el artista utiliza todos esos elementos para crear un objeto de resonancia interior pictórica que se llama "imagen". ${ }^{37}$ "

En aquel Salón de Otoño de 1905 en París que marca el inicio del modernismo, Henri Matisse presenta una decena de obras atrevidas en el color y experimentales en la forma. El crítico de arte y co-organizador del Salón, Louis Vauxcelles, da el nombre de fauvistas a Matisse y a los que como él, hacen del color su arma de expresión.

Tras los primeros años de estilo impresionista y ligera influencia del mismo Cézanne, Matisse define su estilo de colores brillantes y formas relajadas, con lo que principia el fauvismo. En las obras del Matisse fauvista la forma parece desatendida y el dibujo infantilmente simplificado. Se suprimen los detalles, se abandona la perspectiva. La forma, las líneas, la composición misma: visualmente todo pasa a un segundo plano porque en la obra parece importar sólo el color.

Matisse juega con todos los registros posibles del color, combinándolos y

37 KANDinsky, De lo espiritual en el arte, p. 43. La cursiva y las comillas son originales. 
modificándolos siempre en función de la expresión interior y no de la apariencia de los objetos que represente. Es un buscador de lo interno en lo externo, como dice Kandinsky. Los colores que usa son chillones, violentos, intensos, antinaturales; pero sobre todo, subjetivos. Matisse utiliza los colores con la libertad de no ajustarlos al objeto: el cielo no tiene por qué ser azul, un árbol no tiene por qué ser verde. Matisse separa el color del objeto: el color no es una propiedad del objeto, es un medio de expresión en sí mismo.

Algo similar hacía Kandinsky de niño y algo equivalente llevó Kandinsky a su pintura. El viaje de infancia a Italia y el de adulto a la región de Vologda intensificaron la relación especial de Kandinsky con el color. El color es para Kandinsky un ser autónomo, independiente y con existencia propia que no tiene por qué pertenercer a un objeto ni ser una propiedad de él. Esto es lo que tienen en común Matisse y Kandinsky: que ambos usan el color de manera libre e independiente, convirtiéndolo en el protagonista de sus cuadros. $\mathrm{Si}$ Matisse influyó en Kandinsky o si fue Kandinsky el que se "reconoció" en Matisse, no es tan relevante en este contexto.

Kandinsky habla de Matisse en De lo espiritual en el arte, al igual que lo hizo con Cézanne y lo hará con Picasso. En este texto, Kandinsky le reconoce a Matisse que está «dotado de un extraordinario sentido del color» ${ }^{38}$ y que es capaz de darle al color la supremacía e importancia central de la obra. Sin embargo, también parece reprocharle que a veces no logre separarse de la belleza puramente impresionista. No se puede decir con certeza qué cuadros había visto Kandinsky cuando escribió estas líneas, teniendo en cuenta que el libro De lo espiritual... fue escrito a lo largo de muchos años.

Por eso, en la relación Kandinsky-fauvismo, conviene detenerse en una cita de 1910 para asegurarse de que Kandinsky haya visto obras fauvistas de Matisse, en las que el color adquiere, si cabe, un protagonismo aún más exagerado. La cita es de sus Cartas desde Múnich, esas que escribía como corresponsal para la revista rusa Apollon. En el primer trimestre de 1910, un par de meses antes de que Kandinsky viera a Manet, la galería Thannhauser exhibe obras de otro grupo de artistas franceses (Manguin, Puy, Vlaminck...) entre los que se encuentra Matisse. A Kandinsky le horroriza cómo todos los autores siguen considerando inviolables las líneas de la naturaleza y la timidez con la que usan el color. Todos, menos Matisse: «sólo Matisse ha sabido ir más allá de las

38 Kandinsky, De lo espiritual en el arte, p. 43. 
"formas accidentales de la naturaleza" o, mejor dicho, sólo él ha conseguido descartar el aspecto superfluo (negativo) de esas formas, remplazándolas, por así decir, con sus propias formas (elemento positivo)». ${ }^{39}$

Pablo Picasso pinta Las señoritas de Avignon y se reúne con Georges Braque en 1907, año en el que la crítica ha convenido señalar los inicios del cubismo. Dada esta fecha, y considerando que el cubismo duró hasta la Primera Guerra Mundial, es obvio señalar que cubismo y abstracción comparten espacio y tiempo, al menos en lo que se refiere a sus comienzos.

A la vista de un contexto histórico y cultural común, no sería raro establecer una correspondencia entre el cubismo y el arte abstracto: ambos son estilos rompedores, con una nueva forma de concebir la realidad y de plasmarla en el cuadro. Picasso a la cabeza del cubismo y Kandinsky como padre de la abstracción podrían tener múltiples influencias comunes, lecturas compartidas y teorías pictóricas antiacademicistas que les unieran. Pero, al parecer, no fue así. O, mejor dicho, la relación entre Picasso y Kandinsky pudo ser (no hay suficientes documentos al respecto) la de dos genios enfrentados, imitados o envidiados al mismo tiempo.

Kandinsky habla de Picasso en De lo espiritual en el arte, en el mismo contexto que de Cézanne y Matisse. ${ }^{40}$ Picasso, dice Kandinsky, siempre está guiado «por los imperativos de la autoexpresión, a veces arrastrado por ellos violentamente.» Por eso también es un buscador de lo interior en lo exterior. A medio camino entre el reconocimiento y el reproche, Kandinsky señala que Picasso «llega por la vía lógica a la destrucción de lo material»; pero no disolviendo la forma como hacían impresionistas o fauvistas, sino "por una especie de fragmentación de las distintas partes y de una diseminación de ellas sobre el lienzo.» Kandinsky escribe explícitamente que Picasso trabaja de manera diferente con la forma, pero hasta qué punto el comentario guarda alabanza o menosprecio queda a juicio del lector: «Es curioso que en este proceso [de la desfragmentación] [Picasso] parezca querer conservar la apariencia de la materialidad. Picasso no retrocede ante ningún medio; si el color le estorba (...), lo tira por la borda y pinta un cuadro con marrón y blanco.»

La cuestión es: ¿qué cuadros había visto Kandinsky de Picasso cuando

39 Lindsay y Vergo, Complete Writings on Art, p. 68. Las comillas son originales. 40 De nuevo en las páginas 43 y 44 de Kandinsky, De lo espiritual en el arte. 
escribe este texto? Picasso había expuesto en varias exposiciones en Múnich, algunas de ellas incluso organizadas por el mismo Kandinsky. ${ }^{41}$ Por la desfragmentación y la diseminación de las formas sobre el lienzo, parece que habla ya de cuadros cubistas. Al hablar de las últimas obras de Picasso, se refiere a las que Kandinsky pudo ver hasta 1911, que es cuando se publica De lo espiritual en el arte. ${ }^{42}$ En el mismo pasaje, Kandinsky también menciona "el cubismo" («así surgió el cubismo, el último movimiento francés»), por lo que queda claro que Kandinsky, al menos, lo conocía.

Que Kandinsky conoce los cuadros de Picasso queda aún más claro en una carta del 2 de octubre de 1911 a Franz Marc, donde Kandinsky escribe: «Kahnweiler me ha enviado fotos de Picasso: destruye el objeto y dispersa cada una de sus partes por todo el cuadro; y del desorden de esas partes se compone el cuadro. ¡Qué interesante! Picasso sigue su camino. Ojalá sea capaz de superar las ataduras externas de la naturaleza. (...) Esta disolución es muy interesante. Pero a mi parecer completamente "errónea" ${ }^{43}$.

Y sin embargo, en la entrevista que en 1937 concede a Karl Nierendorf dice claramente: «(...) nunca he tenido relación con el cubismo. Cuando vi por primera vez, en fotografías, unas obras cubistas de Picasso (1912), ya había pintado mi primer cuadro abstracto.» ${ }^{44}$

Cuando Kandinsky vivió en París (1933-1944) se relacionó con un amplio grupo de artistas y pintores: Jean Arp, Piet Mondrian, Marcel Duchamp, Joan Miró o André Breton. Oportunidades de conocer personalmente a Picasso, o incluso visitarse mutuamente en sus atelieres, no faltaron. Pero Kandinsky no parecía tener ningún interés en conocer a Picasso. Según su mujer, Nina Kandinsky, el interés de Kandinsky por la evolución de Picasso «había decaído en los años de París [1933-44] ya que al parecer, tras la fase cubista de Picasso,

41 La mayoría de los libros sobre Kandinsky recogen su paso por la Asociación de Pintores NKVM y suelen incluir una lista de los autores que expusieron en ella, entre los que se encuentra Picasso. Véase por ejemplo: Kandinsky, Kandinsky und ich, p. 49. Del mismo modo, en la correspondencia entre Kandinsky y Marc queda patente que Kandinsky y Picasso intercambiaron cartas, se entiende que referidas a la organización de tales exposiciones. Véase la carta del 2 de octubre de 1911 de Kandinsky a Marc, en el libro que recoge su correspondencia: LANKHEIT, Kandinsky-Marc: Briefwechsel.

42 La primera publicación, la de Piper Verlag, lleva la fecha de enero de 1912, aunque se terminara de imprimir en diciembre de 1911.

43 Lankheit, Kandinsky-Marc: Briefwechsel, p. 61 y ss. La cursiva es original.

44 KANDINSKY, Escritos sobre arte y artistas, p. 194. 
Kandinsky había quedado muy decepcionado. Le criticaba su falta de sinceridad.» ${ }^{45}$ También añade Nina que, y es su juicio personal, Picasso no se sentía cómodo con la presencia de Kandinsky en París. Pero eso ya son historias que se escapan a este contexto.

\subsubsection{Los expresionistas}

El expresionismo es otro de los estilos que surgieron a principios del siglo $\mathrm{xx}$ y que participaron directamente en el cambio de rumbo del panorama artístico. Con su centro en Alemania, crece de forma paralela al fauvismo francés y comparte con él las ganas de dejar atrás el impresionismo. Dos grupos bien conocidos definen el expresionismo en la pintura: Die Brücke (El Puente) y Der Blaue Reiter (El Jinete Azul).

El Puente tiene su sede en Dresde y comienza hacia 1905: Ernst Ludwig Kirchner, Erich Heckel, Fritz Bleyl y Karl Schmidt-Rottluff son los cuatro estudiantes de arquitectura que fundan el grupo. Poco después se unen Max Pechstein, Otto Müller y Emil Nolde. Die Brücke siempre quiso desarrollar un arte "alemán", intrínseco, nacional, que reflejara su historia y sus connotaciones históricas. Pero, aun buscando lo que les era propio, la influencia desde y hacia el resto de estilos de la época era inevitable.

En el expresionismo, las formas se relajan y pierden la absoluta fidelidad a la naturaleza, como ya se ha visto en otros estilos. El otro medio pictórico, el color, gana protagonismo y su uso también es violento, descarado. Si hay algo que los expresionistas elevan al máximo es, su propio nombre lo indica, la forma de expresión. El arte expresionista destaca por ser personal, interior e intuitivo. Es un arte subjetivo en el que la expresión (el mundo interior del artista) prevalece sobre la impresión (el mundo exterior, aparente). Bajo el concepto de arte interior y subjetivo se entiende que la naturaleza quede deformada y que los colores se desentiendan pictóricamente de los objetos. Es la expresión personal la que impone las reglas.

La necesidad de expresar el mundo interior, casi a modo de grito, se comprende por el contexto histórico. Por un lado, la amargura prebélica que flota

45 Kandinsky, Kandinsky und ich, p. 179. 
en el ambiente impulsa el deseo de cambiar y de renovar el lenguaje artístico. Por otro lado, los expresionistas aprovechan el ya comentado aire de libertad de la República de Weimar e introducen actitudes muy subjetivas en sus composiciones artísticas. Aunque Einstein no habló en ningún momento de subjetivización y la Teoría de la Relatividad tampoco significa indeterminación, en aquella época se entendió como tal: al eliminar el espacio-tiempo como un sistema de referencia absoluto parecía querer decirse que la objetividad quedaba desterrada, dando pie a la subjetividad.

La historia es muy similar para el otro de los llamados grupos expresionistas, El Jinete Azul. Asumen la idea de arte como expresión interior y subjetiva. Los colores son fuertes, violentos, subjetivos y protagonistas. Las formas se desdibujan, los contornos se diluyen. Si en algo se distinguen de El Puente es en la suavidad de sus formas, que, en vez de ser un grito desgarrado parecen llamar a un mundo espiritual sosegado y alcanzable a través de los sentidos. Kandinsky se lo comenta así a Marc después de recibir de éste unas reproducciones de obras de El Puente: «valoro más nuestro trabajo pausado (pausado pero sólo de cara al exterior), nuestro trabajo cuidadoso con respeto y prudencia. Y además nosotros somos más intimistas. Lo que se explica no sólo por nuestro "gran sentido de lo interior", sino también por la soledad con la que trabajamos» ${ }^{46}$.

El Jinete Azul tiene su centro en Múnich en torno a las figuras de Franz Marc y Wassily Kandinsky. Bajo ese nombre, un grupo de pintores que no siempre fue el mismo organizó tres exposiciones: la primera en la galería Thannhauser en diciembre de 1911, la segunda en la galería Hans Goltz en primavera de 1912 y la tercera y última fue en 1913, en el salón de exposiciones de Der Sturm, en Berlín. Más conocido es el almanaque Der Blaue Reiter (El Jinete Azul) dirigido por Marc y Kandinsky, publicado en 1912 por Piper Verlag y que recogía textos, canciones y poemas además de fotografías de cuadros. A raíz de las exposiciones y del almanaque, la crítica optó por darles ese mismo nombre, El Jinete Azul.

La teoría y creación artística de El Jinete Azul merece tratarse en un capítulo aparte (cap. 3). Porque ya no se puede hablar de la influencia de El Jinete

46 Lankheit, Kandinsky-Marc: Briefwechsel, p. 112. La carta es del 14 de enero de 1912. Las comillas son originales. 
Azul en Kandinsky, sino que él mismo fue parte creadora de él. El expresionismo fue un factor principal en el camino hacia la abstracción: «Fue así como llegué, a través del "expresionismo", a la pintura abstracta». ${ }^{47}$

\subsection{La música}

Otro de los grandes cambios de principios del siglo xx es el que tiene lugar en el panorama musical. Al igual que la pintura o la ciencia, la música empieza a romper con las normas tradicionales de los siglos anteriores y se lanza a la exploración de nuevas formas y lenguajes. La tonalidad, tan sustancial para la música como el objeto lo era para la pintura, parece seguir el mismo camino: dilución, pérdida de protagonismo, cambio radical de perspectiva. Si el mundo subatómico necesitaba nuevas leyes físicas, el mundo del siglo xx también necesita una nueva producción musical.

Alex Ross refleja cuánto y cómo ha cambiado la música a lo largo del siglo pasado en su libro The rest is noise. Listening to the twentieth century ${ }^{48}$, un brillante y singular recorrido por la historia de la música del siglo xx. Si se completa con un buen manual de Historia de la Música, por ejemplo el de Stanley Sadie y John Tyrrell, el contexto musical que vio nacer la abstracción kandinskyana sobrepasaría con creces lo previsto para estas páginas. Al igual que en los apartados anteriores, éste sólo puede presentar el contexto que repercute directamente en Kandinsky y en su obra.

Tampoco es éste el lugar para explicar la teoría musical de la obra pictórica de Kandinsky, que llegará más adelante, ni hacer una duografía -una biografía doble y conjunta- de la relación entre Wassily Kandinsky y Arnold Schönberg. El vínculo entre ambos artistas fue, en efecto, muy interesante desde el punto de vista artístico e intelectual y daría para una investigación independiente del mismo calibre que la presente. Algunos aspectos de ese intercambio artístico se tratan aquí, otros lo harán a propósito de la citada teoría musical de Kandinsky. Este apartado quiere reflejar el contexto musical que rodea el nacimiento del arte abstracto, tal y como se ha venido haciendo. Para completar las biografías relacionadas de Schönberg y Kandinsky, véanse en la bibliografía las obras de

47 KANDINSKY, Escritos sobre arte y artistas, p. 194. Las comillas son originales. 48 El libro ha sido traducido al español como El ruido eterno, en Seix Barral (2009). 
Nikolaus de Palèzieux, de Konrad Boehmer, de Jelena Hahl-Koch o la tesis doctoral de Stephen S. Vise, por citar sólo algunos ejemplos. ${ }^{49}$

\subsubsection{La música pre-atonal: Wagner, R. Strauss, Debussy}

En los años del cambio de siglo, la "Mitteleuropa" germanoparlante atrae innovación científica y creación artística. También la producción musical se instala en la zona. Viena desprende un hálito de lujo y alta sociedad, Dresde crece vertiginosamente e inaugura su Ópera en 1878 y Bayreuth se convierte en el festival wagneriano por excelencia desde 1876 .

Durante diez años, de 1897 hasta 1907, Gustav Mahler dirige la Ópera de Viena y contribuye a dorar aún más esa época de bonanza musical previa al cambio. Tanto en Viena como en Dresde el programa está lleno de estrenos y representaciones de los dos grandes compositores del momento: el hacía poco fallecido Richard Wagner y el muniqués actual, Richard Strauss. A la ópera acude la flor y nata (como la viuda de Johann Strauss) que se mezcla con gente joven y nuevos talentos que empiezan a despuntar: Alexander Zemlinsky, Arnold Schönberg, Alban Berg o el jovencito Adolf Hitler.

Richard Wagner había logrado un puesto fijo en el repertorio musical casi desde mediados del siglo XIX, cuando se estrena Lohengrin en Weimar (1850). Apenas veinte años después de su muerte, en la Viena de Gustav Mahler, Wagner se había convertido en un "coloso cultural, cuya influencia se sentía no sólo en la música sino también en la literatura, el teatro y la pintura». ${ }^{50}$

49 El estudio de Jelena Hahl-Koch de 1983 publica toda la correspondencia conservada, algunos escritos de ambos y comentarios al respecto de Hartmut Zelinsky y de la propia editora, además de añadir fotos, dibujos, cuadros y una tabla biográfica comparativa. Es un estudio muy completo que se ha convertido en una buena guía de referencia. El libro de Palèzieux es una biografía interrelacionada de los dos autores que a pesar de su escritura algo compleja, ofrece interesantes referencias sobre ambos. La tesis de Vise es un acercamiento notable al pensamiento de Schönberg y Kandinsky pero carece de mucha información, seguramente por el año en el que se escribió, 1969. El libro que edita K. Boehmer es una recopilación de artículos de diferentes autores, y por tanto una recopilación de diferentes puntos de vista y estudio sobre el tema. Al margen de estos trabajos, la relación Schönberg-Kandinsky ha sido muy estudiada y es tema recurrente en cualquier libro sobre Kandinsky.

50 Ross, The Rest is Noise, p. 12. Traducción propia, del inglés. 
Wagner introdujo cambios notables en la concepción musico-artística, empezando por encargarse él mismo no sólo de la composición musical sino también de la escenografía y del libreto. Con ello reivindicaba una nueva forma de entender la ópera, una que no se centraba exclusivamente en la música porque pretendía dar cabida al resto de artes visuales y dramáticas. De ahí la importancia de ocuparse él mismo de la escenografía y del libreto. Volviendo la vista a la tragedia griega, Wagner aspiraba a algo similar con una "obra de arte total" (Gesamtkunstwerk) que reuniera las formas y los medios de las diferentes artes mediante un proceso de síntesis. Wagner quería una interrelación entre el teatro, la música, la danza, etc. bajo el techo de una única obra de arte, la obra de arte total. La idea no se quedó en mera teoría, sino que impregnó la composición musical de Wagner, especialmente el ciclo operístico El anillo del Nibelungo. Auspiciado por Luis II de Baviera, se llegó incluso a construir un teatro especialmente diseñado para representar estas óperas: el Bayreuther Festpielhaus, que a partir de su inauguración representa cada año las obras de Wagner en el festival internacional más importante del autor.

El espíritu de la Gesamtkunstwerk no se quedó en Bayreuth. La interrelación artística que proponía Wagner la reasume Kandinsky más de medio siglo después. Con propósitos similares, Kandinsky escribe su obra teatral La sonoridad amarilla ${ }^{51}$, que da cabida a diversas manifestaciones artísticas (danza, teatro, pintura). Y, con la misma idea aunque con diferente aplicación práctica, la Bauhaus de Walter Gropius reordena las artes en torno a la arquitectura, la Gesamtkunstwerk particular de los años veinte alemanes.

La idea de la obra de arte total no fue la única aportación de Wagner a la música. La misma composición musical era innovadora en más de un aspecto. En primer lugar, Wagner refinó y consolidó el uso del leitmotiv, una melodía recurrente que no sólo servía para caracterizar a los personajes, sino que además introducía ideas o sentimientos y les otorgaba una categoría propia. Éstos aparecían con el apoyo de un acorde o unos compases que se repetían, fijándose en la obra y en el espectador. Al leitmotiv se le unía una amplitud cromática extraordinaria, que empezaba a explorar nuevas formas con otros acordes o que cambiaba los centros tonales dentro de la misma obra. El mejor ejemplo

51 La obra de Kandinsky Der gelbe Klang se traduce frecuentemente como La sonoridad amarilla, aunque en alguna ocasión también se lea El sonido amarillo. 
es el "acorde de Tristán”, así llamado porque abre la ópera Tristán e Isolda. Wagner inicia esta ópera con un acorde atrevido y arriesgado y, sobre todo, innovador. Se trata de una sucesión de acordes aumentados que comienza en $\mathrm{Fa}$, le sigue su cuarta aumentada $\mathrm{Si}$, una sexta aumentada Re $\sharp$ y termina con una segunda aumentada Sol $\sharp(\mathrm{Fa}-\mathrm{Si}-\mathrm{Re} \sharp-\mathrm{Sol} \sharp)$. Aunque hoy pueda sonar habitual para una película de intriga o terror, a mediados del siglo XIX cuando se estrena Tristán e Isolda, sonaba ciertamente disonante. Y sin embargo, el "acorde de Tristán" ya dejó su influencia en Strauss y Schönberg. De forma paulatina y preliminar Wagner comienza, con sus ocasionales acordes disonantes y la volubilidad de su centro tonal, a poner fin a la armonía tradicional y a abrir el camino a la música atonal.

Richard Strauss crece a la sombra de Wagner, según cuenta Alex Ross en The rest is noise. En 1906 se estrena en Dresde su ópera Salomé, no sin cierta polémica. $Y$ es que ya desde las primeras notas se adivina una obra atrevida que no se ajusta a las leyes clásicas de la composición. El clarinete abre con una escala que comienza en Do $\sharp$ Mayor y termina en Sol Mayor, dos tonalidades que pertenecen a esferas armónicas opuestas. ${ }^{52}$ Además, la distancia entre las notas Do $\sharp$ y Sol es de una cuarta aumentada o tritono (que no trítono), lo que queda a un semitono (distancia mínima) de la quinta justa. ${ }^{53}$ Si la quinta justa es el sonido más armónico (también se la llama quinta perfecta), el tritono que usa Strauss en Salomé es uno de los sonidos más desagradables al oído humano. No en vano, este acorde recibió en la Edad Media el sobrenombre de diabolus in musica, cuyo nombre lo explica todo.

En Salomé se encuentran disonancias insólitas por doquier, vibraciones superpuestas y, ante todo, mezcla de tonalidades. Strauss fragmenta la tonalidad, que es el eje central de una composición musical, pero aún no prescinde de ella. La pintura expresionista alemana (El Puente y El Jinete Azul) también fragmentaba el objeto, pero aún faltaban unos años para eliminarlo del todo. Strauss, como los expresionistas, empieza a marcar el camino. La tonalidad fragmentada de Salomé en 1906, la recoge y reproduce Schönberg en su Primera Sinfonía de Cámara, que compone el verano de ese mismo año. La siguiente

52 Ross, The Rest is Noise, p. 7.

53 El tritono es un intervalo que abarca tres tonos enteros (una cuarta aumentada o quinta disminuida); el trítono, tres tonos consecutivos, dos mayores y uno menor. 
ópera de Strauss, Elektra en 1909, no sólo destaca por sus disonancias o por una especie de narrativa onírica que recuerda a Freud, sino por estar ya bien cerca de la atonalidad.

Cercano a la atonalidad, aunque no en Viena sino en París, compone Claude Debussy. Debussy escucha de Franz Liszt sus obras de los años 1870-80, como la Bagatelle sans tonalité en la que abundan los acordes aumentados, las séptimas sin resolver y donde el romanticismo habitual de Liszt parece perderse entre tritonos y tonalidades desfiguradas. Además de a Liszt, Debussy escucha a Wagner (su cromatismo y sus pre-disonancias) en el mismísimo festival de Bayreuth, al menos en 1888 y $1889 .{ }^{54}$ Ese mismo año, en la Exposición Universal de París, tiene ocasión de escuchar la música de un gamelán javanés y queda prendido de su escala minimalista de sólo cinco notas. Una música que, según Debussy, «contenía todos los matices, incluidos aquellos que ya no pueden nombrarse, donde la tónica y la dominante no eran más que varios fantasmas para uso de niños obedientes». ${ }^{55}$ Debussy también conocía la obra de Hermann von Helmholtz ${ }^{56}$ sobre las bases fisiológicas del sonido en la sensación humana, y sabía de la "perfecta armonía” de quintas y octavas para el oído humano.

A la luz de estos detalles que rodean la obra de Debussy ha de entenderse su composición. Debussy juega entre los dos mundos, el armónico y el disonante, creando una fantasía de color. El bajo suena mayoritariamente en octavas y quintas, armónicas, serenas, mientras que las voces superiores se llenan de acordes aumentados y disminuidos, cerquísima de las octavas y de las quintas y creando así claras disonancias con ellas. La melodía suele vacilar entre los tritonos y las séptimas que aún así, todavía resuelven en tónica.

La música de Debussy es, como reconoce Kandinsky en un pasaje de De lo espiritual en el arte, equiparable a la pintura impresionista. Se deshace de las normas clásicas de tonalidad y de los acordes de tonos perfectos para volcarse y expresar el contenido interno. Una especie de giro al interior, al color puro, al sonido puro en detrimento de las formas: la forma figurativa y la tonalidad,

54 Ross, The Rest is Noise, p. 43-49.

55 Citado en Ross, The Rest is Noise, p. 44.

56 von Helmholtz, Die Lehre von den Tonempfindungen als physiologische Grundlage für die Theorie der Musik. 
respectivamente. Del mismo modo que los impresionistas y expresionistas marcaron el camino a la abstracción pero no se desprendieron del objeto hasta Kandinsky, las disonancias y tonalidades fragmentadas de Strauss y Debussy no se hicieron realmente atonales hasta la llegada de Arnold Schönberg.

\subsubsection{La música atonal: Arnold Schönberg}

Arnold Schönberg nace en Viena en 1874. Si Kandinsky toma clases de pintura desde niño y rondando los treinta llega a Múnich, centro pictórico de Europa, la vida de Schönberg tiene cierto paralelismo. Schönberg recibe desde los ocho años clases de violín y poco más tarde empieza de manera autodidacta con el violonchelo. En plena juventud, (25-30 años), asiste a los conciertos de la Viena dorada de Mahler.

Desde su adolescencia, Schönberg forma una banda y se dedica a realizar arreglos musicales y breves composiciones hasta que Alexander von Zemlinsky lo invita a entrar en su orquesta. Con Zemlinsky aprende la parte formal, la parte teórica de la música en su contexto más clásico. A finales del siglo (1897-1899), sus obras empiezan a experimentar un cambio que las hace notablemente diferentes de la música habitual. En sus obras hay cada vez menos rastro del cromatismo, de la armonía clásica, incluso de la tonalidad. Tampoco se ciñe a los formatos tradicionales: compone música de cabaret, poemas sinfónicos, obras de teatro musicadas... en lo que podría ser una interpretación personal de la Gesamtkunstwerk wagneriana.

Con una carta de recomendación de Richard Strauss consigue una beca Liszt y una plaza de profesor en el Conservatorio Stern de Berlín. ${ }^{57}$ Años más tarde regresa a Viena (1903, Gustav Mahler como director de la Ópera) y sigue

57 La anécdota con Richard Strauss es curiosa: gracias a él, Schönberg consigue la plaza de profesor. A su vuelta de Berlín a Viena, Strauss le sigue ayudando en la manutención con unos cien marcos (1911) e incluso le pide que componga unas pequeñas obras para una serie de conciertos. Strauss debió de quedarse algo pálido al escuchar las composiciones atonales que le envió Schönberg y, cautelosamente, le dijo que eran unos «experimentos atrevidos para su público», pero no más. Tres años después, Strauss cometió el error de escribir a la cuando menos controvertida Alma Mahler la verdadera opinión que tenía sobre Schönberg: alguien «que sería de más provecho quitando nieve que garabateando pentagramas», comentario que Alma, haciendo gala de su fama, no tardó en sacar a la luz. El episodio puede leerse en las páginas 57 a 59 de Ross, The Rest is Noise. 
dando clases, tanto en una escuela como de forma privada. Al año siguiente comienza a dar clase a sus dos alumnos: Anton Webern y Alban Berg, que acabaron siéndolo de por vida.

Hacia 1908 sus composiciones pierden cualquier rastro de tonalidad. Es año compone su primera obra atonal, Du lehnst wider eine Silberweide ${ }^{58}$. Y en verano de ese mismo año escribe su Segundo Cuarteto, obra que comienza con carácter tardo-romántico pero que finaliza con una secuencia inaudita de cuartas separadas por tritonos. Los acordes se disuelven en intervalos incomprensibles, la disonancia y la atonalidad dominan. Las obras de ese año y los siguientes comparten atonalidad, innovación, disonancia y (posiblemente) escándalo a partes iguales: Tres piezas para piano, Cinco piezas para orquesta y Erwartung (Expectación), que abre con un acorde arrollador de casi dos octavas ( $\mathrm{Si} b$ a Do $\sharp$ ) importado del Parsifal de Wagner. ${ }^{59}$

En su particular idea de obra de arte total, las artes son sólo diferentes medios de una misma expresión. En palabras de Kandinsky, las artes son diferentes instrumentos para un mismo fin. Tan es así, que Schönberg empieza a pintar por esas mismas fechas, 1908. Algunos de sus cuadros se expondrán años más tarde en las exposiciones de El Jinete Azul que organiza Kandinsky. Y a la par que su música se extraña o, mejor dicho, se singulariza en su camino atonal, también comienza a escribir su Harmonielehre (Tratado de armonía) que publicará en 1911.

En la música de Schönberg, como en la pintura de Kandinsky, el camino que lleva al nuevo lenguaje -bien sea atonalidad o abstracción- es un largo proceso de transformación y nueva creación. El primer paso de Schönberg es el ya comentado: la pérdida de la tonalidad. Siguiendo el camino de Wagner, Strauss y Debussy, Schönberg lleva las disonancias al extremo. Enfatiza, por ejemplo, los acordes de séptima aumentada y novena disminuida, que por estar tan próximos a la octava (sólo un semitono de distancia) son los más inestables y por tanto los más disonantes. Y no sólo introduce éstos y otros acordes nuevos, sino que prescinde sin complejos de los acordes clásicos, resultando una obra completamente nueva y atonal.

Una vez eliminada la tonalidad de sus obras, o precisamente para darles

58 Una traducción aproximada es Te apoyas contra un sauce blanco.

59 Ross, The Rest is Noise, pp. 49-66. 
un apoyo teórico, Schönberg se dedica a la creación de un lenguaje, de una nueva armonía. En su Harmonielehre expone lo que él denomina la música dodecafónica. La música dodecafónica recibe este nombre por ser una forma de música atonal basada en los doce sonidos de la escala cromática. ${ }^{60}$ Este método de composición establece que las doce notas son equivalentes, que no están sujetas a una jerarquía ni tienen una relación ordenada. Se contrapone, por tanto, a la música tonal, cuyas notas se insertan en un sistema de mayor y menor, destacan ciertas notas como la tónica (la primera de la escala correspondiente), la subdominante (la cuarta) o la dominante (la quinta) y hay una tonalidad que dirige la composición. Además, el sistema dodecafónico establece con las doce notas una serie, motivo por el cual también recibe el nombre de música serial. En dicha serie han de aparecer las doce notas en el orden que el compositor quiera, pero con la condición de que no se repita ninguna dentro de la misma serie. A continuación, comienza una nueva serie de doce notas y así sucesivamente. El uso de octavas, tan estables y armónicas, queda prohibido. $^{61}$

Así es la música que compone Arnold Schönberg hacia 1910: nueva, sin tonalidad como eje central, de belleza estridente y que al público le cuesta aceptar. Por las mismas fechas Kandisky pinta su primera acuarela abstracta, también innovadora, también sin objeto como eje central, con una belleza fea y sobre la que el público escupe como respuesta. Schönberg está convencido de que ha encontrado una forma de «Arte Mayor» con el que devolverá la primacía a la música alemana durante al menos cien años. Y de que su arte es la expresión de un nivel superior, una entidad divina, una "mano interior" que guía su composición. ${ }^{62}$

Schönberg y Kandinsky no se conocerán hasta 1911, pero el parecido de sus respectivas carreras y su base ideológica es tan notable, que cuando se encontraron, se reconocieron de inmediato.

60 Los doce sonidos de la escala cromática son Do, Do $\sharp, R e, \operatorname{Re} \sharp, \mathrm{Mi}, \mathrm{Fa}, \mathrm{Fa} \sharp$, Sol, Sol $\sharp, \mathrm{La}$, La $\sharp$, Si, Do.

61 Para ampliar referencias, la música dodecafónica de Schönberg es un sistema cercano al de Josef Matthias Hauer, que creó otro sistema atonal en el que agrupaba a las notas de seis en seis, pudiéndolas cambiar de lugar en cualquier momento dentro de cada grupo. Véase von MaUR, Vom Klang der Bilder.

62 DE PAlÈZIEUX, Der geometrische Punkt ist ein unsichtbares Wesen. 


\subsubsection{Kandinsky y la música atonal}

El desarrollo de la música tardorromántica hacia la música atonal influyó en Kandinsky tanto o más que la nueva física o que el paso pictórico del impresionismo al expresionismo. El contexto cultural de la época (y da lo mismo en qué ambito del conocimiento se busque) es de cambio, de búsqueda de nuevas reglas y de un giro en la expresión: de lo externo a lo interno, del mundo de las apariencias al mundo interior de las sensaciones. Éstas pueden ser sensoriales, sentimentales o espirituales pero en cualquier caso pertenecen al mundo interior del individuo, que se hace con el protagonismo.

Esta tendencia a mostrar el contenido interior es la que destaca Kandinsky de Debussy, del que habla en De lo espiritual en el arte. Debussy es capaz de transformar las impresiones de la naturaleza y del mundo exterior en una expresión sentida, encontrando (tal y como lo hacía Cézanne) el ser de las cosas, su valor interno: «Debussy nunca utiliza (...) una nota totalmente material (...) sino que se limita a la utilización del valor interior de lo externo» ${ }^{63}$, dice Kandinsky.

La relación de Kandinsky con Wagner es un poco más amplia. Poco antes de instalarse en Múnich y en la misma época en la que Kandinsky se queda maravillado y estupefacto ante el Almiar de Monet, Kandinsky asiste en el teatro Bolshói de Moscú a una representación de Lohengrin de Wagner. La riqueza sensorial que la ópera le despierta es una sensación visual y auditiva al mismo tiempo, llena de cromatismos y alusiones a la esencia de las cosas, a su vida interna. «Los violines, los contrabajos y, muy especialmente, los instrumentos de viento personificaban entonces para mí toda la fuerza de las horas del crepúsculo. Mentalmente veía todos mis colores; los tenía ante mis ojos. Líneas salvajes, casi dementes, se dibujaban frente a mí.» ${ }^{64} \mathrm{~A}$ esta sinestesia o metáfora sensorial se une el uso tan elaborado que hace Wagner del leitmotiv, que según Kandinsky, permite «caracterizar al héroe no sólo por medio de vestuario, maquillaje y efectos luminotécnicos, sino también por un determinado y preciso motivo, es decir por un medio puramente musical». ${ }^{65}$

63 Kandinsky, De lo espiritual en el arte, p. 41. La cursiva es original.

64 Kandinsky, Mirada retrospectiva, p. 103.

65 Kandinsky, De lo espiritual en el arte, p. 40. La cursiva es original. 
Lo que Kandinsky asume es que los medios exclusivos del arte -para Wagner los musicales, para Kandinsky los pictóricos- son capaces de caracterizar, es decir, de dar el carácter, la esencia, la vida al tema central de la expresión artística. Por tanto, los medios puramente pictóricos (forma y color) son a) capaces de evocar y despertar sensaciones multisensoriales (audio-visuales) y b) de aportar la esencia a la expresión. ¿Para qué utilizar el objeto en la pintura si la forma y el color son capaces de más?

El contexto cultural que acoge el nacimiento de la abstracción es el mismo que asiste a la creación de la música atonal. Schönberg y Kandinsky comparten época y forma de pensar el arte. Tienen, incluso, una idea similar sobre cómo debe ser el nuevo arte, el que se ajuste a ese siglo de cambios que acaba de empezar. Algunos autores creen que las carreras de Schönberg y Kandinsky fueron las de una influencia mutua. ${ }^{66}$ Pero la realidad es que no se conocieron hasta 1911, cuando Schönberg ya tenía encarrilado su tratado de armonía y había compuesto obras dodecafónicas. En esa fecha, Kandinsky tenía guardado en el cajón De lo espiritual en el arte, esperando editor, y ya había pintado su primera acuarela abstracta. Así que el camino hasta la atonalidad o la abstracción fue un camino en paralelo que parece confirmar la influencia del gran contexto cultural de la época. Sólo a partir del encuentro se puede hablar de la influencia de la abstracción en la atonalidad o viceversa y de que el debate intelectual entre ellos les prestara otras ideas o modificara las presentes (como en cualquier relación).

El 2 de enero de 1911, Schönberg ofrece un concierto en Múnich con sus obras Cuarteto de cuerda en Fa $\sharp$ menor, opus 10 y Tres piezas para piano, opus 11. Kandinsky acude acompañado de Gabriele Münter, Franz Marc y otros amigos y sale del concierto entusiasmado. Las obras de Schönberg renuncian casi por completo a la tonalidad, presentan acordes de hasta ocho notas, cambios inesperados y disonancias extremas. Lo que a primera vista puede parecer una composición sin pies ni cabeza, a Kandinsky le maravilla

66 Más de un autor ha querido ver las similitudes entre las obras de Kandinsky y Schönberg como el resultado de un trabajo en común, dando por hecho que se conocieron en 1906, 1907 ó 1908. Por ejemplo, Josef Rufer en su artículo Schönberg als Maler: Grenzen und Konvergenzen der Künste, que se encuentra en STUCKENSCHMIDT y BURDE, Aspekte der neuen Musik, o en los libros Hofmann, Schönberg-Berg-Webern o Stuckenschmidt, Kandinsky et la musique. Schönberg y Kandinsky se conocieron en 1911. 
por su libertad, su independencia, por su formulación de la expresión interior. Poco tarda en hacerse con la dirección postal de Schönberg y menos aún en escribirle una carta mostrándole su admiración y entusiasmo. En la carta, del 18 de enero de 1911, se lee cómo Kandinsky le muestra su simpatía por tener, dice, formas de pensar y sentir en común. Le comenta cuán similares son sus respectivos artes -él con el pincel, Schönberg con la música- y la sensación de que ambos parten de la misma idea interior. A la vez, le deja patente la envidia que siente por ver cómo Schönberg ya ha alcanzado algo que él aún no ha logrado: una composición libre de las ataduras clásicas, sin narrar la realidad exterior, sin tonalidad, sin objeto... Las frases de Kandinsky son las siguientes: «Usted no conoce mis trabajos (...) pero nuestras aspiraciones y el [nuestro] modo de pensar y sentir tienen tanto en común»; «Usted ha conseguido en sus obras (...) precisamente lo que yo intento plasmar de manera pictórica». ${ }^{67}$

Kandinsky no quiere escribir la carta de un admirador o la de un espectador satisfecho, sino la de un artista que investiga una nueva forma de arte y encuentra algo muy similar en otro artista. Kandinsky desea iniciar un contacto, un diálogo intelectual basado en las semejanzas que ha visto en su obra. Así, Kandinsky le pregunta por la explicación de unas frases (impresas en el folleto del concierto) que no logra entender y se permite enviarle una carpeta con trabajos propios (fotos de cuadros, diversos grabados en madera, etc.), invitando directamente a la respuesta.

La similitud entre la obra de Kandinsky y la de Schönberg tampoco se le pasa por alto a Franz Marc. Éste habla del concierto en una carta dirigida a August Macke el 14 de enero, en el que le cuenta sus sensaciones al escuchar la música de Schönberg:

«¿Puedes concebir una música en la que la tonalidad (es decir, mantener un tipo cualquiera de tono constantemente) se haya liquidado por completo? Continuamente me veía forzado a pensar en las grandes composiciones de Kandinsky, que tampoco admiten ni rastro de tono, (...) así como en sus "manchas que brotan" al oir esa música, que deja estar cada sonido que se toca (¡una especie de lienzo blanco entre manchas de color! $)^{68}$ "

67 HaHL-Косн, Der Briefwechsel: Wassily Kandinsky und Arnold Schönberg, pp. 15 y ss. 
La verdad es que la carta de Kandinsky dio resultado y Schönberg se alegró mucho de recibirla. No sólo por el hecho de que alguien estuviera interesado por su música (si ni Strauss ni Mahler le comprendían, qué iba a decir el público ante tales disonancias), sino porque además, era un pintor el que lo hacía y eso reforzaba la idea wagneriana de la Gesamtkunstwerk. La música y la pintura como medios de expresión de una misma idea. Un músico y un pintor que expresaban lo mismo, que compartían sentir y pensar. Dos grandes artistas en busca de un nuevo (y el mismo) camino para el arte acababan de encontrarse. Schönberg le devuelve la carta un par de días después, el 24 de enero, en la que, después de agradecerle la misiva y los cuadros, empieza a exponer sus ideas sobre el arte, sobre la tarea del artista, sobre lo inconsciente... Así comienza la correspondencia entre ambos y el intercambio de ideas, fructífero encuentro que dará lugar a una buena amistad y se prolongará hasta el año $1923 .{ }^{69}$

El cuadro de Kandinsky Impresión III (Concierto) deja constancia del famoso concierto y se erige hoy día como símbolo del encuentro. Es un cuadro que ya apunta maneras abstractas, aunque todavía se reconoce la cola del piano

68 MaCKe, August Macke-Franz Marc, p. 40.

69 La historia de la ruptura entre Schönberg y Kandinsky es ampliación colateral: en 1923, Kandinsky era profesor de la Bauhaus y buscaba, junto con Gropius, alguien que ocupara la plaza de maestro musical. Kandinsky pensó inmediatamente en Schönberg y el 15 de abril le envió una carta con la propuesta. Kandinsky quedó atónito cuando recibe la respuesta (fechada el día 19), en la que Schönberg no sólo rechaza la plaza, sino que se dirige a su querido amigo como «Estimado Sr. Kandinsky» y le acusa de antisemita y traidor (Schönberg era judío). Le dedica frases como ésta: «No soy un alemán, un europeo, quizá ni siquiera un ser humano (al menos los europeos prefieren a los peores de su raza antes que a mí), sino que soy judío. (...) He oído que también un tal Kandinsky ve sólo maldad en los actos de los judíos y que sólo ve lo judío en sus malos actos, y entonces renuncio a toda esperanza de entendimiento. Fue un sueño. Nosotros somos hombres de especies distintas. ¡Definitivamente!» (HaHL-Косн, Der Briefwechsel: Wassily Kandinsky und Arnold Schönberg, p. 80). Kandinsky, que ni era antisemita ni jamás se mezclaba en asuntos de política, le descubre su asombro y le hace ver que lo que dice no tiene ningún tipo de sentido. Pero Schönberg no se convence y pone punto final a la relación con una carta muy larga llena de reflexiones sobre los judíos y la raza aria.

Al parecer, fue Alma Mahler (que había dejado a Gustav Mahler y era mujer de Walter Gropius, pero estaba ya en los brazos de F. Werfel) la que difundió el falso rumor del antisemitismo de Kandinsky por las aulas de la Bauhaus. Las razones para tal brujería son variadas y oscuras, aunque todas coinciden en lo arpía que podía llegar a ser Alma Mahler (Gropius el primero). La versión que prevalece es que el interés amoroso de Alma por Kandinsky no fue correspondido. Una versión de los hechos puede leerse en KANDINSKY, Kandinsky und ich, a partir de la página 191. 
y a los espectadores. Un amarillo brillante inunda el lienzo y se mezcla con rojos y negros. Es aún una obra prematura en relación a lo que conseguirá Kandinsky años después, pero la imagen, unida al intercambio epistolar de los dos artistas, deja constancia del paralelismo de sus trabajos.

Este paralelismo se presenta en tres aspectos. El primer punto en común es el más obvio, la ausencia de eje central. Las obras dodecafónicas de Schönberg carecen de tonalidad y a las obras abstractas de Kandinsky les falta el objeto. La interpretación de por qué Kandinsky renuncia a lo figurativo es el principal objetivo de esta investigación, así que no cabe explicarla aquí en dos líneas. Pero sí se puede citar a Schönberg para constatar que ambos artistas estaban más que de acuerdo: «Yo tampoco puedo creer que la pintura tenga que ser necesariamente figurativa. En realidad, creo más bien lo contrario.» ${ }^{70}$

El segundo aspecto es la expresión de lo interior, en consonancia con el ambiente de la época. Al igual que los expresionistas, al igual que Debussy, al igual que la importancia al inconsciente de Freud, Schönberg se lo explica a Kandinsky en la misma carta del 24 de enero: $«_{i} E l$ arte pertenece al inconscien$t e !_{¡}$ Uno mismo tiene que expresarse! ¡Expresarse directamente [unmittelbar]! Pero no se trata de expresar uno su gusto, o su educación o su intelecto [Verstand], o su conocimiento [Wissen], o su saber hacer [Können]. Ninguna de esas propiedades no innatas. Sino las innatas, las instintivas [triebhaften]». ${ }^{71}$

Y el tercer punto en común se deriva de los dos anteriores: la nueva forma de expresión. Una obra sin tonalidad o sin objeto y con un contenido interior le otorga protagonismo a los medios de expresión, forma y color en el caso de Kandinsky. El abandono de las reglas habituales de la armonía o de la composición pictórica lleva inevitablemente a lo no acostumbrado, a acordes que suenan disonantes y a cuadros que parecen arbitrarios. Se crea así una expresión diferente, nueva, un concepto de belleza no acostumbrado.

Se puede profundizar en cada uno de estos aspectos, y en cierto modo se hará a lo largo de los siguientes capítulos. Sin embargo, teniendo en cuenta que este apartado no pretende una duografía entre Schönberg y Kandinsky sino la influencia del contexto musical en el nacimiento del arte abstracto, lo

\footnotetext{
70 Haнl-Косн, Der Briefwechsel: Wassily Kandinsky und Arnold Schönberg, p. 18. Carta del 24 de enero de 1911.

71 Todas las cursivas son originales.
} 
esencial queda básicamente expuesto. Sólo falta presentar un ámbito cultural más que cierre el contexto de principios del siglo xx: las bases ideológicas.

\subsection{Las bases ideológicas}

Las teorías filosóficas, psicológicas, sociológicas, etc. también son numerosas a principios del $\mathrm{xx}$. Y en cada una de esas disciplinas destacan grandes nombres: Heidegger, Husserl, Freud, Weber... son sólo algunos ejemplos. Todos ellos suponen para el nuevo siglo no sólo cambio, sino también nuevas teorías y abundante producción intelectual. Kandinsky pertenece a esta época y en ella hay que buscar las bases ideológicas que dejaron huella en él. Pero, de todo este enarbolado de ideas: ¿qué fue lo que leyó Kandinsky, de qué estaba al corriente o por qué se interesó?

Salvo en los casos en los que se conserva la biblioteca de un autor o artista tras su muerte, siempre es difícil saber -y más aún precisar- qué libros se leyeron en vida, qué teorías y escritos se conocieron. El caso de Kandinsky no es nada fácil porque no sólo viajó mucho, sino que cambió de residencia varias veces. Las mudanzas eran a larga distancia y la posibilidad de llevar con él sus enseres las complicaba. La salida de Múnich en 1914, obligado por el estallido de la Guerra, ni siquiera le permitió llevarse sus cuadros. De ahí a Rusia, a Francia, de vuelta a Alemania moviéndose con la Bauhaus y de nuevo a Francia. Si existen algunos problemas para constatar la realización y/o el paradero de algunos de sus cuadros, especialmente los de la primera época, es bastante difícil precisar de qué volúmenes constaba su biblioteca. ${ }^{72}$ No obstante, en alguno de sus escritos Kandinsky hace alusión a ciertos autores. Gracias a la información sobre los círculos intelectuales de la época, es posible

72 La mejor información sobre la biblioteca de Kandinsky la recoge Jelena Hahl-Koch en las páginas 190-196 de su libro Kandinsky (1993). La biblioteca de Kandinsky durante sus años de París (los últimos de su vida) está más o menos conservada gracias a su esposa Nina. Los libros de su época de Múnich, época en la que se fraguó la abstracción, están repartidos entre la biblioteca personal de Gabriele Münter (conservada en Múnich en la Fundación Gabriele Münter y Johannes Eichner) y París, que es donde llegaron los cuadros y libros que Gabriele devolvió a Kandinsky en 1926, después de pasar por Alemania. Es decir, aunque los libros en sí más o menos estén localizados, se entremezclan los libros reales de Kandinsky con los de Nina y Gabriele, amén de los que se quedaron en Moscú y de los que se perdieron en los viajes. 
establecer alguna referencia.

Las referencias ideológicas más claras y presentes en Kandinsky son dos: por un lado las nuevas teorías estéticas de Theodor Lipps y Wilhelm Worringer, y por el otro la teoría antroposófica de Rudolph Steiner.

\subsubsection{Empatía y abstracción: T. Lipps y W. Worringer}

Wilhelm Worringer, alumno directo de Theodor Lipps, presenta su tesis doctoral en 1906 con el título Abstraktion und Einfühlung (Abstracción y empatía). Aunque no se distribuyeron muchas copias, enseguida adquirió gran resonancia. Tres años más tarde, la editorial muniquesa Piper (responsable también del almanaque El Jinete $\mathrm{Azul}$ ) publica la disertación con formato de libro. La acogida sigue siendo buena, especialmente entre artistas y críticos de arte.

Lipps dio numerosas conferencias en la Universidad de Múnich entre 1894 y 1913, más o menos los mismos años en los que Kandinsky vivió allí (1896 -1914). Y que Kandinsky leyó la tesis doctoral de Worringer parece no discutirlo nadie. Él mismo lo da a entender en De lo espiritual en el arte. ${ }^{73}$ La mayoría de los autores ${ }^{74}$ coinciden en que las tesis de Worringer fueron un gran estímulo para Kandinsky y su creación del arte abstracto, si no una justificación para eliminar definitivamente el objeto del cuadro. Hay algún autor, léase Wolfgang Hütt, ${ }^{75}$ que afirma incluso que Kandinsky y Worringer llegaron a encontrarse y a discutir sus teorías. Sin embargo, no parece haber constancia de tal encuentro por lo que se queda en mera suposición.

La influencia de Worringer la sintió todo el grupo de artistas en torno a

73 Kandinsky, De lo espiritual en el arte, pp. 11 y 21.

74 Por citar algunos: Grohmann, Wassily Kandinsky: Leben und Werk, p. 85 y ss., Stelzer, Die Vorgeschichte der abstrakten Kunst, p. 125 y ss. o Brinkmann, Wassily Kandinski als Dichter, p. 136 y ss. No así Jelena Hahl-Koch, que aunque reconoce «proyectos en común» entre Worringer y Kandinsky basándose en la carta de Marc de abril de 1911, niega que Kandinsky «pudiera haber aprendido algo de un veinteañero Doctor en Filosofía», refiriéndose a Worringer. Véase la página 193 de su libro Kandinsky, (1993). De toda la bibliografía consultada, Hahl-Koch es la única autora que pone en tela de juicio la conexión ideológica entre Worringer y Kandinsky, a pesar de que el mismo Kandinsky lo cite en sus cartas y libros.

75 Hüтt, Deutsche Malerei und Graphik im 20. Jahrhundert, p. 118. 
El Jinete Azul. Otto Stelzer constata cómo Alexej von Jawlensky y Marianne von Werefkin, por ejemplo, conocían las ideas de Lipps ${ }^{76}$; Franz Marc lo deja patente en una carta que escribe a Kandinsky: «[Worringer es un] tipo listo, que nos podría ser muy útil» ${ }^{77}$. Kandinsky asiente, porque la teoría de Worringer le encaja a la perfección con su idea de que el arte necesita una buena base teórica, una especie de reglas que conduzcan la producción artística, una “gramática de la creación”. Ambos, Marc y Kandinsky, están de acuerdo en incluir la participación de Worringer en el segundo almanaque que estaban proyectando (y que finalmente no se llevó a cabo porque Franz Marc murió en Verdún).

Lipps publica en 1903 la primera parte de su manual de estética (Ästhetik) y dedica el segundo apartado a exponer su teoría de la empatía o Einfühlungstheorie. Ésta establece una relación entre el objeto de arte y el sujeto, entre lo contemplado y el observador. Entre ellos se origina un proceso por el cual el sujeto "se reconoce" en el objeto que observa y adquiere un conocimiento de sí mismo gracias a la empatía con la que se vincula al objeto.

En su tesis doctoral, Worringer se apoya en la Einfühlungstheorie de su maestro Lipps para desarrollar una nueva teoría estética. Worringer conserva el planteamiento entre el objeto y el sujeto, así como la empatía del observador para con el objeto artístico. Pero Worringer considera que esta empatía -y por ende la teoría de Lipps- es sólo una visión parcial de la verdadera relación estética entre el hombre y el arte. Worringer ofrece, pues, una nueva teoría estética que completa la teoría de la empatía de Lipps.

La tesis de Worringer parte de la premisa de que un objeto artístico es un ser completamente diferente de un objeto natural, y por tanto, las leyes que se apliquen al arte no pueden ser las mismas leyes de la naturaleza. La estética del arte difiere de la estética de la naturaleza de lo bello. La obra de arte es un organismo independiente y como tal necesita leyes propias, no las de la naturaleza. Esta idea de que el arte necesita nuevas leyes es similar a la necesidad que tiene la física cuántica de crear nuevas leyes y encaja con la idea kandinskyana de que un nuevo estilo artístico, el abstracto, también necesita nuevas leyes.

76 Stelzer, Die Vorgeschichte der abstrakten Kunst, p. 125.

77 Lankheit, Franz Marc, p. 94. La carta es de abril de 1911. 
La segunda premisa de Worringer, y ésta la toma de Lipps, es que la nueva teoría estética ha de cambiar. Debe olvidarse de la forma del objeto como tema central. Worringer propone pasar del objetivismo al subjetivismo, es decir, de valorar la forma del objeto (por sí o en relación a la naturaleza) a considerar el comportamiento y la percepción del sujeto que observa el objeto. La actitud del espectador frente a la obra de arte, y no la obra de arte en sí, debe ser el tema central del que se ocupe la estética.

Partiendo de estas dos premisas, Worringer comienza a completar la teoría de Lipps. Si éste cree que la empatía es el único impulso (Drang) que marca la relación del hombre con el arte, Worringer afirma que en realidad los impulsos son dos: la empatía y la abstracción. ${ }^{78}$

La tesis central de la empatía la comparten Lipps, Worringer y a su modo Ortega y Gasset, al que le delata su formación alemana. Ortega la prefiere como simpatía (no empatía) y sobre la simpatía y la abstracción se hace eco en el tercer apartado de su artículo Arte de este mundo y del otro ${ }^{79}$. La teoría de la empatía parte de la relación recién comentada sobre el objeto (obra de arte) y el sujeto (espectador). El objeto no es pasivo sino que se da sensorialmente, solicita al sujeto su actividad perceptiva. «Un objeto que ante nosotros se presenta no es, por lo pronto, más que una solicitación múltiple a nuestra actividad ${ }^{80}$, dice Ortega. De este modo, el sujeto se vuelca sobre el objeto a través de la percepción y re-conoce en él su mundo interior: el sujeto simpatiza con el objeto y se une emotivamente a él.

Lipps expresa esta empatía-simpatía del sujeto con la obra de arte pronunciando las siguientes palabras: «sintiéndonos a nosotros mismos en las formas y colores [del objeto artístico] podemos experimentar cómo [estas formas y colores] se expanden y se contraen ${ }^{81}$. Parece que Kandinsky parafrasea a Lipps cuando habla de los efectos del color amarillo y del azul: «el segundo movimiento del amarillo y del azul (...) es excéntrico y concéntrico. (...) el amarillo irradia fuerza, adquiere movimiento desde su centro y se aproxima casi perceptiblemente al espectador. El azul, por el contrario, desarrolla un

78 Einfühlungsdrang y Abstraktionsdrang respectivamente.

79 Incluido en Ortega y Gasset, La deshumanización del arte, pp. 91-115.

80 Ortega y Gasset, La deshumanización del arte, p. 99.

81 Vitz y Glimcher, Modern Art and Modern Science, p. 10o. Las cursivas no son originales. 
movimiento concéntrico (...) que se aleja del espectador.» ${ }^{82}$ Las formas se expanden y se contraen según Lipps; para Kandinsky, el amarillo es excéntrico y el azul concéntrico.

Sobre esta idea de empatía por la que el sujeto se proyecta en el objeto, subjetivizándolo, hay una cita muy apropiada de Ortega y Gasset:

«Si el objeto es angosto y vertical, por ejemplo, nuestros músculos oculares verifican un esfuerzo de elevación: este esfuerzo está asociado en nuestra conciencia a otros movimientos incipientes de nuestro cuerpo, que tienden a levantarnos sobre el suelo y a las sensaciones musculares de peso, de resistencia, de gravitación. Se forma, pues, dentro de nosotros, en torno a la imagen bruta del objeto angosto y vertical un como organismo de actividades, de relaciones vitales: sentimos como si nuestras fuerzas, que aspiran hacia arriba, vencieran la pesantez, por tanto, como si nuestro esfuerzo triunfara. Y como todo esto lo hemos ido sintiendo mientras percibíamos aquel objeto exterior, y precisamente para percibirlo, fundimos lo que en nosotros pasa con la existencia de él y proyectamos hacia fuera todo junto, compenetrado en una única realidad. (...) Este es el placer estético elemental que hallamos en la contemplación de las columnas, de los obeliscos. En realidad, somos nosotros mismos quienes gozamos de nuestra actividad (...) pero lo atribuimos al objeto, volcamos sobre él nuestra emotividad interna, vivimos en él, simpatizamos. ${ }^{83}$ »

Si al contemplar una obra de arte es el espectador quien vuelca sus sentimientos y mundo interior en el objeto, entonces, el placer estético que se obtiene es el placer del mismo sujeto. Así lo expresa Lipps: «el placer estético es placer de sí mismo objetivado» (ästhetischer Genuß ist objektivierter Selbstgenuß). ${ }^{84}$ Ese placer estético es un sentimiento personal, propio del espectador,

82 KANDinsky, De lo espiritual en el arte, p. 72.

83 Ortega y Gasset, La deshumanización del arte, pp. 99-100.

84 Worringer, Abstraktion und Einfühlung, p. 40. 
que Lipps ya no diferencia en agrado o desagrado (Lust-Unlust). Es decir, no importa si el placer estético es de agrado o de desagrado sino el hecho de que es un sentimiento, una vivencia interior. (Lo que indudablemente recuerda qué época es: la del siglo xx y su giro al interior.) Agradable o desagradable quedan como diferentes gradaciones de un mismo sentimiento, son "tonos de un sentimiento" (Gefühlstöne) que denomina Lipps.

Así pues, el objeto u obra de arte es una plataforma que se ofrece al sujeto a través de una acción perceptiva y sensorial: el espectador la percibe y la siente, reconoce en ella sus sentimientos. Kandinsky es el espectador de un mundo externo que le ofrece una fuerte carga emocional, Kandinsky percibe y siente ese mundo. Recuérdense las citas empleadas a raíz de la relación sentida de Kandinsky con el mundo: «Toda cosa muerta palpitaba», o «las experiencias artísticas originan un estado de vibración en el alma». Kandinsky parece encontrar ese "placer estético de sí mismo objetivado" en el mundo externo y en el del arte.

Esta tesis central de la empatía es la que Worringer toma de Lipps. Pero Worringer considera que la empatía es sólo uno de los dos polos que relacionan al hombre con el arte. El otro polo es la abstracción.

El polo de la abstracción es, como la empatía, un sentimiento. La teoría estética de Worringer, aun reuniendo la empatía y la abstracción, sigue teniendo su base en el sentimiento humano. La abstracción es un sentimiento que nace de la angustia y que persigue a todo hombre desde el inicio de su existencia, dice Worringer, en tanto que es un sentimiento que resulta de la relación del hombre con el cosmos. El mundo es un espacio confuso y demasiado grande para el hombre, que no encuentra puntos de apoyo a los que agarrarse, que no encuentra elementos seguros con los que contar. Por eso la postura inicial del hombre en el mundo es una postura de agorafobia. Worringer se refiere a los pueblos primitivos, pero Kandinsky lee entre líneas el mundo inestable e inseguro que ha dejado la división del átomo. Esa especie de miedo que tiene el hombre a la realidad, porque es un mundo borroso, que se difumina, que juega con el sujeto, dice Worringer que se encuentra en todo pueblo en relación con el cosmos: es un sentimiento hacia el mundo (Weltgefühl). Aunque Worringer hable de "pueblo" en su sentido más originario, leer su tesis a principios del siglo xx la hace encajar perfectamente con el contexto de la época: la revolución científica, el cambio de leyes de la física cuántica, la dilución de contornos en 
la pintura, la creación de la música atonal. La situación de desestabilidad que describe Worringer, ese sentimiento de agorafobia hacia para el mundo y ese impulso de abstracción, es la misma sensación que Kandinsky quiere calmar con un nuevo estilo pictórico.

La inquietud que siente el hombre cuando ve el mundo exterior le hace repeler toda forma orgánica y toda forma viva, porque ésas son precisamente las formas que originan el caos. En el arte habitual, el que toma a la naturaleza como modelo, el hombre siente que los sentidos le engañan y le devuelven un mundo arbitrario, azaroso; por eso quiere encontrar un tipo de arte que le calme, que le dé la sensación de sentirse a salvo. Como el mundo exterior está lleno de variables y arbitrariedad, lo que hace es extraer la esencia de las cosas (como Cézanne), sus valores constantes y absolutos y formar con ellos una "tranquilidad ordenada". Es decir, la respuesta al caos y a la inestabilidad es un proceso de abstracción de las cosas.

La abstracción es el camino de escape hacia la tranquilidad porque cada cosa, aislada en sí misma, ofrece al sujeto claridad y reposo. ¿Cómo es ese camino de la abstracción, según Worringer? Dado que las formas de la naturaleza son arbitrarias y además no son comparables a los objetos del arte (primera premisa de Worringer: los objetos artísticos son organismos independientes), la imitación de la naturaleza no puede ser nunca el camino de la abstracción. Para encontrar una "absolutización" que proporcione orden y tranquilidad, se han de reducir los objetos a una forma abstracta, no natural, donde se elimine lo corpóreo, donde se diluyan las líneas marcadas que dibujan lo orgánico. La forma abstracta es la precisa, regulada y clara, porque contiene sólo esencias, lo imprescindible. El modo artístico de proceder, continúa Worringer, es negar la masa de los objetos, traducir lo orgánico a formas geométricas y crear un espacio neutro. Es decir, negar el objeto en sí y retener de él sólo lo esencial. Descartada la imitación de la naturaleza para formas artísticas que expresen placer estético, sólo queda una nueva creación: crear nuevas formas, crear un nuevo lenguaje para el arte. Así nacen las formas abstractas y así lo expresa Worringer: «estas formas estrictamente abstractas son las únicas y las más indicadas con las que el hombre puede descansar de la vasta confusión que le ofrece la imagen del mundo». ${ }^{85}$

85 Worringer, Abstraktion und Einfühlung, p. 53. 
Esta es la base ideológica que a Kandinsky no sólo le abre su particular camino hacia la abstracción sino que en cierto modo se la justifica. Por un lado, la idea de arte que flotaba en Múnich a principios del xx era similar: "No hay mayor error que el de creer que imitar la naturaleza es arte», recoge Gisela Kleine de boca de Gabriele Münter. ${ }^{86}$ Por otro lado, Kandinsky mismo recalca la idea de abstracción como un sentir primigenio (aunque no nombre a Worringer directamente) con la siguiente frase: «la semejanza del sentir íntimo de todo un período [sentimiento de agorafobia] puede conducir lógicamente a la utilización de formas que, en un período pasado, sirvieron eficazmente a las mismas tendencias. Así surgió en parte nuestra simpatía, nuestra comprensión, nuestro parentesco espiritual con los primitivos. Al igual que nosotros, estos artistas puros intentaron reflejar en sus obras solamente lo esencial; la renuncia a la contingencia externa surgió por sí misma». ${ }^{87}$

La frase corresponde a su primer libro De lo espiritual en el arte y aún se ve cómo Kandinsky se expresa con cierta reserva en lo que a la desaparición del objeto se refiere. No habla de eliminar el objeto sino de «renuncia a la contingencia externa». La idea, teórica y práctica, de eliminar completamente el objeto irá madurando a lo largo de los años. Por ejemplo: durante un viaje a Túnez que realiza con Gabriele Münter en 1905, la prohibición islámica de la representación figurativa vuelve a estimular la idea de que el objeto no es imprescindible en la pintura: «los objetos me estorban» ${ }^{88}$, le diría a Gabriele Münter. El objeto estorba y las formas abstractas están justificadas: el camino a la abstracción ha comenzado.

\subsubsection{Rudolf Steiner y la Antroposofía}

La Antroposofía de Rudolf Steiner tiene sus raíces en la Teosofía. En 1875, Helena Blavatsky (también conocida como Madame Blavatsky) funda en Nueva York la Sociedad Teosófica que poco después trasladaría a Adyar (India), que ejerce aún hoy de sede central. Su objetivo principal era vincular el conocimiento místico oriental con las prácticas ocultistas de occidente, y en ese

86 KLEINE, Gabriele Münter und Wassily Kandinsky, p. 103.

87 Kandinsky, De lo espiritual en el arte, p. 21.

88 Roditi, Dialoge über Kunst, pp. 212-213. La cursiva es añadida. 
programa cabía desde el estudio de médiums y espiritismo hasta el análisis comparativo de las religiones, sin dejar de lado una pretensión de fraternidad universal.

Con el cambio finisecular, los grupos teosóficos empiezan a crecer en Europa y especialmente en Alemania. En Berlín o Múnich son frecuentes las conferencias y charlas sobre la Teosofía misma y sus temas adyacentes. Uno de esos conferenciantes es Rudolf Steiner, un filósofo austriaco (1861-1925) y estudioso de la literatura de Goethe que además tiene muchos contactos en los círculos artísticos de la época. En 1902 viaja a Londres a un congreso de Teosofía y conoce a Annie Besant, futura sucesora de Blavatsky. Parece ${ }^{89}$ que ese viaje le cambia profundamente: a la vuelta rompe con algunas de las amistades que tenía y se convierte en el Secretario General de la Sociedad Teosófica Alemana. Steiner conduce la Sociedad con Marie von Sivers, futura esposa, y ambos le dan a la Teosofía alemana un aire ligeramente diferente al habitual, el que marcaba Blavatsky.

Steiner se dedica por completo a la Teosofía durante estos años: publica varios libros (entre ellos una especie de manual, Theosophie, en 1904) y continúa con las conferencias por toda Europa. En 1907 da una charla en Múnich con motivo del Iv Congreso anual de la Federación de Secciones Europeas de la Sociedad Teosófica. Más de un autor afirma que a esa charla pudo haber asistido Wassily Kandinsky.

Por diferencias con Annie Besant (ya presidenta internacional del movimiento teosófico) y otras divergencias sobre el tema del cristianismo y la religión, Steiner se separa en diciembre de 1912 de la Sociedad Teosófica. Crea entonces su propia doctrina, que él denomina Antroposofía y que dice no tener apenas en común con la Teosofía, aunque las similitudes sean más que evidentes. ${ }^{90}$ Planifica también una escuela libre en la que estudiar la verdadera ciencia del espíritu y concibe para ella un edificio especial, el Goetheanum, previsto para Múnich pero construido finalmente en Dornach. Steiner cuenta con un gran número de seguidores, que se adhieren a la "nueva" Teosofía, la Antroposofía.

\footnotetext{
89 Badewien, Die Anthroposophie Rudolf Steiners, p. 13.

90 Véanse, al respecto, los comentarios de Badewien en Die Anthroposophie Rudolf Steiners, capítulo segundo.
} 
La Antroposofía de Steiner arrastra ciertas visiones espirituales de la Teosofía, pero principalmente añade unos componentes más académicos (en consonancia con la formación filosófica e investigadora de Steiner). En la Antroposofía se reflejan el idealismo alemán y la cosmovisión de Goethe, y se unen los conocimientos científicos de la época. Las teorías místicas del lejano oriente que importa de Blavatsky le dan un cierto aire religioso, cuando no esotérico. Pero la Antroposofía no es exclusivamente una doctrina religiosa, sino más bien una teoría que funciona como método de investigación y aplicación. Bajo un mismo objetivo, que es alcanzar la apertura del hombre al mundo suprasensorial, la Antroposofía acoge un amplio número de disciplinas: la pedagogía, aplicada en las escuelas Waldorf; la medicina, que se refleja en la línea homeopática; la danza, que conforma el ámbito de la euritmia; la arquitectura, que sin ángulos rectos será precursora de la arquitectura orgánica; la agricultura de corte ecológico-biológico-dinámico...

Steiner define la Antroposofía como la ciencia de lo espiritual. Si las matemáticas son la ciencia que se ocupa de los números y las figuras geométricas, si la Filosofía es la ciencia de la sabiduría, si la Psicología es la ciencia de las leyes del alma, dice Steiner, entonces la Antroposofía es la ciencia que estudia el mundo espiritual. ${ }^{91}$ Hay que entender esta definición de "ciencia de lo espiritual" como una cosmovisión en la que el hombre se relaciona con el mundo, como un método de alcanzar lo que está más allá de los sentidos. La Antroposofía quiere «abrir las puertas al mundo suprasensorial. Y no quiere hacerlo a través de un simple pensamiento especulativo, sino a través de la percepción real, la que es tan accesible al alma como la percepción de los sentidos físicos» ${ }^{92}$.

Kandinsky pudo asistir o no a esas conferencias de la Sociedad Teosófica en Alemania. Quizá a la de Múnich de 1907 o a la que dio Steiner en Berlín en el invierno de 1908 , que coincidió con un viaje de Kandinsky a la capital. ${ }^{93}$ Lo cierto es que Kandinsky estaba al tanto de las teorías teosóficas o antroposóficas y sabía quién era Blavatsky, como demuestra un pasaje del libro De lo espiritual en el arte: «uno de los más importantes movimientos espirituales

91 SteIner, Theosophie.

92 Steiner, Philosophie und Anthroposophie, p. 145.

93 Hanfstaengl, Wassily Kandinsky. Zeichnungen und Aquarelle, p. 53. 
que une hoy a un gran número de personas y que incluso ha creado una forma material de esta unión espiritual: la "Sociedad Teosófica”. (...) La teoría teosófica (...) fue formulada por Blawatzky [sic], y es una especie de catecismo en el que el alumno encuentra las respuestas concretas del teósofo a todas sus preguntas». ${ }^{94}$

Hasta qué punto Kandinsky conocía las teorías de la Antroposofía, hasta qué punto las compartía e incluso hasta qué punto las introdujo o no en su obra artística, es un tema controvertido que se tratará en el capítulo 6. Lo que sí es necesario señalar en este capítulo dedicado al contexto, es que la Teosofía de Blavatsky o la Antroposofía de Steiner -con sus semejanzas y diferenciasfueron un acontecimiento ideológico coetáneo al nacimiento de la pintura abstracta y que a Kandinsky no le fue indiferente. Como dice Brinkmann, es lícito hablar de un "fermento de motivación teosófica» en el arte abstracto. ${ }^{95}$

El nacimiento del arte abstracto y la Antroposofía de Steiner comparten contexto. Conviven con la explosión de colores del expresionismo y con las disonancias que empiezan a instalarse en la música. Y sobre todo, Kandinsky y Steiner asisten a la par a los descubrimientos de la nueva física, a la revolución de la física cuántica. La división del átomo deja en Kandinsky una huella tan fuerte que le lleva a plantearse la esencia misma del objeto y su papel en el cuadro. Si la ciencia le niega la estabilidad de las cosas, ¿cómo aferrarse a ellas para que sean las protagonistas de su pintura? Steiner, por su parte, también reacciona ante los nuevos avances de la ciencia. Si la división del átomo tuvo consecuencias en la pintura de Kandinsy, el descubrimiento de los quantos y de la materia oscura también tuvo sus repercusiones en la obra de Steiner. La nueva física corroboraba, según Steiner, la existencia del espíritu (Geist); sólo que los científicos no se atrevían a hacer frente a tamaña revelación: «las ciencias naturales han llegado a sus fronteras: en la física cuántica han llegado hasta lo más pequeño y en la astrofísica hasta lo más grande. Pero aunque hace tiempo que los físicos cuánticos han descubierto el espíritu en sus "campos" y "estados quánticos de vacío”, a la mayoría les falta el valor para utilizar la palabra “espíritu”. Y lo mismo ocurre con los astrofísicos: en los últimos años han descubierto algo extraño que denominan materia oscura y energía oscura. (...) Pero no se atreven a llamarlo espíritu (...)» ${ }^{96}$.

94 Kandinsky, De lo espiritual en el arte, p. 37.

95 Brinkmann, Wassily Kandinski als Dichter, p. 127. 
Kandinsky y Steiner aportan un trasfondo académico a sus respectivos campos. El Kandinsky pintor no puede obviar su formación jurista con su fe en la ciencia, en lo objetivo, en lo analítico. Steiner introduce en la Teosofía sus años de Filosofía y sus estudios de Goethe, dotando al espíritu meramente trascendental de Blavatsky de una dimensión analítica y en cierto modo científica. Cada uno interpreta las novedades de la ciencia a su manera, pero ambos coinciden en dos cosas: que la desestabilización de la ciencia exige un cambio y que ese cambio tiene que girar hacia lo esencial, hacia lo espiritual.

Kandinsky busca el cambio con un nuevo lenguaje artístico en el que sacrifica el objeto: un arte sin objeto para llegar a lo esencial, a lo espiritual. Steiner concibe la Antroposofía como un método teórico y estructurado para llegar al nivel suprasensible y espiritual. Según Steiner, el antropósofo es un vidente de lo espiritual, es quien logra ver el espíritu de las cosas (geistiger Seher) y lo transmite a los demás. Para Kandinsky, el proceso de creación de la obra está dominado por la búsqueda de lo espiritual y es el artista quien lo transmite a los demás: «la finalidad del arte no es otra que la espiritualización del alma», dice en el almanaque El Jinete Azul.

Kandinsky y Steiner, como otros tantos coetáneos, aguardaban una nueva época marcada por lo espiritual. ${ }^{97}$ Pero en vez de sentarse a esperar, salen a buscarla: Steiner con la teoría antroposófica, Kandinsky con la creación de un nuevo lenguaje artístico: la abstracción.

Retomando el epigrama de Bornstein que abría el capítulo, ninguna disciplina surge en el vacío ni su desarrollo es ajeno a lo que ocurre a su alrededor. La creación del arte abstracto está, del mismo modo, fuertemente marcada por los acontecimientos de la época. Es decir, por el contexto histórico de principios del siglo $\mathrm{xx}$ que se ha expuesto en estas páginas.

Los ámbitos de conocimiento que rodean al mundo de la pintura experimentan grandes cambios, como el científico, o bien siguen un desarrollo paralelo, como la música. Algunos de esos campos influyen sobremanera en el arte y otros, en cambio, le acompañan y afianzan en la búsqueda del nuevo mo-

96 Burkart, Faszination Rudolf Steiner, p. 162. Las cursivas y las comillas son originales. 97 Brinkmann, Wassily Kandinski als Dichter, p. 123. 
delo artístico. Cada uno de ellos influye directa e indirectamente en el trabajo teórico-práctico de Kandinsky, por lo que conviene tenerlos muy presentes en relación a las cuatro grandes perspectivas del arte abstracto (capítulos 4, 5, 6 y 7). El capítulo ha presentado los acontecimientos históricos en relación al nacimiento del arte abstracto; ahora se cierra con el panorama de lo que implica ese contexto histórico en la creación artística de Kandinsky.

La influencia que ejerce el contexto histórico tiene tres grandes efectos en la obra de Kandinsky: la pérdida del objeto, el protagonismo del color y la expresión de un mundo interior.

La pérdida del objeto es el rasgo más notorio del arte abstracto. Pero eliminar el objeto, que hasta entonces había sido inamovible del cuadro, no fue sólo la conclusión de deliberaciones teóricas ni una decisión rápida y puntual de hacerlo desaparecer. Fue un largo proceso que comenzó con Monet y los impresionistas, fue un camino de desdibujamiento, dilución y borrosidad que culminó consecuentemente en la ausencia del objeto. No se puede precisar hasta qué punto los nuevos descubrimientos científicos exigían este cambio o sólo coadyuvaban, pero lo cierto es que la noticia de que el átomo dejaba de ser indivisible hizo incluso tambalear las convicciones pictóricas. La división del átomo hace que Kandinsky pierda la credibilidad en el objeto: el objeto, por similitud al átomo, no es estable. El objeto ya no es la base de la obra, ni el portador del contenido, ni el elemento central. Si ya no cumple ninguna de estas funciones, el objeto estorba y sólo queda eliminarlo. Recuérdese lo que le dice Kandinsky a Münter: «los objetos me estorban.» ${ }^{98}$

En este proceso de eliminación figurativa contribuye el encuentro de Kandinsky con Schönberg. La música atonal sigue un proceso paralelo al de la pintura abstracta, un camino que ambiciona la desaparición del eje central y que está liberada de la atadura que supone la imitación del mundo externo. Ambas características ofrecen una justificación al proyecto de Kandinsky, le muestran la posibilidad real de crear un arte sin objeto pero con contenido. Se podría decir que el encuentro con Schönberg es para Kandinsky la justificación práctica de su proyecto: "el objeto me estorba, ¿puedo deshacerme de él?” Schönberg le da como respuesta un sí, y como ejemplo la música atonal. Si la justificación práctica es de Schönberg, la justificación teórica se la ofrece

98 Roditi, Dialoge über Kunst, pp. 212-213. 
Worringer con su defensa de la abstracción. La abstracción como solución al sentimiento agorafóbico, como forma de escaparse de la imitación a la naturaleza. Retomando las palabras de Worringer: «estas formas estrictamente abstractas son las únicas y las más indicadas con las que el hombre puede descansar de la vasta confusión que le ofrece la imagen del mundo». ${ }^{99}$

El protagonismo del color es una consecuencia directa de la eliminación del objeto. Cuando lo figurativo pierde su papel central, los medios pictóricos puros (es decir, el color y la forma) se convierten en fundamentales, se hacen con todo el protagonismo. Ya se ha comentado que Kandinsky tiene desde niño una relación especial con el color: «ya de muy joven sentía la inusitada fuerza expresiva del color» ${ }^{100}$; pues lo personifica y lo convierte en una entidad propia. A estas premisas se une la emancipación del color que consiguen los fauvistas: colores libres de pertenecer al objeto, colores subjetivos, fuertes y propios. El color gana así una nueva dimensión para la obra sin objeto de Kandinsky.

El color se singulariza y se convierte en el transmisor del contenido pictórico. Y es que, además, un contenido emocional y la puerta a la dimensión espiritual. Aquí vuelven a cobrar sentido los episodios del viaje a Vologda como etnógrafo o su viaje familiar a Italia.

La carga emocional y espiritual del color es un reflejo de la expresión de un mundo interior, que viene arropada por varios factores. El primer factor es la relación sentida de Kandinsky con el mundo exterior, otro es el acento que pone la pintura expresionista (El Puente y El Jinete Azul) sobre la subjetividad $\mathrm{y}$ del que Kandinsky forma parte. El "giro al interior" del siglo xx, como se ha visto, abarca muchos ámbitos. Schönberg mismo escribe en su tratado de armonía: «En su nivel más alto, el arte se ocupa, únicamente, de reproducir la naturaleza interior ${ }^{101}$.

Otro factor que contribuye es la pérdida de un marco de referencia absoluto que introduce la nueva física con sus múltiples descubrimientos. Sin un sistema de referencia único, surgen múltiples sistemas relativos: artista y

99 WORringer, Abstraktion und Einfühlung, p. 53.

100 KANDINSKY, Escritos sobre arte y artistas, p. 193.

101 SCHÖNBERG, Harmonielehre. 
espectador no tienen por qué compartir el mismo. Y por último, la teoría de la empatía de Worringer y Lipps propone a Kandinsky un nuevo modelo estético. O mejor dicho, la justificación para crear un arte cuyo centro de expresión es el mundo interior y emocional del sujeto. Un arte que gira en torno a la actitud del espectador ante la obra de arte y no se centra en la obra de arte en sí.

La pérdida del objeto, el protagonismo del color y la expresión artística del mundo interior son las características principales del arte abstracto de Kandinsky. 



\section{El proyecto de Kandinsky}

Una vez examinado el contexto de la época que ve nacer el arte abstracto, toca dirigir la mirada al proyecto artístico de Kandinsky. De la misma manera que en el capítulo anterior, el estudio se centra en los años que Kandinsky pasó en Múnich, los años del cambio de siglo y los años prebélicos (1896-1914). Son los años en los que se fragua el arte abstracto.

Si se contempla la trayectoria de Kandinsky a posteriori, como se hará en este capítulo, pudiera parecer un proyecto lineal, con un objetivo bien definido desde sus principios. No fue del todo así. Sí hubo una idea más o menos clara y una fase de creación y experimentación que perseguía esa idea. Pero no un proyecto cerrado y definido desde un principio. Para mejorar la comprensión se ha optado por presentar el proyecto de una manera lógica y clara, pero no se debe perder de vista que la trayectoria de Kandinsky, y por consiguiente la creación del arte abstracto, fue un proceso paulatino, progresivo, con saltos cualitativos y también con suaves transiciones.

En primer lugar (apartado 3.1) se expondrá la trayectoria propia de Kandinsky: sus estudios, experimentos con el arte y sus publicaciones, sin omitir el tiempo de El Jinete Azul que ya se nombró en el capítulo anterior. La idea en sí del proyecto y su formulación ocuparán la segunda parte del capítulo (apartado 3.2).

A través de ambas partes se busca aclarar cómo se inicia, cómo se pone en funcionamiento la maquinaria de la abstracción y, especialmente, cuál es el punto de inflexión al que llega Kandinsky y que le encamina hacia la creación de ese nuevo arte.

Siguiendo el esquema habitual, el texto se centra en todos los aspectos relevantes para esta investigación, dejando para las notas al pie las historias colaterales o las referencias a bibliografía en la que profundizar. 


\subsection{El camino a la abstracción}

\subsubsection{Las escuelas de pintura}

Cuando Kandinsky llega a Múnich en 1896 con formación académica y con ganas de dar rienda suelta a su creatividad, se encuentra una ciudad a la altura de París. Si la capital francesa alberga las nuevas tendencias y el desarrollo artístico, Múnich es el gran imán que atraía a todo aquel que quisiera dedicarse al arte: «En Múnich no sólo había muchísimos pintores, sino que allí estaban los mejores. La Academia [Real de Múnich] era, junto a París, la más famosa de todo el mundo» ${ }^{1}$.

Es en el barrio muniqués de Schwabing donde se reúnen los pintores y se concentran las escuelas de arte. Kandinsky ingresa en mayo de 1897 en la escuela privada de Anton Ažbe, la segunda en número de alumnos (por detrás de la Academia Real) pero la que lleva la voz cantante. En esta escuela llena de estudiantes rusos ${ }^{2}$ Kandinsky conoce a Alexej von Jawlensky y a Marianne von Werefkin, con los que compartirá después amistad y trabajo.

Anton Ažbe es, según Kandinsky, «un artista dotado y un hombre de rara bondad ${ }^{3}$. Pero su carácter desdejado, su cercanía al alcoholismo y, sobre todo, la repulsión que sentía Kandinsky por las clases de anatomía, le hacen sentirse aislado y extraño en aquel medio. Seguramente, su edad tampoco ayuda: «Yo tenía una barba poblada y la mayoría de mis compañeros no llegaban a los veinte» ${ }^{4}$. Y los compañeros veían a Kandinsky con cierta distancia y curiosidad: «Y ahí llega un señor con su caja de pinturas, toma asiento y se pone a trabajar. $\mathrm{Su}$ apariencia es típicamente rusa, con un aire de universitario moscovita y un halo de licenciado... Ése era Kandinsky» ${ }^{5}$

Kandinsky evita con frecuencia el aire enrarecido de la escuela y se marcha

1 KLEINE, Gabriele Münter und Wassily Kandinsky, p. 129.

2 «En Rusia las condiciones de estudio no eran tan buenas como en Alemania. Todos querían estudiar con Ažbe, cuya escuela era El Dorado de los artistas rusos», cuenta Kandinsky en KANDINSKY, Kandinsky und ich, p. 23.

3 KANDinsky, Mirada retrospectiva, p. 116.

4 KLEInE, Gabriele Münter und Wassily Kandinsky, p. 140.

5 Igor Grabar en una carta a su hermano, fechada el 26 de febrero de 1897. En Ebert-SchiffeRER, Die erste sowjetische Retrospektive, p. 47. 
al colindante Jardín Inglés, a las orillas del Isar, a «respirar de nuevo libremente (...) [e] ir a captar a mi manera y con mi caja de pintura [sic] el barrio de Schwabing ${ }^{6}$. A pesar de todo, en la escuela de Ažbe aguanta dos años y aprende a manejar el pincel y la espátula de tal manera que el color, por el que Kandinsky sentía especial atracción, reforzara mucho más su presencia. Ažbe también le enseña cómo trabajar con el color por encima de la forma, provocando que el contorno de los objetos pierda su importancia. Kandinsky no había sino comenzado su carrera como pintor y sus colores y paisajes ya le valían un doble apodo: "el colorista" y "el paisajista". Pero, consciente de sus habilidades (o debilidades), no le queda más remedio que aceptarlo: «Estos dos apodos me afectaban tanto más, cuanto yo debía reconocer que eran legítimos. Efectivamente, yo me sentía mucho más cómodo en el dominio de los colores que en el del dibujo. Y no sabía cómo hacer frente a este peligro que me amenazaba» ${ }^{7}$.

Como manera de luchar contra su colorismo, Kandinsky decide cambiar de maestro y llama a la puerta de Franz von Stuck, uno de los pintores más renombrados de la época. Stuck ve los trabajos de Kandinsky y opina que están bastante mal dibujados, así que le aconseja estudiar un año en la clase de dibujo de la Academia, para aprender a dominar la forma. Kandinsky no pasa el examen de ingreso, lo que le obliga a un año de estudio individual, en casa. Cuando el año siguiente (1900) logra entrar en la Academia, Stuck se opone al trabajo tan expresivo de Kandinsky y a sus «extravagancias de color» y le recomienda pintar en blanco y negro para que estudie únicamente la forma y se olvide del color. Un buen contrapunto a las clases de Azbé, podría decirse.

Stuck es callado, reflexivo y metódico, lo que Kandinsky agradece. Stuck dominaba el juego de las formas, aunque no el de los colores: «en seguida me di cuenta de que [Stuck] era poco sensible a los colores ${ }^{8}$. Y de Paul Klee, que también asiste a las clases de Stuck aunque aún no entabla relación con Kandinsky, se lee: «como escuela de dibujo no estaba mal, pero allí no se podía aprender a pintar porque jamás se hablaba del color» ${ }^{9}$. Consciente de

6 Kandinsky, Mirada retrospectiva, p. 117.

7 Kandinsky, Mirada retrospectiva, p. 118.

8 Kandinsky, Mirada retrospectiva, p. 119.

9 KleE, Paul Klee, p. 47. 


\section{El proyecto de Kandinsky}

ello, Kandinsky aprovecha para aprender dibujo y estudiar únicamente la forma. Stuck, a la cabeza del Modernismo, le prohíbe improvisar, es decir, llegar directamente al motivo central del cuadro sin haber estudiado antes la forma. También le enseña la fuerza de expresión que la línea y el plano tienen de por sí. Kandinsky tiene ganas de aprender y trabaja duro, aunque la obediencia a la forma y el olvido del color le hagan sentirse «como un mono atrapado en una red: las leyes orgánicas de la construcción me paralizaban la voluntad» ${ }^{10}$.

Kandinsky aprende de ambos maestros, Ažbe y Stuck, dos formas de enfrentarse al arte. Cada una de ellas se centra en un medio pictórico: Ažbe en el color y Stuck en la forma. Ambos siguen las reglas clásicas (epocales) de la composición y, aunque lejos del concepto de abstracción, sí enseñan a Kandinsky a dominar las herramientas con las que él, más tarde, creará un estilo individual y novedoso. En 1901, tras finalizar su año de estudio con Stuck, Kandinsky decide dar uso a esas herramientas y se une al proyecto de fundación de una sociedad artística, Phalanx.

Kandinsky tiene ya 35 años y apenas cuadros ni trayectoria. Sólo ha estudiado tres años en un par de escuelas y aún no ha expuesto nada. Consciente de que su posición no es buena y conocedor del gran número de artistas jóvenes y talentosos que hay a su alrededor, decide entrar en la escena del arte directamente desde arriba. Funda una sociedad que le permite ser galerista y director de exposiciones y que además regenta una escuela. Muy pragmático, que diría Armin Zweite: «el Kandinsky pintor podía parecer romántico y distraído, un idealista, pero en la realización de sus proyectos era un pragmático que analizaba a fondo todo el proceso comercial»" ${ }^{11}$. Según cuenta Gisela Kleine a raíz de la revista Simplicissimus, abrir una escuela de pintura era algo habitual en la época. ${ }^{12}$ Lo que no significa que Kandinsky estuviera libre de dudas: «Ojalá tuviera sólo 20 años. Continuamente tengo la sensación de que se me ha hecho tarde, y eso me enfurece» ${ }^{13}$.

Para la fundación de Phalanx, Kandinsky se une a los escultores Waldemar

10 KANDinsky, Mirada retrospectiva, p. 119.

11 Zweite, Kandinsky und München, p. 11.

12 KLeIne, Gabriele Münter und Wassily Kandinsky, p. 699.

13 Carta de Kandinsky a Kardovskij el 13 de marzo de 1901, en Ebert-Schifferer, Die erste sowjetische Retrospektive, p. 50. 
Hecker y Wilhelm Hüsgen, al dibujante Hermann Obrist o al ilustrador Ernst Stern, además de algún antiguo miembro del grupo cabaretístico de vanguardia Elf Scharfrichter, lo que da buena publicidad a la asociación. El objetivo de Phalanx es ofrecer una plataforma que dé cabida "al arte del futuro» ${ }^{14}$ y en la que pintores nacionales y foráneos puedan expresarse. Kandinsky quiere que las exposiciones de Phalanx marquen el camino hacia un arte nuevo, siempre desde la idea de que este arte ha de ser sintético: debe participar de la idea de síntesis. Es decir, las diferentes artes deben colaborar e integrarse para un mismo fin, pues al fin y al cabo, la escultura, la música o la pintura sólo son diferentes maneras de expresar un mismo contenido interior.

La primera exposición del grupo se inaugura el 17 de agosto de 1901 y luce como cartel una litografía a color de Kandinsky, en un estilo aún muy modernista. Pero el contenido de la exposición da cuenta de ese interés sintético comentado: la muestra reúne obras pictóricas, escultóricas, marionetas y las valiosas contribuciones de Elf Scharfrichter, cuyas sátiras también buscaban la síntesis escénica de la música, la mímica y la danza. La pintura se une así a los textos literarios y Kandinsky entra en contacto con el mundo del teatro, que por aquel entonces también apuntaba hacia la renovación artística. Poco después de esta primera exposición, Kandinsky asume la presidencia del grupo ${ }^{15}$ y sus intereses se verán directamente reflejados en la segunda, que, tan vanguardista como la primera, tiene lugar en enero de 1902. Dicha exposición se dedica por entero al ideal de la obra de arte total, remarcando con manifestaciones artísticas tan variadas como jarrones y cuadros, la síntesis de las artes y las reminiscencias a la Gesamtkunst wagneriana.

La crítica no es buena: la primera exposición es tachada de «hipermoderna» y apenas tiene visitantes. En la segunda, los críticos catalogan a Kandinsky de "colorista ruso» y le acusan de querer pintar sólo con color: «[Kandinsky] emplea una mezcla de fuegos artificiales de todos los colores y los aplica a las diferentes técnicas, óleo, témpera y barniz, y por desgracia son tan estridentes, que al final casi no se ve el mismo cuadro». ${ }^{16}$ La quinta y sexta exposición adquieren cierta resonancia en las revistas de arte, a lo mejor por la presencia de obras de Ignacio Zuloaga y Jan Toorop, conocidos en la época. Kandinsky

14 Kandinsky, Kandinsky und ich, p. 43.

15 Como queda recogido en la revista de la época Kunst für Alle, número 17, 1902, p. 90.

16 Реснт, Die Kunst für alle., p. 284 (número 17). 


\section{El proyecto de Kandinsky}

incluye obras de Zuloaga por la cercanía a su idea de síntesis, obras muy reveladoras para su propósito artístico: Zuloaga pinta en colores poco convencionales e incluye en sus pinturas escenas de danza, de teatro y hasta de corridas de toros.

Las revistas de arte (en especial Kunst für Alle) no se reconcilian con Phalanx hasta la novena exposición, en enero-febrero de $1904 .{ }^{17}$ Y no precisamente porque la crítica hubiera por fin entendido las aspiraciones sintéticas de Kandinsky (la exposición de diferentes artes que expresan un contenido común), sino más bien porque entendieron que, por fin, Kandinsky había sabido separar el color de la forma. Kandinsky presenta en esa exposición diez dibujos a todo color, por un lado, y tres grabados en madera por el otro, donde predominaban (habitual en un grabado en madera) las líneas y las formas. Esa separación de color y forma fue vista por la crítica como un buen camino hacia la pintura del futuro, acentuada además por la presencia del joven Alfred Kubin (26 años), que tuvo su hueco en la novena exposición de Phalanx.

El éxito relativo de esta exposición anima a Kandinsky a no tirar la toalla, aunque sólo en cierta medida: «Siento que mi interés por la asociación disminuye, y que cada vez tengo menos ganas de ocuparme de todo yo solo» ${ }^{18}$. Para dar un nuevo impulso a la asociación y a sí mismo, decide alquilar una nueva sala de exposiciones en la distinguida Theatinerstraße, en pleno centro de Múnich. Predominan ahora los cuadros de Monet y de muchos neoimpresionistas, con la intención de acercarse más al público. Pero la crítica se muestra indiferente, en ésta y en el resto de exposiciones (hasta doce).

Phalanx tuvo en general pocos visitantes y para Kandinsky fue una decepción. Al concluir la undécima exposición, Kandinsky abandona la presidencia y a finales de 1904 se disuelve definitivamente el grupo. Parece que el ambiente aún no está maduro para aceptar un arte de ideas tan novedosas como las de Phalanx: «un modo de cultivar el arte completamente diferente, un eclecticismo y una formación mucho más abierta» ${ }^{19}$ que la existente.

Algo mejor le fue a la escuela de pintura que llevaba el mismo nombre, Phalanx, pero sólo porque las clases de Kandinsky tienen éxito (no así las de otros profesores). Kandinsky usa métodos poco convencionales, como irse de

17 Véase Schwartz, Die Kunst für alle., p. 270 (número 19).

18 KLeINe, Gabriele Münter und Wassily Kandinsky, p. 196.

19 Kandinsky, Mirada retrospectiva, p. 25. 
excursión en bici por los campos de Baviera para que sus alumnos tengan más variedad de luz, colores y formas. La idea de Kandinsky es recoger el mayor número posible de impresiones para luego poder utilizarlas en la expresión de su arte. Algo similar a lo que él hacía desde niño en sus viajes gracias a la visión eidética: coleccionar impresiones y almacenarlas en una especie de "baúl interior" que sirvieran después de contenido artístico. Sus clases estaban llenas, Kandinsky tenía fama de ser buen profesor: «En realidad no es nada bueno haber tenido a Kandinsky como maestro, porque después ya no se está contento con ningún otro» ${ }^{20}$, dice Emmy Dresler, amiga de Gabriele Münter y ambas alumnas de Kandinsky en Phalanx. ${ }^{21}$

El método de Kandinsky es innovador, su pedagogía adecuada y su madurez fuera de lo común. A estos aspectos ayudaba la idea que tenía Kandinsky de sistematizar sus conocimientos sobre el arte, de escribir y recopilar una teoría artística, como se verá después en sus futuros libros, De lo espiritual en el arte y Punto y línea sobre el plano. Esta "gran seriedad artística», como la denomina Gisela Kleine, la tenía hacia el arte y hacia los artistas, hombres y mujeres por igual. Y es que en la época no era habitual que las mujeres visitaran escuelas de pintura, se dudaba incluso de que pudieran llegar a tener aptitudes para ello. Simplicissimus, sin ir más lejos, estaba llena de caricaturas sobre las mujeres que iban a la universidad o se dedicaban al arte. ${ }^{22}$

Así que, aunque Phalanx no obtuvo resultados brillantes, sí sirvió para dar a conocer nuevas ideas o para favorecer el arte de las mujeres (como Gabriele Münter, sin ir más lejos). A Kandinsky, Phalanx le ayudó a exponer al público sus cuadros y a adquirir experiencia como galerista; pero sobre todo, le permitió conocer a artistas internacionales y de todas las disciplinas, ampliando su horizonte y completando su idea de una obra de arte sintética. El carácter ecléctico de Phalanx y la posibilidad que le ofrece de trabajar en diferentes campos, es algo crucial para el proyecto artístico de Kandinsky.

20 Carta de Emmy Dresler a Gabriele Münter el 25 de julio de 1907, en KLEInE, Gabriele Münter und Wassily Kandinsky, p. 150.

21 Es aquí, en las clases de Phalanx, donde se encuentran Kandinsky y Münter. Para conocer detalles de su encuentro y relación amorosa se puede leer el capítulo 6 de KLEInE, Gabriele Münter und Wassily Kandinsky o la página 44 y siguientes de Kandinsky, Kandinsky und ich.

22 Véanse los artículos de F. von Reznicek (año 4, núm. 24, p. 189), E. Thöni (año 7, núm. 8, p. 59) o B. Paul (año 7, núm. 49, p. 388). 


\section{El proyecto de Kandinsky}

\subsubsection{Los viajes y la NKVM}

Disuelta en 1904 la asociación Phalanx y clausuradas las clases de la escuela, incluidas las de Kandinsky que se alargaron un poco más, nada retiene a Kandinsky en Múnich. Algo decepcionado por el poco éxito de Phalanx pero convencido de que el arte había de renovarse y de que necesitaba nuevas normas (recuérdese: principios del siglo xx), Kandinsky decide viajar. Como cuenta Nina Kandinsky en sus memorias, ${ }^{23}$ más que por ganas de viajar, fue impulsado por la necesidad de encontrar nuevas ideas para su arte, nuevos colores y nuevos efectos de la luz. Entre 1904 y 1908 Kandinsky viaja solo a su Rusia natal y, acompañado de Gabriele Münter, visita varias ciudades de Italia, Francia, Suiza y Holanda. De diciembre de 1904 a abril de 1905 tiene lugar el viaje a Túnez en el que a Kandinsky parecen «estorbarle» los objetos. Los colores del desierto de Túnez influyen en su paleta de color y la prohibición islámica de la representación figurativa le estimula la idea de que el objeto no es imprescindible.

A Múnich regresa en 1908, lleno de impresiones internas e imágenes eidéticas, y sobre todo, de colores nuevos. Durante el periodo de los viajes, y gracias a los contactos surgidos a raíz de Phalanx, Kandinsky expone a lo largo y ancho de Europa, lo que empieza a darle reconocimiento: Múnich, Dresde, Berlín (Secesión), Varsovia, Moscú, Roma, París (Salón de otoño), Odessa, etc. De esos años son también sus Poesías sin palabras, un álbum de doce grabados en madera que publica la editorial Stroganov de Moscú. En este álbum se hace aún más patente su idea de síntesis, de arte sintético, al presentar imágenes pictóricas y darles nombre literario. Una forma de llamar la atención sobre que las artes (pintura y poesía en este caso) sólo son diferentes medios para expresar un mismo contenido. Su obra Xilografías, de 1906, incide en la misma línea: son grabados en madera que funcionan como poemas visuales. Para acentuar la idea de síntesis, Kandinsky utiliza la palabra Xylographie (xilografía) en vez de su sinónima y más frecuentemente usada Holzschnitt (xilografía, grabado en madera), por acercarlo a la palabra Xylophon (xilófono) y darle un baño de sinestesia musical.

A principios de 1909, asentado de nuevo en Múnich con el "baúl interior"

23 Kandinsky, Kandinsky und ich. 
lleno de impresiones que se ha traído de sus viajes y una visión algo más madurada de su estilo artístico, decide dar un nuevo paso en su carrera. La idea parte de Alexej von Jawlensky. Kandinsky funda con él y con Marianne von Werefkin y Gabriele Münter la Neue Künstlervereinigung München (NKvм, Nueva Asociación de Artistas de Múnich), otra asociación artística cuyas exposiciones quieren ser foro para un arte nuevo y revolucionario. Tal como queda recogido en la primera circular de la Asociación, ${ }^{24}$ parten de que el artista no sólo recibe impresiones del mundo exterior, sino que además, va creando un mundo interior con las experiencias que vive (el "baúl interior" de Kandinsky). El artista quiere expresar ese mundo interior de experiencias e impresiones y para ello ha de buscar las formas apropiadas. Aún no se ha definido que esas formas deban ser abstractas (la primera acuarela abstracta de Kandinsky no llegará hasta 1910), pero sí está claro que tienen que liberarse de lo objetivo y de lo secundario para que puedan expresar lo esencial. La solución que proponen desde la NKVM, y a la que según Kandinsky cada vez más artistas se acogen, es una síntesis artística: una manera de entender el arte que reúna las diferentes expresiones y consiga hacer una unidad de ellas, sin que individualmente pierdan la parte que les es esencial. Es decir, que cada arte (pintura, música, danza) conserve sus medios (color, sonido, movimiento) pero que todas expresen el contenido interior del artista. Bajo esta idea, al grupo se unen pintores y escultores, pero también músicos, poetas, bailarines o historiadores del arte, que hacen posible la colaboración de las diferentes disciplinas.

La Asociación cuenta con un buen mecenas que organiza las exposiciones, Hugo von Tschudi, por aquel entonces director general de los museos de Baviera. Tschudi consigue para la NKVM la prestigiosa galería Thannhauser. Pero tal y como le ocurrió a Kandinsky con Phalanx, el arte y las ideas que se exhibían eran demasiado novedosas y las exposiciones de la NKVM disgustan unánimemente a público y crítica. Franz Marc dice: «En Múnich, los primeros y únicos defensores de las nuevas ideas eran dos rusos [Kandinsky y Jawlensky], que vivían aquí y trabajaban sin notoriedad, hasta que se les unieron algunos alemanes. Con la fundación de la Asociación comenzaron esas exposiciones extrañas, atractivas que traían de cabeza a los críticos» ${ }^{25}$.

24 Salmen, Wassily Kandinsky-Gabrielle Münter, p. 25.

25 Kandinsky, Kandinsky und ich, p. 48. 


\section{El proyecto de Kandinsky}

Marc visita la exposición que muestra, por citar algunas, obras de Kandinsky, Georges Braque, Pablo Picasso, André Derain o Maurice de Vlaminck y queda tan entusiasmado que se une a la NKVM inmediatamente. Aquí comienza la amistad intensa entre Kandinsky y Marc, que fue una base extraordinaria para sus proyectos en común, en especial El Jinete Azul. ${ }^{26}$

Salvo por Marc y alguna otra excepción, el clima de aceptación de la NKVM era hostil. El corresponsal del periódico Münchner Neueste Nachrichten escribió, por ejemplo, que «o aceptamos que la mayoría de los miembros e invitados de la Asociación son unos locos sin remedio o asumimos que se están tirando un farol con todo el descaro, aprovechando la coyuntura y la necesidad de sensacionalismo de nuestro tiempo» ${ }^{27}$. El ideal de Kandinsky se queda, en este ambiente, a medio gas. Más aún cuando en 1911, Kandinsky conoce a Schönberg en aquel concierto del 2 de enero y se le abren las puertas de la pintura abstracta a través de la música atonal. Los cuadros de Kandinsky comienzan a renunciar a lo figurativo y la opinión del jurado de la Asociación comienza a dividirse. A un lado, los "vanguardistas" (Kandinsky, Marc, Münter); al otro, los “anti-abstractos" (Erbslöh, Kanoldt, Wittenstein); y en medio, Jawlensky, el origen de la Asociación, amigo de la idea de síntesis artística pero que jamás pintó un cuadro abstracto. Las diferencias parecen insalvables y Kandinsky deja la presindencia de la NKVM. Marc prevé entonces que el jurado de las exposiciones poco va a tardar en rechazar las obras de Kandsinsky, así se lo cuenta a August Macke en una carta: «Puedo prever claramente, con Kandinsky, que el próximo jurado (a finales de otoño) será la ocasión para un gran altercado, y que ahora o la próxima vez habrá una separación, o incluso la dimisión de alguien de esta parte o de la otra, y entonces la cuestión será, quién es el que se queda ${ }^{28}$. Tal y como había previsto Marc, el jurado rechaza para la tercera exposición de la NKVM el cuadro de Kandinsky Composición v, ya cercano a la abstracción. Kandinsky, Marc, Münter, Alfred Kubin, el compositor Thomas von Hartmann y Henri Le Fauconnier abandonan la Asociación. ${ }^{29}$ Kandinsky

26 La mejor manera de acercarse a la relación entre Kandinsky y Marc es, además de algunas monografías, a través de su correspondencia: LANKHeIt, Kandinsky-Marc: Briefwechsel.

27 Recogido en Kandinsky, Kandinsky und ich, p. 50.

28 Carta del 10 de agosto de 1911. En Macke, August Macke-Franz Marc, p. 65.

29 Sobre los hechos que rodean la salida del grupo de la NKVM se recomienda leer la carta de Maria Marc a August Macke del 3 de diciembre de 1911, en la que ella cuenta de primera mano cómo transcurrieron los días previos y lo que desencadenó la decisión del jurado. 


\subsection{El camino a la abstracción}

tiene el camino libre para dedicarse a su idea del arte, sin trabas que pretendan atarlo al arte figurativo. En breve surge el almanaque El Jinete Azul o su sintética obra de teatro La sonoridad amarilla.

\subsubsection{El Jinete Azul}

La idea del almanaque El Jinete Azul surge, en realidad, antes de que Kandinsky se separara de la NKVM. El 19 de junio de 1911 Kandinsky escribe una carta a su íntimo amigo Franz Marc contándole lo que tiene en mente: «iAtento! Tengo un nuevo plan. Piper tiene que encargarse de la edición y nosotros dos seríamos los redactores. Un tipo de almanaque (anual) con reproducciones y artículos... y iicrónica!! [sic], es decir, informes sobre crítica de exposiciones, que sólo escribieran los artistas.» ${ }^{30}$ Marc siente al instante el plan como suyo y ambos lo llevan en secreto, al menos durante el tiempo en el que siguen perteneciendo a la Asociación: "[Kandinsky a Marc] No hable sobre ello. (...) En estos casos, la discreción es muy importante». Así que su salida de la NKVM no les deja con las manos vacías sino más bien, con el tiempo y la libertad necesarias para llevar a cabo su proyecto.

La idea y objetivo que al final presentó el almanaque no difiere apenas de la idea primigenia que Kandinsky le traza a Marc en esa carta. El almanaque es un libro que recoge aportaciones de diversos artistas (y sólo de artistas) ${ }^{31}$ y que quiere presentar el panorama artístico del momento en una publicación anual (de ahí que se le llame almanaque). La idea que origina y late de fondo

La historia en sí, o bien la manera tan plástica que tiene Maria Marc de contar las cosas, parece sacada de una novela: hay discursos y bofetadas de por medio, alabanzas futuristas sobre el arte de Kandinsky y enfrentamientos dialécticos sobre la capacidad del jurado. El rechazo del cuadro de Kandinsky no fue sólo, como Paul Overy apunta, porque el cuadro fuera muy grande («ostensibly because it [the painting] was too big»). La carta de Maria Marc puede leerse en MaCke, August Macke-Franz Marc, pp. 83-86, y el comentario de Overy en Overy, Kandinsky, p. 19.

30 LANKHeit, Kandinsky-Marc: Briefwechsel, p. 40.

31 La insistencia de que las críticas y aportaciones sólo fueran escritas por artistas viene de la discusión final de la NKvм. Cuando el jurado rechaza el cuadro de Kandinsky, oficialmente porque sobrepasa $2 \mathrm{~cm}$ el tamaño permitido pero realmente porque no entiende el cuadro (léase la carta de Maria Marc ya citada), Kandinsky se enfurece porque alguien que no entiende de arte (Wittenstein, por ejemplo) pueda decidir sobre el "destino" de obras artísticas. Por eso hace hincapié en que los colaboradores de El Jinete Azul sean sólo artistas. 


\section{El proyecto de Kandinsky}

en el libro es la piedra angular en la teoría de Kandinsky: una obra artística que aglutine el trabajo de las diferentes artes, cada una con sus medios pero demostrando que parten de un interior común. Es la «idea de la gran síntesis», como la llamaba Kandinsky. ${ }^{32}$

La idea de síntesis se refleja en la pluralidad de estilos y contribuciones que reúne el almanaque. Kandinsky y Marc son los editores principales, es decir, los únicos que deciden sobre el contenido de El Jinete Azul. La primera norma que se autoimponen es que el almanaque recoja obras de arte de todos los estilos, y no sólo del pictórico. La única condición es que todas expresen ese contenido interior común a todas las artes. Así se entienden las esculturas africanas, la música («Schönberg tiene que estar»), la religión («traeremos algo sobre el movimiento religioso ruso»), las vidrieras, los dibujos japoneses, la danza, la Teosofía ( «hay que mencionar a los teósofos de manera breve y consistente»), artículos sobre el arte y, por supuesto, reproducciones de cuadros. La segunda norma es que el carácter de El Jinete Azul sea internacional. Participan franceses como Le Fancounnier, rusos como Thomas von Hartmann y el propio Kandinsky, Schönberg desde Viena; Kahnweiler envía fotos desde París de los cuadros de Picasso y Matisse aprueba la reproducción de su obra. Lo que consiguen Marc y Kandinsky con El Jinete Azul, reunir obras tan importantes como internacionales y variadas a principios del siglo $\mathrm{xx}$, no fue un proceso sencillo, sobre todo porque muy poca gente creía en la idea. Kandinsky lo confirma años después en una carta al director de la revista Das Kunstblatt, Paul Westheim, en la que le describe en forma de retrospectiva la formación y desarrollo del almanaque: «Hoy [1930] puede parecer extraño que no hallara colaboradores, medios o, simplemente, interés suficiente por esta idea» ${ }^{33}$, pero así fue.

Tras meses de mucho trabajo, como se refleja en la correspondencia entre Marc y Kandinsky a lo largo de 1911, El Jinete Azul va cogiendo forma. Ellos mismos se hacen cargo en un primer momento de toda la financiación: por un lado, porque el editor Reinhard Piper no está muy seguro del éxito que pudiera tener; pero por otro, porque si Piper se involucra económicamente, también tendría derecho a decidir sobre la redacción, algo que ni Marc ni Kandinsky quieren. ${ }^{34} \mathrm{Al}$ final fue Bernhard Koehler, tío de la mujer de August

32 Kandinsky, Kandinsky und ich, p. 63.

33 KANDINSKY, Escritos sobre arte y artistas, p. 124. 
Macke, quien corre con los gastos. En mayo de 1912, Piper publica en Múnich El Jinete Azul.

La salida de la NKVM y la preparación del almanaque fueron además un punto de partida para organizar exposiciones. «La suerte está echada», escribe Franz Marc a su hermano, «Kandinsky y yo hemos dejado la Asociación. ¡Ahora nos toca a nosotros dos seguir luchando! Vamos a intentar convertirnos en el centro del movimiento moderno». ${ }^{35}$ Durante la confección del almanaque, Marc y Kandinsky organizan dos exposiciones con parte del material recogido, con el mismo título y con los mismos planteamientos de síntesis. Obras de Campedonk, Macke, Rosseau, Schönberg o Delaunay para la primera exposición, inaugurada el 18 de diciembre de 1911. Marc aporta sus cuadros La vaca amarilla y Caballo azul, desafiando las fronteras de la naturaleza y la teoría del color. Kandinsky presenta como obra central su casi abstracta Composición v, la misma que había desatado la polémica en la NKVM. Hugo von Tschudi ayuda a Kandinsky y a Marc con la localización y les consigue tres salas de exposición también en la Galería Thannhauser, lo que ocasionó la paradójica situación de que la NKVM y sus “desertores” de El Jinete Azul expusieran pared con pared.

La segunda exposición, marzo de 1912, se muestra en la galería de Hans Goltz bajo un título más específico: "Segunda exposición de la redacción de El Jinete Azul". Cuenta con 135 obras de autores variados, renombrados y de nuevo internacionales: Arp, Bloch, Braque, Delaunay, Vlaminck, Marc, Heckel, Kandinsky, Kirchner, Klee, Kubin, Larionoff, Macke, Malévich, Münter, Nolde, Pechstein o Picasso son algunos de los nombres. A pesar de que la mayoría de estos artistas confiaban en la idea de síntesis de Kandinsky y Marc, conseguir que colaboraran tantos no debió de ser nada fácil, especialmente si se tiene en cuenta que la primera exposición no fue lo que se dice un éxito. Los visitantes escasearon, la crítica ni siquiera consideró necesario escribir recensiones y la gente se expresaba en términos de "birria", "escándalo" o "barbaridad" ${ }^{36}$

La cuestión del título de la segunda exposición no es baladí, y a menudo se

34 Así se desprende de una carta que escribe Marc a Macke el 9 de noviembre de 1911, en Macke, August Macke-Franz Marc, p. 77.

35 Kandinsky, Kandinsky und ich, p. 55.

36 KLeIne, Gabriele Münter und Wassily Kandinsky, p. 385. 


\section{El proyecto de Kandinsky}

pasa por alto el porqué del cambio (de "El Jinete Azul" a "Segunda exposición de la redacción de El Jinete Azul"). ${ }^{37}$ El cambio obedece a una ligera confusión que se estaba fraguando, y que desgraciadamente fraguó, sobre si El Jinete Azul era un grupo o no. El primero que lanza el desconcierto es Herwarth Walden, el crítico, galerista y -entre otras cosas- también fundador de la revista Der Sturm. Walden lleva a Berlín la primera exposición de El Jinete Azul, primavera de 1912, pero modificando ligeramente la idea original. A la exposición añade, por ejemplo, cuadros de Jawlensky y Werefkin, que aunque cercanos en amistad al círculo de Marc y Kandinsky, nunca formaron parte de El Jinete Azul (ni de las exposiciones ni del almanaque) y que, para más inri, seguían perteneciendo a la NKVM. La segunda exposición en Múnich quiso aclarar la relación directa entre la redacción de El Jinete Azul y la muestra, y por eso llevó el título específico de "Segunda exposición de la redacción de El Jinete Azul”. Kandinsky y Marc querían dejar claro, de algún modo, que ellos dos eran los editores y realizadores de la idea y que no había ningún movimiento como tal llamado El Jinete Azul. ${ }^{38}$

Walden volvió a presentar en el Primer Gran Salón de Otoño en Berlín la segunda exposición muniquesa de El Jinete (1913). Esta vez le dio el título de "Círculo de amigos de El Jinete Azul", que volvió a sembrar confusión no sólo porque el almanaque ya se había publicado y no coincidía con la exposición, sino porque además incluyó a antiguos miembros de la ya entonces disuelta NKVM, que ni por asomo pertenecían al círculo de Kandinsky y compañía.

Los errores de Herwarth Walden fueron, según Nina Kandinsky, probablemente involuntarios. $Y$ es posible que la solidaridad que mostraron ciertos artistas con Kandinsy cuando éste salió de la NKVM, se interpretara como la creación de un grupo. A lo mejor porque ambas exposiciones, en sendas galerías de Múnich, y la publicación del almanaque por la editorial Piper (también muniquesa), llevaban el mismo nombre. El caso es que, por una razón u otra, todos esos factores han hecho creer a críticos y especialmente a los historiadores del arte posteriores, que en la capital bávara había nacido un nuevo grupo

37 Obsérvese que la cursiva es intencionada y tiene su razón: El Jinete Azul es el nombre de una obra (el almanaque) y por tanto, para ser consecuente con el resto de títulos de obras, va en cursiva. El Jinete Azul, sin cursiva, se refiere al nombre de la exposición.

38 Hay que reconocer que el asunto no es tan sencillo, porque el almanaque El Jinete Azul no salió publicado hasta mayo de 1912. Es decir, las exposiciones fueron anteriores pero en ellas se habla de la "redacción de El Jinete Azul". 
artístico. Se le denominó El Jinete Azul, en honor a las exposiciones y al libro, pero ese grupo nunca existió como tal. Aunque la recopilación de Kandinsky y Marc pudo poner en contacto a más de un autor, no hubo encuentros de grupo, ni una concepción grupal. El objetivo de Marc y Kandinsky pasaba por exponer el panorama artístico en torno a la idea de síntesis. Después, para el proyecto en concreto de un almanaque se fueron adhiriendo artistas. La idea de El Jinete Azul como grupo está hoy tan extendida y asimilada que parece imposible modificarla, pero vale la pena intentarlo con tres citas que lo dejan bien claro.

La primera sale de las conversaciones de Gabriele Münter con Edouard Roditi: «Éramos sólo un grupo de amigos (...), estábamos muy lejos de considerarnos un "grupo" o una "escuela” (...), nunca fuimos tan pragmáticos» ${ }^{39}$. La segunda viene de la voz de Nina Kandinsky: «El Jinete Azul no era un grupo de artistas, sino el título del almanaque que Kandinsky y Marc editaron juntos. Y para las dos exposiciones que organizaron Marc y Kandinsky tras su salida de la Nueva Asociación de Artistas, se tomó el nombre del libro» ${ }^{40}$. Y la tercera, y más clara, del propio Kandinsky: «En realidad nunca hubo una asociación "El Jinete Azul", tampoco ningún grupo, como a menudo se escribe, erróneamente. Marc y yo hacíamos lo que nos parecía acertado, lo que escogíamos libremente, sin que nos importara cualquier otra opinión o deseo alguno. Así decidimos dirigir nuestro Jinete Azul de una manera "dictatorial”. Los dictadores éramos, claro está, Franz Marc y yo» ${ }^{41}$. Marc y Kandinsky, Kandinsky y Marc, únicos representantes y creadores de lo que hoy se llama "El Jinete Azul".

Fieles a su idea de almanaque anual, empiezan a recopilar material para un segundo volumen, que debería ver la luz en 1913. Basándose en la misma idea de síntesis, la segunda parte de El Jinete Azul prentedía reflejar el panorama científico de la época que tanto influía en Kandinsky: «Mi plan para el siguiente libro de El Jinete Azul era la yuxtaposición de arte y ciencia: su origen, su evolución en el modo de trabajo y su finalidad $»^{42}$. Pero entonces estalló la Guerra y truncó todos los planes. Marc cae en Verdún y tras su muerte,

\footnotetext{
39 Roditi, Dialoge über Kunst, p. 214.

40 Kandinsky, Kandinsky und ich, p. 58.

41 En una carta dirigida a Paul Westheim, editor de Das Kunstblatt, y publicada en el número 14 (1930). Las comillas y las cursivas son originales.

42 KANDINSKY, Escritos sobre arte y artistas, p. 126.
} 


\section{El proyecto de Kandinsky}

Kandinsky se niega a continuar con El Jinete. La siguiente cita vuelve a dejar claro que no había grupo como tal: «El Jinete Azul éramos dos: Franz Marc y yo. Mi amigo está muerto y yo solo no quiero hacerme cargo» ${ }^{43}$. Dado que no había grupo que respondiera por el proyecto y que Kandinsky se negaba a continuar, la historia de El Jinete Azul termina en su primer y único ejemplar.

\subsubsection{Las publicaciones}

El primer libro que escribe Kandinsky es De lo espiritual en el arte, un libro que se publicó a finales de 1911 pero que llevaba tiempo escrito y guardado en un cajón. ${ }^{44}$ El primer manuscrito que se conserva es un ejemplar ya mecanografiado y fechado en Murnau el 3 de agosto de $1909 .{ }^{45}$ Tiene abundantes notas a mano, difíciles de datar con exactitud, pero que sí indican el carácter que tuvo el libro desde un principio. Nació como recopilación de apuntes teóricos, elaborados a raíz de las clases de pintura, de la propia experimentación o de lo vivido en los años de los viajes.

El libro necesitó un tiempo hasta que los apuntes teóricos tomaron forma de publicación. Pero después, aún tuvo que reposar un par de años porque Kandinsky no encontraba editor que apostara por el proyecto. Franz Marc consigue convencer a Reinhard Piper, el editor muniqués, de que las ideas de Kandinsky eran el futuro: «el arte de Kandinsky es tan profético como sus palabras; (...) Kandinsky es realmente el punto central de todo el movimiento (...) ¿Cómo no querer escuchar lo que dice?» ${ }^{46}$ Piper, finalmente, se lanza a publicarlo en diciembre de 1911. El libro lleva sin embargo fecha de enero de 1912 (lo que a veces ha dado pie a confusión) por la costumbre de que los libros que salían a finales de año llevaran la fecha del siguiente y pudieran ser

43 Kandinsky y Marc, Der Blaue Reiter, p. 284.

44 Como ya se comentó en una nota al pie anterior (número 9, en el capítulo 2), dos notas en el prólogo lo aclaran, en las páginas 16 y 8 respectivamente: «Las ideas aquí desarrolladas son resultado de observaciones y experiencias que he acumulado en el curso de los cinco o seis últimos años» $\mathrm{y}$ «De lo espiritual en el arte estuvo terminado y guardado durante varios años en mi cajón».

45 Murnau es el pueblo bávaro donde Gabriele Münter y Kandinsky compran una casa hacia 1909. El manuscrito se conserva hoy en la Fundación Gabriele Münter y Johannes Eichner. Véase Lindsay y Vergo, Complete Writings on Art, p. 114.

46 Buergel-Goodwin y GöBel, Reinhard Piper: Briefwechsel, p. 123. 
considerados “nuevos” doce meses más.

La publicación de De lo espiritual en el arte coincide con la primera exposición de El Jinete Azul, pero a diferencia de ésta, el libro es un éxito instantáneo. Artistas, críticos y universitarios hablan del libro; pronto se convierte en un mito al que se cita aquí y allá, aunque algunos -al parecer- ni siquiera lo habían leído. Piper imprime una segunda edición ese mismo año, 1912, en la que se modificaron sólo un par de párrafos y algún que otro cambio estilístico menor. Hoy suele considerarse esta edición como la estándar, sobre todo porque la tercera edición de 1913 no difiere de la segunda. Aunque la cuarta edición no pudo llevarse a cabo por el estallido de la guerra, Kandinsky siempre contempló De lo espiritual... como parte de una especie de Armonía de la pintura y por tanto como un libro en constante revisión. Prueba de ello es un manuscrito que se ha encontrado en su estudio de Neully y que lleva por título Kleine Änderungen zum, Geistigen' (Pequeños cambios para “De lo espiritual"). ${ }^{47}$

Curiosamente, un libro que nació a raíz de apuntes teóricos, con cierta falta de unidad y bajo la lupa de una revisión constante, constituye el libro más importante de Kandinsky. Las ideas que presenta en De lo espiritual en el arte eran tan novedosas y revolucionarias para el arte como lo estaba siendo la física cuántica para la ciencia, o las nuevas disonancias para la música. El libro encaja bien en la época, Kandinsky se amolda a la necesidad de ofrecer algo nuevo. Introduce en el campo de la pintura conceptos poco habituales, como espiritual o efectos psicológicos del color y la forma, y lo determinante es que lo hace desde un punto de vista teórico y analítico. Kandinsky ofrece en el libro su propia teoría del color, con ligeras reminiscencias goetheanas pero principalmente cargada de innovación. El vínculo especial que le une al color está presente, así como un cierto tono místico que recuerda la relación sentida que tiene Kandinsky con el mundo. No en vano, el mismo título del libro contiene la palabra espiritual.

La teoría del color de Kandinsky es uno de los puntos clave en la interpre-

47 Kandinsky se asentó en Neully, Francia, tras la clausura de la Bauhaus (1933) y permaneció allí hasta su muerte. Kenneth Lindsay ha publicado pasajes del manuscrito en The Genesis and Meaning of the Cover Design for the first Blaue Reiter Exhibition Catalogue, páginas 49-52. En la traducción inglesa de De lo espiritual... que publica George Wittenborn Inc. en 1947 (Nueva York), también se incluyen alguno de esos "pequeños cambios", pero por desgracia sin especificar qué pertenece a la edición estándar y qué al manuscrito de Neully. 


\section{El proyecto de Kandinsky}

tación del arte abstracto, como se verá en el capítulo 5. El color se hace con el protagonismo: la teoría analiza el efecto de cada color por sí mismo y en combinación con las variaciones de la forma. También considera la influencia del color sobre el alma humana: sus efectos psicológicos, su capacidad para despertar sensaciones (y no sólo visuales) o para convertirse en una puerta al mundo espiritual. El color adquiere en De lo espiritual en el arte una nueva dimensión. Ya no es un elemento más, sino el gran medio pictórico. Kandinsky es consciente del potencial que tiene el color, pero en estas primeras ediciones de De lo espiritual... aún no está convencido de que usando exclusivamente los medios pictóricos, es decir, formas abstractas de colores, se pueda llegar a la creación de un arte pleno. Harán falta un par de años y escritos, para que dé por buena la idea de que el arte basado únicamente en forma y color, sí es posible.

Unos meses después de que De lo espiritual en el arte vea la luz, Piper publica el almanaque de Marc y Kandinsky, El Jinete Azul. Kandinsky participa en el almanaque con tres escritos: dos ensayos teóricos y una obra de teatro. Tras unas palabras a modo de obituario por Eugen Kahler, el artículo con el que abre el almanaque es el primer ensayo de Kandinsky y uno de los que más peso tiene en la obra. El artículo lleva por nombre Sobre la composición de la forma y es, en efecto, un análisis teórico sobre ese medio pictórico: la forma. Aunque presentado como artículo y no como libro independiente, el análisis que hace Kandinsky de la forma merece la misma importancia que su teoría del color en De lo espiritual... De hecho, él mismo plantea el artículo como un «complemento sobre la evolución posterior» ${ }^{48}$ de las ideas que expone en De lo espiritual en el arte.

El segundo artículo de Kandinsky incluido en el almanaque es un ensayo teórico acerca del mundo del teatro. Con el título Sobre la composición escénica, el artículo estaba pensado como prefacio a la obra de teatro con la que Kandinsky también colabora, aunque por su profundidad y rigor, al final obtiene un lugar propio dentro del almanaque. El nombre de esa obra de teatro es $L a$ sonoridad amarilla, una obra que no deja indiferente, y menos a principios del siglo xx. No porque le diera fama (que no), ni porque su representación fuera un éxito (que tampoco). En realidad, en aquella época no llegó a representarse,

48 Kandinsky, De lo espiritual en el arte, p. 17. 
y aunque algunos artículos de El Jinete Azul-como Sobre la composición de la forma- tuvieran cierta repercusión, la recepción general se llenó del mismo escepticismo e incomprensión que tenían los cuadros abstractos de Kandinsky o las composiciones de Schönberg.

Kandinsky empieza a escribir La sonoridad amarilla en 1909. Inmerso en la idea de arte como síntesis que ha presentado en Phalanx y que llevará al almanaque, proyecta una obra de arte total donde se combinan las diferentes artes. Así nace La sonoridad amarilla, un nuevo modelo artístico. Una obra de síntesis en la que se dan cita la música, la danza, la poesía y la pintura. Se le ha llamado obra de teatro porque que está pensada para un escenario. Pero también se asemeja a una ópera por su música y canto, o a un cuadro por su uso del color. Y sin embargo, en el momento en el que se empieza a leer o ver la obra, las similitudes se alejan. Los personajes son cinco gigantes, un hombre, un niño, seres indistintos (sic), gente con ropas amplias, gente con ropas ajustadas y un coro. Es difícil imaginarse una obra de teatro clásica con estos ingredientes. La obra tiene una introducción y seis escenas a modo de impresiones paisajísticas, de cuadros que se han hecho reales. Pero no hay argumento, no hay una historia: el transcurso de la obra es puro juego de luces, de colores, de música, cantos del coro, acordes confusos de orquesta, movimientos de personas y objetos, sonoridades indeterminadas.

Los elementos propios de cada arte están presentes en la obra. La música con el sonido; la danza, con el movimiento; la pintura con el color y la poesía con el lenguaje. Para la composición musical, Kandinsky piensa en Thomas von Hartmann, que sí compone la música pero no llega a dirigir la representación (a causa de la Guerra). Aun sin poder ver la obra, las anotaciones escritas de Kandinsky dejan una idea bastante clara de cómo es: acordes disonantes, fusión de notas dispares como un La grave y un Si agudo sonando a la vez, música agitada, contradictoria, estridente, atormentada: «La música cambia de tempo y en ocasiones también se vuelve lánguida»; "comienza a sonar la música, primero en los agudos. Luego pasa directamente y muy rápido a los sonidos graves.» ${ }^{49}$

El movimiento tampoco se ajusta a la clásica compensación de espacios

49 Las citas de La sonoridad amarilla son de la traducción al español que se ha publicado en Kandinsky, Mirada retrospectiva, pp. 176-186. 


\section{El proyecto de Kandinsky}

del mundo del teatro: se pasa del movimiento violento a la completa inmovilidad, los personajes se agrupan de manera heterogénea, movimientos súbitos y de repente pausas destacadas: «cada grupo hace movimientos diferentes», «la muchedumbre se acerca lentamente, como en sueños», «liberándose violentamente de su propia rigidez», «inmovilidad general».

El color, no podría ser de otra manera, se presenta de una manera intensa: los colores están definidos, como si estuvieran en estado puro. Son colores oscuros y claros, pero siempre vivos y precisos. El color impregna el escenario, los objetos y los personajes, pero también los movimientos y la música son de color. El color no es una propiedad de los objetos, es un ser dentro de la obra, con existencia propia. El color es tan protagonista como el sonido o el hacer de los personajes. "Aparecen cinco gigantes de un amarillo vivo»; «una muchedumbre con largos e informes ropajes de colores vivos (el primero es todo azul, el segundo rojo, el tercero verde, etc. Sólo falta el amarillo).»; «la gente lleva en la mano grandes flores blancas»; "el cielo se vuelve completamente negro»; «la parte anterior de la escena se hace azul»; «la escena se sumerge progresivamente en una fría luz roja»...

Y el último elemento, el lenguaje, tampoco responde al diálogo o monólogo acostumbrado. El coro y los personajes recitan frases, pero a veces sólo emiten meros sonidos guturales. En Escritos sobre arte y artistas, Kandinsky escribe una idea que puede aclararlo: «La palabra, suelta o integrada en frases, se puede utilizar para crear una determinada "atmósfera" que libere el alma para recibir. Asimismo, el sonido de la voz humana se puede emplear de manera pura, es decir, sin estar oscurecida por la palabra y su significado». En la segunda escena de La sonoridad amarilla aparece una voz que «se hace nasal, con entonaciones lentas, o con entonaciones bruscas.» Más adelante, los gigantes «cuchichean entre sí sin hacer ruido» y un hombre dice «muy fuerte, imperativo, con voz bonita “¡Silencio!" " ${ }^{50}$

La innovación que supone La sonoridad amarilla en 1912, cuando se publica, sólo puede traer desconcierto. Si hay alguien capaz de entender la obra, tiene que ser alguien cercano a las ideas de renovación de las artes, alguien que camine paralelamente al desarrollo de la abstracción. Ése alguien no es otro que Arnold Schönberg, que en agosto de 1912 escribe a Kandinsky: «me encanta su composición escénica. (...) La sonoridad amarilla (...) es exacta-

50 KANDINSKY, Escritos sobre arte y artistas, p. 52. 
mente lo mismo que he buscado para mi Glückliche Hand». Die Glückliche Hand, que suele traducirse como La mano bendecida o La mano feliz, es una composición de 1913 en la que Schönberg parece predecir años de abstracción y surrealismo. Es otra obra innovadora, una composición lenta e irregular y un juego constante de luces, sonidos e incluso textiles (como el terciopelo). También mezcla música instrumental con texto, coro y silencio. Un personaje puede hablar, mientras que otros dos son mudos. Y el canto del coro a veces se vuelve hablado, ${ }^{51}$ como si quisiera borrar la frontera entre las artes (poesía y música). Schönberg sí consiguió que su obra se representara, aunque la recepción no fue precisamente buena.

La sonoridad amarilla, por su parte, no llegó a representarse, entre otras cosas porque las exigencias técnicas no estaban a la altura de las posibilidades del momento. Por esta razón, y porque Kandinsky siempre destacó más como pintor, la obra ha quedado en el olvido. Esporádicamente, la obra sale a la luz de la mano de algunos investigadores, aunque pocas veces en profundidad. Claudia Emmert, por ejemplo, tiene un estudio de la obra; pero no encuadrada en el proyecto global de Kandinsky sino con un carácter marcadamente literario o dramático. ${ }^{52}$ En los años 70 hubo dos representaciones en Francia, con música de Anton Webern; en los 80 una en Berlín y otra en Berna. Es difícil saber con exactitud quiénes y cómo las llevaron a cabo, y más aún hacerse con un vídeo de la representación. Pero, aunque ni en 1912 tuviera reconocimiento ni actualmente tenga presencia, no se debe pasar por alto la importancia de La sonoridad amarilla, como primer paso hacia un arte que se despoja del clásico objeto y que se apoya solamente en los medios pictóricos más puros: formas y colores.

Los años que precedieron a la Guerra fueron intensos para Kandinsky. Además de publicar De lo espiritual en el arte y El Jinete Azul, Kandinsky expone en salas de todo el mundo. Sus cuadros se ven en Hamburgo, Moscú, París, Chicago, Nueva York, Amsterdam, Londres o Zúrich, y recogen tantos ataques como apoyos, tanta repulsa como simpatía. Citas originales de la época son,

51 Schönberg inventó esta modalidad de "canto hablado", denominado Sprachgesang.

52 Eмmert, Bühnenkompositionen und Gedichte von Wassily Kandinsky. Jelena Hahl-Koch también realiza un breve estudio sobre las obras de teatro en su monografía Kandinsky, en las páginas 143-151. 


\section{El proyecto de Kandinsky}

por ejemplo: «(...) se reconoce en los variados trabajos de Kandinsky (...) un gran talento de originalidad»; «En la exposición (...) se pueden ver las fantasías de tapicero empapelador de Wassili Kandinski [sic], cuyo sentido más profundo ni siquiera con la ayuda del programa teosófico del pintor pueden desentrañarse»; «(...) ni Marc ni Kandinsky saben lo que hacen. (...) A Kandinsky tampoco le ayuda que sus [cuadros titulados como] "Composiciones" e "Improvisaciones" sean aún más coloristas que antes, porque está claro que ese camino le aparta consecuentemente de las artes plásticas y no se va a querer conformar con su fama de pintor de papel de paredes». ${ }^{53}$

La pintura de Kandinsky empezaba a ir más allá de la mera desatención del objeto o la dilución de las formas. Cada vez se hacía más abstracta, y cada vez tenía un mayor componente teórico detrás. No era un mero juego arbitrario de formas, sino que había escritos teóricos que, cuando menos, sustentaban reflexivamente sus maneras de artista. A los libros comentados se unieron conferencias y charlas, algunas de las cuales se recogerían después en el libro Escritos sobre arte y artistas. Y en 1913, Der Sturm le dedica una exposición monográfica y exclusiva, además de publicarle Mirada retrospectiva. ${ }^{54}$

Con la Guerra Mundial termina su primera época en Alemania, donde no volverá hasta que Walter Gropius lo llame para formar parte de la Bauhaus. El camino a la abstracción que comienza con su primera acuarela abstracta (1910) y que va desarrollándose poco a poco a través de los libros, del almanaque, de los cuadros y de los experimentos con las diferentes artes, ha terminado cuando llega a Weimar en 1922. Durante los años de Múnich (1896-1914) y siguientes, Kandinsky va desprendiéndose del objeto paulatinamente. Las obras de 1910-1914 son explosivas, informales; el color está vivo y domina sobre la forma, que va perdiendo objetividad. Cuando llega a la Bauhaus para ser profesor de pintura mural, su estilo aún evoluciona y cambia, pero ya está consolidado en la abstracción. Los cuadros son geométricos, precisos, tranquilos. Prueba de ello no son sólo sus cuadros, sino su última gran publicación, Punto y línea sobre el plano. El libro es de 1926 y presenta, en su habitual estilo teórico, analítico y didáctico, una extraordinaria teoría de la forma y su uso puramente abstracto en la composición.

53 Las citas son de la revista Kunst für Alle: número 20, p. 213; número 27, p. 362 y número 29, p. 66, respectivamente. La cursiva es añadida, las comillas no.

54 De esta obra y de sus ediciones se habló ya en el capítulo 1: pág. 20, nota al pie 20. 


\subsection{El arte abstracto}

La influencia del contexto de la época y su propia trayectoria artística dirigen a Kandinsky a la creación de un estilo novedoso a principios del siglo xx: el arte abstracto. Las nuevas leyes de la física o las teorías teosóficas amoldan en cierta medida el camino. Pero es la trayectoria personal, marcada por los viajes, las publicaciones, los experimentos, etc., la que crea y hace posible el desarrollo de un arte nuevo. La obra de teatro La sonoridad amarilla o las teorías artístico-espirituales de sus libros y artículos no son puros coqueteos intelectuales. Son más bien una exploración de las fronteras y posibilidades del arte, y obedecen a una idea interior. Decir que esa idea interior era un plan cuidadosamente trazado por Kandinsky sería absurdo. Kandinsky no tenía desde un principio la idea del arte abstracto como tal. Pero sí había una idea latente de querer hacer algo nuevo, de querer ofrecer un arte que se ajustara a los nuevos tiempos, de querer expresar una realidad interior que hasta entonces no tenía voz en la pintura. Hasta que supo cómo hacerlo y hasta que la idea dejó de ser difusa para ganar en claridad, pasó un tiempo: son los años del camino a la abstracción que acaban de presentarse.

El proceso que lo llevó hasta el arte abstracto no fue un desarrollo ni previamente planificado ni lineal. No hubo un desarrollo teórico previo al que le siguiera una composición práctica, sino que teoría y praxis se iban retroalimentando. De la misma época son La sonoridad amarilla (práctica), la Primera acuarela abstracta (práctica) y De lo espiritual en el arte (teoría). Tampoco fue un desarrollo ordenado en el que el objeto iba desapareciendo: en el proceso hay saltos cualitativos, hay objetos que desaparecen y luego reaparecen y también hay suaves transiciones. Aún así, hay cierta progresión en los planteamientos, hay una idea interior que va clarificándose y un camino que seguir, aunque éste a veces tenga que ir en zig zag.

Los acontecimientos que acompañan ese camino hacia la abstracción son muchos y variados. A lo largo de estas páginas se han ido exponiendo contextual y paulatinamente con la idea de formar un enjambre de ideas, una base que permita entender ahora el punto de inflexión en el que se encuentra Kandinsky. Evidentemente, no se trata de un momento puntual en el tiempo sino de un punto de inflexión en su planteamiento artístico. En torno a 1909-1912 (son los años de La sonoridad amarilla, las teorías de Lipps y Steiner, De lo espiritual en el arte, el encuentro con Schönberg o El Jinete Azul) hay una 


\section{El proyecto de Kandinsky}

especie de reconocimiento, de darse cuenta de que el arte tiene que cambiar. Kandinsky observa cuatro aspectos ineludibles:

a. el arte necesita un nuevo lenguaje. Si las leyes de la física clásica no pueden explicar lo que sucede en el mundo microscópico, el arte actual es incapaz de dar respuesta a los nuevos acontecimientos del siglo xx. El arte precisa un lenguaje que hable el idioma actual. Pero, ¿cómo construirlo?

b. el nuevo lenguaje no necesita forzosamente el objeto. Monet demuestra en su Almiar que el objeto no es el protagonista del cuadro. El arte islámico (viaje a Túnez) tampoco recurre al objeto para transmitir emociones. El objeto no es imprescindible; pero, ¿cómo se prescinde de él?

c. el color y la forma, los medios pictóricos puros, tienen más cualidades y posibilidades que las evidenciadas hasta el momento. El color y la forma necesitan desempeñar otro papel en el nuevo lenguaje, que ha de reivindicar todo su potencial, toda su fuerza de expresión. ¿Cuál es el lugar que les corresponde?

d. el nuevo lenguaje tiene que habilitar el acceso al mundo espiritual, al mundo interior del sujeto. La pintura, en tanto que arte, ha de reflejar el giro al interior que está dando el hombre del siglo $x x$. ¿Cómo se consigue?

La combinación de estas cuatro necesidades da lugar a un nuevo estilo artístico. Kandinsky lo llamó arte puro y, refiriéndose a la pintura, pintura de composición. Los historiadores, sin embargo, tras un vaivén de nombres y años acabaron llamándolo pintura abstracta.

Kandinsky tarda en darle a su idea de arte puro y no figurativo el nombre de arte abstracto. Es difícil precisar cuándo aparece el término “abstracto” y cuál es su referencia exacta. En De lo espiritual en el arte no aparece hasta relativamente tarde y cuando lo hace, como sinónimo de “arte espiritual”. Se refiere a la poesía de Maeterlinck, ${ }^{55}$ revelando la asociación del término con la estética simbolista. Antes, Kandinsky habla de «arte en sentido abstracto»

55 Kandinsky, De lo espiritual en el arte, p. 38. 
o del «efecto abstracto de la obra». Lo importante es que, con "arte abstracto", Kandinsky se refiere a aquél que prescinde del objeto, opuesto a lo que se entiende como arte figurativo, pero que en ningún momento pierde un contenido interior.

No obstante, a partir de los años 30, cuando el arte abstracto empieza a ganar terreno, se observa que Kandinsky es reticente a utilizar términos como "arte sin objeto" (gegenstandlose Kunst) o "arte no figurativo" (art nonfigurativ), porque considera que los términos que hacen referencia a este arte no son exactos. Se han impregnado de un matiz que revela no sólo la falta de objeto sino también la carencia de un contenido interior, como si fuera un arte meramente racional. Nada más lejos de la intención de Kandinsky.

Un artículo suyo de 1935 ofrece un pasaje revelador al respecto. Se llama Pintura abstracta y fue escrito para la revista Kronick van Hedendaagse Kunst en Kultuur, en Amsterdam. Dice así:

«La expresión "arte abstracto” no está bien vista. Y con razón, ya que dice poco o, cuando menos, confunde. Por eso, los pintores y escultores abstractos de París intentan acuñar un nuevo término: ellos dicen "art nonfiguratif”. Este nombre significa lo mismo que el alemán "gegenstandlose Kunst”. Los elementos de negación de estas expresiones ("non-" y “-los") son inoportunos: borran el "objeto" sin poner nada en su lugar. Hace ya tiempo que se ha intentado (yo lo hice antes de la guerra) reemplazar "abstracto" por “absoluto". En realidad, no supone ninguna mejora. El mejor nombre sería, en mi opinión, “arte real”, porque es un arte que añade al mundo exterior un nuevo mundo artístico, de orden espiritual; un mundo que sólo puede nacer del arte. Es un mundo real. De todos modos, el viejo nombre "arte abstracto" ya se ha generalizado. ${ }^{56}$ "

La primera opción fue entonces "arte absoluto". En 1938, en otro artículo para $x x$ Siècle,${ }^{57}$ le da el nombre de "arte concreto". El arte, como explicó en el

56 KANDINSKY, Escritos sobre arte y artistas, p. 167. Las comillas son originales. Se ha introducido la cursiva en "art nonfiguratif" y en "gegenstandlose" para remarcar el non y el los y facilitar la comprensión de lo que dice Kandinsky. 


\section{El proyecto de Kandinsky}

artículo de 1935, crea otro mundo sujeto a las leyes de una necesidad interior. Es un mundo nuevo, que no tiene relación con la realidad exterior pero que es un mundo igual de real. Es un mundo artístico y concreto. Es un mundo nacido de un componente interior y no de la imitación de la naturaleza. Así justifica Kandinsky el término "concreto", que usa en De lo espiritual en el arte: «... veo la fuerza inmensa de la pintura llamada abstracta o no figurativa, que yo prefiero llamar concreta.» ${ }^{58}$

En cualquier caso, la diferencia de nomenclatura no pasa de ser mera pregunta de denominación. ${ }^{59}$ La idea de la pintura de composición permanece estable y busca satisfacer esas cuatro necesidades que se nombraron antes de la cuestión del nombre. El arte abstracto no es sólo "abstracto" en tanto que prescinde del objeto, sino que es la búsqueda de una nueva forma de expresión.

\subsubsection{La pintura de composición}

La pintura de composición es, por un lado, el arte que quiere crear Kandinsky que satisfaga esas cuatro necesidades (abcd); pero también, o por otro lado, la dirección que según Kandinsky ha de seguir el arte actual. Es decir, Kandinsky no concibe la creación del arte abstracto como un proyecto meramente personal, sino como un proyecto global que "mejorará" la calidad y el valor del arte, en su sentido amplio.

Si se echa un vistazo a las manifestaciones artísticas de la Historia, cuenta Kandinsky, pueden observarse varios periodos. Inicialmente, el hombre tiene un deseo natural de plasmar su cuerpo, de atrapar lo efímero. Y la pintura que crea es realista: pródiga en retratos, paisajes y temas históricos. Es una necesidad inherente e instintiva en el hombre, y por eso el arte tiene un valor más práctico que estético. El hombre crea el arte porque lo necesita en un

57 París, 1939, nº 5-6/I y 1-2/II, también recogido en la edición española de Escritos sobre arte $y$ artistas.

58 KANDINSKY, De lo espiritual en el arte, p. 12.

59 La cuestión de los nombres aquí tratada sólo busca aclarar posibles confusiones. Si se quiere profundizar más sobre el uso de éste o aquél nombre, se pueden leer las páginas 70 y siguientes de Thürlemann, Kandinsky über Kandinsky, que se ciñe a la cuestión del nombre. También la extensa nota al pie número 25 de la página 255 de Kandinsky, Mirada retrospectiva. 
sentido práctico.

Poco a poco, en la creación se va prescindiendo de lo práctico y lo espiritual va ganando terreno. El valor que era práctico comienza a hacerse estético, y la necesidad instintiva que mueve al hombre pierde fuerza frente a la necesidad que le llama desde el alma. La pintura se acerca así a su segundo periodo: la pintura naturalista. Kandinsky incluye en este grupo al impresionismo, neoimpresionismo, expresionismo e incluso, pero sólo parcialmente, al cubismo y al fauvismo. El alejamiento progresivo de lo práctico hace disminuir la importancia de qué es representado en favor de cómo se representa. El componente puramente estético, el componente espiritual, gana peso. La naturaleza se convierte en un pretexto: se busca expresar una emoción interior que se aleje de lo objetivo. No obstante, el objeto exterior, la naturaleza, no llega a ser indiferente y tampoco se hace prescindible, por lo que las formas del cuadro siguen dependiendo de la naturaleza: «la elección de la forma no es libre» ${ }^{60}$.

El tercer periodo, o arte puro, sólo llega cuando el objeto desaparece completamente del cuadro, cuando el elemento práctico ha sido sustituido enteramente por un contenido espiritual, cuando lo figurativo deja paso a lo abstracto sin que el cuadro pierda su entereza ni su capacidad de transmisión. Es el momento, dice Kandinsky, del «estadio superior del arte puro», donde «el instinto corporal y práctico se ha hecho estético». ${ }^{61} \mathrm{La}$ forma puramente artística expresa un contenido interno, que no remite al mundo exterior y que no emplea formas figurativas. Éste es el objetivo de Kandinsky.

La pintura de composición, por lo tanto, se caracteriza por dos aspectos. Uno: su valor ha de ser puramente estético y no práctico. Y dos: sus formas han de ser abstractas y no figurativas. Teniendo en cuenta estas características, la naturaleza, los objetos, etc. quedan descartados como fuente de inspiración o contenido. El arte puro prescinde de ese elemento objetivo y lo sustituye por el elemento constructivo. Kandinsky le da el nombre de constructivo por ser un elemento que, según él, obedece a las leyes racionales de la construcción: «esta combinación racional es la construcción» ${ }^{62}$.

El elemento constructivo, la construcción que conforma la pintura abstrac-

60 KANDINSKY, Escritos sobre arte y artistas, p. 59.

61 KANDINSKY, Mirada retrospectiva, p. 195.

62 KAndinsky, Mirada retrospectiva, p. 194. 


\section{El proyecto de Kandinsky}

ta, no es otra cosa que la combinación de contenido y forma. El contenido es el elemento interno de la obra y la forma es el elemento externo. El contenido es «la emoción del alma del artista» ${ }^{63}$. Es indispensable para la obra y tiene la capacidad de evocar en el espectador un sentimiento similar al que quiere expresar el artista. Dado que el contenido es algo abstracto (la emoción del alma), necesita un medio de expresión que esté a la altura y que sea capaz de expresar algo así. Ese medio de expresión es el elemento externo, la forma. La forma es «la expresión material del contenido abstracto» ${ }^{64}$. Juntos, contenido y forma, establecen el elemento constructivo del arte abstracto. En los dos apartados siguientes se explicará cada uno de ellos (apartado 3.2.2) y (apartado 3.2.3).

Es importante no confundir la forma como elemento externo con la forma como medio pictórico. La primera se refiere a la exteriorización de un contenido, a la parte externa, a la parte visible y aparente de lo interior. El contenido de la obra, que son emociones y sentimientos, se hace externo tomando una forma. Esta forma, elemento externo de la construcción, está compuesta por los medios pictóricos de cada arte: el color y la forma para la pintura. ${ }^{65}$ Aunque la denominación "contenido" y "forma” pueda inducir a error por confundirse con la del binomio "color y forma", el contexto suele dejar las cosas claras. Además, “contenido y forma” es la denominación principal que utiliza Kandinsky y a la que es conveniente atenerse. Véase, principalmente, el artículo Contenido y forma.

\subsubsection{El elemento interior o contenido}

La pintura de composición prescinde del elemento objetivo para la creación, es decir, descarta la imitación de la naturaleza como fuente de inspiración y contenido. La naturaleza no satisface las necesidades que se le presentan a Kandinsky ni reúne las condiciones que demanda el nuevo arte: hace falta un nuevo tipo de contenido.

Si se elimina la naturaleza por ser algo externo, por atar al artista al mundo objetivo y por no ser capaz de habilitar el acceso al mundo espiritual, el nuevo

63 KANDinsky, Escritos sobre arte y artistas, p. 55.

64 Kandinsky, Escritos sobre arte y artistas, p. 56.

65 Contenido (emoción y sentimiento) + Forma (color y forma) = Elemento constructivo. 
contenido sólo puede provenir de un lugar: del mismo individuo. El contenido del arte puro tiene que nacer, necesariamente, del artista. Kandinsky define el contenido de la obra de arte como «la emoción del alma del artista». Es decir, es el mundo interno del sujeto, sus emociones, sus impresiones, su sentir, su espíritu, su ser interior. Kandinsky le da el nombre de «necesidad interior» (innere Notwendigkeit).

El término "necesidad interior" no es exclusivo de Kandinsky, otros autores lo habían usado antes para referirse a las leyes eternas de la naturaleza. La necesidad interior como intuición o como ley cósmica también se ha asociado con la música atonal de Schönberg, con la pintura religiosa de Klee o con ciertas óperas de Wagner. ${ }^{66}$ Kandinsky, por su parte, le da otro acento: la necesidad interior pertenece al propio individuo. El concepto kandinskyano de la necesidad interior es complejo y altamente interpretable (como se verá más adelante), sobre todo porque Kandinsky a veces usa "espíritu" como sinónimo de necesidad interior. Pero es posible dar una primera explicación del término y lo que representa como elemento interno de la obra de arte.

La necesidad interior es un conjunto de sensaciones, intuiciones, sentimientos. Es el "baúl interior" en el que se guardan las impresiones del mundo exterior, las imágenes eidéticas, las experiencias vividas, el espíritu personal. También es la esencia de la vida que ocurre fuera y que se guarda dentro: es el mundo interior. El mundo material, exterior, se filtra en el individuo depositando en él (en su alma, según Kandinsky) la esencia de ese mundo. En palabras de Kandinsky: «En un momento determinado, las necesidades maduran; es decir, el espíritu creador (...) encuentra un acceso al alma y (...) provoca un anhelo, un impulso interior ${ }^{67}$.

En tanto que baúl interior, la necesidad interior es el punto de partida para la creación de la obra. Es el contenido, aporta el qué. Pero como dice Kandinsky, llega un momento en el que provoca un anhelo, un impulso. Y en tanto que impulso, acaba determinando cómo será la forma externa, la forma que lo exteriorice. El contenido, la necesidad interior, es el qué de la obra de arte y determina cómo se representará ese qué, obligando a la forma a

66 Paul Overy añade a Tolstoy o a Henry van der Velde en la lista de los que usaron el término antes de Kandinsky y a Woefflin o Spengler después de él. Véase Overy, Kandinsky, p. 77.

67 KANDINSKY, Escritos sobre arte y artistas, p. 19. La cursiva es original. 


\section{El proyecto de Kandinsky}

expresarse de una manera concreta. La necesidad interior es el concepto clave de la obra de Kandinsky: el principio de la necesidad interior rige de manera absoluta la creación de la obra.

La necesidad interior es propia de cada individuo, pero ese baúl interior que se va conformando a lo largo de impresiones y experiencias personales también siente la influencia de tres elementos. El primero es el elemento de la personalidad: es decir, lo que ha de expresar el artista en tanto que creador, lo que lleva dentro como individuo. «Todo artista, como creador, ha de expresar lo que le es propio». El segundo elemento es el del estilo, que viene constituido por el espíritu y lenguaje de la época: «todo artista, como hijo de su época, ha de expresar lo que le es propio a esa época». El tercer y último, es el elemento artístico: «todo artista, como servidor del arte, ha de expresar lo que le es propio al arte en general». Este elemento se encuentra en todos los hombres, de cualquier pueblo y cualquier época, y su manifestación en la obra artística constituye el elemento principal del arte. ${ }^{68}$

Una característica de la necesidad interior que no se puede pasar por alto aunque sea obvia es la de su carácter cambiante. La necesidad interior, en su faceta de determinar cómo será la forma que lo exprese, está marcando el camino del arte. Pero eso no significa ni que sea universal, ni que sea un valor absoluto ni que sea estática. No es una voz absoluta e inamovible que condicione la expresión artística. La necesidad interior cambia: el contenido del baúl interior se enriquece, se modifica, se purifica, se refina. Y por eso, la necesidad interior «hoy pide una forma y mañana otra» $^{69}$.

La necesidad interior es el contenido y punto de partida para la creación de la obra. Como es un contenido interior y abstracto, la elección de la forma en la que se exprese será decisiva. Es una forma que debe llegar hasta el espectador, que debe transmitir el contenido de la necesidad interior de tal manera que el espectador pueda recibirla. Según Kandinsky, el único modo en el que es posible expresar un contenido tan abstracto, sensorial y emocional es haciendo uso de una capacidad que tienen todos los medios de las artes (y de la que hasta ahora no se ha hecho uso; es una de las novedades que introduce Kandinsky en el arte abstracto). Los medios o elementos de las artes -el color, la forma,

68 Las tres citas pertenecen a Kandinsky, De lo espiritual en el arte, p. 65.

69 KANDINSKY, De lo espiritual en el arte, p. 67. La cursiva es original. 
el ritmo, la palabra, el movimiento, el sonido- tienen, a juicio de Kandinsky, la capacidad de expresar la necesidad interior porque todos ellos, usados en su forma apropiada, transmiten una fuerza expresiva especial. Esa fuerza expresiva especial que se puede percibir sensorialmente y, por lo tanto, que es capaz de llevar hasta el espectador emociones y sensaciones, recibe el nombre de «resonancia interior» (innere Klang). ${ }^{70}$

La resonancia interior es el «espíritu que vemos manifestarse con una fuerza insólita en los objetos» ${ }^{71}$, define Kandinsky. Cada color representado, cada palabra pronunciada, cada movimiento rítmico tiene y emite una resonancia interior que se puede percibir sensorialmente. ¿Cómo? Por vibración. La vibración es el modo en el que la resonancia interior se hace sensorial. La resonancia llega al receptor en forma de vibración.

El espectador recibe una irradiación interna: la vibración de la resonancia interior, que a su vez refleja el contenido de la obra de arte (la necesidad interior). Si el artista ha conseguido expresar su necesidad interior de manera completa, la sensación que le llegue al espectador será idéntica a la del artista. El proceso de transmisión parte del artista -su necesidad interior o emocióny quiere llegar hasta el espectador, a proporcionarle la correspondiente emoción. Como la transmisión directa de emociones es (todavía) imposible, hace falta un intermediario, que será el sentimiento: «mientras el alma esté ligada

70 La traducción habitual de innerer Klang es "sonido interno", que yo no considero del todo oportuna. Parece ser acertada en tanto que el sonido es una sensación producida por el movimiento vibratorio de los cuerpos, lo que acerca bastante a la vibración del innerer Klang que se describirá a continuación en el texto principal. Pero a su vez, la palabra sonido parece impllicar que lo que se oye está bien definido, que es algo concreto que se sabe dónde empieza, dónde acaba y qué frecuencia de onda tiene. Palabras casi sinónimas y/o relacionadas son tono y timbre. Tono no es propiamente un sonido concreto, sino una cualidad de éste; además, como señal acústuica también está definida, bien delimitada. Timbre, calidad del sonido, tiene la asociación mental de ser un sonido concreto, generalmente agudo o estridente. Tampoco es el término apropiado. Klang es, para empezar, más onomatopéyico que todas estas palabras castellanas. No está asociado a ningún sonido concreto, sino que es, más bien, "algo que suena, que se oye". Pero su correspondencia acústica está más difuminada, es más borrosa que la de sonido. Klang, en la obra de Kandinsky, es una resonancia de la que no se puede decir con exactitud cuándo empieza a sonar y cuándo acaba. Es una especie de prolongación acústica de la esencia del objeto. Klang es una fuerza sonora, que resuena, que no sólo va al oído sino que llega hasta la emoción del espectador. Por ello, apuesto por resonancia interior como nueva y posible traducción de innerer Klang en la obra de Kandinsky.

71 KANDINSKY, Escritos sobre arte y artistas, p. 24. La cursiva es original. 


\section{El proyecto de Kandinsky}

al cuerpo, normalmente no puede entrar en vibración, sino por medio del sentimiento ${ }^{72}$. Así pues, el único modo de que el espectador perciba la vibración es sintiéndola. Ese sentimiento es la vía de unión entre la emoción del artista y la emoción del receptor, es «el puente que conduce de lo inmaterial a lo material (el artista) y de lo material a lo inmaterial (el espectador) ${ }^{73}$. Explicando la cita de Kandinsky, el esquema de transmisión desde el artista pasando por la obra de arte hasta el espectador es el siguiente: [emoción-sentimiento]-obra de arte-[sentimiento-emoción]. La emoción y el sentimiento del artista son inmateriales, se exteriorizan en la materialidad de la obra y llegan al espectador de nuevo en forma inmaterial (sentimiento y emoción). La tabla siguiente ayudará a la comprensión.

\begin{tabular}{lll} 
artista & obra de arte & espectador \\
\hline emoción-sentimiento & obra de arte & sentimiento-emoción \\
inmaterial & material & inmaterial \\
contenido & forma & contenido
\end{tabular}

Tabla 3.1

El arte puro o abstracto busca que la vibración que siente el espectador sea idéntica a la emitida por el artista. La obra, como representación de un estado interior propio, ha de llevar al espectador a sentirse identificado con ella. La identificación es una especie de recorrido interior por el cuadro, como aquella sensación de paseo que siente Kandinsky en las casas ornamentales de Vologda: «durante años anduve en busca de la posibilidad de llevar al espectador a que "se paseara" por dentro del cuadro, de forzarlo a que se fundiera con el cuadro olvidándose de sí mismo» ${ }^{74}$. Si el artista consigue tal

72 Kandinsky, Mirada retrospectiva, p. 193.

73 Kandinsky, Mirada retrospectiva, p. 193.

74 Kandinsky, Mirada retrospectiva, p. 110. Las comillas y la cursiva son originales.

A propósito de "pasearse dentro del cuadro" viene el Manifiesto de los pintores futuristas del 11 de abril de 1910, que dice así: «Los pintores siempre nos mostraron los objetos y las personas colocadas ante nosotros. En adelante, nosotros colocaremos en lo sucesivo al espectador en el centro del cuadro». La relación con la cita de Kandinsky es inevitable, aunque Kandinsky escribiera en sendas cartas a Herwarth Walden (noviembre de 1913) que «los futuristas juegan con las ideas más importantes que exponen aquí y allá» y «la ligereza 
cosa, que el espectador sienta la vibración cargada con la emoción del artista, se libera lo que Kandinsky denomina «identidad interior» (innere Identität).

El objetivo final del arte puro es alcanzar la identidad interior. Para ello se necesita que el contenido se transmita del artista hasta el receptor. Como ese contenido es inmaterial y abstracto necesita una forma material en la que exteriorizarse. La elección de la forma es decisiva: ha de ser capaz de transmitir la necesidad interior y ha de permitir que sus medios expresen la resonancia interior.

\subsubsection{El elemento exterior o forma}

«Para que el contenido, que primero vive abstractamente, se convierta en obra, hace falta el segundo elemento -el elemento exterior-, que sirve para materializarlo. Por eso el contenido aspira a un medio de expresión, a una forma material.» ${ }^{75}$

En su artículo Contenido y forma ${ }^{76}$, Kandinsky sostiene que el elemento externo del arte, es decir, su forma de expresión, es «predetermined, preordained and in essence, incapable of change» ${ }^{77}$. No obstante, del mismo modo que el contenido -la parte interior del artista- se va redefiniendo con cada nueva impresión, con cada nueva experiencia, así tiene que ir redefiniéndose

y la gran prisa son hoy las características de muchos artistas radicales; y es así como los futuristas (...) han echado a perder el lado bueno de sus ideas.»

75 Kandinsky, Mirada retrospectiva, p. 193.

76 El escultor Vladimir Izdebsky, uno de los mejores contactos de Kandinsky en Rusia, organizó en Odessa una exposición dedicada a pintores rusos (1910-11, "Salon 2"). Kandinsky estaba presente con nada menos que cincuenta y cuatro obras. El catálogo de la exposición, además de contener artículos sobre música y otras artes que serían un buen precedente para la idea sintética de $E l$ Jinete $A z u l$, ofrece un artículo en ruso del propio Kandinsky titulado Contenido y forma. Este ensayo se confunde a menudo con otro de 1913, La pintura como arte puro, porque ambos comienzan de la misma manera. Entre los papeles de Kandinsky se ha encontrado un manuscrito de Contenido y forma en alemán, pero parece que nunca llegó a publicarse en esa lengua. Sólo existe la versión rusa del catálogo de la exposición de Izdebsky y, actualmente, su traducción al inglés en la obra recopilatoria de Kenneth Lindsay y Peter Vergo. Traducción que, como se verá, trae algunos problemas.

77 Lindsay y Vergo, Complete Writings on Art, p. 88. A falta de la versión rusa con la que cotejar, la cita está inglés para no perder con la traducción al español el matiz del verbo "to ordain", como algo establecido por una instancia, que quedaría ambiguo con el español "ordenar". 


\section{El proyecto de Kandinsky}

y cambiando la forma de expresión. Es decir, el arte tiene que adaptar sus formas al contenido interior. Como éste cambia, así tiene que hacerlo la forma: «la forma de expresión tiene que, incluso parcialmente por adelantado, inevitablemente, indiscutiblemente, ser redefinida». ${ }^{78}$

¿Cómo algo que es inmutable («incapable of change») puede redefinirse y cambiar? Es un mero problema lingüístico o de expresión. Kandinsky quiere decir que los elementos básicos de cada arte son inmutables, en el sentido de que "no pueden ser otros" para cada arte. La música, para ser música, no puede renunciar al sonido y al tiempo; la literatura no puede renunciar a las palabras y al tiempo; la escultura a la extensión y al espacio; y la pintura no puede ser pintura sin el color y la forma. Estos son los medios inmutables, en tanto que son imprescindibles. Pero estos mismos medios han de poder cambiar para ajustarse a la necesidad interior. Que la pintura no pueda cambiar de medios no significa ni implica que sus medios, en sí mismos, no puedan cambiar su manera de presentarse, de combinarse, de expresarse. Así se entiende la frase de Kandinsky: «Thus, both immutability and mutability are the laws of art» ${ }^{79}$. Parece casi un juego de palabras innecesario. Es posible que la traducción - poco acertada - tenga mucho que ver, o que el lenguaje, a veces tan simbólico que Kandinsky usa, se preste a confusión. ${ }^{80}$

La mutabilidad del elemento externo es, precisamente, lo que necesita el nuevo arte o arte puro (que será el arte abstracto). La forma tiene que cambiar, tiene que constituir un nuevo lenguaje para el nuevo arte. El proceso de creación de un nuevo lenguaje, es decir, de redefinición de la forma, se levanta sobre una importante base teórica y se completa con la producción práctica. Es una retroalimentación constante. Si en la práctica empiezan a aparecer cuadros abstractos en torno a 1910-12 (Primera acurela abstracta, Composición II, Acuarela con mancha roja o La sonoridad amarilla), en la teoría el proceso se inicia con la formulación de una "gramática de la creación».

La carrera de Kandinsky como jurista y su dedicación a las cuestiones legales dejan en él una impronta analítica que se ve reflejada en su forma de tratar los problemas artísticos. La teoría, explicada siempre con un matiz

78 Lindsay y Vergo, Complete Writings on Art, p. 88. Traducción propia, del inglés.

79 Lindsay y Vergo, Complete Writings on Art, p. 89.

80 Otro ejemplo confuso, que quizá se deba a la traducción inglesa (?), es nombrar a los medios pictóricos de la pintura "color y espacio", cuando en el párrafo siguiente vuelven a ser, como acostumbrado, "color y forma". 
pedagógico (y no sólo en los escritos de su época como profesor en Phalanx o en la Bauhaus), permite establecer una relación directa con la praxis, ya que en el fondo, la teoría no es sino una formulación lógica y racional de la práctica.

Según el panorama artístico con el que se encuentra Kandinsky, la pintura necesita urgentemente una formulación teórica, pues el resto de las artes ya tienen una amplia investigación analítica. La arquitectura, por ejemplo, cuenta con ella desde sus principios, orientada a mejorar sus indiscutibles fines prácticos. Pero incluso la música, y esto es algo que Kandinsky pone de relieve, que parece estar más cerca de lo abstracto que de un fin concreto, goza desde hace tiempo de teorías, tratados y armonías que se desarrollan constantemente. Algo similar pretende Kandinsky para la pintura: un análisis teórico que la libere de las ataduras clásicas (dependencia de la perspectiva, fidelidad a la naturaleza, etc.) y que le permita evolucionar libre y espiritualmente. Kandinsky quiere formular una teoría que atienda a la parte interior del hombre, que garantice su expresión y que la haga brillar con luz propia.

Kandinsky procura que el sistema teórico ofrezca garantía científica, algo que relativamente consigue, siempre y cuando se tenga en cuenta que la parte que desempeña el mundo interior del hombre no es únicamente reducible a formulaciones teóricas. Por tanto, el objetivo de Kandinsky es crear una teoría tipo "gramática" que tenga una base científica y esté orientada a dos fines: el primero, la creación de una obra de arte que siga los principios de la necesidad interior, es decir, la gramática entendida como el camino que lleva hasta la pintura pura o de composición; el segundo, la formación de la persona como ser humano, el desarrollo de su espíritu: «formular leyes con respecto al desarrollo humano en general $»^{81}$. La teoría o «gramática de la creación» permite alcanzar ambos fines mediante el empleo de formas nuevas, mediante la reformulación del uso del color y de la forma.

La formulación teórica de Kandinsky considera la pintura como un punto de partida y no como un fin en sí mismo. Si la planteara como fin, el artista plasmaría en la obra los conocimientos adquiridos, pero no iría más allá de sus límites sino que permanecería en el terreno de la expresión exterior, el de las pautas marcadas. En cambio, cuando el arte es sólo el punto de partida, cuando «la pintura es tratada como una fuerza coadyuvante» ${ }^{82}$, el artista pone rumbo

81 Kandinsky, Punto y línea sobre el plano, p. 17.

82 KANDINSKY, Escritos sobre arte y artistas, p. 84. 


\section{El proyecto de Kandinsky}

más allá de los límites establecidos y es capaz de crear algo que se corresponda con su mundo interior, y por ende, algo nuevo. Para lograr este proceso, la gramática de la creación lleva a cabo dos procedimientos. El primero es el análisis de los elementos pictóricos (color y forma) y el segundo es la relación con las demás artes, facilitando la creación de la obra sintética.

El primer procedimiento de la gramática de la creación, el análisis de los medios pictóricos, conlleva tres etapas. La primera etapa es el análisis en sí del color y de la forma. Teniendo en cuenta la relación especial que Kandinsky siente por el color, no sorprende que el color tenga un papel protagonista y especial, además de un nuevo enfoque. Kandinsky percibe el color desligado del objeto al que pertenece y la pasión extraordinaria que siente por los colores queda patente en numerosas ocasiones: "[amo] los colores por encima de todas las cosas», "hay colores que me acompañan durante toda la vida (el azul, principalmente)», dice en Mirada retrospectiva.

La teoría de Kandinsky sobre el color comienza con un estudio bien estructurado. En su artículo Curso y seminario sobre el color, que escribe para un libro recopilatorio de la Bauhaus ${ }^{83}$, refleja el método y procedimiento que sigue su análisis; por su parte, el libro De lo espiritual en el arte presenta el contenido de la teoría.

El programa de Kandinsky comienza por investigar el color desde diferentes puntos de vista: el físico-químico (la naturaleza del color), el fisiológico (el medio de la recepción externa); y el psicológico (el efecto que provoca). Es decir, por un lado estudia las propiedades materiales del color: su sustancia, el uso de los pigmentos, de los aglutinantes, etc. Y por el otro, las propiedades psicológicas: la fuerza creadora, su emisión, su recepción. Partiendo de esta posición, el método es analítico a la vez que sintético. Analítico por la consideración del color en sí. Kandinsky estudia cómo actúa el color aislado, los colores entre ellos y su subordinación a la composición general. Por ejemplo: «El calor o el frío de un color están determinados»; «El amarillo se vuelve con facilidad agudo y no puede descender a gran profundidad. El azul se vuelve difícilmente agudo y no puede ascender a gran altura. El equilibrio ideal en

83 Se trata de Staatliches Bauhaus in Weimar, 1919-1923, en el que Kandinsky recoge las ideas con las que organiza su clase de pintura mural y su curso sobre la teoría de los colores, hacia 1922. 
la mezcla de estos dos colores diametralmente opuestos está en el verde» ${ }^{84}$. Y el método es a su vez sintético por su estudio del color en relación a la forma, dado que ambos son los medios de la pintura. Estudia la relación básica entre un color y una forma primaria, luego como una estructura más compleja y, al fin, la subordinación de los elementos a la composición general. Por ejemplo, estudia un triángulo amarillo como relación básica, un compuesto de líneas y planos de colores como estructura más compleja y la subordinación de un grupo de triángulos de colores al cuadro en general.

El estudio que Kandinsky hace de la forma hay que buscarlo en el artículo Sobre el problema de la forma, incluido en el almanaque, y en el libro Punto $y$ línea sobre el plano. Tampoco son los dos únicos lugares donde encontrar respuestas a la pregunta recurrente de cómo debe ser la forma que renuncia al objeto, pero son los fundamentales.

En sentido estricto, Kandinsky considera como forma toda delimitación de una superficie por otra. Forma son todas las líneas o figuras dibujadas sobre la superficie, lo que recubre y delimita los espacios de la superfice. El estudio teórico de Kandinsky ahonda en las posibilidades que la forma pura (no figurativa) ofrece, en sus propiedades y en su manera de expresarse. Analiza a fondo cada uno de los elementos formales: el punto, la línea, el plano básico y todas las figuras geométricas derivadas de las anteriores. Y de nuevo lo hace en sentido analítico, es decir, analizando la forma en sí, por separado: «La izquierda del рв [plano básico] despierta la idea de una mayor soltura, la sensación de ligereza, liberación y, finalmente, libertad $\aleph^{85}$. Y lo hace también de forma sintética, analizando la forma básica en relación a otras formas (cómo se comporta una línea horizontal en relación a un conjunto de verticales), en relación con el color (el efecto de un triángulo en amarillo o un triángulo en azul) y en relación a la composición general del cuadro: «La posición de ambas verticales limítrofes es derecha e izquierda. Se trata de tensiones cuya resonancia interior está determinada por el reposo cálido y que en nuestra imaginación están relacionadas con el ascenso.» ${ }^{86}$

84 Kandinsky, De lo espiritual en el arte, p. 70. Las cursivas son originales.

85 KANDinsky, Punto y línea sobre el plano, p. 107. En el original, la palabra izquierda va en cursiva, pero aquí ha sido eliminada la cursiva porque no aportando, puede dar lugar a confusión.

86 KANDinsky, Punto y línea sobre el plano, p. 107. La traducción ha sido levemente modificada para sustituir "sonido interior" por "resonancia interior", en consonancia con lo explicado 


\section{El proyecto de Kandinsky}

La segunda etapa del análisis de los medios pictóricos es la definición de un vocabulario. El nuevo arte necesita un nuevo lenguaje, y éste debe ir en consonancia con el análisis del color y la forma. El vocabulario tiene que aportar nuevas entradas (las necesarias para el arte puro) y además aclarar y precisar las definiciones ya usadas pero que a lo largo de los estilos artísticos han perdido su significado. El ejemplo anterior de la forma refleja la novedad en la definición: la forma «no es más que la delimitación de una superficie por otra».

Y la tercera y última etapa es la creación de las reglas de construcción. El resultado es un lenguaje con un par de "axiomas" principales de los que se derivan diferentes teoremas. La estructura que ofrece Kandinsky no es estrictamente "lógica" en sentido clásico pero el paralelismo es aplicable. El color y la forma, en tanto que elemento externo de la composición, deben:

- ajustarse a las exigencias del contenido, expresar la necesidad interior;

- posibilitar el acceso al mundo interior y espiritual del individuo;

- expresar su resonancia interior para asegurar una transmisión sensorial del contenido hasta el espectador;

- considerar el color como entidad independiente y no atada a los objetos como si fuera una propiedad de éstos; $y$

- liberar a la forma de lo figurativo, prescindir del objeto y hacerse totalmente abstracta.

A partir de aquí se deriva toda una serie de reglas más o menos concretas y orientadas a la propia ejecución de la obra: se refieren al uso de éste o aquel color, a la colocación de diagonales o rectas, al peso de las líneas, de los espacios, etc. No obstante, y esto es algo de suma importancia, cualquiera de estas reglas nunca posee el carácter de pauta fija: no es un código cerrado ni definitivo. La matematización que utiliza tampoco es estricta: en Punto y línea sobre el plano presenta de forma numérica el peso de los planos frente al de las formas, estableciendo relaciones que podrían decirse fraccionales. ${ }^{87}$

en la nota al pie número 70.

87 Un ejemplo de esa matematización es: «Arriba: peso de las formas, 2; peso del PB, 2; total, 4. Abajo: peso del PB, 4; peso de las formas, 4; total, 8. Caso: “dramatización” arriba: 4:8.» En KANDinsky, Punto y línea sobre el plano, p. 106. 
Pero tanto en De lo espiritual en el arte como en Escritos sobre arte y artistas ${ }^{88}$ deja claro que la matematización que emplea para el arte no sigue las reglas puras de la matemática: «Ponga a su lado una manzana y otra manzana. Como resultado, tendrá dos manzanas. (...) En el arte, sin embargo, la adición es misteriosa: amarillo + amarillo $=$ amarillo $^{2}$. Progresión geométrica. Amarillo + amarillo + amarillo + amarillo ... = gris. El ojo se cansa de ver demasiado amarillo» ${ }^{89}$. A esta forma matemática nueva y personal, Kandinsky la denomina «matematización artística».

Por tanto, las pautas que propone no pueden ser contempladas sólo lógicamente ni tampoco considerarse un manual cerrado. El objetivo siempre es dar mayor libertad al arte, desprenderlo de las reglas fijas tradicionales. Kandinsky, de manera consecuente, no propone entonces un nuevo armazón rígido de reglas, sino que plantea al artista ciertas posibilidades, o le da el punto de vista teórico de sus experimentos prácticos. En cualquier caso, es el propio artista quien al final decide cómo interpretar y/o emplear esos patrones. Entre otras cosas, porque la creación de la obra necesita de manera axiomática seguir los dictados de la necesidad interior, exclusiva de cada individuo. Disponer de los elementos y de las reglas no asegura la creación de una obra, ni tampoco que ésta sea de calidad. La gramática de la creación kandinskyana es un medio que orienta a la confección, pero no es criterio del arte.

El primer procedimiento de la gramática de la creación, ha sido el análisis de los medios pictóricos propiamente dicho, con sus tres etapas (análisis, vocabulario y reglas). El segundo paso es el estudio de la pintura de composición en relación con otras artes, con la finalidad de lograr obras sintéticas. La relación entre las artes puede hacerse de dos maneras.

La primera de ellas es crear una obra pictórica que denote y/o contenga la presencia de otras artes. Es decir, incluir los medios inmutables de otras artes en la misma obra pictórica. Por ejemplo, incluyendo el movimiento en la pintura a través de los medios propios de ésta, el color y la forma (el movimiento como medio de la danza). Parece imposible pero para Kandinsky no lo es. En el análisis de la forma como medio pictórico, Kandinsky explica cómo ésta puede generar movimiento. Frente al punto, que es completo reposo,

88 Véase, por ejemplo, el artículo 31, El valor de una obra de arte concreto.

89 KANDINSKY, Escritos sobre arte y artistas, p. 215. 


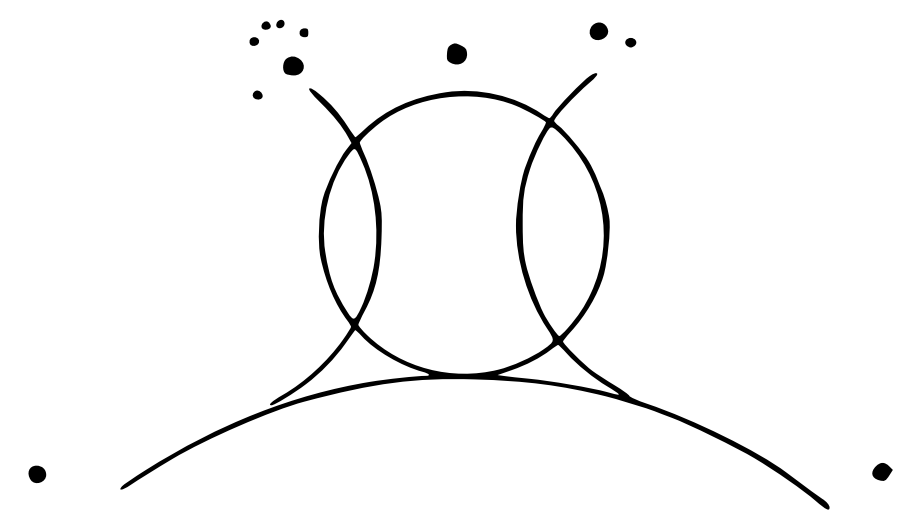

Ilustración 1 Forma pictórica que genera movimiento

la línea es movimiento. La línea es una fuerza exterior que se agarra al punto y lo arroja en otra dirección. Así, la línea surge del movimiento que arranca desde el punto: la línea es la marca o traza que deja el punto al moverse. Al contrario que el punto, que sólo posee tensión interior, la línea dispone de tensión y dirección, lo que le permite el movimiento. De esta forma, el cuerpo de un bailarín puede ser todo él una composición lineal, como indica la ilustración 1. Las líneas marcan el cuerpo; los puntos, la cabeza o los dedos. El cuerpo también puede ser considerado todo él como un punto que, gracias a la fuerza, se mueve por el escenario y va dibujando líneas.

La segunda manera en la que relacionar las artes de manera sintética entre sí es creando un nuevo modelo de obra de arte (no un cuadro) que reúna el trabajo de las diferencias artes. Una obra en la que la danza o la música no se expresen a través de formas y colores sino que estén efectivamente allí. Se trata de una obra en la que colaboren las artes con su presencia directa, un intento de obra de arte total, al estilo wagneriano. Los ejemplos ya se han comentado. El Jinete Azul es un buen punto de partida en esta idea de síntesis, pero no deja de ser un texto en el que la participación de las diferentes artes se ve reducida a la palabra o a la imagen. Las exposiciones de Phalanx, la NKVM o El Jinete Azul también exhibían diferentes muestras artísticas, aunque una exposición no puede considerarse estrictamente un nuevo modelo de obra de arte. Los dos libros de poemas visuales, Poesías sin palabras y Sonidos o su colección de grabados Xilografías se acercan a su manera a esa obra de arte total. Pero sin duda, la obra de arte en la que Kandinsky va más allá y en la 
que todas las artes tienen cabida directa (y no sólo un mero reflejo), son sus composiciones "teatrales" Blanco y negro, Violeta, La sonoridad verde $e^{90}$ y la obra ya comentada La sonoridad amarilla.

Una vez que se ha definido el contenido de la obra a través de la necesidad, resonancia e identidad interior, la gramática de la creación es el proceso que establece las bases teóricas del arte puro, del arte abstracto. El primer paso es el análisis de los medios pictóricos, que contiene tres etapas: el análisis en sí del color y de la forma, la definición de un vocabulario y la construcción de las reglas. El segundo paso es la relación de las diferentes artes con la idea de crear una obra sintética. Puede hacerse importando los medios de un arte en otro (el movimiento en la pintura) o creando directamente un nuevo modelo de obra de arte. Cómo enlaza esta teoría con la práctica y qué significado o interpretación posible se puede dar al arte de Kandinsky, es lo que se expondrá en los próximos cuatro capítulos.

90 De estas tres obras apenas hay estudios y ninguna está traducida al español. Los nombres originales son Schwarz und Weiß (Blanco y negro), Violett (Violeta) y Der grüne Klang (La sonoridad verde). Fueron compuestas en los años de Múnich, previos a la I Guerra Mundial. Ninguna de ellas fue publicada, salvo Violett, que apareció en el tercer volumen de la revista bauhaus (sic), el 1o de julio de 1927, probablemente porque de su edición se encargó Oskar Schlemmer, director de la escuela de teatro experimental. Véase Schreyer, Erinnerungen an Sturm und Bauhaus. Un extracto de Violett puede leerse en Lindsay y Vergo, Complete Writings on Art, pp. 720-721, traducido al inglés. 



\section{Kandinsky y la abstracción: nuevas interpretaciones}


La primera parte de esta investigación ha establecido el marco de referencia en el que se asienta el proyecto de Kandinsky. Considerando ese engranaje biográfico, contextual y teórico que ha sido expuesto, la segunda parte se centra en las interpretaciones del lenguaje abstracto. Se compone de cuatro capítulos (4, 5, 6 y 7), cada uno de los cuales ofrece una perspectiva diferente. Las cuatro interpretaciones quieren explicar el porqué de ese lenguaje y el uso que Kandinsky hace de él en el arte. Todas ellas son consistentes en sí mismas, y contemplándolas de manera aislada, podrían aparentar una explicación plausible del arte abstracto. Pero, partiendo de que la abstracción es un proceso complejo que necesita una explicación compleja, las cuatro interpretaciones no son excluyentes sino que se complementan. Son diferentes perspectivas de una misma realidad. Es decir, las cuatro perspectivas juntas conforman una gran perspectiva global.

El capítulo 4 entiende el arte abstracto desde la perspectiva de la reducción formal. La situación de cambio e inestabilidad de la época lleva a Kandinsky a crear un nuevo lenguaje artístico, que se traduce en la simplificación del contenido externo hasta un minimalismo formal.

El capítulo 5 considera la importancia del contenido interior del arte, reflejado en el mundo interior del artista. La necesidad de expresar tal contenido, rico en sensaciones, es el punto de partida. Kandinsky crea un lenguaje que, a través de la abstracción, es capaz de expresar contenidos multisensoriales y no sólo visuales.

El capítulo 6 interpreta las formas del lenguaje abstracto como portadoras de una experiencia espiritual. La expresión exterior del arte consigue transmitir el contenido espiritual del artista y llevarlo hasta el alma del espectador. El arte abstracto es una creación cósmica que abre la puerta al mundo trascendental.

Y el capítulo 7 interpreta el lenguaje de la abstracción centrándose en la sinestesia como condición neurológica. La hipótesis de que la sinestesia de Kandinsky pudo ser determinante en la creación del arte abstracto se expone a la luz de los nuevos descubrimientos neuroestéticos que, finalmente, se enlazan con creaciones artísticas contemporáneas. 



\section{El arte abstracto como reducción a lo esencial}

Kandinsky's approach to abstraction is reductive

BeEke S. TOWER

El ambiente de cambio e inestabilidad con el que se inicia el siglo $\mathrm{xx}$ afecta a muchos ámbitos, entre ellos el del arte. Kandinsky entiende que este cambio hace necesario un nuevo lenguaje artístico, uno que contrarreste esa inestabilidad y que sitúe el arte al compás de los tiempos. El primer apartado (4.1) expone el proyecto de renovación formal que emprende Kandinsky. Es la búsqueda de un lenguaje que hable en términos de orden y tranquilidad, lo que le obliga a simplificar las formas. Para ello, Kandinsky analiza la apariencia de las formas mínimas de la naturaleza y el uso de la forma abstracta en las artes decorativas.

El segundo apartado (4.2) describe el proceso de creación del nuevo lenguaje. La simplificación de las formas como premisa general obliga a reconsiderar dos cuestiones: por un lado, la relación entre el contenido y la forma en la que éste se expresa en la obra; por otro, hasta dónde puede llevarse dicha simplificación y si es necesario conservar la apariencia figurativa.

Desde la perspectiva del nuevo lenguaje abstracto reducido a sus formas mínimas, el tercer y último apartado (4.3) presenta de manera práctica la depuración formal: a través de la transformación de la figura del caballo en un círculo y mediante el proceso que sigue una imagen: desde su boceto hasta ser definitiva en el cuadro final. 
4 El arte abstracto como reducción a lo esencial

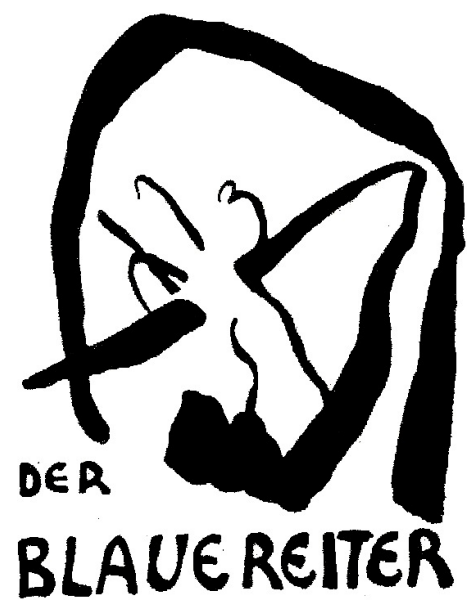

Ilustración 2 Marmosete de El Jinete Azul 


\subsection{La simplificación de las formas como exigencia}

\subsubsection{La búsqueda de la tranquilidad}

El panorama de la ciencia y el arte en los albores del siglo xx se ha presentado en el capítulo 2 a través de sus acontecimientos. Sin necesidad de nombrarlos de nuevo, sí conviene recordar que son los acontecimientos que arropan e impulsan el nacimiento del arte abstracto y que, en especial los descubrimientos relacionados con la ciencia, tienen una influencia determinante.

Los avances de la física obligan a muchas esferas del conocimiento a replantearse sus bases. Los descubrimientos relevantes son muchos y se suceden en tan poco tiempo que apenas dejan espacio para la reflexión. La rapidez con la que se debe asumir el cambio de paradigma conduce a la inestabilidad y al escepticismo epistemológico. Los avances de la física (la división del átomo, la Teoría de la Relatividad, la física cuántica...) siembran el caos intelectual porque rompen el suelo en el que se apoyaban muchas otras creencias además de la ciencia. El problema que presenta la nueva física no es sólo que rompa las barreras que había establecido Newton, sino que muchas de sus leyes quedan intactas... pero sólo para el mundo macroscópico. Sale a la luz un nuevo mundo, el de lo microscópico, que necesita nuevas leyes. Dos mundos, dos sistemas de leyes. $Y$ a la vez, ambos pertenecen al mismo: el mundo en el que el hombre habita y cree unitario. Esta dualidad de los mundos micro y macro genera gran confusión intelectual a principios del siglo xx: ¿qué mundo (y con qué leyes) es el verdadero? ¿El microscópico, el macroscópico? ¿Qué estabilidad ofrece esta dualidad? ¿Cómo asirnos a sistemas de referencia relativos entre ambos mundos?

Las consecuencias de las nuevas leyes cuánticas son de tal magnitud que ni siquiera se podían digerir en un sólo siglo. Cien años después, los filósofos y neurólogos del siglo xxi siguen intentando encajar esa dualidad: ¿es la relación cerebro-mente equivalente a la de los mundos micro-macro? ¿con qué leyes funciona el cerebro: con las cuánticas del mundo microscópico, con las clásicas del mundo macro o quizá precisa de unas nuevas? En definitiva, la pregunta que no ha cambiado desde el siglo xx es la de cómo manejar la pluralidad, cómo entenderla. Cómo poner orden en un mundo que, gracias al nuevo conocimiento, se está volviendo peligrosamente múltiple y paradójicamente 


\section{El arte abstracto como reducción a lo esencial}

desconocido.

La misma pregunta alcanza al arte. La creación artística se ve envuelta en una sensación de caos, de confusión, de inestabilidad. Para Kandinsky la desintegración del átomo es lo mismo que la desintegración del mundo entero: caen los muros más sólidos, todo resulta inseguro. Incluso, dice, una piedra podría fundirse en el aire y hacerse invisible. Este mismo sentimiento es común a otros pintores y artistas. El arte siente la inestabilidad que ha traído la ciencia y trata de expresarla, de comunicarla al mundo exterior. Sin embargo, no sabe cómo, no encuentra la manera. Se podría decir que el lenguaje que viene manejando no le da el vocabulario necesario para expresar algo tan nuevo: la sensación de inestabilidad. Para comunicarla necesita una nueva forma de expresión artística, es decir, un nuevo lenguaje que se ajuste a su tiempo y que ponga orden en esta realidad caótica e inestable.

Kandinsky emprende la búsqueda hacia ese nuevo arte: un arte que, con un lenguaje propio y nuevo, lo libere del martirio de lo relativo, de lo plural, de lo inseguro. Tampoco es tarea imposible si se recuerda que el arte tuvo en su origen cierto carácter apotropaico: gracias a su naturaleza mágica se creía que podía alejar el mal. Ahora no hay por qué concederle esa dimensión mágica, basta con rescatarle la cualidad de alejar lo negativo. Kandinsky quiere conseguir que el arte, con una expresión basada en un lenguaje nuevo, ponga orden y aleje la sensación de malestar ante el caos.

El objetivo es lograr una expresión artística que presente la realidad de forma controlable y comprensible. Es decir, un lenguaje artístico que ofrezca al espectador una realidad ordenada (o la parte ordenada de la realidad). Y el método no es otro que el de buscar las formas artísticas que lo logren. Dar con el lenguaje que sea capaz de expresar la realidad caótica en términos de orden y reposo. Y eso se consigue sacando a la luz la estructura interna de la realidad, la parte estable que no zozobra ante la complejidad, el armazón o esqueleto de la realidad que permanece siempre inalterable: su esencia. Si el arte quiere transmitir tranquilidad, sus formas artísticas -esto es, su lenguajetienen que ser capaces de transmitir la esencia de las cosas sin resultar caóticas ni confusas.

Guiado por la lectura de W. Worringer (Abstracción y empatía), Kandinsky parece tener claro cómo han de ser esas formas artísticas: abstractas. Frente a la agorafobia que le produce la incomprensión del mundo exterior, el hombre primitivo siente la necesidad de reducir lo múltiple a un nivel manejable, 
de abstraer lo complejo a lo básico. Worringer lo llama el "impulso de la abstracción"1 y Kandinsky lo incorpora a su búsqueda por las nuevas formas del arte. Kandinsky entiende que la abstracción de las formas, en tanto que reducidas a su expresión mínima -y por tanto comprensible-, es la clave para traer la tranquilidad interior ante el caos de la realidad.

A la luz del arte de los pueblos primitivos, Kandinsky estudia y descubre cómo crear esas formas abstractas. Su amigo Franz Marc y él son visitantes asiduos del museo etnológico de Múnich. ${ }^{2}$ Del arte "abstracto" de los primitivos, Kandinsky se fija en cómo reducir las formas, en cómo deben simplificarse para transmitir la esencia de la realidad pero dejando de lado toda complejidad: «al igual que nosotros, estos artistas puros intentaron reflejar en sus obras solamente lo esencial; la renuncia a la contingencia externa surgió por sí misma». ${ }^{3}$ Franz Marc utiliza palabras similares para equiparar su arte con el de los pueblos primitivos, apelando a la expresión "pura y sana» del arte, un estilo que renuncia a lo complejo sin perder lo esencial. Dice Marc:

«Me parece tan obvio que nosotros busquemos el re-nacimiento de nuestro sentir artístico en el alba fría de la inteligencia artística [se refiere al arte primitivo] y no en culturas que ya han recorrido un camino milenario, como la japonesa o el Renacimiento italiano. (...) Tenemos que convertirnos en ascetas (...). Tenemos que renunciar con valentía a todo aquello que, como buenos centroeuropeos, hasta ahora nos era valioso e imprescindible. (...) El objetivo (...) es, naturalmente, expresarse desde un instinto de color puro y sano, como lo hacían los pueblos primitivos. ${ }^{4} »$

1 El Abstraktionsdrang (página 72).

2 Como se desprende, por ejemplo, de la correspondencia entre ambos. Véase Lankheit, Kandinsky-Marc: Briefwechsel.

3 Kandinsky, De lo espiritual en el arte, p. 21.

4 Maскe, August Macke-Franz Marc, p. 39 y 41. En esta carta de Marc a Macke, Franz Marc utiliza un lenguaje más literario de lo habitual, casi poético. Cuando escribe «es obvio que nosotros busquemos (...) nuestro sentir artístico en el alba fría de la inteligencia artística» para referirse a los pueblos primitivos, utiliza la palabra alemana Frührot, que apenas se emplea en el lenguaje habitual. De hecho, los diccionarios no suelen recogerla. Para "alba" o "aurora" se utiliza Morgenrot. Lo que hace la metáfora alba-pueblos primitivos aún más rebuscada. El significado se entiende por el contexto, porque más adelante habla del Museo 


\section{El arte abstracto como reducción a lo esencial}

Esta cita de Marc, olvidada por la mayoría de la literatura actual sobre el tema, pone de manifiesto la relación entre la teoría y la práctica. Gran parte de la bibliografía sí reconoce que Worringer, con su tesis sobre el impulso primitivo de abstracción, aporta una nueva luza las teorías de Kandinsky. Pero la literatura se olvida de señalar la búsqueda real y directa de respuestas en las propias pinturas, el análisis práctico e in situ que se une al estudio teórico, una de las características fundamentales de la obra kandinskyana. Lo que a los investigadores de hoy se les suele pasar por alto (o no consideran relevante) es algo que los críticos de entonces ya vieron y que Marc ya señalaba en una de sus cartas: el estudio directo de las formas artísticas abstractas. «Estuve durante mucho tiempo en el museo etnológico, para estudiar las maneras artísticas de los "pueblos primitivos" (como se expresan hoy en día Koehler y la mayoría de los críticos, cuando quieren caracterizar nuestras tendencias)». ${ }^{5}$

La influencia de Worringer en el Kandinsky teórico, así como la presencia de la pureza y simplicidad primitivas en su obra práctica, son un impulso claro en el proceso de creación del arte abstracto, esto es, en la reducción de formas con las que Kandinsky comienza su nuevo lenguaje. Pero aun siendo una influencia directa, no es tan exclusiva como pudiera parecer. Y es que en el fondo, la reducción de lo complejo a sus formas esenciales es un contagio del ambiente analítico y reduccionista de la época. La ciencia avanza mucho por esas fechas y ofrece continuamente resultados y valores fiables, por lo que su método adquiere poco a poco el reconocimiento de ser el único y verdadero. De esta forma, el método científico se impregna de autoridad a principios del siglo $\mathrm{xx}$.

El pensamiento analítico y reduccionista impera en la ciencia. Y, bien porque da resultados, bien por mero contagio, el arte adopta esa misma actitud para enfrentarse a los nuevos problemas de la pintura. La ciencia considera que para entender un fenómeno primero hay que entender la realidad que le subyace, lo que significa analizar esa realidad en partes más pequeñas, sus partes componentes. La ciencia reduce la explicación de un fenómeno a la

Etnológico y en especial del arte camerunés e inca. Lo que no exime para que el texto, con otra interpretación de Frührot, pudiera adquirir otro sentido. Como no hay traducción publicada ni al español ni al inglés, tanto la traducción como la interpretación son propias. La cursiva es añadida.

5 MACKe, August Macke-Franz Marc, p. 39 y 41. Las comillas son originales. 
explicación de sus partes, a la aclaración de los niveles inferiores de complejidad. El arte, que busca cómo deshacerse de esa complejidad, actúa de manera similar: reduce las formas artísticas a sus expresiones mínimas. Si la ciencia explica los fenómenos reduciéndolos a las estructuras básicas, el arte quiere transmitir sensaciones apoyándose en las formas artísticas más puras. Esta conexión entre arte y ciencia relativa al método de trabajo la explica bien López García, sirviéndose del concepto de Zeitgeist o "espíritu de la época":

«El arte moderno comenzó, por tanto, con la aceptación de los artistas del método analítico-reduccionista propio de la ciencia, existiendo un paralelismo conceptual entre arte y ciencia durante esos años debido a la coincidencia en la actitud analítica, lo que vendría expresado por el término alemán Zeitgeist: la emergencia simultánea de un mismo tipo de interpretación en campos diferentes. ${ }^{6}{ }$

No hace falta insistir en cómo el arte adopta el modus operandi de la ciencia; sólo hay que destacar que a Kandinsky, también por su formación académica y analítica, le es fácil entender la necesidad de un arte que hable el lenguaje de los nuevos tiempos y, sobre todo, que aporte tranquilidad al mundo caótico y complejo. Una vez asumido que el camino para lograrlo es la reducción de la forma artística a lo esencial, sólo queda estudiar cómo llevarlo a cabo. El estudio de la naturaleza y la influencia del arte ornamental son dos puntos claves de este proceso.

\subsubsection{El papel de la naturaleza}

Con la reducción de formas como objetivo principal, Kandinsky se enfrenta al proceso de crear un lenguaje nuevo que sea sólido en su expresión artística. Asumiendo que la forma es la gran protagonista del cambio porque ha que ser abstraída a sus esencias, Kandinsky realiza un estudio de la forma por sí misma y de su presencia en la naturaleza. Puede parecer paradójico que, siendo precisamente la naturaleza la que tanta complejidad ofrece, Kandinsky

6 López GarcíA, Kandinsky: los fundamentos del arte abstracto, p. 17. 


\section{El arte abstracto como reducción a lo esencial}

recurra a ella como análisis y modelo de reducción. Pero la paradoja no es tal, porque Kandinsky ni toma la naturaleza como modelo exterior ni como fuente de contenido, sino como mera receptora de un análisis profundo. Kandinsky estudia en ella los tres elementos básicos de la forma pictórica: la línea, el punto y el plano. El análisis de la naturaleza es puramente confrontativo, y así lo recalca Kandinsky: «las leyes de la composición de la naturaleza se ofrecen al artista no para ser imitadas, ya que la naturaleza tiene sus finalidades propias, sino para ser confrontadas con las del arte» ${ }^{7}$.

Kandinsky parte de que el arte y la naturaleza tienen finalidades diferentes y pertenecen a reinos distintos: la naturaleza, al reino de la contemplación; el arte, al de la creación. Por eso, en el estudio que realiza no está interesado en cómo representar el mundo natural, sino en cómo aplica la naturaleza las leyes de la composición. El arte, dice Kandinsky, «no pretende apoyarse en la cáscara exterior de los fenómenos naturales» sino estudiar la naturaleza para entender cómo ésta utiliza los elementos básicos, las estructuras mínimas de los objetos naturales. Continúa: «especialmente valioso para el artista sería advertir hasta qué punto el reino independiente de la naturaleza aplica los elementos básicos: qué elementos aparecen, qué propiedades poseen y de qué modo se combinan». ${ }^{8} \mathrm{El}$ arte no tiene por qué seguir justificándose en la naturaleza ni ésta ser la condición del arte. El arte sólo tiene que aprender cómo se reducen los objetos naturales a sus formas mínimas, a su "esqueleto estable", para aplicarlo después al nuevo lenguaje que necesita el arte abstracto. Es, tal y como escribe Kandinsky, «la necesidad de retroceder a las fuentes, buscando lo elemental no sólo en lo elemental propiamente dicho, sino en la estructura elemental de las cosas.» ${ }^{9}$

En la reducción de la forma artística a su contenido esencial entran en juego los medios pictóricos: el color y la forma. Sin embargo, teniendo en cuenta -como se recordará de los capítulos anteriores- que el color adquiere para Kandinsky una entidad autónoma, es la forma pictórica la que lleva mayoritariamente el peso de la reducción. ${ }^{10}$ Su libro Punto y línea sobre el plano

7 Kandinsky, Punto y línea sobre el plano, p. 94.

8 Kandinsky, Punto y línea sobre el plano, p. 94.

9 Kandinsky, Punto y línea sobre el plano, p. 97.

10 Recuérdese que la obra de arte se construye sobre un elemento interno o contenido y un elemento externo o forma. Esta forma, aquí llamada "forma artística" para evitar confusiones, está compuesta a su vez de los medios pictóricos: el color y la forma, aquí llamada "forma 


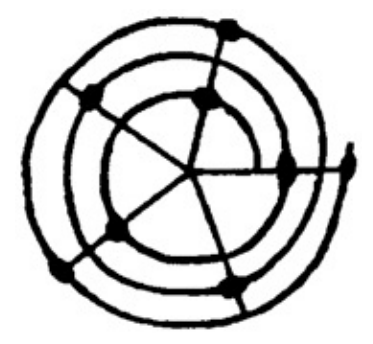

Ilustración 3 Esquema de la posición de las hojas

está dedicado al estudio de la forma pictórica y su presencia en la naturaleza.

Los tres elementos básicos de la forma pictórica son el punto, la línea y el plano. Todos se encuentran en la naturaleza, conformando las estructuras básicas de cualquier objeto natural. La línea, por ejemplo, puede formar construcciones geométricas, como en la formación esquemática de los cristales, que según Kandinsky es «una pura construcción lineal». La ilustración 3 muestra el uso de la línea en la posición de las hojas en el tallo. El desarrollo de las semillas a la raíz también se presenta a través de líneas, y acabará siendo un complejo geométrico, aunque a simple vista no se aprecie.

«Las plantas, en su desarrollo desde las semillas a la raíz (...) hasta el tallo (...), se basan en puntos y líneas (...), lo que en el posterior desarrollo conduce a complejos de líneas y a construcciones de líneas autónomos, como por ejemplo la trama de las hojas o las excéntricas construcciones de los pinos.»

Algunas construcciones tienen formas claras y exactas, como el cuerpo humano (ilustr. 4) o como una tela de araña. En otras, el punto y la línea aparecen de manera más libre, aparentando una precisión arbitraria, como en el trazo de un relámpago. Pero todo elemento orgánico tiene una estructura geométrica basada en puntos, líneas y planos. ${ }^{11}$

Kandinsky aprende de la naturaleza a extraer la esencia de los objetos y a

pictórica". En el proceso de reducir el elemento exterior (la forma artística) a su contenido esencial, el papel principal lo lleva la forma pictórica (la línea, el punto, el plano) porque el color es de por sí una entidad independiente.

11 Todas las citas del párrafo, así como las ilustraciones, se encuentran en Kandinsky, Punto y línea sobre el plano, pp. 92-100. 


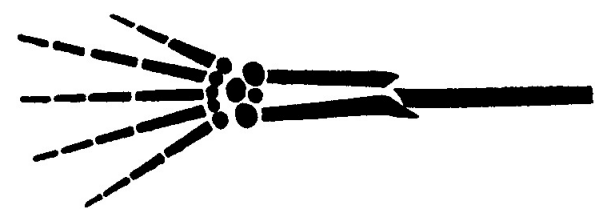

Ilustración 4 Esquema de la extremidad de un vertebrado

reducirlos a un lenguaje geométrico, basado en puntos y líneas. La apariencia externa de la naturaleza (lo que se ve a simple vista) es compleja y plural, pero existe una estructura interna que contiene la esencia del objeto y que se expresa en elementos básicos. Mientras que la apariencia externa es precisamente la que el nuevo arte trata de desechar, la estructura interna de la naturaleza sí puede ayudar en la confección del nuevo lenguaje del arte: un lenguaje basado en estructuras mínimas, constituidas por el uso del punto, la línea y el plano. Es lo que Kandinsky llama las leyes fundamentales: «Este parentesco [el uso de construcciones geométricas en el arte y la naturaleza] es un elocuente ejemplo de las conexiones entre las leyes del arte y la naturaleza. (...) La diferencia entre arte y naturaleza no radica en las leyes fundamentales.»

Las leyes fundamentales que comparten arte y naturaleza se basan en la valoración de la estructura interna. La apariencia externa ya no interesa al arte; algo que ya iniciaron otros pintores y no sólo Kandinsky. Los impresionistas y expresionistas comenzaron paulatinamente a despreciar la apariencia externa y compleja de la naturaleza. Difuminaron bordes (Monet), sustituyeron colores (Matisse), empezaron a reconocer las formas geométricas de su estructura interna (Cézanne). Kandinsky dará un paso más al eliminar por completo toda la apariencia externa. Pero, sobre todo, su innovación consiste en expresar la esencia de las cosas a través de su estructura mínima e interna, valiéndose de las formas artísticas apropiadas.

\subsubsection{La influencia de la ornamentación}

Cuando en el año 1912 la revista Kunst für alle acusa a Kandinsky de pin- 
tar «fantasías de tapicero empapelador» ${ }^{12}$, el crítico que escribe la reseña (no pudiendo adivinar el desarrollo que tendría el arte abstracto) se limita a comparar los cuadros de Kandinsky con las manifestaciones artísticas más cercanas: los diseños para decoración. Dejando de lado su falta de visión comercial, sí se le puede reconocer que señalara el paralelismo entre cómo la decoración usa las figuras abstractas y cómo el arte pictórico reduce sus formas a figuras abstractas.

A raíz de la impronta que el modernismo o Jugendstil deja en Múnich, la abstracción hace su presencia en el mundo del arte valiéndose de la ornamentación. No lo hace ni de un modo consciente ni, hay que resaltar, como un fin en sí mismo, pero las formas abstractas y sin referencia al objeto se hacen presentes en las artes decorativas. Varios son los nombres célebres que a principios del siglo xx y especialmente en el círculo artístico de Múnich, se empapan del modernismo y de la creación de formas ornamentales. Se trata de artistas como Peter Behrends, Karl Scheffler o Adolf Hölzel, artista ornamental al que por cierto, Edouard Roditi considera la verdadera fuente de las teorías abstractas kandiskyanas. ${ }^{13}$ Otro de los nombres relevantes es August Endell, cuyo diseño ondulado, abstracto, casi art-nouvesco para la fachada del famoso Atelier Elvira se termina en 1896, el mismo año en el que Kandinsky llega a Múnich. ${ }^{14}$ Pero el hombre que realmente acerca a Kandinsky el mundo de la ornamentación se llama Hermann Obrist.

Hermann Obrist se establece en Múnich en 1894. En esta ciudad y otras cercanas consigue exponer sus obras de cerámica, así como impartir charlas y conferencias sobre arte y artesanía. El momento exacto en el que Obrist y

12 «En la exposición (...) se pueden ver las fantasías de tapicero empapelador de Wassili Kandinski [sic], cuyo sentido más profundo ni siquiera con la ayuda del programa teosófico del pintor pueden desentrañarse», que se puede leer en Kunst für alle, volumen 27, p. 362.

13 Desgraciadamente Roditi lanza la afirmación sobre Hölzel y Kandinsky (que los estudios ornamentales de Hölzel fueron la verdadera inspiración del arte abstracto de Kandinsky) sin dar mayor explicación, lo que impide una investigación mayor. Quizá porque, cuando lo comenta en una entrevista a Gabriele Münter, ésta no le otorga tanta importancia. Puede leerse el pasaje en Roditı, Dialoge über Kunst, p. 201 y completarse en el artículo de Venzmer, Hölzel and Kandinsky as Teachers.

14 Un estudio más profundo sobre la relación del modernismo en Kandinsky, así como la comparación entre las obras literarias de Kandinsky y August Endell (Um die Schönheit) se puede leer en el capítulo 4 de WeIss, Kandinsky in Munich. 


\section{El arte abstracto como reducción a lo esencial}

Kandinsky se conocen no está claro, pero es muy probable que ocurriera a través de Gabriele Münter, ya que Obrist da clases de teoría del dibujo en la Academia de Mujeres (la Damenakademie) a la que ella asiste. ${ }^{15}$ Lo que sí es seguro es que Kandinsky conoce bien la obra de Obrist y también que durante los años que comparten en Múnich (los años de Phalanx, la NKvM, el Jinete Azul, etc.) se hacen amigos ${ }^{16}$ : «durante un tiempo Obrist y su familia nos invitaron a su casa y por lo tanto tuvimos la oportunidad de ver sus diseños y esculturas abstractas», relata Gabriele Münter. ${ }^{17}$

Como alfarero, escultor, dibujante y pintor perteneciente a la escena muniquesa, Obrist persigue el ideal de la Gesamtkunstwerk empapado de las ideas e influencia del modernismo. Gracias a su formación en ciencias naturales, Obrist es buen conocedor de los motivos de la naturaleza en la que tanto se inspira el arte modernista y trabaja a partir de ellos. Crea, por ejemplo, modelos de decoración para superficies (azulejos, cenefas, etc.) inspirándose en la naturaleza, pero simplifica tanto sus formas que al final no queda objeto natural reconocible. Obrist depura las formas de la naturaleza hasta que sólo quedan esqueletos geométricos o esquemas lineales de ellas. Es un proceso de depuración de las formas, que recuerda de manera evidente al estudio que hace Kandinsky sobre la reducción de la forma pictórica en la naturaleza.

Haciéndose eco de la época, con esa actitud que obligaba a contemplar la escisión de los mundos micro y macro, Obrist trabaja con fotos de elementos naturales tomadas a nivel microscópico. Utiliza fotografías de plantas que muestran su estructura microscópica -y por tanto puramente lineal- y las toma de referencia para sus diseños más variados. Con el microscopio descubre el "armazón" de los objetos naturales. Y esa estructura mínima, que no es sino una suma de líneas y puntos, Obrist la exporta al mundo macroscópico, utilizándola en un elemento decorativo. La mayoría de las veces, el objeto natural que sirve de modelo son plantas o animales, como el despliegue de los brotes en la rama de un árbol o las espirales que forman las plantas en crecimiento, curiosamente el mismo ejemplo que nombra Kandinsky y que se ha visto en la ilustración 3. Pero donde mejor se aprecia este proceso de

15 En la carta del 4 de febrero de 1904, Gabriele Münter le cuenta a Kandinsky impresiones sobre Obrist y el desarrollo de la clase. La carta puede leerse en KLEINE, Gabriele Münter und Wassily Kandinsky, p. 687.

16 Según el relato de Peg Weiss.

17 Roditi, Dialoge über Kunst, p. 213. 
simplificar la forma natural y luego incluirla en un elemento decorativo, es en el diseño de fuentes. Obrist construye fuentes para las que se inspira en formas microscópicas: por ejemplo, en el contorno de una gota de leche que salpica, en las líneas de una onda en movimiento o en el trazado de un pájaro en vuelo.

En resumen, Hermann Obrist incorpora los objetos naturales al mundo decorativo, pero reducidos a su mínima expresión. Y como se trata de elementos puramente lineales, con ello inicia la inclusión del lenguaje abstracto en el arte. Obrist es una especie de modelo que sigue Kandinsky, compartiendo con él la reducción de los objetos naturales a dibujos esquemáticos y lineales (es decir: abstractos, al fin y al cabo). Y Obrist será también un punto de referencia para los trabajos de los científicos del siglo xxi que, cien años después, presentan como obras de arte fotografías ampliadas de neuronas u otros niveles microscópicos del cuerpo humano (o de la naturaleza) ${ }^{18}$. Obrist fue quien inició el juego de los mundos micro y macroscópico y lo utilizó para lograr efectos originales y sorprendentes en el arte.

Al conocer los trabajos de Obrist y su relación con Kandinsky, es fácil que salten a la vista dos cuestiones. La primera, pregunta en qué se diferencia entonces el arte abstracto de los diseños decorativos. Y la segunda objeta si Kandinsky en vez de crear un nuevo lenguaje no se limitó a importar a sus cuadros las formas decorativas. La respuesta a ambas es que, aun compartiendo características, el arte abstracto no es mera ornamentación porque, en su creación y concepción, Kandinsky le hace ir más allá.

Es innegable que la ornamentación de Obrist (entre otros) y el arte abstracto tienen aspectos en común. Por un lado, la simplificación de las formas, la reducción a sus elementos geométricos básicos. Se puede decir que Kandinsky aprende de la ornamentación el método de simplificar la naturaleza y de llevarla al arte. También recoge, aunque de manera algo más difusa, la referencia del lenguaje a los mundos micro y macroscópico.

Por otro lado, arte abstracto y ornamentación comparten el estatus que

18 Cada vez son más frecuentes las exposiciones en las que se presentan como arte, y no meramente ornamental, fotografías de elementos naturales tomadas a nivel microscópico. La Fundación La Caixa realizó una en 2008 titulada Paisajes Neuronales, por poner un ejemplo. La Sociedad Española de Neurología ha publicado a finales de 2010 un libro titulado Neuroestética, que recoge fotografías similares. 


\section{El arte abstracto como reducción a lo esencial}

le otorgan al color. Con la minimización de las formas que emplean las artes decorativas, el color adquiere forzosamente una nueva dimensión. Al eliminar la representación del objeto natural en su forma reconocible, el color deja de estar atado al objeto. El color ya no es una propiedad de lo representado, porque no hay tal objeto, así que se convierte en expresión autónoma. Los dibujos ornamentales son formas y colores, y en ellos, la forma ni está subordinada al color ni viceversa. Karl Scheffler, en su artículo de 1901 Meditaciones sobre el ornamento $^{19}$, insinúa que el color como elemento autónomo y efectivo aún tiene que ser descubierto y explotado por las artes. Éste es uno de los avances que traerá el arte abstracto. Kandinsky crea un lenguaje en el que el color tiene autonomía y capacidad para transmitir emociones. Como se verá más adelante, Kandinsky aporta una sólida teoría del color abstracto, apoyado en los estudios de Itten o Runge (entre otros) e influido por su propia percepción del color, que ya se ha descrito en varias ocasiones («el objeto se funde en los colores», «el color es la puerta a la dimensión espiritual», «el color tiene existencia propia», «el color despierta estímulos sonoros»).

Pero aunque ornamentación y arte abstracto compartan la reducción de las formas y el nuevo acento del color, existe una gran diferencia entre ellos. En las artes decorativas, la abstracción reduce las formas: pero nunca como fin en sí mismo. La abstracción es el método intrínseco de la ornamentación, es su lenguaje nativo. No es un lenguaje creado como solución al problema de la búsqueda de la tranquilidad y de la transmisión de esencias. En la ornamentación, el lenguaje abstracto es principal en cuanto al método, pero secundario o incluso accidental en cuanto a los fines. Como escribe Karl Scheffler, el lenguaje abstracto es sólo el «dominio esencial del ornamentalista» ${ }^{20}$.

Antes de que nazca el arte abstracto o no figurativo, la abstracción sólo se usa como puro dibujo ornamental. Las artes decorativas utilizan elementos abstractos, pero sin cargarlos de intención ni de significado. Las formas naturales se reducen a otras abstractas, eso es todo. La innovación de Kandinsky consiste en hacer de la reducción de formas un fin en sí mismo, un lenguaje propio de un nuevo tipo de arte. Los diseños y las esculturas abstractas de Obrist son «más decorativas que las abstracciones de Kandinsky» ${ }^{21}$, reconoce

19 SCheffler, Meditationen über das Ornament.

20 WeIss, Kandinsky in Munich, p. 110.

21 Roditi, Dialoge über Kunst, p. 214. 
Roditi, porque Kandinsky confiere una finalidad y una entidad propia a esas formas básicas y reducidas. Del mismo modo, las creaciones de Obrist son básicamente lineares: pero lineares en el sentido de planas, puramente decorativas. Kandinsky en cambio prescinde de esa "linearidad plana" y dota al lenguaje, aun siendo lineal, de una capacidad de expresión autónoma. Así se entiende la cita de Paul Overy: «lo que hizo que las primeras obras abstractas de Kandinsky fueran tan revolucionarias fue la ausencia relativa de elementos lineales en comparación con obras proto-abstractas, decorativas, como los diseños Art Noveau de Obrist (...), que son básicamente lineales». ${ }^{22}$

Además de reconocerle a Kandinsky la creación del lenguaje abstracto como un fin en sí mismo, la historiadora Beeke S. Tower no duda en señalar que Kandinsky logró la «transición del ornamento abstracto a la abstracción en la pintura» ${ }^{23}$. Y algo similar le profetiza Alfred Kubin a Kandinsky en una carta de 1910: "su camino es disparatado y lujurioso y seductor: [usted] consigue alejarse de la ornamentación. Tal vez más adelante se vea en usted el comienzo de un nuevo periodo del arte» ${ }^{24}$.

\subsection{El minimalismo formal}

El arte abstracto marca, tal y como profetiza Kubin, un nuevo periodo del arte. Kandinsky presenta un lenguaje nuevo que se convierte en la expresión artística del siglo xx y lo será del xxI, y que está basado en reducir la forma a sus expresiones mínimas. Del estudio realizado sobre la forma natural y decorativa, Kadinsky deriva que el lenguaje ha de mostrar las esencias básicas. Dicho de otro modo, que la forma debe desprenderse de los detalles supefluos para expresar la verdadera esencia de la realidad.

Sin embargo, el proceso de creación del arte abstracto no es tan sencillo ni directo como una simple reducción de formas, porque la forma está en estrecha relación con el contenido. Y esa combinación de contenido y forma es esencial para la construcción de la obra de arte. A esta correspondencia entre uno y otra, Kandinsky la llama "elemento constructivo" e insiste en que

22 Overy, Kandinsky, p. 66. La cursiva es original.

23 Tower, Klee and Kandinsky in Munich and at the Bauhaus, p. 10.

24 HaHL-Kосн, Kandinsky, p. 159. 


\section{El arte abstracto como reducción a lo esencial}

la forma debe ajustarse a las exigencias que le dicta el contenido. Esto significa que la forma, incluso reducida a su expresión mínima, tiene que expresar un contenido. La forma no puede quedarse vacía porque se debe a la necesidad interior. Este aspecto se tratará en el apartado 4.2.1.

La segunda cuestión es qué aspecto tendrá esa forma. Tiene que expresar el contenido interior y además quedarse reducida a su mínima expresión. ¿Pero puede aún hacer referencia a los objetos? El nuevo lenguaje no necesita forzosamente el objeto porque ni es el protagonista del cuadro, ni es imprescindible para expresar emociones. Por lo tanto, la reducción de las formas puede llevarse hasta el extremo y abandonar del todo las apariencias figurativas. La forma abstracta, reducida a su mínima expresión, no tiene por qué conservar la apariencia de los objetos, como se verá en el apartado 4.2.2.

\subsubsection{La esencia mínima o necesidad interior}

La ilustración 4 vista anteriormente y que presenta la extremidad de un vertebrado es un ejemplo claro de un objeto reducido a sus líneas básicas. Parece fácil extraer lo elemental de lo complejo y presentar el esqueleto interno de algo, incluso sin perder la referencia al significado. Viendo sólo el dibujo de líneas y puntos no puede dudarse de que es una mano, una extremidad. Eso es, al fin y al cabo, lo que busca Kandinsky: una reducción de las formas en la que la esencia, el qué de lo representado, siga estando presente.

El problema surge cuando lo representado no es un objeto natural (que de por sí tiene un esqueleto subyacente) sino algo más abstracto: un sentimiento, una emoción, un contenido interno. Y todo arte, enfatiza Kandinsky, tiene que transmitir un contenido. Ese contenido es una emoción que nace del artista y que quiere llegar al espectador. Como la transmisión directa de emociones entre artista y espectador es imposible, la obra de arte hace de intermediario. El artista quiere expresar un contenido, el espectador espera recibir ese contenido y la obra de arte se encarga de la transmisión, adoptando una forma que exprese las emociones. El esquema se expresa en la siguiente tabla: 


\begin{tabular}{lll} 
artista & obra de arte & espectador \\
\hline emoción-sentimiento & obra de arte & sentimiento-emoción \\
contenido & forma artística & contenido
\end{tabular}

Tabla 4.1

La cuestión principal es, ¿qué forma artística (qué apariencia) adopta la obra de arte para ser portadora del contenido? Para que no se pierda en detalles superfluos y pueda transmitir su esencia tiene que reducirse a la mínima expresión. Pero no es fácil reducir hasta dar con la forma justa, con el esqueleto exacto al que no le sobran detalles y además consigue transmitir todo el significado. Es sencillo hacerlo con el dibujo de una mano, como se ha visto. El problema es reducir la apariencia de una emoción y lograr que siga transmitiendo su esencia o contenido interior. Es decir, la dificultad es cómo reducir algo que de por sí no tiene forma estándar (una emoción) a un conjunto de líneas, puntos y colores.

El mayor peligro es reducir excesivamente. Es fácil caer en una reducción tan absoluta que al final no queden ni siquiera las estructuras mínimas. Que se reduzca la forma de tal manera que no sólo lo superfluo desaparezca, sino también lo imprescindible, la esencia de la emoción. Porque si se reduce en exceso, se esquematiza tanto la representación del contenido interior que al final lo único que queda sobre el cuadro es un conjunto de líneas, puntos y colores arbitrarios. Pero ni rastro del contenido. La forma se ha quedado vacía, la esencia se ha perdido en el camino de la reducción.

Si la forma abstracta se reduce hasta llegar a lo arbitrario, se convierte en pura forma ornamental. Ése es el peligro. Kandinsky lo explica en su doble vertiente. Por un lado, la forma puede estilizarse tanto, puede reducirse tanto que se quede vacía: es el «peligro de la forma estilizada, una forma nacida ya muerta o una forma demasiado débil para vivir» porque no entraña contenido alguno. Por otro lado, si la forma se olvida del contenido y se regodea vacuamente en sí misma, se vuelve arbitraria. Posiblemente la forma resulte muy expresiva, pero sólo en apariencia. Es el «peligro de la forma ornamental, que es esencialmente la forma de la belleza exterior, pues puede ser (...) 


\section{El arte abstracto como reducción a lo esencial}

exteriormente expresiva e interiormente inexpresiva». ${ }^{25}$

Para evitar este doble peligro, Kandinsky deja claro que la forma siempre se debe al contenido. Durante todo el proceso de creación del arte abstracto, desde los primeros devaneos con la reducción de las formas hasta los cuadros en los que la forma abstracta se presenta elaborada y consciente, Kandinsky insiste en que el contenido determina la forma, en que lo interno exige lo externo, en que el arte debe nacer de un contenido interior. La forma, por muy reducida que se la quiera, nunca debe perder su contenido, no puede quedarse vacía. La forma tiene que expresar la emoción del artista y hacérsela llegar al espectador.

La emoción del alma del artista que ha de llegar hasta el espectador recibe el nombre de «necesidad interior». ${ }^{26}$ Esta necesidad interior es el contenido interno que ha de estar presente aun después de la reducción de las formas. Es la esencia mínima de las cosas que la forma reducida se ve obligada a respetar. La forma artística (líneas, puntos, espacios, colores) puede reducirse hasta el límite que le marca la necesidad interior, porque sin ella el arte no tiene contenido y por tanto pierde validez. La necesidad interior es la esencia mínima, es el contenido ineludible: «la ineludible voluntad de expresión de lo objetivo es la fuerza que aquí llamamos necesidad interior ${ }^{27}$, dice Kandinsky. La ecuación parece clara: reducir las formas, eliminar lo externo y superfluo y dejar sólo la forma artística necesaria para transmitir la necesidad interior: «el camino (...) [es que nos] despojaremos de lo externo, para oponerle su contrario: la necesidad interior ${ }^{28}$.

Las características del lenguaje que Kandinsky quiere para su nuevo arte, el arte abstracto, son de momento dos: por un lado, la forma artística (color y forma) ha de reducirse a su expresión mínima; por el otro, esa misma forma reducida tiene que ser capaz de transmitir el contenido interno del artista o necesidad interior. De la unión de ambas se deduce una tercera característica: el lenguaje se convierte en un lenguaje visual y simbólico.

25 Kandinsky, Mirada retrospectiva, p. 208.

26 KandinsKy, Escritos sobre arte y artistas, p. 55.

27 KANDinsky, De lo espiritual en el arte, p. 67. La cursiva es original.

28 Kandinsky, De lo espiritual en el arte, p. 69. 
El lenguaje de formas reducidas, que hoy se conoce como lenguaje abstracto, no hace sino dar una apariencia formal (líneas, colores) a un contenido interior (una emoción). En tanto que ese contenido es la necesidad interior de lo que se quiere expresar, esto es, su esencia mínima, el lenguaje de líneas y colores se convierte en su representación. Lo que significa que un conjunto de líneas y colores representan una emoción. El lenguaje de formas y colores se convierte en una especie de símbolo visual que representa una emoción, un símbolo creado a través de su esencia. Paul Overy acierta con las palabras, incómodas de traducir al español: el lenguaje del arte abstracto «stands for something». Y añade de manera clara: «Kandinsky creó formas que son una especie de notación o lenguaje visual, pero también son símbolos con una vida propia que interactúan con otros para crear un mundo autosuficiente de formas (...) pero que no necesariamente representan una traducción exacta de esas relaciones ${ }^{29}$.

El lenguaje abstracto es un lenguaje que permite representar la esencia mínima de las cosas: de las emociones, de los sentimientos, de las expresiones, de las sensaciones... de todo aquello que es la necesidad interior. El vocabulario que forman las líneas, los puntos, los espacios y los colores no es una traducción exacta ni formal, es una representación, es una especie de código o símbolo visual. Kandinsky lleva este lenguaje al límite, creando con los elementos básicos de la forma y el color toda una gramática de la creación, todo un lenguaje visual. No hay que olvidar que los expresionistas ya habían empezado a trabajar con ello. Por ejemplo, la cara de El grito de Munch aún conserva líneas que identifican ojos, nariz y boca, pero la expresión está contenida en una apariencia más cercana a la abstracción que a lo figurativo. Sin línea alguna figurativa son las caras que August Macke pinta en sus mujeres contemplando escaparates, como en Sombrerería de 1914. Las caras -mera forma ovalada de color rosáceo- también contienen toda la expresión femenina, aunque siguen apoyándose en formas figurativas que proporciona el contexto (la sombrilla, el tocado, el pelo). Es Kandinsky quien definitivamente consigue expresar toda la emoción interior basándose en puras líneas abstractas, sin contexto y sin referencias figurativas: usando el lenguaje abstracto como un lenguaje visual y simbólico.

El lenguaje abstracto comienza de esta forma a «expresarse en un idioma

29 Overy, Kandinsky, p. 77. 


\section{El arte abstracto como reducción a lo esencial}

cada vez más significativo», y lo que hasta ahora en el arte no decía nada (un punto, una línea suelta), ahora se llena de significado: «Así, se vuelven símbolos los signos muertos y lo muerto resucita». Son palabras del mismo Kandinsky en Punto y línea sobre el plano, que continúa igual de poético: «la nueva ciencia artística sólo podrá surgir cuando los signos se vuelvan símbolos y el ojo y el oído abiertos permitan saltar del silencio a la palabra». ${ }^{30}$

\subsubsection{La pérdida de lo figurativo}

¿No sería mejor renunciar por completo a lo figurativo, desparramarlo a todos los vientos y desnudar por completo lo puramente abstracto?

W. KANDINSKY

El lenguaje que Kandinsky elabora para crear lo que será el arte abstracto exige reducir la forma artística hasta su mínima expresión. La reducción puede llevarse hasta el extremo, sólo tiene el límite que le marca la necesidad interior. Porque las formas, aun reducidas, siempre tienen que ser portadoras de un contenido interior.

Reducir la apariencia de un objeto hasta que sólo queden de él manchas de color y líneas abstractas no implica directamente deshacerse de la forma figurativa. La conocida paloma de Picasso, por ejemplo, es un dibujo de formas reducidísimas, reducidas verdaderamente hasta su esencia mínima. $Y$ conserva su apariencia figurativa: de ahí que se la reconozca sin problemas. A Kandisnky «los objetos le estorban». No se puede olvidar que el proceso de la eliminación del objeto fue algo paulatino. Al principio, Kandinsky habla de «renunciar a la contigencia externa», luego reconoce que «no tenía todavía bastante madurez para experimentar la forma abstracta sin apoyo objetivo» o que «el objeto todavía no quería ni debía desaparecer completamente de mis cuadros». Hasta el día en el que Kandinsky sabe que «llegaría a la pintura absoluta». ${ }^{31}$

Uno de los episodios clave sobre la decisión de eliminar la forma figurativa

30 KANDinsky, Punto y línea sobre el plano, p. 22, para todas las citas del párrafo.

31 Kandinsky comienza llamando "pintura absoluta" a lo que será el arte abstracto (véase la pág. 108). Las citas pertenecen a Kandinsky, Mirada retrospectiva, p. 204-205. 
es el del cuadro en su atelier. El relato ha sido malcontado en numerosas ocasiones, las suficientes para convertir el descubrimiento de que el objeto es prescindible en la dejadez de afirmar que el arte abstracto puede mirarse del revés sin que eso influya en el resultado. Lo que revela el episodio es que la forma figurativa (más bien, el hecho de reconocer un objeto en un cuadro) deja de ser imprescindible para la transmisión de un contenido interior. Las palabras exactas de Kandinsky son las siguientes:

«ya en Múnich (...) hube de quedar cautivo por el encanto de una visión inesperada. Era la hora del naciente crepúsculo. Llegaba a mi casa con mi caja de pinturas después de haber llevado a cabo un estudio y todavía me encontraba sumido en mis sueños y absorbido por el trabajo que acababa de terminar, cuando de pronto vi un cuadro de una belleza indescriptible, impregnado de un vigoroso ardor interior. Al principio me quedé paralizado, pero en seguida me dirigí rápidamente hacia ese cuadro misterioso, en el cual sólo veía formas y colores y cuyo tema era incomprensible. Pronto encontré la clave del enigma. Era uno de mis cuadros puesto a un lado y apoyado sobre la pared. Al día siguiente traté de revivir a la luz matinal la impresión que experimentara la víspera frente al cuadro. Pero sólo lo logré a medias: aun de costado, no dejé de reconocer los objetos; era que faltaba la fina luz del crepúsculo. Ahora ya estaba seguro: el objeto perjudicaba a mis cuadros. ${ }^{32}$ »

Así pues, el proceso de reducir la forma artística (color y forma) hasta llegar a la abstracción viene marcado por dos premisas: una, la necesidad o contenido interior marca el límite de la reducción; y dos, la forma puede ser puramente abstracta, sin vestigios de forma figurativa. Para comprender este proceso, hay que observarlo en tres frentes: la modificación del espacio, la autonomía del color y la simplificación de la forma.

Eliminar toda apariencia figurativa del cuadro, es decir, prescindir del ob-

32 Kandinsky, Mirada retrospectiva, p. 110. 


\section{El arte abstracto como reducción a lo esencial}

jeto, influye obviamente en la apreciación general de la forma. Pero también influye directamente en la percepción del espacio del cuadro. En la ciencia, la concepción del espacio cambia radicalmente cuando Einstein introduce el tiempo como cuarta dimensión y con ello parece borrar la clásica ordenación kantiana. De la misma manera, el espacio de los cuadros kandinskyanos adquiere un nuevo papel: casi más temporal que propiamente espacial.

En el momento en el que la superficie del cuadro se queda sin objeto ni figura reconocible se pierde toda referencia espacial. Se pierde la posibilidad de comparar espacialmente, de determinar qué está aquí y qué allí. Los grupos de formas abstractas se presentan sobre la superficie del cuadro no arbitrariamente, pero sí sin centro ni foco composicional. Es como si dejara de haber un lugar central o privilegiado al que hacer referencia: ya no existe un lugar sobre el que las figuras tienen que ordenarse dentro del cuadro. Las formas abstractas copan el espacio del cuadro sin aparente orden ni jerarquía. Por su similitud con la pérdida de un sistema de referencia absoluto que proclama Einstein, Charles P. Webel no duda en comparar el método de Kandinsky con los acontecimientos físicos que le fueron contemporáneos: «en lugar de un centro composicional, Kandinsky introdujo un espacio esférico, simultaneidad de eventos pictóricos y una constelación de puntos. De muchas de estas innovaciones también podría decirse que caracterizan la Teoría Especial de la Relatividad $»^{33}$.

El espacio pictórico de Kandinsky juega con las dimensiones. Al introducir simultáneamente varios eventos pictóricos, como dice Webel, Kandinsky incluye el tiempo -la cuarta dimensión- en el espacio. Pero al prescindir del objeto y sustituirlo por un lenguaje de formas abstractas, esto es, de sólo dos dimensiones, elimina del espacio la tercera dimensión. Así lo explica el propio Kandinsky: «La renuncia a lo figurativo -uno de los primeros pasos hacia el reino abstracto- correspondió en el sentido gráfico-pictórico a la renuncia a la tercera dimensión: es decir a contener el "cuadro" como pintura sobre una superficie. (...) [Esto] condujo naturalmente a prescindir de la superficie.» ${ }^{34}$

La dimensión que aporta vitalidad a los objetos es precisamente la tercera, la cúbica. Por eso, al eliminar toda referencia figurativa, la tercera dimensión se pierde por sí misma. El cuadro prescinde de la superficie, pierde la categoría

33 Webel, Modernist Creativity, p. 549.

34 KANDinsky, De lo espiritual en el arte, p. 86. Las cursivas y comillas son originales. 
clásica del espacio, se deslocaliza. Pero gana la cuarta dimensión, la del tiempo. Utilizar el lenguaje de las formas abstractas permite a Kandinsky incluir simultaneidades, eventos, transiciones, figuras temporales: «La metamorfosis del PB [plano básico] material en un espacio indefinible proporciona la posibilidad de aumento de las medidas temporales» ${ }^{35}$.

El elemento central de esta reestructuración del espacio es la perspectiva. Kandinsky se da cuenta de que eliminar el objeto es un paso importante hacia la abstracción, pero sólo si va acompañado de la pérdida de la perspectiva. En sus primeras obras, Kandinsky intenta ordenar las formas y colores de tal manera que se aprecie su significado, que se reconozcan como grupos de formas. Un ejemplo es Vida abigarrada de 1907, en el que la abstracción asoma tímidamente. El cuadro lo componen manchas de color que aún hacen referencia a personas, objetos y paisajes. Y para que el espectador pueda "entender" esas formas sin contornos ni colores fieles a la realidad, recurre a la perspectiva aérea. Sin embargo, Kandinsky se da cuenta de que incluir la perspectiva no hace sino confundir y entorpecer la transmisión de esencias puras, porque vuelve a situar el cuadro incipientemente abstracto a las puertas de la figuración. La perspectiva establece referencias y eso entorpece la redimensionalización del espacio. Y se ve en la tesitura de tener «que encontrar un pretexto cada vez para legitimar la perspectiva ${ }^{36}$. Tres años más tarde, en su Composición II de 1910, parece haberlo conseguido. Así lo explica: «este cuadro representa una libre utilización de los colores sin mirar a las exigencias de la perspectiva $»^{37}$. Los historiadores corroboran años después esta ausencia de perspectiva. De nuevo Charles P. Webel: « Kandinsky construyó un mundo espacial sin perspectiva, sin ni siquiera las múltiples perspectivas de los cubistas, e introdujo elementos gométricos distorsionados en una textura espacial, pareciendo no tener referentes temporales o externos $»^{38}$.

La falta de perspectiva y la eliminación del objeto suponen, además de lo visto, la reconsideración obligada del color. Sin objeto, el color se convierte a la fuerza en una entidad independiente. Ya no tiene objeto del que ser propiedad.

35 Kandinsky, Punto y línea sobre el plano, p. 132.

36 KANDINSKY, Mirada retrospectiva, p. 204.

37 Kandinsky, Mirada retrospectiva, p. 204.

38 Webel, Modernist Creativity, p. 549. 


\section{El arte abstracto como reducción a lo esencial}

El color se presenta en el cuadro con la misma fuerza propia que las líneas abstractas; pertenece al cuadro como elemento autónomo porque no depende de la forma sino que se interrelaciona con ella.

Aunque la pérdida del objeto deja al descubierto la autonomía del color, tampoco es ésa la causa principal. Como se ha visto en repetidas ocasiones, el color siempre tuvo para Kandinsky un estatus especial. Ya en aquel viaje infantil a Italia los colores se le revelaron con un brillo diferente. El color y su objeto eran para Kandinsky dos entidades diferentes, así percibía el mundo y así lo guardaba en su memoria. Y éste es el tipo de percepción que influye en su obra: el color como entidad autónoma que, como pura y aparentemente simple mancha, es capaz de transmitir toda la fuerza de un contenido interior. Por sí misma, sin estar ligada a un objeto.

Además de la transformación que sufre el color, los elementos básicos de la forma (esto es, la línea y el punto) también están sujetos a cambios sustanciales. El proceso de reducción exige eliminar todo detalle superfluo y al mismo tiempo simplificar la forma hasta su mínima expresión. Una vez que ha prescindido de las proporciones y de la perspectiva, Kandinsky «elimina progresivamente las referencias a los objetos para obtener la esencia abstracta ${ }^{39}$ de las formas. El mismo Kandinsky lo expresa así en su libro sobre la forma, Punto y línea sobre el plano: «En el camino de la simplificación, éste es el último paso de una serie progresiva de disoluciones (...) con exclusión de todos los elementos complejos y reducción de la composición a un elemento primario único. De modo que (...) constituye la imagen primaria de la expresión pictórica» ${ }^{40}$.

La referencia al objeto es precisamente uno de esos elementos complejos que conviene eliminar. El primer paso es suprimir los contornos porque, de este modo, la figura pierde su definición y se transforma automáticamente en una mancha de color. Las líneas se liberan de la apariencia real y pueden desdibujar el objeto, simplificándolo de manera aún más directa y sencilla. Ya no hay un contorno al que atenerse, las líneas pueden reducirse libremente. Perdido el contorno, la figura se olvida de la naturaleza y se vuelve abstracta. Y esta supresión del contorno enfatiza, además, la bidimensionalidad. O como

39 Tower, Klee and Kandinsky in Munich and at the Bauhaus, p. 88.

40 Kandinsky, Punto y línea sobre el plano, p. 31. La cursiva es original. 
se expresó más arriba, la pérdida de la tercera dimensión. Es lo que ocurre en el ejemplo antes nombrado, Vida abigarrada, donde ninguna figura conserva el contorno y el cuadro se convierte en plano. La falta de contorno enfatiza la flatness de las figuras, por utilizar la expresión de Tower.

Tras la pérdida de los contornos, Kandinsky simplifica paulatinamente las formas hasta llegar al armazón interno de lo que quiere expresar. Las líneas se abrevian, toda alusión figurativa se pierde y un par de líneas bastan para llevar a cabo la representación. En el cuadro Montaña, de 1909, tres líneas que sólo son un triángulo representan la esencia mínima de la montaña, en cuyo pico se intuye una representación del Kremlin, también reducido a trazos mínimos y sólo identificable por aquellos familiarizados con la obra de Kandinsky. Las figuras de un jinete y de otro hombre en la parte inferior apenas presentan líneas; incluso el caballo que monta el jinete puede pasarse por alto, de tan reducida y simplificada que está su figura. El cuadro es pura reducción, pero eso no le impide expresar su fuerza interior o "dinamismo", como lo llama Jelena Hahl-Koch: «[las formas] están aún más simplificadas, de tal manera que logran efecto sólo a través de su color llamativo y su trazo sin contornos. Con esta reducción aumenta claramente el efecto del color y su dinamismo» ${ }^{41}$.

La simplificación de la forma llegará hasta la pura abstracción. A medida que Kandinsky evoluciona en su proyecto abstracto, las formas se volverán puramente geométricas, ensalzando la pureza de la línea simplificada. Sin necesidad de ir hasta el final de su carrera, los retratos son un buen ejemplo de cómo simplifica la forma. Salvo en un único retrato realista que pinta de su compañera Gabriele Münter, el resto de figuras humanas que incluye Kandinsky tienen siempre los rasgos faciales tipificados, casi despersonalizados. Son rasgos tan esquemáticos que transmiten una expresión, un modo de ser, pero nunca un reflejo o parecido con la realidad. De hecho, las formas se han reducido tanto que han dejado de ser únicas y se han hecho intercambiables, como apunta Tower no sin cierto sarcasmo: «ya en muchos de los estudios (...) de Kandinsky, ciertas formas como los árboles o las casas han sido simplificadas hasta el punto en el que se han vuelto intercambiables en varios cuadros, vaticinando los motivos formales recurrentes [que vendrán en su pintura abstracta]» ${ }^{42}$.

41 Hahl-Koch, Kandinsky, p. 168.

42 Tower, Klee and Kandinsky in Munich and at the Bauhaus, p. 20. 


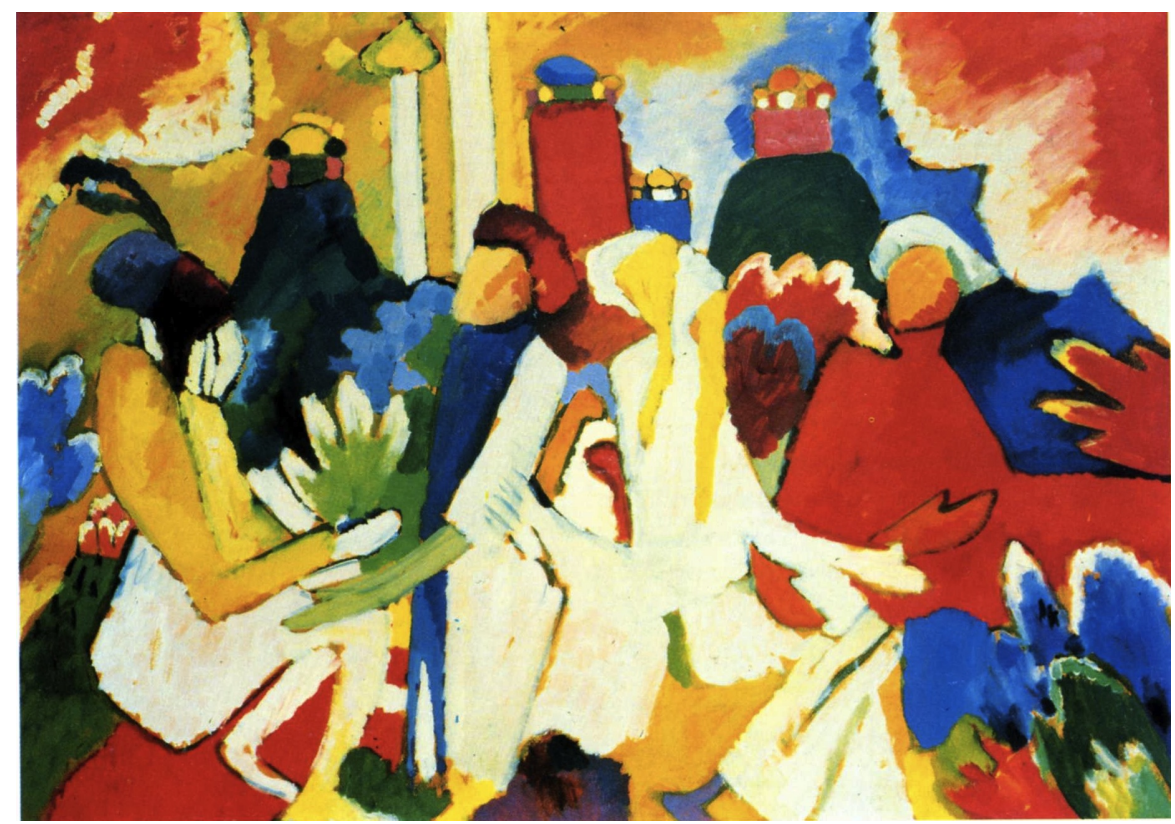

Ilustración 5 Oriental, 1909

Pero aunque las formas se "repitan", la expresión de la forma no tiene por qué ser la misma. Para dejarlo claro con un ejemplo se pueden comparar dos cuadros. Uno es Oriental de 1909 y el otro Improvisación 19 de 1911: en ambos aparecen rostros humanos, cada uno en su contexto. En Oriental son formas ovaladas de color rosáceo-anaranjado, en cierto modo al estilo de las mujeres observando escaparates de Macke. En la Improvisación 19 los rostros están definidos por líneas libres (sin forma geométrica precisa), de mayor o menor grosor. En ninguno de los cuadros aparecen elementos faciales (ojos, nariz, boca), pero no hay problema en reconocer que son rostros. Ahora bien, la expresión de cada uno de ellos, es bien distinta.

En Oriental, el rostro de la izquierda expresa cierta reticencia ante la petición de la figura central; es un rostro contenido en sí mismo, concéntrico, no se abre al resto del cuadro. En cambio, el rostro central pide, pregunta, inquiere, aunque sin llegar a irradiar: en cierto modo también está encerrado en sí mismo. La mancha de color de este segundo rostro es casi idéntica al óvalo anaranjado de la figura situada a la derecha del cuadro. Y sin embargo la expresión es diferente. A pesar de asemejarse en color, forma, inclinación y 


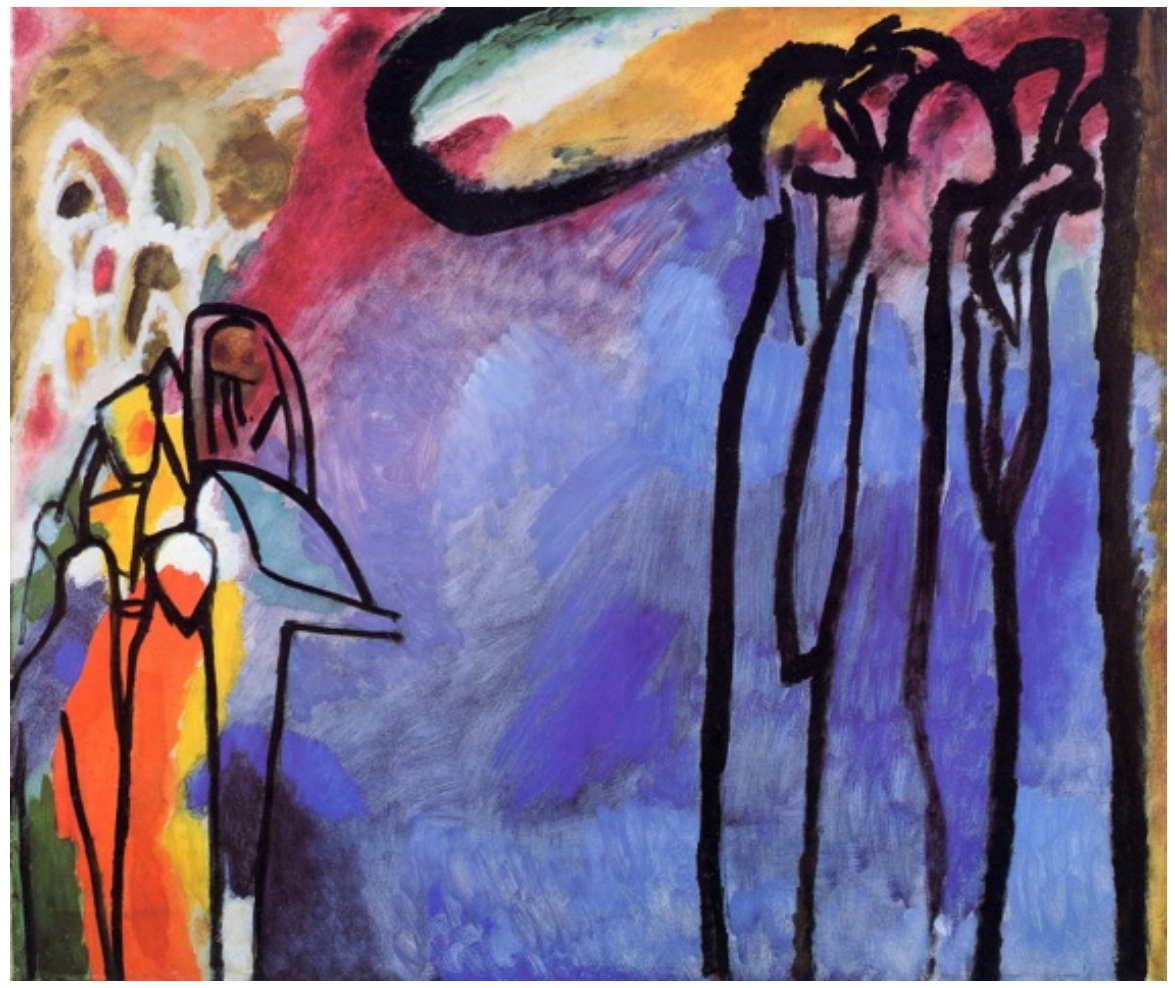

Ilustración 6 Improvisación 19, 1911

posición, el segundo rostro mira con curiosidad: se olvida de sí mismo para interesarse por lo que sucede más a la izquierda.

En Improvisación 19, las líneas reducidas a la máxima simplificación también consiguen expresiones diferentes. La figura pequeña, a la izquierda, parece que mira atentamente al espectador, inquisidor, como si quisiera ser ajeno a lo que pasa en el resto del cuadro. Su mirada está contenida, casi se hace hasta incómoda. Y en la parte superior, a la derecha, hay un grupo de rostros. Su figura central parece pensante, algo cabizbaja. Pero está integrada en el grupo y no ajena como la figura de la izquierda.

Ambos cuadros son un ejemplo de la teoría kandinskyana: Oriental consigue diversos efectos con manchas de color; Improvisación 19 utiliza no tanto el color sino la fuerza de la forma libre. Ambos son un ejemplo de cómo la forma pictórica, reducida a sus elementos básicos (forma y color), es capaz de transmitir un contenido interno. De cómo se puede eliminar el detalle, 


\section{El arte abstracto como reducción a lo esencial}

simplificar la forma y seguir conservando la necesidad interior. Son el ejemplo de la teoría que Kandinsky expresa del siguiente modo: «todo lo secundario desaparece automáticamente y sólo queda lo esencial: el objetivo artístico» ${ }^{43}$.

\subsection{La depuración de la forma}

El proceso en el que lo secundario va desapareciendo y lo esencial gana terreno lleva su tiempo. La mejor manera de apreciarlo sería estudiar cada cuadro por separado, desde su concepción primigenia hasta su manifestación definitiva. Así se podría observar y verificar cómo ha ido depurándose la forma hasta dar con su apariencia adecuada: aquella que está reducida a su mínima expresión, que nació de un contenido interior del artista y que en su forma final sigue conservando esa expresión interna. Lamentablemente, no se conservan imágenes de la mayoría de los cuadros en sus fases preparatorias. Sólo quedan algunos bocetos de ciertos cuadros y una secuencia de cuatro fotografías de Composición VII, que se corresponden con los cuatro días anteriores a terminar el cuadro una vez concebido. ${ }^{44}$

Por este motivo, además de tener en cuenta esos pocos bocetos, conviene añadir el estudio de los grabados en madera. La razón es que Kandinsky ejercitó en forma de grabado muchas de las secuencias formales que luego introdujo en sus cuadros, por lo que algunas imágenes sirven hoy en día casi como bocetos.

Antes de entrar a analizar los bocetos, conviene detenerse en el proceso de reducción de una forma recurrente y concreta: el caballo. En sus primeros cuadros, Kandinsky utiliza a menudo la figura del caballo, bien solo con un jinete, bien formando parte de una troika.

43 Kandinsky, De lo espiritual en el arte, p. 64.

44 Las fotografías, realizadas por Gabriele Münter, suelen venir reproducidas en las grandes monografías sobre Kandinsky y en algunos catálogos, como por ejemplo, en BEHR, Kandinsky. Malerei 1908-1921. Su inclusión en esta tesis no es relevante porque ilustra el proceso de finalización de un cuadro y no el proceso previo de concepción en el que se trabaja con la depuración de la forma. 


\subsubsection{Del caballo al círculo}

Como le sucede a todo artista, en la obra de Kandinsky también hay ciertas figuras recurrentes. Aparecen una y otra vez, en distintos tamaños, en diferentes colores, en nuevos contextos: pero son el mismo motivo, representan el mismo símbolo. Kandinsky utiliza a menudo castillos en una colina, montañas, barcos con filas de remeros como en los barcos vikingos, caballeros de estilo medieval y cierta connotación religiosa o soldados portando lanzas. Pero la figura central a lo largo de su carrera, figura que no sólo ha ocupado sus cuadros sino también sus escritos teóricos, es la del caballo. El caballo puede aparecer con un jinete o con otros dos caballos formando una troika. El caballo es la figura de Kandinsky, especialmente durante sus primeros años. A medida que se acerca a la abstracción, el caballo sufre la reducción o simplificación que sufren todas sus figuras y va adoptando una figura curvilínea, circular. A medida que la abstracción obtiene madurez expresiva, el círculo irá sustituyendo al caballo. Hasta que llegue el momento en el que el círculo se haga autónomo como forma abstracta y ya no necesite ni siquiera parecerse al caballo.

La transformación de la figura del caballo a la del círculo es, sin lugar a dudas, una de las reducciones más importantes en la obra de Kandinsky. Es la constatación del paso de lo figurativo a lo abstracto y la constatación del cambio de estilo artístico. El caballo es la figura central de su época expresionista; el círculo, la de su lenguaje abstracto.

Desde el inicio de su carrera como pintor e incluso en los primeros años de la abstracción (i.e. 1900-1910), la figura recurrente es el caballo, con o sin jinete. El caballo aparece como título del almanaque $\mathrm{El} \mathrm{Jinete} \mathrm{Azul}$ y antes ya lo había hecho en un cuadro homónimo de 1903, en numerosos grabados en madera o en los cuadros Composición II (1910) e Improvisación 12, por citar algunos ejemplos. Al parecer, el caballo siempre tuvo un significado especial para Kandinsky. En su libro autobiográfico, Mirada retrospectiva, recuerda un pasaje de su infancia en el que explica su amor por los caballos: «En un juego de caballitos había un caballo pío (...) que yo y mi tía queríamos muy especialmente. (...) Ni aún hoy me ha abandonado el amor que siento por esa clase de caballos. Me procura gran alegría ver un caballo semejante en las 


\section{El arte abstracto como reducción a lo esencial}

calles de Múnich. (...) Ese caballo despierta el sol que vive en mí» ${ }^{45}$.

En el libro que su segunda mujer, Nina Kandinsky, escribe sobre el pintor, la figura del caballo y su significado también están presentes. Nina habla del caballo y de lo que éste representa desde un punto de vista más adulto, una visión más racional que viene a completar el relato emocional del propio Kandinsky. «¿Que por qué los caballos? Yo creo que todos esos caballos hay que entenderlos como la representación simbólica del impulso hacia adelante del artista: la apertura hacia lo venidero, hacia lo nuevo», aclara Nina. ${ }^{46}$ Otros estudiosos de Kandinsky, como Paul Overy o Jelena Hahl-Koch completan con sendas opiniones la simbología del caballo. El primero apuesta por que «el jiinete parece ser una imagen lírica de alegría y liberación energética; hombre y caballo son uno (una especie de centauro expresando la unidad triunfante del hombre y la naturaleza) ${ }^{47}$, mientras que Hahl-Koch resalta la figura del caballo como «imagen de lo bello, de la armonía y la nobleza» ${ }^{48}$.

Cuando llega la etapa de la abstracción, es el círculo la figura protagonista de la mayoría de sus cuadros. Círculo negro de 1923, Círculos en un círculo (1923), Círculo azul (1925), Algunos círculos (1926) o Círculo amarillo (1926) son cuadros que no hace falta ver para intuir el papel relevante de la forma circular, gracias a sus títulos. El caballo se ha ido transformando en una forma abstracta circular, y ésta es ahora la figura recurrente. En Punto y línea sobre el plano, su libro teórico sobre la forma, deja claro que el círculo es una figura especial: es precisa, pero variable; es estable y al mismo tiempo inestable; es una forma mínima, pero con gran fuerza de expresión interior. El círculo es una figura llena de significado interior, de la misma forma que el caballo es un símbolo lleno de fuerza y matices. Así lo explica Kandinsky: «El motivo (o la razón) por la que en los últimos años, por ejemplo, uso tan frecuente y apasionadamente el círculo, no es por la forma «geométrica» del círculo, o sus propiedades geométricas, sino mi fuerte sensación de la fuerza interior del círculo en sus innumerables variaciones; hoy amo el círculo como antes amé, por ejemplo, el caballo... y tal vez ame más el círculo porque en él encuentro más posibilidades interiores, por eso vino a reemplazar al caballo» ${ }^{49}$.

45 Kandinsky, Mirada retrospectiva, p. 95-95.

46 Kandinsky, Kandinsky und ich, p. 55.

47 Overy, Kandinsky, p. 62.

48 Hahl-Koch, Kandinsky, p. 197.

49 Plaut, Die Psychologie der produktiven Persönlichkeit, p. 308. Las comillas son originales. 

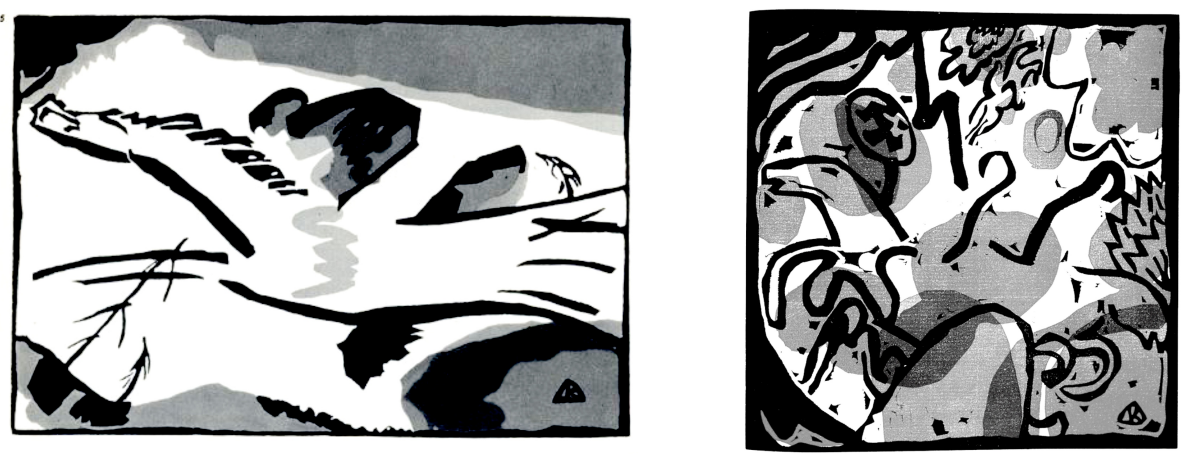

Ilustración 7 Lírico (izq.) y Tres Jinetes (dcha.)

Es por esta razón por la que el caballo acaba convirtiéndose, a través de la depuración de su figura, en una forma circular. La simbología es similar, y la fuerza de expresión del círculo como forma mínima es capaz de transmitir todo lo que Kandinsky quiere expresar con el caballo. No obstante, conviene aclarar que el círculo no sólo aparece con la reducción del caballo. El círculo también es un símbolo importante para Kandinsky desde sus comienzos, por ser la figura que tantas posibilidades le ofrece. A medida que madura su lenguaje abstracto, el círculo adquiere incluso nuevos significados, como adelanta esta cita de Kandinsky y quedará claro en los capítulos posteriores: "Los límites "geométricos" o "libres", que no dependen de un objeto, suscitan, como los colores, emociones menos definidas que los de un objeto. Son más libres, más elásticos, "más abstractos". Su forma abstracta no tiene ni vientre, como el caballo, ni pico, como el ganso. Cuando uno quiere someter una idea plástica a un objeto, normalmente tiene que cambiar y restringir sus límites naturales. Para alargar un caballo, hay que estirarle la cabeza o la cola. Esto es lo que yo hacía en el pasado antes de hallar en mí la posibilidad de liberarme del objeto» ${ }^{50}$.

La transformación gradual que sufre el caballo, desde símbolo figurativo a símbolo abstracto como círculo, se puede observar en casi toda la obra de Kandinsky; especialmente en sus grabados en madera y algunos cuadros. Hacia 1908, el caballo y su jinete empiezan a experimentar cierta simplificación,

50 KANDINSKY, Escritos sobre arte y artistas, p. 154. Las comillas son originales. 

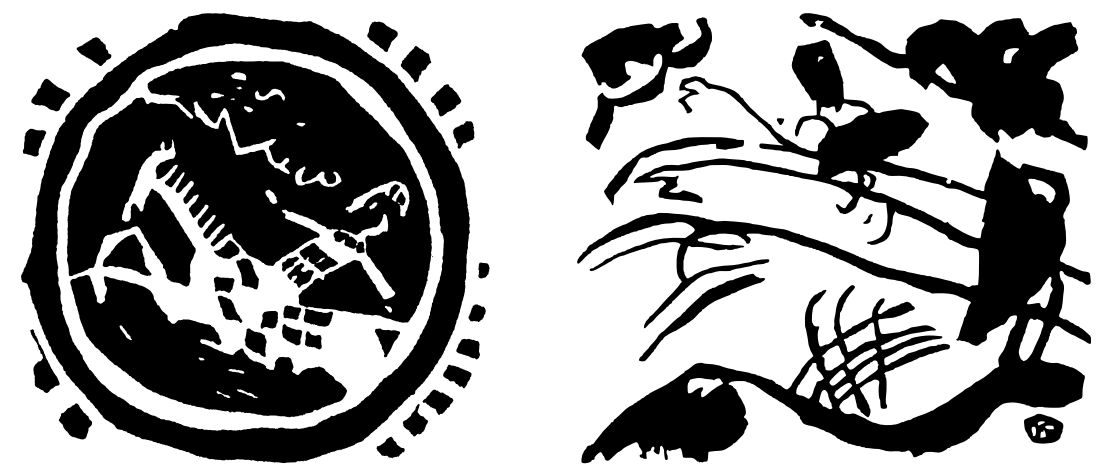

Ilustración 8 Grabados de los poemas Hojas (izq.) y Salida (dcha.)

como ocurre en un pequeño grabado que realiza para la revista Tendances Nouvelles. A partir de aquí, la figura del caballo se va despojando poco a poco de sus características figurativas y va adoptando una forma cada vez más circular. Un buen ejemplo es el grabado Lírico, que pertence al libro Sonidos y que muestra la figura de un caballo con su jinete (ilustr. 7). Ambas figuras son claramente reconocibles, pero la disolución de las formas ya ha comenzado. La forma del caballo es más un esqueleto, un armazón mínimo ("la forma mínima") que la copia de la figura realista de un caballo. Y aún mayor disolución se aprecia en Tres Jinetes. El caballo aún se reconoce gracias a la cabeza, pero el resto del cuerpo ya es pura línea curva. De la misma manera, los tres jinetes son líneas libres que parecen flotar en el aire. Son reconocibles como jinetes sólo por el título y el caballo. Las figuras, en otro contexto, serían ya puramente abstractas.

También en el libro Sonidos se encuentra otro doble ejemplo de la transformación del caballo en círculo (ilustr. 8). Se trata de las ilustraciones que acompañan respectivamente los poemas Hojas y Salida. En Hojas se combina la presencia del caballo y la del círculo: éste envuelve a aquel y ambos parecen unirse en la expresión de la fuerza interior. Un doble símbolo usado al unísono, como si el círculo reforzase la expresión del caballo. Paulatinamente, el caballo se irá desfigurando y haciéndose uno con el círculo. La transformación se puede apreciar directamente en la xilografía de Salida: el caballo se ha convertido en líneas curvas, algo más estilizadas que las vistas anteriormente en Lírico y aún no tan redondeadas como se verá en breve, pero sin duda alguna, sin aspecto figurativo de caballo. Las líneas que lo rodean lo envuelven a modo 

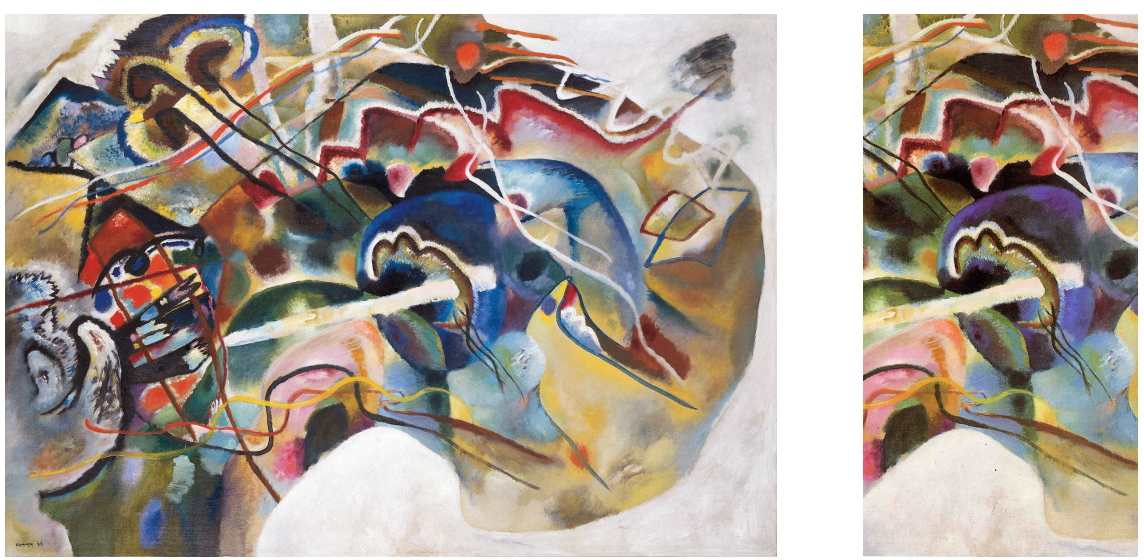

Ilustración 9 Cuadro con orla blanca, 1913 y fragmento del caballo

de círculo: sin serlo del todo, sin llegar a serlo. Caballo con jinete y círculo vuelven a fundirse y a reforzar la simbología, pero esta vez tras el proceso de la depuración de la forma.

Gracias a la conservación de algunos bocetos de Cuadro con orla blanca (1913), se puede aislar la figura del caballo y acercarse a su circularidad. La ilustración 9 muestra el cuadro en su versión final y, a la derecha, el fragmento en el que aparece el caballo. Más que un círculo geométrico cerrado en sí como dicta su definición, el caballo es una curva abierta con tres salientes o “jorobas". De izquierda a derecha, la primera representaría la cabeza del caballo, la segunda la del jinete y la tercera y más larga, el cuerpo del jinete fundido en el cuerpo del caballo. El caballo se ha reducido a su forma mínima sin dejar de expresarse como caballo: Kandinsky logra aquí la forma mínima sin renunciar al contenido interior. En los bocetos de la ilustración 10 se puede apreciar el estudio de la figura aislada del caballo y su utilización en la figura general. Kandinsky trabaja la forma del caballo variando la longitud de la línea, la apertura de la curva o la separación de los salientes. En el boceto de la derecha queda patente la circularidad de la figura del caballo, reforzada además por otra aureola curva -de manera similar a la de los grabados anteriores (Hojas y Salida) - y que en la obra final la asume el color azul.

Hasta ahora se ha visto la figura del caballo por sí sola o con uno o varios jinetes, pero el caballo también aparece dentro del motivo de la troika rusa. 

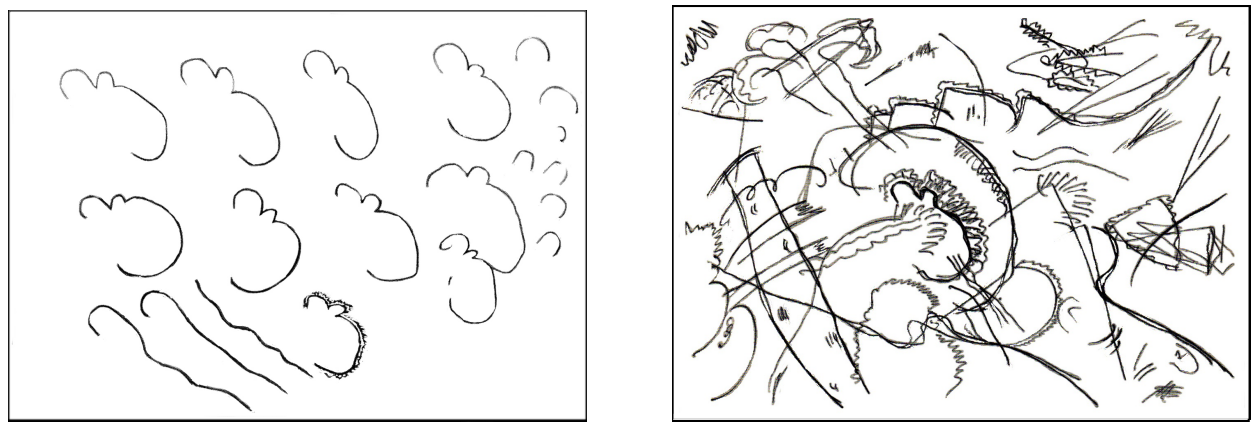

Ilustración 10 Bocetos para Cuadro con orla blanca

Una troika es un trineo o carruaje tirado por tres caballos que están unidos por una rienda que les mantiene la cabeza alzada. El caballo central es un caballo trotador y quien realmente tira del carro. El detalle no es irrelevante porque se apreciará en los cuadros. Kandinsky utiliza el motivo de la troika a menudo, y en una ocasión, al describir él mismo su Cuadro con orla blanca, incluso lo nombra y lo sitúa dentro del cuadro. Esta descripción ha ayudado mucho posteriormente a identificar la reducción de formas que experimenta la troika.

En su escrito, Kandinsky describe la troika del siguiente modo: «Carruaje de tres caballos. Así llamo a tres líneas paralelas un tanto separadas que se tuercen hacia arriba. Llegué a concebir este motivo mirando las líneas dorsales de los tres caballos de tiro ruso». ${ }^{51} \mathrm{~A}$ raíz de esta descripción y observando algunos ejemplos, se identifica sin problemas el motivo de la troika. Kandinsky reduce las figuras de los tres caballos a tres líneas estiradas y paralelas con ligeras desviaciones que terminan en forma de gancho. Las tres líneas se tuercen en la parte superior formando una especie de círculo que no llega a cerrar. Como Kandinsky siempre dibuja la troika en su posición real (es decir, no da la vuelta a los caballos, ni los inclina desmesuradamente, ni los coloca boca arriba o boca abajo), las líneas se tuercen siempre en el mismo lado, el izquierdo desde el punto de vista del espectador. Como si los caballos se movieran de derecha a izquierda y las curvas, que representan sus cabezas, quedaran entonces a la izquierda. La línea central suele sobresalir o destacar de alguna manera (mayor o menor separación, mayor o menor grosor): es la cabeza del

51 Kandinsky, Mirada retrospectiva, p. 137. 


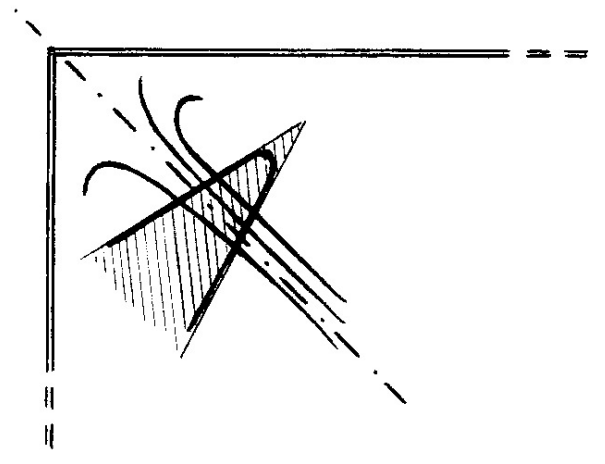

Ilustración 11 Esquema de F. Thürlemann para la troika

caballo trotador. Por último, las tres líneas están cortadas por una doble línea (la rienda que les mantiene la cabeza en alza) que se hace puntiaguda en el doblez, resultando una forma atriangulada.

Este aspecto de la troika, las tres líneas que al final se curvan y cortadas por una doble línea, es el aspecto de la troika una vez pasado el proceso de reducción. Felix Thürlemann publicó un libro en 1956 en el que interpreta parte de la simbología de Kandinsky y sus elementos recurrentes. ${ }^{52}$ En el estudio que hace de la troika añade un esquema visual, que pone en imagen la descripción de líneas recién detallada (ilustr. 11).

El esquema de Thürlemann ayuda significativamente a reconocer el motivo de la troika en la obra de Kandinsky, como en los siguientes ejemplos. En Cuadro con orla blanca (ilustr. 12), al igual que se hizo con la figura sola del caballo también se puede aislar la troika para reconocerla mejor (parte superior izquierda, del espectador). La curva o gancho final de las tres líneas está reforzada no sólo por el grosor de la línea, sino también por el acento que le confiere el color marrón. La línea central sobresale, recordando al caballo trotador y se distingue de las otras dos por el color de la aureola (amarilla en la línea central, morada en las líneas de los lados). La rienda que une los caballos vuelve a estar reducida a una línea que corta horizontalmente y a modo de triángulo las tres líneas verticales o caballos.

Dos grabados del libro de poemas Sonidos son otro buen ejemplo para

52 Thürlemann, Kandinsky über Kandinsky, p. 184. 

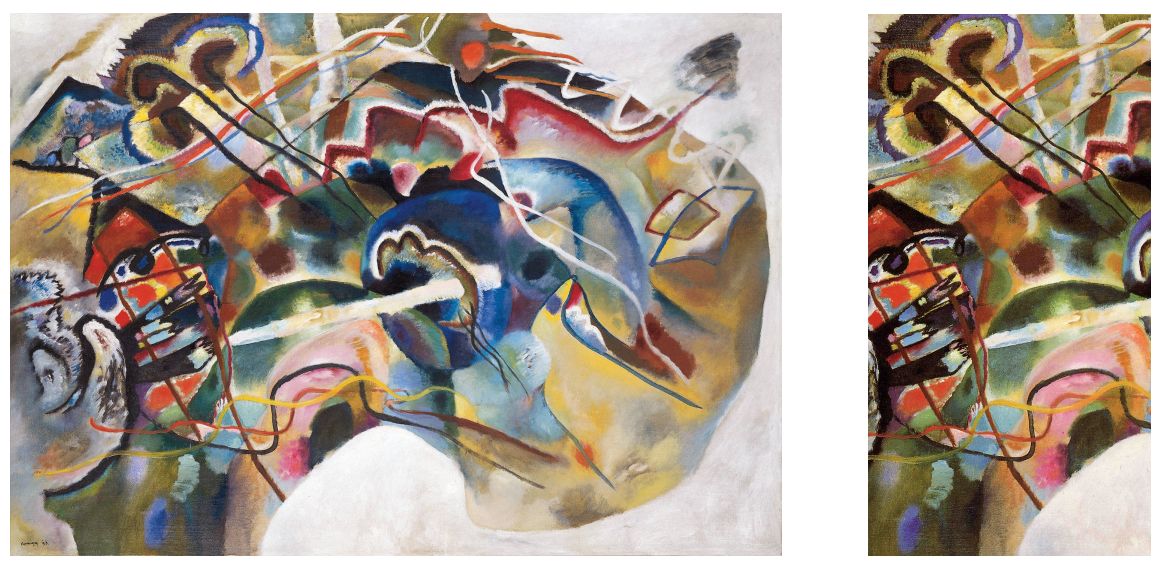

Ilustración 12 Cuadro con orla blanca, 1913 y fragmento de la troika

apreciar la figura de la troika. El motivo está claramente reducido al mínimo y, en cierto modo, amoldado al contexto de cada ilustración. En Blanco colorido (ilustr. 13) destaca sobremanera la fuerza que se le da a la rienda que une los caballos. En este caso, la línea se ha convertido en un triángulo abierto, tan fuerte en su expresión, que subyuga las líneas de los caballos. A pesar de ello, la presencia del caballo trotador sigue siendo identificable. En el otro grabado, Jaula, la rienda no tiene tanto protagonismo, aunque su tamaño también sea destacado. El caballo central vuelve a diferenciarse de los otros dos y, por su situación esquinada, recoge toda atención. Lo que le hace destacar, sin embargo, es el contraste de diagonales con otra línea presente de mayor grosor y que no pertenece a la troika propiamente dicha. Si se observa el conjunto, la troika de Jaula ha sufrido un proceso de reducción más acusado, pero la esencia mínima sigue estando presente.

Una vez expuesto el proceso de depuración y transformación del caballo (bien con jinete, bien en una troika) la imagen que abría este capítulo 4, en la página 132, se explica por sí misma. Es una viñeta que pertenece al folleto publicitario del almanaque El Jinete Azul y se conserva en la Galería Lenbachhaus de Múnich. En ella se reconocen sin problemas la figura del caballo con jinete, la figura de la troika y el círculo que las envuelve. 

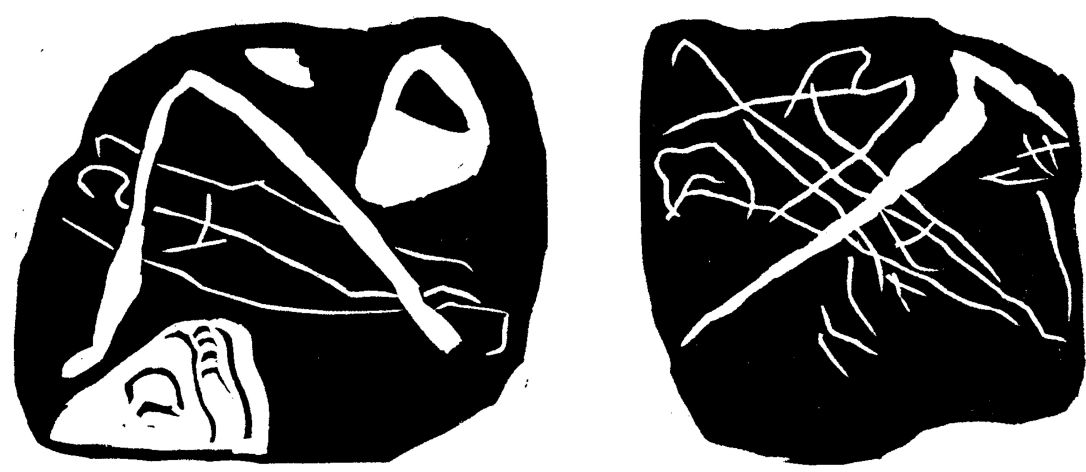

Ilustración 13 Blanco colorido (izqda.) y Jaula (dcha.)

\subsubsection{Del boceto al cuadro}

Cuando Kandinsky ingresa en la escuela de pintura de Franz von Stuck (h. 1900, en Múnich), ha estado un par de años trabajando con la forma y el color en un estilo entre impresionista y expresionista: es decir, de colores llamativos y formas subyugadas. Von Stuck cree que la forma de pintar de Kandinsky es demasiado expresiva y, oponiéndose a sus extravagancias de color, le aconseja pintar en blanco y negro para que estudie únicamente la forma. ${ }^{53}$ Ésta es una de las primeras ocasiones en las que Kandinsky se enfrenta a la forma pura y, gracias a ese estudio, aprende a dominarla y a dotarla de expresión contando sólo con sus elementos mínimos.

Un efecto similar lo obtiene trabajando con grabados en madera. La técnica del grabado obliga a reducir las figuras a sus líneas principales, porque no deja espacio alguno para el detalle. La madera tiene que cortarse de manera precisa y clara, y el dominio de la forma es imprescindible. Kandisnky utiliza el grabado en madera como expresión artística en sí (es decir, como fin artístico en sí mismo) pero también, según le comenta en una carta a Gabriele Münter, como preparación para trabajar los objetivos artísticos de las pinturas. Según la monografía de Jelena Hahl-Koch, Kandinsky conocía las técnicas del grabado japonés y lo valoraba como medio de expresión autónomo (y no secundario, como muchos otros artistas), hasta el punto de incluir grabados no sólo en sus exposiciones (Phalanx, NKVM, etc.) sino como ilustraciones

53 La historia puede releerse en el capítulo 1, nota al pie 21. 


\section{El arte abstracto como reducción a lo esencial}

de sus propios libros (De lo espiritual en el arte, El Jinete Azul, etc.). ${ }^{54}$ Según revela la crítica de entonces (véase por ejemplo Der Sturm o Kunst für Alle), los grabados de Kandinsky destacaban no sólo por su belleza, sino especialmente por su calidad técnica y el dominio de las formas.

El trabajo en madera obliga a reducir la forma. El formato tiene que ser pequeño para que luego pueda ser imprimible y la dificultad del corte exige formas mínimas y despojadas de todo detalle. El color suele estar reducido al puro contraste del positivo y negativo, blanco y negro, lo que realza aún más las formas. Y la perspectiva es casi imposible. El grabado en madera es un trabajo de formas mínimas, donde la forma -incluso la figurativa- tiene que reducirse a su mínima expresión.

Sin embargo, ni siquiera en los grabados en madera las formas mínimas prescinden del contenido interior. Incluso reducidas, siguen conteniendo toda la expresión que les quiere dar el artista. De hecho, Kandinsky publica en 1906 una serie de ilustraciones de grabados a las que da el nombre de Poemas sin palabras, dejando claro que la mínima expresión formal no impide la máxima expresión interior. Así lo pone de manifiesto Peg Weiss: «[esos grabados] eran capaces de sugerir un profundo significado de la misma manera que la poesía, por medio de una imagen condensada $»^{55}$.

El grabado supone para Kandinsky una base de trabajo idónea para aprender a depurar la forma (porque le obliga la técnica y el material) pero sin desproveerla de su expresión interior (porque es exigencia como artista). Podría decirse que los grabados que Kandinsky realiza durante sus primeros años contienen muchos indicios de lo que será su obra posterior no figurativa o, incluso como dice Weiss, que los grabados son el camino que llevan a Kandinsky a la abstracción: «fue el grabado en madera lo que iba a servir como puente gracias al cual Kandinsky fue capaz de avanzar del arte decorativo a la abstracción ${ }^{56}$. Weiss señala cómo, por ejemplo, muchos de los cuadros de paisajes de Murnau (el pueblo bávaro donde Gabriele Münter compra una casa), tienen un parecido más que notable con sus grabados. De la madera, Kandinsky importa al cuadro la flatness de la superficie y la reducción de las líneas; utiliza sólo un par de colores, muy saturados y sin transiciones, y las

54 HaHL-Косн, Kandinsky, p. 96.

55 WeIss, Kandinsky in Munich, p. 127.

56 WeIss, Kandinsky in Munich, p. 127. La cursiva es original. 


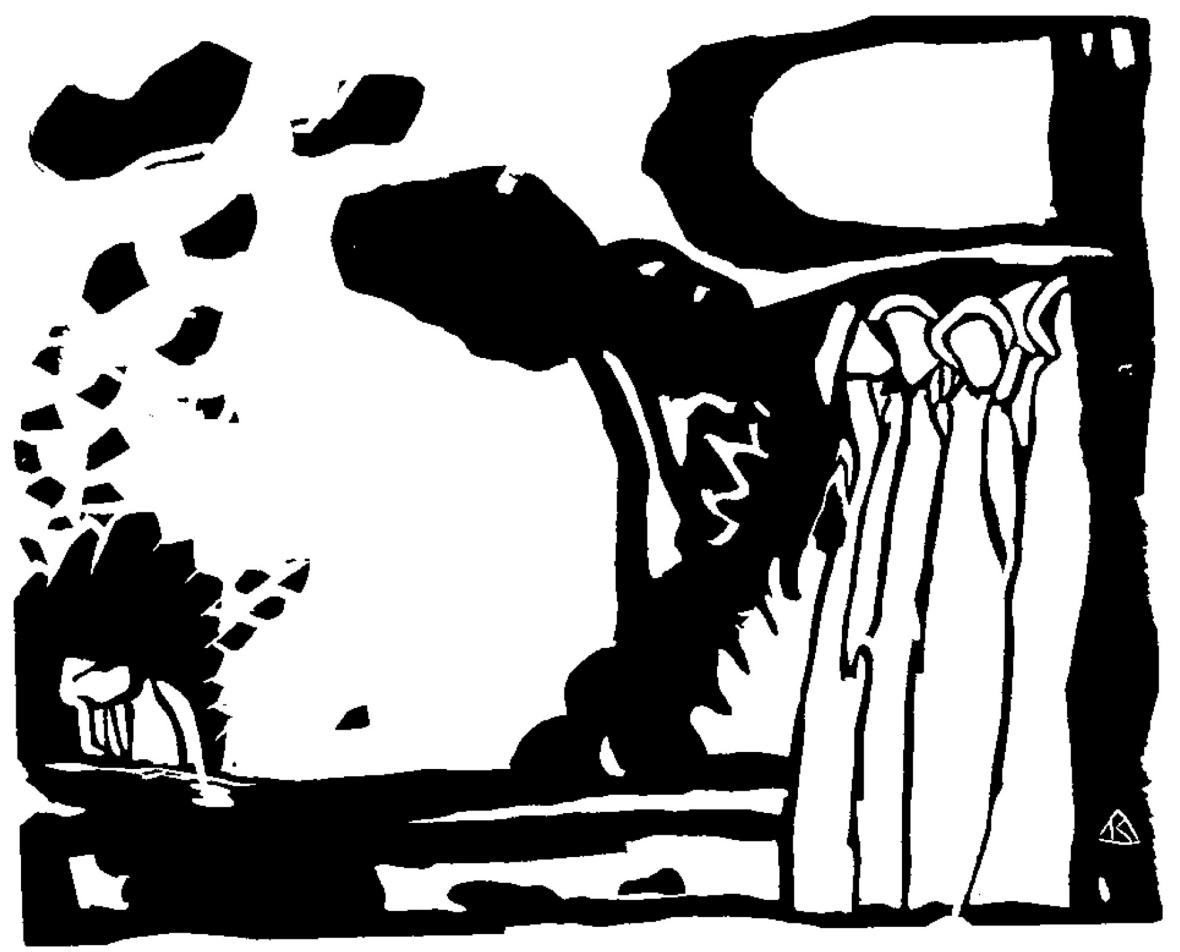

Ilustración 14 Grabado para Improvisación 19

zonas de luz y sombra contrastan excesivamente, recordando el efecto de positivo-negativo que tienen los grabados. El cuadro no es la ilustración de un grabado, pero la técnica y la apariencia lo asemejan considerablemente a él.

La depuración de la forma a la que le obliga el grabado no significa para Kandinsky una restricción, sino la posibilidad de trabajar la forma como el elemento que reforzará su obra principal, la pintura abstracta. Considerando alguno de estos grabados como bocetos de ciertos cuadros, se puede hacer un breve recorrido por su obra y así analizar el proceso de depuración de la forma, que completa el analizado mediante la figura del caballo. Se presentarán tres ejemplos: Improvisación 19, Composición IV y Impresión III.

Improvisación 19 de 1911 (ilustr. 6), es uno de los cuadros cuyos bocetos previos no se conservan, pero sí un grabado en madera que sin duda fue su base de trabajo (ilustr. 14). En el apartado anterior se ha analizado la expre- 


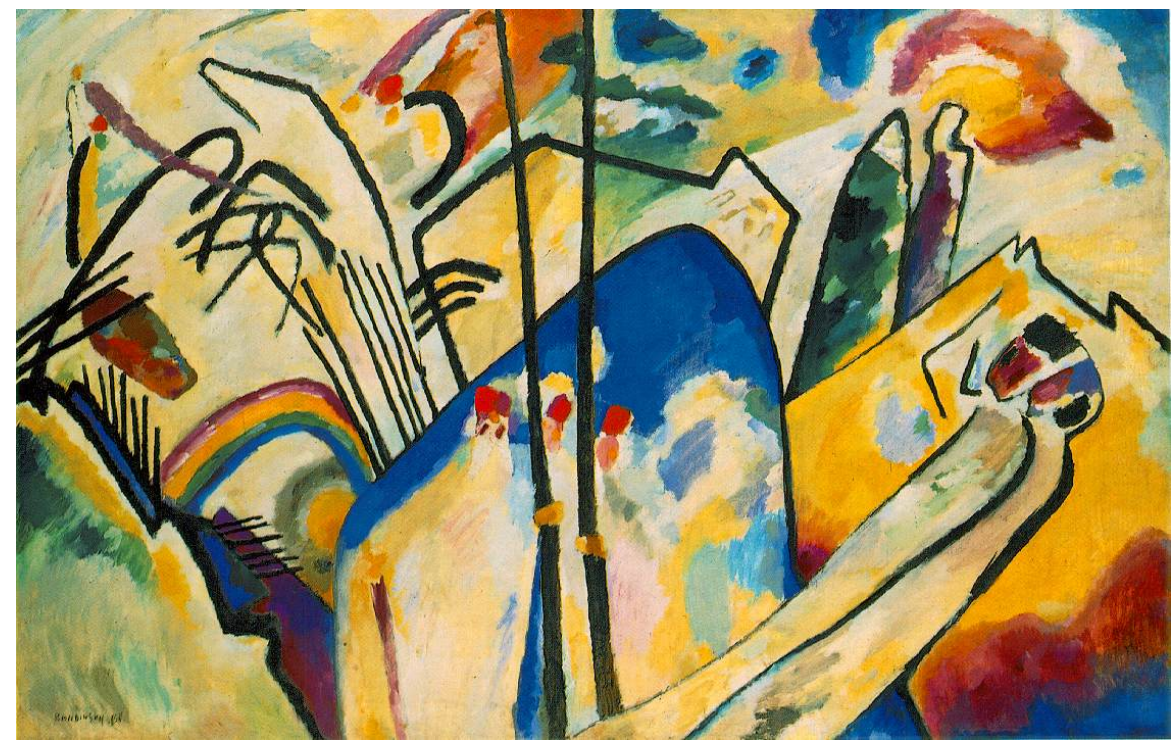

Ilustración 15 Composición IV, 1911

sión interna de los rostros, conseguida tan sólo a través de formas libres que han sido reducidas al máximo. Esas mismas formas se aprecian también en el grabado, no cabe duda de que éste fue un buen ejercicio de reducción para el cuadro final. El grabado es, en idea, una radiografía en blanco y negro del cuadro. En el primero aún no aparecen las figuras de la izquierda, pero el planteamiento de la imagen es el mismo. Improvisación 19 es un buen ejemplo para constatar el uso del grabado como paso previo a los cuadros, incluyendo el trabajo y aprendizaje de la reducción de la forma. Y también es un buen ejemplo para verificar la calidad del grabado por sí mismo, como medio autónomo de expresión artística. Las figuras del grabado, aun estando reducidas en color y forma, derrochan fuerza interior. Es innegable que son capaces de transmitir una gran expresión.

De Composición IV se conservan varios bocetos, por lo que es una buena obra para comprobar los cambios que se han dado hasta llegar a la imagen final. Es un cuadro con un lenguaje abstracto bastante avanzado, aunque las líneas negras y gruesas parezcan jugar a ser contornos y dejen una leve impronta figurativa. La ilustración 16 es uno de los estudios preliminares 


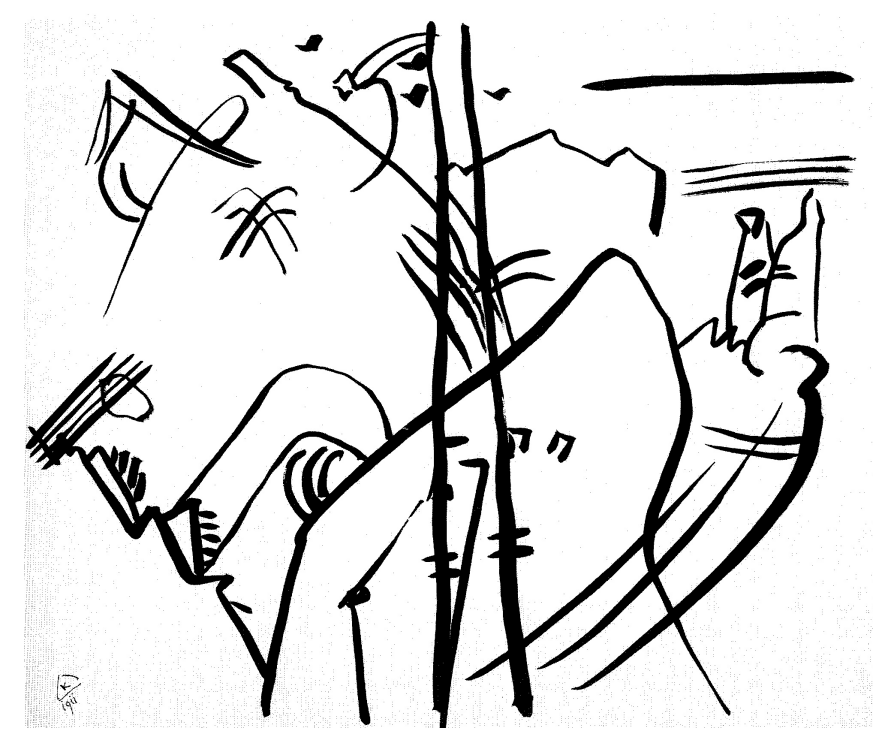

Ilustración 16 Boceto para Composición IV, general

que se conservan y resume de manera excelente la idea del cuadro. El boceto presenta únicamente las formas y líneas, en blanco y negro, como si fuera un grabado en madera. En él está esquematizado lo que será después la obra final. Sus líneas recogen la expresión que se completará con el color y con ligeros cambios. Hay tres grupos de figuras que merecen especial atención.

El primero es la patente reducción a la que ha sido sometida la figura del caballo. Si se siguen con la vista las dos lanzas o líneas verticales centrales, arriba a la izquierda aparece el motivo ya comentado del caballo con un jinete. En el boceto (ilustr. 16) está reducido a una línea libre, curva, que asemeja al número 3 ó a una letra $\mathrm{z}$ antigua, con dos “jorobas”. En la obra final, el caballo con forma de 3 ó zeta se ha convertido en un semicírculo al que acompaña un punto rojo, que delata la presencia del jinete.

El segundo grupo lo constituye la pareja que, de pie, está situada a la derecha de las lanzas. En el dibujo previo (ilustr. 17) son dos figuras de rasgos elementales. Las líneas son en cierto modo breves, pero aún se entretienen en los ropajes, en los pies, en resaltar algunas zonas. En la obra final (ilustr. 15) ya son dos formas completamente libres, sin ningún recuerdo figurativo. No hay ropajes, no hay dobles líneas, no hay distinciones de ningún tipo. El proceso de reducción es claro: el número de líneas disminuye, la figura grotesca se estiliza, 
4 El arte abstracto como reducción a lo esencial

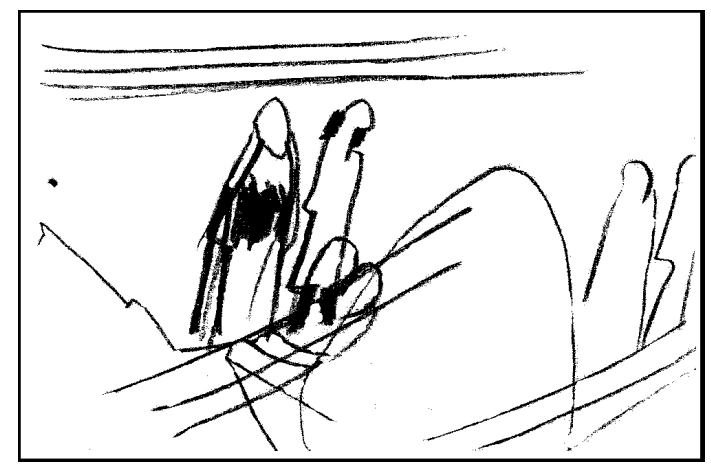

Ilustración 17 Boceto para Composición IV, figuras de pie

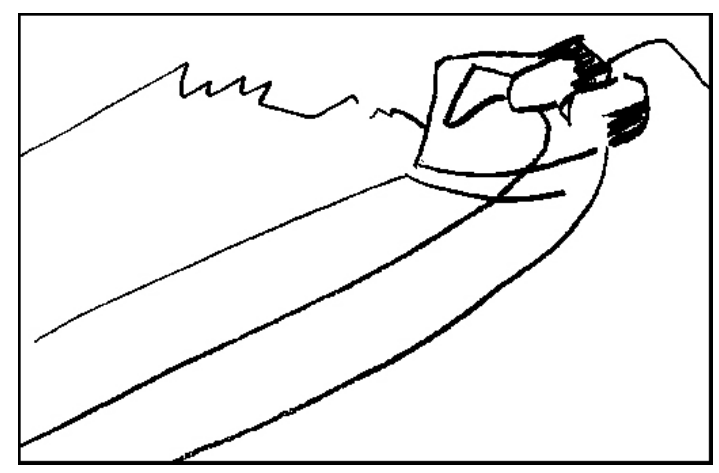

Ilustración 18 Boceto para Composición IV, figuras yacentes

la forma se depura. Y el resultado es una forma pura e indefinida. Tanto que, como decía Tower un poco antes, las formas podrían ser intercambiables. De hecho, la figura de la izquierda, casi triangular, podría ser una montaña en cualquier otro cuadro.

Y el tercer grupo de figuras es el de la pareja yacente o inclinada que aparece en el cuadrante inferior derecho del cuadro (derecha del espectador). Un dibujo inicial (ilustr. 18) muestra a dos personas tumbadas: una parece tener el brazo debajo de su cabeza y la otra parece pasarle el brazo por la cintura. En el boceto general (ilustr. 16) se aprecia una reducción drástica de ambas figuras, en la que, sin embargo, los elementos relevantes siguen estando presentes. En este boceto son sólo líneas, pero después de haber visto 


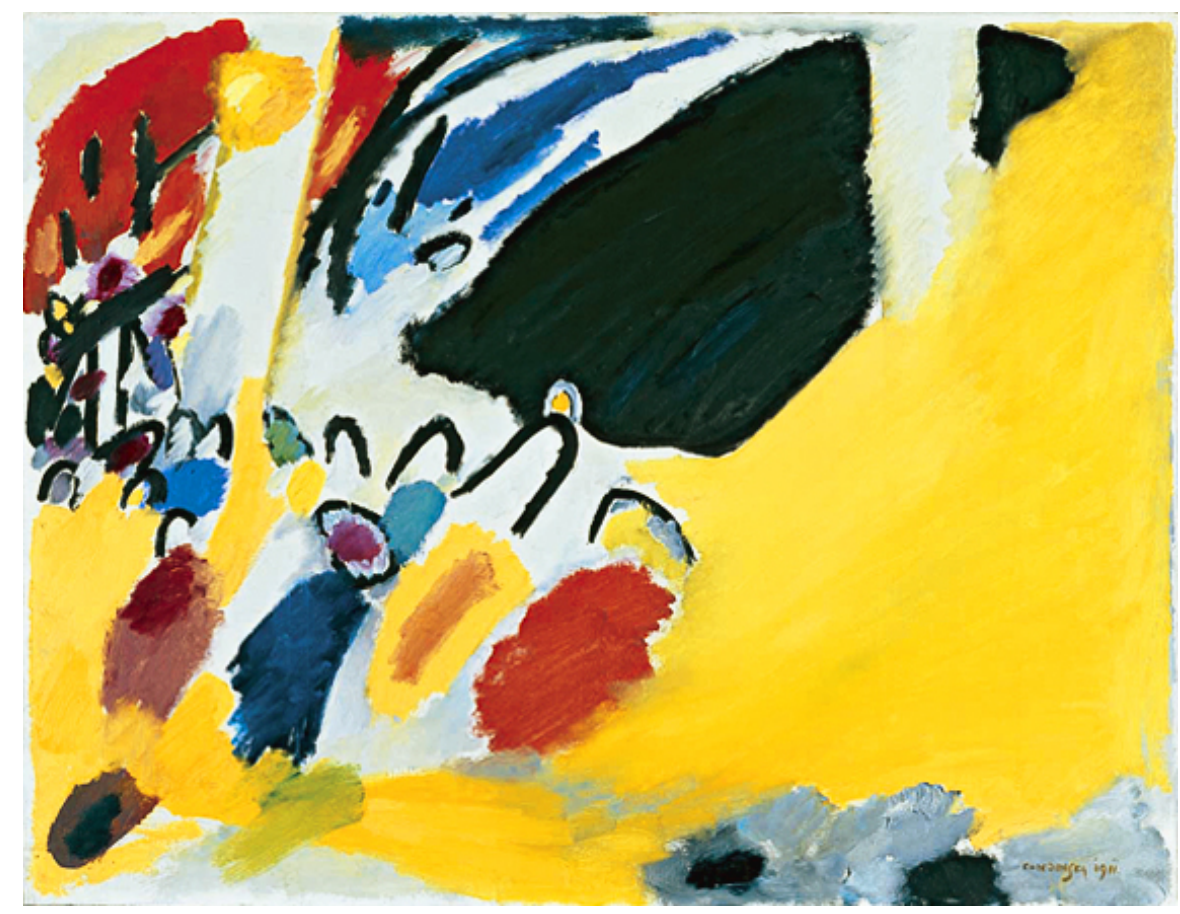

Ilustración 19 Impresión III, (Concierto)

el dibujo primero, se pueden reconocer las formas que representan ambos brazos. El proceso de reducción de las figuras yacentes continúa hasta la obra final (ilustr. 15), en la que las líneas se han depurado aún más. Dos líneas angulares -puras, indefinidas- son ahora el brazo que pasa por debajo de la cabeza y el resto de detalles que la forma ha perdido (el otro brazo, la redondez de las cabezas) los asume el color. La mancha de blanco que resalta ocupa el lugar que tenía el otro brazo; el rojo y el azul confieren expresión a la parte superior de las figuras. Como se ve, el color se ha hecho independiente y ahora contiene su propio significado. Ya no depende de la forma ni del objeto para justificar su presencia en el cuadro, tal y como se ha venido explicando.

Impresión III (Concierto), 1911. Este cuadro, en posesión de la Galería Lenbachhaus en Múnich, simboliza hoy el encuentro entre Kandinsky y Arnold Schönberg y la relación artística que ambos mantuvieron. Concierto hace referencia a aquel concierto que Schönberg dirige en Múnich el 2 de enero de 


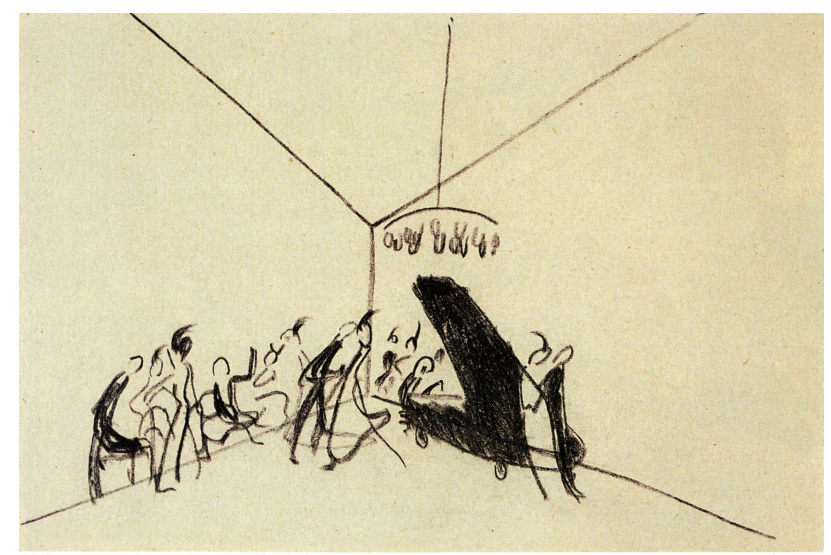

Ilustración 20 Primer boceto para Impresión III

1911, ese concierto cuyas obras renuncian casi por completo a la tonalidad, presentando acordes de hasta ocho notas, cambios inesperados y disonancias extremas. Kandinsky queda impresionado por la composición de Schönberg, especialmente por cómo consigue liberarse de las ataduras clásicas y expresar todo el contenido interior. En la carta que días más tarde envía a Schönberg, Kandinsky le comenta: «Usted ha conseguido en sus obras (...) precisamente lo que yo intento plasmar de manera pictórica ${ }^{57}$. Y eso es lo que Kandinsky intenta en este cuadro: librarse de las ataduras clásicas (es decir, de la forma figurativa), y expresar todo el contenido interior (es decir, las impresiones del concierto).

Los bocetos, aunque sólo sean dos, son un ejemplo muy ilustrativo para comprender cómo se va depurando la forma. En el primero de ellos (ilustr. 20) se reconocen todas las figuras, no importa que estén dibujadas a vuela pluma. De negro están representadas las figuras humanas y en blanco sus intrumentos, lo que recuerda inevitablemente al contraste de positivo y negativo que Kandinsky trabajó en los grabados en madera. El dibujo del piano, puro negro, vuelve a constrastar con el blanco de la habitación. Y la presencia de perspectiva delata claramente que se trata de un primer boceto. La perspectiva, como ya se ha visto, es de las primeras cosas que se eliminan. Así se aprecia en el segundo boceto (ilustr. 21), que presenta la flatness característica de los graba-

57 HaHL-Koсн, Der Briefwechsel: Wassily Kandinsky und Arnold Schönberg, p. 15. 


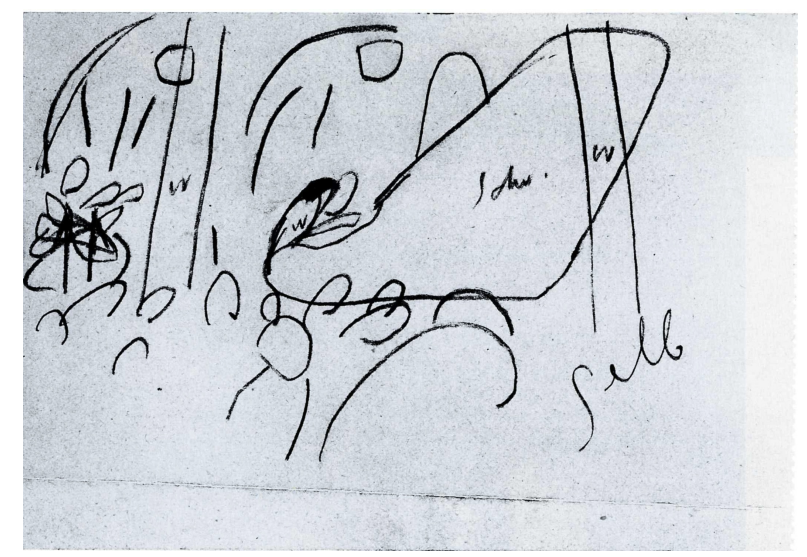

Ilustración 21 Segundo boceto para Impresión III

dos y el nuevo concepto de espacio, reducido a dos dimensiones. Las figuras han perdido toda forma reconocible, ahora son sólo formas libres reducidas a su mínima expresión. El piano, como elemento fuerte de la expresión interior (Schönberg toca su opus 11, Tres piezas para piano), gana protagonismo sin que la perspectiva o ninguna jerarquía formal se lo impida. La forma es libre y se adapta al contenido interior, insiste Kandinsky, de ahí su tamaño y lugar en la composición.

El resultado final (ilustr. 19) es un cuadro muy cercano a la pura abstracción aunque, especialmente después de haber visto los bocetos, todavía se reconozcan la cola del piano y a los espectadores. A pesar de ello, Concierto es un ejemplo muy apropiado para reconocer la teoría de reducción que se ha venido analizando hasta ahora. Las formas se han reducido a su mínima expresión. No hay rastro de perspectiva, y el espacio se ha vuelto a-superficial, ha perdido cualquier posibilidad de incluir una tercera dimensión. Por su parte, el color se ha hecho el protagonista del cuadro sin necesidad de agarrarse a ningún objeto. El piano se ha convertido en una mancha negra, sin más forma que la puramente delimitada por el color. La estridencia cálida del amarillo que inunda el cuadro o el contraste de los tres colores primarios (rojo-amarillo-azul) hacen que la forma apenas tenga qué decir: está reducida a su mínima expresión y es el color quien aporta todo el contenido interno (la necesidad interior, la experiencia vivida del concierto). Es el color quien irradia, de algún modo, sonoridad; y le confiere una melodía suave a las formas 
4 El arte abstracto como reducción a lo esencial

redondeadas que, sin contornos, representan a músicos y espectadores.

Es aún un cuadro prematuro en relación a lo que conseguirá Kandinsky con su nuevo lenguaje del arte, pero queda patente que el arte abstracto tiene que ser algo más que sólo la reducción de las formas. 


\title{
5 El arte abstracto como expresión multisensorial
}

\begin{abstract}
Estamos en el umbral de un arte totalmente nuevo, un arte con formas que nada significan ni nada representan, nada recuerdan y que, sin embargo, puede emocionar nuestras almas tan profundamente como sólo los sonidos de la música hubieran podido hacerlo.
\end{abstract}

August Endell

El rechazo del mundo exterior como fuente de inspiración y de contenido para el arte vuelve los ojos al mundo interior del artista. El peso principal de la representación lo llevan ahora las sensaciones y las experiencias personales. El primer apartado (5.1) describe cómo es el mundo interior de Kandinsky, un mundo sensorialmente complejo y marcado por la relación sentida y emocional que tiene con el mundo exterior (según la descripción del capítulo 1). La búsqueda de un lenguaje que le permita proyectar ese mundo interior guarda cierto paralelismo con las teorías de August Endell, que se expondrán únicamente en lo que atañen a la relación con Kandinsky.

El segundo apartado (5.2) explica detalladamente cómo Kandinsky construye un lenguaje capaz de expresar tal riqueza sensorial. Las limitaciones técnicas de la pintura (pigmento sobre lienzo, al fin y al cabo) llevan a un lenguaje cargado de metáforas que incluye la revalorización del espacio y la presencia de otras artes. La expresividad del lenguaje abstracto y la interrelación entre pintura, música y danza completan la perspectiva de arte sintético que se introdujo en el capítulo 3.

El tercer y último apartado (5.3) desgrana los elementos básicos del lenguaje expresivo. Analiza y expone la teoría del color de Kandinsky y su cercana relación con la música. De la misma manera, presenta la teoría de la forma y su relación con el campo de la danza. La interpretación de una obra pictórica a raíz de la resonancia de color y forma cierra el capítulo y ofrece una perspectiva multisensorial del arte abstracto.

Las ilustraciones gráficas o esquemáticas de líneas, puntos, etc. son todas de Kandinsky salvo que se indique lo contrario. 
5 El arte abstracto como expresión multisensorial

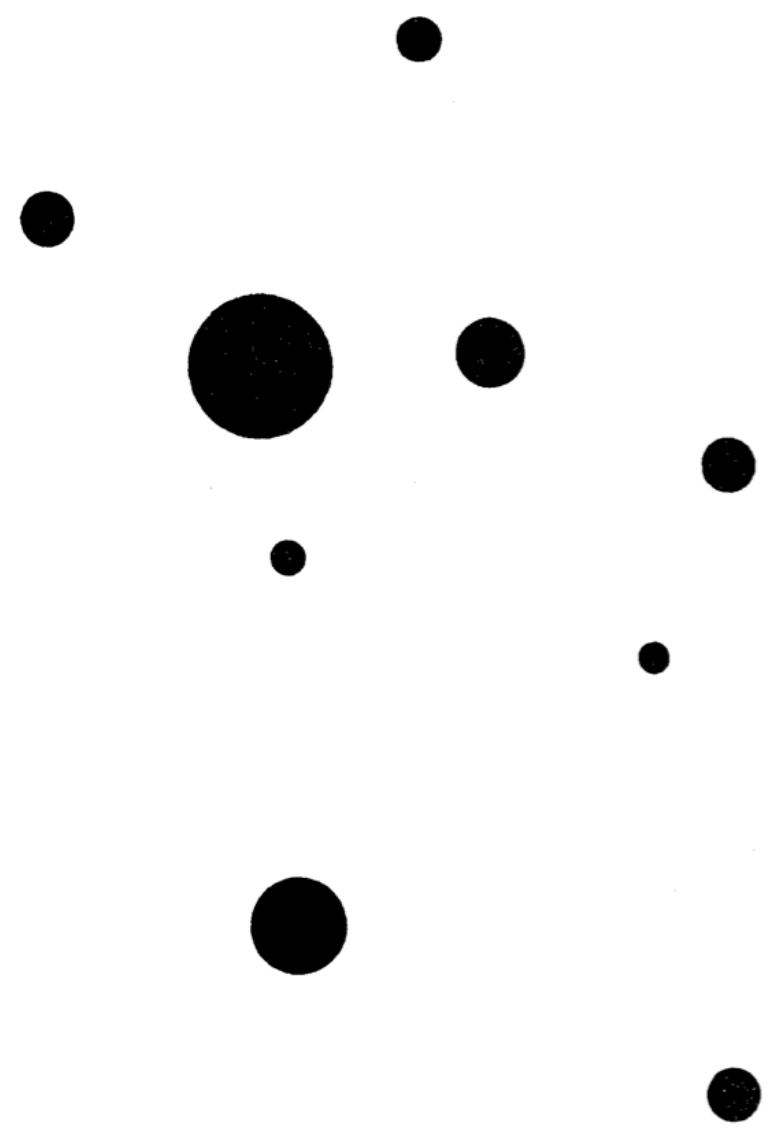

Ilustración 22 Nueve puntos en ascensión 


\subsection{La riqueza sensorial}

\subsubsection{El mundo interior}

El color amarillo no es sólo amarillo, con frecuencia también es chillón. El azul suele ser relajante, como un estudio de Chopin o como respirar junto al vaivén del mar. Las sensaciones raramente vienen aisladas. El hombre es un ser que percibe el mundo de manera compleja, mezclando sensaciones que en principio van destinadas a diferentes órganos sensoriales. A veces se busca la conexión de manera directa, pero generalmente toda sensación suele ir acompañada de otra de un modo indirecto e inconsciente: lo visual de lo sonoro (amarillo chillón), lo sonoro de un estado de ánimo (una melodía triste), un estado de ánimo de lo táctil (una situación áspera) y a la vez, todas ellas se recombinan entre sí (un color cálido, una voz aterciopelada, un olor amargo).

Los dominios sensoriales se entremezclan de manera personal, creando conexiones individuales y mayoritariamente subjetivas. Pero es algo común: todo ser humano comparte la creación de esas asociaciones sensoriales que, unidas a las ideas y creencias, terminan por conformar lo que se denomina "mundo interior". El mundo interior del individuo es multisensorial porque acumula y fusiona sensaciones. Y también es variable con el paso del tiempo, rico en detalles a menudo indescriptibles, poliestético e inclasificable bajo una única rúbrica. No hay duda de que cualquier percepción nueva aumenta el contenido del mundo interior y lo reconfigura, amoldándose a las nuevas sensaciones que se originan. Cuando el mundo que rodea al ser humano cambia bruscamente, bien en el tiempo o bien por la magnitud de los acontecimientos, el mundo interior cambia con él.

Eso es lo que sucede a principios del siglo xx. El vaivén de cambios que llena los primeros lustros afecta, como ya se ha visto, a disciplinas académicas y al sentir de los hombres. Afecta a la filosofía y a la pintura; a la música y a la ciencia. Afecta a la percepción del color y a la sensación de caos y entropía de la física. Y afecta en concreto a Kandinsky, obligándole a crear un lenguaje artístico que vaya al compás de las nuevas sensaciones. A la impresión de inestabilidad que le originan los nuevos descubrimientos de la ciencia («en 


\section{El arte abstracto como expresión multisensorial}

mi alma, la desintegración del átomo era lo mismo que la desintegración del mundo entero») se le suman otro tipo de experiencias que van modelando su mundo interior: «la pintura generó también una serie de estímulos de otra clase que hicieron temblar y, en algunos casos, derribaron unos muros mucho más sólidos del siglo pasado. Estos estímulos ya se alejan del terreno del arte y son mucho más generales» ${ }^{1}$.

Todos estos estímulos y sensaciones nuevas que trae el siglo se unen a las impresiones habituales, propias de la percepción del mundo exterior a través de los sentidos (lo que vemos, lo que oímos, etc.). Y todo ello conforma el mundo interior. Si las novedades de la época originan en Kandinsky estímulos y sensaciones especiales, las impresiones que recibe no lo son menos. Kandinsky percibe el color desligado del objeto desde aquel viaje de infancia a Italia, a lo que se suma que la percepción en sí tampoco es de tipo básica sino compleja. Compleja significa, en este caso, especialmente sensible para distinguir diferentes matices de un mismo color. Según el psicólogo alemán Ewald Hering, ${ }^{2}$ la mayoría de las personas percibe los colores como una ayuda a la hora de reconocer un objeto, sin poder apreciar el matiz del color de manera aislada. Mentalmente, “ajustamos” el color que vemos a una lista de doce colores que la memoria guarda según su experiencia. Esto no significa que, examinando el objeto, sea imposible reconocer más colores ni más matices, porque está claro que cualquier persona es capaz de distinguir más de esos doce colores, amén de los artistas. La diferencia estriba en que algunas personas, entre ellas Kandinsky, son capaces de distinguir los matices nada más percibirlos, porque el color aparece desligado del objeto y ese proceso de "ajuste" con los colores de la memoria no sucede. Además, son capaces de memorizar los colores y sus matices, de retrotraerlos a la mente y hasta cierto punto, de reproducirlos en una obra de arte.

Esta sensibilidad especial para percibir los colores enriquece a Kandinsky la calidad de la percepción. Y más aún porque se complementa con la visión eidética que se le atribuye. Según la definición de imagen eidética dada por A. Luria, Kandinsky es capaz de guardar una imagen en la memoria durante mucho tiempo e incluso volver a suscitarla cada vez que lo desea. Las imágenes no son vagas y abstractas, sino que están llenas de matices y de detalles, lo que

\footnotetext{
1 KANDINSKY, Escritos sobre arte y artistas, p. 96.
}

2 Katz, The World of Colour, pp. 4-8. 
le recrea una sensación vívida y precisa.

Así es como se va conformando el mundo interior de Kandinsky, con la unión de todos estos estímulos. Por un lado, las sensaciones de cambio e inestabilidad que le suscita la época; por otro, la riqueza de matices que percibe y que perfeccionan las imágenes eidéticas. Todo ello se une a otras sensaciones más particulares y a sus estados de ánimo. Así se forma el mundo interior, una especie de baúl interno rico en detalles y complejo en sensaciones. Es difícil describir con precisión el carácter de estas sensaciones. De hecho, son sensaciones en las que se fusionan varias esferas sensoriales y eso dificulta su expresión exterior. Explicar con palabras el dolor visual de un amarillo chillón que obliga a encoger los párpados es tan difícil como lograr que un cuadro transmita la sensación de aspereza que deja una voz. No son sensaciones unívocas ni simples las que quiere transmitir Kandinsky, porque «los sentimientos más toscos como el miedo, la alegría, la tristeza, etc. (...) atraerán poco al artista», son más bien «emociones más matizadas que nuestras palabras no pueden expresar». ${ }^{3}$

Kandinsky trata de definir la complejidad de las sensaciones que componen el mundo interior refiriéndose a ellas, al principio, como estados de ánimo. «El observador debe aprender a mirar el cuadro como la representación gráfica de un estado de ánimo y no como la representación de los objetos». ${ }^{4}$ Pero hay que entender el término en un sentido más amplio de lo habitual. De hecho, el mismo Kandinsky se da cuenta de lo "profanado" [sic] que está el término y maldice al final de su carrera haberlo empleado, escribiendo directamente «No quiero pintar estados de ánimo» ${ }^{5}$, para evitar confusiones. No se trata de un estado de ánimo como se entiende en el lenguaje común, no es un mero estado de ánimo triste o contento o melancólico, es una sensación más amplia, un "estado anímico del ser”, podría decirse. Es la sensación de pensar directamente en colores, por ejemplo. Y la expresión es del propio Kandinsky, que escribe en una carta: «hoy vuelvo a pensar en colores» ${ }^{6}$. O es

\footnotetext{
3 Kandinsky, De lo espiritual en el arte, p. 22.

4 Fragmento de una carta de Kandinsky a Arthur Jerome Eddy, coleccionista de Chicago y uno de los primeros y más importantes compradores de cuadros de Kandinsky. Se conservan sólo fragmentos de las cartas. No están fechadas, pero se calculan de entre 1910 y 1913. Pueden leerse en EdDy, Cubist and Post-Impressionism, pp. 125-137 o en Lindsay y Vergo, Complete Writings on Art, p. 403. Traducción propia, del inglés.

5 Kandinsky, Mirada retrospectiva, p. 209.
} 


\section{El arte abstracto como expresión multisensorial}

como, de nuevo Kandinsky, la sensación de que ya llega el verano y uno puede quitarse la chaqueta sin temor a resfriarse: «un color verde, por ejemplo, hace frecuentemente resonar (...) la tonalidad del verano. (...) ¡Por ejemplo, que es agradable poder quitarse la chaqueta sin peligro de resfriarse!» ${ }^{7}$ Las sensaciones que componen el mundo interior son, sin duda, sensaciones amplias y complejas.

Este concepto de mundo interior no es exclusivo de Kandinsky ni tampoco del mundo del arte. Incluso en el lenguaje común se hace uso del término y, aunque no siempre queda claro qué clase de sensaciones, ideas o creencias pertenecen a él, sí se coincide en que es algo interno, propio y privado del individuo. Kandinsky en concreto utiliza el término "mundo interior" en algunas ocasiones, pero generalmente se refiere a él llamándolo «necesidad interior».

Kandinsky define la necesidad interior como el contenido de la obra de arte. Es esa especie de baúl interno que recoge impresiones y sensaciones, ideas y creencias y estados de ánimo en general. Kandinsky recalca, eso sí, que de ella nace la obra de arte, porque del cúmulo de sensaciones y por ende de su riqueza multisensorial emerjen las formas artísticas. La necesidad interior es el contenido de la obra y su punto de partida para la creación.

Pero aunque mundo interior y necesidad interior sean dos conceptos paralelos, al refinar la expresión de mundo interior en "necesidad interior», Kandinsky resalta sus dos aspectos claves. El adjetivo "interior" enfatiza el mundo al que pertenecen las sensaciones, el interno. A su vez, revela la importancia de que el contenido pertenece a uno de los dos mundos: la importancia de ser contenido privado del artista y, por lo tanto, de no ser todavía parte de la obra artística, donde el contenido ya se ha hecho exterior. Por otra parte, el sustantivo "necesidad" hace hincapié en la característica principal del contenido. El mundo interior es para Kandinsky una necesidad interior porque la exteriorización es obligada, es una necesidad. El mundo interior tiene que exteriorizarse, no le queda otro remedio. Es un impulso, una fuerza, una necesidad. Es, en palabras de Kandinsky, una «ineludible voluntad de expresión» ${ }^{8}$,

6 Carta de Kandinsky a Gabriele Münter el 13 de julio de 1904. Véase KLEINE, Gabriele Münter und Wassily Kandinsky, p. 209.

7 Kandinsky, Mirada retrospectiva, p. 137. 
porque «el artista (...) quiere y tiene que expresar su mundo interior» ${ }^{9}$. Lo interior necesita hacerse exterior.

De ahí que, para Kandinsky, la pregunta del arte no sea ¿para qué?, ¿cuál es su objetivo, qué persigue el arte?, sino más bien la pregunta del arte sea en realidad una respuesta a un ¿por qué? ¿Por qué el arte? Porque tengo una necesidad interior cuya voluntad de expresión es ineludible, podría responder Kandinsky. Algo similar escribe él en una carta a Gabriele Münter: «todos los demás tienen una finalidad... yo sólo tengo que hacerlo, porque no puedo liberarme de las ideas (o de los sueños) de otro modo. (...) [El artista] se atormenta, busca una forma de expresión para sus sentimientos y sensaciones, habla con colores, formas, dibujos, sonidos, palabras» ${ }^{10}$. La necesidad queda patente. Para Kandinsky, buscar una forma de expresar ese cúmulo de sensaciones que es el mundo interior es un imperativo. Por eso es una necesidad interior. La pregunta clave es cómo llevarlo a cabo, cómo proyectar la necesidad interior en un lenguaje que pueda llegar hasta el espectador. Kandinsky no fue el primero en hacerse esa pregunta. Y de la misma manera en que Hermann Obrist acerca a Kandinsky el mundo de la ornamentación abstracta, August Endell le acompaña en el camino de la exteriorización de sensaciones.

\subsubsection{La proyección del mundo interior}

En el centro artístico que es Múnich a principios del siglo xx, el modernismo o Jugendstil está presente de la mano de autores como Peter Behrends, Karl Scheffler, Adolf Hölzel o Hermann Obrist. Con metáforas y tropos sinestésicos en los poemas, con formas sugerentes en la escultura y con diseños orgánicos en la arquitectura, el modernismo renueva en el arte el deseo de transmitir sensaciones. Todos quieren, de alguna manera, hacer llegar al espectador un contenido interno y sensorial, lejos de la pura imitación de la naturaleza.

Asentado en Múnich y alumno directo de Theodor Lipps, August Endell está especialmente interesado en la teoría de la empatía, como muchos de sus

8 Kandinsky, De lo espiritual en el arte, p. 67.

9 Kandinsky, De lo espiritual en el arte, p. 46. La cursiva es original.

10 Carta del 10 de agosto de 1904. Véase Kleine, Gabriele Münter und Wassily Kandinsky, p. 210. 


\section{El arte abstracto como expresión multisensorial}

coetáneos. A caballo entre la arquitectura y la escultura, escribe su tesis doctoral sobre la construcción de los sentimientos (Gefühlskonstruktion), donde manifiesta su interés por la experiencia estética en su sentido más práctico. Quiere saber cómo influyen determinadas formas en la percepción estética o qué formas despiertan una mayor empatía en el espectador. Poco después de terminar la tesis conoce a Hermann Obrist y tiene acceso a sus trabajos abstractos ornamentales. El intercambio de ideas con Obrist se deja notar en un artículo que publica Endell, Um die Schönheit (Sobre la belleza), en el que hace referencia al efecto psicológico de la percepción. Más concretamente, en el artículo examina cómo se perciben las formas y colores que no tienen un objeto como contenido, es decir, cómo se perciben las formas abstractas.

Endell está interesado en crear formas que apelen directamente a los sentidos y por tanto, que consigan transmitir emociones. Si la música es capaz de despertar sentimientos con el sonido como único medio, Endell cree que la escultura y la arquitectura pueden conseguir algo similar valiéndose únicamente de las formas visuales.

Kandinsky acompaña a Endell en esta búsqueda, pero en el campo de la pintura. Aunque no se pueda decir con seguridad que Endell y Kandinsky se conocieran, sí parece cierto que Kandinsky leyera el artículo de Endell, según se desprende de los comentarios de Peg Weiss. ${ }^{11}$ Lo que está claro es que ambos buscan soluciones para un mismo problema: cómo se construye un lenguaje artístico que sea capaz de expresar sensaciones. Endell inventa nuevas formas y estudia el efecto psicológico que tienen. Kandinsky analiza la capacidad cromática del color y el efecto que provoca en el espectador. Endell quiere que el espectador «sienta las formas», según él, requisito básico del placer estético y de la creación. ${ }^{12}$ Kandinsky estudia la capacidad que tienen las formas y los colores para despertar sensaciones en el hombre.

La importancia para ambos artistas, Endell y Kandinsky, recae en que la forma externa de una obra de arte tiene, según ellos, la capacidad de expresar algo más que lo puramente visual. Independientemente de cuáles sean los medios de expresión (forma, color, volumen, movimiento...), ambos creen que es posible crear un lenguaje que transmita sensaciones y emociones al

\footnotetext{
11 WeIss, Kandinsky in Munich.

12 Véase el artículo Möglichkeit und Ziele einer neuen Architektur (Posibilidades y objetivos de una nueva arquitectura), en Helge, An die Schönheit, pp. 141-153.
} 
espectador. O más bien, que es posible crear un lenguaje que permita al espectador apreciar la riqueza de matices sensoriales que el artista le envía desde su mundo interior. Con tal fin, ambos analizan los elementos básicos del arte y su efecto psicológico en el espectador. Un buen ejemplo es el análisis que hacen de la línea recta.

Endell escribe en su artículo Um die Schönheit que la línea recta provoca en el espectador una sensación de movimiento, debido al recorrido de principio a fin que realizan los ojos para percibirla. A la sensación de movimiento que desprende la línea se le añaden la expresión de tiempo o la de tensión. Porque diferentes tipos de línea (gruesa, delgada, larga, corta) provocan diferentes efectos en el espectador. La longitud de la línea establece la dimensión del tiempo, mientras que el grosor indica la tensión del movimiento. Conjugando ambas características, tiempo y tensión, no es difícil imaginar que las múltiples variaciones de una línea pueden reproducir múltiples matices sensoriales: rapidez, energía, tensión contenida... Especialmente si se combinan con otro tipo de líneas y no sólo rectas.

Kandinsky también analiza la capacidad expresiva de la línea. En su gramática de la creación (el proceso de creación de un nuevo lenguaje artístico), uno de los pilares fundamentales es la concepción de las formas como elementos temporales. ${ }^{13}$ El punto es el elemento básico del que parte toda composición y es pura tensión contenida en sí misma. Como elemento básico, es además la «mínima forma temporal» ${ }^{14}$. Y a partir del punto nacen el resto de formas. El punto, al moverse, deja una marca o traza que da lugar a la línea. Así, la línea es, también para Kandinsky, movimiento. La línea nace de la tensión del punto y se lanza en una dirección, creando el movimiento al desplazarse. La línea es, en el fondo, un punto desplazándose.

Salta a la vista el paralelismo entre la línea en movimiento de Endell y la línea desplazándose de Kandinsky. Cada uno a su manera, ambos coinciden en que la línea es una forma temporal y que ésta produce en el espectador una sensación de movimiento, de recorrido, de desplazamiento. Si se enlaza con el interés que ambos mostraron por la teoría de la empatía de Theodor Lipps,

13 La explicación de la gramática de la creación puede leerse en el apartado 3.2.3, a partir de la página 118. En cuanto a las capacidades sensoriales de la línea, aquí se tratan brevemente para poder establecer el paralelismo con Endell. La resonancia interior de los medios pictóricos según Kandinsky se puede leer a partir de la página 217.

14 Kandinsky, Punto y línea sobre el plano, p. 30. 


\section{El arte abstracto como expresión multisensorial}

cómo no acordarse de aquella cita de Ortega y Gasset sobre la simpatía de los obeliscos. Ortega afirma que los objetos verticales producen en nosotros una sensación de movimiento vertical, de elevación, de tal manera que la contemplación estética sensorial se ve influida directamente por las características externas de la forma. He aquí un extracto de la cita ${ }^{15}$ : «Si el objeto es angosto y vertical, por ejemplo, nuestros músculos oculares verifican un esfuerzo de elevación: este esfuerzo está asociado en nuestra conciencia a otros movimientos incipientes de nuestro cuerpo, que tienden a levantarnos sobre el suelo y a las sensaciones musculares de peso, de resistencia, de gravitación. (...) Este es el placer estético elemental que hallamos en la contemplación de las columnas, de los obeliscos» ${ }^{16}$.

Las similitudes entre Endell y Kandinsky son notables. Ambos buscan la manera de hacer llegar al espectador algo más que pura imagen visual. Ambos quieren utilizar el potencial expresivo de las formas para transmitir con él todo un mundo interior. Sin embargo, Kandinsky logra dar un paso más. En dos aspectos. Por un lado, Endell estudia las sensaciones que despiertan las formas, anima incluso al público a dejar de pensar y a empezar a sentir cuando se trata de arte. Pero al margen de ciertas esculturas o edificaciones en las que intentó llevar su teoría a la práctica, Endell no supo dar solidez y consistencia a su idea. La formulación de que es posible un lenguaje artístico capaz de transmitir la riqueza del mundo interior, no llegó a convertirse en una teoría sólida. Es Kandinsky quien lo consigue al formular la gramática de la creación. Kandinsky elabora una teoría cuidando todos los aspectos: introduce el concepto de mundo interior como una necesidad interior y ofrece un análisis completo de la capacidad de los medios pictóricos introduciendo un nuevo concepto, el de resonancia interior. La resonancia interior es precisamente esa capacidad que tienen los elementos de las artes para expresar sensaciones. Es la fuerza expresiva que tienen el color, la forma, el sonido y el resto de medios y que se puede percibir sensorialmente, logrando que el espectador reciba las emociones y sensaciones de la necesidad interior. Kandinsky consolida la idea de que las formas son capaces de expresarse sensorialmente mediante el concepto de la resonancia interior.

15 La cita completa se encuentra en la página 73.

16 Ortega y Gasset, La deshumanización del arte, pp. 99-100. 
Por otro lado, y éste es el segundo aspecto, Endell no consiguió que la crítica apreciara su arte como transmisor de sensaciones. La única obra de Endell con cierto reconocimiento es la fachada del Atelier Elvira, que termina en 1896 pero que queda destruido (probablemente) por la Primera Guerra Mundial. ${ }^{17}$ La crítica tampoco entiende a Endell como el precursor de un movimiento nuevo, lo circunscribe a estilos ya definidos aunque variopintos: desde el rococó o el gótico tardío hasta lo oriental o lo morisco. Si bien Kandinsky tampoco lo tuvo fácil al principio, sí es capaz a lo largo de su trayectoria de instaurar un nuevo estilo artístico e instalarse como su creador, consolidando no sólo sus cuadros sino también sus teorías.

Sin embargo, y al igual que pasara con Hermann Obrist, no puede obviarse la influencia de August Endell en el desarrollo artístico de Kandinsky.

\subsection{La expresividad del lenguaje abstracto}

La necesidad interior es el término con el que Kandinsky engloba la variedad de sensaciones que componen el mundo interior y con el que resalta la exigencia de ser expresadas. La necesidad interior marca el desarrollo de la obra desde el comienzo, porque es quien aporta el contenido. Ahora bien, una necesidad interior tan rica en detalles, tan compleja en sensaciones y tan multisensorial como se la ha descrito, exige un lenguaje artístico concordante. Un lenguaje que sea capaz de expresar toda la riqueza sensorial y de hacérsela llegar al espectador.

\subsubsection{El lenguaje como metáfora}

La búsqueda de un lenguaje que hable en términos de la necesidad interior no es una empresa fácil para Kandinsky. El camino es progresivo y está lleno de elaboración teórica y experimentación práctica. Quiere un lenguaje que exprese mucho más de lo que la pintura venía haciendo durante el "perídodo de la tentación materialista (...) [que el buen artista] rechaza como una mala

17 Algunas fotos del atelier, generales y de detalles, se pueden ver en WeIss, Kandinsky in Munich, fotos 23 a 29 del apéndice. 


\section{El arte abstracto como expresión multisensorial}

tentación». Kandinsky quiere un nuevo lenguaje con el que el artista «intentará despertar sentimientos más sutiles que actualmente no tienen nombre (...) y la obra nacida de él provocará necesariamente en el espectador capaz de sentirla, emociones (...) que nuestras palabras no pueden expresar». ${ }^{18}$

Kandinsky es consciente de que la creación de un lenguaje tal no es tarea fácil ni inmediata, pero una vez lograda, el arte -y no sólo la pintura- saldrá ganando: «aumentarán las dificultades del arte, pero al mismo tiempo aumentará -cuantitativa y cualitativamente- la riqueza de formas en los medios de expresión» ${ }^{19}$. Aunque el camino hasta lo que él llama «arte puro» (hoy abstracto) no transcurre en línea recta, sí pueden distinguirse ciertas directrices acordes con su gramática de la creación: la pérdida del objeto, la resonancia interior de los medios pictóricos y la revalorización del espacio.

Cuando Kandinsky aún estudia Derecho en Moscú y se dedica a la pintura sólo en sus ratos libres, intenta plasmar su mundo interior en el lienzo. Las impresiones del atardecer en Moscú, tan sonoras como ricas en matices, le producen una sinfonía de color: «el sol hace que toda Moscú se funda en una mancha (...) como una tuba enloquecida. (...) [El] acorde final de la sinfonía que lleva cada color al paroxismo de la vida» ${ }^{20}$. Pero plasmar este tipo de sensaciones no le resulta nada fácil: «Yo hacía esfuerzos desesperados para llegar a expresar toda la fuerza con que aquello resonaba, pero sin el menor resultado» ${ }^{21}$. Ésta es una de las razones por las que Kandinsky inicia la búsqueda de un lenguaje nuevo, uno que le permita expresar toda la fuerza con la que resuena su mundo.

También antes de iniciar su carrera como pintor, un año antes de trasladarse a Múnich, tiene lugar el encuentro con las parvas de heno de Monet. Aquel cuadro, Almiar, que le anuncia la posibilidad de representar la fuerza inospechada de los colores y donde al principio no reconoce objeto alguno: «sentía oscuramente que el cuadro no tenía objeto y notaba asombrado y confuso que no sólo me cautivaba, sino que (...) flotaba (...) hasta el último detalle ante mis ojos. (...) Comprendí con toda claridad la fuerza insospechada (...) de

\footnotetext{
18 Ambas citas son de KAndinsky, De lo espiritual en el arte, p. 22.

19 KANDinsky, De lo espiritual en el arte, p. 64.

20 Kandinsky, Mirada retrospectiva, p. 97.

21 Kandinsky, Mirada retrospectiva, p. 99. La cursiva es original.
} 
los colores ${ }^{22}$. El encuentro con Monet es uno de los puntos de inflexión en la carrera de Kandinsky. Porque le ofrece la posibilidad de prescindir del objeto como solución a su problema, el de cómo expresar toda la fuerza interior de las cosas.

Otros episodios vitales que se han narrado en los capítulos anteriores colaboran asimismo en este proceso de des-figuración, de eliminación de lo figurativo. Uno es el del cuadro puesto del revés, ese que Kandinsky encuentra un atardecer en su estudio y que le revela que la forma figurativa deja de ser imprescindible para la transmisión de un contenido interior: «Ahora ya estaba seguro: el objeto perjudicaba a mis cuadros». Otro es el viaje a Túnez que hace con Gabriele Münter, donde la prohibición islámica de la representación figurativa vuelve a estimular la idea de que el objeto no es imprescindible en la pintura, de ahí el comentario de Kandinsky de «los objetos me estorban».

El caso es que a raíz de estos momentos y otros descubrimientos, Kandinsky se da cuenta de que el objeto, más que ayudar en la expresión de la necesidad interior, realmente estorba. La forma figurativa entorpece la expresión del artista y ata al espectador a percibir sólo lo que ve. El objeto impide apreciar otras dimensiones sensoriales e imposibilita la transmisión total de esas sensaciones complejas que forman la necesidad interior. Si se contempla una forma figurativa es casi imposible salir de ella y recibir otra impresión. Frente a un pez, el espectador ve un pez. En cambio, una forma no figurativa ofrece un abanico más amplio de interpretaciones y con ello de expresiones. El espectador no está atado al pez y frente a una línea ondulada tiene la posibilidad de experimentar otro tipo de sensaciones. Como cuando percibe el verde-verano que le deja quitarse la chaqueta sin temor a resfriarse. El ejemplo del pez es del propio Kandinsky, que en un artículo para la revista londinense Axis escribe: «se hace esencial la diferencia entre la línea y el pez. Esta diferencia consiste en que el pez puede nadar, comer y ser comido. Posee cualidades que no posee la línea. Sin embargo, estas cualidades del pez son ingredientes necesarios para el propio pez y para la cocina, pero no para la pintura. Y como no son necesarias, sobran. Éste es el motivo por el que prefiero la línea al pez; al menos en mi pintura $»^{23}$.

22 Kandinsky, Mirada retrospectiva, p. 102.

23 El artículo se llama Linie und Fisch (Línea y pez) y se publicó en el núm. 2 de Axis, año 1935. La traducción al español se encuentra, por ejemplo, en KANDINSKY, Escritos sobre arte y 


\section{El arte abstracto como expresión multisensorial}

Eliminar el objeto del cuadro significa eliminar sólo lo superfluo, lo que estorba a la hora de transmitir sensaciones. Kandinsky sabe, apoyado en su afición a la música y por su amistad con Arnold Schönberg, que sólo con los medios pictóricos se puede expresar todo un mundo de sensaciones: «del mismo modo que un músico puede reproducir sus sentimientos sobre el amanecer sin utilizar los sonidos del canto de un gallo, el pintor dispone de medios puramente pictóricos para dar forma a sus impresiones de la mañana sin necesidad de pintar un gallo» ${ }^{24}$. Ni gallo ni pez hacen falta. Porque Kandinsky también sabe que la supresión del objeto no es sólo la eliminación de lo que sobra, sino la posibilidad de una expresión mucho más rica. Y es que la forma y el color poseen una fuerza especial de expresión, la resonancia interior, que no tienen los objetos. Kandinsky lo deja claro en repetidas ocasiones, como en este par de ejemplos: «el objeto suprimido no reduce los medios de expresión, sino que los multiplica hasta el infinito» ${ }^{25} \mathrm{o}$ "un punto en un cuadro puede llegar a decir más que un rostro humano» ${ }^{26}$.

La resonancia interior que poseen los medios pictóricos es el elemento que hace posible que un cuadro, no teniendo objeto, sea capaz de transmitir un contenido interior. Todos los medios o elementos de las artes tienen una resonancia interior: el color, la forma, el ritmo, la palabra, el movimiento, el sonido. Si se emplean en su forma apropiada, son capaces de transmitir el contenido de la necesidad interior y de llevarla hasta el espectador. Éste siente una vibración interna al percibir la obra, una irradiación de sensaciones. La resonancia interior es una fuerza expresiva especial que se puede percibir sensorialmente (y no sólo por la vista) y, por lo tanto, es capaz de llevar emociones y sensaciones hasta el espectador. En el caso de la pintura de Kandinsky, eso significa que el color y la forma tienen que adoptar un lenguaje en el que su resonancia interior se haga externa y salga a la luz.

En la elaboración de su gramática de la creación, Kandinsky resalta esta capacidad de "resonar" que tienen el color y la forma. Investiga teórica y prácticamente sobre los efectos que produce cada color y cada forma, aislados

artistas, p. 160.

24 KANDINSKY, Escritos sobre arte y artistas, p. 152.

25 KANDINSKY, Escritos sobre arte y artistas, p. 217.

26 KANDINSKY, Escritos sobre arte y artistas, p. 138. 


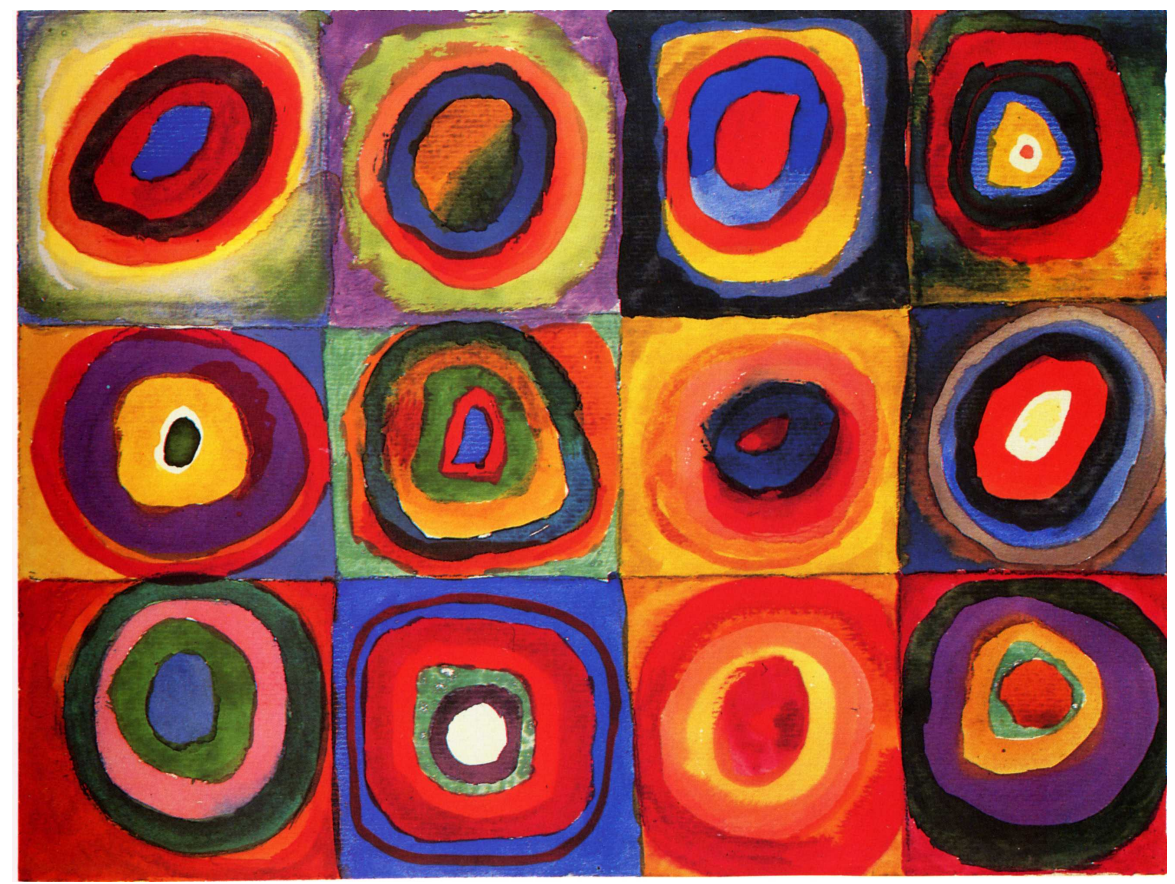

Ilustración 23 Estudio sobre el color, 1913

y en combinación con otras formas. Estudia la «calidad acústica» de los colores y su evocación sensorial. Trabaja con formas y las sensaciones básicas que éstas despiertan. Y siempre partiendo de la base de que lo percibido con la vista no provoca sólo impresiones visuales, sino que van dirigidas a los cinco sentidos:

«la vista no sólo está en relación con el sabor sino también con todos los demás sentidos. Y así ocurre en efecto. Algunos colores parecen ásperos, erizados, otros tienen algo pulido, aterciopelado, que invita a la caricia (azul ultramar oscuro, verde óxido de cromo, barniz de granza). Hay colores que parecen blandos (barniz de granza) y otros que parecen tan duros (verde cobalto, óxido verde-azul) que el color recién salido del tubo parace seco. ${ }^{27}$ "

27 Kandinsky, De lo espiritual en el arte, p. 53. 


\section{El arte abstracto como expresión multisensorial}

El resultado teórico de estas investigaciones se va entretejiendo en todos sus libros y especialmente en Punto y línea sobre el plano, por ser el libro más cercano a su época en la Bauhaus. Durante su estancia como profesor, Kandinsky lleva a cabo diferentes experimentos para ahondar en las propiedades expresivas del color y la forma. Uno de ellos es un cuestionario que reparte entre todos los alumnos en 1923 y en el que pide colorear de rojo, azul o amarillo las formas de un triángulo, un círculo y un cuadrado. Las respuestas de todos los alumnos no se conservan, pero Kandinsky establece un paralelismo en su libro que bien pudo haber nacido de esa encuesta: "presentamos a continuación la indicación esquemática de las correlaciones de línea-plano-color: ángulo agudo-triángulo-amarillo; ángulo recto-cuadrado-rojo; ángulo obtuso-círculo-azul». ${ }^{28}$

También entre la obra pictórica de Kandinsky hay numerosos estudios sobre el color y estudios gráfico-formales, como el relativamente conocido de 1913 (ilustr. 23). En él estudia la resonancia interior de cada color según su posición dentro del círculo y del cuadrado, así como la influencia que pueden ejercer otros colores cercanos. Kandinsky no escribió un acta completo de cada uno de esos estudios o experimentos (o al menos no se conserva) pero sí hay alguna que otra alusión en sus escritos:

«he aquí un experimento sencillo: se colocan dos rectángulos de los tamaños $2 \times 4 \mathrm{~cm}$ y $4 \times 8 \mathrm{~cm}$ sobre un trozo de papel de $20 \times 40 \mathrm{~cm}$. Así se consigue, de un modo esquemático, a través de la proporción, una armonía. (...) Ahora bien, aquí se nos presenta otro obstáculo: los colores cambian las dimensiones. Por dar un ejemplo banal: un cuadrado negro sobre un fondo blanco parece ser más pequeño que un cuadrado blanco sobre un fondo negro. ${ }^{29}{ }$ »

De esta manera, Kandinsky va estableciendo un lenguaje nuevo para la forma y el color. A través de relaciones entre ellos (triángulo-amarillo), de asociaciones multisensoriales (colores blandos como el barniz de granza) y de análisis expresivo (un cuadrado negro parece ser más pequeño que uno

\footnotetext{
28 Kandinsky, Punto y línea sobre el plano, p. 65 y ss. La cursiva es original. En el texto original se representan gráficamente un triángulo, un cuadrado y un círculo.

29 KANDINSKY, Escritos sobre arte y artistas, p. 220.
} 
blanco), construye un lenguaje que permite utilizar la resonancia interna de los elementos pictóricos. Así aumenta «el valor de los elementos imprescindibles: la forma y el color ${ }^{30} \mathrm{y}$ así consigue llevar hasta el espectador un mundo interior de sensaciones.

\begin{tabular}{llll} 
color & amarillo & rojo & azul \\
\hline claridad & blanco & gris & negro \\
vocales & $\mathrm{i}$ & $\mathrm{a}$ & $\mathrm{o}(\mathrm{u})$ \\
cadencia & presto & moderato & adagio \\
pulso & 135 & 75 & 50 \\
temperatura & cálido & templado & frío \\
pensamiento & rápido & deliberado & cerebral (necesario) \\
sentimiento & afectuoso & controlado & profundo \\
acción & espontáneo & reflexivo & cuidadoso \\
tacto & afilado & duro & suave \\
olfato & picante & fuerte & fragante \\
gusto & picante & - & dulce \\
oído & alto & medio & bajo \\
música & agudo & tranquilo & profundo
\end{tabular}

Tabla 5.1

Kandinsky nunca quiso que su gramática de la creación fuera un puro manual de pintura para otros artistas, porque la necesidad interior es propia de cada artista y única en cada momento. Sin embargo, sí estaba interesado en señalar el resultado de sus investigaciones y presentar al público (los alumnos, otros artistas) su sistema de "correspondencias". Beeke Sell Tower ${ }^{31}$ recoge una de las tablas de asociaciones que, al parecer, data del invierno de 1927-28. En ella (tabla 5.1), Kandinsky establece relaciones no sólo entre colores y formas -es decir, lo puramente visual-, sino que incluye los otros cuatro sentidos: tacto,

30 KANDINSKY, Escritos sobre arte y artistas, p. 134.

31 Tower, Klee and Kandinsky in Munich and at the Bauhaus, p. 172. 


\section{El arte abstracto como expresión multisensorial}

olfato, gusto, oído. También aparecen los medios de otras artes (las vocales, la cadencia, el ritmo) y referencias directas al pensamiento y la acción. Todas estas referencias dejan un elenco de adjetivos y asociaciones físicas, emocionales, musicales, visuales, etc. nunca antes utilizadas en la pintura. Kandinsky explora a fondo la resonancia interna de todo elemento, y no sólo de los pictóricos, para ampliar la expresión pictórica del nuevo arte abstracto. Gracias a estas relaciones, su lenguaje adquiere una dimensión expresiva extraordinaria y es capaz de transmitir sensaciones hasta entonces prácticamente inalcanzables. El amarillo transmite calidez y espontaneidad, es un sonido agudo con ritmo rápido. El rojo es más moderado, templado, tranquilo. Y el azul, que Kandinsky siempre asocia al círculo, es profundo, suave y fragante, con un ritmo lento y frío.

El resultado es un lenguaje que, aun siendo "oficialmente" sólo visual, es capaz de despertar sensaciones en el espectador que requieren de los otros sentidos, ofreciéndole una vivencia plenamente subjetiva y sensorial.

\subsubsection{La revalorización del espacio}

Cuando las sensaciones que se quiere transmitir son tan amplias como las de la necesidad interior, es casi imposible encuadrarlas en un eje de coordenadas espacio-temporal. Reduciría toda expresión artística a una única superficie, idéntica para el artista y el espectador. El problema es que ese sistema de referencia absoluto sólo constriñe la expresión de la sensación multisensorial y, precisamente, Kandinsky aspira a lo contrario. Para dar libertad a la expresión artística, hace falta un soporte que «tenga el poder de transpor$\operatorname{tar}(\mathrm{me})$ fuera del tiempo y del espacio ${ }^{32}$, un soporte que sea relativo al artista $y$ al espectador.

La solución pasa por crear un lenguaje artístico que elimine la superficie única e idéntica para artista y espectador. Como el cuadro no es posible sin superficie, Kandinsky busca la manera de que la superficie se convierta en relativa. Y en vez de transformarla, lo que hace es aumentar su número: diversifica las superficies. El cuadro devuelve al espectador la necesidad interior,

32 Kandinsky, Mirada retrospectiva, p. 101. 
pero no en un bloque único, sino repartida en diferentes superficies. Hay dos momentos biográficos de Kandinsky ya comentados que, de alguna manera, anunciaban esta multi-superficialidad.

Uno de esos episodios vitales es el viaje que Kandinsky hace como etnógrafo a Vologda, región en la que las gentes de la zona visten de manera tan abigarrada y con colores tan vivos que parecen cuadros móviles con dos piernas. Las casas también están adornadas y pintadas de tal manera -excesiva-, que Kandinsky siente que ha cruzado la frontera espacio-temporal: ya no está dentro de una casa, sino dentro de una casa que está dentro de un cuadro. En su Mirada retrospectiva escribe al respecto: «Esas casas me enseñaron a moverme en el seno mismo del cuadro, a vivir dentro del cuadro. (...) Me sentí rodeado por todas partes de la pintura en la cual había, pues, penetrado». ${ }^{33} \mathrm{La}$ idea de que el cuadro puede ser algo vivo que se siente y por donde se puede "pasear", se complementa con otro de sus relatos biográficos. Estando en un baño ruso, lleno de vaho, ve a un hombre que se halla de pie en medio del vapor y que «no está cerca ni lejos; está en alguna parte» ${ }^{34}$. El hombre está, sin duda, apoyado en el suelo o sobre una superficie, pero a Kandinsky (en este caso un espectador), el hombre se le parece en medio de la nada, como flotando en el espacio. Es precisamente ese alguna parte lo que Kandinsky quiere para sus cuadros. Una superficie flotante que se aleje de la superficie material (el lienzo), que actúe como un holograma y que llegue hasta el espectador, haciéndole perder la referencia espacio-temporal.

Kandinsky crea un lenguaje capaz de reinventar el espacio, expandiéndose más allá de los límites físicos del lienzo. Según Paul Overy, Kandinsky desafía las leyes habituales de la organización espacial. ${ }^{35}$ Según Robert McTague, Kandinsky elimina el foco central de sus pinturas, cuya ausencia conduce al espectador a considerar la existencia de otras dimensiones que se escapan a las clásicas de tiempo y espacio. ${ }^{36}$ Lo cierto es que ambos tienen razón. Kandinsky revela en una conferencia cómo la «diversidad de las superficies daba a mis telas una profundidad nacida de la [nueva] perspectiva» y también que «distribuía las masas de manera que no apareciera ningún centro arquitectó-

33 Kandinsky, Mirada retrospectiva, p. 109.

34 Kandinsky, Mirada retrospectiva, p. 135. La cursiva es original.

35 Overy, Kandinsky, p. 122.

36 McTague, Modern Physics, Kandinsky, and Klee, p. 68. 


\section{El arte abstracto como expresión multisensorial}

nico». ${ }^{37}$ Kandinsky consigue que el cuadro se convierta en un espacio flotante (una superficie ideal) que se contrapone a la superficie real, y la relación entre ambas superficies potencia las posibilidades de los medios de expresión: «la fusión de ambas extensiones, en armonía o contraste, constituye uno de los más ricos y poderosos elementos de la composición gráfico-pictórica» ${ }^{38}$.

Son precisamente los medios de expresión, el color y la forma, los que consiguen la diversidad de superficies. Siguiendo la definición de David Katz ${ }^{39}$ (de la que también se hace eco Paul Overy) ${ }^{40}$, los colores que percibimos en el mundo real se nos aparecen de tres maneras diferentes. Los colores que vemos en las cosas, que son los colores con los que estamos más familiarizados y que nos parecen sólidos e inseparables del objeto, Katz los denomina surface colours (colores de superficie). Los colores que parecen no tener una textura definida ni un lugar concreto en el espacio, como por ejemplo los del arcoiris, son para Katz film colours (colores película o envoltorio). Y por último, los colores que parecen rellenar el espacio cuando vemos en tres dimensiones, son los volume colours (colores volumen).

Es difícil, por no aventurarse a decir imposible, encontrar un artista anterior al siglo xx que pinte un objeto separado de su color. Para empezar porque la ciencia aún no había puesto en entredicho que los colores sean o no propiedad de los objetos y mucho menos, que ni siquiera es el ojo el que ve el color, sino el cerebro. Por eso se puede decir que la mayoría de los pintores se limitan a utilizar en sus cuadros los surface colours o colores de superficie, empleando la definición de Katz. Pero Kandinsky, probablemente sin saber que su cerebro es quien "ve" el color pero sí consciente de que para él, el color no pertenece al objeto o que, como se explicó hace un par de páginas, percibe los colores y todos sus matices separados del objeto, la triple tipificación de Katz adquiere mucho sentido. Porque Kandinsky consigue crear esa superficie ideal o flotante precisamente haciendo uso de los film y de los volume colours.

Al prescindir por completo del objeto, los colores están presentes en el cuadro como grandes manchas de color. El espectador es incapaz de apreciar

37 Se trata de una conferencia impartida en Colonia en 1914. La transcripción del texto se encuentra, además de en las obras completas (Lindsay y Vergo, Complete Writings on Art, p. 392), en la edición española de Mirada retrospectiva (2002, p. 199).

38 Kandinsky, De lo espiritual en el arte, p. 87.

39 Katz, The World of Colour, pp. 8 y ss.

40 Overy, Kandinsky, capítulo 5. 
el color como un color de superficie, porque no tiene objeto al que encajarlo y por tanto, se convierte en un color de envoltorio $($ film) o de volumen ( $\mathrm{vol}$ ume), dependiendo de la consistencia que le dé Kandinsky. Los colores van desde la transparencia hasta la opacidad y a menudo se solapan unos a otros ofreciendo diversas texturas. ${ }^{41}$ Yuxtaponiendo grandes áreas de colores que contrastan, Kandinsky provoca efectos de deslumbre y contraste simultáneo, lo que hace que los colores parezcan vibrar y produzcan la ilusión de que no están anclados a la superficie del cuadro, sino que floten delante del espectador. El azul parece que retrocede, el amarillo parece que avanza. Kandisky lo expresa a su manera: «el segundo movimiento del amarillo y del azul (...) es excéntrico y concéntrico. (...) el amarillo irradia fuerza, adquiere movimiento desde su centro y se aproxima casi perceptiblemente al espectador. El azul, por el contrario, desarrolla un movimiento concéntrico (...) que se aleja del espectador». ${ }^{42}$

Con la diversificación de superficies, Kandinsky crea una realidad autónoma dentro del cuadro. En ella ya no es posible separar la sensación de la percepción, uno de los puntos claves para que el espectador reciba en toda su amplitud la necesidad interior. El cuadro Composición VI, de 1913, es uno de los mejores ejemplos para percibirlo, según el propio Kandinsky: «aquí el color rosado y blanco es cual una espuma, de suerte que me parece que no descansa ni sobre la superficie de la tela ni sobre una superficie ideal cualquiera. Más bien se halla suspendido en los aires y parece rodeado de vapor. (...) Esa "alguna parte" del centro principal determina la resonancia interior de todo el cuadro. Trabajé en esa zona del cuadro hasta que cobró forma en mí lo que había anhelado al principio oscuramente y después deseado cada vez con mayor claridad en mi fuero interno ${ }^{43}$.

41 Tower, Klee and Kandinsky in Munich and at the Bauhaus, p. 148.

42 Kandinsky, De lo espiritual en el arte, p. 72.

43 Kandinsky, Mirada retrospectiva, p. 135. Las comillas son originales. 


\title{
5 El arte abstracto como expresión multisensorial
}

\subsubsection{La obra sintética o la presencia de otras artes}

\author{
Nacemos bajo el signo de la síntesis
}

\section{W. KANDINSKY}

La riqueza multisensorial de la necesidad interior no sólo conduce a la pérdida del objeto y a la revalorización del espacio. La presencia de sensaciones acústicas o rítmicas en el lenguaje abstracto reclama, necesariamente, la inclusión de otras artes. La idea de incluir varias artes en una, o de hacer a todas partícipes de una misma expresión sintética, sobrevuela desde el siglo xix bajo el nombre de la Gesamtkunstwerk que le pone Wagner. Kandinsky se siente cómodo con esta idea y desde el inicio de su carrera intenta incorporarla a su obra teórica y práctica.

El proceso de crear una obra sintética es parte del camino a la abstracción, ese camino que no es recto ni directo sino que va y viene, mejora y retrocede. Pero a posteriori se puede establecer, a grandes rasgos, una línea continua que muestra cómo va evolucionando el concepto de síntesis en la obra kandinskyana.

Kandinsky no se dedica exclusivamente a la pintura hasta los 30 años, pero el contacto con el arte empieza desde niño. Pinta como aficionado, recibe clases de música y muestra interés por la literatura y el teatro. Por propia experiencia, y probablemente por influencia de textos que leyera, Kandinsky cree que las artes sólo son diferentes en su apariencia y que poseen un valor interior común. Es decir, que las artes son diferentes maneras de expresar un mismo contenido interior. Esta idea, un contenido interno con diversa apariencia externa, impregna la primera etapa de Kandinsky como pintor. Son los primeros años en Múnich, en los que tras recibir clases de pintura en academias, Kandinsky toma la iniciativa para poner en práctica la idea de síntesis. En poco más de una década, funda la escuela de pintura Phalanx, la asociación NKVM y edita el almanaque de El Jinete Azul.

Su objetivo es en todas ellas reunir diferentes expresiones artísticas bajo una misma obra o exposición. De este modo, es posible contemplar en paralelo obras pictóricas, literarias o escultóricas y apreciar que, a pesar de expresarse cada una de ellas con diferentes medios, todas buscan transmitir un contenido interior. No significa que todas quieren transmitir la misma sensación interna 
(el mismo estado de ánimo personal), sino que todas ellas son la expresión exterior de un contenido interior. Todas las artes son una exteriorización de lo interno, ésa es la idea que quiere resaltar Kandinsky.

Las exposiciones que organiza con Phalanx son la primera muestra de arte sintético. Con la idea de marcar el camino hacia un arte nuevo (por aquel tiempo el «arte del futuro», hoy arte abstracto), Kandinsky reúne a artistas de diferentes disciplinas y exhibe sus obras de manera conjunta. Cuadros, marionetas, sátiras, textos literarios o jarrones comparten espacio y presentan una idea común, acercándose a la obra de arte total wagneriana. Todas ellas, cada una con sus medios, exteriorizan un contenido interior. Ésta es la idea de síntesis que persigue Kandinsky. En aquel momento, a Phalanx se le reconoce su carácter ecléctico, pero la idea de la síntesis y su porqué pasan desapercibidas para el gran público.

Después de unos años de viajes, Kandinsky regresa a Múnich habiendo madurado la idea de síntesis. En compañía de otros pintores organiza una nueva asociación, la Neue Künstlervereinigung München (NKVM), en la que se dan cabida artistas de diversas disciplinas. En la NKVM vuelve a estar presente, como en Phalanx, el deseo de reunir diferentes artes que expresen un contenido interior. Al grupo se unen principalmente pintores y escultores, pero también músicos, poetas, bailarines o historiadores del arte. Es precisamente esta diversidad la que hace posible empezar a entender el arte como una unidad interior, a pesar de las diferencias externas.

Kandinsky se separa de la NKVM por desavenencias con el jurado por su Composición v, cuadro que ya roza la abstracción, y emprende un nuevo proyecto con Franz Marc. Es el almanaque El Jinete Azul, una obra ecléctica y sintética que presenta de manera excelente el panorama artístico de principios del siglo xx. Marc y Kandinsky quieren hacer del libro una publicación anual que refleje la «idea de la gran síntesis» ${ }^{44}$ : una obra artística que aglutine el trabajo de las diferentes áreas, cada una con sus medios pero demostrando que parten de un interior común. Y esta idea de síntesis, que es la que origina el nacimiento del almanaque, es la misma condición que se impone a los artistasa para participar en él: todo estilo artístico es bienvenido (y no sólo el pictórico) siempre que sus medios exterioricen el contenido interior del artista.

44 KANDInsky, Kandinsky und ich, p. 63. 


\section{El arte abstracto como expresión multisensorial}

A medida que Kandinsky gana experiencia con las exposiciones multiartísticas, la idea de síntesis va consolidándose. De la misma manera, el concepto de "contenido interior" del artista también empieza a coger forma, hasta llegar a definirse como «necesidad interior». Aclarado cuál es ese mundo interior que el artista debe exteriorizar a través de su arte, la necesidad interior, Kandinsky se centra ahora en los medios artísticos. La reunión de diferentes estilos bajo una misma rúbrica sigue estando presente, pero el foco ilumina especialmente los propios medios. La pregunta es cómo consigue la palabra en la poesía, el sonido en la música, o el ritmo en la danza llevar el contenido de la necesidad interior hasta el espectador.

Kandinsky parte de que todos los medios son igualmente capaces de expresar el contenido interno. Sólo que a veces, unos son más apropiados que otros. En esos momentos en los que un medio se presenta más conveniente para expresar una sensación determinada, Kandinsky simplemente "cambia de instrumento": "Hace ya muchos años que suelo escribir con cierta regularidad "poemas en prosa” y, a veces, “versos”. Para mí, eso es un “cambio de instrumento": aparto la paleta y coloco en su lugar la máquina de escribir. Digo "instrumento" porque la fuerza que me impulsa al trabajo es la misma; es una “presión interna". Y es esa fuerza la que me pide un cambio de instrumento». ${ }^{45}$

Esa "presión interna", que no es otra que la necesidad interior, determina qué medio (la palabra, el color, etc.) es el más adecuado para cada sensación. Hay medios que refuerzan las transmisiones sonoras (como la palabra o el sonido), hay otros que son más visuales (como el color o la forma ) y los hay principalmente espaciales (como el ritmo o el movimiento). Para aprender a utilizarlos correctamente $y$, sobre todo, para aprender a extraer de ellos su resonancia interior, Kandinsky se adentra en otras artes y realiza un doble estudio. Por un lado, analiza cómo se expresan esos medios en su ambiente: el sonido en la música, el ritmo en la danza, la palabra en la poesía. Y por otro, intenta descubrir cómo emplear la fuerza interna de esos medios en un arte que no es el propio: por ejemplo, cómo expresar la fuerza interna del ritmo en un cuadro pictórico.

Una de las primeras obras en la que trabaja con dos medios es Poesías sin palabras. Esta obra es un álbum de grabados en madera que lleva por título un nombre literario, lo que inicialmente acentúa su carácter sintético. Kandinsky

45 KANDINSKY, Escritos sobre arte y artistas, p. 207. Las comillas son originales. 
considera los doce grabados como doce poemas visuales, indicando que las artes (pintura y poesía en este caso) sólo son diferentes medios para expresar un mismo contenido. La palabra y la forma se expresan de manera diferente porque son diferentes medios, pero ambas son expresiones de la necesidad interior. Algo similar sucede en su obra Sonidos, un volumen que combina treinta y ocho poemas en prosa y cincuenta y seis imágenes (doce grabados en color y cuarenta y cuatro en blanco y negro). Kandinsky observa en estas obras cómo actúa cada uno de esos medios, cómo se comportan y cómo emplean su fuerza expresiva -esto es, su resonancia interior- para transmitir el contenido interno. ${ }^{46}$

Varios poemas de Sonidos reciben nombres de instrumentos musicales: Oboe, Fagot, Campana. Y a menudo recurre a la repetición de palabras para separarlas de su significado habitual y engrandecer el sonido puro de los fonemas. Un buen ejemplo es el poema ¿Por qué?, cuyos fragmentos más relevantes son los siguientes:

Nadie ha salido de allí.

¿Nadie?

Nadie

¿Alguien?

No

(...)

¿Nadie ha entrado allí?

Nadie

(...)

¿Y nadie, nadie, nadie ha salido de allí?

Nadie, nadie $^{47}$

También las imágenes de la obra Xilografías son poemas visuales con

46 Alguno de estos poemas visuales de Sonidos se han mostrado en el capítulo 4 (ilustraciones 7 y 8).

47 Salmen, Wassily Kandinsky: Klänge, p. 42. El título original es Warum? y la versión original dice así: «Keiner ist da herausgekommen/ Keiner?/ Keiner/ Einer?/ Nein/ (...) Keiner ist da hineingekommen?/ Keiner/ (...) Und Keiner, Keiner, Keiner ist herausgekommen?/ Keiner, Keiner/». Traducción propia, del alemán. 


\section{El arte abstracto como expresión multisensorial}

referencia a la música. Recuérdese que, para el título, Kandinsky utiliza la palabra Xylographie (xilografía) en vez de su sinónima y más frecuentemente usada Holzschnitt (xilografía, grabado en madera), por acercarlo a la palabra Xylophon (xilófono) y establecer la referencia musical. Con la inclusión del xilófono, Kandinsky quiere indicar que, en lo que a resonancia interior se refiere, la expresión visual de la forma y la expresión sonora de la música son equiparables.

Además de la poesía, la música es otra de las artes que Kandinsky quiere incluir en su pintura. En sus primeras obras y exposiciones sintéticas la música aparece, por ejemplo, en forma de partituras (como las de Schönberg en El Jinete $\mathrm{Azul}$ ). Pero Kandinsky no se queda ahí. De la misma manera que compara y contrasta los medios de la poesía con los de la pintura, Kandinsky quiere que la música se haga presente, de algún modo, en sus cuadros. Kandinsky envidia de la música la libertad con la que ésta es capaz de expresarse: no está atada al objeto figurativo como la pintura que él "hereda"; y tampoco tiene por qué tener tonalidad ni eje central como le demuestra Schönberg. Y esta libertad, que Kandinsky emula en la pintura eliminando el objeto, también es capaz de transmitir directamente cualquier contenido interior. La música no sólo es el arte con mayor capacidad de abstracción, también es un arte que, por estar liberado de las ataduras clásicas, no está obligado a narrar la realidad exterior. ${ }^{48}$ Gracias a esta exención, la música consigue llevar hasta el espectador sensaciones que van más allá de las sonoras. Consigue cambiar el estado de ánimo del que escucha, guiarle hasta mundos soñados o provocarle sensaciones nuevas.

Precisamente, esta capacidad expresiva de la música es la que Kandinsky quiere llevar a su pintura. En primer lugar, examina cómo se expresan sus medios: el sonido, el ritmo, la armonía. Y no sólo de manera práctica y directa (Kandinsky tocaba el chelo y el piano) sino también teórica. A raíz de su amistad con Arnold Schönberg y el entusiasmo que le provoca aquel concierto del 2 de enero de 1911, Kandinsky estudia y traduce al ruso un fragmento del manual de armonía de Schönberg (Harmonielehre). Y en segundo lugar, intenta proyectar la fuerza expresiva de la música utilizando los medios pictóricos. Es decir, busca la manera en la que el color y la forma transmitan, a través de su resonancia interior, sensaciones que hasta entonces sólo podía expresar la

48 Hahl-КосH, Kandinsky, p. 152. 
música.

Es importante recalcar que Kandinsky quiere importar la fuerza expresiva de la música a los medios de la pintura: no quiere pintar música ni tampoco hacer una traducción de obras musicales a cuadros. El mismo Kandinsky tuvo que luchar contra esta malinterpretación en la que, hay que reconocerlo, es bien fácil caer. La idea de síntesis apenas se entendía; los fenónemos sinestésicos no eran populares, lo que hacían extraña cualquier conexión entre tonos y colores; y, además, Kandinsky, como buen oriental, siempre fue un tanto místico en sus textos. Consciente de todo ello y para zanjar cuestiones mayores, Kandinsky es explícito en un par de ocasiones: «no quiero pintar música» ${ }^{49}$, dice en una conferencia de 1914 . Y también, un año antes: «Se dice que pinto música. Esta afirmación viene de quien ha leído superficialmente mi libro De lo espiritual en el arte. (...) Es decir, el [lector superficial] lee palabras y frases y realmente no tiene ni idea del contenido del libro. En mi libro, el lector se topa a menudo con la palabra "música" y de ahí concluye que yo pinto música» ${ }^{50}$.

El concepto de síntesis y el estudio de los medios de las artes siguen evolucionando con las obras de teatro que escribe Kandinsky. La principal es La sonoridad amarilla, una verdadera obra de arte total que combina diferentes artes. Casi se podría decir que es el resumen o el punto de unión de los diferentes trabajos y experimentos de Kandinsky sobre la síntesis, porque en ella se dan cita la pintura, la poesía, la música y la danza. Las seis escenas que ocupan el cuerpo central de la obra están concebidas como cuadros por los que se puede pasear (como aquella vez que Kandinsky sentía que estaba dentro de un cuadro, en su visita a Vologda). Las seis escenas son una especie de impresiones paisajísticas que ponen a prueba la fuerza expresiva del color y su capacidad para transmitir sensaciones sin pertenecer a un objeto. El color aparece en forma de haces de luz o de manchas informes, sin objeto que lo sustente. La palabra tampoco es clara: hay gritos, sonidos guturales, frases bien construidas pero sin sentido. Hay canto y coro, hay juego de luces y de sonidos, hay baile y coreografías. Además del propio ritmo de la música, también se establece ritmo entre el sonido y el silencio, entre el movimiento y

49 KANDINSKY, Mirada retrospectiva, p. 209.

50 Lindsay y Vergo, Complete Writings on Art, pp.344-345. Traducción propia, del inglés. 


\section{El arte abstracto como expresión multisensorial}

la pausa, entre el cambio de formas y colores. Los medios de las cuatro artes están presentes: el color y la forma de la pintura; la palabra de la poesía; el sonido y ritmo de la música; y el ritmo y movimiento de la danza.

La inclusión de la danza en La sonoridad amarilla permite a Kandinsky estudiar -junto al resto de medios- el ritmo y el movimiento. El objetivo es el mismo que con las otras artes: importar la fuerza expresiva de los medios de la danza a los medios de la pintura. Kandinsky quiere que la forma y el color resuenen de tal manera que sean capaces de transmitir lo que habitualmente transmite la danza: ritmo y movimiento. Pero así como establecer una relación entre colores y sonidos puede ser algo más intuitivo, la relación entre la danza y la pintura siempre ha sido más lejana. A primera vista parecen dos artes con medios opuestos: el color tan estático, el movimiento tan dinámico. Parece imposible unificarlos o incluso buscar un solo punto en común que permita establecer equivalencias entre ambos.

Kandinsky no tiene la formación de baile que sí tiene en la música, pero siempre se interesó por el ballet y la danza. De su correspondencia se deduce que acude a representaciones y lee al respecto. Entre sus amigos también cuenta con gente del mundo de la danza, como el bailarín ruso Alexander Sacharoff o la muniquesa Gret Palucca ${ }^{51}$. Palucca desarrolla a principios del siglo xx una forma de danza muy innovadora que obliga al dominio acrobático completo de la expresión corporal y potencia el uso de una sola figura sobre el escenario. En la década de los 20, Palucca participa en las actividades de la Bauhaus y Kandinsky escribe un artículo basándose en ella: Curvas de la danza, publicado en la revista Kunstblatt. ${ }^{52}$ En él, Kandinsky vuelve a hacer hincapié en la posibilidad de un arte sintético que incluya -y no represente, y no traduzca- la danza en la pintura.

La idea de síntesis artística está presente a lo largo de toda la carrera de Kandinsky. Empieza por aunar diferentes artes bajo una misma obra, como se ha visto con Phalanx, el Jinete Azul o sus poemas visuales, y continúa con un estudio más exhaustivo y aplicado de los medios de expresión, como en

51 Gret Palucca (1902-1993) se llamaba en realidad Margarete Paluka, cambió de nombre en 1921. Bailó en la gala de apertura de los Juegos Olímpicos de Berlín de 1936.

52 El artículo se encuentra recogido en la versión española de Escritos sobre arte y artistas, número 7 . 
La sonoridad amarilla. Kandinsky quiere que el lenguaje de su nuevo arte sea capaz de transmitir sensaciones que hasta entonces le estaban privadas a la pintura: sonido, ritmo, cadencia, movimiento. Poco a poco, consigue establecer una relación entre los diversos medios y aislar así la fuerza expresiva de cada uno de ellos, identificando su resonancia interior. Y de este modo, Kandinsky puede dotar a los medios pictóricos, el color y la forma, de una fuerza expresiva especial, de una resonancia interior que es capaz de expresar no sólo sensaciones visuales sino también sonoras, rítmicas o candenciales. Los ejemplos concretos y directos de cómo el lenguaje abstracto se llena de resonancias vienen a continuación.

\subsection{La resonancia de los medios pictóricos}

\subsubsection{El color}

Miro por mi ventana. Hay una serie de chimeneas de fábrica frías y calladas. Son inflexibles. De repente sale humo de una de ellas. El viento lo dobla y a cada momento cambia de color: el mundo entero ha cambiado.

W. KANDINSKY

El color es un elemento protagonista en la obra de Kandinsky. Es uno de los dos medios pictóricos básicos y además, la relación que Kandinsky tiene con el color es especial ya desde su infancia. Kandinsky no sólo percibe el color de forma diferente (con vida propia, desligado de los colores, etc.), también quiere transmitirlo de manera singular. Quiere que llegue al espectador de la manera más cercana posible a como lo percibe el artista, y eso incluye la exigencia de que el color transmita sensaciones visuales y también sonoras.

La relación que Kandinsky tiene con el color, tanto para la percepción como para la transmisión, le lleva a elaborar una teoría del color única. El carácter de esa teoría está marcado por su formación sistemática y racional y por el deseo de escribir una "armonía” para la pintura, un conglomerado de leyes ordenadas como tiene la música. La teoría del color kandinskyana se basa en un estudio teórico y tiene una aplicación práctica, como si de un 


\section{El arte abstracto como expresión multisensorial}

tratado científico se tratara.

Para la parte teórica, Kandinsky se basa en la observación propia y, cómo no, en otros tratados de pintura. Gracias a unas anotaciones al margen en unos apuntes de la Bauhaus, se sabe que Kandinsky conoció el estudio de Karl Scheffler sobre el color que lleva por título Notizen über die Farben (Apuntes sobre los colores). En él, Scheffler establece una primera relación entre el color y el estado anímico, porque cree que a determinados tonos de color les corresponden cierto tipo de sensaciones. De otra anotación al margen se infiere que Kandinsky también leyó el libro que editan Felix Krüger y August Kirschmann, Licht und Farbe (Luz y color), y en el que estudian la relación entre la impresión visual que causa un color y la impresión interna o sensación. Kirschmann sugiere que ciertos colores evocan ciertos sentimientos y llega incluso a hablar de "tonos de sentimientos" o Gefühlstöne, exactamente la misma palabra que usa Theodor Lipps en su teoría de la empatía.

El investigador López García ${ }^{53}$ apunta que Kandinsky pudo haber conocido las obras de Berger, Schmid-Breitenbach y Czapek, por las referencias que hace ocasionalmente a la importancia de la posición del color en referencia a otros elementos del cuadro. Tampoco se puede olvidar la influencia que el químico y estudioso del color Wilhelm Ostwald tuvo en la Bauhaus y por ende sobre Kandinsky. Ostwald se basó en principios psicofísicos para establecer unas leyes de aplicación del color y fundar así una especie de "métrica del color”. En la biblioteca que se conserva de Kandinsky en París hay tres ejemplares de Ostwald: uno sobre el estudio de los pigmentos, otro sobre la armonía de los colores y una colección de mini cuadernillos que tratan el color desde diferentes perspectivas.

Con exactitud no se puede asegurar qué teorías leyó Kandinsky y cómo y cuánto le influyeron. Estas referencias son aproximaciones, de la misma manera que en algunas ideas se intuyen las teorías de Newton o de Philipp Otto Runge. Sí se pueden añadir con seguridad las que él mismo cita en su libro De lo espiritual en el arte: a Goethe y a Delacroix. ${ }^{54}$

53 López García, Kandinsky: los fundamentos del arte abstracto, pp. 89 y ss.

54 El investigador John Gage cree bastante probable que Kandinsky leyera el Manifiesto de Signac sobre Delacroix, que se publicó en alemán en 1903. Y también que leyera el libro de Osborne Eaves sobre la fuerza terapéutica del color. Véase GAGE, Kulturgeschichte der Farbe. 
La teoría de Kandinsky sobre el color queda recogida principalmente en dos textos. El contenido propiamente dicho se puede leer en De lo espiritual en el arte, aunque su presentación es algo desordenada. Con mucho más rigor, en el artículo Curso y seminario sobre el color, Kandinsky recoge el método y procedimiento que sigue en su análisis. El artículo es posterior al libro y se nota que la teoría ha alcanzado otro grado de elaboración. ${ }^{55}$

Los estudios del color que Kandinsky lleva a cabo para confeccionar su teoría son múltiples y variados. No se centran exclusivamente en la capacidad cromática, sino que muchos de ellos analizan el color en relación a la luz, al efecto que produce en el ser humano o según su capacidad de transmitir nuevos tipos de resonancias (sonoras, por ejemplo). Kandinsky comienza la investigación desde diferentes puntos de vista: el físico-químico (la naturaleza del color), el fisiológico (el medio de la recepción externa) y el psicológico (el efecto que provoca).

Una vez analizado el color en base a sus pigmentos y propiedades puramente químicas, el primer efecto del color es físico y de corta duración. Se percibe con la vista y el espectador experimenta una sensación inmediata. Por ejemplo, el azul o verde reportan calma y sosiego, el amarillo chillón obliga a encoger los párpados y el bermellón atrae como la llama de un fuego. Poco a poco, el color va transmitiendo toda su fuerza expresiva al espectador y éste termina por apreciar su resonancia interior. En este momento, el color ya tiene un efecto psicológico. El espectador no sólo lo percibe por la vista, sino que entran en juego el resto de órganos para captar toda la riqueza sensorial de la necesidad interior. Con ejemplos del propio Kandinsky, el verde óxido de cromo invita a la caricia con su tono aterciopelado, el verde cobalto resuena duro y seco y el amarillo canta como una soprano.

Algunas de estas asociaciones entre el color y el efecto que provocan, Kandinsky las toma o las asemeja a la teoría de otros autores. López García señala que, para el negro y el rojo, Kandinsky se acerca mucho a la relación entre arte y vida de los pueblos primitivos, lo que en cierto modo viene a recalcar el vínculo que Kandisky siente con estos pueblos a través de la teoría de la

55 El título original del artículo es Farbkurs y Seminar y fue incluido en el libro que editó la Bauhaus con el nombre de Staatliches Bauhaus in Weimar 1919-23. En este artículo, Kandinsky recoge las ideas con las que organiza su clase de pintura mural y su curso sobre la teoría de los colores, hacia 1922. 


\section{El arte abstracto como expresión multisensorial}

abstracción de Worringer. López García escribe: [en Kandinsky] «el negro es asociado con un cadáver inmóvil o una hoguera apagada, el rojo con la llama, el dolor y la sangre. (...) Su biblioteca contiene un escrito sobre las antiguas runas, un alfabeto arcaico atribuido al dios germánico Wuotan de significado mágico y esotérico. Varios fragmentos fueron subrayados al margen, entre ellos los que destacan el rojo intenso como color mágico empleado para escribir las runas por su relación con el fuego y la sangre, así como su empleo preferente en la heráldica medieval ${ }^{56}$.

Pero la mayoría de las relaciones que Kandinsky establece entre el color y la forma, las sensaciones y el resto de medios de las artes, nacen de la experimentación propia. El estudio sobre el color de 1913 (ilustr. 23, pág. 191) le ayuda a analizar la resonancia interior de cada color según su posición dentro del círculo y del cuadrado, y la influencia de los colores cercanos. En sus artículos deja también constancia de sus experimentos, como los vistos más arriba («un cuadrado negro sobre un fondo blanco parece ser más pequeño que un cuadrado blanco sobre un fondo negro») o este otro: «he dibujado, por ejemplo, el cuadro proyectado según las proporciones matemáticas sobre una superficie calculada, y resultaba que ya sólo el color cambiaba las proporciones» ${ }^{57}$.

A esta experimentación puramente pictórica se le suma el análisis a través de otros experimentos en los que envuelve a alumnos y otros artistas de diferentes disciplinas, para así establecer conexiones y paralelismos entre los medios de todas las artes (pintura, música, poesía, danza). Además del cuestionario de 1923 que reparte en la Bauhaus, ${ }^{58}$ Jelena Hahl-Koch recoge otros tantos formularios con preguntas referidas claramente al efecto que provoca el color y su relación con otros medios: « ¿se ha preguntado alguna vez hasta qué punto los medios expresivos del arte como tales tienen un efecto en la psique (por ejemplo, el color en la pintura, el sonido en la música, etc.)?» ${ }^{59}$

Las investigaciones, los experimentos, el análisis teórico-práctico y la

\footnotetext{
56 LóPez García, Kandinsky: los fundamentos del arte abstracto, pp. 59-60.

57 KANDINSKY, Escritos sobre arte y artistas, p. 136.

58 El cuestionario citado en la pág. 192.

59 Una copia de los cuestionarios que Kandinsky repartió y con la que llevó a cabo sus investigaciones teórico-prácticas se encuentra en el apéndice de LindSAY y Vergo, Complete Writings on Art, traducidas al inglés, o en el alemán original en $\mathrm{HAHL}-\mathrm{KocH}$, Kandinsky, pp. 259 y ss.
} 
propia elaboración concluyen en la teoría del color que presenta Kandinsky. Ésta se apoya en dos grandes pilares: por un lado, la creación de efectos a partir de las antinomias; por otro, la resonancia acústica del color por su relación con la música.

Las antinomias son dos. Una es la pareja calor y frío, otra la de claridad y oscuridad. El calor o frío de un color está determinado por su tendencia y cercanía cromática al amarillo o al azul (respectivamente). Entre ambos polos (calor-amarillo, frío-azul) discurre un movimiento horizontal que tiene al espectador como punto medio: cuanto más cálido sea un color, más cerca se situará del espectador. Y viceversa: la frialdad o proximidad al azul aumenta la distancia entre el color y el receptor. Este movimiento es posible gracias a la revalorización del espacio, esa superficie flotante que crea Kandinsky. Además de este movimiento horizontal, cada color posee un movimiento propio. El amarillo irradia su fuerza hacia afuera, excéntricamente, desde el centro al exterior. El azul, por el contrario, se retrae en sí mismo, en un movimiento puramente concéntrico: siempre hacia dentro.

La claridad y oscuridad de los colores viene determinada por la tendencia del color al blanco (claridad) o al negro (oscuridad). El movimiento entre ambos no es horizontal, pero tampoco vertical. Es más bien un no-movimiento, un movimiento estático caracterizado por la resistencia. El blanco encarna la resistencia eterna que sin embargo está llena de posibilidades, capaz de acoger en sí todo lo demás. El negro, en cambio, es un ente muerto y sin posibilidades, al que le falta incluso la resistencia al movimiento.

De la mezcla del amarillo y el azul, surge el verde. Surge por enfriamiento del amarillo, que al acercarse al azul pierde dinamismo, energía y movimiento. El verde, situado justo a medio camino, concentra las características de azul y de amarillo, pero en un punto tan intermedio, que las características de ambos acaban por anularse. El verde es por ello pasivo e inmóvil: «es como una vaca gorda, sana e inmóvil, que rumiando contempla el mundo con ojos adormilados y bobos» ${ }^{60}$, describe Kandinsky. De la otra pareja de antinomias, el blanco y el negro, surge el gris. El gris es incluso más pasivo que el verde porque sus colores fuente carecen de fuerza y vida. El gris se resiste inmóvilmente, con una pasividad suprema.

Y alrededor de las parejas de antinomias, van surgiendo el resto de colores,

6o Kandinsky, De lo espiritual en el arte, p. 75. 


\section{El arte abstracto como expresión multisensorial}

que forman el esquema siguiente: a la izquierda, como origen, el blanco. En el centro, un círculo cromático con amarillo y azul como primera pareja de opuestos; rojo y verde como segunda; y naranja y violeta como tercera pareja. A la derecha, ya fuera del círculo cromático, el negro como muerte y destrucción.

El segundo pilar en el que se apoya la teoría es en la resonancia acústica del color. Ya se ha visto que Kandinsky, de la música, no sólo envidia su libertad armónica por no estar sujeta a las leyes clásicas de la composición. También envidia la capacidad que tiene de despertar emociones nuevas y de transmitir sensaciones multisensoriales. Y cree que el color, si se libera de las reglas a las que le ata la pintura, sería capaz de esa misma fuerza expresiva. Así se lo cuenta Kandinsky a Karl Nierendorf, su representante en Estados Unidos: "sentía la inusitada fuerza del color. Envidiaba a los músicos el poder hacer arte sin tener que "narrar" nada "realista". Sin embargo, me parecía que el color era igual de expresivo y fuerte que el sonido» ${ }^{61}$.

La idea de que el color tenga la capacidad de expresarse como lo hace el sonido no es un mero constructo teórico de Kandinsky. Para él, el color ya se le revela acústico porque además de las visuales, el color le produce desde niño sensaciones sonoras. En el capítulo 1 se nombraron aquellos momentos biográficos que serían relevantes en la confección de su teoría. Uno de esos momentos es la narración sobre el atardecer de Moscú, que deja patentes las referencias musicales que le producen ciertos colores: «el sol hace que toda Moscú se funda en una mancha (...) como una tuba enloquecida. (...) El rosa, el lila, el amarillo, el blanco, el azul, el verde pistacho, el rojo flamígero de las casas, de las iglesias - cada una con su melodía propia-, la nieve de mil voces cantarinas». La correlación entre la expresividad del color y del sonido también ocurre en la otra dirección, cuando son los sonidos los que despiertan sensaciones visuales. El ejemplo viene de otro episodio biográfico. La audición de la ópera Lohengrin de Wagner origina en Kandinsky imágenes visuales, llenas de color y, además, cierto parecido con el atardecer de Moscú: «Lohengrin me pareció que era una realización perfecta de ese Moscú, los violines, los contrabajos (...) personificaban entonces para mí toda la fuerza de las horas del crepúsculo. Mentalmente veía todos mis colores, los tenía ante mis ojos.».

61 KANDINSKY, Escritos sobre arte y artistas, p. 193. Las comillas son originales. 
Experiencias como éstas y seguramente otras que o no fueron descritas o se han perdido con el tiempo, llevan a Kandinsky a considerar que el color y el sonido son dos medios equivalentes en la expresión. Por eso afirma, ya a principios de su carrera abstracta, estar seguro de que «la pintura podía desplegar las mismas fuerzas que la música» ${ }^{62}$. Esta es la idea clave en la teoría que llega después: conseguir que la pintura alcance el mismo grado de expresión que la música.

Probablemente, las teorías del color de Newton y de Franz Schmid-Breitenbach que de alguna manera ya relacionaban música y pintura, colaboran en el desarrollo de la teoría de Kandinsky. ${ }^{63}$ Newton, en los escritos que envía a la Royal Society en 1672 y en su Tratado de Óptica de 1704, establece una relación entre siete colores y los siente sonidos de la escala musical. El físico se basa en sus experimentos de la luz y el prisma para afirmar que la luz blanca es la suma de siete colores: rojo, naranja, amarillo, verde, azul, índigo y violeta. $\mathrm{Y}$ apoyado en las propiedades vibratorias de la luz y el sonido, presenta una analogía entre esos siete colores y la octava musical, en concreto con la escala dórica, ${ }^{64}$ donde cada tono se corresponde con la frontera entre dos colores.

Por su parte, la teoría del color de Schmid-Breitenbach también describe paralelismos entre tonos musicales y colores e incluso los vincula a impresiones anímicas concretas. López García señala que Kandinsky tenía subrayados varios párrafos del libro, entre ellos uno que hace hincapié en que la armonía de los colores consiste en «el sonido simultáneo de todos ellos en un acorde» ${ }^{65}$.

A diferencia de Schmid-Breitenbach, que establece muchas de las relaciones entre colores y tonos musicales basándose en analogías con la naturaleza, Kandinsky rechaza este tipo de asociaciones: "podemos suponer que, por

62 Kandinsky, Mirada retrospectiva, p. 103.

63 No cabe duda de que Newton y Schmid-Breitenbach no fueron las únicas influencias en Kandinsky para su teoría del color sonoro, pero dado que esta investigación no es un tratado de la historia del color, valen ambas como representación.

64 La escala dórica es una escala menor que cambia la sexta menor por una mayor. Los semitonos quedan entre la segunda y la tercera nota, y entre la sexta y la séptima.

65 Schmid-Breitenbach, Stil- und Kompositionslehre in der Malerei, p. 6. López García señala en el apéndice de su libro (2001, p. 240) que «el volumen [de Schmid-Breitenbach] contiene anotaciones y subrayados a lápiz en los márgenes. Entre las páginas 100-101 se encuentra un telegrama con fecha 23-10-1906 remitido a la ciudad de Munich [sic] desde la localidad francesa de Sévres, donde el artista vivió una larga temporada entre 1906-07, que dice: "Llegado. Besos. Kandinsky". Su presencia indica que el libro estaba en poder de la pareja [Münter-Kandinsky] ya en 1906». 


\section{El arte abstracto como expresión multisensorial}

ejemplo, el amarillo claro produce una sensación ácida por asociación con el limón. Sin embargo, este tipo de explicaciones es casi imposible. Precisamente en lo que se refiere al sabor del color, conocemos varios ejemplos en los que este tipo de explicación no sirve» ${ }^{66}$. Desechada la naturaleza, Kandinsky elabora su sistema de equivalencias basándose en la resonancia interior de los medios. El color no es una traducción del sonido ni el sonido traduce el color, la equivalencia se explica por la fuerza expresiva. El azul oscuro está emparentado con el violonchelo porque ambos resuenan de manera comparable: la resonancia de cada uno de ellos consigue transmitir al espectador una sensación interna similar. Las equivalencias entre tonos y colores se encuentran repartidas en $D e$ lo espiritual en el arte y algún que otro artículo. La tabla 5.2 es una exposición conjunta de todas ellas.

\begin{tabular}{ll} 
color & tono \\
\hline amarillo & trompeta tocada con fuerza \\
azul claro & flauta \\
azul oscuro & violonchelo \\
azul profundo & contrabajo, bajos del órgano \\
verde claro & violín: tonos medios \\
verde absoluto & violín: tonos tranquilos \\
verde-azul & violín con sordina \\
rojo saturno & trompeta, clarín \\
rojo cinabrio & tuba, redoble de tambor \\
rojo frío & violín: tonos altos y claros \\
marrón & sonido retardado \\
naranja & campana de iglesia \\
violeta & corno inglés, gaita \\
violeta profundo & fagot
\end{tabular}

Tabla 5.2

66 Kandinsky, De lo espiritual en el arte, p. 53. 
La descripción completa de cada color es extensa y está llena de referencias a los medios de otras artes: al sonido, a la cadencia, al ritmo, al movimiento. Y por supuesto, a todo color se le reconoce una resonancia interior propia, capaz de establecer una conexión directa entre la necesidad interior del artista y el alma del espectador. La descripción de cada color que se presenta a continuación es un resumen conciso de la fuerza expresiva de cada color.

El amarillo es el color típicamente terrestre. Su movimiento excéntrico y cálido inquieta al espectador. Es un color agresivo, que puede llegar a ser estridente y volverse insoportable. Musicalmente resuena como una trompeta tocada con fuerza o un clarín. Si se le enfría, (esto es, si se le añade azul) su resonancia se vuelve furiosa, delirante, cercana a la locura. Y a mayor calidez, mayor movimiento excéntrico, casi como un derroche de fuerzas.

El azul es, contrario al amarillo, el color típicamente celeste. Su movimiento concéntrico le acerca al espectador. $\mathrm{El}$ azul resuena profundo, quieto, tranquilo. Es una llamada a la pureza, a la inmaterialidad, afirma Kandinsky. Sus tonos claros suenan a flauta, sus tonos medios al violonchelo, y los tonos más graves son los mismos tonos graves del contrabajo. Enfriar el azul, es decir, acercarlo al negro, lo convierte en un color grave, como de «tristeza inhumana». Y acercarlo al calor, le provoca insonoridad, indiferencia, quietud silenciosa.

El verde es el color que equilibra el azul y el amarillo, anulando las fuerzas de ambos. Por este motivo resuena a calma y a máxima tranquilidad, pero en seguida pasa a convertirse en aburrimiento. El verde es indiferente, un color que ni pide ni llama ni se acerca ni se aleja. Es la "calma satisfecha del verano», dice Kandinsky, que llega después del derroche de fuerzas de la primavera (más cercana al amarillo). Los tonos tranquilos del violín resuenan a color verde. El verde frío es grave y pensativo. Según se le aclara (se le acerca al amarillo), empieza a cobrar vida, juventud y alegría.

El rojo es un color cálido, ilimitado, que arde en sí mismo. Rezuma potencia, tenacidad, es terrestre y viril: «ardor brioso, esencialmente centrado en sí mismo y poco extravertido, es un signo de madurez viril ${ }^{67}$. No llega a desbordar como el amarillo, sino que más bien se concentra en sí mismo, imponiéndose. El rojo presenta una gran gama de variaciones: desde el rojo cálido (rojo saturno) que resuena con la energía y decisión de una tuba, el rojo

67 Kandinsky, De lo espiritual en el arte, pp. 78-79. 


\section{El arte abstracto como expresión multisensorial}

medio (rojo cinabrio) como pasión incandescente, hasta el rojo frío de los sonidos bajos del violonchelo, un rojo que casi ha perdido su sonido, aunque sin llegar al insulso azul.

El blanco es un mundo sin color ni cualidad. Es el gran silencio, pero es un silencio lleno de posibilidades: «el gran silencio preñado de cosas posibles». ${ }^{68}$ Es la nada previa que sin embargo puede engendrar todo. En la música, el blanco son las pausas entre compases y entre frases musicales. Son las pausas necesarias que dan pie a lo nuevo, a lo que está por llegar.

El negro es la antítesis del blanco. Es el silencio sin futuro, que muere. Es la nada que no crea, es el final de la vida. Es la tristeza profunda, insonora, que en una composición resalta el color de los demás. Y en una composición musical es la pausa final y definitiva.

El gris es una mezcla pasiva llena de desesperanza y asfixia. Comienza a respirar a medida que se va acercando al blanco. Pero en cuanto se le enfría, pierde toda esperanza.

El marrón es el oscurecimiento del rojo, acercándose al negro, y su resonancia es chata y dura, con poco movimiento. Externamente es flojo, pero en el interior guarda la pasión del rojo y provoca un sonido retardado pero intenso, como un redoble de tambor.

El naranja, como unión de rojo y amarillo, conserva el matiz grave del rojo y la fuerza radiante del amarillo. El naranja resuena saludable, como las campanas de una iglesia.

Por último, el violeta es un rojo enfriado. A causa del azul frío que contiene, se aleja del espectador y se torna enfermizo, triste, apagado. Resuena melancólico, como la gaita, como el fagot, como el corno inglés.

A pesar de que las teorías de Kandinsky no son un manual estricto para "leer" sus cuadros y aunque, además, la resonancia de cada color varíe según su uso y colocación, sí es posible guiarse a través de estas explicaciones para comprender y sentir de otro modo la obra pictórica de Kandinsky. El color en Kandinsky resuena multisensorialmente.

68 Kandinsky, Mirada retrospectiva, p. 206. 


\subsubsection{La forma}

La forma es el segundo gran protagonista en la obra kandinskyana. Liberada de representar la naturaleza, alejada de toda apariencia figurativa y sin ninguna finalidad práctica, la forma adquiere una nueva dimensión en el arte abstracto. En consonancia con la teoría de Kandinsky, la forma debe transmitir el contenido de la necesidad interior empleando toda su fuerza expresiva o resonancia interna. Para lograrlo, es imprescindible que la línea se libere del objeto y que, además, su fuerza interior sea capaz de transmitir sensaciones que no sean sólo visuales, al igual que ocurre con el color. «Por consiguiente, si una línea en un cuadro se libera de la finalidad de describir un objeto (...), su sonido interno no será amortiguado por ninguna función secundaria, y la línea recibe su plena fuerza interna. La línea no es aquí sino un solo ejemplo del sinnúmero de elementos "abstractos" que pueden usarse para construir un cuadro». ${ }^{69}$

Kandinsky lleva a cabo un estudio exhaustivo de la forma y sus propiedades para descubrir y fomentar su resonancia interna. En los primeros años de abstracción, Kandinsky escribe un artículo en que expone sus teorías y preocupaciones acerca del aspecto formal de la pintura. El artículo, que lleva por título Sobre el problema de la forma (1912), está incluido en el almanaque de El Jinete Azul y trata de responder a la pregunta de qué hacer cuándo desaparece el objeto, qué forma darle al contenido si se rechaza lo figurativo. Unos años más tarde, siendo ya profesor de la Bauhaus, Kandinsky se enfrenta al problema de la forma desde una perspectiva puramente abstracta. En el libro que publica entonces, Punto y línea sobre el plano (1926), está más interesado en mostrar los elementos básicos de la forma y la resonancia interna de cada uno de ellos.

La forma tiene, en principio, una sola resonancia interior: «una forma determinada, bajo condiciones idénticas, suena siempre de la misma manera ${ }^{70}$. El problema es que las condiciones siempre son diferentes porque una forma

69 KANDINSKY, Escritos sobre arte y artistas, p. 177. Las comillas de "abstractos" son originales y seguramente se explican por el vaivén de nombres que tuvo el arte de Kandinsky, desde puro hasta abstracto pasando por concreto o real. Sobre la cuestión del nombre véase la pág. 108, capítulo 3 .

70 Kandinsky, De lo espiritual en el arte, p. 63. 


\section{El arte abstracto como expresión multisensorial}

nunca aparece de la misma manera ni rodeada de los mismos elementos. Una línea puede ser recta o curva, larga o corta, azul o amarilla. Esto significa que la resonancia de la forma es muy variada, según cómo aparezca, pero también, y a priori, que modificando la forma se puede obtener un gran abanico de posibles e infinitas resonancias. Las posibilidades de resonancia de la forma son infinitas, según Kandinsky. Y están, por tanto, abiertas a expresar todo el repertorio de sensaciones multisensoriales de la necesidad interior.

Es imposible analizar cada una de las posibles resonancias, por lo que el estudio ha de ceñirse a los elementos básicos de la forma. Los elementos formales del arte abstracto son tres: el punto, la línea y el plano. Junto con el color, el punto, la línea y el plano conforman todo el vocabulario de su gramática de la creación.

El punto es el elemento primario de toda forma, porque toda forma nace de él. El punto pictórico, que no siempre es igual al punto puramente geométrico, es el elemento básico de la forma abstracta. El punto pictórico nace del choque de un instrumento con la superficie: del pincel con el lienzo, del lápiz con el papel, del punzón con la madera. Tras el choque, el punto adquiere necesariamente un tamaño y una forma, y estas características determinan su resonancia interior.

Respecto al tamaño, el punto es, en origen, la forma mínima. Pero puede crecer hasta formar un pequeño círculo y luego uno más grande, y engordar más y más y hasta convertirse en un plano. A veces es dífícil señalar dónde acaba el punto y dónde empiezan el círculo o el plano, pero esa frontera tampoco es determinante. Respecto a la forma del punto, es decir, el aspecto de su borde exterior, éste puede variar libremente. En abstracto siempre se piensa un punto redondo, pero una vez que ha tomado lugar sobre una superficie, el borde exterior puede hacerse puntiagudo, rectangular o dentado (ilustr. 24). Y cada una de estas variaciones produce una sensación diferente.

El punto es el origen del resto de formas. La modificación del tamaño del punto genera el círculo y, aumentando éste, llega a convertirse en plano. Y si el punto se prolonga longitudinalmente, entonces genera la línea. El punto se afirma como elemento principal en el cuadro y resuena como tal: enérgico, conciso. «El punto se instala sobre la superficie y se afirma indefinidamente» ${ }^{71}$,

71 Kandinsky, Punto y línea sobre el plano, p. 27. 


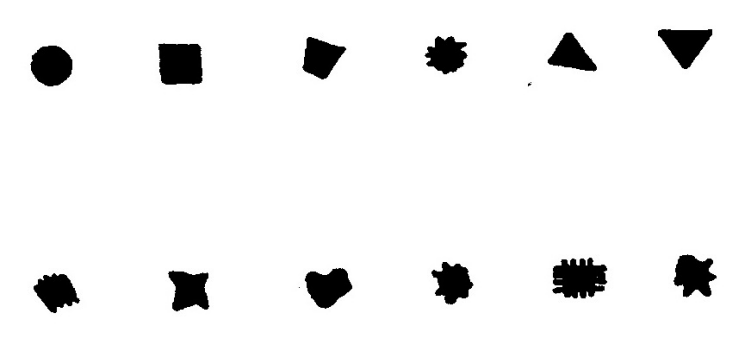

Ilustración 24 Ejemplos de puntos

son las palabras de Kandinsky. El punto se caracteriza por tener una fuerte tensión interna, concéntrica, que le hace replegarse en sí mismo y autoafirmarse de manera clara. Se afirma en su sitio porque el punto es reposo, en el sentido de que no tiende a desplazarse, ni vertical ni horizontalmente. El punto es inmóvil en el espacio, aunque su resonancia pueda extenderse en el tiempo (igual que una nota musical).

Por este motivo, la resonancia básica del punto es precisa, enérgica y clara. Pero en el momento en el que se juntan dos o más puntos en el cuadro, la resonancia varía. La concentración de varios puntos puede dar lugar a una sensación de ascenso, de descenso, de frío, de calidez, de tensión, de dispersión, de pesadez, de ligereza... El tamaño y la forma de los puntos, así como el color, son los responsables de todas estas modificaciones. Varios puntos de tamaño medio y forma redondeada que se sitúan cerca de otros, producen ligereza, como si fueran burbujas. Es el caso de Acento en rosa, un cuadro de 1926. En cambio, si los puntos son gordos y grandes resuenan pesados, completamente inmóviles y parece que paralizan el cuadro. Así ocurre en Balanceo, de 1925.

La línea nace del punto y es a la vez su antítesis, porque frente al punto -que es completo reposo- la línea es movimiento. La línea es una fuerza exterior que se agarra al punto y lo arroja en otra dirección. La línea aniquila la tensión interior del punto, haciendo desaparecer el reposo. Surge del movimiento que arranca desde el punto: es la marca o traza que deja el punto al moverse. Si el punto sólo posee tensión interior, la línea dispone de tensión y además de dirección, lo que le permite el movimiento.

Kandinsky distingue tres tipos de líneas: la recta, la quebrada y la curva. La descripción que hace en sus textos de cada una de ellas es extensa. Al 


\section{El arte abstracto como expresión multisensorial}

igual que con el color, Kandinsky no sólo se centra en las propiedades físicas (geométricas) de la línea, sino también en las psicológicas y en cómo las percibe el espectador. Gran parte del libro Punto y línea sobre el plano está dedicado a la explicación detallada de todas las líneas, cuya reproducción aquí sería abrumadora. Baste con el ejemplo de la línea recta para entender cómo las líneas pueden resonar de manera multisensorial.

La línea recta es la forma más sencilla de movimiento, porque su fuerza desplaza al punto en una dirección invariable y tiende a prolongarse de manera indefinida. Según la dirección que tome, puede ser horizontal, vertical o diagonal. La línea horizontal se desplaza sobre el plano, como si estuviera unida a él. Ejerce de base protectora sobre la que se asientan el resto de formas y según Kandinsky, esto hace que su resonancia sea fría, chata y profunda. La vertical, por el contrario, se caracteriza por su altura, elevándose a lo largo del cuadro. Tampoco es fría, su resonancia interior es cálida. A la misma distancia angular $\left(45^{\circ}\right)$ entre la horizontal y la vertical se sitúa la diagonal. Su resonancia interior es templada, por estar tan cerca del frío horizontal como de la calidez vertical. La desviación de las rectas diagonales son las rectas libres, que según se acerquen más o menos a la horizontal, determinan su resonancia interior. Cuanto más cerca de la horizontal, más fría resuena, y cuanto más se aleje de ésta o más se acerque a la vertical, su resonancia se vuelve más cálida. La característica principal de todas las líneas rectas es su temperatura, que marca su resonancia interior.

Las características de cada recta permiten establecer un paralelismo con los colores. La unicidad de las rectas horizontal y vertical en el plano las acerca al lugar que ocupan el blanco y el negro en la escala cromática. Bajo el aspecto de la temperatura, el blanco es cálido y el negro todo lo contrario: su interior es completamente frío. Del mismo modo, las rectas libres avanzan y retroceden por el plano, desplazándose entre el frío y el calor. Son las tensiones opuestas que también tienen el azul y el amarillo, que se acercan y se alejan del frío-calor. La gama de rectas libres, más o menos inclinadas, resuenan de manera similar a la gama que va del amarillo al azul. La diagonal, en tanto que no es ni vertical ni horizontal sino justo el punto medio entre ambas, resuena a veces como el gris, también a medio camino entre el blanco y el negro. Y como origen de las rectas libres, azules y amarillas, la diagonal puede resonar como el verde. Por último, por la fuerte tensión interior de la diagonal, por su equilibrio de temperatura frío-calor, la diagonal resuena con la misma ebullición interior 
que tiene el rojo.

El plano es la superficie que forma o cierra una línea en movimiento: un triángulo, un cuadrilátero o un círculo son planos de figuras reconocibles, pero también hay planos libres formados por líneas libres. La variedad de planos posibles es inagotable, dado que los elementos de los que nace (las líneas) son también infinitas. Sin embargo, hay un plano común a toda obra y más o menos estable en lo que a variaciones se refiere. Se trata de la superficie material que recoge el contenido de la obra y que Kandinsky denomina plano básico. El plano básico es un ser viviente que nace blanco, intocado, inconsciente y que se va transformando según los elementos que se le añadan.

El plano básico (en los libros de Kandinsky abreviado como PB) es una entidad independiente que está formada por cuatro líneas rectas que lo limitan: dos horizontales y dos verticales. Esta configuración le proporciona una resonancia objetiva, templada, por la unión equilibrada de dos componentes fríos (las dos horizontales) y dos cálidos (las dos verticales). La parte superior del PB resuena con «soltura, ligereza, liberación», lo que supone la negación de la densidad. Los elementos que se colocan en este lugar quedan desligados, sueltos, ligeros. Pierden peso y poder de sustentación según ascienden. La ligereza y la falta de retención potencia sin embargo la resonancia de los elementos muy pesados, les otorga un sonido más fuerte al permitirles moverse libremente y destacar sobre el resto de elementos.

La parte superior del PB se caracteriza por su afirmación, condensación y ligazón de las formas que se sitúan en ella. Los elementos resuenan pesados en una atmósfera espesa y densa. La ascensión se dificulta: el esfuerzo por subir se ve frenado por la tensión que obliga a caer. La retención en esta parte del plano es máxima, el movimiento se ve limitado. Los elementos pesados soportan esta atmósfera sin necesidad de esfuerzo, se camuflan entre ella, lo que amortigua o disminuye su resonancia interior. Es decir, las formas pesadas (como un gran punto rojo o una línea gruesa) ven reforzado su sonido sólo en la parte de arriba, por el contraste que originan con la ligereza y soltura superiores.

Dado el carácter de sendas partes del plano, la colocación de determinadas formas arriba o abajo puede contribuir a fortalecer la resonancia del Pв o bien a neutralizarla. También influye en la resonancia la proporción que haya entre el ancho y el alto del plano: un Рв más ancho que alto prepondera la sensación 


\section{El arte abstracto como expresión multisensorial}

de frío frente a la de calidez, porque las horizontales son más largas que las verticales. En un plano alargado (más alto que ancho) ocurre justo lo contrario: aumentan las líneas cálidas y con ellas la sensación de calidez.

El paralelismo que Kandinsky establece entre la forma (punto, línea y plano) y todo tipo de sensaciones refuerza la idea de que diferentes medios pueden resonar de manera similar. Porque la resonancia no sólo se limita a lo visual. Hay referencias a la temperatura, a la gravidez, a la densidad. Y en la teoría completa hay aún más adjetivos que Kandinsky utiliza para referirse a la resonancia interior, como muestra esta descripción de la línea curva: «libre, vibrante, esquiva, flexible, elástica, aparentemente indefinida, como el destino que nos espera». ${ }^{72}$ Sin embargo, toda esa variedad de sensaciones que puede transmitir la forma alcanza su punto máximo cuando entra en contacto con otras formas. Así como cada color tiene una resonancia más o menos definida, la forma es, en ese aspecto, mucho más variable. Cada forma tiene una resonancia básica (la horizontal es fría y suena como el blanco-amarillo, o la parte superior del plano transmite soltura y ligereza), pero sólo cuando la forma se combina entre sí, adquiere su resonancia plena.

Kandinsky explica varias de las técnicas con las que consigue potenciar la resonancia interior de la forma; otras no las expone directamente, pero se infieren de la práctica. La influencia de la música, la literatura o la danza queda patente.

Una de estas técnicas es enfatizar la resonancia interior. La colocación de las formas en un lugar determinado del plano puede acentuar su pesadez o ligereza, su capacidad de movimiento y hasta su calidez. Pero también se puede acentuar la resonancia de la forma de la misma manera que se acentúa una palabra: poniéndole una tilde. El énfasis de la línea, por ejemplo, se consigue aumentando o disminuyendo su grosor. Una línea curva ascendente, cuya base es más gruesa que su parte superior, consigue aumentar la tensión vertical (cálida), elevándose aún más. Se puede enfatizar cualquier parte de la línea, según qué resonancia se quiera acentuar. Y el énfasis puede ser uniforme, si se reparte por igual a lo largo de la línea; proporcional, si el grosor varía proporcionalmente; o irregular, si se enfatizan partes concretas para favorecer un tipo de resonancia interior determinada. Un ejemplo del énfasis que se

72 Kandinsky, Punto y línea sobre el plano, p. 71. 


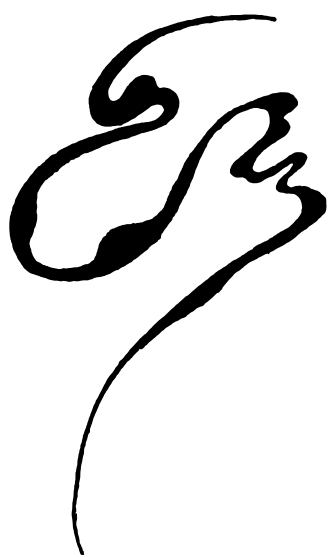

Ilustración 25 Énfasis de una línea

le puede dar a una línea, irregular en este caso, es el de la ilustración 25. La curva juega con la resonancia cálida de la verticalidad, porque es más alta que ancha, pero el grosor de las partes horizontales le imprime un carácter frío. El énfasis aplicado consigue cierto equilibrio de temperatura pero de ningún modo estable: la línea se balancea entre el aquí y el allí, entre lo suave y lo áspero, entre lo débil y lo fuerte. El énfasis de los recovecos convierte a la línea en puntos, recordando su origen (la línea es un punto en movimiento). De esta manera, la resonancia aúna el movimiento de la línea y la estaticidad del punto, retando al espectador a responder una pregunta de por sí abierta: ¿dónde comienza a moverse y dónde resuena estática, dónde empieza la línea y dónde termina el punto? Kandinsky da como respuesta otra pregunta: «¿cómo podría contestarse la pregunta: “dónde termina el río y dónde comienza el mar"?» ${ }^{73}$

La armonía o disarmonía de las formas es otra manera de reforzar la resonancia interior. Ninguna forma es armónica o disarmónica de por sí, depende de su composición con el resto de formas. De la misma manera que un acorde armónico en Do Mayor puede espantar al oído en Fa menor, una forma puede armonizar o no en un contexto determinado. Hay, sin embargo, formas que tienden a la armonía y cuya resonancia se puede acentuar o debilitar

73 Kandinsky, Punto y línea sobre el plano, p. 80. 

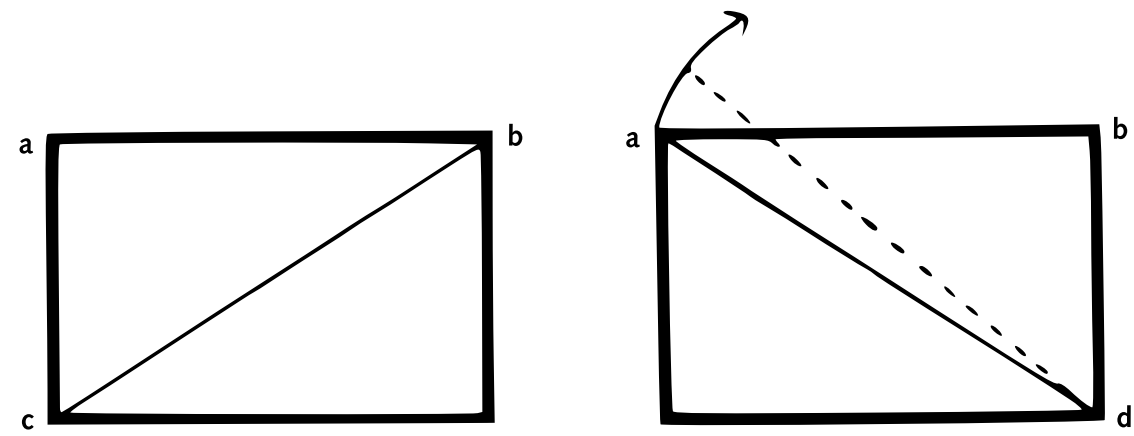

Ilustración 26 Diagonal armónica (izq.) y disarmónica (dcha.)

según el efecto deseado. Un ejemplo de armonía y disarmonía es la diagonal. La inclinación de las rectas determina su resonancia cálida o fría, según se acerque más o menos a la vertical y, siguiendo la relación que establece Kandinsky, su cercanía al amarillo o al azul. Sumando estos factores y considerando su situación en el plano básico, de las dos diagonales posibles una emite una resonancia armónica y la otra no (véase la ilustración 26). La trazada desde la esquina inferior izquierda hasta la superior derecha es la armónica, pues su dibujo divide al plano en dos triángulos uniformes. Uniformes porque el triángulo superior recoge las líneas horizontal superior y vertical izquierda, que resuenan de manera similar (ligereza y soltura). Y el triángulo inferior recoge la horizontal de abajo con la vertical derecha, ambas de resonancia pesada y fuerte tensión.

En cambio, si se traza la diagonal en sentido inverso (esquina inferior derecha a esquina superior izquierda), los triángulos resultantes combinan resonancias opuestas: la liviana horizontal superior con la densa vertical derecha, y la densa horizontal inferior con la liviana vertical izquierda, lo que deja dos triángulos disarmónicos. Además, el punto inferior derecho concentra toda la tensión que proviene de abajo y de la derecha, a lo que se une que es punto de partida (o de llegada) para la diagonal. Esta sobreconcentración convierte al punto en una especie de resorte que, a modo de palanca, desplaza a la diagonal hacia la derecha, como si quisiera transformarla en una línea vertical. La construcción no es estable y por tanto, resuena disarmónica.

El uso de estas diagonales y, con él, el refuerzo armónico o disarmónico de la resonancia, puede presentarse de varias formas: directamente, es decir, empleando una línea recta o curva que ocupe esa parte del plano (como suce- 

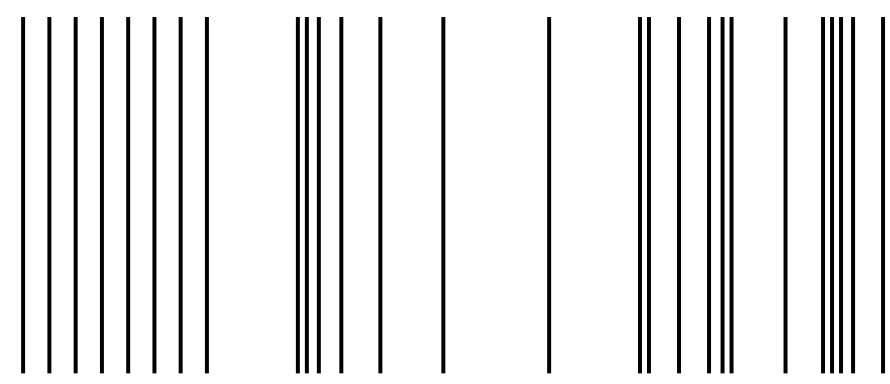

Ilustración 27 Ritmo por repetición de líneas

de en el cuadro Triángulo negro o en Línea transversal, ambos de 1923); o de manera más velada: situando un reguero de puntos, que pueden ser las huellas de un bailarín, de manera diagonal. Un ejemplo es la figura que abre este capítulo (pág. 178). Son nueve puntos que inducen la presencia de la diagonal disarmónica: el peso inferior activa "el resorte" y consigue que los puntos se muevan en dirección ascendente, al igual que lo hace la diagonal disarmónica en el plano (ilustr. 26). Gracias a la colocación disarmónica, Kandinsky consigue que nueve puntos en un plano se muevan, esto es, que resuenen con el movimiento de la danza.

Otra de las técnicas empleadas por Kandinsky para aumentar la expresividad de la resonancia interior es el uso de la repetición y el ritmo. En un poema, como el suyo de «Nadie ha salido de allí. ¿Nadie? Nadie.» (pág. 201), se utiliza la repetición de una palabra para impregnarlo de ritmo. Kandinsky traslada esta ténica a los medios abstractos de la pintura, para conseguir que la resonancia de una composición pictórica también pueda impregnarse de ritmo. La manera más sencilla de lograrlo es la repetición de líneas, como se ve en la ilustración 27. Modificando la distancia entre las líneas se obtienen nuevos
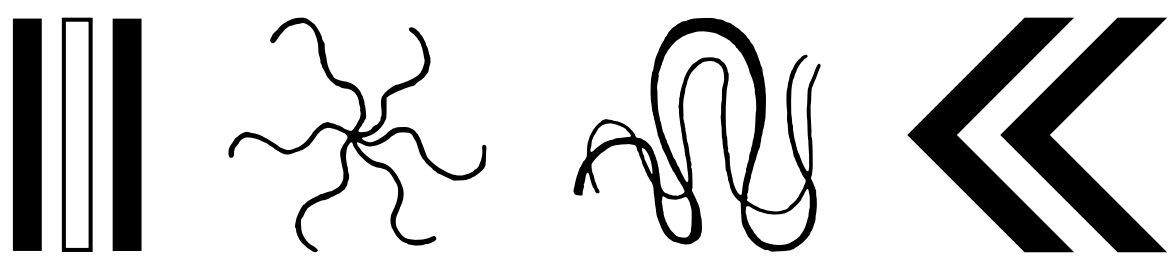

Ilustración 28 Ritmo por combinación de líneas 


\section{El arte abstracto como expresión multisensorial}
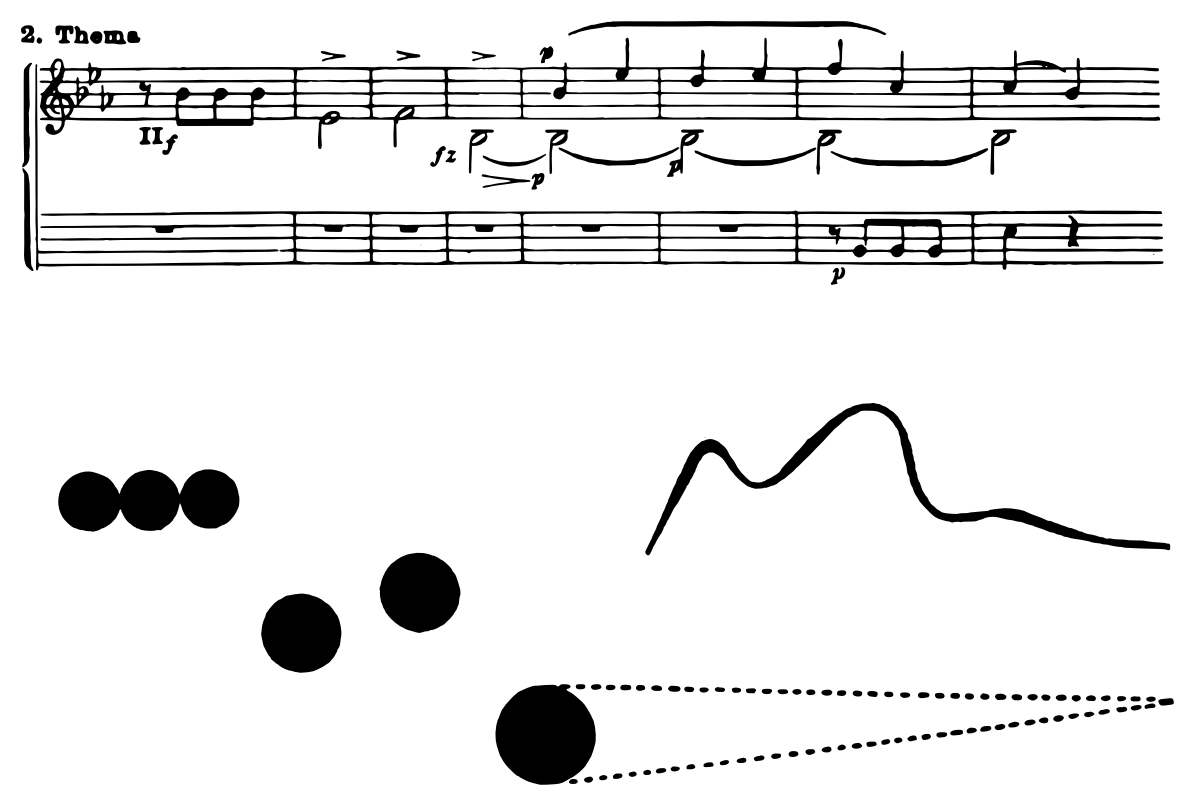

Ilustración 29 Resonancia de puntos y líneas

ritmos. Se puede jugar con distancias de aumento uniforme o desigual y la resonancia varía cuantitativamente. Pero también es posible combinar diferentes tipos de líneas, como en la ilustración 28, y se añaden nuevos patrones de ritmo: la resonancia aumenta cualitativamente. El refuerzo cuantitativo de líneas intensifica el color de la resonancia interior; el cualitativo aumenta el abanico de colores. En los cuadros de Kandinsky es fácil encontrar este tipo de formas, bien como las de las ilustraciones o similares: todas ellas impregnan de ritmo a la composición.

Por último, la sonoridad acústica que Kandinsky otorga a la forma enriquece aún más la expresividad de la resonancia interior. El punto en un cuadro es una nota negra o blanca en una partitura, un sonido que llega directamente al espectador. La línea es longitud sonora, es la melodía que sale de un instrumento. Punto y línea resuenan en el cuadro como lo hacen en una partitura, 
sólo que en el cuadro se le añade la resonancia del color. Un punto rojo oscuro suena a violonchelo en sus tonos medios y una línea violeta resuena como un fagot. Para explicar este tipo de resonancia, Kandinsky también ofrece un ejemplo pictórico. Es la comparación entre los primeros compases de la Quinta Sinfonía de Beethoven y la forma abstracta (puntos y líneas). Aunque Kandinsky la pretende como constatación práctica de cómo la forma es capaz de sonar, a menudo se ha interpretado como mera traducción. En realidad, lo que la ilustración 29 quiere mostrar, es que un punto en un cuadro puede leerse de la misma manera que una nota en un pentagrama, originando un sonido que recibe el espectador.

\subsubsection{La obra pictórica}

Empezando por el "punto", el arquetipo de todas las formas, ese pequeño punto es un ser vivo. Si el artista logra colocarlo adecuadamente en el lienzo, el pequeño punto estará satisfecho y satisfará al contemplador: Dirá: "Sí, ése soy yo; ¿oyes mi diminuto sonido necesario dentro del gran coro de la obra?"

W. KANDINSKY

El arte abstracto posee un lenguaje expresivo y multisensorial gracias a la resonancia interior de la que son capaces sus medios. Cada forma y cada color tienen una resonancia especial, por sí mismas y en combinación con otros medios. La teoría de Kandinsky analiza todas ellas de manera exhaustiva, pero hay una a la que le dedica especial atención. Es la figura del círculo, por ser la figura que más posibilidades le ofrece y por su «fuerte sensación de la fuerza interior».

La resonancia interior del círculo recuerda en cierto modo a la del punto: es una tensión llena de tensiones. Pero el círculo es, además, una forma más completa, porque lleva el movimiento consigo (una línea que ni empieza ni acaba sino que se mueve continuamente) y a la vez es muy estable (la fuerza vuelve donde nace, repartiéndose por toda la figura). Es precisa y variable. Es sonora en sí misma y a la vez puede ser silenciosa. El círculo es una síntesis de contradicciones, es la concentración de mucha expresión, un cúmulo de sentimientos y sensaciones contenidos que pueden explotar en cualquier 


\section{El arte abstracto como expresión multisensorial}

momento. El círculo es silencio pero concentra todo el sonido.

Para Kandinsky, el círculo es la figura central del lenguaje del arte abstracto porque aúna lo romántico y la lírica. ${ }^{74} \mathrm{Y}$ porque, gracias a sus múltiples variaciones, la cantidad de tensiones se hace inagotable. La preferencia de Kandinsky por el círculo se basa en la enérgica sensación que le reporta su fuerza interior: «El motivo (o la razón) por la que en los últimos años, por ejemplo, uso tan frecuente y apasionadamente el círculo (...) [es por] mi fuerte sensación de la fuerza interior del círculo en sus innumerables variaciones; hoy amo el círculo como antes amé, por ejemplo, el caballo... y tal vez ame más el círculo porque en él encuentro más posibilidades interiores» ${ }^{75}$.

El círculo ocupa una posición importante en muchos de los cuadros de Kandinsky, como en Rojo pesado (1924) o en Balanceo (1925), y en algunos es el protagonista indiscutible. Es el caso de Algunos círculos (1926), de Círculos en un círculo (1923) o de Azul (1927).

La obra $A z u l$ presenta un círculo azul colocado en el centro del cuadro, desplazado ligeramente a la parte superior. Abajo, a la derecha, un punto rojo. Son los dos únicos elementos. El fondo es azul pero no uniforme, tampoco lo es el azul del punto. Es un cuadro largo, es decir, más alto que ancho. El círculo concentra toda la tensión y a la vez emana tranquilidad. El azul refleja su pasividad, la densidad. No parece que el círculo vaya a moverse y sin embargo, es inevitable percibir la potencia, la capacidad de movimiento que tiene el círculo. Las tensiones circulares resuenan con fuerza pero el cuadro es silencioso. Está quieto y a la vez en marcha. Es la síntesis de las contradicciones que alberga el círculo.

El resto del cuadro refuerza estas características. Para empezar, el contraste entre el color y el formato del cuadro. El azul es un color que resuena horizontal, frío, profundo y que está asociado a los formatos anchos. Contrasta pues con el cuadro alto, cuya resonancia como plano básico está marcada por dos largas verticales y el color amarillo: vitalidad, calidez, energía. En Azul se combina el formato alto con el azul, las verticales con la pasividad, la calidez con la profundidad. La forma pesada que es el círculo azul se coloca en la parte superior del cuadro, la parte liviana, ligera. El ligero punto rojo ocupa la parte

74 WeIss, Kandinsky in Munich.

75 Plaut, Die Psychologie der produktiven Persönlichkeit, p. 308. Las comillas son originales. 


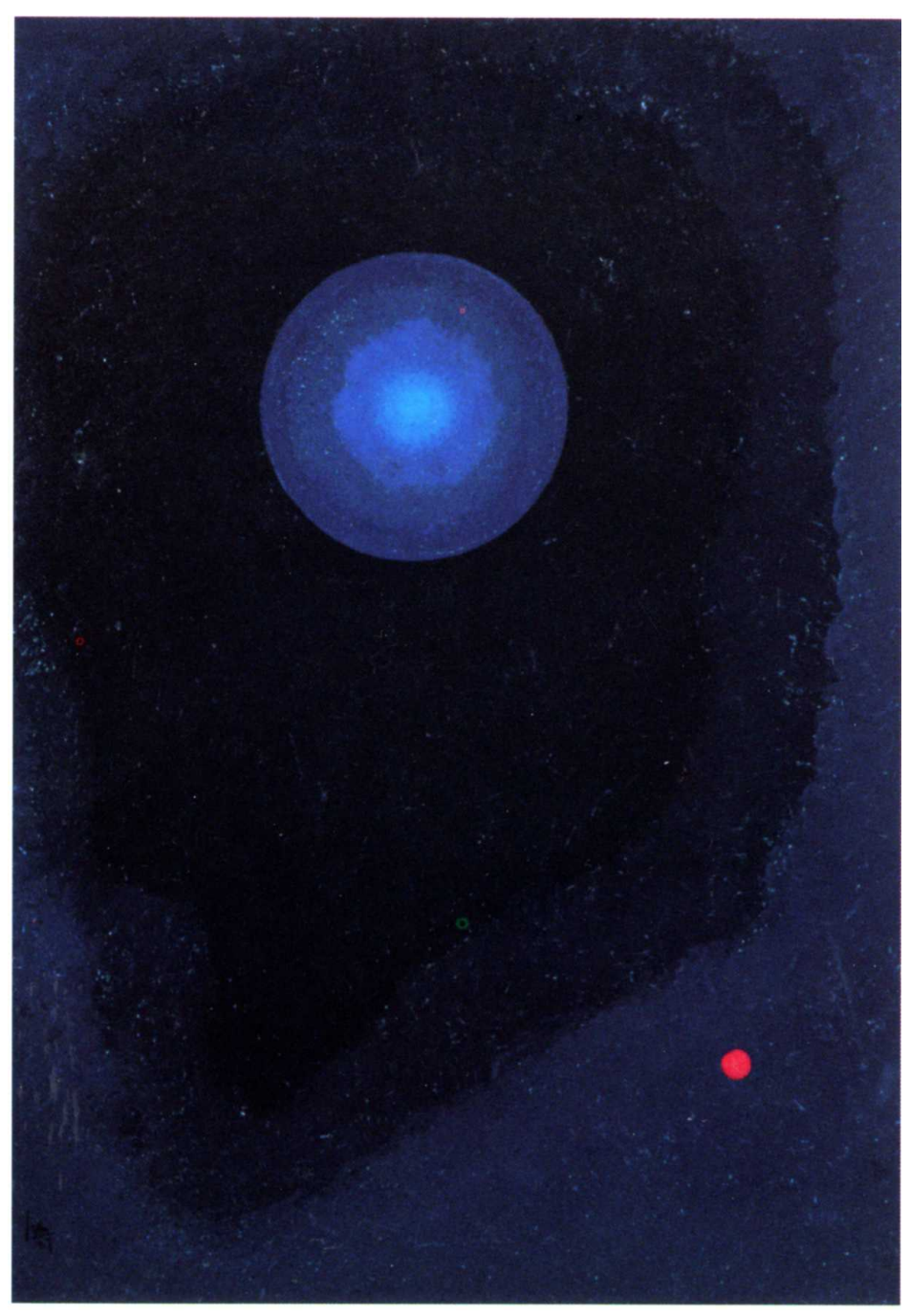

Ilustración 30 Azul, 1927

inferior, la pesada, la densa. Es de nuevo una síntesis de contrarios: refuerza la resonancia del círculo y se ofrece a él como su mejor marco.

Abajo a la derecha, el punto rojo. La tensión concéntrica del punto, su afirmación enérgica y concisa, se combina con el vigor que irradia el rojo y juntos logran que el punto resuene tanto como el círculo, a pesar de la diferencia de tamaño. Es una prueba de que la resonancia interior de una 


\section{El arte abstracto como expresión multisensorial}

forma no es proporcional a su tamaño, sino que se deriva de la combinación de todas sus características. El punto está situado relativamente lejos del círculo y sin embargo está unido a él. Es imposible percibir el cuadro centrándose sólo en el círculo, o sólo en el punto. La resonancia interior que ambos despiden y la tensión que hay entre ambos, los hace inconcebibles el uno sin el otro, como si fueran dos imanes que están a punto de juntarse, pero se quedan ahí, en el "a punto". El punto es reposo, pero su color rojo parece que lo lanza al movimiento; el círculo quiere moverse pero le pesa el azul. Punto y círculo se atraen pero conservan cada uno su posición. Forman una unidad pero siguen siendo dos. He aquí la sinestesia: la composición transmite sensorialmente mucho más que la visión de un círculo y un punto.

El círculo resuena como un violonchelo que está afinando, que se mantiene en la nota La pero se mueve dentro de sus márgenes, como el azul que cubre el cuadro. $\mathrm{Y}$ en un momento resuena una trompeta, un sonido breve pero conciso, sordo, firme pero vital, como el punto rojo. El círculo es como el sabor de una sopa densa y uniforme al que se le da un toque de pimienta. Es un ser que resuena frío con un punto de calor. Hacia el espectador se avalanza el círculo saltando hasta la superficie ideal, se desliga del lienzo y resuena con más fuerza. El punto también salta, pero no a la superficie que ha creado el círculo, sino a una intermedia. El cuadro se convierte en un pequeño acordeón desde el lienzo al espectador, con tres superficies (lienzo, punto, círculo) que le hacen móvil y temporal. Los elementos del cuadro flotan y su resonancia adquiere temporalidad: suenan, están sonando.

$A z u l$ es uno de los cuadros donde mejor se aprecia la teoría kandinskyana. Por la unión de contrastes que refleja la síntesis; por la fuerte resonancia interior que tienen el círculo y el punto; porque pone de manifiesto que forma y color son suficientes para dotar de contenido a una obra, sin necesidad de objeto; y porque la aparente sencillez del cuadro (sólo un círculo y un punto) facilita su percepción multisensorial y su comprensión téorica, sin miedo a perderse en un mar de líneas, puntos y colores. El cuadro Azul logra que el alma del espectador vibre y se vea envuelto en un mundo de resonancias que no sólo son visuales. La necesidad interior ha encontrado una apariencia externa adecuada que le permite resonar en toda su amplitud. Las sensaciones del artista llegan hasta el espectador: un hombre se comunica con otro hombre a través de imágenes que no sólo se ven, sino que resuenan. Una forma más completa de comunicación. Es la teoría de Kandinsky llevada a la práctica. 


\section{El arte abstracto como experiencia espiritual}

Kandinsky saw the elimination of representationalism as a way of expressing his rejection of materialistic values.

R. C. WASHTON-LONG

La presencia del mundo espiritual en el arte de Kandinsky es evidente, especialmente desde que titulara una de sus obras más importantes utilizando ambos términos: De lo "espiritual" en el "arte". Sin embargo, los cómos y porqués de esa presencia son un tema muy discutido en la literatura secundaria. $\mathrm{El}$ ambiente de rechazo al materialismo que respira la época deja su poso en Kandinsky, así como las teorías teosóficas y antroposóficas del momento de las que se habló en el capítulo 2. Es precisamente la relación y posible influencia de Rudolf Steiner en Kandinsky lo que centra la mayor parte de la controversia académica. El primer apartado (6.1) expone esta situación y presenta las posibles razones de la controversia, sin entrar en comparaciones detalladas entre Kandinsky y Steiner porque ya existe literatura específica al respecto (Ringbom, 1970). La creencia y teoría de Kandinsky de que el arte tiene un valor espiritual cierra el apartado con muchas citas propias del autor, para dejar poco espacio a interpretaciones confusas.

El segundo apartado (6.2) se centra en la capacidad del arte para transmitir el contenido espiritual del artista y llevarlo hasta el alma del espectador. Este tema, previamente introducido en el capítulo 3, se desglosa ahora en dos partes: cómo sucede la transmisión de ese contenido y qué tipo de lenguaje es necesario para lograrlo.

Por último, el apartado 6.3 ofrece un estudio de la obra pictórica a la luz de la teoría expuesta. Se retoma el uso de la figura del círculo, ahora como elemento cósmico, y la del caballo, esta vez con atención a la figura del jinete, la encarnación de San Jorge. 
6 El arte abstracto como experiencia espiritual

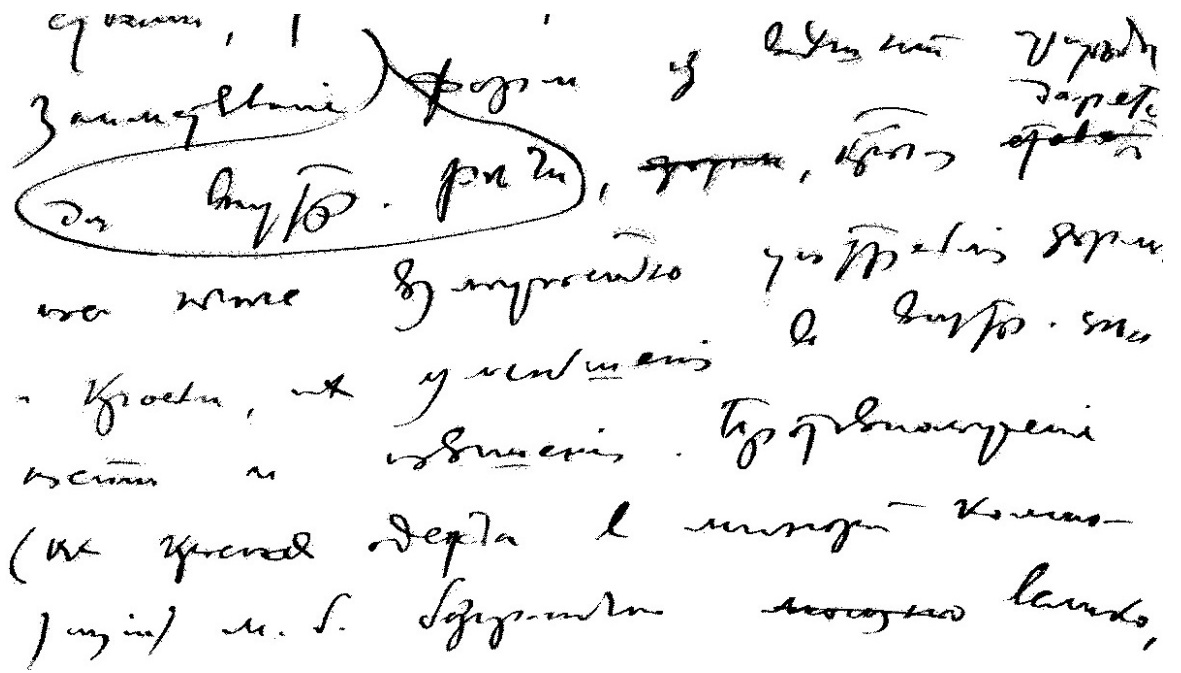

Ilustración 31 Manuscrito de De lo espiritual en el arte 


\subsection{La búsqueda de lo espiritual}

\subsubsection{El rechazo al materialismo}

Además de la terrible crisis económica, existe hoy una crisis mucho más terrible: la crisis del espíritu.

W. KANDINSKY

A finales del siglo XIX, en Europa empieza a sobrevolar un cierto rechazo al materialismo y un renacer de las actitudes románticas, que se unen al trascendentalismo alemán de la época. Los descubrimientos que aporta la ciencia a principios del siglo $\mathrm{xx}$, con resultados tan novísimos como por entonces incomprensibles (la división del átomo, la teoría de los quantos, etc.) fortalece la creencia de que las explicaciones positivistas de las ciencias empíricas son incapaces de esclarecer las causas últimas de las cosas. Se origina entonces una reacción natural al racionalismo y cienticifismo que, a su vez, desencadena un auge de las teorías idealistas, espiritualistas y teosóficas.

El rechazo de la vía racional y la búsqueda de un nuevo camino espiritual promueven la creencia en intelectuales y artistas de que está sobreviniendo un gran cambio y de que es hora de una nueva época. En las obras expresionistas, por ejemplo, un halo de religiosidad y un cierto misticismo se hacen presentes, y el antimaterialismo de los simbolistas rusos también es notable. En la misma Bauhaus se diseminan las teorías antroposóficas de Rudolf Steiner entre alumnos y profesores, algunos de ellos buscan incluso experiencias místicas en claustros y monasterios católicos al sur de Alemania. Más de un historiador apunta que el mismo Johannes Itten, embebido en el mazdeísmo, llega a formar una mini secta dentro de la Bauhaus. ${ }^{1}$

En la Rusia ortodoxa y conservadora comienza a ponerse en entredicho la postura sobre determinados aspectos religiosos (la libertad o la tolerancia, por ejemplo), discusiones que traen a primer plano el tema de lo espiritual. Un grupo de estudiosos rusos, entre los que se encuentran Bulgalow, Solowjow o

1 Véase, por ejemplo, Schreyer, Erinnerungen an Sturm und Bauhaus, p. 197 u Overy, Kandinsky, p. 32. 


\section{El arte abstracto como experiencia espiritual}

Belyj, aprovechan este debate religioso para hablar de un «renacer espiritual» y con él, del «renacer de una nueva cultura» que permita a Rusia encontrar una identidad propia, más allá del pensamiento moderno occidental. En este renacer cultural va incluido el renacimiento del arte, en la idea de que el arte es una de las mejores herramientas para abrir el camino de lo espiritual. El arte es entendido como la puerta que conduce al hombre hacia el mundo suprasensorial, motivo por el que debe encabezar el movimiento del renacer cultural. Los tres estudiosos nombrados no son sólo maestros de Kandinsky durante su etapa de jurista en la Universidad de Moscú; Bulgalow es, además, el marido de una de sus primas, lo que facilita el contacto y el debate religioso-intelectual entre ellos, también durante los años en los que Kandinsky ya no vive en Rusia sino en Múnich como pintor. ${ }^{2}$

Kandinsky se trae de Rusia las reflexiones culturales y espirituales de sus maestros y las deliberaciones sobre el papel del arte en ese nuevo renacer. En Múnich, esas ideas tampoco suenan a nuevas. La relación entre Alemania y Rusia durante las primeras décadas del siglo xx es manifiesta. Marc Chagall cuenta a Roditi que en el barrio bávaro de Berlín «había tantos samovares y adeptos a la teosofía o condesas admiradoras de Tolstoy como antiguamente en Moscú» ${ }^{3}$, lo que da una idea clara de la situación de la época. En Múnich, las escuelas de pintura están llenas de artistas rusos (Kandinsky y Jawlensky entre ellos), la mayoría buscando un camino renovador en el arte. De las escuelas de pintura, la relación salta fácilmente a otras áreas: exposiciones, revistas literarias o encuentros germano-rusos, como refleja este comentario del propio Kandinsky: «En los últimos años de antes de la guerra, esos representantes de la joven Alemania no oficial, a quienes yo antes no conocía, fueron a visitarme cada vez con mayor frecuencia a mi casa de Munich [sic]. Manifestaban no solamente un vivo interés por la esencia de la vida rusa, sino que además abrigaban una fe firme en "la salvación venida del Este". Nos comprendíamos claramente los unos a los otros y experimentábamos el vivo sentimiento de residir en una misma y única esfera espiritual $»^{4}$.

\footnotetext{
2 Sobre la situación del movimiento espiritual en Rusia y los trabajos de Bulgalow, Solowjow o Belyj se puede consultar el artículo de Noemi Smolik Auferstehung und kulturelle Erneuerung, pp. 137-156 de BeHr, Kandinsky. Malerei 1908-1921.

3 Roditi, Dialoge über Kunst, p. 51.

4 Kandinsky, Mirada retrospectiva, p. 247. El fragmento pertence a la versión rusa de Mirada retrospectiva. Como la edición española es traducción de la versión alemana, el fragmento se
} 
En este ambiente de renovación espiritual tan alemana como rusa, los tintes religiosos en los grupos de artistas comienzan a ser frecuentes. Franz Marc escribe en un texto que titula Religiöses que «no hay gran arte ni arte puro sin religión; el arte ha sido más puro, más real, más artístico cuanto más religiosa era la época, y menos artístico cuanta menos religiosidad» ${ }^{5}$. Y también que, en la nueva época espiritual que comienza más o menos con el siglo, «los artistas deben ser sus profetas» ${ }^{6}$. Idea similar a la compartida por Kandinsky y sus maestros rusos de que el arte debe encabezar el movimiento espiritual.

A la sensación de que está llegando una nueva época, más espiritual, se suma el desencanto con las doctrinas de la religión tradicional y con la aparente incapacidad de la ciencia para dar respuestas seguras. Este comentario de Kandinsky resume bien la idea: “¿Acaso estamos en vísperas del fracaso de los métodos puramente "positivos"? ¿No se evidencia la necesidad de complementarlos con métodos desconocidos (u olvidados), con métodos que apelen al "subconsciente", al "sentimiento", y que frecuentemente se llaman "místi$\cos$ "?» ${ }^{7}$ Ante esta situación, no es de extrañar que muchos de ellos aceptan con agrado las teorías de Madame Blavatsky o de Rudolf Steiner, que desde la Teosofía y Antroposofía (respectivamente) ${ }^{8}$ ofrecen los misterios de la experiencia religiosa desde una visión pseudocientífica, pseudofilosófica y pseudoestética. ${ }^{9}$ Steiner habla de la Antroposofía como la «verdadera ciencia del espíritu» o la ciencia que estudia el mundo espiritual, pero, gracias a su formación filosófica, le añade un cierto componente académico que es bienvenido. La Teosofía también aúna, de algún modo, la relación entre Rusia y Alemania. Blavatsky es rusa, y Steiner un alemán que no oculta su simpatía por el pueblo ruso ni la confianza depositada en él, que se aprecia cuando afirma que «[el pueblo ruso] es el pueblo cristiano dentro de la civilización europea» ${ }^{10}$.

encuentra añadido en el apéndice, nota 224.

5 LANkHEIT, Schriften, p. 111.

6 Citado en Brinkmann, Wassily Kandinski als Dichter, p. 105.

7 KANDINSKY, Escritos sobre arte y artistas, p. 224.

8 El inicio de estas teorías y la diferencia entre Teosofía y Antroposofía se explica en el apartado 2.4.2.

9 WeIss, Kandinsky in Munich, p. 6. 


\section{El arte abstracto como experiencia espiritual}

Las teorías teo-antroposóficas proclaman la llegada inminente de una gran época espiritual, una época que sabe abordar la desconfianza en la ciencia y responder a las necesidades humanas desde un punto de vista artístico. Kandinsky no sólo está algo desencantado con la ciencia ${ }^{11}$, también cuenta con el trasfondo espiritual del movimiento ruso y además está convencido de que el arte es quien tiene que dar respuestas y confianza al hombre ${ }^{12}$. Kandinsky encuentra en la Antroposofía de Steiner un panorama que encaja muy bien con el suyo propio: la unión de lo ruso y lo alemán, la importancia del arte para hacer frente al desafío espiritual, la búsqueda de nuevas formas de expresión no necesariamente figurativas. Para Kandinsky, las doctrinas teosóficas y su claro rechazo al materialismo son un buen escenario para exponer un nuevo lenguaje artístico, un lenguaje que, sin representación figurativa, intenta transmitir un contenido interno y no material.

\subsubsection{La controversia sobre la Antroposofía}

La relación entre Kandinsky y las teorías antroposóficas es clara y perceptible y no hay investigador que la niegue. Sin embargo, la cantidad y calidad de la influencia de esas teorías en Kandinsky, es decir, cuánto, cómo y hasta qué punto la Antroposofía influye directamente en el nacimiento del arte abstracto es un tema muy discutido. Temas como la musicalidad del lenguaje o la síntesis de las artes pueden ser más o menos subjetivos y/u ortodoxos, y curiosamente los críticos se limitan a negarlos o a secundarlos, sin mayor interés que el de exponer cada cual su teoría. Sin embargo, cuando el tema de la espiritualidad, de la religión, de la antroposofía (a veces por separado, a veces tratado como uno solo) sale a colación, los autores parecen estar obligados a puntualizar con una retahíla de argumentos, justificaciones, peros y notas al pie. Por qué el tema es algo tan espinoso quizá puede entenderse por el carácter trascendente del mismo, tema en el que incluso los filósofos caminan con pies de plomo. Por qué ha surgido esta controversia respecto al

10 Steiner lo pronuncia en una de las conferencias que imparte en 1918 en Dornach. Se recoge en von SKerst, Altrussische Kulturstätten, p. 236.

11 «...la división del átomo. (...) Me parecía que la ciencia había sido aniquilada»

12 En palabras de Nina Kandinsky: «Kandinsky veía en el arte una alternativa que no estaba amenazada por la descomposición del mundo». 
tema, puede tratar de explicarse echando un vistazo a los acontecimientos.

En primer lugar, Kandinsky usa de manera frecuente las palabras "alma” (Seele, en alemán) y "espíritu" (Geist). Lo emplea tanto en los textos como en las cartas como en el título de su primer libro, De lo espiritual en el arte. Pero exactamente qué quiere decir con estos términos, no está nada claro. Kandinsky no escribe con la prolijidad de un buen filósofo ni define previamente el vocabulario con el que escribe. Tampoco hay que olvidar que Kandinsky escribe mayoritariamente en alemán, lengua que domina pero que no es su lengua materna. Hay quien señala ${ }^{13}$ que espíritu o alma son una traducción aproximada de la palabra rusa $d u c h$, un concepto con cariz algo más religioso que el de la alemana Geist (espíritu) pero cuyo sentido es más débil que el de Seele (alma), pudiendo significar en ocasiones simplemente el "yo". En lo que casi todos los críticos e investigadores coinciden es que, a menudo, la palabra "espíritu” y la palabra "alma” las usa casi como sinónimas, y con ellas quiere apelar a la dimensión no material del hombre (la dimensión interna, etérea, no corporal) sin entrar en distinciones ni connotaciones metafísicas. "Espiritual" es, para Kandinsky, una manera de designar lo no material, lo que el individuo tiene dentro de sí y le comunica con lo trascendente. Espiritual puede ser la necesidad interior del artista, por ejemplo, o también la sonoridad del círculo, porque le acerca a la dimensión cósmica.

La religiosidad de Kandinsky tampoco está muy clara. Sí que era creyente y que fue criado en el cristianismo ortodoxo, pero no su grado de afiliación religiosa ni cómo de determinante fue para el nacimiento de su arte. Dirk Heißerer ${ }^{14}$ le adjudica el mismo énfasis religioso de Franz Marc, bávaro de fuertes creencias cristianas. Paul V. Vitz incluso afirma que Kandinsky «fue durante toda su vida un cristiano ortodoxo de la variante mística y tolstiana» ${ }^{15}$. Paul Overy ${ }^{16}$ señala que conservó la fe hasta el final de sus días, a pesar de un período de alejamiento en su juventud ${ }^{17}$ y una suavización de creencias a medida que envejecía. Kandinsky nunca escribe claramente al respecto, por lo

13 Jelena Hahl-Koch (HaHL-Koch, Kandinsky, p. 173) o Jean-Paul Bouillon (Kandinsky, Mirada retrospectiva, p. 57), por ejemplo.

14 Heisserer, Wo die Geister wandern, p. 186.

15 Vitz y Glimcher, Modern Art and Modern Science, p. 99.

16 Overy, Kandinsky, p. 29.

17 El propio Kandinsky escribe sobre esta fase de alejamiento en Mirada retrospectiva, p. 121. 


\section{El arte abstracto como experiencia espiritual}

que abundan las conjeturas o las referencias indirectas, como las de sus mujeres o la de Sadler. Michael Sadler, padre del Sadler que tradujo por primera vez De lo espiritual en el arte al inglés, visita a Kandinsky en su casa de Murnau (h. 1910), llena de objetos y pintura religiosa, y relata el encuentro en una carta dirigida a su mujer. En ella se lee el comentario de que «[Kandinsky] tenía la tendencia (pero no inoportunamente) de hablar sobre temas religiosos y estaba muy interesado en libros místicos y en la vida de los santos. Había tenido experiencias extrañas de curación a través de la fe» ${ }^{18}$. Heribert Brinkmann recoge en su tesis doctoral que Kandinsky rezaba todas las noches (también lo menciona Overy) y que durante su estancia en la Bauhaus, acudió a misa todos los Domingos de Resurrección.

A estos comentarios sobre la religiosidad de Kandinsky se unen los paralelismos entre la teoría del lenguaje abstracto que elabora Kandinsky y la teoría antroposófica de Rudolf Steiner. Además de la creencia en la llegada de una nueva época espiritual, Steiner y Kandinsky comparten referencias a la teoría del color de Goethe o a la representación no figurativa de un contenido abstracto o espiritual. En la literatura ${ }^{19}$ se lee que Kandinsky asiste a las conferencias de Steiner en Múnich y en Berlín y que entre sus alumnas se cuentan adeptas y miembros de la Antroposofía: Emmy Dresler (también amiga íntima de Gabriele Münter), Lisa Epstein, Olga Meerson o Maria Strakosch-Giesler, cuyo marido llega a ser secretario personal de Rudolf Steiner. Es precisamente a través de él, Alexander Strakosch, como Gabriele Münter y/o Kandinsky consiguen textos y revistas antroposóficas que se han encontrado en su biblioteca de Murnau.

Las anotaciones a mano en estas revistas son, precisamente, las que introducen un punto de inflexión entre los investigadores, por evidenciar la relación -más directa de lo que hasta entonces se creía- de Kandinsky con la Antroposofía. Sixten Ringbom publica un libro en 1970 en el que compara el contenido de las teorías de Steiner con los textos y pinturas de Kandinsky, estableciendo un paralelismo directo. El mismo Ringbom es consciente de la polémica que puede crear establecer una fuente de influencia para el arte

\footnotetext{
18 El episodio y parte de la carta se encuentra narrado en Overy, Kandinsky, p. 20.

19 Véase Kleine, Gabriele Münter und Wassily Kandinsky, p. 699, Heisserer, Wo die Geister wandern, p. 194, HaHL-Koch, Kandinsky, p. 177 o Brinkmann, Wassily Kandinski als Dichter, p. 126, por citar sólo unos ejemplos.
} 
abstracto tan nueva como trascendente, pero se justifica arguyendo que las teorías reduccionistas sobre la abstracción (el lenguaje abstracto como pura reducción fría y calculada de las formas) que se habían dado hasta el momento no son suficientes para explicar el surgimiento del arte abstracto. Las palabras de Ringbom son las siguientes: «como la pintura abstracta no se explica por sí misma, tenemos que volcarnos en su teoría para poder entender su surgimiento ${ }^{20}$. Esta frase, que en cualquier contexto tendría sentido y buenas intenciones, significa para Ringbom ahondar en la teoría antroposófica para encontrar el origen de las ideas de Kandinsky.

Al libro de Ringbom le siguen adeptos confesos que publican libros similares y también detractores enfurecidos que se indignan al pensar que el arte abstracto pueda reducirse a una interpretación meramente espiritu-religiosa o que consideran un sacrilegio que tal tipo de explicación tenga algo que ver con el arte abstracto, tan frío, materialista y alejado de la divinidad. Entre los primeros, los adeptos, se encuentran Rose Carol Washton-Long, Paul Fechter o Claudia Emmert, que cree que las ideas antroposóficas bastan para explicar la obra de Kandinsky, especialmente la parte lírica y teatral. ${ }^{21}$ También hay un tercer grupo que no obvia la relación entre Kandinsky y la Antroposofía, pero que la maneja como una influencia más. De este ámbito surgen voces que intentan evitar que la explicación de Ringbom se asiente dogmáticamente como la única y verdadera.

Jelena Hahl-Koch comienza la contienda investigando los ejemplares conservados de la biblioteca de Murnau y llega a la conclusión de que las obras antroposóficas no pertenecieron a Kandinsky sino a Gabriele Münter, la verdadera interesada en esas cuestiones. ${ }^{22}$ Con esto elimina la influencia directa de la Antroposofía en Kandinsky de un plumazo. Pero la premisa de la argumentación de Hahl-Koch tampoco está clara. Porque cuando Kandinsky tiene que abandonar Múnich al estallido de la Guerra, casi todas sus pertenencias se quedan en la casa de Murnau: no sólo cuadros y pinturas, también libros. Los libros antroposóficos podían ser tanto de Münter como de Kandinsky. ${ }^{23}$

20 Ringbom, The Sounding Cosmos, p. 15.

21 Washton-Long, Kandinsky. The Development of an Abstract Style; Fechter, Der Expressionismus; y EMmert, Bühnenkompositionen und Gedichte von Wassily Kandinsky.

22 HaHL-Koch, Kandinsky, pp. 177, 190 y 406.

23 Evidentemente, aquí surge una pregunta obvia y clave. ¿Es imposible analizar caligráficamen- 


\section{El arte abstracto como experiencia espiritual}

En la misma dirección, la de intentar parar la avalancha antroposófica, hay que entender el comentario que le hace Gabriele Münter a Roditi en los años 50 , indicando que «Kandinsky no era, en absoluto, una persona religiosa» ${ }^{24}$, a pesar de haber convivido con él durante años en una casa llena de símbolos religiosos, cuadros con temática religiosa pintados por Kandinsky o haber compartido lecturas y charlas antroposóficas con él, como se desprende de la correspondencia ${ }^{25}$ entre ambos. El mismo Kandinsky no oculta su interés por las ideas de Steiner cuando se refiere largamente a él en el tercer capítulo de su libro De lo espiritual en el arte. La negativa de Münter hay que entenderla como reacción al libro de Ringbom y a las tesis que reducían la abstracción a la Antroposofía. Parece que, si se niega la religiosidad de Kandinsky, ya no hay opción a la Antroposofía, ni siquiera a una mínima influencia. En realidad, el comentario que la segunda mujer, Nina Kandinsky, escribe en su libro es algo más acertado y explícito: «es absurdo afirmar que Kandinsky fue antropósofo. Él se mostraba receptivo a la Antroposofía, pero esa cosmovisión nunca la hizo propia. (...) En su clase de pintura en Múnich había una alumna que pertenecía a la Sociedad Teosófica y Rudolf Steiner una vez le invitó a formar parte de su organización. Kandinsky rechazó» ${ }^{26}$. Nina Kandinsky niega la pertenencia directa de Kandinsky a asociaciones antroposóficas, pero no niega la relación, ni que Kandinsky estuviera abierto a sus teorías.

Con el libro de Ringbom y los comentarios de Jelena Hahl-Koch, Gabriele Münter y Nina Kandinsky se desata la controversia. Y, a partir de ahí, el tema aparece en el resto de la bibliografía: bien a vuela pluma (en los libros superficiales y/o en quien no quiere entrar en la disputa) o bien lleno de justificaciones, peros y notas al pie, como ya se ha indicado. Lo cierto es que el rechazo tan enfurecido a la relación entre Kandinsky y la Antroposofía parece deberse a otras causas, quizá por ser un tema que toca la trascendencia. Porque el mismo Ringbom no afirma que Kandinsky fuera miembro de la Sociedad Teosófica o que fuera uno de esos seguidores acérrimos poco críticos, como

te las anotaciones al margen para saber, al menos, si las escribió Kandinsky o Münter? No he encontrado información al respecto y, aun habiéndolo intentado, me ha sido imposible acceder a los originales.

24 Roditi, Dialoge über Kunst, p. 217. La cursiva es añadida.

25 Por ejemplo, la de noviembre de 1910.

26 KANDINSKY, Kandinsky und ich, p. 235. 
se lee en su texto: «es verdaderamente erróneo decir que Kandinsky era un teosofista en el sentido de miembro de la Sociedad o un devoto sin sentido crítico». Ringbom destaca de Kandinsky su «simpatía con los objetivos y métodos del movimiento a pesar de su punto de vista más crítico en otros aspectos de él» y establece un paralelismo entre ambas teorías. ${ }^{27}$ Es cierto que en la comparación apenas considera otros aspectos, pero también que suaviza la fuerza de la influencia: «el problema de la influecia teosófica es muy complejo y al acercarnos a él deberíamos tener siempre presente que las influencias directas son muy raras en la obra escrita o artística de Kandinsky» ${ }^{28}$. Sin entrar de lleno en la controversia, porque la intención aquí no es ni alimentarla ni resolverla, no se puede obviar la influencia de la Antroposofía en la obra teórica y pictórica de Kandinsky, ni tampoco las similitudes manifiestas entre ambos. $^{29}$

\subsubsection{El arte como salvación}

Quisiera añadir que, según mi opinión, nos acercamos cada vez más a la época de la composición; que pronto el pintor estará orgulloso de poder declarar composicionales sus obras; que ya estamos en el tiempo de la creación útil y, finalmente, que este espíritu de la pintura está en relación orgánica directa con la ya iniciada construcción del nuevo reino espiritual, ya que este espíritu es el alma de la época de la gran espiritualidad.

W. KANDINSKY

El nacimiento del arte abstracto coincide con esa época de rechazo al materialismo que se vive en Alemania y Rusia a principios del siglo xx. La Teosofía promueve la llegada de una nueva época espiritual que combata el materialismo y que devuelva al hombre su verdadero origen y razón de ser, el espíritu. Los artistas e intelectuales del momento no sólo reciben con cierto agrado ese

27 Ambas citas se encuentran en Ringbom, The Sounding Cosmos, p. 18.

28 Ringbom, The Sounding Cosmos, p. 85.

29 Para un estudio profundo y concreto sobre Kandinsky y la Antroposofía, véase RingBom, The Sounding Cosmos. 


\section{El arte abstracto como experiencia espiritual}

postulado, a menudo lo fomentan con nuevas teorías. Aparecen explicaciones espirituales para problemas que hasta entonces eran exclusivos del discurso racional, comienza la revalorización de algunas esferas del conocimiento en detrimento de la de la ciencia y el arte explora nuevos caminos de expresión.

En Kandinsky se conjugan estos mismos factores. Su confianza en la ciencia ha mermado: «illegará la ciencia a resolver estos enigmas? (...) Y si llega, ¿podremos fiarnos de su respuesta? ${ }^{30} \mathrm{La}$ esperanza en la llegada de una nueva época espiritual también está presente: «estamos a las puertas de una de las mayores épocas que el hombre ha presenciado, la época de la gran espirituali$\mathrm{dad} »^{31}$. Y la idea de que el arte tiene el papel protagonista en el movimiento espiritual, que hereda de sus compatriotas rusos, completa los síntomas.

El problema, según Kandinsky, es que el arte actual no puede hacerse cargo de la renovación espiritual porque sigue anclado en el materialismo: «el arte, que en estas épocas vive humillado, es utilizado exclusivamente para fines materiales» ${ }^{32}$. La esperanza que Kandinsky tiene depositada en la época espiritual no sólo parte de las creencias personales o de la pérdida de confianza en la ciencia; parte, además, de que la situación artística del momento no lo complace. El arte está sometido a fines puramente materiales, prácticos, en ningún caso estéticos, lo que resalta la apariencia (el cómo) frente al contenido (el qué). El arte materialista tampoco es capaz de expresar sensaciones ni de transmitir un contenido al espectador, con lo que el fin en sí mismo del arte, comunicar, se queda vacío. Para Kandinsky, transmitir un qué, un contenido, es fundamental. Y el arte materialista no lo logra. En De lo espiritual en el arte, Kandinsky esboza el panorama artístico de la época y deja claro, implícitamente, que es necesario un gran cambio:

«Un edificio (...), las paredes de las salas llenas de lienzos (...), lienzos que reproducen (...) flores, figuras sentadas (...), retrato del Consejero $\mathrm{N}$; anochecer; dama en rosa; patos volando; retrato de la baronesa X; gansos volando; dama en blanco, terneras en la sombra con manchas de sol amarillas, retrato de su excelencia el señor Y; dama en verde. Todos estos datos están impresos en un libro

30 Kandinsky, De lo espiritual en el arte, pp. 34-35.

31 Kandinsky y Marc, Der Blaue Reiter, p. 313.

32 Kandinsky, De lo espiritual en el arte, p. 29. La cursiva es original. 
(...) Las personas llevan estos libros en la mano y van de un lienzo a otro, los miran y leen los nombres. Luego se marchan, $\tan$ pobres o tan ricas como entraron. (...)

Los expertos admiran la "factura"33 (así como se admira a un equilibrista), paladean la "pintura" (como se paladea una empanada). Las almas hambrientas se van hambrientas. ${ }^{34}$ »

Un arte que no transmite sensaciones, que deja al espectador tal cual entró y que está sometido a fines materiales, es imposible que encabece ningún cambio, y menos uno de corte espiritual. Kandinsky se propone renovarlo o, más bien, crear un arte nuevo que camine al compás de los nuevos tiempos: un arte que sea «espiritual y [que] por eso contiene el germen del futuro» ${ }^{35}$. Kandinsky lo llama arte concreto, arte real, arte absoluto, arte puro. ${ }^{36}$ Para la pintura prefiere el nombre de "pintura de composición", pero todas las nomenclaturas hacen referencia al mismo objetivo artístico: un arte cuyo contenido espiritual consiga transmitir al espectador el mundo interior del artista.

La renovación del arte y, con ello, la posibilidad de que el arte lidere el nacimiento de una época espiritual, pasa por que logre dos objetivos. El primero es revalorizar la importancia del alma, ya que en toda época espiritual el alma es uno de los protagonistas. El materialismo relega a un segundo plano el papel del alma, confinando al ser humano a una existencia mayoritariamente corpórea. Según Kandinsky, «nuestra alma, que después de un largo periodo materialista se encuentra aún en los comienzos del despertar (...) todavía no ha pasado toda la pesadilla de las ideas materialistas que convirtieron la vida del universo en un penoso juego sin sentido» ${ }^{37}$. Depreciada por el materialis-

33 Factura, según Kandinsky: «tipo de relación exterior de los elementos entre sí y con el plano básico», en Kandinsky, Punto y línea sobre el plano, p. 44.

34 Kandinsky, De lo espiritual en el arte, pp. 23-24. Hoy, unos cien años después de que Kandinsky escribiera este texto, es imposible no esbozar una sonrisa irónica y pensar en cuántas veces se repite actualmente esta misma situación, a menudo incluso con los cuadros de Kandinsky.

35 KANDinsky, De lo espiritual en el arte, p. 22.

36 Para la cuestión de los diferentes nombres que recibió el arte abstracto véase la página 108.

37 Kandinsky, De lo espiritual en el arte, pp. 21-22. 


\section{El arte abstracto como experiencia espiritual}

mo, el alma necesita volver a primer plano. Kandinsky está convencido de que el arte nuevo es capaz de devolverle ese protagonismo, porque «el arte (...) [es] una fuerza útil que sirve al desarrollo y a la sensibilización del alma humana (...). El arte es el lenguaje que habla al alma ${ }^{38}$. La manera de revalorizar el alma es crear un arte cuyo contenido sea puramente interior o espiritual y a su vez, dotarlo de un lenguaje cuyas formas posibiliten esta espiritualidad. Porque «estas formas, cuando son verdaderamente artísticas, cumplen su finalidad y son (...) alimento espiritual, especialmente [en el caso] en el que el espectador encuentra una consonancia con su alma ${ }^{39}$. Es decir: como el arte es el lenguaje que entiende el alma, el arte es capaz de cambiar (mejorar) el estado del alma. Sólo tiene que encontrar las formas pictóricas adecuadas.

El segundo objetivo es conseguir que el espectador se vuelva más receptivo a este tipo de arte. Poco vale que el contenido sea espiritual y el alma se vuelva importante si el espectador no es capaz de recibir las sensaciones que emanan del cuadro. Y eso es precisamente lo que ocurre, según Kandinsky, en la época materialista. Que el espectador, ése que va de un lienzo a otro sin comprender más que el título de la obra, no sabe percibir el contenido del cuadro: «el espectador está demasiado acostumbrado a buscar la coherencia externa de las diversas partes del cuadro. El período materialista ha producido en la vida, y por lo tanto también en el arte, un espectador incapaz de enfrentarse simplemente al cuadro, (...) en el que lo busca todo (imitación de la naturaleza, (...) anatomía, perspectiva, ambiente externo, etc.), todo menos la vida interior del cuadro y su efecto sobre la sensibilidad $»^{40}$. El espectador sigue buscando cómos que se parezcan a la naturaleza, al mundo exterior que conoce. Y se olvida de buscar un qué interior que le pueda producir sensaciones nuevas, encajen o no con el mundo de ahí fuera. Kandinsky quiere re-sensibilizar al espectador a través del arte, capacitarlo para que sienta emociones sutiles, «emociones más matizadas que nuestras palabras no pueden expresar» ${ }^{41}$.

El nuevo estilo artístico que crea Kandinsky supera los principios anquilosados del materialismo, concede al alma la importancia que se merece y

38 Kandinsky, De lo espiritual en el arte, p. 102.

39 Kandinsky, De lo espiritual en el arte, pp. 22-23.

40 Kandinsky, De lo espiritual en el arte, p. 93. Se ha eliminado la cursiva de la palabra cuadro por no aportar, en este caso, significación alguna.

41 Kandinsky, De lo espiritual en el arte, p. 22. 
consigue que la percepción estética del hombre se vuelva sensible a todo tipo de sensaciones. Para Kandinsky, éste es el único arte capaz de liderar la nueva época espiritual. No sólo porque «colabora en la creación de la atmósfera espiritual ${ }^{42}$ acutal, sino porque además es capaz de llevarlo hacia el futuro: es un arte «capaz de evolución (...), no sólo es eco y espejo de él [del periodo espiritual] sino que posee una fuerza profética vivificadora $»^{43}$. Esta capacidad de futuro es la que permite al arte liderar el proceso de espiritualización, no sólo en el panorama artístico sino también en el social.

De la misma manera que Kandinsky espiritualiza el arte -lo hace más humano y le otorga mayor riqueza sensorial-, el arte puro o abstracto, a su vez, es capaz de conseguir el refinamiento espiritual de la sociedad. Que el arte sea capaz de liderar el movimiento espiritual de la sociedad es la idea que Kandinsky comparte con sus maestros rusos. Su aportación personal, y clave, es la de crear el lenguaje artístico concreto, el que supera la época materialista y es capaz de tal refinamiento espiritual.

El proceso de creación del arte abstracto es un proceso de espiritualización. En primer lugar, el artista debe reconocer la necesidad interior; es decir, debe reconocer el espíritu de las cosas, su valor interior. En segundo lugar, tiene que dominar la fuerza expresiva de los medios pictóricos; es decir, tiene que aprender a exteriorizar ese valor o contenido interno. $Y$ en tercer lugar, tiene que deshacerse de las formas figurativas; es decir, tiene que renunciar a lo material. El devenir de la vida espiritual de la sociedad sigue un camino similar, de ahí la posibilidad de que el arte sea su guía.

La vida espiritual, representada por Kandinsky de manera esquemática, ${ }^{44}$ es un triángulo grande que está dividido en tres secciones desiguales. La mayor ocupa la base, la mediana la parte central, y la tercera es la más pequeña, que ocupa el pico más agudo. A medida que la sociedad se despoja de lo material, el triángulo va estilizándose progresivamente. Se desplaza hacia delante, del hoy al mañana. La espiritualidad de la que gozan hoy unos pocos elegidos, los que ocupan la parte superior, la disfrutará mañana la parte baja, la gran masa. Para que el triángulo se mueva hace falta un proceso de espiritualización que, similar al del arte abstracto, consiste en despojarse de lo material (equivalente

42 Kandinsky, De lo espiritual en el arte, p. 101.

43 Kandinsky, De lo espiritual en el arte, p. 25.

44 Kandinsky, De lo espiritual en el arte, pp. 27 y ss. 


\section{El arte abstracto como experiencia espiritual}

a la supresión de lo figurativo), expresar las sensaciones internas (la fuerza de los medios pictóricos) y en reconocer el valor espiritual en las cosas materiales y abstractas (la necesidad interior). La época de la gran espiritualidad llegará cuando el hombre sea capaz de llevar a cabo este refinamiento de lo material a lo espiritual, de lo objetivo a lo subjetivo, de lo figurativo a lo abstracto. El arte abstracto, por seguir un desarrollo similar, puede guiar al hombre en su proceso de espiritualización. Así lo concibe Kandinsky: «mi libro De lo espiritual en el arte y también Der Blaue Reiter [sic] tenían ante todo la finalidad de despertar esa capacidad (...) de vivir lo espiritual en las cosas materiales y abstractas. El deseo de hacer nacer esa capacidad, fuente de tan alta dicha, en los hombres que todavía no la tenían constituía el objeto esencial de las dos publicaciones ${ }^{45}$.

En el vértice superior del triángulo se sitúa a menudo un único hombre que ha alcanzado un nivel alto de espiritualidad y que sin embargo, o por ello, es incomprendido por la masa. Es un hombre que ve más allá, un profeta para su tiempo. Escribe Kandinsky: «entonces surge inevitablemente un hombre en todo semejante a nosotros, pero que lleva dentro una fuerza "visionaria" y misteriosa. Él ve y enseña. A veces quisiera liberarse de ese don superior que a menudo es una pesada cruz. Pero no puede. Acompañado de burlas y odios, arrastra hacia adelante y cuesta arriba el pesado y obstinado carro de la Humanidad que no se atasca entre las piedras». ${ }^{46}$ En el arte, este hombre es el artista que consigue expresar la necesidad interior a través de los medios pictóricos y sin recurrir a la forma figurativa. Para comprender su arte, el "triángulo social" necesita más tiempo, hasta que las capas inferiores se muevan lo suficiente y alcancen ese grado de espiritualidad.

El profeta que ve más allá, el hombre incomprendido, el guía espiritual. La contemplación gozosa de la realidad que en el fondo es una tristeza interior, generada por la incomprensión ajena. El planteamiento no sólo recuerda a Platón y a su caverna. También a la doctrina cristiana. Las similitudes son obvias y ni al propio Kandinsky se le pasan por alto. Ya en Mirada retrospectiva, ese libro semiautobiográfico que escribe en 1913, apenas después de publicar De lo espiritual en el arte y con él gran parte de su teoría anímico-espiritual,

45 Kandinsky, Mirada retrospectiva, p. 125.

46 Kandinsky, De lo espiritual en el arte, p. 25. 
Kandinsky reflexiona sobre cuál es la verdadera exigencia del arte y qué es lo que ésta implica: «una exigencia única: la exigencia de la vida interior de la obra. Advertí entonces con gran sorpresa que esa exigencia creció a partir de lo que Jesucristo postulaba como fundamento de la calificación moral. Advertí que esa concepción del arte es cristiana y que al propio tiempo lleva en sí los elementos indispensables para acoger la "tercera” Revelación, la Revelación del Espíritu» ${ }^{47}$. Años más tarde, siendo profesor de la Bauhaus, su idea no parece haber cambiado mucho. En una conversación con Lothar Schreyer que éste recoge en un libro posterior, Kandinsky no tiene reparo en decirle que «no se asuste si ahora le digo que, especialmente desde que pinto sin objeto y más cuanto más mayor me hago, entiendo mis propios cuadros como cuadros cristianos» ${ }^{48}$. Y acto seguido añade un comentario -juego de palabras incluido- que quita un poco de seriedad al tema y relaja la importancia de "lo cristiano", pero sin llegar a negar su existencia: "Los papas de todo el mundo no estarán de acuerdo en eso. Los papas (Popen) de todo el mundo me considerarán un espantajo (Popanz)».

El profeta que guía al arte, y el arte que guía a la sociedad. En esta idea no sólo se ve a sus maestros rusos, también a la Antroposofía de Steiner. Es posible que unos la tomaran de los otros o viceversa. En cualquier caso, el arte de Kandinsky pone el acento en la vida interior del hombre, en su alma. Y es capaz de guiar a la sociedad porque tiene un halo de superioridad. Según Steiner, el arte es una necesidad vital para el hombre y está destinado al sentimiento o elemento anímico. Las artes fueron originadas en la percepción suprasensible y recibidas por los hombres como regalo de los mundos superiores. Si las artes «no son alimentadas constantemente por esta fuente [suprasensible], se tornarán estériles e incapaces de sostener la vida anímica del hombre». El arte es más que necesario para guiar a la sociedad porque «sin el arte (...) el conocimiento en sí se ve condenado a una helada esterilidad». Steiner y Kandinsky también coinciden en señalar que el origen de los males es el materialismo y que el arte es la única esperanza de salvación: «... vida que, en nuestros días, se encuentra en constante amenaza por parte del intelectualismo, y que solamente puede ser nutrida por el arte». ${ }^{49}$

47 Kandinsky, Mirada retrospectiva, p. 123.

48 Schreyer, Erinnerungen an Sturm und Bauhaus, pp. 232-233. 


\section{El arte abstracto como experiencia espiritual}

Al margen de las similitudes, lo que más destaca en la teoría de Kandinsky es que, a principios del siglo xx, coloca al (buen) artista no sólo como profeta, no sólo como salvador del mundo espiritual, sino como auténtico creador. Y no sólo como auténtico creador de una obra de arte, sino como creador de un mundo nuevo. Ése es el gran salto. La espiritualización llega a tal punto que la creación de la obra es la creación del mundo. No "es equiparada”, no "es comparada". La creación de la obra "es" la creación del mundo (Werkschöpfung ist Weltschöpfung).

Decir que Kandinskyk renuncia al mundo figurativo y con ello al mundo natural, material, exterior, sería quedarse cortos. Kandinsky renuncia directamente a expresar el mundo exterior porque él, mediante el arte abstracto, crea un mundo nuevo. A partir del mundo interior, y de ahí la importancia de su riqueza sensorial, Kandinsky configura un nuevo mundo exterior. Kandinsky crea:

«La pintura es el choque rugiente de mundos diferentes destinados a crear en su combate y por su combate el mundo nuevo que llamamos la obra. Desde el punto de vista técnico, cada obra nace exactamente como nació el cosmos..., por obra de catástrofes que, partiendo de los caóticos rugidos de los instrumentos, terminan por crear una sinfonía que es lo que se llama la música de las esferas. La creación de una obra es la creación del mundo. (Werkschöpfung ist Weltschöpfung) ${ }^{50}{ }_{\text {» }}$

La creación de la obra de arte como creación de un mundo nuevo es lo que otorga el verdadero valor al arte. La obra se llena de vida. Gracias a su contenido espiritual, la obra de arte adquiere la entidad necesaria para convertirse en sujeto independiente y para impulsar el desarrollo del alma. Así lo explica Kandinsky: «la verdadera obra de arte (...) adquiere vida propia, se convierte en una personalidad, un sujeto independiente que respira individualmente y que tiene una vida material real. (...) La obra de arte vive y actúa, (...) tiene una vida interior total» ${ }^{51}$.

49 Todas las citas del párrafo se encuentran en EAston, El hombre y el mundo a la luz de la antroposofía, pp. 291 y 292.

50 Kandinsky, Mirada retrospectiva, p. 115. 
El comentario de Jelena Hahl-Koch, a medio camino entre el respeto y la reverencia, reconoce así esa calidad de creador: «¿ha habido alguna vez en la historia de la humanidad una situación comparable en la que el artista, en vez de reproducir el mundo, se sienta él mismo como demiurgo y de manera tan evidente (¿o autoritaria?) cree un mundo propio?» ${ }^{52}$

\subsection{La expresión interior}

El arte abstracto de Kandinsky es la creación de un arte espiritual que responde a la superación del materialismo y a la llegada de una nueva época. El lenguaje del arte abstracto se basa en la expresión de un contenido interior, que se exterioriza gracias a la fuerza de los medios pictóricos y con ello despierta sensaciones en el espectador. Esta cadena de transmisión revela dos cuestiones fundamentales: por un lado, cómo se transmite ese contenido interior, cómo consigue llegar hasta el receptor (apartado 6.2.1); por otro, cómo actúan los medios pictóricos para transmitir el contenido, cómo es el lenguaje propiamente dicho (apartado 6.2.2).

\subsubsection{La vibración del alma}

El arte, dice Kandinsky, es el medio de transmisión del alma. El arte consigue que el artista exteriorice su mundo interior de sensaciones y que éste llegue hasta el alma del espectador, estimulándole una respuesta multisensorial y abriéndole el camino a la dimensión espiritual. Para que el contenido interior consiga llegar hasta el espectador, tiene que nacer del «principio del contacto adecuado con el alma humana», que no es otro que el «principio de la necesidad interior ${ }^{53}$.

La necesidad interior no es sólo el contenido del que nace el arte. Debido a su carácter de necesidad, impulsa al artista a exteriorizarse y en ese punto, se convierte en una especie de guía que le indica el camino. Es el camino de

51 Kandinsky, De lo espiritual en el arte, p. 101. La cursiva es original.

52 Hahl-Koch, Kandinsky, p. 195.

53 Kandinsky, De lo espiritual en el arte, p. 62. 


\section{El arte abstracto como experiencia espiritual}

la exteriorización, o dicho de otra forma, el camino de lo espiritual: «éste es el único camino para expresar la necesidad mística. Todos los medios son sagrados, si son interiormente necesarios. Todos los medios son sacrílegos si no brotan de la fuente de la necesidad interior ${ }^{54}$. Sólo una obra nacida de la necesidad interior puede expresar el contenido místico del arte.

La verdadera "categoría” espiritual de esta necesidad interior es algo que no queda claro. Jelena Hahl-Koch la identifica con algo cercano a una «voz interior» (innere Stimme) ${ }^{55}$, superior a la conciencia y que le dirige en la creación de la obra. Esa voz interior es, según Hahl-Koch, el puente que conduce a la dimensión cósmica que Kandinsky quiere plasmar en sus cuadros. Por su parte, Arnold Schönberg se refiere a un concepto similar, una “inspiración” de carácter divino, como «la mano de Dios» que le ayuda a componer. Leyendo la correspondencia entre Kandinsky y Schönberg podría decirse que Kandinsky no se siente del todo incómodo con este término, aunque nunca llega a hacerlo suyo.

Algunos fragmentos de los libros de Kandinsky incitan a identificar la necesidad interior con la intuición. En tanto que «el principio de la necesidad interior» es el punto de partida para la creación del contenido y para la elección de la forma, puede decirse que la necesidad interior es el principio creador. Y eso mismo es lo que Kandinsky dice en De lo espiritual en el arte acerca de la intuición: «en el arte todo es cuestión de intuición, especialmente en los comienzos. Lo artísticamente verdadero sólo se alcanza por la intuición. (...) Es la intuición quien da vida a la creación ${ }^{56}$. Y sin embargo, con sólo un par de años de diferencia entre este texto y el de la conferencia de Colonia (es decir, realmente no puede argumentarse el paso del tiempo y con él la maduración de la idea), queda claro que la necesidad interior no es la intuición. Porque «la génesis de una obra es de carácter cósmico. El creador de la obra es pues el espíritu» ${ }^{57}$.

La necesidad interior es, entonces, el espíritu creador. La obra existe de manera abstracta en la mente del artista, escribe Kandinsky, y el espíritu es quien dirige su materialización. En este proceso de hacerse exterior, el espíritu

54 Kandinsky, De lo espiritual en el arte, p. 68.

55 HaHL-Косн, Kandinsky, p. 174. Aunque emplee el mismo término, innere Stimme, no parece que Hahl-Koch quiera aludir en ningún momento a la voz interior de la que habla Schiller.

56 Kandinsky, De lo espiritual en el arte, p. 68.

57 Kandinsky, Mirada retrospectiva, p. 202. 
cuenta con la ayuda equilibrada de la lógica y la intuición (luego espíritu e intuición tampoco son lo mismo). La lógica y la intución participan en la creación de la obra de arte, pero no tienen la última palabra: «el espíritu creador (...) rechaza lo que es falso en uno [la lógica] y en el otro [la intuición]. (...) Sin el control del espíritu, los dos factores son en sí mismos estériles y están desprovistos de vida. En ausencia del espíritu, ni la lógica ni la intuición pueden crear obras perfectamente buenas» ${ }^{58}$.

Kandinsky no ofrece una definición clara y cerrada de la necesidad interior, lo que, si se observa en el conjunto de su obra, tampoco impide su comprensión. Posiblemente entorpezca el análisis conceptual. Y sin embargo, a la vez, hace de la necesidad interior un concepto más abierto y más abstracto, lo que precisamente flexibiliza la interpretación y con ella la comprensión. Al fin y al cabo, la importancia reside en que la necesidad interior es el punto de partida para la espiritualización de la obra -y por ende del arte- por determinar el contenido interior y también la elección de la forma exterior. La pregunta clave no es qué es exactamente esa necesidad interior, sino cómo llega ese contenido espiritual hasta el espectador y, más concretamente, cómo consigue sensibilizar su alma.

La necesidad interior del artista se hace exterior en la obra de arte. Gracias a la fuerza expresiva de los medios, el color y la forma consiguen despertar en el espectador sentimientos sutiles, complejos, ricos en sensaciones multisensoriales. Esa fuerza expresiva de los medios pictóricos es la resonancia interior.

La resonancia interior, en tanto que hace perceptible un contenido espiritual, es un puente que sirve de unión entre la necesidad interior y el exterior. Es una proyección cósmica del contenido de la obra a través de su transmisión, como afirma Ulrika-Maria Eller-Rüter. ${ }^{59}$ Según esta investigadora, la resonancia interior posee la capacidad de evocar dimensiones cósmicas, lo que le permite acceder al alma del espectador.

Sixten Ringbom identifica esas dimensiones cósmicas de la resonancia interior con un concepto de la Antroposofía, los arquetipos. ${ }^{60}$ Según Steiner,

58 Kandinsky, Mirada retrospectiva, p. 202.

59 ELLER-RüTER, Kandinsky, pp. 38-39.

6o Ringbom, The Sounding Cosmos, p. 117. 


\section{El arte abstracto como experiencia espiritual}

en el mundo espiritual existen unos arquetipos (Urbilder) de todos los objetos del mundo físico. Estos arquetipos vienen a ser la esencia sonora, abstracta, espiritual de las cosas, y están hechos del mismo "material" que los pensamientos humanos. El hombre percibe estos arquetipos a través del oído espiritual de su alma: «todo color, toda percepción lumínica se corresponde con un sonido espiritual ${ }^{61}$. Lo que añade Steiner es que a ese estadio perceptivo se llega por la vía de la meditación o de la alta concentración, de cuyo ejercicio resulta que «todas las cosas adquieren a partir de ahora un nuevo significado para los hombres. [Las cosas] se hacen audibles espiritualmente en su esencia más interior; hablan a los hombres de su esencia verdadera» ${ }^{62}$.

Kandinsky no hace referencia alguna a Steiner en este aspecto, y tampoco a la necesidad de la meditación para percibir la resonancia espiritual. Sí es necesario un grado de espiritualización, y en eso precisamente trabaja el arte. Pero en los estadios previos, cuando aún no se ha llegado a la parte delantera y superior de ese triángulo espiritual, también es posible percibir la resonancia interior.

La resonancia interior accede al alma humana del espectador a través de la vibración. El alma del espectador vibra al percibir la resonancia interior. El proceso de transmisión ocurre de la siguiente manera. La necesidad interior se hace externa en los medios pictóricos. Éstos, el color y la forma, desprenden una resonancia espiritual que llega al espectador y lo estimulan en forma de sentimiento. El espectador siente cómo la obra de arte irradia una vibración a su alma. Y el alma del espectador vibra: recibe el contenido espiritual del alma del artista.

A propósito de la vibración, Ringbom vuelve a señalar las similitudes entre las ideas teosóficas y las de Kandinsky. Las compara con la teoría de Annie Besant (sucesora de Blavatsky), de que todas las cosas deben su existencia a la vibración: las formas divinas se asientan en la materia mediante vibración. El universo está formado, pues, por vibraciones, y el hombre ha de aprender a responder y reaccionar ante ellas. ${ }^{63}$ Ringbom ve en esta idea la base de la vibración kandinskyana, aunque lo cierto es que Kandinsky no hace referencia

61 SteIner, Theosophie, p. 101.

62 Mötteli, Rudolf Steiner-Gesamtausgabe, p. 144.

63 Besant, Die Entwicklung des Lebens und der Form, pp. 20-36. 
alguna a las formas divinas y tampoco a que el universo esté formado por ellas. Kandinsky introduce el concepto de vibración simplemente en relación al arte, como el culmen de la transmisión de un contenido espiritual.

Según Kandinsky, «las cuerdas del alma [son] sensibles, perceptivas y particularmente aptas para vibrar» ${ }^{64}$, y esa propiedad hace posible la transmisión de un contenido espiritual. La vibración que produce la resonancia interior espiritualiza el alma, es decir, "permite que el alma se haga más sensible y sea más capaz de vibrar. Y con ello la enriquece, la amplía, la afina y la hace más apta para alcanzar sus propios fines» ${ }^{65}$. De ahí que, si el objetivo del arte es la espiritualización de la sociedad y la revalorización del alma, el arte abstracto de Kandinsky tenga como finalidad crear obras que produzcan tales vibraciones:

«Un conjunto complejo y preciso de vibraciones: tal es el objetivo de una obra. Afinar el alma gracias a ese conjunto que la suma de las vibraciones hace preciso: tal es el objetivo del arte. Por eso el arte es indispensable. ${ }^{66}{ }^{\prime}$

\subsubsection{El lenguaje espiritual}

La transmisión del contenido interior del artista hasta el alma del receptor sucede a través de la obra de arte. Si se realiza adecuadamente, el alma del espectador vibra y recibe la emoción que quiso expresar el artista. Además de que el artista sea bueno y de que el espectador se muestre abierto y sensibilizado, en este proceso es imprescindible otro factor: que el lenguaje de expresión sea el apropiado. Si el lenguaje no es capaz de transmitir la espiritualidad que desprende el contenido interior del artista, el espectador no puede percibir la espiritualidad ni sentir vibración alguna.

Kandinsky deja claro que el arte materialista y su representación de la realidad no sirven en la nueva época espiritual. El arte necesita un nuevo lenguaje, uno que sea espiritualmente expresivo. El simbolista ruso Vjacheslav Ivanov afirma en 1910 que el lenguaje materialista no sirve porque es demasiado descriptivo o demasiado racional para transmitir el lenguaje de Dios, y esta idea

64 KAndinsky, Mirada retrospectiva, p. 100 65 Kandinsky, Mirada retrospectiva, p. 124. 66 KAndinsky, Mirada retrospectiva, p. 167. 


\section{El arte abstracto como experiencia espiritual}

la utiliza Washton-Long para argumentar la búsqueda kandinskyana de un nuevo lenguaje espiritual. ${ }^{67}$

Incluyendo o no a Dios en la búsqueda, lo cierto es que Kandinsky sí pretende un lenguaje espiritual. Es decir, un lenguaje cuyas formas expresen espiritualidad. Esto significa que las formas han de ser las «expresiones, perceptibles sensorialmente, de los movimientos del espíritu o del alma» ${ }^{68}$, como bien define Roessler. Y eso, en el proceso de abstracción que lleva a cabo Kandinsky, significa dos cosas: que el lenguaje ha de surgir del mismo espíritu y que el lenguaje debe renunciar a las formas corpóreas.

El lenguaje surje del mismo espíritu cuando nace de la necesidad interior: «amo toda forma nacida de manera necesaria del Espíritu» ${ }^{69}$. Es decir, cuando el color y la forma expresan realmente el contenido interno, cuando hay una consonancia entre el contenido y los medios de expresión. Porque sólo así, «el espectador encuentra una consonancia con su alma ${ }^{70}$ y la espiritualidad fluye entre artista y receptor.

En segundo lugar, el lenguaje renuncia a las formas corpóreas cuando elimina todo rastro figurativo. «El deseo de expresar la espiritualidad en el arte lleva a Kandinsky a buscar nuevas formas de pintura desmaterializada ${ }^{71}$. Tower la llama pintura desmaterializada, también se la puede llamar espiritual o simplemente pintura sin objeto, pintura abstracta. El hecho es que prescinde del objeto; la razón es que el objeto estorba en la percepción espiritual. La familiaridad del objeto entorpece el reconocimiento de la resonancia espiritual. Si el espectador reconoce el objeto, se contenta con esa percepción y no busca la resonancia espiritual. Kandinsky explica que todo objeto tomado en sí mismo, es decir, en esencia, «emite una resonancia espiritual determinada que puede servir y sirve efectivamente de material al arte, en todos los dominios». La pregunta clave es cómo transmitir esa resonancia, y la respuesta pasa por eliminar la forma figurativa. Kandinsky describe cómo al comienzo de su carrera «estaba aún demasiado deseoso de buscar las formas pictóricas puras

67 Ivanov lo escribe en Zavety Simvolizma, publicado en la revista Apollon (vol. I, p. 11) y queda recogido en Washton-Long, Kandinsky. The Development of an Abstract Style, p. 76.

68 Roessler, Neu-Dachau, p. 119.

69 Kandinsky, Mirada retrospectiva, p. 125.

70 KANDINSKY, De lo espiritual en el arte, p. 23.

71 Tower, Klee and Kandinsky in Munich and at the Bauhaus, p. 11. 
a través de esa resonancia espiritual; de manera que en mis cuadros disolvía más o menos los objetos a fin de que no se los pudiera reconocer de golpe y para que, por consiguiente, el espectador pudiera experimentar poco a poco y una después de otra esas resonancias espirituales concomitantes» ${ }^{72}$.

La supresión del objeto conlleva entonces el acercamiento al mundo espiritual o incluso, como propone Hahl-Koch, conlleva directamente la espiritualización del arte: [Kandinsky] «reduce cada vez más la forma y la presencia humana para hacer que el contenido principal sea un acontecer cósmico universal» ${ }^{73}$. Y como consecuencia de ello, la supresión del objeto también conlleva un cambio obligado en el espectador. El espectador no está acostumbrado a contemplar cuadros sin objeto ni figura reconocible, por lo que su alma tampoco está habituada a reconocer contenido espiritual en una percepción visual. Hay que adiestrarla, hay que enseñarla a percibir lo espiritual en el arte. Así lo considera Kandinsky: «me parece igualmente lógico que la supresión del objeto en la pintura comporte grandes exigencias en lo que respecta a la experiencia interior de la forma puramente pictórica, y en consecuencia que sea absolutamente indispensable una evolución del espectador en esa dirección» ${ }^{74}$.

La evolución del alma del espectador, o su sensibilización, se consigue a través del arte abstracto. Porque el lenguaje abstracto, al nacer del mismo espíritu y al renunciar al objeto, es el único capaz de transmitir el contenido espiritual. El arte abstracto accede al alma: «el espíritu creador (al que podemos llamar espíritu abstracto) encuentra un acceso al alma, y más tarde, a las almas, y provoca un anhelo, un impulso interior ${ }^{75}$. El espectador se familiariza con este arte y poco a poco, su alma se va volviendo más sensible: «mientras más [sic] utiliza el artista las formas casi abstractas o abstractas, más se familiariza con ellas y más se adentra en su terreno. Lo mismo le sucede, guiado por el artista, al espectador, que va reuniendo conocimientos del lenguaje abstracto y acaba por dominarlo» ${ }^{76}$.

El arte abstracto consigue sensibilizar el alma del artista y del espectador.

72 KANDinsky, Mirada retrospectiva, p. 205.

73 HaHL-KoсH, Kandinsky, p. 152.

74 KAndinsky, Mirada retrospectiva, p. 124.

75 KANDINSKY, Escritos sobre arte y artistas, p. 19.

76 Kandinsky, De lo espiritual en el arte, p. 63. 


\section{El arte abstracto como experiencia espiritual}

El artista se sensibiliza porque aprende a expresar su mundo interno utilizando un lenguaje que refleja la espiritualidad; el espectador, porque la desaparición de las formas figurativas lo ayuda a percibir esa resonancia suprasensorial. El artista crea un lenguaje basado en colores y formas, el espectador aprende a percibirlo. El lugar donde se proyecta ese lenguaje y que comparten artista y espectador es la superficie del cuadro, es decir, el espacio. El espacio no es un sistema de referencia absoluto, fijo e inamovible, sino que es relativo al artista y al espectador. Durante la creación de la obra el espacio es relativo al artista; durante la percepción, el espacio se vuelve relativo al espectador: «durante la ejecución el PB [plano básico] es completamente dependiente del artista, está unido a él. (...) este fenómeno se repite con relación a la obra terminada, y tal vez no sólo con relación al artista, sino también al eventual observador» ${ }^{77}$.

La relatividad del espacio al artista y al espectador facilita que cada uno de ellos se proyecte en ese espacio de manera personal, involucrando al alma en la interpretación de la obra. Overy entiende esta relatividad como una referencia al yo, como si el espacio fuera el reflejo del ego de cada uno de ellos (artista y espectador). Overy se apoya en la perspectiva gestáltica de Kurt Koffka ${ }^{78}$ para decir que el espacio de la obra kandinskyana es un behavioural space, un espacio del comportamiento en el que se ven reflejadas las características del "yo o ego" de quien lo contempla. ${ }^{79}$

Kandinsky no llega a hablar en términos de yo o de ego, pero sí compara las tensiones del plano básico con los movimientos humanos, es decir, el espacio del cuadro con el estar del hombre en el mundo: «podríamos proyectar nuestras características humanas sobre el Рв y de este modo definir ambos lados del mismo» ${ }^{80}$. El desplazamiento hacia la izquierda significa para el hombre poner distancia, alejarse de lo habitual. Se corresponde con la ligereza y liberación de la línea y parte izquierda del plano:

«[hombre]: el movimiento hacia la izquierda, hacia la libertad, es un movimiento en distancia. El hombre se aleja de

77 Kandinsky, Punto y línea sobre el plano, p. 108. La cita pertenece al texto y a la nota al pie número 2 de esa misma página.

78 KoffKa, Principles of Gestalt Psychology.

79 La interpretación de Overy basada en la Psicología de la Gestalt puede leerse en OverY, Kandinsky, pp. 132-143.

80 Esta cita y las siguientes se encuentran en Kandinsky, Punto y línea sobre el plano, pp. 107-109. 
su contorno cotidiano, se libera de lo habitual que pesa sobre él. (...) Emprende una "aventura”.

[espacio]: La izquierda del рв despierta la idea de una mayor soltura, la sensación de ligereza, liberación y, finalmente, libertad.»

Con el lado derecho propone un paralelismo similar. En este caso, el desplazamiento hacia la derecha es un movimiento que hace el hombre hacia la seguridad, hacia lo conocido, hacia el hogar. Y la parte derecha del plano básico es asimismo la de resonancia más densa, más lenta.

«[hombre]: El movimiento hacia la derecha es un retorno hacia la casa. Este movimiento se une a un cierto cansancio y su finalidad es el reposo. Cuando más hacia la derecha, menos brillante y más lento se vuelve el movimiento. (...)

[espacio]: La derecha [es] el mismo debilitamiento. La condensación, pesadez, ligazón disminuyen, pero las tensiones chocan. (...) Las posibilidades dinámicas son cada vez más limitadas.»

La presencia del hombre en el mundo se refleja en la tensión pictórica que emana la superficie básica del cuadro. El artista aprovecha la "pesadez" de la parte derecha del espacio para colocar elementos que o bien refuercen o bien debiliten esa sensación, según lo que quiera transmitir. El artista refleja su presencia humana en el espacio del cuadro. Y el espectador, frente a la obra terminada, vuelve a proyectar su propia presencia humana en ese mismo espacio. De ahí que el espacio sea relativo a ambos y a la vez constituya el punto de encuentro.

Junto a la nueva concepción del espacio, el lenguaje del arte abstracto logra su espiritualidad a través de los medios pictóricos: el color y la forma. Ambos son la expresión espiritual del contenido interior. El color tiene acceso directo al alma; la forma está dotada de vida interior.

El color tiene acceso directo al alma, según Kandinsky. Es capaz de provocar emociones similares a las del sonido, y con ello de establecer un contacto directo con el alma del espectador. «El color es un medio para ejercer una 


\section{El arte abstracto como experiencia espiritual}

influencia directa sobre el alma», escribe Kandinsky, y lo explica con una metáfora: «El color es la tecla. El ojo el macillo. El alma es el piano con muchas cuerdas. El artista es la mano que, por esta o aquella tecla, hace vibrar adecuadamente el alma humana». ${ }^{81}$ Kandinsky está convencido de que el color emite una vibración similar a la vibración física del aire o de la luz: «las vibraciones del aire (el tono) y de la luz (el color) son ciertamente la base de esta analogía física» ${ }^{82}$. Es una vibración que, a través del ojo («el ojo es el macillo»), llega hasta el alma. Cada color emite una vibración diferente y la combinación de colores, muchas vibraciones más. Si el artista domina el lenguaje de los colores, puede crear una sinfonía de vibraciones, esto es, de sensaciones que alcancen y sensibilicen el alma del espectador.

La premisa de que el color tiene acceso directo al alma ha llevado a muchos investigadores a asociar la teoría de Kandinsky con la teoría del color de Goethe (Farbenlehre). En general, se da por cierto que Kandinsky conoce la teoría de Goethe a través de Steiner, que comenta una edición de Farbenlehre publicada en 1898. Difícil de confirmar, lo cierto es que Kandinsky nombra a Goethe en De lo espiritual en el arte y que sus teorías guardan cierto paralelismo. ${ }^{83}$ Goethe describe los colores desde un enfoque psicológico y destaca el efecto que tienen sobre el ánimo o el alma, al que acceden a través de los ojos. Kandinsky también estudia el color desde la perspectiva psicológica y, salvo por el concepto de la vibración, su esquema de transmisión es similar: el color llega al alma pasando por el ojo (tecla-macillo-piano).

Goethe asienta su sistema en la antinomia claridad-oscuridad y en la consideración del amarillo y el azul como los colores puros, que son los más cercanos a la luz y oscuridad, respectivamente. Kandinsky también propone su pareja de antinomias: calor-frío y claridad-oscuridad. Sólo que, para Kandinsky, el amarillo y el azul son los colores que determinan la temperatura (calor-frío) y no la claridad o la oscuridad. Aún así, los adjetivos que utiliza Goethe para describir el azul y el amarillo son muy cercanos a los que emplea Kandinsky. Goethe dice que el amarillo es luz, claridad, fuerza, calor, cercanía. Kandinsky habla de calidez, derroche de fuerzas, cercanía al espectador,

81 Kandinsky, De lo espiritual en el arte, p. 54.

82 Kandinsky, De lo espiritual en el arte, p. 201.

83 Una relación más profunda entre la teoría de Goethe y la que Kandinsky expone en De lo espiritual en el arte puede leerse en Hentschel, Kandinsky und Goethe. 
espontaneidad. El azul es para Goethe sombra, oscuridad, privación, lejanía. Y para Kandinsky, el azul es profundo, quieto, tranquilo, concéntrico, replegado en sí mismo, lejano al espectador. Las similitudes son notables, aunque no exclusivas de ambos autores. Muchos estudio del color coincidirían con Goethe y Kandinsky.

La capacidad que tiene el color de acceder al alma humana no sólo relaciona a Kandinsky con las teorías de Goethe. La Antroposofía también ofrece un planteamiento similar, ya que deriva la percepción estética de una obra de la armonía de sus colores y de cómo el color «afecta a nuestra naturaleza anímica». ${ }^{84}$ Steiner afirma que «con el color tenemos un vínculo espiritual», $\mathrm{y}$ que «tener acceso a ese género de realidades será, pues, la tarea y el privilegio de los artistas del futuro» ${ }^{85}$, una idea cercana a la que se encuentra en los textos de Kandinsky. Para Steiner, el color es una realidad viva y la expresión de una entidad espiritual o anímica. En el mundo real el color está unido al objeto, pero en el mundo interior, el color se desliga de él y se convierten en entidades independientes. ${ }^{86}$ De nuevo, una idea similar a la teoría de Kandinsky: en el mundo interior del artista, el color se desliga del objeto y como entidad abstracta que es, adquiere capacidad para influir directamente en el alma.

El color expresa la espiritualidad del contenido interno gracias a la capacidad de acceder directamente al alma. La forma, el otro de los medios pictóricos, expresa la resonancia espiritual porque está dotada de vida interior.

Los tres elementos básicos de la forma abstracta (punto, línea y plano) expresan espiritualmente la vida del hombre. El plano es el espacio de referencia en el que se desarrolla la vida, y las otras formas (punto y línea) son la expresión directa de las sensaciones del hombre: del artista durante la creación, del espectador después de ella. Todas las formas, incluido el punto, son formas vivas: «empezando por el punto, el arquetipo de todas las formas, ese pequeño punto es un ente vivo» ${ }^{87}$. Al ser formas dotadas de vida, son capaces de transmitir el contenido interior del artista y de despertar emociones en

84 EAston, El hombre y el mundo a la luz de la antroposofía, p. 309.

85 De una conferencia publicada en el verano de 1914, texto que se encuentra en STEINER, Wege zu einem neuen Baustil y que Bouillon recoge en su edición comentada a Mirada retrospectiva.

86 De Palèzieux, Der geometrische Punkt ist ein unsichtbares Wesen, p. 34.

87 KANDINSKY, Escritos sobre arte y artistas, p. 201. 


\section{El arte abstracto como experiencia espiritual}

el alma del espectador: «un triángulo provoca una emoción viva porque es un ser vivo ${ }^{88}$. Las líneas expresan el devenir humano: la línea recta es dura, «reafirmándose sin perdón constantemente, con aparente naturalidad, como el destino ya vivido»; la línea curva, en cambio, es «libre, vibrante, esquiva, flexible, elástica, aparentemente indefinida, como el destino que nos espera». ${ }^{89}$

La forma es la voz del hombre en el cuadro, es quien relata las sensaciones, las emociones, la expresión del mundo interior. Kandinsky lo explica de manera casi poética: «cada línea dice: “ ¡Estoy!” Se afirma y muestra su rostro hablador: “¡Escuchad!, jescuchad mi secreto!” Maravillosa es una línea. (...) Un pequeño punto. Muchos puntitos, (...) muchas pequeñas tensiones que no paran de repetir al unísono: “Escuchad, escuchad!” (...)»” Cada punto, cada línea, cada combinación de formas es una voz que expresa la vida interior del artista. La reunión de todas las voces es la expresión completa del mundo interior, la comunicación espiritual entre el artista y el espectador a través de la obra de arte. Y así se consigue que «la pintura abstracta es un fenómeno vivo, lleno de vida» ${ }^{91}$.

El lenguaje abstracto es la transmisión del mundo espiritual del hombre, desde el artista hasta el espectador. La renuncia a lo figurativo facilita la percepción de la resonancia espiritual, el espacio refleja el estar del hombre en el mundo y la fuerza expresiva del color y la forma consiguen sensibilizar el alma humana. Ése es el lenguaje espiritual del arte abstracto, que según Kandinsky «creará la atmósfera que hará a los hombres en general capaces de sentir el espíritu de las cosas, de vivir ese espíritu aun de modo enteramente inconsciente. (...) Pero ésta es la condición para que los hombres en general tengan la experiencia de lo espiritual en las cosas abstractas. Gracias a esta nueva capacidad (que se halla bajo el signo del "Espíritu") se llegará al goce del arte abstracto, es decir, absoluto». ${ }^{92}$

88 KANDINSKY, Escritos sobre arte y artistas, p. 153.

89 KANDINSKY, Escritos sobre arte y artistas, pp. 163-164.

90 KANDINSKY, Escritos sobre arte y artistas, p. 164.

91 KANDINSKY, Escritos sobre arte y artistas, p. 168.

92 Kandinsky, Mirada retrospectiva, p. 125. Las comillas son originales. 


\subsection{La presencia del mundo espiritual}

\subsubsection{La pintura religiosa}

El lenguaje abstracto de Kandinsky transmite el mundo espiritual del artista al espectador y añade un halo de trascendencia a la obra de arte. El arte alcanza así el estadio más elevado del arte puro, dice Kandinsky. Y añade que gracias a esta lengua artística, "la pintura habla de espíritu a espíritu». ${ }^{93}$ El lenguaje espiritual, sin embargo, no es lo único que revela la presencia del espíritu, el alma, la religión o la trascendencia (según cómo se entienda la religiosidad de Kandinsky, véase la controversia). La temática escogida para los cuadros y el uso de elementos claramente simbólicos contribuyen a veces en la misma medida.

La mayoría de las obras abstractas de Kandinsky no llevan título descriptivo. Muchas se llaman sólo "Impresión", "Improvisación" o "Composición”, según de qué fuente procedan: las Impresiones son una «impresión directa de la "naturaleza externa", expresada de manera gráfico-pictórica»; las Improvisaciones son una «expresión principalmente inconsciente (...) de procesos de carácter interno, es decir, impresión de la "naturaleza interna" "; y las Composiciones son una «expresión (...) que se crea con lentitud extraordinaria y que analizo y trabajo larga y pedantemente después del primer esbozo». ${ }^{94}$ Es decir, en los títulos de las obras, Kandinsky no revela nada sobre el tema de la composición. Algunos comentarios suyos y ciertas anotaciones descubiertas en sus cuadernos indican sin embargo que algunos cuadros sí fueron concebidos bajo un tema.

La Composición v, por ejemplo, trata el tema de la Resurrección, y la Composición VI el del Diluvio: «pinté la Composición II sin tema (...) En cambio, tomé tranquilamente la Resurrección como tema de la Composición $v$ y el Diluvio como tema de la Composición VI». ${ }^{95}$ Los bocetos de la Composición VII permiten reconocer elementos que han sido completamente reducidos en la versión final, lo que da pie a relacionar el cuadro con temas como el Juicio Fi-

93 KANDINSKY, Mirada retrospectiva, p. 196.

94 Kandinsky, De lo espiritual en el arte, p. 108.

95 Kandinsky, Mirada retrospectiva, p. 208. 


\section{El arte abstracto como experiencia espiritual}

nal, la Resurrección o la llegada del fin del mundo. Y a estas obras de temática religiosa pero de título velado se añaden otras cuyo título nada esconde: San Jorge, Todos los santos o San Vladimiro.

Noemi Smolik afirma que «si se compilan todos los motivos que acompañan a Kandinsky en su camino a la abstracción, salta a la vista que se trata casi exclusivamente de la Resurrección o de la Ascensión del Espíritu» ${ }^{96}$. Smolik no es la única investigadora que cree que, aunque el tema concreto de una obra sea otro (el Diluvio, por ejemplo, o San Jorge), el resto de elementos funcionan como símbolos de la resurrección. No sólo de la Resurrección de Cristo, sino más bien de la resurrección de la época espiritual, de la resurrección entendida como el «nuevo renacer cultural», esa idea que Kandinsky comparte con sus maestros rusos y en la que el arte es el protagonista. Así, la mayoría de investigadores coinciden en que el jinete a caballo simboliza la victoria de lo espiritual sobre lo terrenal, el arcoiris expresa la unión entre Dios y los hombres tras el Diluvio, ${ }^{97}$ el castillo sobre una colina es la mansión celestial en la tierra, ${ }^{98} \mathrm{o}$ el "tablero de ajedrez" (una rejilla de cuadros blancos y negros como en Sonidos opuestos de 1924 o en Treinta de 1937) simboliza el origen y el final de la vida, porque el blanco es «vida, el gran silencio preñado de cosas posibles» y el negro es «muerte, oscuridad, destrucción».

La mayoría de los cuadros con temática o elementos claramente religiosos son pinturas sobre vidrio. Algunas de esas pinturas sirven después de inspiración para cuadros $y$, aunque algunos símbolos ya no se reconozcan, el boceto previo de la pintura permite identificarlo. Kandinsky y Gabriele Münter conocen este tipo de pintura en Murnau, el pueblo situado al pie de los Alpes en el que viven entre 1909 y 1914, aproximadamente los mismos años en los que se fragua el nacimiento de la abstracción.

La pintura sobre vidrio es un tipo de arte muy extendido en el sur de Alemania y algunas zonas de Austria, y tiene un marcado componente religioso y popular. Originariamente es una pintura de profanos, utilizada como agradecimiento. Cuando un campesino quiere agradecer, por ejemplo, una buena cosecha a un santo, pinta en colores fuertes y brillantes una imagen del

96 BeHR, Kandinsky. Malerei 1908-1921, p. 153.

97 KLeIne, Gabriele Münter und Wassily Kandinsky, p. 441.

98 Overy, Kandinsky, p. 62. 
santo; algo torpe, pero marcada por los sentimientos, pintada con el corazón.

Gabriele Münter aprende a pintar sobre vidrio directamente de uno de los artistas de la zona. Kandinsky empieza algo más tarde, pero ambos sienten especial atracción por este tipo de arte. Compran varios cuadros, y uno con San Jorge como motivo central ocupa un lugar destacado en el salón, encima del armonio que toca Kandinsky. ${ }^{99}$ En la carta que Michael Sadler escribe a su mujer, esa carta en la que le relata la visita que hace con su hijo a Kandinsky y a Münter, Sadler describe lo que ve en la casa de Murnau: "pintura sobre vidrio, con colores muy intensos, de temática religiosa la mayoría; algunas obras del siglo XVIII de campesinos bávaros, algunas pintadas por un hombre de Murnau, el último que practica este arte antiguo y tradicional, y unas pocas [obras] (místicas y de apariencia primitiva) del propio Kandinsky». ${ }^{100}$ El hombre de Murnau que practica este arte tradicional es al que Kandinsky, Münter y los Sadler van a visitar después de un paseo por el pueblo, lo que indica la relación entre ellos: «luego fuimos a ver al pintor de vidrio -el último que lo hace - a su taller cerca de la oficina de correos. No estaba, pero su hermano nos enseñó las obras. Madonas y santos de colores bizantinos intensos». ${ }^{101}$

La carta de Sadler confirma el interés de Kandinsky por la pintura sobre vidrio, que le atrae por varios motivos. Uno de ellos es la presencia de lo espiritual, la religiosidad pura de los campesinos bávaros que lo retrotraen a su gusto por la iconografía rusa. Otro es la expresión directa y sincera del campesino que pinta, una expresión artística casi naif que, si se usaran las palabras de Kandinsky, sale directamente de la necesidad interior. El uso tan puro e intenso del color sobre el vidrio es seguramente otro de los motivos, a juzgar por un comentario de Gabriele Münter. Edouard Roditi le pregunta en una entrevista si los colores planos y brillantes que utiliza son influencia de Gauguin. Münter responde que no, que ella lo aprende «de Kandinsky y a la vez de los colores vivos de la pintura sobre vidrio que pintan los campesinos de la región de Murnau desde hace siglos» ${ }^{102}$.

La expresión interna, naif, religiosa y los colores brillantes de la pintura sobre vidrio atraen a Kandinsky, y no hay duda de que estos elementos se ven

99 Hahl-Косн, Kandinsky, p. 124.

100 Overy, Kandinsky, p. 20.

101 Overy, Kandinsky, p. 29.

102 Roditi, Dialoge über Kunst, p. 214. 


\section{El arte abstracto como experiencia espiritual}

reflejados después en su pintura. Pero si hay algo que influye esencialmente en Kandinsky, es la técnica de la pintura sobre vidrio. La palabra alemana para la pintura sobre vidrio es más descriptiva, y ayuda a entender la técnica: Hinterglasmalerei. Literalmente se traduce por "pintura sobre el dorso de un cristal", lo que significa que se pinta la parte de atrás del vidrio y la parte frontal queda libre de pintura. Esto obliga a pintar al revés, como cuando se rayan dibujos en el esmalte trasero de un espejo, y a cambiar el orden de la composición. No se puede empezar con el fondo, porque cubriría todo el cristal. Primero se pintan las líneas de los contornos, luego se rellenan las figuras principales y por último se pintan los espacios del entre que, mirándolo de frente, viene a ser el fondo. La superposición de colores hay que realizarla en sentido inverso y la calidad del vidrio no siempre lo permite, lo que lleva a usar los colores de manera plana, basta y algo torpe. Esta técnica obliga al artista profesional, acostumbrado a pintar "del derecho" sobre un lienzo, a cambiar completamente su modo de pensar la obra. A un «cambio radical» (radikales Umdenken), como expresa Jelena Hahl-Koch. ${ }^{103}$

La pintura sobre vidrio obliga a Kandinsky a concebir la composición de otra forma, o al menos a pensar sobre ella, a trabajarla desde otra perspectiva. Pintar al revés supone considerar como elementos diferentes la forma y el color porque las figuras se hacen frontales, el color se vuelve plano, los contornos se magnifican. Es un ejercicio espléndido para estudiar la fuerza expresiva de cada medio por separado y desde todos los ángulos, incluido el inverso. También supone separar tajantemente la figura del fondo y de los espacios del entre, lo que le ayuda a despedazar o desmaterializar la pintura en sus elementos mínimos. Y la perspectiva es muy difícil, por no decir imposible. Pero sobre todo, pintar sobre vidrio cambia la concepción del espacio. La superficie donde se pinta es claramente relativa, porque artista y espectador lo contemplan desde dos ángulos opuestos. El dorso pertenece al artista mientras lo crea, la parte frontal al espectador cuando lo observa. El artista está obligado a entender la concepción del espacio del espectador, tiene que pintar de tal manera que el espectador - y no él- perciba la pintura. La técnica de la pintura sobre vidrio exige, realmente, un cambio radical en la concepción de la obra.

Kandinsky tarda unos años en dominar la técnica. San Vladimiro de 1911

103 HaHL-Косн, Kandinsky, p. 127. 


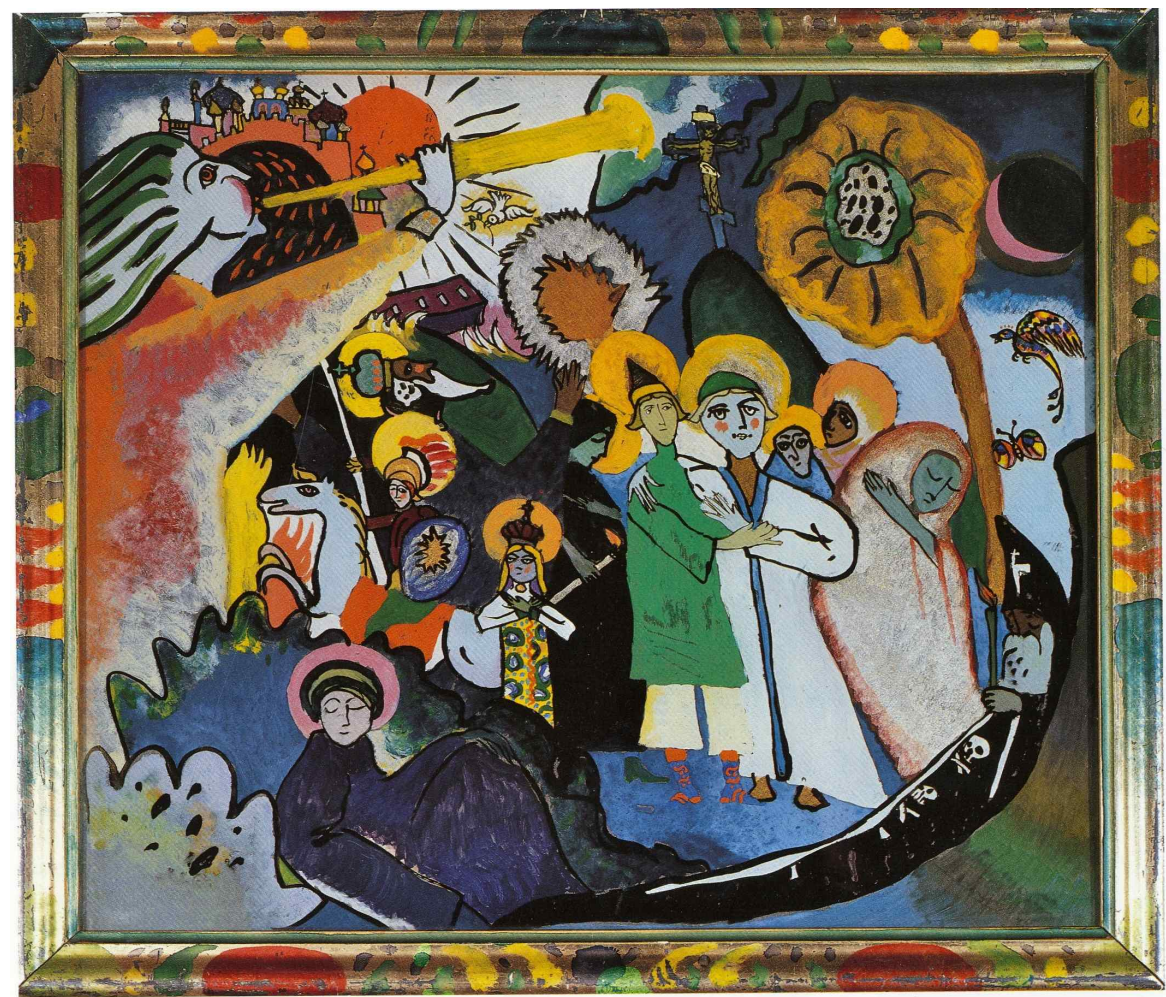

Ilustración 32 Todos los santos I

es uno de los primeros cuadros con buen resultado y que muestra las características de la pintura sobre vidrio: figuras frontales, encuadre plano y sin perspectiva, contornos marcados, algo naif, colores fuertes y la característica temática religiosa. Más conocida es la obra Todos los santos, que nace como pintura sobre vidrio (ilustración 32) y posteriormente sirve de boceto para un cuadro sobre lienzo (ilustración 33). Ambas imágenes son del mismo año, lo que permite una comparación aproximada.

La reducción que sufren las formas al pasar del vidrio al lienzo es clara. Pero la sensación que transmiten es similar. La mayoría de los elementos sigue presente, sólo que reducidos a su mínima expresión. La forma se reduce para eliminar lo figurativo, que estorba a la hora de percibir la resonancia espiritual. El color se reduce a una mancha, pero conserva la tonalidad como signo de su resonancia sonora interior. 


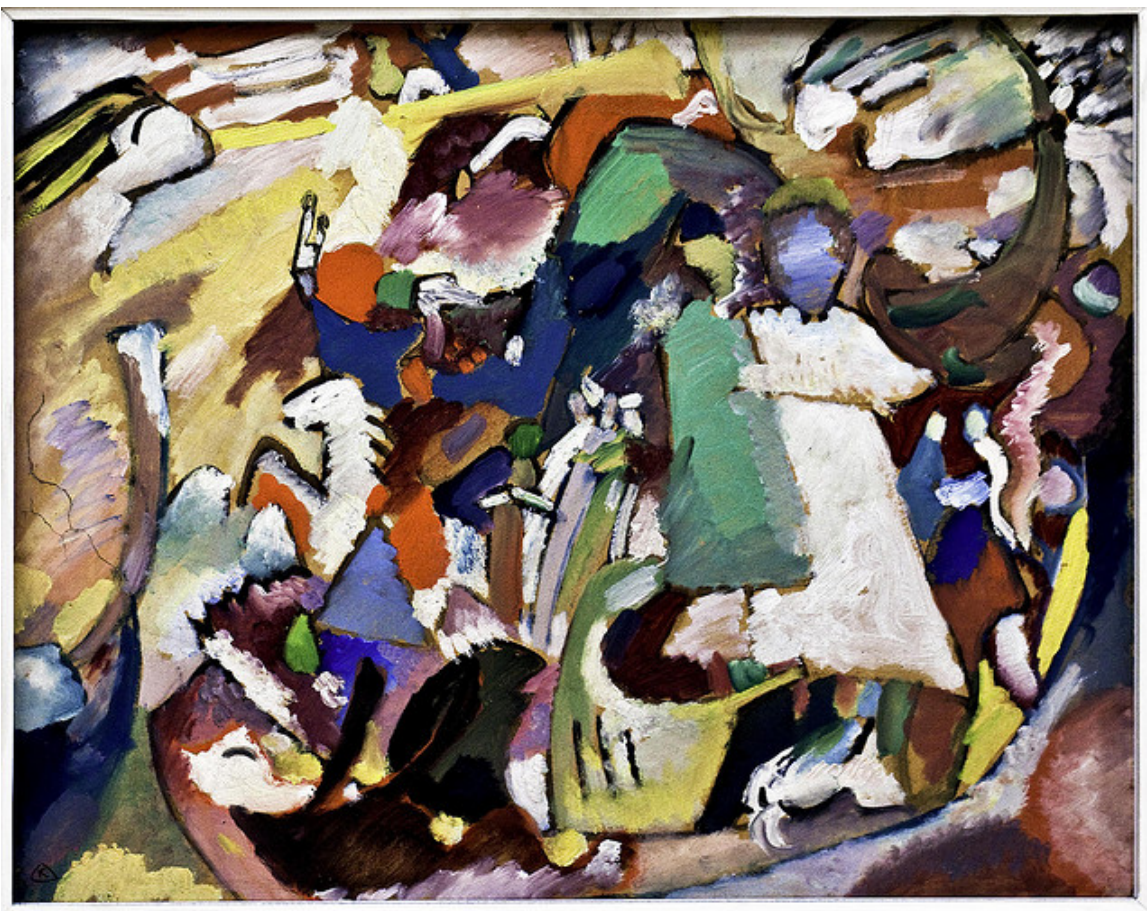

Ilustración 33 Todos los santos II

En el centro, las dos figuras principales representan a los hermanos Boris y Gleb, hijos de Vladimiro, mártires y santos cristianos. En la pintura sobre vidrio se distinguen los ropajes, los cuerpos, el rostro y las aureolas que rodean sus cabezas. En el lienzo pierden el detalle, pero no la presencia. El verde y el blanco ayudan a conservar la resonancia interior. El borde de la izquierda lo ocupa una de las siete trompetas del Apocalipsis. De nuevo, en la pintura sobre vidrio la figura es clara: los cabellos, el rostro, la mano, la trompeta. En el lienzo pierde el contorno pero no los colores ni la expresión, sigue transmitiendo la misma fuerza expresiva. El resto de figuras necesitan una atención más exhaustiva, pero terminan por reconocerse. Una de ellas destaca entre la trompeta y los hermanos, un caballo que mira hacia la izquierda. Es un caballo blanco con las patas delanteras levantadas, cabalgado por un jinete con casco, escudo y lanza sobre unas llamas: está derrotando a un dragón. 


\subsubsection{El jinete que vence al dragón}

El caballo es una de las figuras centrales de la obra de Kandinsky. En la etapa de la primera abstracción (1911-13), cuando las formas aún no han sido reducidas por completo al lenguaje abstracto, el caballo cabalgado por un jinete aparece con frecuencia en sus obras. Kandinsky no tiene ningún interés en la representación realista del caballo o del jinete, por lo que el empleo de esta figura sólo puede ser simbólico. Todos los investigadores concuerdan en que el caballo de Kandinsky es un símbolo lleno de alusiones y de matices. Unos resaltan la unión del jinete y del caballo como imagen de la unidad triunfante del hombre y la naturaleza, otros apuestan por la expresión de la belleza, nobleza y armonía que representa el animal. Pero cuando se trata del jinete en sí, la mayoría de ellos acepta que el símbolo tiene un cariz claramente religioso o espiritual.

Noemi Smolik, en su artículo sobre el renacer cultural ruso, ${ }^{104}$ asegura convencida que Kandinsky importa la figura del jinete de la iconografía rusa, sin lugar a dudas (ohne Frage). Según Smolik, Kandinsky conoce bien la pintura iconográfica y el poder de expresión de sus símbolos. Para él, los iconos rusos representan el nexo de unión entre la materialidad del presente y el mundo de lo espiritual, por lo que su uso equivale, en cierto modo, a construir un puente que permite mediar entre ambos mundos. Los iconos guían desde lo visible (lo material, la forma figurativa) hasta lo invisible (lo espiritual, la forma abstracta).

De entre todos los jinetes, la figura de San Jorge es una de las más distinguidas en la tradición rusa. El icono del mártir Jorge se venera desde la Edad Media, su figura preside el escudo de Moscú y la iglesia ortodoxa celebra su fiesta como patrón de Rusia. Aunque la historia del santo no siempre coincide a lo largo del tiempo y del espacio, el libro Legenda sanctorum del arzobispo de Génova (siglo XIII) populariza una versión. La leyenda dice que San Jorge mata a un dragón que tiene atemorizado a todo un pueblo y con ello libera a la hija del rey de morir sacrificada para apaciguarlo. El pueblo, agradecido por la hazaña, se convierte al cristianismo. A San Jorge se lo representa (también en la iconografía rusa) a las puertas de una ciudad, montado en un caballo blanco y luchando contra un dragón ante la presencia de una joven dama.

104 BeHr, Kandinsky. Malerei 19o8-1921, pp. 137-156. 


\section{El arte abstracto como experiencia espiritual}

Según la mayoría de los investigadores, la figura de San Jorge es la que da vida al jinete que pinta Kandinsky. ${ }^{105}$ Smolik cree que Kandinsky importa el concepto de San Jorge no sólo por ser un elemento de su tradición ruso-ortodoxa, sino especialmente por la fuerza simbólica que lleva consigo. Y es que la leyenda de San Jorge está cargada de simbolismo. San Jorge matando al dragón y la posterior conversión del pueblo al cristianismo alude al triunfo de la creencia cristiana sobre el paganismo. La interpretación tradicional de San Jorge dice que Cristo, en forma de caballero San Jorge, salva a la iglesia (representada como princesa) porque consigue vencer al mal (representado como el dragón).

El San Jorge de Kandinsky no es el elemento cristiano que vence el paganismo, pero la simbología sí guarda cierta semejanza. El jinete que pinta Kandinsky es el elemento espiritual que tiene que combatir las fuerzas del materialismo, es la representación de la nueva época espiritual venciendo la vieja etapa material. El San Jorge de Kandinsky es el pintor abstracto que vence al dragón, el materialismo del siglo xIx, y con ello libera a la princesa, la espiritualidad que necesita el arte. El jinete simboliza la victoria de lo espiritual sobre lo material, la llegada de una época que sensibiliza el alma del hombre, la creación de un nuevo lenguaje artístico que supera el estancamiento del actual. La espiritualidad vence la época materialista gracias a la pintura abstracta.

La presencia de San Jorge a caballo es destacada en la obra de Kandinsky (además del cuadro de San Jorge que preside el salón y cuelga encima de su armonio). En muchas pinturas sobre vidrio aparece la figura del jinete, $y$ también en los grabados en madera que a menudo sirven de bocetos para cuadros. Incluso en la tarjeta de miembro que realiza para la NKVM emplea la figura del jinete con su caballo blanco. ${ }^{106} \mathrm{El}$ caballo suele ser blanco y con las patas delanteras levantadas, en señal de victoria. En los cuadros iniciales, y especialmente en pinturas sobre vidrio como San Jorge I y San Jorge II de

\footnotetext{
105 Peg Weiss no niega que el jinete de Kandinsky sea San Jorge, pero sí añade que los caballeros que pinta tienen un parecido físico "demasiado" notable con el del poeta Stefan George. Peg Weiss establece además un paralelismo entre la obra del poeta y la de Kandinsky, destacando semejanzas que pudieran sugerir tal "encarnación”. Weiss es la única investigadora que lo señala y apenas ha habido resonancia sobre el tema. Puede leerse en WeIss, Kandinsky in Munich, pp. 85-91.

106 En Lindsay, The Genesis and Meaning of the Cover Design for the First Blaue Reiter Exhibition Catalogue hay una reproducción (imagen 4).
} 


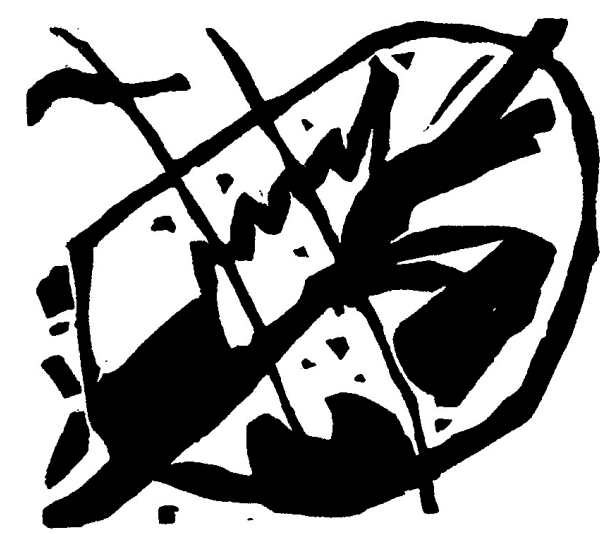

Ilustración 34 Jinete que abre el capítulo dos

1911, el jinete porta una lanza que clava en la boca del dragón. A medida que avanza el proceso de abstracción, la lanza desaparece o se convierte en un rayo o línea de color que sale disparada de la figura, como la línea blanca que sale del caballo central de Cuadro con orla blanca (ilustr. 9, en el capítulo 4).

El libro De lo espiritual en el arte no sólo hace referencia escrita a la superación del arte material por uno abstracto y espiritual, también contiene imágenes del jinete y su caballo vencededor. En la portada aparece un jinete en postura victoriosa, blanco sobre fondo negro, saltando o sobrevolando la cumbre de una montaña, símbolo de la Trinidad según Smolik ${ }^{107}$, símbolo de los obstáculos que el jinete ha de superar hasta llegar a la mansión espiritual según Overy ${ }^{108}$. El capítulo dos abre con un grabado en madera de apariencia claramente circular, pero en el que (conociendo la obra de Kandinsky) aún se reconocen la figura del jinete y del caballo. El caballo mira hacia la derecha, las patas delanteras levantadas. El jinete ocupa la parte central, en blanco, su contorno zigzagueado. Y todo ello está rodeado por una forma circular. Es la ilustración 34 .

La portada del almanaque El Jinete Azul muestra un San Jorge a caballo con casco aunque esta vez sin lanza, teñido de azul para subrayar aún más la espiritualidad. Porque el color azul es «el color típicamente celeste», una

107 BeHr, Kandinsky. Malerei 1908-1921, p. 153.

108 Overy, Kandinsky, p. 62. 


\section{El arte abstracto como experiencia espiritual}

llamada a la pureza, a la inmaterialidad. El hecho de que el caballero fuera San Jorge es causa, al parecer, ${ }^{109}$ de disconformidad entre Marc y Kandinsky, que además de reparar la disputa por carta, ofrecen para la posteridad una versión oficial y casi superficial de por qué el título del almanaque es el que es: «el nombre "El Jinete Azul" lo inventamos en el cenador de Sindelsdorf; a los dos nos gustaba el color azul, a Marc los caballos, a mí los jinetes. Y el nombre vino por sí solo» ${ }^{110}$. La veracidad de la historia la pone en entredicho la segunda mujer de Kandinsky. También por el hecho de que en 1903, ocho años antes de publicar el almanaque, Kandinsky ya pintó un cuadro con ese mismo nombre, El Jinete Azul, y porque en 1909 realizó una segunda versión que luego desechó pintando encima. ${ }^{111} \mathrm{O}$ que la figura del jinete, incluso bajo el nombre de San Jorge, aparezca en numerosas obras de Kandinsky, entre ellas las Improvisaciones II, III, IX o XII. La idea de que a Kandinsky y a Marc "simplemente les gustaban los caballos azules", idea que descuida el componente espiritual de esta figura, está por desgracia bien extendida. ${ }^{112}$

\subsubsection{El círculo cósmico}

La figura del jinete a caballo representa a San Jorge y el triunfo de lo espiritual en el arte. El jinete simboliza la lucha contra el materialismo y anuncia la llegada de un nuevo arte. Todavía con rasgos figurativos, es la figura central de la época expresionista de Kandinsky. A medida que la abstracción obtiene madurez expresiva, el jinete y su caballo se transforman paulatinamente en una forma circular, hasta que la forma se vuelve autónoma y se convierte en un círculo geométrico.

La figura del círculo concentra tanto o más significado que el caballo y

109 KLeIne, Gabriele Münter und Wassily Kandinsky, pp. 398-399.

110 Kandinsky, Kandinsky und ich, p. 59.

111 Lindsay, The Genesis and Meaning of the Cover Design for the First Blaue Reiter Exhibition Catalogue, p. 48.

112 Kenneth Lindsay no duda de la veracidad de la historia y sin embargo apuesta por la espiritualidad del símbolo. Según Lindsay, «this undramatic name-giving episode does not lead me to doubt my interpretation of the meaning of the desing. On the contrary, the casual development of the ideal seems to correspond to the slow, irregular, and hesitant evolution of the artistic form-idea», en Lindsay, The Genesis and Meaning of the Cover Design for the First Blaue Reiter Exhibition Catalogue, p. 49. 
su jinete. Nace de ellos, y por eso arrasta toda la connotación espiritual del San Jorge. Pero además tiene otras características que lo convierten en una forma más evolucionada. Es lo que viene a decirle Kandinsky a Paul Plaut en una entrevista: «El motivo (o la razón) por la que en los últimos años, por ejemplo, uso tan frecuente y apasionadamente el círculo, no es por la forma "geométrica» del círculo, o sus propiedades geométricas, sino mi fuerte sensación de la fuerza interior del círculo en sus innumerables variaciones; hoy amo el círculo como antes amé, por ejemplo, el caballo... y tal vez ame más el círculo porque en él encuentro más posibilidades interiores, por eso vino a reemplazar al caballo» ${ }^{113}$.

La ausencia de ángulos confiere una tensión constante a la línea curva que forma el círculo, es una tensión que ni empieza ni acaba sino que está en continuo movimiento. A la vez, como la tensión se reparte por todo el perímetro, el círculo es una figura estable, quieta, precisa. Esto hace que el círculo sea una síntesis de contradicciones, la unión de diferentes propiedades que le dotan de un carácter único. El círculo concentra en una sola imagen el movimiento y la quietud, tensiones inagotables, fuerza expresiva, el ser todo y a la vez no ser más que una línea curva cerrada en sí misma. El círculo es, en potencia, cualquier sensación.

Todas las formas son seres vivos que despiertan emociones vivas («un triángulo provoca una emoción viva porque es un ser vivo»), también el círculo. Pero su unicidad, la concentración de todas las fuerzas expresivas que alberga el círculo, le hacen capaz de crear, de ser un creador. De la sencillez aparante que despide, el círculo puede crear porque engendra en sí el todo. El círculo de Kandinsky tiene un rasgo de creador, de figura demiúrgica dentro del cuadro. El círculo se impone al resto de las formas con solemnidad, como el jinete vence al dragón o el mundo espiritual prevalece sobre el material. Es el símbolo cósmico por excelencia, la figura cósmica que todo lo abarca ${ }^{114}$, es el vínculo con el mundo cósmico y espiritual ${ }^{115}$, es la forma que acerca al espectador a la cuarta dimensión ${ }^{116}$.

113 Plaut, Die Psychologie der produktiven Persönlichkeit, p. 308. Las comillas son originales.

114 WeIss, Kandinsky in Munich, pp. 129-132.

115 Bunge, Zwischen Intuition und Ratio, p. 177.

116 HaHL-Koch, Kandinsky, p. 289. 


\section{El arte abstracto como experiencia espiritual}

La fuerza espiritual que desprende el círculo se percibe en muchos cuadros. Azul, Rojo pesado o Círculos en un círculo son algunos ejemplos. El círculo imprime al cuadro un carácter solemne o espacial y cierto halo de trascendencia. Es la expresión contenida de una sensación indescriptible, interna, espiritual, que se transmite directamente al alma. Con Algunos círculos, un cuadro de 1926, Kandinsky alcanza el punto culminante de la expresión espiritual. Es un cuadro creado exclusivamente con el círculo como elemento de composición, lo que no impide que su fuerza expresiva sea extraordinaria.

Algunos círculos es un fondo negro con muchos círculos sobre él. El color negro no es uniforme, está lleno de matices. La figura principal es un gran círculo azul, situado más o menos céntrico. Está directamente rodeado por una aureola blanquecina, algo difusa. Sobre él se superponen otros círculos de tamaño y color variados, sin orden o estructura aparente. A su alrededor sólo hay más círculos: cada uno de un tamaño y de un color. Las dimensiones del cuadro son casi las de un cuadrado, por lo que la resonancia que emite es equilibrada. No tiende al frío ni tampoco al calor, no tiende a la altura ni a la profundidad, no es activo ni es pasivo. La resonancia de la superficie del cuadro es puro equilibrio. El negro, como color de fondo, ofrece un soporte neutro, que no se decanta por un color ni refleja ningún otro. Los círculos dominan el cuadro y se imponen frente a todo lo demás. El protagonismo del círculo es irrefutable.

El espacio en el que se asientan los círculos es equilibrado y de color neutro. Pasa claramente a un segundo plano, alejándose del espectador y permitiendo que los círculos se acerquen a él. El espacio negro, anodino y lejos del espectador parece quedar deslocalizado, como si fuera un espacio sin espacio ni tampoco tiempo. Es un cosmos infinito, que flota, que sirve de base a la creación.

El gran círculo azul ejerce de centro de gravedad alrededor del cual se dispersan el resto de círculos, como estrellas atraídas por una fuerza magnética. La aureola blanca que rodea el círculo azul proporciona una gran sugestión cromática y refuerza su expresión cósmica. El halo blanco y el círculo menor de color negro que lo tapa recrean en el gran círculo azul la imagen de un eclipse lunar.

Los círculos flotan en el espacio como planetas sometidos a la gravedad. Son círculos de diferentes tamaños y colores que vagan en un espacio de silencio. Cada círculo produce una resonancia diferente y provoca en el alma una 


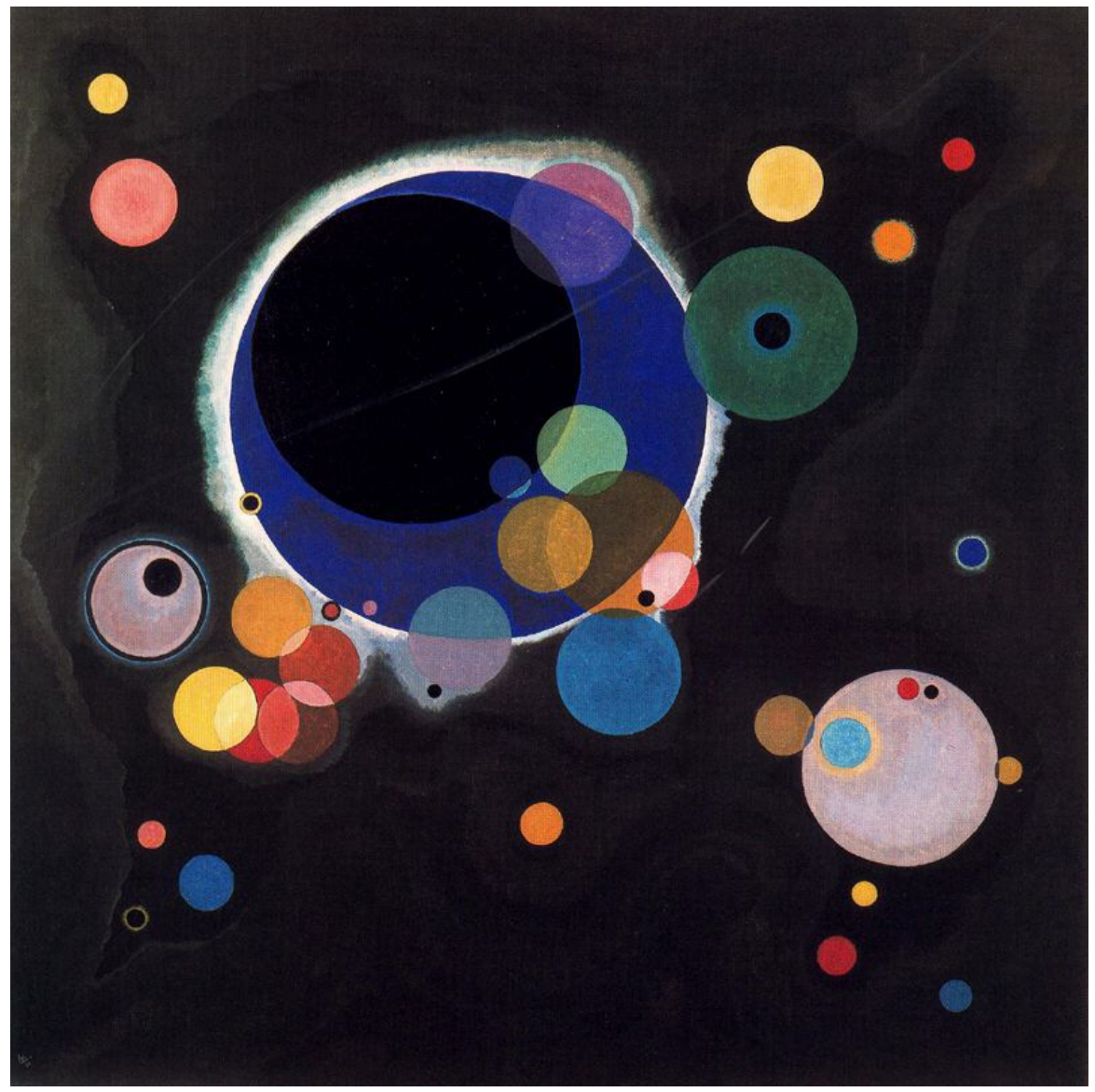

Ilustración 35 Algunos círculos, 1926

sensación única. Hay círculos livianos, ligeros, que se desplazan por el espacio lentamente, como si fueran burbujas. Hay círculos pesados, de movimiento lento, replegados en sí mismos. Colores cálidos que transmiten potencia y tenacidad. Círculos inestables, atrapados entre fuerzas de otros círculos. Cada círculo tiene una expresión individual y hace vibrar al alma de manera diferente. Cuando los círculos se encuentran y chocan producen nuevas sensaciones. Se superponen las tonalidades, las resonancias aumentan y se crean más tensiones. Crean un mundo nuevo. La creación de la obra es la creación del mundo (Werkschöpfung ist Weltschöpfung). 



\section{El arte abstracto como condición neuroestética}

Was Hirnforscher heute entdecken, das wusste die Kunst schon immer.

ERNST PÖPPEL

Los descubrimientos de la neurología en relación a la percepción visual, y por ende, en relación a las artes visuales, son aún muy recientes. La disciplina que intenta combinar ambos campos, arte y neurología, se ha estrenado bajo el nombre de neuroestética hace apenas treinta años. Aún es pronto para asegurar la calidad de los temas, los investigadores y sus resultados. Por este motivo, el primer apartado de este capítulo (7.1) presenta una breve recopilación de lo que actualmente parece más relevante, sin olvidar que es sólo una parte de todo el panorama. La investigación neuroestética es por el momento mayoritariamente científica, lo que significa que la literatura se compone de artículos (papers) escritos por grupos de trabajo, que las publicaciones están marcadas por fuerte presión competitiva o que los métodos son mayoritariamente de ensayo y error. Los temas y los resultados están en revisión constante; las discusiones aún llevan la etiqueta de la controversia.

El estudio de la obra de Kandinsky bajo la perspectiva neurológica es muy escasa y la que hay, es superficial y con poco rigor académico. El segundo apartado (7.2) presenta una hipótesis neuroestética que interpreta el lenguaje abstracto de Kandinsky basándose en la sinestesia como condición biológica. Como toda hipótesis, está abierta a discusión, así como a nuevas teorías y experimentos que la confirmen o la descarten.

La última sección (7.3) introduce ejemplos artísticos que reinterpretan la obra de Kandinsky, bien considerando aspectos neurológicos en general, bien partiendo en concreto de la sinestesia. La presentación de una artista sinestésica y su creación artística basada en este fenómeno, cierra el capítulo.

El capítulo incluye referencias directas a los episodios vitales de Kandinsky marcados por la sinestesia (capítulo 1) y al contexto pictórico de la época (capítulo 2, sección 2.2), especialmente a la pintura de Cézanne. 
7 El arte abstracto como condición neuroestética
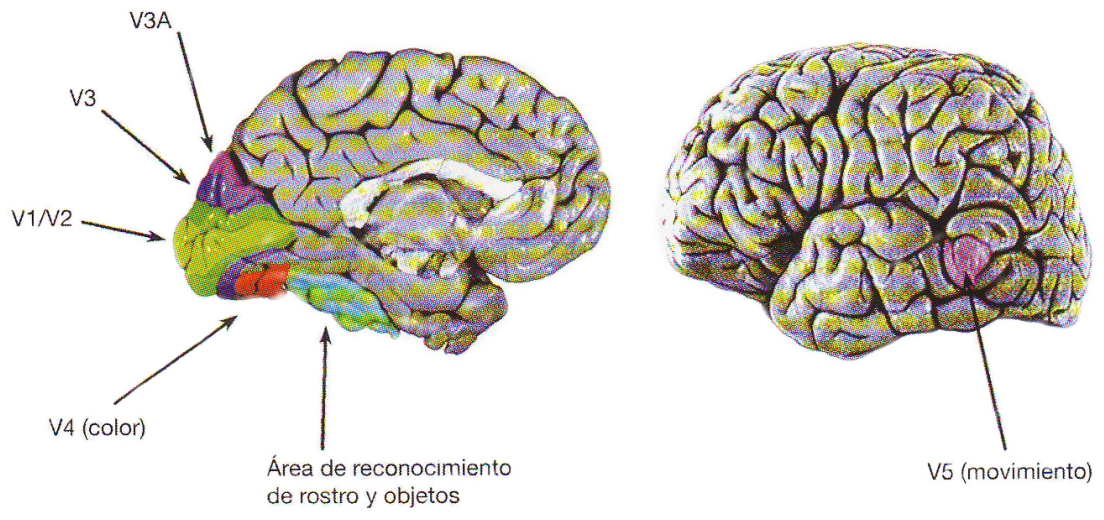

Ilustración 36 Áreas de la parte visual del cerebro 


\subsection{Lo neuro-}

Los avances que la física presenta a lo largo del siglo xx son de tal magnitud que provocan un cambio de paradigma. Los descubrimientos de Einstein o Planck obligan a una reformulación de teorías, tanto en el campo de la ciencia como en los colindantes. Pero al margen de la conmoción que esto produce, la física también consigue mejorar las condiciones de vida y hacer del mundo un lugar más cómodo y manejable.

Hoy en día parece que se ha llegado a un nivel de confort que la física ya no puede mejorar, o no con la rapidez que lo hizo el láser, por poner un ejemplo. Los ordenadores cuánticos tardarán en llegar y la teoría de cuerdas está aún en sus primeras fases. La física aporta nuevo conocimiento, es obvio, pero actualmente es difícil que introduzca cambios sustanciales en la calidad de vida. Parece que ha llegado el turno de las ciencias más cercanas a lo biológico, cuyos avances y logros pueden mejorar directamente el bienestar personal del hombre: mejorar la salud, conocer la herencia genética o curar enfermedades.

El conocimiento del sistema neural es uno de los pasos claves en esta investigación por el bienestar del hombre, y de ahí la emergencia de la neurología. El interés por esta ciencia aumenta a pasos agigantados. Cada vez hay más publicaciones en journales científicos y también en revistas divulgativas. Las universidades han creado en los últimos años nuevos puestos y departamentos relacionados con el tema, lo que refleja, además, la gran inversión. La neurología está planteando y empezando a resolver cuestiones decisivas para la comprensión del ser humano, especialmente porque las relaciona con otros campos de investigación. La neurobiología, la neurofísica, la neuroeconomía, la neuroestética y hasta el neuromárketing: todas estas disciplinas acaban de nacer al amparo de la neurología y sus respectivos campos. Poco más de una década transcurrida, y el siglo xxi ya lleva, entre otros calificativos, el prefijo de lo neuro-.

La neuroestética es la nueva disciplina en la que colaboran el arte y la neurología. El contacto entre el arte y la ciencia viene, sin embargo, de muy lejos. A lo largo de la historia, muchos científicos, historiadores, artistas o filósofos han relacionado estas dos disciplinas. Por ejemplo, los estudios científicos sobre la sensación y la percepción han ayudado a muchos artistas a entender técnicas o métodos de representación. A su vez, la ciencia está presente en mu- 
chas obras de arte, bien como tema central, bien en una presencia insinuada o como fuente de inspiración. Desde La lección de anatomía del Dr. Tulp hasta las imágenes ampliadas de neuronas que expone CosmoCaixa ${ }^{1}$, pasando por personajes de cuadros en los que se reconoce el signo de Babinski ${ }^{2}$. Incluso la biografía personal y pictórica de los artistas ha ayudado a psicólogos y filósofos a desentrañar muchos aspectos del proceso creativo. John Onians, el renombrado historiador y fundador de la revista Art History, ha publicado un libro en el que desgrana esta relación a lo largo de los siglos, desde Aristóteles hasta Zeki, y sin desaprovechar la ocasión para acuñar un nuevo término de prefijo neuro-: neuroarthistory. ${ }^{3}$

La novedad de la relación actual entre el arte y la ciencia es el enfoque claramente biológico, centrado en lo neuronal. Martin Skov, uno de los autores que investigan las bases cerebrales de los procesos estéticos, señala que la ciencia -la bioestética, precisa- está actualmente (2006) interesada en responder tres preguntas. ${ }^{4}$ La primera es qué es el arte y la estética. La segunda, cómo surgen el arte y la estética del cerebro humano. Y la tercera, por qué evoluciona esta habilidad cognitiva en los seres humanos. Las tres preguntas requieren respuestas desde campos diferentes. El qué, relaciona el trabajo de biólogos, antropólogos, historiadores y filósofos que buscan el significado y/o la función de los primeros objetos artísticos, la naturaleza del arte en las sociedades o cuáles son los rasgos que definen el arte. El por qué evoluciona el arte, también pone en común estudios genéticos, arqueológicos, bioevolutivos o incluso psicológicos. Es la segunda pregunta, la del cómo surgen el arte y la estética del cerebro la que requiere de investigación común entre neurólogos, artistas y estéticos, y que hace surgir la nueva disciplina de la neuroestética.

1 Exposición Paisajes neuronales en CosmoCaixa de Barcelona, del 06.04. al 26.11.2006, o en CosmoCaixa de Madrid del 17.06.2008 al 17.05.2009.

2 Signo de Babinski: extensión dorsal del dedo gordo del pie en respuesta a una estimulación plantar que, salvo en los neonatos que es normal, indica lesión del tracto piramidal. El niño de Virgen con el Niño y Ángel de Botticelli refleja el síntoma. Véase Massey y Sanders, Babinski's Sign in Medieval, Renaissance, and Baroque Art para más ejemplos.

3 Onians, Neuroarthistory.

4 Véase la entrada o post $A$ short bibliographic guide to the emerging field of bioaesthetics, donde además de plantear las tres preguntas, ofrece una jugosa lista bibliográfica sobre el tema. En su blog, http://brainethics.wordpress.com/2006/09/27. 


\subsubsection{Qué es la neuroestética}

Las teorías estéticas sólo son inteligibles y verdaderamente profundas cuando se basan en el trabajo del cerebro. Ninguna teoría estética podrá estar completa, y no digamos ser profunda, a menos que tenga una base biológica.

SEMIR ZeKI

La neuroestética como disciplina nace aproximadamente en la década de los 80 , años en los que ven la luz las primeras publicaciones catalogables bajo ese término, neuroestética. ${ }^{5}$ Es difícil precisar la sucesión cronológica de ideas y acontecimientos que dan lugar a la neuroestética (mejor dicho, sería tarea de la neuroarthistory), pero para establecer un marco de referencia se pueden nombrar algunas. Las técnicas de estudio del cerebro mejoran notablemente, la inversión económica también crece. Ya es posible visualizar el cerebro en vivo mientras la persona realiza una acción, lo que abre el campo a estudios nuevos e imaginativos, antes impensables. ¿Cómo estudiar la respuesta al arte en un cerebro muerto o totalmente "quieto"? Ahora es posible ver cómo responde el cerebro humano mientras se contempla un cuadro de Mondrian. En segundo lugar, se publican estudios clínicos sobre personas con daños cerebrales que, casualmente, guardan cierta relación con el arte. Por ejemplo, el caso de un pintor que después de sufrir una lesión cerebral cambia radicalmente de estilo artístico, ${ }^{6}$ que es uno de los casos que seguro invitó a otros experimentos y encendió la chispa de la imaginación en más de un neurólogo. Nacía la pregunta de ¿qué relación hay entre el daño cerebral y la expresión artística? Si el estudio llevó a la idea o la idea organizó el estudio es como ordenar huevos y gallinas. En cualquier caso, la cronología no es tan importante como empezar a dar forma a una disciplina que se está gestando. Los primeros pasos de esta tarea, y parece que nadie lo pone en duda, los emprende el neurobiólogo Semir

5 Un primer ejemplo puede ser el artículo de Semir Zeki sobre la representación de los colores en el córtex cerebral, publicado en Nature en 1980, aun cuando Zeki todavía pertenecía al Departamento de Anatomía porque no se había creado la cátedra de Neuroestética. Véase ZEKI, The Representation of Colours in the Cerebral Cortex.

6 AnNoni et al., Changes in Artistic Style After Minor Posterior Stroke. Otros ejemplos similares son Sacks y Wasserman, The Case of the Colorblind Painter o Miller y Hou, Portraits of Artists. 
Zeki.

Semir Zeki ocupa la primera cátedra mundial de neuroestética en el Institute of Neuroesthetics -también el primero en esta especialidad- que está asociado al Wellcome Laboratory of Neurobiology (Vislab) en el University College de Londres. ${ }^{7}$ Su tarea es estudiar las bases biológicas del arte o de la estética para impulsar y consolidar la idea de que el proceso creativo es una manifestación de las funciones del cerebro. Aunque la investigación va paso a paso y de momento está centrada en el arte, entre sus objetivos señalan el de «promocionar la importancia de saber más sobre el cerebro cuando se trata de temas como el arte, la moralidad, la religión, la justicia o los asuntos públicos en general. (...) En concreto, aumentar la conciencia pública de la importancia que la investigación cerebral tiene a la hora de entender la actividad humana» ${ }^{8}$.

El dominio $w w w$.neuroesthetics.org es la página de referencia de la neuroestética en general, incluyendo al instituto londinense. Zeki presenta en la página todo tipo de eventos relacionados con el tema, su blog académico, enlaces a otras páginas destacadas y una referencia directa a artistas, galerías y exhibiciones vinculadas al mundo neurocientífico través de su arte. La página también alberga la ya famosa Statement on Neuroesthetics (Declaración sobre la neuroestética) de Semir Zeki, escrito en el que explica el porqué y las pretensiones de la disciplina. ${ }^{9}$

El enfoque de la neurología que a su vez adopta la neuroestética es que toda actividad humana depende de y obedece a las leyes del cerebro. Si Zeki escribe en su Declaración toda actividad humana es porque realmente alude a todas ellas, incluyendo actividades tan poco materiales como la religión o la justicia. El arte, como actividad humana que es, depende entonces del cerebro y obedece a sus leyes. Ésta es la clave, según Zeki, de por qué la pregunta qué es el arte no ha obtenido una respuesta satisfactoria hasta ahora: se ha obviado la relación del arte con el cerebro. Si el arte es una actividad humana y como

\footnotetext{
7 http://www.vislab.ucl.ac.uk/

8 En la página web sobre neuroestética creada por Zeki, en relación al Instituto de Neuroestética: http://www.neuroesthetics.org/institute.php. Traducción propia, del inglés.

9 http://neuroesthetics.org/statement-on-neuroesthetics.php
} 
tal su proceso es cerebral, la respuesta de qué es el arte ha de tratarse desde el punto de vista neurológico.

Zeki apuesta por que conocer las bases neurales del cerebro visual permitirá conocer las bases del arte visual. ${ }^{10}$ Esta convicción es una de las tres premisas sobre las que trabaja la neuroestética. La primera supone que todo arte visual debe obedecer las leyes del cerebro visual, bien sea en la concepción, en la ejecución o en la apreciación. La segunda premisa, que la función del arte visual es una extensión de la función del cerebro visual, principalmente la de adquirir conocimiento. Zeki lo explica así: «Tengo la convicción de que, en gran medida, la función artística y la función de la parte visual del cerebro son una y la misma cosa o, al menos, las intenciones artísticas constituyen una extensión de las funciones del cerebro» ${ }^{11}$. Y la tercera premisa afirma que todo artista es, de alguna manera, un neurocientífico que estudia a través de su arte las capacidades del cerebro visual, sólo que con técnicas propias (y diferentes de las neurológicas). ${ }^{12}$

Estas tres premisas sientan las bases de trabajo de la neuroestética. El objetivo no es otro que el de encontrar las bases biológicas de la estética o, dicho de otro modo, el de entender el funcionamiento del cerebro visual para explicar el funcionamiento de la experiencia estética. En palabras de Onians, Semir Zeki propone una nueva teoría estética basada en la neurociencia. ${ }^{13} \mathrm{~A}$ partir de aquí, neurólogos, psicólogos, filósofos y artistas tratan de dar contenido y resultados a la disciplina. $\mathrm{Ni}$ el proceso ni los métodos ni las preguntas están realmente definidas, aún es pronto para ese tipo de rigidez académica. Sí parece haber, al menos, un cierto esquema general subyacente al que todos se acogen, al margen de las desviaciones esperables. Es el siguiente: los neurólogos (1) investigan la organización neuronal el cerebro, (2) apoyándose en la

\footnotetext{
10 De momento parece que la neuroestética se está centrando en el arte visual, aunque sus intenciones finales sean abarcarlo todo. Probablemente se haya comenzado la investigación por ahí porque el 50\% de la corteza cerebral está dedicada a los procesos visuales (frente al $2 \%$ auditivo, por ejemplo).

11 ZeKI, Visión interior, p. 19.

12 Las citas originales de las tres premisas, en su página web, dicen así: (1) «all visual art must obey the laws of the visual brain, whether in conception or in execution or in appreciation»; (2) «visual art has an overall function which is an extension of the function of the visual brain, to acquire knowledge»; y (3) «artists are, in a sense, neurologists who study the capacities of the visual brain with techniques that are unique to them».

13 Onians, Neuroarthistory, p. 192.
} 
experimentación artística y la reflexión estética, para (3) explicar el proceso de creación y percepción de la experiencia estética. En cada uno de estos pasos hay experimentos neuronales, reflexiones filosóficas y ejemplos artísticos.

Los neurólogos quieren entender cuáles son los principios que rigen la organización del cerebro visual. Es decir, cómo funciona el cerebro frente a una tarea visual. Cómo percibe, cómo procesa la información, cómo le da sentido o significado. Uno de los métodos que siguen (el mayoritario, hasta ahora) es localizar qué neuronas o regiones cerebrales participan en el proceso visual. Para ello utilizan las técnicas clásicas de la neurociencia, las resonancias magnéticas. Según los estudios publicados, las más frecuentes son tres. La tomografía por emisión de positrones (PET, por sus siglas en inglés), la imagen por resonancia magnética (MRI) y la imagen por resonancia magnética funcional (fMRI). Sin entrar en detalle de cómo funciona cada una, estas técnicas no invasivas permiten descubrir qué zonas utiliza el cerebro para realizar una actividad concreta. Cuando una neurona determinada responde a una señal (como ver una imagen) aumenta su actividad y con ella su porcentaje metabólico, lo que incrementa la demanda de sangre oxigenada. La fMRI, por ejemplo, muestra en la imagen este aumento de flujo sanguíneo y con él la localización de la neurona "encargada" de responder a una imagen visual. La gran ventaja de esta técnica es que puede ser utilizada en vivo, mientras el sujeto realiza una acción como pintar, observar, recordar, fantasear o sentir una emoción. El uso de estas y otras técnicas permite establecer un patrón de activación de las áreas del cerebro, revelando qué neuronas o regiones son responsables de qué actividad o actividades (si son simultáneas).

La localización neuronal por actividades construye poco a poco un mapa estructural del cerebro. Este mapa ayudará a entender los principios que rigen la organización del cerebro visual, uno de los objetivos de los neurólogos. Y a su vez, obligará a los filósofos a replantearse viejas preguntas desde otra perspectiva. ¿Hay criterios objetivos para el juicio estético? ¿Son comunes a todo hombre (a todo cerebro) o son propios de cada individuo? ¿Depende el concepto de belleza (únicamente) del cerebro humano? ¿Existe para el cerebro un concepto de belleza a priori o es una construcción a posteriori? ¿Está determinada la creación estética por la organización cerebral personal? Son sólo un par de preguntas, la lista será larga y replanteable a cada paso que dé la neuroestética. 
Uno de los mejores campos para descubrir la organización del cerebro visual es, según los neurólogos, el campo del arte. Como científicos que son, parten de que el arte, por ser indispensable para la supervivencia humana, ha de tener una base biológica. Por este motivo y porque consideran que el cerebro artístico es una extensión del cerebro visual (Zeki: «todo arte visual obedece las leyes del cerebro visual»), el arte se convierte en un campo idóneo de experimentación. Y más si la historia del arte ofrece siglos y siglos de imágenes, o en terminología neuroestética, de experimentación visual. Los artistas, a través de obras, métodos y estilos, han explorado la capacidad que tiene el cerebro de enfrentarse a lo visual. Reproducción fiel de la naturaleza, perspectiva, trampantojos, escenas surrealistas, separación del color y la forma, arte abstracto o colores fauvistas: a la neurología no le faltan ejemplos con los que enfrentar al cerebro en una resonancia magnética. Los artistas, en su mayoría, no han sido conscientes de que la exploración visual de la pintura suponía una exploración indirecta de la organización del cerebro, pero la consciencia o inconsciencia de tales experimentos y obras de arte parece no tener (aún) importancia en la investigación neuroestética. Los neurólogos aprovechan toda esa exploración como punto de partida. Así lo resume Zeki: «la mayoría de los pintores también son neurólogos, aunque en un sentido diferente: experimentan y entienden, inconscientemente, la organización de la parte visual del cerebro mediante unas técnicas que son exclusivamente suyas. (...) Que los pintores experimentan es algo sabido. Lo hacen trabajando un cuadro una y otra vez hasta que logran el efecto deseado, hasta que les gusta, que es lo mismo que decir que complace a sus cerebros» ${ }^{14}$.

El estudio del cerebro a través del arte permitirá entender cómo percibe el cerebro, cómo transforma los inputs de la percepción y cómo clasifica esa información. El paso siguiente será entender cómo una obra de arte consigue despertar emociones, cómo maneja el cerebro esas emociones estéticas y cómo asocia el cerebro valor estético a una obra de arte. Zeki es claro al respecto: "cómo pueden despertar experiencias estéticas tales creaciones [artísticas] es algo que sólo puede ser plenamente entendido en términos neurales. Un entendimiento tal está hoy a nuestro alcance. El primer paso es entender mejor la organización común de nuestros cerebros visuales (...). Cómo una actividad visual común puede despertar estados emocionales dispares, constituirá el

14 ZEKI, Visión interior, p. 20. 
siguiente paso» ${ }^{15}$. Las conclusiones a las que llegue la neuroestética, e incluso a las que ya va llegando, descifran la estructura cerebral. Sin embargo, las pretensiones van más allá (al menos hoy en día): la idea es que artistas y espectadores, al conocer los mecanismos que intervienen en el proceso estético, entiendan y valoren el arte de otra manera. O que incluso, las revelaciones de la neuroestética supongan una revolución en la producción artística.

La situación actual de la investigación neuroestética es difícil de determinar, por su juventud y por su multidisciplinariedad. Aún es algo difuso concretar qué trabajos son decisivos y de qué calidad. ${ }^{16}$ En Europa hay (al menos) dos centros de investigación dedicados exclusivamente a la relación entre la neurología y las humanidades. Uno de ellos es el Institute of Neuroesthetics que dirige Semir Zeki en Londres desde 2001. El otro es la Berlin School of Mind and Brain ${ }^{17}$, otra de las instituciones pioneras en la investigación neuroestética, incluyendo programas doctorales y postdoctorales.

Además de estos centros de investigación directa, hay varias asociaciones que tienen como tema central la neuroestética. En ocasiones sin ánimo de lucro, organizan simposios, congresos, exposiciones o concursos y sirven de plataforma o lugar de encuentro y discusión para artistas, profesores, científicos, filósofos y toda persona relacionada con la neuroestética. Uno es la Association of Neuroesthetics ${ }^{18}$, que nace en 2008 en Berlín y que cuenta con la colaboración de más de una docena de instituciones: desde el propio Instituto londinense en el que trabaja Zeki hasta la fundación Guggenheim alemana o el Human Science Center de la Universidad de Múnich ${ }^{19}$. En Italia destaca la Italian Society of Neuroesthetics Semir Zeki ${ }^{20}$, fundada en $2005 \mathrm{y}$ con el nombre de su presidente honorífico. A pesar de ser una asociación levantada sólo con trabajo de voluntarios, su programa de exposiciones, publicaciones y conferencias es de consideración. En México, Luc Delannoy ha fundado el Centro de Investigaciones en Neuroestética y Neuromusicología (CINNe) ${ }^{21}$,

\footnotetext{
15 En su Statement on Neuroesthetics.

16 El peligro de obviar alguno importante es inevitable. Pero tampoco se pretende una lista del panorama actual, sólo un par de ejemplos.

17 http://www.mind-and-brain.de/

$18 \mathrm{http}: / /$ www.association-of-neuroesthetics.org/

19 http://www.hwz.uni-muenchen.de/

20 http://www.neuroestetica.it/
} 
otra asociación con muchas expectativas pero aún en fase inicial de desarrollo. Y en España, la Sociedad Española de Neurología (SEN) ${ }^{22}$ empieza a colaborar con artistas y filósofos y a dar sus primeros pasos en neuroestética.

Al margen de las asociaciones o institutos propiamente neuroestéticos, lo cierto es que gran parte de los experimentos se están realizando en los centros universitarios o de investigación habituales, aunque no lleven el sobrenombre de la neuroestética. Vilayanur S. Ramachandran y William Hirstein son dos figuras de peso en este campo, de la misma manera que no se puede obviar la referencia a la obra de Eric Kandel o a la de Oliver Sacks. Edward M. Hubbard, Carlos Redies, Gemma Calvert, Francisco Mora, Daniel J. Levitin o Niels Birbaumer encabezan una lista inabarcable de nombres que el tiempo y los resultados redefinirán.

Los temas de investigación que abre la neuroestética son muy amplios, de ahí que los experimentos necesarios para confirmarlos o refutarlos sean tan diversos. De momento, las líneas de investigación o las posibilidades técnicas tienden a cercar la diversidad, pudiendo agrupar - por mera cuestión metodológica- los experimentos en tres tipos. Uno de ellos consiste en comparar el cerebro de un profesional con el de un aficionado mientras realizan la actividad que les une (por ejemplo, tocar el piano en el caso de un músico). Los neurólogos intentan descubrir las diferencias y similitudes entre ambos para descifrar la respuesta cerebral al aprendizaje, la percepción, la ejecución o la memoria. La fMRI suele revelar grandes diferencias entre el cerebro del profesional y el del aficionado. Un ejemplo publicado es el de Lotze, Scheler y Birbaumer, que analizan la relación entre la percepción y la creación musical basándose en el estudio del cerebro de un músico profesional y de un aficionado. ${ }^{23}$ En el caso de la pintura, en el año 1999 se llevó a cabo un experimento similar, ${ }^{24}$ que comparaba el cerebro de un pintor profesional de retratos, Humphrey Ocean, con el de un aficionado copiando otro retrato. La

\footnotetext{
21 http://www.lucdelannoy.com/CIN.html

22 http://www.sen.es/

23 Véase el artículo From music perception to creative performance: Mapping cerebral differences between professionals and amateur musicians, publicado en Deliege y Wiggins, Musical Creativity, pp. 275-289.

24 El experimento es parte del proyecto SciArt del Wellcome Trust de Londres. Véase Berger, The Painter's Eye, Miall y Tchalenko, A Painter's Eye Movements, y también el comentario al respecto en Onians, Neuroarthistory, p. 166. Otro experimento de características similares es Solso, Brain Activities in a Skilled versus a Novice Artist.
} 
resonancia magnética volvió a revelar divergencias de activación cerebral. El cerebro del profesional activa más regiones que el del aficionado.

Otro tipo de experimentos se centra en el tema de la sinestesia, fenómeno por el que el cerebro parece responder a un solo estímulo con una sensación doble (ve colores al escuchar un sonido musical, por ejemplo). Sobre la sinestesia hay experimentos de varias clases. Unos están centrados en descubrir el porqué del fenómeno, comparando el cerebro de un sinestésico con el de alguien que no lo es. Ramachandran y Hubbard son los investigadores principales, ${ }^{25}$ que han demostrado la base biológica de la sinestesia: el cerebro sinestésico reacciona de manera diferente al cerebro del que no lo es. Otros experimentos indagan en el cómo, en la reacción del cerebro sinestésico expuesto al estímulo que le produce sinestesia. Suele realizarse una fMRI mientras el sujeto contempla los colores que le provocan un sonido para ver qué áreas del cerebro se activan. En los sinestésicos, suelen activarse las dos áreas implicadas, aunque sólo haya estímulo externo para una de ellas. ${ }^{26}$

Un tercer tipo de experimentos investiga directamente sobre el concepto de belleza. El español Cela Conde y sus colaboradores publicaron un artículo en $2009^{27}$ en el que investigan las posibles diferencias de género en los correlatos neuronales de la experiencia estética. Los resultados constatan diferencias significativas en la actividad cerebral, según fuera hombre o mujer. Pero sin duda, el experimento que más ha dado que hablar en los círculos neuroestéticos es el que llevaron a cabo Semir Zeki y Hideaki Kawabata. ${ }^{28}$ En él, expusieron trescientas imágenes a un número de personas que debían catalogarlas como bellas, neutras o feas en una escala del uno al diez. ${ }^{29} \mathrm{~A}$ continuación les presentaron las mismas imágenes mientras se les realizaba una resonancia magnética, para ver qué estructuras cerebrales reaccionaban al visionado y cómo lo hacían según la belleza de la imagen. El córtex órbito frontal medial presentó una actividad más intensa (mayor flujo sanguíneo) al percibir los

25 Véase Ramachandran y Hubbard, Hearing Colors, Tasting Shapes, Ramachandran y Hubbard, The Phenomenology of Synaesthesia o Ramachandran y Hubbard, Synaesthesia - A Window Into Perception, Thought and Language.

26 Véase el e-book de Dermietzel, Musik als Entwurfsgrundlage für Architektur?, por ejemplo, y cualquiera de los artículos recién citados de Ramachandran y Hubbard.

27 Cela-Conde et al., Sex-related Similarities and Differences in the Neural Correlates of Beauty.

28 Kawabata y Zeki, Neural Correlates of Beauty.

29 Bellas ( 7 a 10), neutras ( 5 a 6 ) y feas ( 1 a 4). Las imágenes eran variadas: paisajes, retratos, pintura abstracta y bodegones. 
cuadros más bellos. El córtex motor, en cambio, reflejó mayor actividad al presenciar lo que previamente habían catalogado como fealdad. El experimento concluyó que el córtex órbito frontal medial (también relacionado con el placer y la recompensa) y el córtex motor son las áreas cerebrales vinculadas al juicio estético. Evidentemente, esta localización ha despertado comentarios, agrados y recelos por parte de la comunidad filosófica, por concluir una posible objetividad del juicio estético.

La neuroestética como disciplina no ha hecho más que empezar. A los nombres y experimentos brevemente presentados hay que añadir muchos más y, sobre todo, en constante desarrollo. De momento, los temas se centran (a grandes rasgos) en la localización cerebral de actividades artísticas y en las diferencias de activación, según ciertas características de los sujetos. Muchas preguntas aún no pueden responderse porque la técnica no ha avanzado lo suficiente, porque no se han diseñado experimentos adecuados o simplemente por falta de tiempo. La neuroestética ha empezado a resolver algunas preguntas, pero muchos de los grandes temas de la estética como la calidad, la belleza, la creatividad, la inspiración o la genialidad siguen estando abiertos.

\subsubsection{Los primeros resultados}

La neurología ha presentado en estos últimos treinta años un buen número de estudios que tienen relación directa con el arte. La gran mayoría han sido realizados según las directrices de la ciencia, es decir, con metodología analítica, pruebas experimentales y rigurosidad en los procedimientos. Incluso antes de publicarse han sido sometidos al escrutinio de dos o más árbitros (los referees de cada revista). Con este proceso, parece indudable la veracidad de los resultados obtenidos, o al menos dentro de lo que la ciencia considera hoy como válido. Sin embargo, la exactitud de las pruebas o la solidez de las conclusiones son sólo hechos científicos -neurológicos-. Para que verdaderamente pueda hablarse de neuroestética no basta con que el tema de estudio sea el arte, también hace falta una interpretación o aplicación estética.

De todos los resultados que se están presentando, hay tres con los que la filosofía del arte, los artistas e incluso los espectadores pueden empezar a trabajar. El primero es la confirmación de que el ojo no ve, lo hace el cerebro. 
El segundo es la modularidad del cerebro. Y el tercero es la semejanza que presentan las leyes del cerebro respecto a las del arte.

Durante siglos se ha dado por cierto la teoría de que el ojo cumple la función de ver, de que el ojo es quien ve. Incluso hoy en día es una creencia difícil de desterrar, tal vez porque, además de los siglos de tradición, parece contraintuitiva. En realidad, no es que el ojo deje de ser el órgano visual, sino que cambia la función que se le ha estado atribuyendo. Hasta mediados del siglo $\mathrm{xx}$ se cree que los sentidos son un reflejo perfecto del mundo exterior y el ojo una especie de cámara fotográfica que todo lo capta. El ojo recibe a través de la retina una imagen fiel a la realidad, una especie de fotografía que envía al cerebro y éste la recibe pasivamente.

Sin embargo, esta teoría tan intuitiva y lógica en apariencia, era contradicha por numerosas obras de arte sin que, durante un tiempo, se reparara en la posible relación imagen-cerebro. La mera existencia de la perspectiva o de las ilusiones ópticas, indica que la imagen que "ve" el ojo no puede ser la misma que recibe el cerebro, porque de algún modo, el cerebro "entiende" profundidad en una obra con perspectiva pintada en un lienzo plano o "reconoce" dos imágenes contradictorias donde en apariencia "ve" una sola, como en ciertas ilusiones ópticas. Los cuadros de Magritte juegan a menudo con lo que podría llamarse el sentido común visual, aludiendo a una distancia entre la visión de la imagen y el procesamiento de ésta. De alguna manera, la distancia entre lo visto y lo procesado deja un momento de perplejidad, lo que parece indicar que el cerebro no recibe tan pasivamente la imagen "fotográfica" que le envía la retina. Cézanne y sus cuadros de la montaña de Santa Victoria son otro ejemplo que contradice la teoría de que el ojo transmite la imagen elaborada al cerebro. Ejemplo utilizado, por cierto, por muchos neuroestéticos, empezando por Zeki. ${ }^{30}$ Los cuadros de Cézanne ponen de manifiesto que el cerebro es capaz de construir una imagen, la de una montaña, allí donde sólo hay manchas de color. Si el ojo sólo ve esas manchas de color y así, como imagen terminada, se la transmite al cerebro, ¿cómo es que el cerebro logra

30 Además del capítulo 12 de ZeKI, Visión interior, también hay que reseñar la obra de LEHRER, Proust Was a Neuroscientist, que dedica un capítulo entero a la obra de Cézanne desde un punto de vista neurológico. El libro de Lehrer se ha publicado recientemente en español como Proust y la neurociencia, en Paidós (2010). 
darle una interpretación, logra "ver” una montaña?

Los primeros científicos que empezaron a investigar estos contraejemplos fueron los psicólogos de la Gestalt, en torno a 1930. Basándose en formas determinadas y en ciertas ilusiones ópticas, fueron los primeros en señalar que la percepción visual no refleja la realidad exterior como un espejo y así se lo transmite al cerebro. Retomaron en cierto modo la teoría kantiana de que la percepción exterior necesita de una aportación interior. La teoría de la Gestalt afirma que el cerebro organiza de la mejor manera posible lo que percibe y lo procesa como una totalidad, siguiendo unas leyes generales. Estas leyes, que recibieron el nombre de Leyes de la percepción, explican de qué manera el cerebro organiza lo que percibe. Ejemplos conocidos son la ley del cierre, por la que el cerebro construye una forma conocida agrupando detalles (como líneas discontinuas que "forman" un cuadrado); la ley de la semejanza, que relaciona elementos por proximidad (el cerebro forma líneas cuando sólo se ven puntos, por ejemplo) o la ley que permite al cerebro distinguir las figuras del fondo en una imagen. Más que las leyes en concreto, la importancia de la teoría de la Gestalt consistió en disociar el proceso visual. Anunciaron que la percepción es un proceso en el que no sólo interviene la vista, sino en el que el cerebro también participa "organizando" las imágenes.

La neurología moderna ha confirmado la exploración artística de Cézzane o Magritte y las hipótesis de la Gestalt. La visión comienza en el ojo, pero sólo como puerta de las partículas de luz. El ojo se limita a la fotorecepción, deja pasar los estímulos luminosos que la retina convierte en impulsos eléctricos. El nervio óptico transmite esos impulsos hasta el cerebro, a la región de la corteza visual. Lo que la corteza visual recibe sólo es información suelta de color, forma, profundidad, brillo o movimiento. El cerebro se encarga de procesar esa información y darle un sentido, reconocer una forma, identificar distancias o detectar movimiento. Antes de que el cerebro organice la información, la imagen percibida se acerca más a las manchas de color que a la montaña de Santa Victoria. Sólo cuando el cerebro trabaja la información, puede reconocer la montaña. ${ }^{31}$

Los inputs de información entran por el ojo y llegan hasta el cerebro siguiendo dos caminos, uno rápido y otro lento (la diferencia son milisegundos). El rápido transmite una imagen general, difusa, algo borrosa de lo percibido

31 LeHrer, Proust Was a Neuroscientist, pp. 96-119. 
a la corteza prefrontal, la región del cerebro que participa en el pensamiento consciente. Mientras tanto, en el camino lento la información es parcial (sólo color, por ejemplo) pero más meticulosa, y la recibe la corteza visual (la llamada región $\mathrm{V}_{1}$ ). 50 milisegundos después, esta información llega al córtex prefrontal. Una vez unidas ambas informaciones, el cerebro organiza la imagen, asimila todos los elementos y le da un sentido: forma el objeto, con color, movimiento y su localización espacial.

El papel que tiene el cerebro en la percepción visual es uno de los casos que ratifican a Zeki cuando afirma que los artistas son neurólogos que exploran el cerebro con otros instrumentos. Cézanne explica con sus cuadros postimpresionistas cómo la experiencia visual va más allá de la mera percepción, sacando a la luz que el cerebro es capaz de transformar manchas de color en formas conocidas y que el cerebro sabe rellenar los huecos de información que le deja el artista para tener una sensación visual completa. Parece que adelantaba años de neuroestética en las palabras que se le atribuyen: «El ojo no basta. Uno necesita pensar también ${ }^{32}$.

El descubrimiento de que el cerebro interviene activamente en la percepción visual ha sido el punto de partida para descifrar otras claves neurológicas. La modularidad de la visión es el segundo de los resultados que no sólo ayudan a comprender cómo trabaja el cerebro, sino que pueden modificar planteamientos artísticos pasados y futuros. ${ }^{33}$

Los últimos experimentos neurológicos han demostrado que el cerebro tiene más de un área visual o, mejor dicho, que la corteza visual primaria (V1) está subdvidida en otras regiones, cada una de ellas con una tarea propia. Cuando el nervio óptico envía las señales a $V_{1}$, la información se agrupa en compartimentos diferentes según sus características, que se distribuyen al área especializada correspondiente. Es decir, V1 distribuye información de un solo atributo (color, o forma, o profundidad) al área especializada en procesar ese atributo. En palabras de Zeki: «el cerebro maneja atributos diferentes de la escena visual en subdivisiones diferentes, geográficamente distintas» ${ }^{34}$. Cada

32 Becks-Malorny, Cézanne, p. 46.

33 Algunos de los muchos artículos que demuestran la modularidad de la visión son ZEKI y BARtels; The Autonomy of the Visual Systems and the Modularity of Conscious Vision; ZeKI, Colour Vision and Functional Specialisation in the Visual Cortex; ZeKI, The Representation of Colours in the Cerebral Cortex; o el capítulo 7 de ZEKI, Visión interior. 
área es autónoma y procesa un tipo de información sin depender de un área central, como si cada una de ellas fuera un "módulo".

La especialización funcional del cerebro visual no se limita sólo a esas áreas o subregiones. Las células individuales que componen cada área también están especializadas en procesar un solo tipo de información. En el área del color, por ejemplo, las células son tan selectivas que responden sólo a un tipo de señal, es decir, de color: «una célula puede ser selectiva ante el color y responder al rojo pero no al blanco ni a otros colores» ${ }^{35}$. A su vez, estas células sólo son receptivas al color, lo que significa que les es indiferente qué forma tiene ese color, si se mueve o en qué dirección lo hace. De la misma manera, las células que en el área de la forma sean receptivas a las líneas horizontales no responderán ante el color o al movimiento.

Existe un área anatómicamente identificable para cada uno de los atributos de la escena visual, o al menos para los que se han descubierto hasta ahora (véase la ilustr. 36, pág. 274.) ${ }^{36}$ Lo que significa que cada atributo se procesa en partes diferentes de la corteza visual del cerebro: $V_{4}$ es la región encargada de responder al color, tanto al natural como al artificial; ${ }^{37} \mathrm{~V}_{3}$ parece especialmente sensible a las formas y $\mathrm{V}_{5}$ está especializada en el movimiento. Hay, por tanto, una diferencia espacial o geográfica en la recepción. Y también la hay temporal, porque no todos los atributos se perciben a la vez y por tanto no todos los impulsos son simultáneos. El color es el impulso que más rápido recibe el cerebro, seguido de la forma (unos 40 milisegundos después). El movimiento tarda unos 60 y 80 milisegundos más que el color. Es decir, de una imagen el cerebro recibe primero de qué color es, luego qué forma tiene y por último si se mueve o no y cómo lo hace. Para la neurología, esto sugiere que existe cierta jerarquía temporal en la visión, al margen de que cada área especializada funcione modularmente en paralelo. Para el arte, esto puede suponer un cambio en la percepción y creación artística. Teniendo en cuenta las técnicas y soportes multimedia de hoy, se podría “jugar” con el cerebro ofreciéndole movimiento antes que color o forzando las distancias mínimas, convirtiéndolas en perceptibles conscientemente.

34 ZEKI, Visión interior, p. 77.

35 ZeKI, Visión interior, pp. 78-79.

36 La ilustración pertenece a ZEKI, Visión interior, p. 34.

37 Zeki y Marini, Three Cortical Stages of Colour Processing in the Human Brain. 
Zeki vuelve a señalar cómo esta especialización o modularidad cerebral que ahora confirma la neurociencia la han explorado los artistas con antelación. Mondrian hace de las líneas rectas un elemento composicional clave, aislándolas del color y de otros elementos, tal y como organiza el cerebro. $\mathrm{O}$ el arte cinético de Jean Tinguely (1925-1991), por ejemplo, tiende a eliminar el color de sus obras móviles para enfatizar el movimiento, como si estuviera ofreciendo al cerebro una información previamente diseccionada.

El tercer resultado que ofrece la neurología y que presenta estrecha relación con el arte tiene que ver con las leyes de organización cerebral. Zeki afirma que el cerebro visual y el arte visual comparten un gran número de leyes, de las que destacan dos.

Una es la ley de la constancia. La función principal del cerebro visual es adquirir conocimiento del mundo exterior, como puede ser reconocer un objeto o una cara. El problema principal al que se enfrenta es la mutabilidad, porque el mundo exterior está en continuo cambio. El cerebro aprende a extraer lo constante, la esencia de cada objeto o escena visual para reconocerlo, independientemente de si alguno de sus atributos ha cambiado: otro color, otra dimensión, otras condiciones de luz. El cerebro sabe reconocer lo constante. El arte, o al menos ciertos estilos, operan de manera similar. También buscan lo constante en lo mutable para representar la esencia de lo exterior. Los cubistas quisieron representar lo constante de las cosas al margen de los detalles, un punto de vista único o toda perspectiva. En lenguaje de Zeki, los cubistas llevaron a cabo «un intento inconsciente de imitar las habilidades perceptivas del cerebro». La reducción a las esencias que introduce Kandinsky en su nuevo lenguaje abstracto es otro ejemplo de la ley de la constancia. Por eso Zeki concluye: «la adquisición de conocimiento mediante el registro de las características constantes y esenciales de los objetos es la función primordial del cerebro visual. También es la función primordial del arte». ${ }^{38}$

La otra, estrechamente relacionada, es la ley de la abstracción. Zeki se refiere al proceso por el que lo particular se subordina a lo general, de tal manera que se crea un concepto o una representación que puede aplicarse después a muchos particulares. El cerebro abstrae constantemente, aunque la neurología aún no ha sabido determinar cómo. Sí el porqué: seguramente para

38 Ambas citas en: ZeKI, Artistic Creativity and the Brain, pp. 51-52. 
superar las limitaciones de la memoria y no tener que recordar cada detalle o cada objeto individual, que sería un verdadero lastre. Cuando habla del uso de la absrtacción en el arte, Zeki no se refiere al arte abstracto como tal, sino más bien a que el arte es la expresión de un proceso de abstracción cerebral, lo cual puede decir mucho neurológicamente, pero apenas es relevante estéticamente. Explica que el arte «exterioriza el trabajo interno del cerebro y por eso su función primordial es reflejo de la función del cerebro» ${ }^{39}$, una formulación tan amplia como aplicable a distintas teorías artísticas.

A raíz de que cerebro y arte comparten al menos estas dos leyes, y basándose en su premisa de que las leyes del cerebro visual son las del arte visual, Zeki no tiene reparos en afirmar que si la visión es modular, «la estética también es modular» ${ }^{40}$. Esta afirmación parece categórica, aunque es la conclusión obvia (eso sí, neurológica y no estética) de las leyes con las que funciona el cerebro.

La especialización del cerebro significa que cada área procesa un tipo de información diferente. El área $\mathrm{V}_{4}$ es responsable del color y el $\mathrm{V}_{5}$ del movimiento, lo que implica que se dan dos percepciones diferentes: una sobre el color y otra sobre el movimiento. Una persona que tenga una lesión en la región $\mathrm{V}_{5}$ será incapaz de percibir el movimiento, pero eso no le impide apreciar el color. De la misma manera en la que está especializado el cerebro, el sentido estético también lo está. No existe un solo sentido estético como no existe un solo área que perciba toda la escena visual. Existe un sentido estético por cada área de percepción visual. Dice Zeki: «no existe un solo sentido estético visual, sino muchos, cada uno vinculado a la actividad de un sistema visual, procesual y funcionalmente especializado ${ }^{41}$. Lo que significa que la persona con daños en la región $V_{5}$ será incapaz de apreciar la estética de un móvil de Tinguely, pero podrá seguir disfrutando del colorido de un cuadro fauvista porque tiene sana la $\mathrm{V}_{4}$.

Esta primera conclusión no implica que el efecto estético del color se deba exclusivamente a la actividad del área $\mathrm{V}_{4}$, precisa Zeki, pero que, siendo $\mathrm{V}_{4}$ imprescindible para la visión del color, ésta no sería posible sin aquella. ${ }^{42}$

39 ZEKI, Artistic Creativity and the Brain, pp. 51-52.

40 ZEKI, Visión interior, p. 77.

41 ZEKI, Visión interior, p. 107.

42 ZEKI, Visión interior, p. 104. 
Evidentemente, un paciente con el área $\mathrm{V}_{4}$ dañada sería incapaz de apreciar la estética de un cuadro impresionista. Pero un paciente con el área del lenguaje dañada, también sería incapaz de hablar o leer.

En definitiva, Zeki matiza que el área $\mathrm{V}_{4}$ no es la única responsable de la estética del color, pero sí mantiene que la estética, como la visión, es modular y por tanto, que se puede hablar de la estética del color, la estética del movimiento o la estética de la forma. El planteamiento ha llegado a la comunidad filosófica y psicológica, pero aún es pronto para hablar de reacciones o incluso hipótesis. Zeki, obviamente, cree que la explicación a la modularidad de la estética pasa por descifrar la estructura cerebral:

«Todavía no sabemos cómo la información de las áreas visuales individuales nos proporciona nuestra imagen acabada del mundo visual, en la que están registrados todos los atributos de la visión. Sin duda, una vez sepamos algo de este problema fundamental, comenzaremos a saber más de la estética superior a la que contribuyen las distintas estéticas individuales. ${ }^{43}$ "

\subsubsection{Las primeras reacciones}

Las primeras reacciones a la neuroestética no se han hecho esperar. Algunos comentarios han surgido a raíz de los primeros resultados y al menos otros tantos, de la mera declaración de intereses de la neuroestética. Por eso, y porque la neuroestética aún está en fase de desarrollo, hay que observarlos con cierta cautela.

Por el momento, la neuroestética ofrece más hipótesis que resultados. Y en muchos casos tampoco está claro a quién corresponde confirmar o descartar esas hipótesis, si al neurólogo, al filósofo, al artista o a la labor de un trabajo en común. Las tareas no están delimitadas ni mucho menos definidas, lo cual provoca una sana heterogeneidad pero también situaciones algo esperpénticas, de neurólogos simplificando el concepto de belleza o de filósofos empeñados en que es el ojo el que ve. Actualmente, la presencia de neurólogos en el campo

43 ZEKI, Visión interior, p. 108. 
de la neuroestética es mucho mayor que la de los filósofos y se puede caer en la falacia de que cantidad llegue a implicar calidad. El dogmatismo de algunos neurólogos, como Zeki en ocasiones (y la perplejidad de ciertos filósofos), tampoco ayuda. En la mayoría de los artículos o libros que se están publicando parece que la neuroestética resolverá de un plumazo y simplemente con una explicación neuronal todas las cuestiones artísticas y estéticas que llevan siglos preocupando a filósofos e historiadores del arte (y que según Zeki no han sabido responder porque se han olvidado del cerebro). Lo que sí tiende a olvidarse es que la relación entre arte y ciencia debería ser bidireccional. En cualquier caso, tampoco se puede dudar rígidamente de una disciplina que todavía no está asentada y que apenas ha dado unos primeros resultados, sobre todo porque una buena conjunción de arte y ciencia además de fascinante puede ser muy prometedora.

La neuroestética ha despertado muchas opiniones, algunas bien negativas, pero en su mayoría cargadas de interés constructivo. Una de las críticas que más se repiten se refiere al uso del vocabulario. Los filósofos, acostumbrados al rigor semántico, echan en falta una definición clara de ciertos términos, como el de "estética". Zeki habla de la estética del color o de la modularidad de la estética, pero no ofrece una definición clara de qué quiere decir con ello, una precisión que es de esperar si realmente quiere definir una teoría estética basada en la neurociencia.

En realidad, éste es uno de los mayores problemas que presenta la neuroestética cuando sienta en la misma mesa de trabajo a neurólogos y filósofos del arte: que no siempre hablan el mismo lenguaje. Las connotaciones filosóficas que tienen palabras como cerebro, entendimiento o mente suelen desaparecer entre los neurólogos, o son drásticamente reducidas a "cerebro". Citas en las que Goethe habla del color y su influencia en el alma se resuelven en la neuroestética traduciendo alma por cerebro, lo que quita el sueño a muchos filósofos. ${ }^{44}$ También que se mezcle sin pudor el tema de la empatía con el de las neuronas espejo, por citar otro ejemplo.

El concepto de belleza es otro punto discordante. Los neurólogos suelen referirse al concepto de belleza hablando, generalmente, en términos helénicos

44 Otro ejemplo: Winckelman habla de la imaginación y Zeki traduce "para nosotros, cerebro». En ZEKI, The Neurology of Ambiguity, p. 192. 
de armonía, proporción y equilibrio, adjetivos que al parecer le son gratos al cerebro. ${ }^{45}$ La filosofía del arte, sin embargo, ha renovado y redefinido el concepto de belleza en varias ocasiones a lo largo de estos últimos siglos, y no siempre identificándolo con la belleza clásica. Parece obvio que, al menos en este punto, hace falta acercamiento.

Otra de las críticas recurrentes es la de acusar a la neuroestética de ser una simple localización neuronal y no una verdadera teoría estética. Es cierto que hasta el momento, los resultados neuroestéticos se han centrado en localizar las áreas y neuronas encargadas de las tareas relacionadas con el arte, como la apreciación del color en $\mathrm{V}_{4}$ o del movimiento en $\mathrm{V}_{5}$. La localización puede ser un primer paso hacia la comprensión de cómo percibimos, el arte visual entre otras cosas, pero señalar el lugar de la actividad no equivale a explicar los porqués. Sólo explica qué parte del cerebro está trabajando al percibir los colores de un cuadro impresionista, pero nada sobre el gusto o el carácter de la belleza. Filósofos y neurólogos discrepan en la pregunta de si la producción mental y artística se explica únicamente con la estructura neuronal. Los porqués, que tanto gustan a los filósofos, no parecen tener respuesta concluyente en los dóndes de los neurólogos. Mientras la neuroestética sólo localice dónde se activa el cerebro, la filosofía no cree que pueda responder todas esas preguntas con las que lleva años bregando. No obstante, la localización de ciertos fenómenos como el de la sinestesia, o el hallazgo de la especialización del cerebro visual no pueden desdeñarse de ningún modo en la construcción de una nueva teoría estética. Es posible que sólo haga falta tiempo y nuevos experimentos.

Al hilo de las críticas por la localización, surgen otras voces (algo más disconformes) que desdeñan la neuroestética porque la acusan de reduccionista. Dicen que tratar de explicar algo tan etéreo, tan sensorial, tan espiritual como el arte basándose en la organización cerebral es una burda simplificación. El artículo de Zeki que presenta el experimento sobre la belleza ${ }^{46}$ puso a muchos artistas y filósofos en pie de guerra con la neuroestética, por la posible conclu-

45 Un curioso ejemplo: la Sociedad Española de Neurología organizó un curso de neuroestética para la xxiII Edición de los Cursos de Verano de El Escorial (2010), Neuroestética: cerebro, mente y belleza. La presencia de ponentes neurólogos fue mayoritaria. El tema de la belleza desde el punto de vista de la estética se trató en una sola ponencia: la de Carlos García Gual, extraordinaria, pero centrada en la belleza griega.

46 Kawabata y Zeki, Neural Correlates of Beauty. 
sión (reducción) de que el juicio estético se convirtiera o resultara ser asunto de un grupo de neuronas objetivas. Además, las investigaciones de Ramachandran sobre la sinestesia destilan un marcado carácter materialista, ${ }^{47}$ lo que ha levantado más de una ampolla entre la comunidad filosófica y artística. Sólo hay que echar una ojeada al volumen especial que el Journal of Consciousness Studies dedicó en 1999 al arte y al cerebro ${ }^{48}$ para comprobar la de comentarios que responden a Ramachandran, suaves o mordaces pero todos bien críticos.

La opinión de muchos historiadores del arte, curadores y algún filósofo es que la neuroestética no define una nueva teoría, sino que se limita a reducir el arte a pura ciencia, y eso es precisamente lo que el arte no es ni será. Critican, como el historiador del arte Partha Mitter o la curadora Julia Kindy, que los neurocientíficos se olvidan de los factores culturales, tan determinantes en la creación estética. O que se basan en ejemplos simples, superficiales o únicos para generalizar sobre toda la creación artística. También cuestionan, como ya se ha comentado, la noción de belleza que utilizan los neurocientíficos, especialmente la simplista de Ramachandran.

Lo cierto es que, por muy materialista que sea el enfoque de Ramachandran, a la hora de explicar la sinestesia no se le puede negar que ha dado un valioso paso al frente para las teorías estéticas. Ha esclarecido biológicamente la existencia de la sinestesia, un fenómeno a caballo entre la realidad y la imaginación hasta hace bien poco. La existencia probada de la sinestesia permite a los filósofos acercarse y reinterpretar bajo una nueva perspectiva a ciertos artistas como Charles Baudelaire, Oliver Messiaen o Wassily Kandinsky. Y en lo que atañe a la creación artística, los experimentos sinestésicos han servido de punto de partida para nuevas obras de arte de nuevos artistas, que hacen de la sinestesia uno de sus temas capitales.

Es verdad que muchas de estas críticas ponen a la neuroestética bajo la lupa exigente de la filosofía, pero eso no la desautoriza completamente. La neurología y la estética tienen que aprender a trabajar conjuntamente, a ser realmente neuro- y -estética, lo que implica un gran esfuerzo por ambas par-

47 Joseph A. Goguen define el enfoque de Ramachandran como «decidedly unapologetically materialist and reductionist», en Goguen, Art and the Brain, p. 6.

48 El especial se titula Art and Brain, siguiendo el título del famoso artículo de Semir Zeki, también incluido. Journal of Consciousness Studies, volumen 6, número 6-7, año 1999. 
tes. Uno que supere los aires de grandeza de la ciencia que la filosofía no soporta y otro que permita a la ciencia realizar su trabajo en consonancia con la prolijidad y suspicacia de la filosofía. Goguen parece que apunta en esta dirección mediadora cuando escribe que «por supuesto, los resultados de la ciencia siempre están abiertos a una variedad de interpretaciones filosóficas y culturales, y el reduccionismo es en sí mismo una postura filosófica. Por este motivo, el trabajo científico en las áreas humanísticas no puede eliminar las humanidades. Por otra parte, como las artes desempeñan un papel completamente diferente en la sociedad, están en una posición aún más resistente. Pero esto sólo significa que ambas partes tienen puntos fuertes desde los cuales pueden contribuir al gran debate» ${ }^{49}$.

Y en medio de este gran debate, los mismos que empezaron explorando inconscientemente el funcionamiento del cerebro, los artistas, son quienes vuelven a aportar su gran grano de arena a la neuroestética. Hay artistas que se acogen al marco neuroestético para presentar obras de temas científicos, como las fotografías de neuronas aumentadas que emanan cierto halo de arte abstracto. Si bien en el fondo, esas imágenes poco difieren -funcionalmentede los dibujos originales de Ramón y Cajal o de Golgi. Ni siquiera de los diseños originales que hacía Hermann Obrist para sus fuentes, inspirándose en la imagen microscópica de elementos macroscópicos.

Pero también hay artistas en cuyas obras de arte se adivinan los resultados de la neuroestética y cómo intentan aplicarlos o reflejarlos. Puede ser de manera inconsciente, como lo hizo Cézanne con su montaña de Santa Victoria, Malévich con sus cuadrado ${ }^{50} \mathrm{o}$ Kandinsky con su nuevo lenguaje abstracto. $\mathrm{O}$ de forma consciente y plenamente buscada, enfatizando el uso de una forma $o$ de un color a sabiendas (neuroestéticas) de que el cerebro siente cierta sensibilidad por él o lo percibe de manera especializada. Hay artistas que juegan con la luz en el espacio (al parecer hay un área para la percepción del brillo y otra para la profundidad) como el arquitecto Philippe Rahm; hay quien explora a través del movimiento como Isia Leviant; o hay quien se ayuda de los efectos multisensoriales de la sinestesia como Ditte Lyngkær Pedersen.

49 Goguen, Art and the Brain, p. 6.

50 Zeki opina que Malévich «may have such coloured squares in [his] paintings precisely because they provide such cells with maximum stimulation», en OnIans, Neuroarthistory, p. 198. 


\subsection{Lo -estético}

\subsubsection{La sinestesia, condición biológica}

Algunos científicos (sobre todo, los físicos) y algunos artistas (sobre todo, los músicos) llevan tiempo observando que, por ejemplo, un sonido musical provoca la asociación de un determinado color. Dicho de otro modo: ustedes "oyen" el color y "ven" el tono.

W. KANDINSKY

El tema de la sinestesia ha sido tratado a lo largo de los años de diferentes maneras y desde diferentes puntos de vista, con pocas coincidencias en los resultados obtenidos. Durante siglos, la sinestesia fue un fenómeno del que se desconocía casi todo, incluido si era real o pura imaginación del paciente. La extrañeza de los síntomas, como escuchar colores o ver números en el espacio, hizo que inicialmente fuera objeto de estudio de psicólogos y psiquiatras, que ni siquiera disponían de medios eficaces para investigarlo. Con frecuencia, la sinestesia encontró mejor asiento en la literatura, donde esas asociaciones raras y multisensoriales eran fácilmente encubiertas por la metáfora. La poesía aceptaba sin problemas "caricias rosas" o "sonidos azules de un violonchelo".

En el último tercio del siglo xix, la neurología empieza a investigar la sinestesia a través de pacientes que aseguran saborear idiomas o escuchar colores. Pero como es un fenómeno que no afecta a la vida diaria -incluso la hace más agradable y rica en matices-, no está incluida en la lista de trastornos $\operatorname{cognitivos}^{51}$ y de ahí la falta de atención clínica. A la luz actual de la neuroestética, cuyos objetivos van más allá de analizar sólo los trastornos cerebrales, la sinestesia ha cobrado protagonismo. No sólo porque la neurología dispone ahora de nuevas técnicas y métodos, sino porque la localización de las áreas del cerebro visual ayuda a identificar las zonas sinestésicas y, sobre todo, porque la sinestesia puede tener una estrecha relación con el arte (se vislumbra alguna teoría sobre la relación entre creatividad y sinestesia o sobre la sinestesia como base del lenguaje artístico). Actualmente hay grandes investigadores dedicán-

51 Ramachandran, Neuroscience: Beauty or Brains?, p. 193. 
dose al tema de la sinestesia. V. Ramachandran y Edward M. Hubbard por un lado y S. Baron-Cohen y J. E. Harrison por otro, han publicado numerosos artículos científicos; otros, como Richard E. Cytowic, tratan de acercar el tema al público escribiendo además libros divulgativos. ${ }^{52}$

La palabra sinestesia tiene origen griego: deriva de syn (junto) y aisthesi (sensación). A modo de primera definición, puede decirse que se trata de una fusión de sensaciones que se unen en el acto de la percepción. Una mezcla de impresiones de diferentes sentidos. Los neurólogos la definen como una "condición en la que un individuo tiene experiencias perceptuales multimodales de un evento sensorial unimodal ${ }^{53}$ o como «la condición en la cual la estimulación de una modalidad sensorial causa experiencias inusuales en una segunda modalidad no estimulada ${ }^{54}$. Es decir, la sinestesia es un aglutinamiento de percepciones: un estímulo provoca una respuesta sensorial no sólo en el área que estimula, sino además en otra diferente. Por ejemplo, un color provoca una percepción visual y también auditiva (el sujeto ve un color y a la vez escucha un sonido).

Hay muchos tipos de sinestesia, Ramachandran cataloga actualmente unos cincuenta. ${ }^{55}$ Las más frecuentes son la de ver letras o cifras en colores y la que mezcla el sentido visual y auditivo, que hace percibir un color al escuchar un sonido o viceversa. Otras consisten en mezclar sabores y colores (una sopa que sabe azul), en asignar a conceptos temporales una localización espacial (los días de la semana, al escucharse o verse, se "colocan" en el espacio) o que un idioma o una sola palabra provoque la audición de un tono musical ${ }^{56}$. La neurología sigue trabajando en la definición y catalogación de los tipos de la sinestesia.

Los sinestésicos oyen colores, ven sonidos y saborean formas. Si hay algo que se les ha dicho a menudo es que simplemente hablan en sentido metafórico, que es una asociación que traen de la infancia o que han consumido algún tipo de droga. Pero la neurología ha demostrado que la sinestesia no es ninguna de

52 Véase la bibliografía para publicaciones de estos autores.

53 Palmeri et al., The Perceptual Reality of Synesthetic Colors, p. 4127.

54 Hubbard y Ramachandran, Neurocognitive Mechanisms of Synaesthesia, p. 509.

55 Ramachandran y Hubbard, Hearing Colors, Tasting Shapes, p. 22

56 Sobre este caso en concreto hay un estudio documentado, véase PAulesu et al., The Physiology of Coloured Hearing. 
estas tres cosas. Para empezar, sinestesia y metáfora no son lo mismo, al menos para el cerebro. La sinestesia es un efecto sensorial y no cognitivo, como sílo es la metáfora. El color que ve un sinestésico es una percepción real, mientras que la metáfora es una asociación conceptual. En palabras de Ramachandran, la sinestesia es una cross-activation perceptual y la metáfora una cross-activation conceptual. La base neurológica de la sinestesia también tira por tierra la posibilidad de que sea una asociación infantil (que de pequeño se hubiera jugado con figuras de números de colores, por ejemplo). Y la diferencia entre la sinestesia y las alucinaciones inducidas por drogas es que los sinestésicos, además de no tener que recurrir a ellas, experimentan asociaciones constantes y estables a lo largo del tiempo.

Los experimentos neurológicos han demostrado que la sensación sinestésica es real. Los colores sinestésicos activan las mismas áreas cerebrales que la percepción de colores reales; un sinestésico percibe el color que le produce un sonido de la misma manera que un no sinestésico percibiría ese color en la realidad. Si bien los colores que experimentan los sinestésicos no siempre encuentran un correlato directo en el mundo exterior. No es un simple verde o un rojo, son colores con mayor riqueza de matices; es por eso que los sinestésicos suelen tener que definirlos con varios adjetivos, a veces incluso multisensoriales. Las asociaciones sinestésicas son, además, consistentes e invariables a lo largo de la vida de la persona. No todos los sinestésicos coinciden entre sí, unos pueden ver el 3 morado y otros amarillo, pero cada sinestésico conserva sus propias asociaciones de por vida. Otra de sus características es ser una percepción involuntaria que se da siempre, sin que puedan prescindir de ella o reprimirla. ${ }^{57}$

Para entender cómo funciona la sinestesia cerebralmente se están utilizando las técnicas clásicas de la neurología: tomografías y resonancias magnéticas (PET, MRI, fMRI). Se expone a los sinestésicos al estímulo que les produce la

57 En los artículos citados en la bibliografía sobre sinestesia hay numerosos ejemplos de los experimentos que se han realizado en torno a ella. Uno de ellos, a modo de ejemplo, se realizó con sinestésicos que veían palabras en colores. Frente a una palabra escrita en un color, el sinestésico debía decir lo más rápido posible de qué color era la tinta con la que estaba escrita. Cuando el color de la tinta era el mismo que su color sinestésico, la respuesta era rápida. Pero cuando los colores diferían, la respuesta tardaba en llegar, porque el sinestésico tenía que resolver el conflicto perceptivo entre dos colores reales. Véase What is synesthesia?, en Scientific American (11 de septiembre de 2006). 
respuesta doble y se revisa qué partes del cerebro se activan. También se coteja el mismo procedimiento con personas no sinestésicas. Los sinestésicos presentan pluriactividad cerebral, en ellos se activan las áreas referentes a las dos sensaciones y no sólo a la del estímulo, como ocurre en los no sinestésicos. Además, las personas sinestésicas suelen experimentar emociones negativas si los estímulos son diferentes de los que ellos ven. Por ejemplo, una persona para la que el 8 es rojo, se alterará si ve un 8 amarillo, algo que no ocurre en un no sinestésico. Ese grado de alteración, según los psicólogos, puede incluso medirse objetivamente.

La causa de la sinestesia es algo que aún se desconoce. Algunos científicos creen que todos los niños nacen sinestésticos y que la separación de sensaciones forma parte del proceso evolutivo. Según van muriendo neuronas, las destinadas a las sensaciones se van quedando aisladas, provocando así la diferenciación entre los diferentes sentidos: olfato, gusto, tacto, vista y oído. Bajo este supuesto, los adultos sinestésicos serían individuos que conservan esa red neuronal que interrelaciona todos los sentidos. Pero tampoco se sabe por qué se dan estos casos. Otras teorías apuntan a que el cerebro sí sigue siendo capaz de experimentar sensaciones unidas (lo cual estimularía las oportunidades del arte), sólo que en el día a día, la práctica cae en desuso.

Los mecanismos neuronales de la sinestesia, es decir, qué ocurre exactamente en el cerebro de los sinestésicos, tampoco son muy claros. A medida que avanza la investigación se conocen imágenes más completas y complejas del cerebro, pero aún no se ha dado una solución única o definitoria. Ramachandran y Hubbard proponen cuatro hipótesis, ${ }^{58}$ de las cuales apuestan por una: la hiperconectividad cerebral. Hace ya más de un siglo se propuso que la sinestesia podría ser el resultado de una actividad cruzada (cross-activity) entre diferentes áreas del cerebro. Ahora, gracias a las imágenes del cerebro, se ha identificado dónde podría tener lugar esa conexión. En el caso de los sinestésicos que ven cifras en colores, por ejemplo, Ramachandran y Hubbard

58 Las cuatro hipótesis son (1) cross-activation o cross-wiring, (2) long-range disinhibited feedback, (3) re-entrant processing y (4) hyperbinding, cuya explicación es altamente científica y puede leerse en HubBard, Neurophysiology of Synesthesia; HubBard y Ramachandran, Neurocognitive Mechanisms of Synaesthesia; RamaCHANDran y HubBard, The Phenomenology of Synaesthesia; o RAmACHANDran y HubBard, Synaesthesia - A Window Into Perception, Thought and Language. 
apuestan por una activación entrecruzada del área numérica (zona fusiforme) y del área $\mathrm{V}_{4}$, el responsable del color. Creen, incluso, que esta hiperconexión se debe a una mutación genética que provoca una separación deficiente entre determinadas áreas, lo cual no sólo explica la respuesta múltiple sino también el hecho de que la sinestesia parezca ser hereditaria.

La demostración de que la sinestesia tiene una base neuronal ofrece una nueva perspectiva para planteamientos estéticos. Supone la veracidad de la sinestesia como condición biológica y por tanto, la oportunidad de incluirlo en el arte como medio propio de composición. También la posibilidad de confirmar teorías que intuyeron expresiones multisensoriales en artistas pasados, como es el caso de Kandinsky.

Los textos de Kandinsky, en especial Mirada retrospectiva y De lo espiritual en el arte, revelan numerosas comparaciones entre diferentes tipos de impresiones sensoriales. Algunas parecen ser comentarios puntuales, como la relación entre el tacto y la vista: «conocerá también el fenómeno de que su dedo, cuando lo "pasea" mentalmente por determinadas combinaciones sonoras o cromáticas, de pronto es "pinchado" como por espinas; o el de que, en otra ocasión, su dedo "pasea" por una pintura o por una música como sobre terciopelo o seda»; o la relación entre la vista y el olfato: «¿no es cierto que, por ejemplo, el violeta despide otro olor que el amarillo? ¿Y el naranja? ¿O el claro azul verdoso?» ${ }^{59}$. Pero lo cierto es que hay una combinación sensorial que se repite a menudo y que parece ser un indicio claro de experiencia sinestésica. Es la relación entre estímulos visuales (colores) y auditivos (sonidos), que queda reflejada en numerosas ocasiones. Alguno de los pasajes más claros incluyen la percepción de colores al escuchar el Lohengrin de Wagner, la percepción auditiva cuando los colores (pigmentos) salen del tubo o la gran sinfonía que componen los colores del atardecer de Moscú (todos ellos ya nombrados en el capítulo 1):

«Lohengrin me pareció que era una realización perfecta (...). Mentalmente veía todos los colores; los tenía ante mis ojos. Líneas salvajes, casi dementes, se dibujaban frente a

59 KANDINSKY, Escritos sobre arte y artistas, p. 201. Las comillas son originales. Se ha suprimido la cursiva en los colores. 
mí.

(...)

El pincel, que con una voluntad inflexible arranca fragmentos de ese ser vivo de los colores, hacía nacer una tonalidad musical cada vez que arrancaba un fragmento. A veces oía el sonido sibilante de los colores al mezclarse.

$$
\text { (...) }
$$

El sol hace que toda Moscú se funda en una mancha que, como una tuba enloquecida, hace entrar en vibración todo el ser interior, el alma entera. ¡No, no es la hora del rojo uniforme la más bella de todas! Ella no es más que el acorde final de la sinfonía que lleva cada color al paroxismo de la vida y triunfa sobre toda Moscú haciéndola resonar como el fortissimo final de una orquesta gigante. El rosa, el lila, el amarillo, el blanco, el azul, el verde pistacho, el rojo flamígero de las casas, de las iglesias - cada una con su melodía propia-, el césped de un verde demente, los árboles de grave zumbido, o la nieve de mil voces cantarinas, o también el allegretto de las peladas ramas, el anillo rojo, rígido y silencioso de las paredes del Kremlin.»

La descripción de estas experiencias multisensoriales viene corroborada por la teoría del color que Kandinsky presenta en De lo espiritual en el arte. La asociación entre colores y sonidos musicales es clara y está bien definida. El amarillo suena como una trompeta tocada con fuerza, el rojo cinabrio es una tuba y el violeta profundo un fagot. ${ }^{60}$ Kandinsky explica cómo suenan esos colores de la misma manera que lo hace un sinestésico: las asociaciones son constantes a lo largo de la vida y de su obra, son invariables e involuntarias. Kandinsky nunca emplea la palabra "sinestesia" como tal, pero viene a indicarla cuando dice que «el color tiene una fuerza enorme (...) que puede influir sobre todo el cuerpo humano» ${ }^{61}$, que «a veces, una mancha de un azul límpido y de una vigorosa resonancia (...) me subyugaba tan intensamente» ${ }^{62}$ o que «la calidad acústica de los colores es tan concreta que a nadie se le ocurriría

60 La relación completa puede releerse en la tabla 5.2, en el capítulo 5.

61 Kandinsky, De lo espiritual en el arte, p. 54. La cursiva es añadida.

62 Kandinsky, Mirada retrospectiva, pp. 202-203. 
reproducir la impresión que produce el amarillo claro sobre las teclas bajas del piano» ${ }^{63}$. No hay rastro de la palabra "sinestesia". Pero, a raíz de sus experiencias y de leer el relato de un médico cuyo paciente saboreaba azul una salsa, Kandinsky trata de explicar(se) el fenómeno diciendo que «un efecto a través del sabor alcanza inmediatamente el alma y provoca vibraciones en las vías que unen el alma con otros órganos sensoriales (en nuestro caso el ojo). (...) Si aceptamos esta explicación, tenemos que aceptar también que la vista no sólo está en relación con el sabor sino también con todos los demás sentidos. Y así ocurre, en efecto» ${ }^{64}$. Lo cierto es que la explicación de Kandinsky para la "sinestesia" a primeros del siglo xx tiene un notable parecido con la explicación de la sinestesia como cross-activity que Ramachandran ofrece a principios del xxi. Sólo hay que leer "alma” como "cerebro" y "provoca vibraciones" como "provoca actividad" en el área de otros órganos sensoriales.

Además de esta similitud hay otro episodio más que, según ciertos autores, evidencia la sinestesia audio-visual de Kandinsky. Se trata de la imagen eidética o extraordinaria memoria visual que posee, la que le permite retener cualquier detalle y "pintar en casa y de memoria cuadros que [le] habían cautivado particularmente en exposiciones». El investigador Peter Vergo se apoya en A. Luria y sus experiencias clínicas con un paciente mnemonista ${ }^{65}$ para afirmar que «clínicamente, el fenómeno de la memoria visual total suele asociarse con el de la respuesta sinestésica» ${ }^{66}$. Y en base a estas premisas, Vergo concluye que Kandinsky,

«cuando describe lo que sintió mientras oía Lohengrin o veía cómo salían los colores del tubo, en lugar de utilizar una elaborada metáfora o cualquier otro recurso literario, lo que nos está contando no [es] nada más ni nada menos que la verdad. Es decir, era genuinamente un sinestésico (...): alguien que ha experimentado de manera involun-

63 Kandinsky, De lo espiritual en el arte, p. 54.

64 En De lo espiritual el el arte (pág. 54) Kandinsky hace referencia a un médico de Dresde que tiene un paciente con la «sensación de que una determinada salsa sabía azul», pero el término "sinestesia" parece que le es desconocido. Teniendo en cuenta la descripción que hace y la nota a pie que añade Kandinsky, sería improbable que conociera el término y lo ocultara intencionadamente

65 Véase LuRIA, The Mind of a Mnemonist.

66 Arnaldo, Actas Symposium Analogías, p. 92. 
taria la sensación de color mientras escuchaba música -y también, probablemente, que ha oído algunos sonidos concretos como parte de su sensación de color-, todo ello sin intencionalidad ni intervención alguna de su mente consciente. ${ }^{67}{ }$ ”

Muchos autores están de acuerdo con Peter Vergo en que Kandinsky era sinestésico, aunque algunos sólo lo hagan desde la repetición de lo que parece una teoría más o menos consolidada; otros creen que era sinestésico desde la experiencia personal. Christine Söffing, artista sinestésica que colabora en el proyecto sobre música y arte experimental de la Universidad de $\mathrm{Ulm}^{68}$, cree que los «los cuadros de Kandinsky están hechos para ser escuchados». Ditte Lyngkær Pedersen, otra artista sinestésica, cree que «[Kandinsky] habla sin lugar a dudas como un sinestésico ${ }^{69}$. Pero, al no haber estudio neurológico que confirme la sinestesia de Kandinsky (ni serlo ya posible), la puerta queda abierta para ponerlo en duda. Algunos autores dejan la cuestión en el aire, por no considerarla determinante (como Hahl-Koch); otros rechazan la certeza de la sinestesia tratándola exclusivamente como metáfora (como López García). Amy Ione y Christopher Tyler quisieron zanjar el asunto en 2003 con un artículo titulado Was Kandinsky a Synesthete ${ }^{70}$ (¿Era Kandinsky sinestésico?) en el que concluyen que Kandinsky efectivamente lo era, aunque sus argumentos no tienen la fuerza necesaria para instalarse en la bibliografía posterior.

En cualquier caso, la duda sobre la realidad fisiológica no elimina la posibilidad de que la sinestesia, en tanto que se la sabe condición biológica, pueda influir de manera determinante en el proceso artístico. Aun cuando Kandinsky interpretara la fusión de sensaciones como algo más metafórico que real, no se puede dudar de la intención - patente y manifiesta en sus textosde querer transmitir experiencias multisensoriales que reflejen esa fusión de sensaciones. Kandinsky no compone pinturas cromáticas como Oliver Messiaen o Aléxander N. Scriabin, tampoco es su intención traducir sonidos a

67 Arnaldo, Actas Symposium Analogías, p. 92.

68 Página oficial del proyecto: http://www.uni-ulm.de/emu

Página personal de la autora: http://www.synaesthesiewerkstatt.de/

69 En su e-book Why is green a red word?

70 Ione y Tyler, Neurohistory and the Arts. 
colores («No quiero pintar música»). El objetivo de Kandinsky es transmitir al espectador una experiencia sinestésica para que éste sea capaz de recibirla multisensorialmente pero sólo a través de la percepción visual. Kandinsky quiere transmitir una sensación compleja que haga vibrar el alma y ésta active diferentes órganos sensoriales. En términos neurológicos, Kandinsky quiere ofrecer al espectador una percepción visual que active en su cerebro no sólo la región $\mathrm{V}_{4}$ sino, por lo menos, también el área auditiva. Con esta intención artística y bajo una perspectiva neurológica, Kandinsky crea un lenguaje nuevo: un lenguaje que incide directamente en cómo el cerebro percibe los estímulos visuales.

\subsubsection{El lenguaje abstracto cerebral}

Kandinsky certainly had a special talent for representing the essence of a sensory fusion, for transcending the synesthetic system into a form-language.

Ditte Lyngkær Pedersen

La corteza visual recibe información sobre el mundo exterior a través del nervio óptico. El cerebro procesa esa información (cada área un atributo) y le da un sentido, identifica las formas, reconoce el objeto. De esta forma, el cerebro adquiere conocimiento. Adquirir conocimiento del mundo real es un proceso idéntico al que requiere la pintura realista. Durante siglos, el arte tenía como fuente temática y de inspiración a la naturaleza o al mundo exterior, y la percepción de tales obras artísticas significaba para el cerebro -básicamente, dejando de lado otras evaluaciones- la identificación de las formas y el reconocimiento de objetos.

Cézanne y los cubistas empiezan a cambiar el juego de la percepción visual y la identificación cerebral, la relación entre lo que el cerebro "ve" y lo que el cerebro ha de procesar. Cézanne ofrece al cerebro manchas de color, de tal manera que éste ya no tiene que identificar una imagen sino construirla, basándose en similitudes sacadas de la memoria o de experiencias pasadas. Los cubistas eliminan al cerebro la información de la perspectiva única, obligándole a colaborar aún más activamente en el procesamiento de lo visto porque no puede identificar las formas sin más, tiene que de algún modo revisar la 
información recibida y construir una que le parezca plausible, una a la que pueda darle sentido.

El lenguaje abstracto de Kandinsky también obliga al cerebro a trabajar de otra manera. Para empezar, porque elimina no sólo la perspectiva única, sino todo rasgo de apariencia figurativa. Las manchas de color tampoco acaban formando una imagen final, como la montaña de Santa Victoria, sino que son realmente manchas, sólo manchas. Porque en Kandinsky, el color y la forma han pasado de ser medios pictóricos a ser los elementos sustanciales de la composición (al menos una vez que el lenguaje abstracto está definido y consolidado). Además, si la intención es transmitir al espectador una sensación sinestésica que implica actividad en diferentes áreas perceptivas, el cerebro está obligado a revisar su proceso "clásico" de información - identificación (recibe información e identifica los objetos).

La creación y realización práctica del lenguaje abstracto fue un camino progresivo. Como en todo proyecto, el desarrollo no es completamente lineal, siempre hay saltos cualitativos y suaves transiciones. Sin embargo, retrospectivamente y desde la perspectiva neurológica del arte abstracto, pueden diferenciarse dos etapas. La primera comienza con las primeras reducciones de la forma, con los primeros cuadros abstractos en los que aún se reconocen ciertas formas (como el jinete, la troika o los rostros humanos). Son los inicios del arte abstracto: las formas se han reducido a lo esencial, pero no han desaparecido del todo; el color y la forma han ganado peso, pero aún no se han hecho completamente autónomos. La segunda etapa es la de plena abstracción. No hay rastro de la forma figurativa y el círculo ha ocupado plenamente el lugar del caballo. El color y la forma son independientes y su capacidad de expresión, su resonancia interna, ha alcanzado el potencial máximo. Las formas resuenan en color y además son sonoras.

Desde el punto de vista neurológico, el primer Kandinsky se acerca mucho a Cézanne. Como dice Lehrer, las pinturas postimpresionistas, "incompletas", de Cézanne «eran realmente una metáfora del proceso visual» ${ }^{71}$. Cézanne deconstruye la imagen que quiere pintar hasta llegar a sus partes esenciales, como si fueran las unidades mínimas de información que el cerebro recibe a través de las distintas áreas. En el cuadro sólo se aprecian manchas de color, sin

71 LeHrer, Proust Was a Neuroscientist, p. 114. Traducción propia, del inglés. 
contornos, sin forma delimitada. Es la presentación artística de lo que recibe el cerebro antes de procesar la información. Por eso Lehrer afirma que las pinturas de Cézanne «en realidad nos muestran el mundo tal y como éste se le aparece por primera vez al cerebro» ${ }^{72}$. Cézanne presenta la información visual deconstruida, separada por atributos, y el espectador la procesa, construyendo con esa información la imagen final. Es lo que hace el cerebro: construir una imagen con sentido a raíz de la información desarticulada. Cézanne pinta en esas manchas de color la información justa y suficiente para que el cerebro pueda entender la imagen: «[Cézanne] quería dar al cerebro sólo lo suficiente para que pudiera descifrar, y ni una pincelada más. Si sus representaciones eran demasiado precisas o demasiado abstractas, todo se desmoronaría» ${ }^{73}$.

Las formas semiabstractas del primer Kandinsky consiguen el mismo efecto. Kandinsky reduce la expresión artística a sus formas esenciales, reduce el objeto a sus formas mínimas. Lo que el espectador ve, es lo que el cerebro percibe antes de someterlo al proceso de identificación. En el cuadro Oriental (ilustr. 5, pág. 156), los rostros humanos sólo son una mancha de color anaranjado, sin más contorno ni delimitación que la de ser una forma algo ovalada. No hay más detalles, no hay elementos faciales. Pero el cerebro (se cree que el reconocimiento facial está en la zona fusiforme) no tiene problema en dar sentido a esos datos, a primera vista inconexos (color anaranjado, forma oval). A base de recuerdos, asociaciones o como sea que procese, el cerebro es capaz de construir la imagen de un rostro. Lo mismo ocurre con los rostros de la Improvisación 19 (ilustr. 6, pág. 157), que ni siquiera tienen color anaranjado ni forma ovalada. El cerebro construye sin problemas un rostro humano. Incluso cuando falta el color, que al fin y al cabo es el primer atributo que el cerebro percibe, el cerebro es capaz de construir cualquier imagen, siempre que tenga la información necesaria. Muchos jinetes de Kandinsky son siluetas en blanco y negro y sólo presentan las curvas mínimas, una para la cabeza y otra más rectilínea para el cuerpo. Y aún así, el cerebro construye la imagen del hombre montando a caballo.

Esa capacidad de construcción a partir de lo mínimo es útil e indispensable para el cerebro a la hora de adquirir conocimiento del mundo exterior. Pero

72 Lehrer, Proust Was a Neuroscientist, p. 98. Traducción propia, del inglés. 73 Lehrer, Proust Was a Neuroscientist, p. 110. Traducción propia, del inglés. 
entorpece el proyecto de abstracción de Kandinsky. A pesar de reducir la imagen a líneas y manchas de color, el cerebro sigue siendo capaz de completar la imagen, de construir el objeto del que Kandinsky quiere desprenderse. La construcción del objeto estorba, porque vuelve a anclar al cerebro a una imagen puramente visual. El objeto ya no está como tal en el cuadro, el caballo no es un caballo sino sólo una semilínea circular, pero el cerebro sigue identificando el caballo, consigue crear la imagen del caballo. El objeto que Kandinsky rechaza, el que intenta eliminar porque estorba, porque al espectador le hace fijarse en él y no ver más allá (si en el cuadro hay un pez, el espectador sólo percibe el pez), esa imagen figurativa desterrada por Kandinsky resulta que la crea el cerebro. Y si el cerebro termina construyendo una imagen figurativa, no hay verdadero lugar para el lenguaje abstracto. Kandinsky quiere ir más allá, dar un paso más. Lograr que el cerebro no acabe suplantando la imagen figurativa que se quería borrar. Empieza el segundo Kandinsky, donde las formas se hacen completamente abstractas. Ya no hay líneas o manchas de color con las que el cerebro pueda completar la imagen. Sólo hay color y forma.

Si no hay imagen figurativa que construir, el cerebro está obligado a buscar otra información. Tiene que suplantar la construcción de un objeto por la construcción directa de una sensación. Si en el proceso habitual el cerebro percibe (ve), reconoce/construye el objeto (entiende) y luego experimenta la sensación o placer estético (siente), en el arte abstracto tiene que saltarse el paso intermedio. No hay objeto que reconocer o construir, sólo hay una imagen que percibir y sensaciones que sentir. El cerebro tiene que responder a una percepción visual sin construir una imagen acorde con el mundo exterior, sino directamente con sensaciones de carácter interno.

Y se trata de sensaciones, en plural. Porque Kandinsky quiere transmitir al espectador un contenido sinestésico, multisensorial. Eso significaría para el cerebro que un solo estímulo le planteara en respuesta dos posibilidades igual de válidas, una visual y otra auditiva, por ejemplo (respuesta sonora al percibir un color). La escena visual (la imagen, el cuadro) tiene que evitar que el cerebro construya una imagen figurativa y por ende plausible con el mundo exterior, para que el cerebro pueda construir una nueva realidad interior y sensorial como respuesta a lo percibido. Una realidad que combine varias respuestas sensoriales como igualmente válidas. Es decir, que el cerebro admita la multiplicidad de sensaciones como respuestas posibles y plausibles a un sólo estímulo visual. Para una persona sinestésica, la simultaneidad de 
sensaciones es habitual. Su cerebro está acostumbrado a percibirlo. Un no sinestésico podría tener que considerar cada opción -cada respuesta sensorial por separado- y "alternarlas" mentalmente en su contemplación.

Esta capacidad cerebral no es ninguna quimera sino, según Zeki, una de las habilidades básicas del cerebro para poder adquirir conocimiento. Es la capacidad de la ambigüedad. ${ }^{74}$ Zeki no se refiere con el término a su uso habitual como algo incierto o que está abierto a más de una posibilidad. Zeki define la ambigüedad neurológica como «la certidumbre de muchas condiciones esenciales, diferentes, cada una de ellas igual que las demás ${ }^{75}$. Es decir, el cerebro es capaz de contemplar diferentes respuestas, todas ellas con la misma validez. Si el cerebro percibe un estímulo visual cuya información le proporciona los datos claves y constantes, responde de manera unívoca o construye una imagen única. Pero si se le confronta con varias posibilidades de respuesta y cada una de ellas tiene la misma validez o plausibilidad, el cerebro acepta todas ellas (aunque no las asuma a la vez, sino que las alterne entre milésimas de segundo). Un ejemplo sencillo de imágenes ambiguas es el jarrón de Rubin, en el que el cerebro percibe o dos rostros o un jarrón: ambas imágenes le son al cerebro igual de válidas, pero no puede contemplarlas a la vez, o ve el jarrón o ve los rostros. La conocida imagen de la joven y la vieja o la del indio y el esquimal son otros ejemplos básicos. Otro ejemplo, del propio Zeki, son los cuadros de Vermeer. Frente a La joven de la perla, el cerebro acepta diferentes interpretaciones de su expresión, todas ellas como interpretaciones válidas. La joven está en actitud distante y a la vez atrayente, cargada de erotismo y de casticidad, resentida y simpática. La imagen consigue transmitir todas esas expresiones, aunque el espectador sólo es consciente de una de ellas cada vez. ${ }^{76}$ El cerebro es capaz de dar múltiples interpretaciones a una misma percepción visual, tengan que ver con lo conceptual (¿hay dos rostros o un jarrón?) o con lo sensorial (¿me está invitando o me está rechazando?).

Las formas puramente abstractas de Kandinsky también provocan esa ambigüedad. No es una ambigüedad conceptual, porque frente a un cuadro abstracto el cerebro es incapaz de identificar o de construir una imagen figurativa (no tiene que decidir si es un jarrón o dos rostros, porque lo que ve es lo

74 ZeKI, The Neurology of Ambiguity.

75 ZeKI, Visión interior, p. 45.

76 ZEKI, The Neurology of Ambiguity, pp. 189-190. 
que hay, un círculo es un círculo). Es una ambigüedad sensorial. El lenguaje abstracto evita la fase en la que el cerebro "entiende" las formas. La respuesta a la percepción es directamente sensorial. Kandinsky ofrece al cerebro las formas mínimas -color y forma- deconstruidas, diferenciadas, modulares, tal y como las percibe el cerebro. Como no hay imagen que construir, llega la sensación. Y es ahí donde nace la ambigüedad, en la posibilidad de responder multisensorialmente a un único estímulo visual. Las formas del cuadro ofrecen múltiples interpretaciones, todas ellas igual de válidas. El color puede despertar una sensación de frialdad pero también sonora, la línea puede provocar sensación de profundidad o de movimiento, de reposo o de excentricidad. Kandinsky sólo ofrece al cerebro las formas mínimas y éste puede construir con ellas una realidad sensorial. Esta realidad es ambigua porque obliga al cerebro a considerar multiplicidad de interpretaciones, si bien todas ellas son válidas, todas son posibles.

Esta forma de entender el arte abstracto plantea claramente una doble dificultad. Por un lado, la que tiene el artista en el momento de la creación. Por otro, la del espectador cuando contempla visualmente el cuadro.

El artista necesita dominar el color y la forma como herramientas de la creación artística, porque la eficacia de su lenguaje abstracto -es decir, la capacidad de provocar sensaciones en el espectador- depende de hallar la expresión adecuada: la que consigua estimular el área y las células del cerebro que responden exactamente a esa percepción visual y que desencadenan las respuestas sensoriales deseadas. El artista busca la expresión visual que estimule en el cerebro una respuesta sensorial concreta, la que quiere transmitir. A este proceso, Kandinsky siempre lo llamó «ajustarse al principio de la necesidad interior», y estaba convencido de que si el artista obedecía esa «ley interna», el alma del espectador vibraría de la misma manera (sentiría la misma emoción). Ahora se pueden leer las palabras de Kandinsky con una interpretación neuroestética. El alma del espectador que vibra es el área del cerebro que se activa ante el estímulo visual, y que provoca una respuesta sensorial. El artista tiene que buscar las formas precisas, las que estimulen el cerebro de manera selectiva. Además de contar con la intuición, como en todos estos siglos, ahora también puede ayudarse de los nuevos resultados de la neuroestética. La localización de las áreas especializadas del cerebro y la explicación de cómo y qué percibe cada célula puede facilitar el camino de la 
creación artística.

Por otro lado, el arte abstracto también supone una dificultad para quien lo contempla. Los espectadores sinestésicos parecen tenerlo más fácil, porque neurológicamente son capaces, involuntariamente, de percibir una doble sensación. Además, según Cytowic, esta doble condición les facilita tener una tercera sensación o al menos, ser capaces de percibir más sensaciones con mayor facilidad. Pero el espectador no sinestésico pocas veces siente un complejo de sensaciones nada más visualizar el cuadro. En general, le envuelve el desencanto, la incomprensión o la indiferencia (o todo junto). Los primeros críticos de Kandinsky que veían en sus cuadros «fantasías de un tapicero empapelador» o modelos para alfombras siguen siendo de actualidad. El espectador habitual no es capaz de apreciar el lenguaje abstracto como un lenguaje de sensaciones.

La razón es que el cerebro tiende a interpretar. El cerebro, porque uno de sus fines principales es adquirir conocimiento, está acostumbrado a entender, a identificar y reconocer objetos en aquello que percibe. Cuando recibe información incompleta sobre una forma, busca completarla, encajarla con lo conocido o con lo plausible. Es lo que hace con la montaña de Santa Victoria de Cézanne o con las líneas curvas de los jinetes de Kandinsky. También cuando consulta el título de una obra de arte abstracto, en la esperanza de que le aclare algo. El cerebro quiere entender. Y por eso le cuesta no ver lo que, construyendo un poco, parece o podría tener sentido. La pareidolia es uno de los mejores ejemplos. El cerebro identifica formas reconocibles en estímulos aleatorios e incluso vagos: reconoce animales en las nubes, caras en Bélmez y unos ojos risueños en los faros delanteros del Lupo de Volkswagen. El cerebro sobrereconoce formas donde no las hay, y por eso Rorschach tiene éxito con sus test.

De ahí que el arte abstracto exija un aprendizaje. El cerebro tiene que aprender a no interpretar. Frente a un cuadro puramente abstracto, el cerebro tiene que habituarse a responder sensorial y no conceptualmente. Tiene que aprender a relacionar la información percibida visualmente con una respuesta sensorial no exclusiva, abierta a la ambigüedad sensorial. Tiene que "alfabetizarse visualmente", es decir, ser capaz de percibir las formas abstractas y responder a ellas con una sensación, sin recaer en la interpretación conceptual. Kandinsky decía que había que «habituar al alma» del espectador a reconocer el contenido interno del cuadro, y también que «el espectador está demasiado 
acostumbrado a buscar la coherencia externa de las diversas partes del cuadro (...) y por lo tanto, [es] un espectador incapaz de enfrentarse simplemente al cuadro [y de percibir] la vida interior del cuadro y su efecto sobre la sensibilidad $»^{77}$. La solución de Kandinsky para percibir esa vida interior y sentir un efecto sensorial pasa por habituar al espectador al arte abstracto y por darle tiempo: «al principio esos tonos (...) sólo debían revelarse con el tiempo al espectador profundamente atento, primero de manera confusa y como tanteando, para resonar luego cada vez más con una fuerza creciente» ${ }^{78}$. Un siglo después de estas palabras, el espectador del siglo xxI está más que habituado a las formas abstractas pero sigue sin saber sentir. Comprender cómo funciona el cerebro (cómo responde a los estímulos visuales, cómo percibe el color y la forma) y, especialmente, entender neurológicamente fenómenos como el de la sinestesia, puede ayudar al espectador actual a contemplar el arte abstracto bajo una nueva perspectiva. Además de esta explicación neuronal, la práctica estética también ayuda: las nuevas tecnologías permiten "traducir" experiencias sinestésicas a medios de por sí audio-visuales, lo que facilita al cerebro "entender" cómo funciona la sensación múltiple y poder ejercitarla después.

\subsection{La obra neuroestética}

\subsubsection{Reinterpretando a Kandinsky}

La obra de Kandinsky ha servido de fuente de inspiración a muchos otros artistas, profesionales y aficionados. Como suele ocurrir, la influencia de sus teorías y de su estilo artístico es clara en algunos autores, en otros, algo más indirecta. Pero además de la influencia, la obra pictórica de Kandinsky se ha utilizado a menudo como base para otras creaciones y experimentos artísticos, dando pie a nuevas y diversas reinterpretaciones de su obra.

La mayoría de estas creaciones que nacen a raíz de cuadros de Kandinsky son de soporte audiovisual. Cada una tiene su estilo y sus medios, pero se pueden generalizar tres línes de interpretación. Unas ahondan en la condición

77 Kandinsky, De lo espiritual en el arte, pp. 21-22.

78 Kandinsky, Mirada retrospectiva, p. 106. 
sinestésica de Kandinsky, es decir, en su percepción audio-visual o sonoridad de los colores. Es la interpretación musical de un cuadro concreto. Suelen presentar el cuadro de manera progresiva, induciendo en el espectador una percepción temporal. Desglosan partes del cuadro que aparecen o desaparecen en comunión con música o sonidos concretos. La percepción visual es simultánea a la percepción auditiva (el color aparece a la vez que el tono), lo que emula una respuesta sinestésica en la que el cerebro asocia un color a un sonido. Buena parte de estas interpretaciones selecciona composiciones de Schönberg para la realización. Se basan, claramente, en la similitud teórica de ambos autores y en las comparaciones que el mundo académico ha llevado a cabo entre la música atonal y la pintura no figurativa. También hay otras creaciones que interpretan el lenguaje de Kandinsky con todo tipo de música, desde autores clásicos a los más modernos. Un ejemplo es el grupo de jazz experimental The Kandinsky Effect, que en algunos de sus conciertos proyectan vídeos basados en obras de Kandinsky mientras tocan. Su vídeo de presentación ${ }^{79}$ es un buen ejemplo, combina formas y colores de la obra kandinskyana con su propia música, creando así un soporte visual de la obra auditiva y por tanto, un efecto sinestésico.

Otra línea de interpretación es la que analiza los cuadros de Kandinsky basándose en el color y la forma como elementos de composición autónomos. Algunas creaciones descontextualizan las formas y juegan con ellas, cambiándolas de lugar o de color y provocando nuevos efectos. ${ }^{80}$ Otros se basan en la revalorización del espacio pictórico y la eliminación de la superficie única para crear vídeos en los que el cuadro se convierte en un espacio tridimensional ${ }^{81}$ o incluso en los que la sensación de espacio se pierde por completo ${ }^{82}$.

La tercera línea de interpretación incide en la presencia del movimiento en la obra visual. Kandinsky presenta el movimiento en su obra a través del color (el amarillo irradia velocidad y se acerca a la espectador) y de la forma (la línea es un punto en movimiento). Hay interpretaciones que aprovechan la teoría kandinskyana para crear vídeos en los que las formas se desplazan siguiendo estas características, impregnando movimiento a las formas. $\mathrm{Al}$

\footnotetext{
79 En http://www.kandinskyeffect.tk/

80 Por ejemplo: http://www.youtube.com/watch?v=-QcOXmj2VZk\&NR=1

81 Por ejemplo: http://www.youtube.com/watch?v=wcWoZmvvXoI

82 Por ejemplo: http://www.youtube.com/watch?v=778BTf7WAs8\&NR=1
} 
utilizar el vídeo como soporte, el ojo percibe directamente el movimiento del color o la forma y crea de nuevo una asociación sinestésica. Otra opción para presentar la movilidad de manera visual son las esculturas móviles que Jean Tinguely realizó en la década de 1950, entre las que se incluye una serie sobre Kandinsky, los MétaKandinsky (1956). ${ }^{83}$ La obra consiste en un soporte rectangular (como un lienzo) pintado en tono monocromo. Sobre él, y hacia el espectador, están colocadas diversas partes móviles, cuya forma y color se reconocen como elementos composicionales de los cuadros de Kandinsky. Un motor pone en movimiento todas las piezas, vinculando la percepción del color y de la forma a la percepción del movimiento.

La obra de Tinguely es una de las primeras creaciones artísticas que reinterpretan directamente una obra de Kandinsky. Tinguely se centra en la expresión del movimiento: impregna movilidad real a una imagen visual compuesta por colores y formas. La percepción visual de esta relación (movimiento-forma-color) interesa no sólo a otros artistas sino también a los neuroestéticos. La neurología ha descubierto que la contemplación del movimiento activa grupos de células específicos en la corteza visual del cerebro, lo que signfica que hay un área especial para su percepción (V5). La posibilidad de crear obras que directamente estimulen estas áreas, bien solas o bien en combinación con otras de la corteza visual (color, forma, etc), abre un nuevo campo para el arte. Zeki le reconoce a Tinguely el mérito de ser pionero en la experimentación con el movimiento: «sin darse cuenta o sin siquiera haberlo pensado, [Tinguely] estaba haciendo un arte a la medida de la fisiología de las células del cerebro que responden a líneas de orientación y bordes en movimiento» ${ }^{84}$.

Uno de los proyectos claramente enfocados a la reinterpretación sinestésica de Kandinsky es Das Kandinsky Projekt (El proyecto Kandinsky, 2008), una instalación audiovisual basada en el cuadro Amarillo-Rojo-Azul de 1925 (ilustr. 37). La obra se ha presentado en diferentes conferencias y mostrado en varios museos, ${ }^{85} \mathrm{y}$ además ha quedado recogida en las actas del congreso sobre sinestesia que tuvo lugar en la Universidad de Hannover en $2008 .{ }^{86}$ En ellas se

83 Vídeo de MétaKandinsky en movimiento: http://www.youtube.com/watch?v=s1mAtrBsmZI 84 ZeKI, Visión interior, p. 155.

85 Del 7 de abril de 2011 al 26 de febrero de 2012 se puede ver en el Museo Nacional de Historia Natural de Luxemburgo, como parte de la exposición Haut en couleurs.

86 Hannover, agosto de 2008. Die fröhliche Sieben: Synästhesie, Personifikation und Identifika- 
incluye un artículo de los autores y el vídeo con la instalación audiovisual. ${ }^{87}$

La idea del proyecto la firman Christine Söffing y Hinderk M. Emrich. Söffing, que es quien lleva a cabo la realización del vídeo, es una artista sinestésica que colabora e investiga en $\mathrm{EMU}^{88}$, un grupo de proyectos de investigación sobre música y arte asociado a la Universidad de Ulm, en Alemania. El grupo fue fundado en 1986 y lo forman estudiantes de arte (artes plásticas, música, danza) que colaboran con investigadores de la rama científica. El propósito es aunar el arte y la ciencia a través de todo tipo de experimentos y valiéndose de las nuevas tecnologías. Hinderk M. Emrich es director médico de Psiquiatría y Psicoterapia, además de profesor emérito en Filosofía. Sus investigaciones buscan combinar las bases neurológicas con los interrogantes de las ciencias humanas y, además de colaborar en numerosos proyectos artísticos, parte de su investigación está centrada en el estudio de la sinestesia.

Söffing y Emrich interpretan la teoría y obra de Kandinsky como la manifestación artística de un sinestésico. Bajo esta premisa, el proyecto tiene como objetivo exteriorizar la sinestesia audio-visual del artista y crear una obra que sea sinestésica incluso para los no sinestésicos. Es decir, presentar artísticamente la simultaneidad de sensaciones visuales y auditivas (colores y tonos). La idea es hacer «los cuadros de Kandinsky sonoros».

El cuadro que eligen como base de trabajo es Amarillo-Rojo-Azul, una obra con el lenguaje abstracto ya consolidado y sin rastro por tanto de apariencia figurativa. Los colores que dominan son los del título, el amarillo, el rojo y el azul; sólo se les añade el negro de ciertas líneas y puntos. La asociación sinestésica de esos colores con sonidos se basa primariamente en las indicaciones de Kandinsky en De lo espiritual en el arte, reinterpretadas después por las propias asociaciones de C. Söffing, también sinestésica audio-visual. La reinterpretación sensorial propia permite a la autora comprobar y asegurar que el color se ajusta al sonido, en espacio y tiempo. Tras analizar el matiz de los colores empleados por Kandinsky en este cuadro concreto y la asociación sinestésica de Kandinsky (amarillo-trompeta, rojo-tuba, azul-violonchelo, órgano), Söffing escoge el sonido de campanas tubulares para el amarillo, el de

tion.

87 Rani Sinha, Synästhesie der Gefühle, pp. 94-113.

88 Grupo Experimentelle Musik und Kunst (Música y Arte experimental), dirigido por Dieter Trüstedt: http://www.uni-ulm.de/emu 


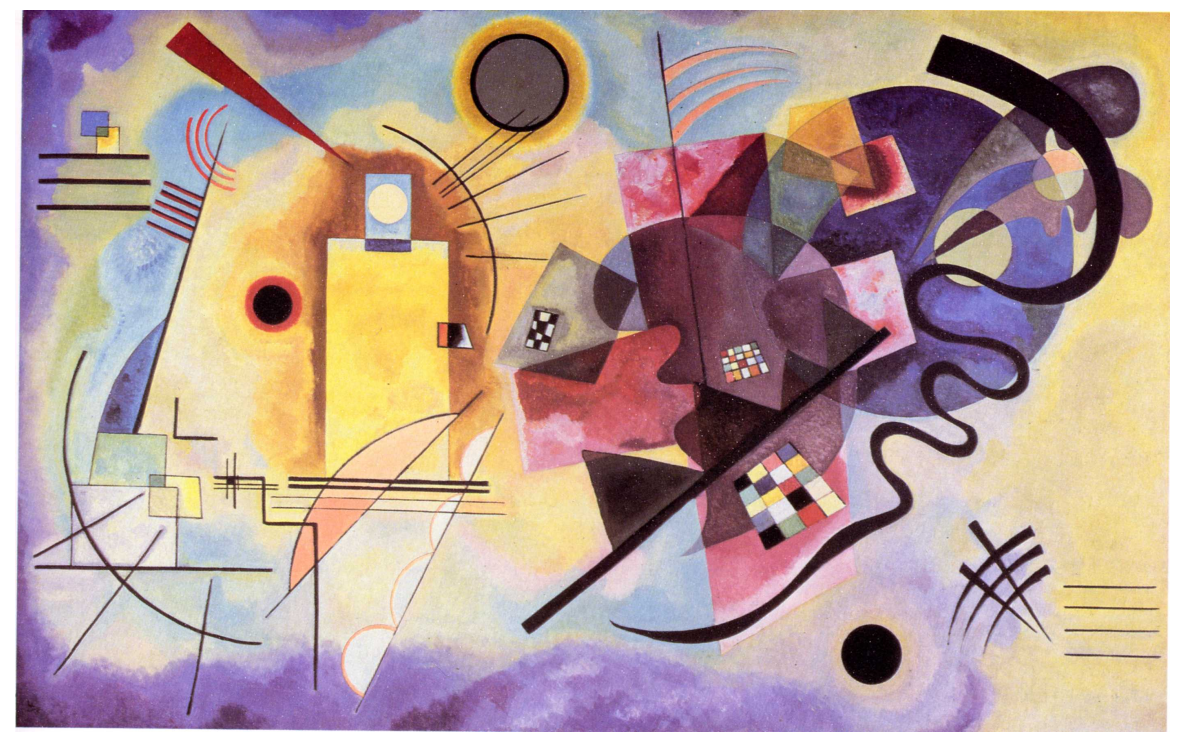

Ilustración 37 Amarillo-Rojo-Azul, 1925

un Bassrohr ${ }^{89}$ para el rojo y el piano para el azul. La música se compone siguiendo las normas de la música atonal, basándose en la relación ya comentada entre Schönberg y Kandinsky.

La aplicación de los sonidos a los colores se combina con el análisis formal de los elementos del cuadro. Las figuras principales son un cuadrado amarillo, una cruz roja y un círculo azul. El cuadrado amarillo ocupa la parte izquierda del cuadro, aunque no la llena, y actúa en equilibrio con la parte derecha, que se reparten la cruz roja y el círculo azul. El resto de formas pasan a un segundo plano.

El vídeo comienza con la aparición de las tres figuras principales, por orden lateral de izquierda a derecha (cuadrado, cruz, círculo) y cada una con su sonido sinestésico asociado. Poco a poco van apareciendo los demás elementos composicionales y van desplazándose por el espacio hasta encontrar su lugar, acorde con el lienzo. Las formas interactúan y los sonidos se van mezclando. Con todas las formas, colores y sonidos se forma una composición que el

89 El Bassrohr es un instrumento inventado por Dieter Trüstedt que consiste en un caño de cobre al que se ha añadido una boquilla de saxo tenor. Explicación de Christine Söffling en: RANi SinHa, Synästhesie der Gefühle, p. 105. 
espectador percibe visual y auditivamente. Para una persona no sinestésica, el resultado se acerca a la sensación multisensorial original de un sinestésico: en este caso, a la sensación de Kandinsky reinterpretada por Christine Söffing.

\section{7-3.2 La sinestesia en el arte actual}

Semir Zeki considera que los artistas son neurólogos que, inconscientemente, exploran el funcionamiento del cerebro con otros instrumentos. Y así ha sido, al menos hasta que la neurología ha empezado a revelar las estructuras cerebrales de la percepción visual. A medida que se van conociendo más detalles sobre cómo funciona el cerebro, también surgen artistas que realizan el proceso contrario: se valen de los resultados neurológicos para explorar las fronteras del arte. Las primeras explicaciones del fenómeno de la sinestesia y, especialmente, la demostración de que tiene base neuronal han abierto la puerta a nuevas creaciones artísticas. Son creaciones que no sólo quieren transmitir expresiones multisensoriales, sino que tratan la sinestesia como tema mismo de la experiencia artística. Ésa es una de las grandes diferencias: Kandinsky quiso expresar un contenido emocional de manera sinestésica; los artistas de hoy hacen de la sinestesia la base misma de la creación.

Ditte Lyngkær Pedersen es una de las artistas actuales que centran parte de su trabajo en el tema de la sinestesia. Su trabajo se reparte entre Berlín y Århus (Dinamarca), donde dirige el departamento de vídeo de la Århus Art Academy. ${ }^{90}$ Sus experiencias sinestésicas, que marcan el punto de partida de su obra, son de dos tipos: sinestesia grafema-color, por la que las letras y los números tienen un color propio, tanto al verlos escritos como al escucharlos; $y$ sinestesia espacial-conceptual, por la que las unidades de tiempo se convierten en una sensación espacial. Sus sensaciones multisensoriales son vívidas, constantes e involuntarias y la percepción es real, como en la sinestesia descrita por los neurólogos. La letra A la percibe como «dark-bluish-ash-gray» y siente «los meses del año, las semanas de cada mes y los días de la semana circulando

90 Las citas e información de la artista provienen del material artístico que tiene en su página web (www.dittelyngkaerpedersen.com/), así como de encuentros en congresos y correspondencia personal con ella. Las traducciones son todas propias, del inglés. 
alrededor de mi cintura, en un sistema espacial».

A raíz de sus propias experiencias y de su trabajo sobre la sinestesia y con otros sinestésicos, Lyngkær Pedersen cree que la investigación de este fenómeno aporta una nueva perspectiva al tema de la percepción y puede ayudar en otras áreas como el pensamiento o la memoria. El mayor problema que comporta la sinestesia es un problema de expresión pues, según ella, «los sinestésicos nunca están satisfechos con las palabras que eligen para describir sus experiencias». Esta dificultad (casi imposibilidad) de expresión y, por tanto, de difusión del conocimiento relega el tema de la sinestesia a la pura descripción científica o a la privacidad del sinestésico. La artista quiere utilizar el espacio del arte para dar a conocer el fenómeno y concederle un nuevo medio de expresión.

Lyngkær Pedersen cree que la experiencia sensorial es un componente imprescindible para percibir la obra de arte. El arte contemporáneo necesita con frecuencia marcos de referencia que permitan comprender la obra. Si se quiere comunicar un contenido al espectador, éste necesita conocer las reglas y el vocabulario con el que poder leerla. Y la capacidad de experimentar sensaciones es, precisamente, una parte de ese vocabulario que necesitan las obras de arte contemporáneo: "podemos usar la conciencia sensorial [sic] para construir un vocabulario y un marco de referencia común» ${ }^{91}$. De este modo, presentar el fenómeno de la sinestesia a través del arte significa acercar el entendimiento sobre la experiencia estética. Es decir, entender el fenómeno de la sinestesia confiere al espectador un nuevo vocabulario sensorial, con el que aumenta su capacidad para comprender el arte contemporáneo.

Con este objetivo, la artista quiere que sus obras den a conocer la sinestesia y acerquen a los no sinestésicos el mundo de las sensaciones múltiples, intentando que ellos mismos las experimenten. Quiere poner el tema de la sinestesia sobre la mesa de debate para que los espectadores aprendan un nuevo vocabulario sensorial, para que los sinestésicos que aún no lo saben se reconozcan como tales y para que la ciencia y la filosofía impulsen e investiguen el fenómeno.

La producción artística de Lyngkær Pedersen explora la sinestesia desde diferentes ámbitos y para ello utiliza diferentes técnicas y soportes. A través de

91 Lyngkær Pedersen, Why is green a red word?, e-book, p. 9. 
la escultura intenta recrear las sensaciones espaciales de una persona sinestésica, es decir, crear esculturas que reproduzcan la imagen espacial que provoca un número o un día de la semana. En otro proyecto, experimenta fotografiando colores del mundo exterior que se acercan sensorialmente a los colores que percibe un sinestésico. El proyecto no ha podido llegar muy lejos porque, como bien han demostrado los neurólogos, los colores que perciben los sinestésicos son reales pero no parecen existir en el mundo exterior. Actualmente trabaja con formas en tres dimensiones y efectos de luz, con la intención de encontrar un medio que permita acercar aún más las experiencias sinestésicas a las personas que no lo son, siempre de la manera más fiel y real posible.

El mayor proyecto sobre sinestesia que ha llevado a cabo hasta ahora se llama Synesthesia Project (Proyecto Sinestesia), una recopilación sobre los trabajos realizados entre 2003 y 2010. Algunos de ellos se presentaron originariamente en museos, hoy están recogidos en un DVD compilatorio. El conjunto es una videoinstalación compuesta por una obra principal, tres estudios experimentales y una selección de entrevistas con científicos, investigadores y personas sinestésicas. ${ }^{92}$

El primero de los tres estudios experimentales es Study of a name-Ditte (Estudio de un nombre: Ditte), un vídeo de seis minutos y medio de duración en el que varias personas sinestésicas explican las sensaciones que les produce el nombre y la voz de la artista. Los relatos están llenos de referencias sensoriales cruzadas: «[tu nombre] es marrón con algo de verde, [tu voz] es tridimensional con los bordes muy suaves, es sucia como la tierra, es suave y redonda...» El experimento muestra dos aspectos que son fundamentales en la obra de la artista. Uno es la dificultad de los sinestésicos para expresar con precisión sus sensaciones, tan claras para ellos y tan ilógicas para el espectador, lo que incide en la necesidad de encontrar un medio de expresión adecuado. El otro es la riqueza sensorial que tienen las cosas mínimas y esenciales como un nombre o una voz, y que invita a utilizar la sinestesia como herramienta sensorial en los procesos artísticos.

El segundo estudio es A study of the questions that define types of synesthesia

92 La obra y los tres estudios pueden verse en la página web: http://www.dittelyngkaerpedersen.com/ 

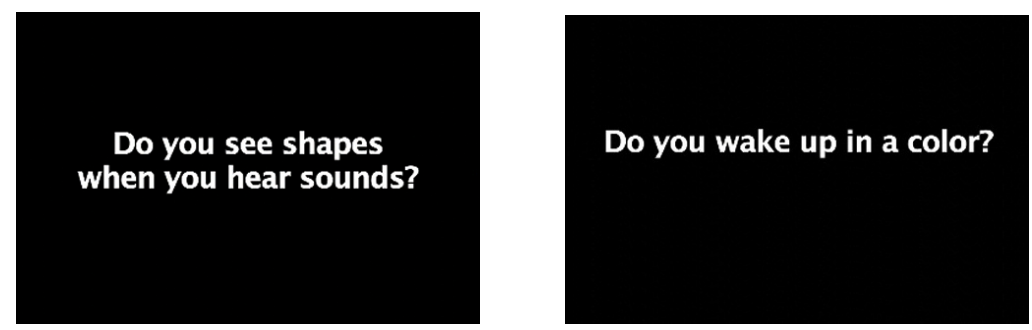

Ilustración 38 Fotogramas de A study of the questions...

(Estudio de las preguntas que definen los tipos de sinestesia), que se presentó con formato de videoinstalación en la Galería Peep de Malmö (Suecia), en 2004. El vídeo es una sucesión de preguntas, una por imagen, letras blancas sobre fondo negro. De fondo, sonido atmosférico y el latir de un corazón. La idea visible es acercar el fenómeno de la sinestesia a los no sinestésicos, a la vez que reconocer a quienes ignoran que lo son. De manera subyacente, la artista quiere profundizar en la complejidad de las sensaciones y sacar a la luz detalles de la percepción individual, que a menudo no coinciden con lo que creemos es la percepción generalizada. El sonido de fondo está elegido para crear un ambiente de tranquilidad, necesario para reflexionar sobre los detalles de la percepción sensorial. El latido del corazón pretende recordar que la experiencia sinestésica es corpórea, real, sentida, y no mental o imainaria.

Las preguntas son directas y gramaticalmente están bien construidas, pero son semánticamente ilógicas para el mundo tradicional y uni-sensorial. El sinestésico reconoce sus experiencias en algunas de ellas o descubre entonces que es sinestésico. El espectador que no lo es, descubre que hay un mundo de percepciones y sensaciones múltiples, un mundo al que hasta ahora no ha tenido acceso pero que resulta ser real. La autora resume así el porqué de las preguntas: "para entender los detalles de la sensación sinestésica uno tiene que hacer preguntas imposibles o no existentes. Estas preguntas parecen ser ilógicas, pueden sonar naíf o tontas, pero son muy efectivas para descubrir la realidad de las percepciones.» El vídeo comienza con tres preguntas clave que centran al espectador en el tema de la percepción: «¿Lo percibes? ¿Lo ves? ¿Ves lo que yo veo?» Y continúan con la serie de preguntas “imposibles” que, de la manera más sencilla y directa posible, llevan al espectador por el terreno de las sensaciones múltiples: «¿Puedes ver el año? ¿Qué tamaño tiene el año? ¿Ves las vocales en color? ¿Tienen idiomas diferentes, colores diferentes? ${ }_{i}$ Recuerdas 

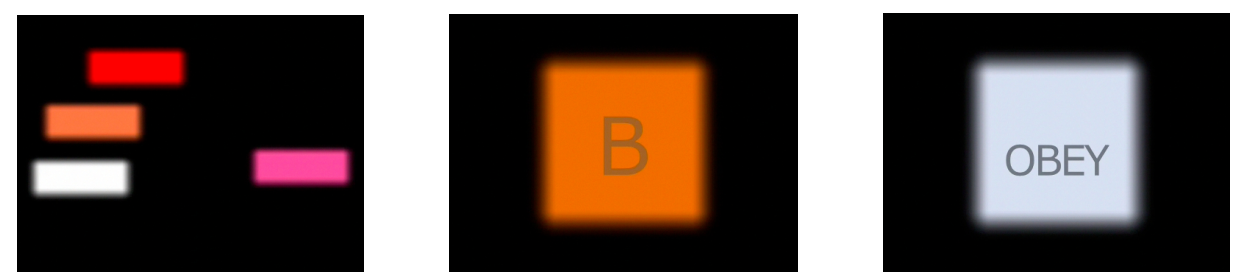

Ilustración 39 Fotogramas de Code Breaking

números de teléfono por su color? ¿Ves los días de la semana en el espacio? ¿Escuchas música en colores?»

El tercer y último estudio lleva por título Code Breaking - a study of the film Close Encounters Of A Third Kind, referencia directa a la película de Steven Spielberg Encuentros en la tercera fase. El vídeo es una relectura de la comunicación entre los científicos y los alienígenas, que utilizan un lenguaje basado en colores y sonidos. Cada unidad lingüística de los alienígenas (cada palabra, cada letra o cada idea) emite un color que va acompañado de un sonido. La lectura que hace Lyngkær Pedersen es en clave sinestésica, asumiendo que tono y color no son separables sino una manifestación simultánea que, como tal, debe también percibirse a la vez. Según la artista, el lenguaje que utilizan en la película es una demostración excelente de cómo funciona la sinestesia: «me impresiona que Spielberg tuviera la imaginación de crear una lengua extranjera para estos seres ficticios del espacio exterior que tanto se parece a la sinestesia. Es una película hermosa, conmovedora que juega con los principios de la condición sinestésica de todas las maneras posibles» ${ }^{93}$.

Lyngkær Pedersen reinterpreta el lenguaje de la película tomando como base el conocido acorde de cinco notas, el que emiten los extraterrestres cuando aterrizan por primera vez (Si b - Do - La $\sharp-$ La $\sharp$ (una octava menor) $\mathrm{Mi} \sharp$ ) y sus correspondientes colores (naranja - rojo - rosa - naranja -blanco). Como su sinestesia es de tipo grafema-color, Lyngkær Pedersen traduce los colores de los extraterrestres a letras, según su respuesta sinestésica. La traducción artística crea un nuevo código, cuya combinación de letras termina formando la palabra oBEY (obedece).

93 Lyngkær Pedersen, Why is green a red word?, e-book, p. 17. 


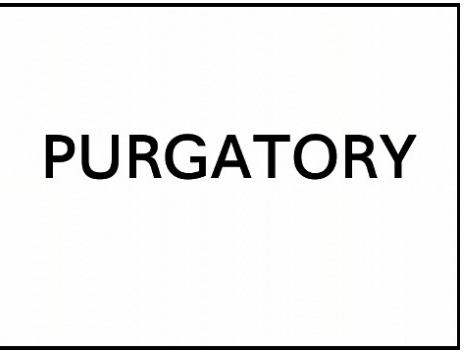

Ilustración 40 Fotograma de What the Hell does Purgatory Look Like?

La obra principal de Synesthesia Project se titula What the Hell does Purgatory Look Like?, un vídeo de ocho minutos de duración que se presentó en The Living Art Museum de Reikiavik en 2005. La imagen es un plano fijo en el que se lee la palabra PURGATORY (purgatorio) en negro sobre fondo blanco. En voz en off, nueve personas con sinestesia describen las sensaciones que les provoca la palabra según sus propias asociaciones sinestésicas. A veces son relaciones con colores, a veces con música, a veces con sabores: «purgatory es redonda, morada como un metal sin pulir, como el plomo, un poco como una coma gorda que llena casi toda la página»; «[su] color tiene una ligera ondulación, un sonido fuerte, como la gran cuarta nota de la quinta [sinfonía] de Beethoven»; "su sabor es como el de un queso dulce sobre verduras amargas envuelto en manzana con limón exprimido encima» ${ }^{94}$.

El efecto audio-visual es desconcertante, a medio camino entre la provocación y la simpatía. Las connotaciones histórico-culturales de la palabra purgatorio están sutilmente presentes, especialmente para el espectador sin sinestesia que no percibe más experiencia que el alcance semántico de la palabra. En contraposición, las voces sinestésicas hablan de sensaciones vivas, agradables y múltiples que nada tienen que ver con el significado de purgatorio. El efecto de contrastes es provocador: una palabra oscura, llena de connotaciones, sobre un fondo blanco, anodino, muerto y la superposición de voces que hablan de un mundo rico en sensaciones, que reinventan la palabra a base

94 Las voces hablan en inglés y el vídeo no tiene subtítulos, para que el texto no interfiera con la palabra "purgatory". La transcripción original de las citas es la siguiente: «is round, purple like an unpolished metal like plumb, a bit like a fat comma which almost fills the page»; «the color has a slightly wavering, heavy sound, like the big fourth note of Beethoven's Fifth»; «it tastes like a sweet cheese on bitter greens wrapped in an apple with lemon squeezed on». 
de sensaciones aparentemente ilógicas o imposibles pero reales. Es un juego entre las sensaciones semánticas y las perceptivas, entre lo sinestésico y lo no sinestésico. El espectador descubre el mundo paralelo de sensaciones que experimentan los sinestésicos, la carga sensorial que puede evocar una sola palabra. El vídeo abre la puerta a nuevas dimensiones sensoriales: la complejidad sensorial que nace de la sencillez visual. 



\section{Conclusión}

Desde que el lenguaje abstracto de Kandinsky es considerado arte -y no sólo «fantasías para alfombras»- la lectura que se le ha dado ha sido, con frecuencia, la del reduccionismo formal. La simplificación de las formas es evidente, pero a la hora de interpretar, la mera reducción no implica prescindir del objeto ni tampoco explica el porqué. Con el propósito de sugerir una respuesta nueva a ese porqué del lenguaje abstracto, mi investigación ha querido distanciarse de la versión reduccionista y ha apostado por la pluralidad de perspectivas. Las cuatro interpretaciones que he ofrecido pueden ser más o menos convincentes, más o menos plausibles o incluso más o menos reprobables, pero no cabe duda de que abren un abanico de posibilidades. He dado mayor protagonismo a aspectos que hasta ahora se consideraban secundarios, como la expresión del mundo interior o la expresión de la sinestesia, lo que ha reorganizado el peso interpretativo. $Y$ es que, si ahora se quisiera ver el arte abstracto de Kandinsky como un lenguaje dominado por la reducción formal, el argumento a favor de esta interpretación debería ser revisado como una afirmación que niega los otros aspectos (por las razones que fueren), pero en cualquier caso, estaría obligado a considerarlos.

Aunque todas parten del mismo contexto biográfico e histórico, las cuatro interpretaciones son bien diferentes. Es fácil, e imagino que inevitable, considerar una de ellas más afín, pero eso queda a juicio del lector y del espectador. La intención ha sido presentarlas todas en el mismo nivel, y no sólo sin jerarquía alguna entre ellas, sino como partes diferentes de un enjambre común. La interpretación del lenguaje abstracto como minimalismo formal (cap. 4) se ha basado en la versión reduccionista habitual, pero añade la relación directa e imbricada con el contexto histórico y el peso de los acontecimientos ajenos al mundo de la pintura. La intepretación contigua (cap. 5) se hace eco de la relación del arte abstracto con otras artes y eleva así a protagonista lo que venía siendo un aspecto secundario; pero, sobre todo, revela la posibilidad de una reducción formal que no implica una reducción sensorial, demostrando que el mundo interior del artista puede expresarse de manera multisensorial haciendo uso de las formas mínimas. La interpretación del arte abstracto como experiencia espiritual (cap. 6) es algo controvertida en sí misma y en relación 
al resto de perspectivas, pero es una parte esencial si se quiere comprender a Kandinsky, para quien el arte y su desarrollo están estrechamente vinculados con la evolución de la sociedad. La interpretación final (cap. 7) que nace al amparo de la neuroestética, es sin duda la hipótesis más novedosa. La actualidad de los descubrimientos sobre la percepción visual hacen que el marco teórico sea inédito y a la vez versátil, lo que obliga a considerar esta perspectiva como un primer paso de una investigación mayor.

Considero que la lectura de las cuatro interpretaciones consigue que el lector cambie su manera de apreciar el arte de Kandinsky, pero también creo que sería pretencioso afirmar que con ellas están cubiertos todos los puntos de vista. Hay otras perspectivas desde las que contemplar el lenguaje abstracto de Kandinsky. Algunas no las he considerado por la notoria escasez bibliográfica, como la explicación del arte abstracto a través de la cristalografía o la (improbable) cercanía de Kandinsky al sufismo y al animismo. Otras, porque no me han parecido lo suficientemente relevantes o eran ideas extremadamente minoritarias, como la lectura erótica de las formas abstractas de Kandinsky. Y, sin reparos, he desechado la interpretación más común entre el público -la de que el arte abstracto es un puro juego arbitrario de formas- por su evidente irrelevancia filosófica.

Por otro lado, las mismas interpretaciones que he presentado dan pie a nuevas investigaciones. Sería interesante relacionar el lenguaje abstracto de Kandinsky con el de otros autores para comprobar, si es que existe, cuál es la base común desde la que interpretar el arte abstracto. En esa línea, también habría que cuestionarse cuánto de generalizable es el contexto histórico de Kandinsky y quizá establecer un paralelismo entre los tres grandes creadores de la abstracción: Kandinsky, Mondrian y Malévich. Pero el camino más atractivo es, seguramente, el de mirar al futuro y entender el arte abstracto como una puerta a la experiencia multisensorial. La neuroestética y la filosofía, si trabajan juntas, tendrán mucho que decir al respecto en los próximos años. 
<smiles></smiles> 



\section{English version}

\section{Introduction}

Already a century has gone by since Kandinsky painted his first abstract watercolor (1910), and yet abstract art is still incomprehensible to the general public. Despite having a good place in both well-known museums and popular science magazines, abstract art continues to pose more questions than answers among viewers, not to mention the widespread feeling of being teased. Of the numerous questions that arise in front of an abstract painting most of them relate to its understanding or misunderstanding ("what does this color spot with three lines mean?") or concern the quality and value of the artwork ("why is this painting considered so valuable?")

Of course, it would still be interesting to try to answer these questions. Nevertheless, in my opinion they actually mask a broader question, which is even more interesting: the question of why. Why is the object removed from the picture? Why does a painting dispense with the essential thing? What is the reason for that? A quick look at art history shows that different styles, forms, themes and theories have succeeded one another in the last twenty centuries. They are all different, but if they share something in common it is the presence of the figurative form. Philosophers have propounded several hypotheses, and art historians have also suggested a number of theories, but most of them are focused on the evolution of abstract art, on how art developed from being figurative to being abstract. That means, they are essentially focused on the question of how and not on answering why.

Trying to give a reason to abstract art in general terms would be pretentious for a $\mathrm{PhD}$ thesis. This is why I have retained my original idea and tried to furnish an answer to the question of why art dispenses with the object. Here I have decided to focus my research on only one author. If the aim is to explain what happens in the transition from figurative to abstract painting, then the choice of the painter Wassily Kandinsky is almost obligatory. He is one of the founders of abstraction, if not the first who painted an abstract picture, and moreover, he was the only one to write a solid theory to support his artworks. Kandinsky's work is complex and full of questions, and his writings obviously 
do not answer all of them. But as direct sources, these writings provide a foundation on which to base research, and this is a main difference to other authors who are limited to secondary literature.

I originally approached Kandinsky with two questions. First, I wanted to know why someone with a mastery of the realistic technique and a gift for an extraordinary visual vision decided to create a new art style like abstraction. And what is the reason for breaking with centuries of figurative tradition. On the other hand, the parallel between abstract painting and atonal music forced me to consider many aspects from the perspective of an interdisciplinary context. And this gave rise to the question of what the relationship between Kandinsky's abstract art and other arts like music might be.

As with all research projects, the interest in responding to the initial questions is combined with the quantity and quality of the literature. Indeed, studying the literature not only brings some answers but also leads to new questions and highlights where there is a lack of investigation. Kandinsky's work, and more the pictorial than the theoretical, has been studied from different points of view: the historical, the artistic and the aesthetical. But there still remain many open questions, and there is especially a lack of interpretation: that is the task I have focused on.

The lack of interpretation is manifested in the treatment Kandinsky research has given to the historical and biographical context. It has to be admitted that the published biography of Kandinsky is poor, and it is therefore not easy to establish a relation with his artwork. However, some historical and personal events had a decisive influence on his artistic creation, and in my opinion they have not always been accorded the attention they deserve. For example, the discovery of the splitting of the atom and hence the necessity to create new laws in the field of physics considerably affected Kandinsky and his way of understanding art. But apart from a couple of authors who refer to the subject, most recount the story anecdotically. The same may be said of W. Worringer's PhD thesis on empathy and abstraction. Kandinsky read this thesis and understood it as one of the justifications for abstract art, which makes the influence of Worringer so significant. These are just two examples from a list including, among others, Kandinsky's synaesthesia or the partial vision offered on Anthroposophy and its link with abstract art. Much of the 
literature explains the birth of abstraction without interpreting it in either the historical or biographical context of Kandinsky. I have tried to remedy this fragmented situation in my research. Chapter 1 presents the personal events in Kandinsky's biography directly relating to his intellectual project. Chapter 2 interprets the historical events in the light of the birth of abstract art. Because it is impossible to capture the entire the context of an epoch, I have focused on the most relevant facts, especially those most neglected by the literature.

Another weak point, in my mind, is the individualized study of the theoretical works of Kandinsky. He wrote two main works, Concerning the spiritual in art and Point and line to plane. Both constitute the theoretical basis of artistic abstraction: the first focuses on the analysis of color and the second is devoted to the study of form. However, Concerning the spiritual in art was written when Kandinsky was still bound to the figurative form and Point and line to plane already reflects the years of pure abstraction. This means that the time elapsed between the two works is almost fifteen years, and these are the years marking the point of inflection. During this period of time, the transition from the figurative form to abstraction becomes forged and defined. Current literature has devoted much time and effort to analyzing the above two works, but often separately. It has not established a relationship between them, there is no explication about what happened during these years and why the two works are so related. Obviously, there is a description of the biographical, artistic and contextual events, but there is no interpretation. For this reason, I have paid special attention to these works of Kandinsky, as well as to the intermediate writings (including articles and personal correspondence) and to the artistic activities he carried out. The relationship between all of these aspects forms the foundation of Kandinsky's project, which I present in Chapter 3.

The evolution of abstract art has been well documented by art critics and historians. The phases of Kandinsky's painting have been distinguished according to the degree of abstraction and the main monographs have collected secondary but valuable information: drafts, unpublished letters or transcriptions of handwritten annotations. The information is often detailed, clear and complete but the exposition is mostly descriptive. Monographs and research studies present the birth of abstract art describing the artistic results. Their interpretation of the causes and results is confined to a secondary level. With certain exceptions, this interpretation is not even secondary but only remains 
focused on one aspect, which in my view turns out to be a partial aspect. Kandinsky's abstract art is principally explained as the abstraction from real pictures to geometrical forms. And the relationship with music, the affinity with Anthroposophy or his possible synaesthesia are mostly only cited incidentally. The dominant interpretation is that real images are converted to lines and colors.

At first sight, it is true that Kandinsky's abstract art is a formal reduction. But the theoretical and practical project that supports the birth of abstraction is in fact much more complex. Here complex signifies "interwoven", because the formal reduction is not the main pillar, and music or synaesthesia are accessory issues. In my view all of these aspects have the same interpretative weight. For this reason I have opened my research up to a plurality of interpretations, and I have considered all of them as potential protagonists in a global interpretation. The result is four different interpretations, and each of them consistently explains the reason for abstract art in Kandinsky. There is no hierarchy among them, neither are they mutually exclusive: they are different interpretations which complement and require each other in order to give a complex explanation to a complex project. It is sometimes possible that ideas in one interpretation seem to contradict what is stated in another. But if one looks at the four perspectives as a part of a global interpretation, it will be found that the apparent logical discomfort eventually becomes as an aesthetic richness. This is because they are ideas reflecting the coexistence of many aspects, an assembly of different realities. The birth of abstract art must be viewed from the standpoint of complexity. For the creation of abstract art is not an orderly progression, although it is often presented this way. But until it settles, it is a project that comes and goes, jumps in time and is based on different ideas, artistic experiments and justifications. Though at first glance these interpretations seem contradictory, in the background all of them are complementary.

Each of these four interpretations is presented in a chapter of the second half. Chapter 4 understands abstract art from the perspective of formal reduction. Chapter 5 focuses on the expression of inner content and considers abstraction as a multisensory language. Chapter 6 interprets abstract forms as bearers of a spiritual experience. Finally, Chapter 7 closes with a new proposal: the hypothesis that Kandinsky's synaesthesia, as a neurological condition, might have been decisive for the creation of abstract art. 
The parallel consideration of four interpretations, simultaneously different and complementary, not only demanded a lot of reading but a very critical kind of reading. Kandinsky tried to be didactic and analytical in his works, but his language is also often symbolic and imprecise, which hinders the reading and renders the interpretation too flexible. Major monographs (Grohmann 1958, Overy 1969, Weiss 1979, Kleine 1991 and Hahl-Koch 1993) offer many details, but their interpretations are somewhat closed and self-contained. After extracting these closed ideas, the difficulty then arises of linking the ideas together while at the same time unpacking them from different perspectives. The secondary literature provides multiple points of view, but they are only valuable once the statements based on clichés have been filtered out ("Kandinsky painted music"), the ideas from the major studies and the erroneous but fixed details ("The Blue Rider was a group" or "Kandinsky did not master the technique"). While critical reading is characteristic of any investigation, the added difficulty in the present study has been the consideration of the distances. During the research, and especially during the writing process, it was necessary to examine the four perspectives at a distance from each other -to study them in themselves, but also with proximity -to relate them to each other. I had to consider every artistic expression and every theoretical idea as a component of a multiple interpretation, and at the same time give them the consistency of a single interpretation without hindering the structure of the others. This difficulty demanded a lot of critical and comparative work, but it has also enriched the responses since they were always viewed from different points of view.

The theme of synaesthesia, a controversial subject in itself, was another difficulty. There is no consensus on this phenomenon in the literature, neither in a general way nor with regard to the personal situation of Kandinsky (was he a synaesthete?). This is probably the reason why Kandinsky research prefers to ignore it or only comments on it in passing. However, recent discoveries in neuroscience about visual perception have shed new light on the phenomenon. Synaesthesia now has a recognized neural basis, allowing further study to relate it to artistic creation: this is what neuroaesthetic is discovering at present. The final interpretation (Chapter 7) proceeds from precisely this perspective, and examines the birth of abstract art with synaesthesia as the protagonist. This hypothesis not only restores synaesthesia to the role that it lacks in the literature, but also treats abstract art as the key explanation for what appears 
to be the art of the future: an art focused on multiple and poliaesthetical sensations; in other words: on synaesthetical perceptions. 


\section{Summary}

Kandinsky and abstract art is the central theme of this research. It is divided into two parts: the first part is devoted to the artist's context and his intellectual project; the second one is focused on new interpretations. The first part consists of three chapters $(1,2$, and 3$)$ that provide the required common framework for understanding Kandinsky's project. This also constitutes the biographical and contextual basis that serves as a support for the interpretations of the second part. Chapters 4 to 7 make up the second part, which is focused on the interpretations of abstract art. Each chapter offers a new and different perspective: every one explains by itself why abstract art was born, and how Kandinsky made use of this abstract language in his painting.

\section{Chapter 1. Wassily Kandinsky}

Kandinsky's biography is not an incidental introduction but an invaluable starting point for understanding his artwork. It frames Kandinsky in an historical context. Apart from some biographical data, there are also personal details or events that influence his later artistic work.

Kandinsky was born in Moscow in 1866. An artistic education is already visible during his childhood (he takes painting classes and plays violoncello). He chooses to study law and begins a good career at the university until, at the age of 30, he decides to become an artist. He lives and studies art in Munich for almost fifteen years. During the First World War he goes back to Russia and undertakes artistic activities. In 1922, he becomes a faculty member of the Bauhaus movement in Weimar, where he remains as a teacher until its closure in Dessau (1932) by the Nazis. In 1933 Kandinsky moves to France, where he dies in 1944 .

There are four personal details or aspects that are relevant for his artwork. The first is the way in which Kandinsky perceives the world and how he recalls his impressions. Kandinsky has an extraordinary visual memory, converting the outside world into a host of visual impressions that he can remember in

great detail. This kind of memory, described by psychologists as an "eidetic 
image", forms a rich inner world, and Kandinsky will use it to flesh out many of his paintings.

The second aspect is the sort of relationship Kandinsky has with the external world. It is a deep and emotional relationship. He feels a direct connection between what is perceived by the senses and what is sensed by the soul. The world "soul" often appears in his writings, revealing that it plays an important role in art. Color and form, for example, are a way to get directly to the soul, and artistic experiences in general give rise to a state of vibration in the soul. He feels the world this way, and later, as an artist, he wants the viewer to experience the same.

The third element is the role that color plays for Kandinsky. His special attraction to color comes from his childhood, because he perceives it in a special way. For him, color is loaded with an expressive power that overrides the presence of the figurative. Kandinsky perceives color as an autonomous being that does not belong to the object. It is as if color and object were two separate realities. This internal strength of color can also build a direct path to the soul and therefore to the spiritual dimension.

And the fourth aspect is his synaesthetic perception. Kandinsky perceives color by sight but it not only generates in him visual sensations, he can also hear it. This sensory fusion is known as synaesthesia, a phenomenon by which two sensory areas are mixed in the act of perception. There are many kinds of synaesthesia. Kandinsky's type is hearing-colors and seeing-sounds. Kandinsky himself does not use this term but many passages in his work unmistakably reveal it: he describes seeing colors when listening to Wagner or hearing sounds when looking at the colors of sunset in Moscow.

These four factors are the basis for understanding his artwork because they lead to the creation of a new language: his extraordinary visual memory plays a decisive role in the creating process, spirituality shrouds his art in transcendence, the autonomous color is the main character of the artistic language and the synaesthetic perception opens up a new artistic dimension.

\section{Chapter 2. The historical context: around 1900-1914}

The historical context that witnesses the birth of abstract art is the beginning of the twentieth century: an intense period with enormous upheavals. 
The years before the Great War are full of scientific discoveries and artistic flourishing. Some of these events influence Kandinsky either personally or indirectly, but all of them reflect how abstract art began to emerge. The main fields in this respect are physics, painting, music and philosophy.

New physics. The great revolution of the early twentieth century is the one carried out by science. These new scientific discoveries not only influence the field of science, but also other spheres of knowledge, including art. The splitting of the atom, the theory of relativity and the birth of quantum physics are some of the most important progresses originating in this century, and all leave their mark on the art of Kandinsky.

The further division of the atom affects Kandinsky so much that he believes the world is reeling and that science cannot be trusted anymore. He describes how the splitting of the atom is for him equated with the collapse of the whole world, and he has the sensation that everything becomes uncertain, precarious and insubstantial. The new atomic model actually represents a paradigm shift. The indivisible atom was synonymous with robustness, security and stability, and if it happens to be divisible, the basis of the world seems to be an illusion. This finding affects the physic world but also calls into question many philosophical theories. What had seemed clear, fixed and secure, now vanishes.

Kandinsky interprets "atom" as "object", extending the recent discovery of the atom to the objects themselves. And this gives rise to two questions: on the one hand, having lost his confidence in the stability of the atom, Kandinsky feels a new skepticism towards the objects and the integrity of the appearance of the external world. If the atom is no more the foundational element of the world, can the object still constitute the main part of the painting? On the other hand, if the new atomic concept requires new laws in the field of physics, Kandinsky thinks that perhaps the field of painting likewise needs new laws to represent the object.

The publication of the theory of relativity by Einstein is another scientific revolution. One of the tenets of his theory postulates that there is not a preferred or absolute system of reference, but that the perception of space and time depends on the state of motion of the observer, i.e., it is relative to him 
or her. This postulate also affects philosophy, because one is now required to reinterpret the received Kantian concepts of space and time. This new concept of space may also be seen in the field of art, where paintings are beginning to show the absence of a specific and defined space. Similarly, Kandinsky's paintings do not have an absolute reference system where all viewers appreciate the same. This lack of defined space appears in many of Kandinsky's pictures, creating a kind of open canvas, relative to each viewer.

Max Planck introduced the concept of quanta in 1900 and other hypotheses and assumptions that contradicted the hitherto accepted notions of theoretical physics, and hence furnish the foundations of something totally new: quantum physics. The new laws of quantum physics can now explain something that classical physics was unable to: the subatomic phenomena. This new discipline does not replace the old one, both of them coexist, but there is a rift between the classic and the quantum world and each one has its own laws.

From quantum physics, Kandinsky assimilates two ideas. One: the break with classical physics signifies for Kandinsky the removal of the classic world of art, breaking with realism and figurative painting. And two: accepting that new laws need to be formulated in order to explain the subatomic world leads him to consider the possibility of new laws for his new kind of painting, since the object becomes less important, and the space is relative to the viewer.

Painting. Like in science, the twentieth century brings new ideas and styles to pictorial art. French Impressionists begin an artistic revolution which goes against conventional standards of representation and against academic formalism. This transgression leads to innovative styles such as Fauvism, Expressionism and Abstraction.

Kandinsky knows and appreciates much of the work of the Impressionists. As he develops his own artwork, he rejects the impressionist themes and style, yet there are some formal aspects from which he learns or to some extent even assimilates. It is about the use of color and form. Impressionism wants to capture visual impressions dominated by certain lighting conditions, since light takes on a new importance. In combination with pure and vivid colors, the result is a more energetic and vigorous impression on the canvas. 
Departing from this relation between light and color, Kandinsky develops a color theory focused on the chromatic capacity of color with regard to light and the sensory perception of the viewer.

A second aspect is the use of form. With the Impressionists, the form starts to lose prominence, partly because color now takes on this role, and partly because it is the logical continuation of the neglect of form started by Manet. The form is subordinated to color: the areas are blurred, the absence of contours are emphazised.

The idea of the loss of the significance of the form comes to Kandinsky through a painting, one of the haystacks of Monet. Kandinsky sees this picture, and at first glance, he does not recognize what it is about. Despite not having identified the object, he feels that the painting conveys a great expressive force. The fact that a picture communicates inner power even when the viewer does not recognize the object marks a turning point for Kandinsky. He realizes that it is not the object that bears the expressive force, and therefore it is not essential in a painting.

The expression of the inner world of the artist begins to be more present in the painting. Kandinsky pays attention to three artists who, in his opinion, know how to externalize this inner world: they seek the internal in the world of the external. The first figure is Cézanne. He not only blurs the contours and the space, but also synthesizes the basic elements of painting and manages to order the outside world into simple shapes and colors. Kandinsky appreciates Cézanne's ability to abstract nature, to discover the essence and structure of things and put them on a canvas. It is the first step towards abstraction.

The second artist is Matisse, who defines his style using bright colors in relaxed figurative forms. The form seems to be unattended and proceeds into the background, because color dominates the painting. Matisse uses the colors subjectively, making them independent of the object that they normally belong to. This way of using color is similar to how Kandinsky perceives it, separating the color from the object, as if color and object were independent beings.

And the third person is Picasso, who initiates Cubism with a new way of conceiving reality, close to that of physics. Cubism breaks, as does the new physics, with the idea that there is an absolute system of reference, a single point of view. Kandinsky does not want to represent simultaneously the multitude of views as Cubism does, but it shares with it the loss of a single 
system of absolute reference.

Expressionism is another style which emerges at the beginning of the century and is directly involved in the reversal of the art scene. The Bridge (Die Brücke) and The Blue Rider (Der Blaue Reiter) are the greatest exponents of this style, in which forms are relaxed and they lose the resemblance to nature. The use of color become important and the expression of the personal world of the artist prevails over the impressions and appearance of the real world. Kandinsky not only takes from Expressionism the idea of expressing the inner world, he is actually part of this movement as the protagonist of The Blue Rider.

Music. Like painting or science, music begins to break with traditional standards of earlier centuries and sets out to explore new forms and languages. The tonality, as substantial in music as the object in painting, seems to follow the same path: dilution, loss of importance, radical change of consideration.

In the years at the turn of the century, the works of Wagner and Richard Strauss dominate the music scene. Wagner had earlier introduced significant changes in musical conception, claiming a new way of understanding the opera: one that focuses not only on the score but intends to accommodate the other visual and performing arts. Wagner aspires to a kind of art, the Gesamtkunstwerk, that collects the forms and methods of different arts in a process of synthesis or interrelation of the arts. Half century later, Kandinsky adopts this idea of the Gesamtkunstwerk with a similar purpose: to create an artwork in which different arts are present. A good example of this is Yellow Sound, a sort of play or stage composition written by Kandinsky around 1911.

Richard Strauss writes Salome in 1906, a daring opera that does not conform to the laws of composition, for example by using dissonant chords, unusual modulations or a wide range of keys. Strauss fragments the tonality, the core of every composition, but he does not eliminate it. It is something similar to what Kandinsky does during his Expressionist period: he fragments the object and relaxes the forms, but he does not dispense with it.

Claude Debussy is another artist who begins to break the traditional rules. He does not compose without tonality, but he plays between two tonal worlds, the harmonic and the dissonant. The bass sounds consistent and is composed 
with fifths and octaves, but the upper voices are filled with augmented and diminished chords that create a partial dissonance with the bass. Kandinsky compares the music of Debussy to Impressionist painting, because both dispense with the classic rules regarding tonality in order to express the inner content of the artist.

Arnold Schönberg continues the line of non-compliance to the traditional rules of composition, but he takes it to its conclusion. There comes a time, around 1908, when his compositions lose all trace of tonality: the chords are dissolved in incomprehensible intervals, and dissonance and atonality dominate. Schönberg creates a new musical style, calling it atonal, serial or twelve-tone music, which he expounds in a complete treatise on harmony (Harmonielehre).

By the time Schönberg writes his atonal works, Kandinsky paints his first abstract watercolor. The similarities between the two styles are considerable, and both protagonists recognize this. Kandinsky attends a concert staged by Schönberg in Munich in 1911 and realizes that the music he is listening to is the expression of the idea he wants for his painting: an art that breaks the traditional rules to fully express the artist's inner world, a world of emotions and sensations. Kandinsky is delighted with the freedom, the independence and the formulation of the inner expression revealed by the music of Schönberg. Kandinsky wants to create a new art style which is similar to atonal music, where color and form are independent of the figurative form and hence free to express the inner world. Kandinsky and Schönberg become friends and share many aspects of their respective artistic projects.

Philosophy. Numerous philosophical, psychological and sociological theories also flourished at the beginning of the century. It is difficult to know precisely what Kandinsky read and which ideological ideas left their mark on him. Nevertheless, thanks to some handwritten annotations and references he made in some of his works it is possible to make a fairly accurate assumption about the ones that were the most important to him: the aesthetic theories of Lipps and Worringer and also Steiner's Anthroposophy.

Wilhem Worringer, a student of Theodor Lipps, wrote his doctoral thesis on abstraction and empathy (Abstraktion und Einfühlung). Lipps theory of 
empathy states that there is a relationship of sympathy between the art object and the perceiving subject. Worringer completes this theory, expressing that the relation between art and viewer is based on empathy but also on an impulse to abstraction (Abstraktionsdrang). Abstraction is a feeling that arises from the anguish that haunts every man since the beginning of his existence. The world is confusing and too big for the human being. Because of this agoraphobic feeling towards the world, man tries to sort out what he sees outside through an abstraction process. Abstracting the complexity to basic shapes, man tries to alleviate his sense of anxiety and disorientation.

Worringer's theses were well-received among artists and critics and also by Kandinsky. The theory of empathy seems to explain his feeling that artistic experiences generate a state of vibration in the soul. And the theory of abstraction not only convinced him, but also offered him a justification for using abstraction as a tool for a new artistic style. Worringer talks in his works about primitive peoples, but the feeling of confusion and instability present in the early twentieth century seems to be equally applicable. Kandinsky sees in abstraction a way to bring calm and order to an unsafe and unstable outside world.

The situation of change that science brings, and the consequent mistrust towards it, leads to idealistic, spiritualistic and theosophical theories. Blavatsky's theosophical theories and Rudolf Steiner's Anthroposophy were disseminated in books and lectures in Germany, and also became known in the circles close to Kandinsky. The extent to which Anthroposophy had an influence on Kandinsky is a somewhat controversial issue, but there is no doubt that this discipline is an ideological event, contemporary with the birth of abstract art, and that Kandinsky is not indifferent to it because he names Anthroposophy in his books.

Anthroposophy is the science that studies the spiritual, and aims to become the science that teaches man how to reach the supersensory world, the world beyond the senses. Steiner also wants to give Anthroposophy a theoretical and structured method with an academic background. In a similar way, Kandinsky believes in the importance of the spiritual world, since for him the process of creating an artwork is dominated by the search for the spiritual. And he also wants to give his art a new theoretical framework, a kind of treatise on painting that he calls the "grammar of creation". 
As Robert F. Bornstein says, no intellectual discipline exists in a vacuum but evolves in response to events taking place in other neighboring fields. Likewise, the creation of abstract art is strongly marked by the events of the time. Some of them are more relevant than others, but every one of them directly or indirectly influences the artwork of Kandinsky. This influence has three important effects: the loss of the object, the new role of color and the expression of an inner world.

\section{Chapter 3. Kandinsky's Project}

Kandinsky's art project was a gradual process with leaps and smooth transitions, even though it is often presented for methodological reasons as a linear process. This may give the wrong impression of being a project with a clear objective from the outset. However, in order to clarify how the path to abstraction starts, and in particular what the decisive turning point for the creation of this new style is, it is useful to analyse the artistic career of Kandinsky as a whole.

The path to abstraction. When Kandinsky came to Munich to do art, he studied painting at the two most famous art schools of the time. Firstly, under the supervision of Ažbe, he reinforced his knowledge of color, because Ažbe taught him how to work with color over form, with the result that the contour of the objects then loses its significance. Secondly, the time Kandinsky spends with Franz von Stuck at his school is a time to learn about form. Stuck places great emphasis on form, often forcing Kandinsky to paint in black and white so as to forget color and purely focus on form. Kandinsky learned from both teachers two different ways of dealing with art, each one focused on a pictorial means: color and form.

After learning at these schools, Kandinsky then founds his own school of painting, Phalanx, which is additionally a society that organizes exhibitions. The aim of Phalanx is to offer a platform to house the art of the future. Kandinsky wants the exhibitions to lead the way towards a new art, where disparate disciplines (music, painting, theatre, etc.) cooperate and integrate with one another, supporting somehow the idea of Wagner's Gesamtkunstwerk. Phalanx did not succeed, but it gave Kandinsky the opportunity to meet many 
artists from other disciplines and to work in different artistic fields.

After the dissolution of Phalanx, Kandinsky spent many years traveling in search of new experiences and visual impressions. During this time he exhibited his artwork in many European cities. Upon returning to Munich he founded an association, NKVM, another artistic society that once again aims to be a platform for new and revolutionary art. The articles of the association emphasize the synthesis of the arts and the idea that art should be an expression of the inner world of the artist and not a copy of the outside world.

Not all association members seem to agree with these ideals and there are problems with some artworks. One of them is Composition $v$, a painting by Kandinsky that the jury does not accept to exhibit because it is too close to abstraction. This incident is the last straw and Kandinsky and others artists leave the association. Afterwards, Franz Marc and Kandinsky begin a new project, the almanac The Blue Rider.

Kandinsky and Marc want to publish a book containing contributions from various artists, and presenting the art scene of the moment. It should be an almanac, a kind of calendar that brings together the work of different arts, styles and artists, showing that although they may be different, they are ultimately expressions of an inner world. Kandinsky and Marc are responsible for editing the book and for organizing several exhibitions with some of the works present in the almanac and other new things. As the exhibitions had a name similar to "Blue Rider" (but not The Blue Rider), it was assumed they were a closed group of artists with that name. For methodological reasons, it became easier and more practical for scholars to think and treat them as a group, but several quotations in the works and letters of Kandinsky reveal that there was no group at all.

In addition to the almanac The Blue Rider, Kandinsky at this time published a number of other important works. Concerning the spiritual in art arose from theoretical notes on painting and on the expression of the inner world. It became a book after a couple of years, and was an instant success. The ideas are new and revolutionary, offering an independent theory of color from a theoretical and analytical perspective, yet also including original and innovative terms such as the psychological effects of color and its access to the spiritual world. This book is the first foundation for abstract art, because it 
already shows the importance of color and the expression of the inner world, even if does not mention the total elimination of the object.

His second book, Point and line to plane, is written years later during his period as professor at the Bauhaus. Abstraction in now well-established in his painting and the book is focused on the study of pictorial form, unrelated to the figurative form. Written in a theoretical and educational style, the book presents an extraordinary theory of form and its use in a purely abstract composition.

In the intervening years, Kandinsky publishes important articles and studies dealing with the color or form. He also publishes compilations of engravings that he identifies with visual poetry, and also several works like plays or stage compositions that are in fact a new artistic model for the presence of different arts. The writings and artworks of these years demonstrate the transition of ideas regarding the theory of abstraction.

Abstract art. Through all the publications and works of Kandinsky, the path leading to abstraction is gradually being forged. In addition to the influence of the historical and biographical context, there comes a turning point in his artistic approach. It is marked by four aspects: art needs a new language; this new language does not necessarily need the object; color and form must play a new role; and this new language has to enable an access to the spiritual and inner world. The combination of these needs leads to a new artistic style that Kandinsky calls "pure art" or "compositional painting", and years later it receives the name of "abstract art".

In contrast to figurative art, in which according to Kandinsky the practical aspect dominates over the aesthetic, compositional painting expresses a content that does not refer to the outside world and does not use figurative forms. The painting ignores the objective element and puts the constructive element in its place.

The constructive element is the combination of form and content. The content is the internal element, and the form the outer. The content is «the emotion in the soul of the artist». It is indispensable for the work and has the capacity to evoke a feeling in the viewer similar to what the artist wants to convey. The form is the externalization of this content, the way to express the content, or to put it another way: it is «the material expression of the abstract 
content».

The inner element does not take nature as source of inspiration but comes from the interior of the human being. The content of the work is therefore born from the inner world of the artist, that is to say, from his emotions, impressions and the sensations from his inner being. Kandinsky terms this inner world "internal necessity" (innere Notwendigkeit). It is internal because it is the set of inner feelings, intuitions, etc. And it is a necessity, because it is like an impulse forcing the artist to express it.

The internal necessity needs to be expressed in a suitable external form, so that the viewer can receive it. To express such an abstract, sensory and emotional content, the pictorial medium must act in a certain way. As Kandinsky says, if used properly color and form can convey abstract and sensory content because they have a special expressive power, which Kandinsky designates as "inner sound" (innerer Klang).

If the artist uses the inner sound of color and form properly, the viewer then receives a kind of inner vibration that conveys the emotion and feelings of the artist. The work of art, therefore, is a bridge from the emotion of the artist to the emotion of the viewer. If the viewer is capable of experiencing the emotion of the artist through the vibration transmitted by the inner sound, then the "inner identity" (innere Identität) is released. This release is the ultimate goal of compositional painting or pure art.

The choice of the external form is essential for releasing the inner identity. It must be able to convey the internal necessity and allow the pictorial medium to express the inner sound. Kandinsky does not want to write a closed manual with strict indications concerning the nature of this form, rather he attempts to establish a theoretical formulation, a kind of treatise to guide the artist in his search. This theoretical basis is called by Kandinsky the "grammar of creation" and it is carried out in two steps. First, the analysis of the pictorial elements, and second, the relation of painting to other arts.

The analysis of the pictorial medium involves three stages: first, Kandinsky analyzes color and form with regard to both its natural (substance, pigments, etc.) and its psychological properties (the effect they have on the viewer). Second, he defines a vocabulary for the new language, that is to say, he defines the basic elements of the painting. Some of them are reinterpreted (e.g. "form" is not "figurative" anymore), and some of them are new (as "inner sound"). 
And third, he establishes a set of rules of construction -similar to axioms that help with the formulation of the language.

The second step is a study of the relation of painting to other arts. With an eye on Wagner's Gesamtkunstwerk, Kandinsky wants to create paintings that denote and/or contain the presence of other arts. To achieve this, Kandinsky attributes to color and form the capacity to express other realities, like the sound of music or the movement of dance. His woodcuts work, Poems without words is a good example of the fusion of poetry and painting, because form is here able to express rhythm or cadence.

\section{Chapter 4. Abstract art as a reduction to essentials}

This interpretation understands abstract art from the perspective of formal reduction.

The simplification of the forms. The atmosphere of change and instability required Kandinsky to find an artistic language in harmony with the beat of time. Kandinsky sought an art that, with its own new language, gives the viewer an ordered reality without the torment of the relative, of plurality, of insecurity. Guided by Worringer's ideas and by the analytical and reductive environment of the time, Kandinsky built a language based on abstract forms which shows the essence of things, their internal structure, their stability. It is a reduction of the complexity to the essential. Kandinsky's art tries to eliminate the external complexity by reducing the forms to their minimum and basic structures.

For the creation of this language of reduced forms, Kandinsky examines form both by itself and through its presence in nature. Kandinsky analyzes the presence of point, line and plane in nature, not as source of inspiration but as a confrontational analysis. Kandinsky wants to understand how nature uses the basic elements of natural objects. For example, he learns how a human skeleton can be reduced to lines and points in order to show its internal structure.

The study of abstract forms in ornamentation also helps Kandinsky in the creation of the language of formal reduction. The artist Hermann Obrist is one of the most important influences, he uses minimal forms of nature to embellish his artworks. Obrist refines the forms of nature until they are only 
abstract and geometric skeletons and decorates his works with them. From ornamentation, Kandinsky learns how to simplify the forms to an abstract appearance, and how to use them in art. However, the difference for Kandinsky is that the reduction of forms becomes an aim in itself. Ornamentation uses reduced and abstract forms as a mean, whereas Kandinsky uses them as an end, as a solution for a new art style.

Formal minimalism. Kandinsky presents a new language based on the reduction to minimum terms. Yet the form must still convey the essence of things, and express the true essence of reality. The form must also meet the requirements of the content, because content determines form. The precise difficulty is how to convey this inner world, because a series of sensations or feelings are something ethereal after all. An excessive reduction of the form could be very dangerous, because it might end up being inwardly expressionless. Form would seem arbitrary, just a set of lines, dots and colors, with no difference to an ornamental form. That is why Kandinsky emphasizes that form must always convey a content. Form, no matter how reduced it is, always has to express the internal necessity of the artist.

This means that Kandinsky's language of reduced forms (what is nowadays labeled "abstract art") actually gives a formal appearance (lines, colors) to an internal content (emotions, feelings). Thus, the language of form and color becomes a kind of symbol, the forms stand for something, as Paul Overy has observed. The vocabulary of lines and colors is not a translation of emotions or feelings, but it is a representation, a sort of code or visual symbol.

At the same time, the language needs to reduce the artistic form to a minimum. This reduction would not necessarily mean the elimination of all figurative signs. However, on account of Monet's haystack and other personal events Kandinsky believes that the object is not essential and may therefore be disregarded. Moreover, Kandinsky maintains that the object or figurative form can indeed hinder the transmission of the inner content to the viewer. And so abstract language not only reduces the form but dispenses with any signs of figurative form.

As soon as the picture surface is devoid of an object or recognizable figure, the spatial reference is lost. The dimension that adds vitality to the objects is the cubic or third dimension, and by eliminating any figurative reference, 
Kandinsky eliminates in turn the third dimension of space, shifting the picture surface into a new space. Abstract art changes the conception of space, just as Einstein did in the field of physics.

The loss of the object furthermore requires reconsideration of the role of color. Color gains expression and new prominence - it is no longer simply a support for the objects, but becomes autonomous. The paintings Oriental (1909) and Improvisation 19 (1911) are two examples exhibiting this change. (See page 156, and page 157.)

The formal refinement. The best way to appreciate the formal refinement would be by looking at the picture from its primitive conception until its final manifestation. Unfortunately, the images of pictures in their preparatory phases have usually not been preserved. There are some sketches of certain pictures, and also woodcuts which served as a preparation for real paintings. With these images, it is possible to follow a part of the whole reduction process, both the general reduction and the special reduction of recurring figures, as in the celebrated figure of the horse.

The horse is a central figure in Kandinsky's paintings. It may appear alone, be ridden by a rider, or together with another horse, as two horses forming a troika. As Kandinsky's art evolves, the horse suffers a reduction or simplification like the other forms, and finally becomes a curved figure and then a circle. As abstraction comes to fruition, the circle will replace the horse. When Kandinsky's art is completely abstract, the circle becomes an abstract form by itself and no longer resembles the horse.

Most researchers agree that the horse has a special meaning for Kandinsky, but not all of them point to the same reasons. The horse is for Overy a lyrical image of joy and energetic release, for Hahl-Koch it is the image of beauty, harmony and nobility, and for Nina Kandinsky, the horse symbolizes the representation of the future, the thrust forward, towards what is coming. The symbolism of the horse is similar to the significance of the circle, which is the reason why the horse ends up becoming, through reduction, a circular shape. Both forms express a similar inner content but at different stages of abstraction. The phasing out of the horse to the form of the circle can be traced in the images in Section 4.3.1. 
The study of the woodcuts sheds a great deal of light on the reduction process. The production of a woodcut requires a large amount of formal refinement, and so it is considered that it plays a decisive role in the path of Kandinsky to abstraction. From woodcuts, Kandinsky imports into painting the surface flatness, the reduction of lines and the use of highly saturated colors without transitions. These three features can be clearly seen in the preparatory woodcut to Improvisation 19 and may then be compared with the real painting.

The sketches of the paintings may also be used to visualize the process of simplification. It is possible to see how forms are reduced to their minimal appearance. From the sketch to the final form, the number of lines decreases, the figure is stylized, the form becomes refined: nevertheless, they still retain the inner expression. Several sketches of the paintings Impression III and Com-

position IV have been preserved, which makes them two excellent examples for analysis (see images in Section 4.3.2).

\section{Chapter 5. Abstract art as a multisensory expression}

The rejection of the outside world as a source of inspiration and content for the artwork turns the focus on the inner world of the artist. Feelings and personal experiences now constitute the main part of the content. Kandinsky looks for a language that, through abstraction, is able to express this inner and multisensory content.

The sensory richness. The inner world of the human being is full of impressions that respond to both external stimuli and to pure subjective feelings and emotions. These sensations tend to be multisensory; they combine different senses and can be hardly expressed in words. The inner world of Kandinsky is similar, but there are certain personal characteristics that make his world even more richly detailed: for example his extraordinary visual memory or autonomous perception of color that is not linked to the object. This inner world is the content of the artwork. The concept of inner world is not exclusive to Kandinsky, but his reformulation into internal necessity broadens the term to embrace new connotations.

Of course, Kandinsky is not the only artist who tries to find a language capable of expressing feelings and emotions. In general, art at the beginning 
of the century wants to transmit a sensory and inner content to the viewer, far removed from the mere imitation of nature. The artist August Endell is particularly interested in how a work of art can express inner feelings. Endell researches in his $\mathrm{PhD}$ how certain forms can influence aesthetic perception, and which forms arouse the greatest empathy in the viewer. Like Endell, Kandinsky is interested in creating forms that directly appeal to the senses and which manage to convey emotions. Both want to construct a language capable of expressing sensations with the greatest possible richness. Endell is a notable influence on Kandinsky. However, Kandinsky is the one who produces a solid theory and constructs a language with vocabulary and rules.

The expressivity of abstract art. A multisensory, complex and rich content requires an appropriate artistic language. According to Kandinsky, to express the inner world and reach the viewer this language needs two things. One of them is to eliminate the object, because it hinders the transmission of the content. If the artist paints a fish, the viewer will only see a fish. In contrast, if there is no object to recognize but only shapes and colors, the viewer is forced to look further to see if these forms arouse other kind of sensations. The second thing that the language needs, is an external form that conveys to the viewer a multiplicity of sensations; i.e. all the different sensations and not just the visual ones. Abstract forms are capable of precisely this -because form and color have a special form of expression, their inner sound. The artist just has to know how to properly use them.

In the development of his grammar of creation, Kandinsky investigates both theoretically and practically how to express multisensory content by means of abstract forms. He studies the acoustic quality of the color, its temperature or the sensation of movement it evokes. The results of his research and theories can be found in his main writings (Concerning... and Point an line...) as well as in several articles published during his time at the Bauhaus. In terms of artistic practice, one of the studies about how color acts in relation to other colors and forms is the watercolor Color Study (1913; Figure 23).

If the sensations to be transmitted are as broad and multisensory as the internal necessity, then it is almost impossible to fit them into a canvas that operates like an axis of classical space-time coordinates. This is because it would reduce the artistic expression to a single surface that is identical to the 
artist and viewer. Abstract expression requires a certain amount of flexibility, and metaphorically this means a canvas that can accommodate several surfaces. With his artistic language, Kandinsky manages to put an end to the single surface. The different use of color achieves a variety of surfaces because Kandinsky is not just using «surface colors», as defined by David Katz, but also «film colors» and «volume colors». In this way the picture conveys the internal necessity to the viewer, not at once but rather spread over different surfaces, like a hologram that is close to the viewer. Composition sc vi (1913) is one of the best examples to see it.

The diversity of surfaces and the multisensory expression allows acoustic or mobile sensations to be present in a painting. This enables Kandinsky to incorporate other arts into a painting, which is a reinterpretation of the Gesamtkunstwerk or synthesis idea. The manner in which Kandinsky includes other arts is in line with his intellectual project. In a first phase, the Phalanx exhibitions and the almanac The Blue Rider are a way of bringing together different art forms under the same work. They allow a parallel view of paintings, sculpture and poetry. Although expressed with different means, this demonstrates that all works seek to convey an inner content.

As the project progresses, the synthesis idea becomes consolidated. Kandinsky studies how the different media of the different arts (e.g. color-painting, rhythm-poetry, movement-dance) express their inner sound. Thus, he creates artworks that combine several media. An example of this is his work Sounds, a synthesis project in which he combines pictorial (color and form) with literary media (word and sound).

Kandinsky attempts to import the expressive power of music or dance into the medium of painting. His aim is not to paint music, but to make color and form express the sensations that are usually conveyed in the other arts. Kandinsky establishes a relation among the different artistic media and isolates the expressive power of each one. This permits Kandinsky to construct a language capable of conveying sensations that until then were considered unfeasible for painting, such as sound, rhythm, cadence or movement.

The sound of the pictorial means. Color and form are the protagonists of abstract art. Kandinsky studies the chromatic capacity of color in relation to light, the effect it has on human beings, and its ability to convey different types 
of resonances or inner sounds. He develops a theory that associates each color with a temperature, a sound, a kind of movement and a degree of lightness. Yellow for example is light and warm, it sounds like a trumpet, moves fast, and «easily becomes acute and cannot sink to great depths». Blue, on the contrary, is dark, cold, sounds like a flute or violoncello, moves in adagio tempo and «becomes acute only with difficulty and cannot rise to great heights». The color theory can be mostly read in Concerning the spiritual in art.

Form also acquires a new power of expression. Since it is released from representing the outside world and removed from any resemblance to objects, form now takes on a new inner sound. The basic elements of form are the point, line and plane. Through movement, the point gives rises to the other forms. The point itself is at rest, but if it moves longitudinally, it then generates the line. And the line, by moving, generates the figures (circle, square, etc.). In addition to movement, form can also express temperature, rhythm, strength, density, harmony or other sensations. The whole theory of form can especially be found in On the question of form and in Point and line to plane.

Every color and every form has a special sound by themselves and in combination with other forms and colors. Kandinsky studies all of them deeply, but there is one form to which he devotes more attention: the figure of the circle. The circle is the main figure in the abstract language because it is able to concentrate a large amount of expression. It is a precise and variable form, it is sonorous and silent, still and in movement, stable and full of tension. It is a synthesis of contradictions that can express a lot of sensations if used properly, according to the internal necessity. This is the reason why the circle occupies such an important position in many of Kandinsky's paintings, such as in Several circles, Circles in an circle or Blue. Blue is one of the best pictures to appreciate the sound of pictorial media and the circle in particular. It demonstrates that form and color are sufficient to express content without an object, and the apparent simplicity of the painting (it is just a circle and a point) is still able to facilitate a multisensory perception without being distracted by other forms. (See Figure 30.) 


\section{Chapter 6. Abstract art as a spiritual experience}

The presence of the spiritual world in Kandinsky's art is obvious, but the hows and whys of that presence is a contentious issue in Kandinsky research. Although the exact influence of Anthroposophy on Kandinsky is still debated, it is clear that Kandinsky believes art has the ability to communicate a spiritual content and bring it to the soul of the viewer. This is because abstract forms are bearers of a spiritual experience.

The search for spirituality. The new century is pervaded by an atmosphere that rejects materialism, an atmosphere that leaves its mark on Kandinsky. The rejection of the rational way, and the search for a new spiritual path promoted the belief in intellectuals and artists that a great change was coming and that it was eventually time for a spiritual period. Orthodox and conservative Russia starts to call into question the status and truth of certain religious issues. Kandinsky's Russian teachers speak of a 'spiritual rebirth' and the 'rebirth of a new culture'. This rebirth also includes the revival of art, where art is understood as the key opening the path to the spiritual. Kandinsky partakes in these cultural reflections as well as the idea of the new role of art, in which art can lead the spiritual change in society.

The atmosphere of spiritual renewal was pronounced in Russia and Germany. It seems clear that this religious debate affected Kandinsky both personally and artistically. Anthroposophical theories are much discussed at this time and Kandinsky refers to them in some of his writings. But how and to what extent Anthroposophy directly influences the birth of abstract art is a contentious issue. The reason may be the transcendent character of the subject, the symbolic use of the word Geist (spirit) and Seele (soul) by Kandinskyy, or even certain contradictory statements that may be found in the secondary literature on Kandinsky. For example, Sixten Ringbom's book, The Sounding Cosmos, is based primarily on the relation of Kandinsky to Anthroposophy. It provides a lot of information about this topic, but it has also provoked much controversy.

Despite the controversy with Anthroposophy, it is clear that Kandinsky believes art has a spiritual character and is therefore the ideal tool to combat 
materialism. Present-day art is subject to material and purely practical aims, says Kandinsky, and this prevents the expression of feelings that move the soul of the viewer. Kandinsky therefore intends to create a new art which is capable of expressing a spiritual content, and in this way to lead to the birth of a new era.

The spiritual renewal of art has to accomplish two goals. The first one is to highlight the importance of the soul, because materialism has relegated it to a secondary place, confining the human being to a mostly corporeal existence. The second goal is to enable the viewer to become more receptive to this new kind of art and able to receive the content of the artwork.

This new artistic style of Kandinsky gives the soul the importance it deserves, and makes the aesthetic perception of the viewer more sensitive to every kind of sensation. In this way, art can lead to a new era and spiritually ennoble society. Just as the creation of abstract art is a process of spiritualization, so the evolution of society follows a similar path.

At the forefront of society there are usually men who see one step ahead, who guide society along new ways. In art, such a prophet would be the artist who manages to express the inner content through the work of art. Incidentally Anthroposophy defends a similar idea. Kandinsky goes further by interpreting the artist not only as creator of a new art, but also as creator of a new world. If art expresses a spiritual content, then the creation of the work involves the creation of the world (Werkschöpfung ist Weltschöpfung).

The inner expression. The language of abstract art is based on the expression of an inner and spiritual content, which is externalized through the pictorial means and can arouse feelings in the soul of the viewer. This chain of transmission addresses two issues: first, how this content becomes transmitted to the viewer; and second, what this language itself is, what exactly does it look like.

The artist externalizes his inner world in a work of art and the soul of the viewer receives sensations that open the way to the spiritual dimension. The process begins with the inner world of the artist, with an internal necessity. This internal necessity is the content of the work, but also, in Kandinsky's words, the creative spirit, the "principle of the purposeful touching of the human soul». 
The internal necessity of the artist become external in the work of art. Thanks to the expressive power of the medium, color and form evoke spiritual feelings and sensations in the viewer. This expressive power is the inner sound, and because it renders visible a spiritual content, it is a bridge from the inside to the outside, a cosmic projection of the work.

The inner sound reaches the human soul through vibration. The pictorial medium, color and form, emit their inner sound or spiritual resonance that conveys the sensations. The viewer feels how the work of art radiates a vibration to the soul. The viewer's soul vibrates by perceiving the work and thus receives the spiritual content of the artist's soul.

This process is only possible if the artistic language is appropriate, with forms expressing spirituality. According to Kandinsky, this is accomplished in two steps: the language must come from the spirit itself, and the language has to renounce bodily forms.

The language comes from the spirit when it originates from the internal necessity. Or to put it another way: color and form really express the inner content when there is harmony between the inner and the outer. Only in this way can spirituality flow between artist and viewer.

The language renounces bodily forms when it dispenses with any figurative form. The removal of the object involves an approach to the spiritual world because it allows the viewer an access to new sensations. The viewer does not linger on the contemplation of the object anymore, and is open to new experiences. Obviously, the viewer has to learn to appreciate the spiritual content, and to unravel the language of the abstract and spiritual forms.

The presence of the spiritual world. The abstract art of Kandinsky conveys the spiritual world primarily through a transcendent language. However, there are other aspects that also help with the transmission: the choice of religious themes or the use of symbolic elements are just two examples.

Most of Kandinsky's abstract paintings do not have a descriptive title that reveals something about the topic of the painting. Notwithstanding, various comments and notes found in his notebooks indicate that some pictures were conceived with a religious theme, and others were created from an image of a religious reverse glass painting. 
Composition $v$ deals with the Resurrection, Composition VI is about the Flood. Other works do have a title and the religious component is more than clear: St. George, All Saints, St. Vladimir. Kandinsky also uses some figures as religious symbols. For example, the rider stands for the victory of the spiritual over the earthly, the rainbow for the union between God and men after the Flood, the castle on a hill is the heavenly mansion on earth, and the chessboard symbolizes the origin and the end of life.

Many of the paintings with religious themes or elements are reverse glass paintings (Hinterglasmalerei). This technique, widespread in the south of Germany, has a strong religious and popular component. The farmers were grateful to the saints for a good harvest and painted small glass pictures with bright colors and rough patterns, but as the highest expression of their inner feeling. Kandinsky knew this technique and used it for years. He later incorporated not only this religious character into his abstract paintings, but strong and bright colors and the expression of an inner feeling as well.

Reverse glass painting requires the artist to conceive the composition in different way, because the image has to be painted on the back of the glass. The artist has to consider each form separately, distinguish the form from the ground, and forgo all trace of perspective. This technique taught Kandinsky to consider the minimal elements of painting, and especially to alter his conception of space. The artist has to paint on the back of the glass, but the viewer contemplates it from the front. The surface of the picture is completely relative, because the artist and viewer do not see the same thing at all. Kandinsky imports this aspect of glass painting into his later abstract work. A good example to see how this happens is the artwork All Saints, because there exists one model in glass and another one in canvas (see Figure 32 and Figure 33).

One of the most important symbols in Kandinsky's work is the figure of the horse with a rider. There is little doubt in Kandinsky research that the rider stands for St. George, not simply because it is an outstanding figure in the Russian tradition, but especially on account of what it represents. St. George slaying the dragon refers to the triumph of the Christian belief over paganism. Kandinsky's St. George is not specifically a Christian element, but something similar: it is the spiritual element fighting against the forces of materialism, it is the representation of the new spiritual epoch vanquishing the old materialistic one. Kandinsky's St. George is the abstract painter who slays the dragon, the 
materialism of the nineteenth century, and liberates the princess, spirituality.

When abstract art is already consolidated, the rider and his horse are transformed gradually into a circular shape, and finally into that of the geometric circle. The circle contains all the spiritual connotations of St. George, and also has other features. The circle is a synthesis of different properties, it concentrates in a single image the ability to be everything (movement, stillness, cold, heat, while just being a curved line. Potentially, the circle is any sensation and any feeling, and it therefore has a creator character.

The circle, like all forms, is a living form. It is apparently simple but it can create everything, it engenders the whole. These characteristics make it a creator, a demiurge figure inside the painting, according to Kandinsky. The circle is a cosmic figure which links the viewer to the cosmic and the spiritual world. The creative capacity of the circle can be appreciated especially well in the painting Some Circles (Figure 35), in which each circle produces a different sound in the soul and causes a unique sensation. All circles together create a new world, since the creation of the work is the creation of the world (Werkschöpfung ist Weltschöpfung).

\section{Chapter 7. Abstract art as a neuroesthetic condition}

The findings of neuroscience in relation to visual perception and thus, in relation to the visual arts, are still very fledging and new. The discipline that tries to combine both these fields, art and neurology, has been recently given the name of neuroesthetics. It is still early for decisive results, and the study of Kandinsky's work from the neurological perspective is virtually nonexistent. But it is worth launching a first hypothesis on this subject, which perhaps might pave the way for new theories and generate more research.

Neuro-. The rise and success of neuroscience in the last years has led to new disciplines. One is neuroesthetics, a collaboration between neurology and the philosophy of art. It adopts the approach that art, as a human activity, depends upon and obeys the laws of the brain. Therefore, neurologists believe that knowing the neural basis of the visual brain will teach us about the basis of visual art. They want to establish an aesthetic theory based on neuro-scientific 
knowledge.

Using both scientific techniques like PET, MRI or fMRI and works of art, neuroesthetics seeks to discover how the visual brain works: how it perceives, how it processes information in order to interpret or try to understand how the artistic process works (aesthetic perception and creation). They are trying to unravel the brain's map: scientific techniques offer direct information about the brain, and the variety of artistic styles, neurologists say, is an indirect exploration of the visual brain.

The neural localization gradually builds a map of the brain that helps neurologists to understand its mechanism but also forces philosophers to rethink old aesthetic questions from another perspective. Does the concept of beauty depend only on the human brain? Or are there objective criteria for aesthetic judgments?, are just two examples.

The current state of research is difficult to determine, since neuroesthetics is not older than 30 years and its character is highly interdisciplinary. At present there are many names and places related to the study of neuroesthetics. Just to cite a few of them: Semir Zeki, at the Institute of Neuroesthetics in London, is one of the pioneers in this research and the first professor to hold a chair in neuroesthetics. Berlin is another leading centre of research, and hosts the Berlin School of Mind and Brain. There also good researchers in the United States, either investigating directly neuroesthetics, or on related themes. In fact, the list of centres and investigators is growing every day.

Neuroesthetics opens up a wide range of research topics, and this variety of topic also requires very different experiments. New experiments are being carried out every day. For methodological reasons, it is possible to group them into three types. Some experiments compare the brain of a professional with the brain of an amateur while they are performing an activity (e.g. playing or listening to music), so as to decode brain's response to learning, perception or execution. Other experiments focus on synaesthesia, either to describe the neuronal phenomenon, or to find the difference between the brain of a synaesthete and a non-synaesthete. A third type of experiment investigates the concept of beauty, analyzing how the brain reacts to ugly or beautiful pictures.

Many of the results of neurology in the field of art are still in their infancy, they are being published at present. However, there already exist a number 
of findings with which philosophers of art, artists and even art spectators can now work with. One of them is the confirmation that the eye cannot see, but the brain does. For centuries, it was believed that the brain receives an accurate photographic image of reality through the eye. However, neuroscience has confirmed what Gestalt psychology and some elements of artistic language (like perspective, optical illusions, etc) seemed to have suggested. The eye does not send a photograph to the brain, rather it sends separate information that the brain has to afterwards process. This means that the brain is actively involved in visual perception.

Knowing that the brain is involved in perception has led to attempts to decipher other neurological keys. The modularity of vision is another important result of neuroscience that is relevant for neuroesthetics. Recent experiments have shown that the primary visual cortex $\left(\mathrm{V}_{1}\right)$ is divided into regions. Each region is specialized to process an attribute, each area processes only one type of information: e.g. color, motion, depth. This means that the visual brain is functionally modular, something that artists should consider from now on if they want to experiment with new possibilities of aesthetic perception.

A third result, according to Semir Zeki, is that the visual brain and visual art share a large number of laws, among which especially stand out two. One is the law of constancy: in the same way the brain learns to extract the constant from the plural world, so art attempts to represent essential qualities on the canvas, just like in Cubism or an abstract painting of Kandinsky. The other is the abstraction law. The brain constantly subordinates the particular to the general, creates abstract concepts that fit many particulars. Art, too, abstracts and thus externalizes the inner working of the brain, as Zeki affirms.

First reactions to these findings were not long in coming. Nevertheless, as neuroesthetics is still under development these reactions should be considered with caution. At the moment, there are more neurologists present in the field of neuroesthetics than philosophers, who sometimes offer a homogeneous point of view to many questions. A considerable number of papers and books being published now seem to assert that neuroesthetics will at a stroke, and just with a neural explanation, resolve all the artistic and aesthetic issues that have preoccupied philosophers and art historians for centuries, issues that according to Zeki they could not answer because they had forgotten to consider the brain. 
Philosophers in turn criticize neuroesthetics for not using a proper vocabulary, for not defining a common language with which neuroscientists and philosophers could work together. The philosophical connotations that some words possess, such as brain, mind, reason or understanding, often disappear among neurologists, or they become dramatically reduced to brain.

Another common criticism of neuroesthetics is the accusation that it is only a simple neural localization and not a true aesthetic theory. The point is that neuroesthetics only explains the area of the brain that is working while carrying out an activity like perceiving a picture, but it does not say anything about taste or the nature of beauty. There is no doubt that localization can help to decipher the structure of the brain, but to pinpoint the location of an activity is not the same thing as explaining the activity.

There are also voices that criticize neuroesthetics because it does not define a new theory but only attempts to reduce art to science. This criticism also complains that neurologists are using simplistic and superficial artistic examples to support a generalization about all art creation.

It is true that many of these criticisms place neuroesthetics at a lower level than the high requirements of philosophy, but that does not undermine its authority. Neurology and philosophy of art have to learn to work together if they want to be neuro-and-esthetics.

-Esthetics. Synaesthesia has been a great unknown for long time. Now, neurology has revisited the issue for its aesthetic goals, and has shed new light on this phenomenon.

Synaesthesia is a «remarkable, rare condition where an individual has multimodal perceptual experiences from a unimodal sensory event», in words of Thomas J. Palmeri et al. It is a fusion of perceptions by which, for example, a color causes an auditive perception. There are many types of synaesthesia, although all of them share common features: synaesthetic perceptions are real, unintentional and remain for a lifetime. Contrary to what was believed for a long time, that synaesthesia was an illusory sensation, neuroscience has now demonstrated that synaesthesia has a neural basis. There are several theories that try to explain the phenomenon but for now, V. Ramachandran's theory that synaesthesia is a perceptual cross-activity seems to be the dominant one.

The proof that synaesthesia has a neural basis offers a new perspective for aesthetic approaches. It signifies the veracity of synaesthesia as a biological 
condition, and therefore the opportunity to include it in art as a proper means of composition. It also provides the possibility of confirming those theories that had suspected multisensory expressions in artists from the past, such as in the case of Kandinsky.

Kandinsky never used the word synaesthesia, but many of his writings show comparisons between different types of sensory impressions, which leads to the suggestion that Kandinsky was a synaesthete. In his case it would seem to be a fusion of visual and acoustic perception (fusion of colors and sounds). In his theory of color Kandinsky's manner of explanation is the same as a synaesthete, i.e. he explains how color sounds. In a passage of Concerning the spiritual in art, he specifies that colors reach the soul, and set up vibrations along the corresponding paths leading from the soul to the other sensory organs. An explanation that appears naive in Kandinsky, however, is highly similar to the synaesthesia cross-activity explanation of Ramachandran, if Kandinsky's word "soul" is read as "brain".

Although Kandinsky's synaesthesia can no longer of course be demonstrated clinically, texts reveal that Kandinsky did want to convey multisensory experiences that reflect a fusion of sensations. Kandinsky attempted to convey to the viewer a synaesthetic experience, and make the viewer capable of receiving it in a multisensory manner by using only visual perception. In current and neurological terms, Kandinsky sought to offer the viewer a visual perception that activates not only the visual region of the brain but also other areas (the auditory, for example). The new hypothesis that can be formulated using the results of neuroesthetics is that Kandinsky's abstract art explores fresh avenues of visual perception.

The visual cortex receives information about the outside world, and the brain processes this information, it identifies the forms and recognizes the object. The process is similar when the brain contemplates realistic painting, because the images on the picture are similar to the images in the real world. But when art breaks with the imitation of nature, the game of visual perception begins to change. The works of Cézanne or Cubism only provide the brain with spots of color, not a completed image of an object. Hence, the brain no longer has to recognize the object but to build it up from the color spots. The impressionist color spots of Cézanne do not depict the St. Victoria mountain, yet the brain ends up distinguishing the shape of the mountain because it 
manages to construct the image.

The abstract language of Kandinsky also forces the brain to work differently. In a first stage, Kandinsky reduces the artistic expression to their essential forms. What the viewer sees at first glance, is what the brain perceives before submitting to the identification process. Neurologically speaking, Kandinsky's first paintings are similar to those of Cézanne. The brain receives color spots in an undetermined form, in which it (the brain) cannot recognize an image, but has to construct it.

Although the ability of the brain to construct complete images from minimal information may be very useful for acquiring knowledge, it actually hinders the abstraction project of Kandinsky. Kandinsky wants to eliminate the figurative form in the painting, so that the viewer does not recognize any object at all, and can thus access other sensory areas. That means: the object that Kandinsky rejects and tries to eliminate because it hinders the multisensory perception is the object or figurative form that is finally created by the brain. If the viewer (or his brain) can in the end recognize an object, then it is not real abstraction.

In a second stage, when abstraction is well-established, the forms become completely abstract, there are no lines or color spots with which the brain can complete or build a figurative image. Now, the brain has to replace the activity of constructing the image of an object with the construction of a feeling or sensation. In the usual process the brain perceives, recognizes or builds the object, to then experience the feeling or aesthetic pleasure, however, in the abstract art of Kandinsky the brain has to skip the middle step. The brain has to respond to visual perception without building a consistent image of the outside world, but proceed directly to sensations and internal feelings.

In Kandinsky's abstract art, this sensory response can be multiple, i.e., a single stimulus may pose the brain two possible interpretations or sensory answers, with the two of them being equally valid. Hence, the brain is faced with ambiguity, a perception that is open to more than one interpretation. The neuroesthetical concept of ambiguity is defined by Zeki as the «certainty of many different, and essential, conditions, each of which is equal to the others».

This understanding of abstract art clearly poses a double difficulty. On the one hand, the difficulty of the artist during the period of creation. The artist needs to master color and shape as tools of artistic creation, because the effectiveness of the abstract language depends on finding the right expression, 
the one which stimulates the area and the cells that respond exactly to the visual perception, and that trigger the desired sensory responses. And on the other hand, abstract art also presents a difficulty for the viewer. It is easier for synaesthete viewers because they are neurologically able to involuntarily receive a twofold sensation. But non-synaesthetes have to learn to interpret an abstract painting.

Neuroesthetics artwork. Kandinsky's work has been a source of inspiration for many other artists. Besides the direct or indirect influence of his theories and artistic style, the paintings of Kandinsky are used as a basis for other artistic creations and experiments, leading to a reinterpretation of his work.

Many of these reinterpretations concern the audio format. Although every one is different, has its own style and media, it is still possible to generalize up to three major lines of interpretation. A number of them analyze certain pictures of Kandinsky, focusing on color and form as autonomous elements of the composition. They usually decontextualize the shapes and play with them, changing the place in the painting, their size or color, and what causes new effects. Other reinterpretations delve into the synaesthetic condition of Kandinsky. For instance, they present a painting in a video, making a visual and auditive perception simultaneous, so that it emulates a color-sound synaesthetic perception in the brain. A prominent example is the video The Kandinsky Project, a work by Christine Söffing and Hinderk Emrich based on Kandinsky's work Yellow-Red-Blue. They interpret the theory and paintings of Kandinsky as an artistic manifestation of a synaesthete, and present the painting in video format in which visual forms and sounds become combined.

A third line of reinterpretation investigates motion in the visual work of Kandinsky. There are interpretations that create videos and sculptures with moving forms, following the characteristics explained in Kandinsky's theory about color and shape. MetaKandinsky by Jean Tinguely is an example of this.

Artists and their visual explorations are helping neuroscientists to unravel the brain's structure. But at the same time there are artists undertaking the reverse process: they are making use of neurological outcomes to explore the frontiers of art. The initial scientific explanations of the phenomenon of synaesthesia and the demonstration that it has a neural basis have paved the way for new artistic creations. There now exist artworks dealing with 
synaesthesia as the theme itself of artistic creation.

One of these artists is Ditte Lyngkær Pedersen. Synaesthesia is a central theme of her visual artwork, not simply because she is a synaesthete. Moreover, she attempts to use the space of art to raise awareness of this phenomenon, and to discover new concepts for describing the exchange of subjective visual experiences. Her main synaesthetical work is Synesthesia Project (DVD-Box), a work that tries to help viewers comprehend synaesthesia, and also give them a new sensory vocabulary that can enhance their ability to understand contemporary art.

The work is a video installation consisting of a major work, three experimental studies and a selection of interviews with scientists, researchers and synaesthetes. Interviews and studies revolve around questions and answers from synaesthetes and non-synaesthetes, trying to create a framework for understanding the phenomenon. The main work is a video that consists of a fixed shot with the word "Purgatory" and the voice-overs of nine synaesthete people explaining how they perceive this word. The effect is at once disconcerting and daring, a game between semantic and perceptual sensations, between the synaesthetic and the non-synaesthetic world of perception. The video opens the door to new sensory dimensions: to the sensory complexity that arises from visual simplicity. 


\section{Conclusion}

Since the abstract language of Kandinsky is considered art and not just "pretty carpet patterns», the standard explanation for this language is formal reductionism. The simplification of forms is evident, but when it comes to providing an interpretation, it must be said that the reduction does not necessarily imply an elimination of the object nor explain why the object is no longer there. With the aim of proposing a new solution for these unsolved questions, my research has sought to distance itself from the reductionistic interpretative model and has opted for a plurality of perspectives. The four interpretations I present may be more or less convincing, more or less plausible, or even more or less open to criticism, but I am convinced that they open up a new range of possibilities. I give greater prominence to areas hitherto considered as secondary, such as the expression of the inner world, or the expression of synesthesia, and have restored their interpretative weight. This means that if we now want to view Kandinsky's abstract art as a language dominated by formal reduction, then any argument in favour of formal reductionism should be re-interpreted as a statement rejecting these other aspects but still under an obligation to explain them.

Although all of the four interpretations start from the same biographical and historical context they are quite distinct. It would be easy, and ultimately inevitable, to consider one of the interpretations as more attractive, but that is left up to the reader and the spectator. My intention was to place all four at the same level: not only without any hierarchy between them but as different parts of a common nexus. The interpretation of abstract language as formal minimalism (Chapter 4) is based on the standard reductionist model, but adds the direct and interconnected relation within a historical context and emphasizes events exterior to the sphere of painting. The next interpretation (Chapter 5) echoes the relationship between abstract art and other arts, such as music or dance, attributing a primary role to what used to be a secondary aspect. But above all, this perspective reveals the possibility that formal reduction does not necessarily involve sensory reduction, proving that the inner world of the artist can be expressed in a multisensorial way just by using the minimal forms. The interpretation of abstract art as spiritual experience (Chapter 6) is controversial in itself, and also in relation to the other perspectives. However, it is essential for any understanding of Kandinsky, since for him art and its 
development are closely linked to the evolution of society. The final interpretation (Chapter 7), placed under the umbrella of neuroesthetics, is undoubtedly the newest hypothesis. Recent discoveries in visual perception provide both an unprecedented and versatile theoretical framework making it necessary to consider this perspective as the first step in a larger investigation.

I believe that the reading of the four interpretations permits the reader to change their way of appreciating the art of Kandinsky, yet it would also be pretentious to claim that they cover every possible point of view. Naturally there are other perspectives. On the one hand, I did not consider certain of them because of the notorious paucity of literature: for example, explaining abstract art through crystallography or through the (unlikely) proximity of Kandinsky to Sufism and Animism. Nor did I consider a number of others because in my mind they were not relevant enough or were extremely minor, such as the erotic reading of the abstract forms of Kandinsky. And I rejected without any hesitation the most common interpretation among the public (abstract art as just an arbitrary game of forms) because of its obvious philosophical irrelevance.

On the other hand, the interpretations I present additionally open up new research avenues. It would be very interesting to relate the abstract language of Kandinsky to the language of other authors in order to unravel (in the event that it exists) the common basis for abstract art in general. In a similar vein one could also question the extent to which the historical context of Kandinsky may be generalized and perhaps draw a parallel between the three great founders of abstraction: Kandinsky, Mondrian and Malevich. But the most attractive avenue for further investigation is surely to look to the future and understand art as a gateway to multi-sensory experience. Neuroesthetics and philosophy, if they work together, will no doubt have much to say about this in the coming years. 



\section{Materiales}

Lista de materiales y recursos online utilizados durante la investigación y citados en el texto. Última visita: 30.03 .2011

\section{- Autores}

- Cytowic, Richard

http://www.cytowic.net/

- Dermietzel, Markus

e-book: Musik als Entwurfsgrundlage für Architektur?

en: www.gro.de/media/gro_m_a_ebook.pdf

- Eagleman, David

http://www.eagleman.com/

- The Kandinsky Effect

http://www.kandinskyeffect.tk/

- Lyngkær Pedersen, Ditte

http://www.dittelyngkaerpedersen.com/

e-book: Why is green a red word?

vídeos de Synesthesia Project

- Skov, Martin: Brainethics

http://brainethics.org/

- Söffing, Christine

http://www.synaesthesiewerkstatt.de/

vídeo de Das Kandinsky Projekt

- Zeki, Semir

http://profzeki.blogspot.com/

\section{- Instituciones}

- Academy of Neuroscience for Architecture http://www.anfarch.org/

- Association of Neuroesthetics

http://www.association-of-neuroesthetics.org/

- Berlin School of Mind and Brain

http://www.mind-and-brain.de/

- Centro de Investigaciones en Neuroestética y Neuromusicología 
http://www.lucdelannoy.com/CIN.html

- Grupo emu de la Universidad de Ulm

http://www.uni-ulm.de/emu/

- Human Science Center - Munich

http://www.hwz.uni-muenchen.de/

- Institute of Neuroesthetics

http://www.neuroesthetics.org/institute.php

- Sociedad Española de Neurología

http://www.sen.es/

- Italian Society of Neuroesthetics Semir Zeki

http://www.neuroestetica.it/

- Wellcome Laboratory of Neurobiology (Vislab)

http://www.vislab.ucl.ac.uk/

\section{- Páginas web}

- Artbrain

http://www.artbrain.org/

- Neuroartes

http://www.neuroartes.org/

- Neuroesthetics

http://www.neuroesthetics.org/

- Neurophilosophy

http://scienceblogs.com/neurophilosophy/

- Neuroquantology

http://www.neuroquantology.com/

- See this sound: Bild und Ton in Kunst

http://www.see-this-sound.at/

- Vídeos

- 3 D Animation: Gelb-Rot-Blau

http://www.youtube.com/watch?v=wcWoZmvvXoI

- 3D Animation: Wassily Kandinsky

http://www.youtube.com/watch?v=-QcOXmj2VZk\&NR=1

- Kandinsky em Movimento

http://www.youtube.com/watch?v=778BTf7WAs8\&NR=1

- MétaKandinsky en movimiento

http://www.youtube.com/watch?v=simAtrBsmZI 


\section{Bibliografía}

AdLER, Hans, editor (2002). Synästhesie. Interferenz - Transfer - Synthese der Sinne. Königshausen \& Neumann, Würzburg.

Adorno, Theodor W. (200o). Sobre la música. Paidós I.C.E. / U. A. B., Barcelona.

Adorno, Theodor W. (2003). Filosofía de la Nueva Música, volumen 12 de Obra Completa. Akal, Madrid.

Aiken, Nancy (1998). The Biological Origins of Art. Praeger, Westport.

Albers, Josef (1970). Interaction of Color. DuMont, Köln.

Andersen, Troels (1966). Some Unpublished Letters by Kandinsky. Artes: periodical of the fine arts, 2:90-110.

Annoni, Jean-Marie, Devuyst, G., Carota, A., Bruggimann, L. y Bogousslavsky, Julien (2005). Changes in Artistic Style After Minor Posterior Stroke. Journal of Neurology, Neurosurgery, and Psychiatry, 76(6):797-803.

Anschütz, Georg, editor (1927). Kurze Einführung in die Farbe-Ton-Forschungen Número 1. Akademische Verlagsgesellschaft, Leipzig.

Armel, K. C. y Ramachandran, Vilayanur S. (1999). Acquired Synesthesia in Retinitis Pigmentosa. Neurocase, 5:293-296.

ArnAldo, Javier, editor (2004). Actas Symposium Analogías: El mundo suena.

Celebradas en Madrid el 4, 5 y 6 de abril de 2003. Fundación Colección Thyssen-Bornemisza, Madrid.

Arnheim, Rudolf (1956). Art and Visual Perception. Faber and Faber, London.

BADEwien, Jan (1994). Die Anthroposophie Rudolf Steiners. Evangelischer Presseverband, München.

Baron-Cohen, S., Wyk, Maria A. y Binnie, Colin (1987). Hearing Words and Seeing Colours: an Experimental Investigation of a Case of Synaesthesia. Perception, 16(6):761-767.

Baron-Cohen, Simon y Harrison, John E., editores (1996). Synaesthesia: Classic and Contemporary Readings. Blackwell Publishers, Oxford.

BARtels, Andreas y Zeki, Semir (2004). The Neural Correlates of Maternal and Romantic Love. Neuroimage, 21(3):1155-1166. 
BAXANDALL, Michael (1990). Ursachen der Bilder: ̈̈ber das historische Erklären von Kunst. Reimer, Berlin.

Becker, Kurt E., Hiebel, Friedrich y Schreiner, Hans-Peter, editores (1982). Rudolf Steiner: der anthroposophische Weg. Kindler, München.

BeCKs-Malorny, Ulrike (1993). Wassily Kandinsky. 1866-1944. Aufbruch zur Abstraktion. Benedikt Taschen, Köln.

Becks-Malorny, Ulrike (2001). Cézanne. Taschen, London.

BeHr, Shulamith, editor (2006). Kandinsky. Malerei 1908-1921. Hatje Cantz, Ostfildern.

Berger, Abi (1999). The Painter's Eye. British Medical Journal, 318(7195):1427.

Berka, Walter, Brix, Emil y Smekal, Christian, editores (2003). Woher kommt das Neue? Kreativität in Wissenschaft und Kunst. Böhlau, Wien.

Besant, Annie (1902). Die Entwicklung des Lebens und der Form. Schwetschke \& Sohn, Berlin.

BILl, Max (1951). Wassily Kandinsky. Maeght Éditeur, Paris.

BoDE, Ingrid (1966). Die Autobiographien zur deutschen Literatur, Kunst und Musik, 1900-1965; Bibliographie und Nachweise der persönlichen Begegnungen und Charakteristiken. Metzler, Stuttgart.

BöHM, Johannes y QuAISSER, Erhard (1991). Schönheit und Harmonie geometrischer Formen. Akademie-Verlag, Berlin.

Boenmer, Konrad, editor (1997). Schönberg and Kandinsky. An Historic Encounter. Harwood Academic Publishers, Amsterdam.

BoIssel, Jessica, editor (1998). Wassily Kandinsky. Über das Theater - Du théâtre - O teatpe. DuMont Schauberg, Köln.

Bornstein, Robert F. (2009). Heisenberg, Kandinsky, and the Heteromethod Convergence Problem: Lessons From Within and Beyond Psychology. Journal of Personality Assessment, 91(1):1-8.

BoullLon, Jean-Paul y Kandinsky, Wassily (1974). Regards sur le passé et autres textes, 1912-1922. Hermann, Paris.

Bowlt, John E. y Washton-Long, Rose Carol, editores (1980). The life of Vasilii Kandinsky in Russian Art. A Study of "On the espiritual in art». Oriental Research Partners, Newtonville.

von Brauchitsch, Boris (1999). Das 20. Jahrhundert. Meisterwerke Jahr für Jahr. DuMont Schauberg, Köln.

Brinkmann, Heribert (1981). Wassily Kandinski als Dichter. Tesis doctoral, Universität zu Köln. 
BRUCHer, Günter (1999). Kandinsky. Wege zur Abstraktion. Prestel, München. Bryant, Donald A. y Devuyst, G. (2003). The Beauty in Small Things Revealed. Proceedings of the National Academy of Sciences of the United States of America, 100(17):9647-9649.

Buergel-Goodwin, Ulrike y GöBeL, Wolfram, editores (1979). Reinhard Piper: Briefwechsel mit Autoren und Künstlern 1903-1953. Piper Verlag, München-Zürich.

Bunge, Matthias (1996). Zwischen Intuition und Ratio. Pole des bildnerischen Denkens bei Kandinsky, Klee und Beuys. Steiner, Stuttgart.

Burkart, Axel (2008). Faszination Rudolf Steiner. Kailash, München.

Buswell, Guy T. (1935). How People Look at Pictures. University of Chicago Press, Chicago.

Carroll, Joseph (2004). Literary Darwinism. Routledge, New York.

Cela-Conde, Camilo J., Marty, Gisèlle, Maestú, Fernando, Ortiz, Tomás y Munar, Enric et al. (2004). Activation of the Prefrontal Cortex in the Human Visual Aesthetic Perception. Proceedings of the National Academy of Sciences of the United States of America, 101(16):6321-6325.

Cela-Conde, Camilo J., Ayala, Francisco J., Munar, Enric, Maestú, Fernando y NADAL, Marcos et al. (2009). Sex-related Similarities and Differences in the Neural Correlates of Beauty. Proceedings of the National Academy of Sciences, 106(10):3847-3852.

Changeux, Jean-Pierre (1994). Art and Neuroscience. Leonardo, 27(3):189-201. Changeux, Jean-Pierre (1997). Razón y placer. Tusquets, Barcelona.

Conil Lacoste, Michel (1979). Kandinsky. Südwest Verlag, München.

ConsI, Pietro, editor (1991). The Enchanted Loom: Chapters in the History of Neuroscience. Oxford University Press, Oxford.

Сүтоwic, Richard E. (1989). Synaesthesia: a Union of the Senses. Springer, New York.

СүтоwIC, Richard E. (1995). The Man Who Tasted Shapes. Warner Books Inc., New York.

Сутоwic, Richard E. (1996). Farben hören, Töne schmecken. Die bizarre Welt der Sinne. Deutscher Taschenbuch Verlag, München.

Cytowic, Richard E. y Eagleman, David M. (2009). Wednesday is Indigo Blue: Discovering the Brain of Synesthesia. The MIT Press, Massachusetts. DÄMmER, Elisabeth (1986). Kandinskys erste sieben Kompositionen. Betrachtung, Analyse, Versuch einer Deutung. Tesis doctoral, LMU, München. 
Deacon, Terrence (1998). The Symbolic Species: the Co-evolution of Language and the Human Brain. Penguin, London.

Debrunner, Hugo, editor (1947). Wir entdecken Kandinsky. Origo, Zürich.

Deliege, I. y Wiggins, G. A., editores (2006). Musical Creativity. Oxford University Press, Oxford.

Denhoff, Michael (1984). Die blaue Vier. Für Cembalo und Schlagzeug. Musik nach Bildern von Jawlensky, Klee, Kandinsky und Feininger. Gravis, Bad Schwalbach.

Dessoir, Max, editor (1929). Zeitschrift für Ästhetik und allgemeine Kunstwissenschaft Número 23. Verlag von Ferdinand Enke, Stuttgart.

DíAz de la Fuente, Alicia (2005). Estructura y significado en la música serial $y$ aleatoria. Tesis doctoral, UNED, Madrid.

Dissana Yake, Ellen (1988). What is Art for?. University of Washington Press.

Dissanayake, Ellen (1992). Homo Aestheticus. University of Washington Press.

Dissana Yake, Ellen (2000). Art and Intimacy. How the Arts Began. University of Washington Press.

Droste, Magdalena, editor (1979). Klee und Kandinsky: Erinnerung an eine Künstlerfreundschaft anlässlich Klees 10o. Geburtstag. Staatsgalerie, Stuttgart.

EAston, Stewart C. (1984). El hombre y el mundo a la luz de la antroposofía. Editorial Rudolf Steiner, Madrid.

EBert-SCHIfFerer, S. (1989). Wassily Kandinsky. Die erste sowjetische Retrospektive. Schirn Kunsthalle Frankfurt, Frankfurt am Main.

EdDy, Arthur Jerome (1914). Cubist and Post-Impressionism. Mc Clurg \& Co., Chicago.

EICHNER, Johannes (1957). Kandinsky und Gabriele Münter. Von Ursprüngen moderner Kunst. Bruckmann, München.

EInstein, Albert (1905). Zur Elektrodynamik bewegter Körper. Annalen der Physik, 322(10):891-921.

ELLER-RüTER, Ulrika-Maria (1990). Kandinsky. Bühnenkomposition und Dichtung als Realisation seines Synthese-Konzepts. Georg Olms Verlag, Hildesheim.

Ellis, Ralph D. (1999). The Dance Form of the Eyes: What Cognitive Science Can Learn From Art. Journal of Consciousness Studies, 6(6-7):161-175.

Elton, William, editor (1970). Aesthetics and Language. Basil Blackwell, Oxford. 
EMmert, Claudia (1998). Bühnenkompositionen und Gedichte von Wassily Kandinsky im Kontext eschatologischer Lehren seiner Zeit, 1896-1914. Peter Lang GmbH, Frankfurt am Main.

Endell, August (1896). Um die Schönheit, eine Paraphrase über die Münchener Kunstausstellung 1896. Emil Franke, München.

Endicott Barnett, Vivian y Zweite, Armin, editores (1992). Kandinsky. Kleine Freuden. Aquarelle und Zeichnungen. Prestel, München.

Etthinger, Leopold D. (1961). Kandinsky's «At rest». Oxford University Press, London.

Fechter, Paul (1919). Der Expressionismus. Piper Verlag, München.

Fineberg, Jonathan David (1984). Kandinsky in Paris. 1900-1907. Umi Research Press, Michigan.

Freedberg, David (1989). The Power of Images. University of Chicago Press, Chicago.

FrIEDEL, Helmut, editor (1995). Das bunte Leben. Wassily Kandinsky im Lenbachhaus. DuMont Schauberg, München.

GAGE, John (1994). Kulturgeschichte der Farbe. Otto Maier Ravensburg, Ravensburg.

Gage, John (1999). Die Sprache der Farben. Bedeutungswandel der Farbe in der bildenden Kunst. Ravensburger Buchverlag, Ravensburg.

Galton, Francis (1880). Visualised Numerals. Nature, 21:252-256, 494-495.

GAY, Peter (1970). Weimar Culture: The Outsider as Insider. Harper Torchbooks, New York.

GIERSCH, Harald, editor (1991). Rudolf Steiner über die Wiederkunft Christi. Verlag am Goetheanum, Dornach.

von GoETHE, Johann Wolfgang (1953). Farbenlehre. Wiss. Buchgemeinschaft, Tübingen.

Goguen, Joseph A. (1999). Art and the Brain: Editorial Introduction. Journal of Consciousness Studies, 6(6-7):5-14.

Gombrich, Ernst H. (1993). Die Kunst, Bilder zum Sprechen zu bringen. Klett-Cotta, Stuttgart.

Gondorf, Ulrike (2000). Wassily Kandinsky und Gabrielle Münter. Lege dein Ohr an dein Herz und horche. Tympano Verlag, München.

Gotтschall, Jonathan y Wilson, David Sloan, editores (2005). The Literary Animal. Northwestern University Press. 
Gray, Camilla (1963). Die russische Avantgarde der modernen Kunst: 1863-1922. DuMont Schauberg, Köln.

Grohmann, Will (1958). Wassily Kandinsky: Leben und Werk. DuMont Schauberg, Köln.

Guimón Ugartechea, José (2003). Mecanismos psico-biológicos de la creatividad artística. Desclee de Brouwer, Bilbao.

HАнL-Kосн, Jelena, editor (1983). Briefe, Bilder und Dokumente einer außergewöhnlichen Begegnung. Deutscher Taschenbuch Verlag, München.

Haнl-Kосн, Jelena, editor (1993). Der Briefwechsel: Wassily Kandinsky und Arnold Schönberg. Gerd Hatje Verlag, Stuttgart.

Hahl-Koch, Jelena (1993). Kandinsky. Gerd Hatje Verlag, Stuttgart.

Hahn, Peter, editor (1984). Kandinsky - Russische Zeit und Bauhausjahre 1915-1933. Bauhaus-Archiv, Berlin.

Hanfstaengl, Erika, editor (1974). Wassily Kandinsky. Zeichnungen und Aquarelle. Prestel, München.

Harrison, John E. (2001). Synaesthesia: The Strangest Thing. Oxford University Press, New York.

Harten, Jürgen, Honisch, Dieter y Kern, Hermann, editores (1983). Neue Malerei in Deutschland. Prestel, München.

Heemsbergen, Bastiaan (2006). The Leader's Brain. Trafford Publishing, Victoria.

Heilman, Kenneth (2005). Creativity and the Brain. Psychology Press, New York.

Heimendahl, Eckart (1961). Licht und Farbe: Ordnung und Funktion der Farbwelt. Verlag de Gruyter, Berlin.

HeISSERER, Dirk (2008). Wo die Geister wandern. Literarische Spaziergänge durch Schwabing. C. H. Beck, München.

Helge, David (2008). An die Schönheit. August Endells Texte zu Kunst und Ästhetik; 1896 bis 1925. VDG, Weimar.

Heller, Reinhold (1983). Kandinsky and Traditions Apocalyptic. Art Journal, 43(1):19-26.

von Helmholtz, Hermann (1896). Die Lehre von den Tonempfindungen als physiologische Grundlage für die Theorie der Musik. Vieweg, Braunschweig.

Hentschel, Barbara (200o). Kandinsky und Goethe. Wissenschaftlicher Verlag Berlin, Berlin. 
Hoberg, Annegret (2000). Wassily Kandinsky und Gabriele Münter in Murnau und Kochel. 1902-1914. Briefe und Erinnerung. Prestel, München.

Hoffman, Banesh (1972). Albert Einstein: Creator and Rebel. The Viking Press, New York.

Hofmann, Werner (1969). Schönberg-Berg-Webern. Museum des 20. Jahrhunderts, Wien.

Hofstätter, Hans H. (1965). Symbolismus und die Kunst der Jahrhundertwende. DuMont Schauberg, Köln.

Hölz, Christian, editor (1997). Grenzgänger. Wassily Kandinsky - Maler zwischen Murnau, Moskau und Paris. Bayerische Vereinsbank, München.

HölzEL, Adolf (1905). Über künstlerische Ausdrucksmittel und deren Verhältnis zu Natur und Bild. Die Kunst für alle, 20(11):81-88.

Hubbard, Edward M., Arman, Cyrus., Ramachandran, Vilayanur S. y Boynton, Geoffrey M. (2005). Individual Differences among Grapheme-Color Synesthetes: Brain-Behavior Correlations. Neuron, 45(6):975-985.

Hubbard, Edward M. y RAmachandran, Vilayanur S. (2005). Neurocognitive Mechanisms of Synaesthesia. Neuron, 48(3):509-520.

Hubbard, Edward M. (2007). Neurophysiology of Synesthesia. Current Psychiatry Reports, 9(3):193-199.

Hurvich, Leo M. (1981). Color Vision, Sinauer Associates. Sunderland, Mass.

Hüтt, Wolfgang (1969). Deutsche Malerei und Graphik im 20. Jahrhundert. Henschelverlag, Berlin.

Ione, Amy y Tyler, Christopher (2003). Neurohistory and the Arts: Was Kandinsky a Synesthete?. Journal of the History of the Neurosciences, $12(2): 223-226$.

Ione, Amy (2004). Klee and Kandinsky. Polyphonic Painting, Chromatic Chords and Synaesthesia. Journal of Consciousness Studies, 11(3-4):148-58.

ITTEN, Johannes (1961). Kunst der Farbe. Subjektives Erleben und objektives Erkennen als Wege zur Kunst. Maier, Ravensburg.

Jacobs, Gerald H. y Nathan, Jeremy (2009). Color Vision: How Our Eyes Reflect Primate Evolution. Scientific American, 4:8.

JAENSCH, Erich Rudolf (1999). Eidetic Imagery and Typological Methods of Investigation. Routledge, London.

Jawlensky, Alexej (1983). Meditationen. Dr. Hans Peter Verlag, Hanau.

JEWANski, Jörg (1999). Ist $C=$ Rot?. Studio, Sinzig. 
Juslin, Patrick y Sloboda, John, editores (2001). Music and Emotion. Oxford University Press, Oxford.

Kandel, Eric R. (2007). Auf der Suche nach dem Gedächtnis. Pantheon, München.

Kandinsky, Nina, editor (1970). Kandinsky: Aquarelle und Zeichnungen. Mit unveröffentlichten Aufzeichnungen Kandinskys und einer biographischen Übersicht. Editions Beyeler, Basel.

Kandinsky, Nina (1976). Kandinsky und ich. Kindler, München.

Kandinsky, Wassily (1952). Über das Geistige in der Kunst. Benteli-Verlag, Bern-Bümpliz.

Kandinsky, Wassily (1955). Rückblick. Woldemar Klein Verlag, Baden-Baden.

Kandinsky, Wassily (1973). Essays über Kunst und Künstler. Benteli-Verlag, Bern-Bümpliz.

Kandinsky, Wassily (1973). Punkt und Linie zu Fläche. Benteli-Verlag, Bern-Bümpliz.

Kandinsky, Wassily (1996). De lo espiritual en el arte. Paidós Estética, Barcelona.

Kandinsky, Wassily (1996). La gramática de la creación. El futuro de la pintura. Paidós Estética, Barcelona.

Kandinsky, Wassily (1996). Punto y línea sobre el plano. Paidós Estética, Barcelona.

Kandinsky, Wassily (2002). Mirada retrospectiva. Emecé Editores, Barcelona. KANDINsKy, Wassily (2003). Escritos sobre arte y artistas. Editorial Síntesis, Madrid.

Kandinsky, Wassily y Marc, Franz, editores (2004). Der Blaue Reiter. Piper Verlag, München, Jubiläum edición.

KATZ, David (200o). The World of Colour. Routledge, London.

KawABATA, Hideaki y ZEki, Semir (2004). Neural Correlates of Beauty. Journal of Neurophysiology, 91(4):1699-1705.

Kayser, Hans (1950). Lehrbuch der Harmonik. Occident-Verlag, Zürich.

Kelly, Michael, editor (1998). Encyclopedia of Aesthetics. Oxford University Press, Oxford.

Kimball, Edward J. y Weiss, Peg (1983). A Pictorial Analysis of «In the Black Square». Art Journal, 43(1):36-40.

KLEE, Felix (1960). Paul Klee: Leben und Werk in Dokumenten. Diogenes-Verlag, Zürich.

KLeE, Paul (1965). Pädagogisches Skizzenbuch. Kupferberg, Mainz. 
KleE, Paul (1981). Das bildnerische Denken. Schwabe, Stuttgart.

KLEINE, Gisela (1991). Gabriele Münter und Wassily Kandinsky. Biographie eines Paares. Insel, Frankfurt am Main.

Koenler, Karen (1998). Kandinsky's «Kleine Welten» and Utopian City Plans. The Journal of the Society of Architectural Historians, 57(4):432-447.

KoffKa, Kurt (1936). Principles of Gestalt Psychology. Kegan Paul, London.

KRÜGER, Felix y Kirschmann, August, editores (1926). Licht und Farbe. Neue psychologische Studien. C. H. Beck, München.

Kugler, Walter (1979). Rudolf Steiner und die Anthroposophie. DuMont, Köln.

Lankheit, Klaus (1976). Franz Marc. Sein Leben und seine Kunst. DuMont, Köln.

LANKHeit, Klaus, editor (1978). Schriften. DuMont, Köln.

LANKHEIT, Klaus, editor (1983). Wassily Kandinsky-Franz Marc: Briefwechsel mit Briefen von und an Gabriele Münter und Maria Marc. Piper Verlag, München.

Leadbeater, Charles W. (2004). Gedankenformen. Aquamarin, Grafing.

LeAdBeater, Charles W. (2004). Man Visible and Invisible. Examples of Different Types of Men as Seen by Means of Trained Clairvoyance. Aquamarin, Grafing.

LeHrer, Jonah (2008). Proust Was a Neuroscientist. Houghton Mifflin Harcourt, New York.

Levitin, Daniel J. (2006). This is your Brain on Music. The Science of a Human Obsession. Dutton, New York.

Levitin, Daniel J. (2008). The World in Six Songs. Dutton, New York.

Lewis-Williams, David (2002). The Mind in the Cave. Consciousness and the Origins of Art. Thames and Hudson, London.

Lindsay, Kenneth C. (1951). An Examination of the Fundamental Theories of Wassily Kandinsky. Tesis doctoral, University of Wisconsin, Madison.

Lindsay, Kenneth C. (1953). The Genesis and Meaning of the Cover Design for the First Blaue Reiter Exhibition Catalogue. The Art Bulletin, 35(1):47-52.

LindsaY, Kenneth C. (1983). Kandinsky and the Compositional Factor. Art Journal, 43(1):14-18.

Lindsay, Kenneth C. y Vergo, Peter, editores (1994). Kandinsky. Complete Writings on Art. Da Capo Press, Boston. 
Lipps, Theodor (1886). Grundlegung der Ästhetik. Verlag von Leopold Voss, Leipzig.

Lipps, Theodor (1903). Ästhetik. Psychologie des Schönen und der Kunst. Verlag von Leopold Voss, Hamburg-Leipzig.

Livingstone, Margaret (2002). Vision and art: The Biology of Seeing. Harry N. Abrams, New York.

Löcher, Paul, Martindale, Colin y Dorfman, Leonid, editores (2006). New Directions in Aesthetics, Creativity and the Arts. Baywood, New York.

Loef, Carl (1974). Farbe, Musik, Form: Ihre bedeutenden Zusammenhänge. Musterschmidt, Göttingen.

López, Alberto, Hernández, Fernando y Barragán, José M. (1997). Encuentros del Arte con la antropología, la psicología y la pedagogía. Angle, Barcelona.

López García, Luis (2001). Kandinsky: los fundamentos del arte abstracto. La relación con las ciencias experimentales. Metáforas del movimiento moderno, Madrid.

Luria, Aleksandr R. (1968). The Mind of a Mnemonist. Basic Books, New York.

LURIA, Aleksandr R. (1986). Atención y memoria. Ed. Martínez Roca, Barcelona. MACKE, Wolfgang, editor (1964). August Macke-Franz Marc: Briefwechsel. DuMont Schauberg, Köln.

Margolis, Joseph Zalman (1987). Philosophy looks at the Arts. Contemporary Readings in Aesthetics. Temple University Press, Philadelphia.

MARChán Fiz, Simón (2008). La metáfora del cristal en las artes y en la arquitectura. Ediciones Siruela, Madrid.

Martindale, Colin, Löcher, Paul y Petrov, Vladimir, editores (2006). Evolutionary and Neurocognitive Approaches to Aesthetics, Creativity and the Arts. Baywood, New York.

Massey, E. Wayne y Sanders, Lynda (1989). Babinski's Sign in Medieval, Renaissance, and Baroque Art. Archives of Neurology, 46(1):85-88.

von MAUR, Karin, editor (1985). Vom Klang der Bilder. Die Musik in der Kunst des 20. Jahrhunderts. Prestel, München.

von MaUr, Karin (1999). Vom Klang der Bilder. Prestel, München. 
Mazur-Keblowski, Eva (2000). Apokalypse als Hoffnung. Die russischen Aspekte der Kunst und Kunsttheorie Vasilij Kandinskijs vor 1914. Ernst Wasmuth Verlag, Tübingen.

McTague, Robert (1997). Modern Physics, Kandinsky, and Klee. The European Legacy, 2(1):68-73.

Messer, Thomas M., editor (1966). Vasily Kandinsky. Painting on glass (Hinterglassmalerei). The Solomon R. Guggenheim Museum, New York.

Messiaen, Olivier (1987). Colours de la cité céleste. Alphonse Leduc, Paris.

Messiaen, Olivier (1993). Quatour pour la fin du temps. Durand S. A. Editions Musicales, Paris.

Metzger, Heinz-Klaus y Riehn, Rainer (1982). Olivier Messiaen, volumen 28 de Die Reihe über Komponisten. Edition Text + Kritik, München.

Miall, R. C. y Tchalenko, John (2001). A Painter's Eye Movements: A Study of Eye and Hand Movement during Portrait Drawing. Leonardo, 34(1):35-40.

Miller, Bruce L. y Hou, Craig E. (2004). Portraits of Artists: Emergence of Visual Creativity in Dementia. Archives of Neurology, 61(6):842-844.

MilLer, Geoffrey F. (2000). The Mating Mind. William Heinemann, London.

Mithen, Steven (1996). The Prehistory of the Mind. Thames and Hudson, London.

Mithen, Steven (2005). The Singing Neanderthals. Weidenfeld \& Nicolson, London.

Moeller, Magdalena M., editor (1994). Der frühe Kandinsky. 19oo-1910. Hirmer Verlag, München.

Moeller-Sally, Betsy F. (2002). Inner Simmering: Unveiling the Erotic in Kandinsky. The Russian Review, 61:52-72.

Mora, Francisco (2006). ¿Enferman las mariposas del alma? Cerebro, locura $y$ diversidad humana. Alianza Editorial, Madrid.

Moss, David (2001). A Performer's Lexicon of Synesthesia (Abridged). Leonardo, 34(1):69-71.

MötтeLI, Emil, editor (1961). Rudolf Steiner - Gesamtausgabe. Rudolf-Steiner-Verlag, Dornach.

Müller, Katharina y Aschersleben, Gisa, editores (2000). Rhythmus. Ein interdisziplinäres Handbuch. Hans Huber, Bern.

Onians, John (1994). Sight and Insight: Essays on Art and Culture in Honour of E. H. Gombrich at 85. Phaidon Press, London. 
Onians, John (2007). Neuroarthistory: from Aristotle and Pliny to Baxandall and Zeki. Yale University Press, New Haven and London.

Ortega y Gasset, José (2002). La deshumanización del arte y otros ensayos de estética. Alianza Editorial, Madrid.

Ostwald, Wilhelm (1923). Die Harmonie der Farben. Unesma, Leipzig.

Overy, Paul (1969). Kandinsky: The Language of the Eye. Praeger, New York.

De Palèzieux, Nikolaus (1998). Der geometrische Punkt ist ein unsichtbares

Wesen. Wassily Kandinsky und Arnold Schönberg. Europäische Verlagsanstalt, Hamburg.

Palmeri, Thomas J., Blake, Randolph, Marois, René, Flanery, Marci A. y Whetsell, William (2002). The Perceptual Reality of Synesthetic Colors. Proceedings of the National Academy of Sciences, 99(6):4127-4131.

Patel, Aniruddh D. (2008). Music, Language and the Brain. Oxford University Press, Oxford.

Paulesu, E., Harrison, J., Baron-Cohen, S., Watson, J. D. G. y Goldstein, L. et al. (1995). The Physiology of Coloured Hearing. A PET Activation Study of Colour-Word Synaesthesia. Brain, 118(3):661-676.

PeCht, Friedrich, editor (1901). Die Kunst für alle. Número 16. Bruckmann, München.

PeCht, Friedrich, editor (1902). Die Kunst für alle. Número 17. Bruckmann, München.

Peretz, Isabelle y Zatorre, Roberts, editores (2003). The Cognitive Neuroscience of Music. Oxford University Press, Oxford.

Plaut, Paul (1929). Die Psychologie der produktiven Persönlichkeit. Verlag von Ferdinand Enke, Stuttgart.

PoAst, Michael (200o). Color Music: Visual Color Notation for Musical Expression. Leonardo, 33(3):215-221.

Poling, Clark V. (1982). Kandinsky - Unterricht am Bauhaus. Farbenseminar und analytisches Zeichnen dargestellt am Beispiel der Sammlung des Bauhaus-Archivs. Weingarten, Berlin.

Pöppel, Ernst (1993). Lust und Schmerz. Vom Ursprung der Welt im Gehirn. Sammlung Siedler, Berlin.

Pöppel, Ernst y Edingshaus, Anna-Lydia (1994). Geheimnisvoller Kosmos Gehirn. C. Bertelsmann, München.

Pöppel, Ernst (2008). Zum Entscheiden geboren. Hirnforschung für Manager. Carl Hanser, München. 
Porta-Etessam, Jesús, Gómez-Escalonilla, C., Martínez-Salio, A. y Berbel-García, A. (2002). Platitude Theory or Picasso Stroke. European Journal of Neurology, 9(1):117.

Pushkin, Alexander S. (1855). Werke, volumen v. Annenkoff, San Petersburg. Ramachandran, Vilayanur S. y Hirstein, William (1999). The Science of Art. A Neurological Theory of Aesthetic Experience. Journal of Consciousness Studies, 6(6-7):15-51.

Ramachandran, Vilayanur S. y Hubbard, Edward M. (2001). Psychophysical Investigations into the Neural Basis of Synaesthesia. Proceedings of the Royal Society B, 268(1470):979-983.

Ramachandran, Vilayanur S. y Hubbard, Edward M. (2001). Synaesthesia - A Window Into Perception, Thought and Language. Journal of Consciousness Studies, 8(12):3-34.

Ramachandran, Vilayanur S. y Hubbard, Edward M. (2003). The Phenomenology of Synaesthesia. Journal of Consciousness Studies, 10(8):49-57.

RAMACHANDRAN, Vilayanur S. (2004). Neuroscience: Beauty or Brains?. Science, 305(5685):779-780.

Ramachandran, Vilayanur S. y Hubbard, Edward M. (2005). Hearing Colors, Tasting Shapes. Scientific American Mind, 2005(10):16-23.

RANi Sinha, Jasmin (2009). Synästhesie der Gefühle. Synaisthesis, Luxemburg. Rebay, Hilla, editor (1945). In Memory of Wassily Kandinsky. The Solomon R. Guggenheim Foundation, New York.

ReIfENSCHeID, Beate, editor (2000). Die innere Notwendigkeit. Gedanken zu Musik, Malerei und Bühne bei Schönberg, Kandinsky und anderen. Kerber Verlag, Bielefeld.

Rewald, John (1957). Geschichte des Impressionismus. Rascher, Zürich.

Richardson, John Adkins (1971). Modern Art and Scientific Thought. The University of Illinois Press, Chicago.

RiedL, Peter Anselm (1983). Kandinsky. Rowohlt, Reinbek.

Ringbom, Sixten (1970). The Sounding Cosmos: a Study in the Spiritualism of Kandinsky and the Genesis of Abstract Painting. Åbo Akademi, Åbo.

Robertson, Lynn C. y Sagiv, Noam (2005). Synesthesia. Perspectives from Cognitive Neuroscience. Oxford University Press, New York.

Roditi, Edouard (1991). Dialoge über Kunst. Suhrkamp, Frankfurt am Main. Roessler, Arthur (1905). Neu-Dachau. Velhagen \& Klasing, Bielefeld. 
RoRschach, Hermann (1992). Psychodiagnostik: Methode und Ergebnisse eines wahrnehmungsdiagnostischen Experiment (Deutenlassen von $\mathrm{Zu}$ fallsformen). Huber, Bern.

Roskill, Mark (1992). Klee, Kandinsky, and the Thought of Their Time. The University of Illinois Press, Chicago.

Ross, Alex (2007). The Rest is Noise. Listening to the Twentieth Century. Picador, New York.

Röthel, Hans Konrad, editor (1966). Kandinsky. Das Druckgraphische Werk. Städtische Galerie im Lenbachhaus, München.

Röтнel, Hans Konrad y HaHL-Koch, Jelena, editores (1980). Kandinsky. Die gesammelten Schriften. Benteli-Verlag, Bern.

Runge, Philipp Otto (1959). Die Farbenkugel und andere Schriften zur Farbenlehre. Verlag Freies Geistesleben, Stuttgart.

Sacks, Oliver y Wasserman, Robert (1987). The Case of the Colorblind Painter. The New York Review of Books, 34(18):25-34.

Sacks, Oliver (1987). Tics. The New York Review of Books, 34(1):37-41.

SACKs, Oliver (2007). El hombre que confundió a su mujer con un sombrero. Anagrama, Barcelona.

SAcks, Oliver (2007). Musicophilia. Tales of Music and the Brain. Picador, London.

Sadie, Stanley y Tyrrell, John, editores (2001). The New Grove Dictionary of Music and Musicians. Número 22. Macmillan Publishers Limited, London.

Salmen, Brigitte (2003). Wassily Kandinsky-Gabrielle Münter. Künstler des Blauen Reiter in Murnau. Schloßmuseum Murnau, Bonn.

SAlmen, Brigitte, editor (2004). Wassily Kandinsky: Klänge. Lyrik / Bild / Klang. Verlag Bild-Kunst, Bonn.

Salmen, Brigitte y FäthKe, Bernd, editores (2008). Kandinsky, Münter, Jawlensky, Werefkin in Murnau. Schlossmuseum, Murnau.

SAnz Rodríguez, Juan Carlos (1985). El lenguaje del color. Hermann Blume, Madrid.

SCHAPIRO, Meyer (1937). Nature of Abstract Art. Marxist quarterly, 1:77-98.

SCHEFfLER, Karl (1901). Meditationen über das Ornament. Dekorative Kunst, VIII:401. 
Schmid-Breitenbach, Franz (1903). Stil- und Kompositionslehre in der Malerei unter besonderer Berücksichtigung der Farbengebung. Paul Neff, Stuttgart.

Schneede, Uwe M. (1979). Die zwanziger Jahre: Manifeste und Dokumente deutscher Künstler. DuMont, Köln.

SChÖNBERG, Arnold (1950). Erwartung. Universal Edition, Wien.

Schönberg, Arnold, Berg, Alban y von Webern, Anton (1971). Die Streichquartette der Wiener Schule. Ellermann, München.

SchönBERG, Arnold (2001). Harmonielehre. Universal Edition, Wien.

SchönberG, Arnold (2005). El estilo y la idea. Idea Books, Huelva.

Schopenhauer, Arthur (1854). Über das Sehn und die Farben. Verlag von Johann Friedrich Hartknoch, Leipzig.

SCHreIER, Christoph (1991). Wassily Kandinsky. Bild mit schwarzem Bogen. Insel Taschenbuch, Frankfurt am Main.

SCHREYER, Lothar (1956). Erinnerungen an Sturm und Bauhaus. Albert Langen, Georg Müller, München.

SChUppert, Maria y Altenmüller, Eckart (2001). Test zur Überprüfung der Musikwahrnehmung. Institut für Musikpädagogische Forschung, Hannover.

Shlain, Leonard (1991). Art and Physics: Parallel Visions in Space, Time and Light. William Morrow, New York.

Silvestrini, Narciso, editor (1998). Farbsysteme in Kunst und Wissenschaft. DuMont Schauberg, Köln.

von SKerst, Herman (1975). Altrussische Kulturstätten. Urachhaus, Stuttgart.

Solana, Guillermo, editor (1997). El impresionismo: la visión original. Antología de la crítica de arte (1867-1895). Siruela, Madrid.

Solso, Robert L. (2001). Brain Activities in a Skilled versus a Novice Artist: An fMRI Study. Leonardo, 34(1):31-34.

Solso, Robert L. (2003). The Psychology of Art and the Evolution of the Conscious Brain. The MIT Press, Massachusetts.

SPITZer, Manfred (2006). Vorsicht Bildschirm! Elektronische Medien, Gehirnentwicklung, Gesundheit und Gesellschaft. Deutscher Taschenbuch Verlag, München.

Stein, Susan Alyson (1983). Kandinsky and Abstract Stage Composition: Practice and Theory, 1909-1912. Art Journal, 43(1):61-66. 
STEINER, Rudolf (1908). Theosophie. Einführung in übersinnliche Welterkenntnis und Menschenbestimmung. Rudolf-Steiner-Verlag, Dornach.

Steiner, Rudolf (1965). Philosophie und Anthroposophie. Rudolf-Steiner-Verlag, Dornach.

SteINER, Rudolf (1992). Wege zu einem neuen Baustil. Rudolf-Steiner-Verlag, Dornach.

SteINer, Rudolf (1998). Texte zur Einführung in die Anthroposophie. Kösel, München.

Stelzer, Otto (1964). Die Vorgeschichte der abstrakten Kunst. Piper Verlag, München.

Stiles, Walter S. (1987). Mechanisms of Colour Vision. Academic Press, New York.

Strauss, Monica (1983). Kandinsky and "Der Sturm". Art Journal, 43(1):31-35.

Stubis, David (2009). Fear of Music: Why People get Rothko but don't get Stockhausen. Zero Books, Winchester.

Stuckenschmidt, Hans Heinz (1966). Kandinsky et la musique. xx Siècle.

Stuckenschmidt, Hans Heinz y Burde, Wolfgang, editores (1968). Aspekte der neuen Musik: Professor Hans Heinz Stuckenschmidt zum 65. Geburtstag. Bärenreiter, Kassel.

SCHWarTz, Fritz, editor (1904). Die Kunst für alle. Número 19. Bruckmann, München.

Schwartz, Fritz, editor (1905). Die Kunst für alle. Número 20. Bruckmann, München.

Schwartz, Fritz, editor (1912). Die Kunst für alle. Número 27. Bruckmann, München.

Schwartz, Fritz, editor (1914). Die Kunst für alle. Número 29. Bruckmann, München.

Thürlemann, Felix (1956). Kandinsky über Kandinsky. Der Künstler als Interpret eigener Werke. Benteli-Verlag, Bern.

Ticini, Luca F. (2009). Connessioni inattese: crossing tra arte e scienza, capítulo La neuroestetica: un passo verso la comprensione della creatività umana?, páginas 165-173. Politi Editore, Milano.

Tower, Beeke Sell (1981). Klee and Kandinsky in Munich and at the Bauhaus. uMi Research Press, Michigan.

Utz, Peter (1990). Das Auge und das Ohr im Text. Wilhelm Fink Verlag, München. 
VenzMER, Wolfgang (1983). Hölzel and Kandinsky as Teachers: An Interview with Vincent Weber. Art Journal, 43(1):27-30.

de Vignemont, Frederique y Singer, Tania (2006). The Empathic Brain: How, When and Why?. Trends in Cognitive Sciences, 10(10):435-441.

VISE, Stephen Solomon (1969). Wassily Kandinsky and Arnold Schönberg. Parallelism in Form and Meaning. Tesis doctoral, Washington University, Washington.

Vitz, Paul V. y Glimcher, Arnold B. (1984). Modern Art and Modern Science: The Parallel Analysis of Vision. Praeger, New York.

Waddington, Conrad H. (1969). Behind Appearance: a Study of the Relations between Painting and the Natural Sciences in this Century. Edinburgh University Press, Edinburgh.

WAGNER, Richard (1850). Das Kunstwerk der Zukunft. Wigand, Leipzig.

Walden, Herwarth, editor (1918). Expressionismus. Die Kunstwende. Der Sturm, Berlin.

Wallin, Nils, Merker, Björn y Brown, Steven, editores (2001). The Origins of Music. The MIT Press, Massachusetts.

Wanner-Meyer, Petra (1998). Quintett der Sinne. Synästhesie in der Lyrik des 19. Jahrhunderts. Arsthesis Verlag, Bielefeld.

Ward, Jamie, Moore, Samantha, Thompson-Lake, Daisy, Salih, Shireen y Beck, Brianna (2008). The Aesthetic Appeal of Auditory - Visual Synaesthetic Perceptions in People without Synaesthesia. Perception, 37(8):1285-1296.

Washton-Long, Rose Carol (1980). Kandinsky. The Development of an Abstract Style. Clarendon Press, Oxford.

Washton-Long, Rose Carol (1983). Kandinsky's Vision of Utopia as a Garden of Love. Art Journal, 43(1):50-60.

Webel, Charles P. (2007). Modernist Creativity and the Construction of Reality in Einstein and Kandinsky. World Futures, 63(7):526-557.

Wegener, Maria, editor (2002). Kandinsky. Probedrucke zu «Klänge». Kunsthandel Wolfgang Werner, Berlin.

Weiss, Peg (1975). Kandinsky and the "Jugendstil" Arts and Crafts Movement. The Burlington Magazine, 117(866):270-279.

WeIss, Peg (1979). Kandinsky in Munich. The Formative Jugendstil Years. Princeton University Press, Princeton. 
Weiss, Peg (1983). Are We Ready to Memorialize Kandinsky?. Art Journal, 43(1):9-13.

Weiss, Peg (1985). Kandinsky and the Symbolist Heritage. Art Journal, 45(2):137-145.

WeIss, Peg (1995). Kandinsky and old Russia. The Artist as Ethnographer and Shaman. Yale University Press, New Haven.

Wellek, Albert (1963). Musikpsychologie und Musikästhetik. Akademische Verlagsgesellschaft, Frankfurt am Main.

Westheim, Paul, editor (1930). Das Kunstblatt. Número 14. Reckendorf, Berlin.

Whitford, Frank (1967). Kandinsky. Paul Hamlyn, London.

WinkLer, Walter (1949). Psychologie der modernen Kunst. Alma Mater Verlag, Tübingen.

Wolschina, Reinhard (1996). Kandinsky. Musik für Flöteninstrumente und Klavier. Keturi Musikverlag, Rimsting.

Worringer, Wilhelm (1987). Abstraktion und Einfühlung. Piper Verlag, München.

Zeki, Semir (1980). The Representation of Colours in the Cerebral Cortex. Nature, 284(5755):412-418.

ZeKI, Semir (1990). Colour Vision and Functional Specialisation in the Visual Cortex. Discussions in Neuroscience, 6(2):1-64.

Zeki, Semir (1993). A Vision of the Brain. Blackwell Scientific Publications, Oxford.

Zeki, Semir, Watson, J. D. G. y Frackowiak, R. S. J. (1993). Going beyond the Information Given: The Relation of Illusory Visual Motion to Brain Activity. Proceedings of the Royal Society of London. Series B: Biological Sciences, 252(1335):215-222.

Zeki, Semir y Lamb, M. (1994). The Neurology of Kinetic Art. Brain, $117(3): 606-636$.

Zeki, Semir y Bartels, A. (1998). The Autonomy of the Visual Systems and the Modularity of Conscious Vision. Philosophical Transactions of the Royal Society B, 353(1377):1911-1914.

Zeki, Semir y Marini, L. (1998). Three Cortical Stages of Colour Processing in the Human Brain. Brain, 121(9):1669-1685.

Zeki, Semir (1999). Art and the Brain. Journal of Consciousness Studies, 6(6-7):76-96. 
ZEKI, Semir (1999). Inner Vision. An Exploration of Art and the Brain. Oxford University Press, Oxford.

ZEKI, Semir (2001). Artistic Creativity and the Brain. Science, 293(5527):51-52.

ZEKI, Semir (2004). The Neurology of Ambiguity. Consciousness and Cognition, 13(1):173-196.

ZEKI, Semir (2005). Visión interior. Una investigación sobre el arte y el cerebro. A. Machado Libros, Madrid.

ZEKI, Semir (2009). Splendours and Miseries of the Brain. Wiley-Blackwell, Chichester.

Zimmermann, Reinhard (2002). Die Kunsttheorie von Wassily Kandinsky. Mann Verlag, Berlin.

Zrenner, Eberhart (1983). Neurophysiological Aspects of Colour Vision in Primates. Springer, New York.

Zumdick, Wolfgang (1995). Über das Denken bei Joseph Beuys und Rudolf Steiner. Wiese, Basel.

Zweite, Armin (1982). Kandinsky und München. Prestel, München.

(1957). Kandinsky und Gabriele Münter. Werke aus fünf Jahrzehnten. Städtische Galerie im Lenbachhaus München, München.

(1962). Wassily Kandinsky. 1866-1944. Gesamtausstellung. Kunsthalle Basel, Basel.

(1970). Gegenklänge. Aquarelle und Zeichnungen von W. Kandinsky. M. DuMont Schauberg, Köln.

(1970). Kandinsky: Gemälde 190o-1944. Staatliche Kunsthalle, Baden-Baden.

(1973). Oil Paintings and Watercolours by Wassily Kandinsky. The Lefevre Gallery, London.

(1974). Die Zeichnungen Wassily Kandinskys. M. DuMont Schauberg, Köln.

(1977). Wassily Kandinsky, 1866-1944. Austellungsleitung Haus der Kunst, München.

(1977). Kandinsky. 82 Oeuvres sur papier de 1902 à 1944. Galerie Karl Flinker, Paris.

(1987). Wassily Kandinsky. ZwölfFarbtafeln. Woldemar Klein Verlag, Baden-Baden. 
